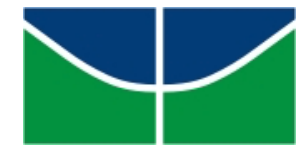

Universidade de Brasília

Faculdade de Arquitetura e Urbanismo

Programa de Pós-graduação

\title{
A INDISCIPLINA QUE ORIENTA \\ Design no espaço urbano
}

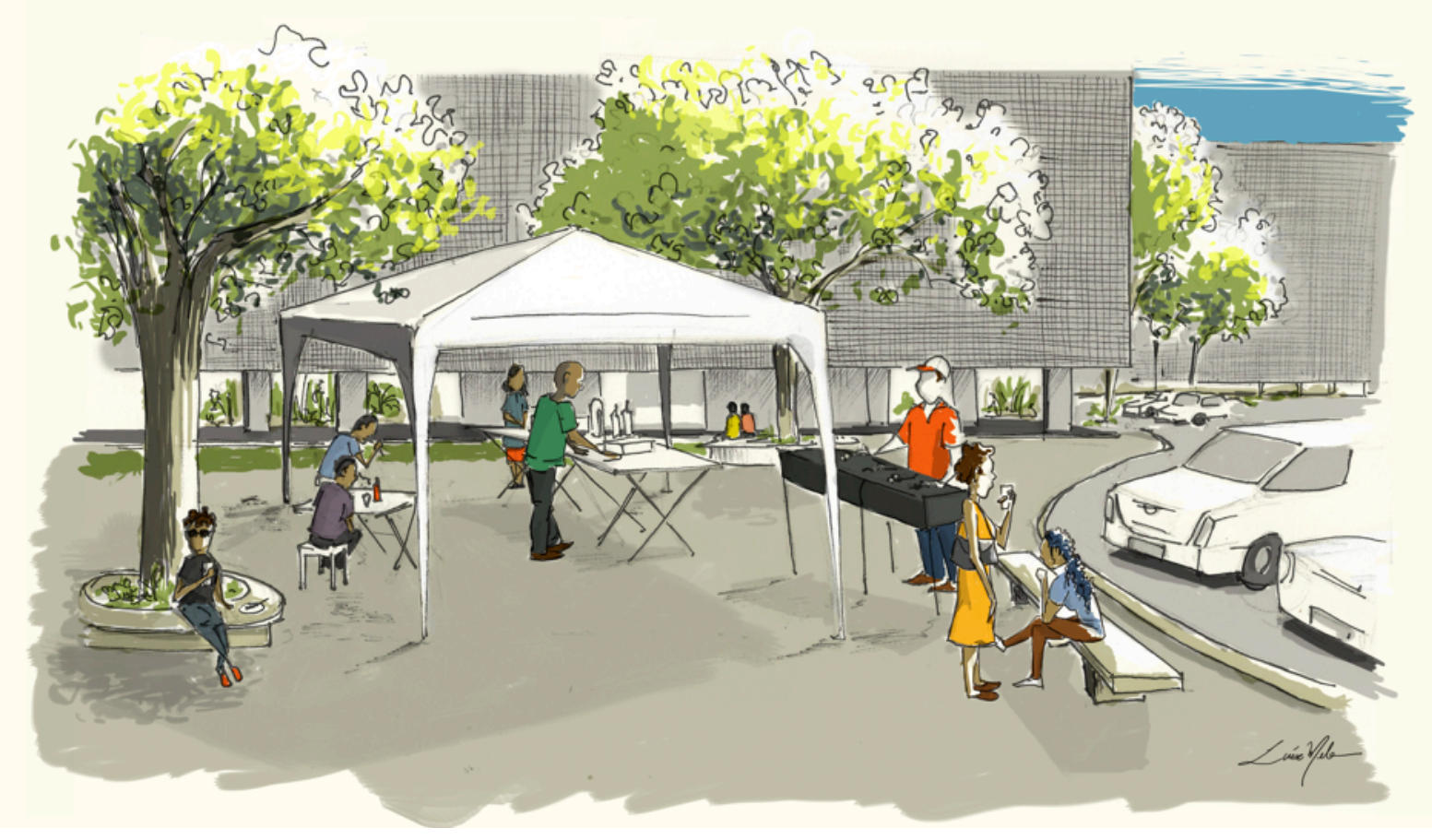

Nayara Moreno de Siqueira

Brasília, 2016 


\section{A INDISCIPLINA QUE ORIENTA Design no espaço urbano}

Tese de doutoramento apresentada como requisito parcial à obtenção do título de Doutor pelo Programa de Pesquisa e PósGraduação da Faculdade de Arquitetura e Urbanismo, da Universidade de Brasília.

Orientador: Professor Doutor Frederico Rosa Borges de Holanda

BRASÍLIA

2016 


\title{
TERMO DE APROVAÇÃO
}

\author{
NAYARA MORENO DE SIQUEIRA
}

A INDISCIPLINA QUE ORIENTA - DESIGN NO ESPAÇO URBANO

Tese aprovada como requisito parcial para obtenção do grau de doutor no Programa de Pós-graduação da Faculdade de Arquitetura e Urbanismo da Universidade de Brasília, pela comissão examinadora:

Prof. Dr. Frederico Rosa Borges de Holanda (orientador)

Faculdade de Arquitetura e Urbanismo - FAU/UnB

Profa. Dra. Gabriela de Souza Tenorio

Faculdade de Arquitetura e Urbanismo - FAU/UnB

Profa. Dra. Ana Elisabete de Almeida Medeiros

Faculdade de Arquitetura e Urbanismo - FAU/UnB

Profa. Dra. Fátima Aparecida dos Santos

Departamento de Design - DIN/UnB

Profa. Dra. Paula da Cruz Landim

Faculdade de Arquitetura, Artes e Comunicação - UNESP

Brasília, 27 de junho de 2016. 
Para meus filhos Maya e Theo. 


\section{| AGRADECIMENTOS}

Quantos foram os que estiveram comigo nesta jornada, em presença ou à distância, apoiando, confiando e dando as mais diversas contribuições para a realização desta tese!

Tomo este pequeno espaço para os agradecimentos especiais aos meus pais, Denise e Pedro Paulo, pela força e por sempre acreditarem na minha capacidade de realização, apesar das adversidades enfrentadas no caminho. Aos meus filhos, Maya e Theo, pela espera, pela torcida quieta, pela paciência com as mudanças de humor, pela compreensão nas minhas ausências, por estarem comigo sempre e incondicionalmente, tenho certeza. Ao José, pelo apoio e pela torcida (ansiosa) também em silêncio, dividindo os afazeres todos, porque "a vida não para"! Por aceitar o convite e pela orientação na tese e na postura diante da vida acadêmica, agradeço imensamente a Frederico de Holanda.

Minha sincera gratidão à Manuela Ribeiro e Carlos, amiga que tanto me ajudou no trabalho de campo, nas discussões sobre as variáveis e na confecção da maioria dos mapas dentro da Sintaxe Espacial. E com isso, Carlos e Anice tiveram uma participação muito especial neste meu momento.

Às professoras Fátima Maria dos Santos e Gabriela Tenório pelas contribuições valiosas no momento da minha qualificação.

Aos colegas, funcionários e alunos do Departamento de Design da UnB, pelo apoio, pela confiança e espera paciente. Destaco os professores Evandro Perotto, Geórgia Castro, Shirley Queiroz, Marisa Maass, Fátima Maria dos Santos, Rogério Câmara e Tiago Barros. E os secretários Patrícia Carlos (DIN) e Diego Luna (PPGFAU).

À Isabella Brandalise, pelas discussões inteligentes sobre o espaço urbano e pelo apoio sempre, mesmo à distância. À Luisa Melo pela bela ilustração de um ponto de comércio idealizado.

Às amigas Nana e Lora, pelos encontros, pela torcida, pela bela amizade.

Agradeço imensamente a Henrique Meuren por aceitar a minha demanda, pela prontidão e pelo tratamento gráfico da tese.

À Vânia Loureiro e Matias Ocaranza pelas contribuições no apagar das luzes!

Minha gratidão a todos vocês! 
A primeira linha no papel já é uma medida do que não se pode expressar completamente.

Louis Kahn 


\section{RESUMO}

Dentro do universo de possibilidades de soluções inseridas no espaço urbano, abordar a indisciplina permite entender a lógica subjacente ao comportamento de indivíduos anônimos. Como parte do coletivo, eles recriam, se reapropriam e refazem seu cotidiano de maneira simples, frequente e inovadora. Por meio do entendimento dessas práticas na apropriação do espaço urbano, esta pesquisa contribui com a reflexão sobre a relação do design com a arquitetura. Trata-se de entender a lógica social que subjaz esse comportamento de indisciplina em relação ao que foi oferecido nos lugares abertos das cidades, em termos de configuração de espaço-forma. Usar o espaço urbano é fazer escolhas por uma via, por um banco de praça, por um local mais iluminado, mais arborizado ou mais frequentado. Nessas escolhas são acionados, em conjunto, vários elementos que traduzem os desempenhos das configurações de espaço-forma dos lugares e objetos. Este trabalho é resultado da pesquisa que busca contribuir com reflexões e projetos de design e arquitetura com relação a essas posturas não previstas em relação ao espaço urbano. Ela compõem um tipo de indisciplina, que informa sobre as expectativas sociais em relação aos lugares da cidade. De maneira mais específica, a indisciplina aqui abordada tem relação com a necessidade de sustento que caracteriza o comércio informal em via pública. Nas escolhas de uso e apropriação do espaço urbano são acionados elementos que traduzem os desempenhos das configurações de espaço-forma, conjunto de volumes e vazios, dos lugares e objetos. A conjugação desses elementos constitui parâmetro primordial para projetos nestas áreas. A questão aqui colocada trata de sociedade, espaço e materialidade na atualidade. A propriedade dos artefatos da arquitetura e do design de imprimir ordem e transformação no meio social justifica a escolha pelo desenvolvimento desta pesquisa.

Palavras-chave: design, arquitetura, configuração urbana, indisciplina, Brasília. 


\section{| ABSTRACT}

Within the universe of possibilities for solutions embedded in the urban space, addressing indiscipline allows us to understand the logic behind the behavior of anonymous individuals. As part of a collective, they recreate, reappropriate and transform their daily lives in a simple, frequent and innovative way. By understanding these practices of urban space appropriation, this research contributes with a reflection on the relation between design and architecture. It is concerned with understanding the social logic behind this disruptive behavior in relation to what was offered in open spaces across the cities, in terms of space-shape configuration. To use the urban space is to make choices for a certain path, a park bench, a brighter, more wooded or more visited place. In these choices are triggered together various elements that reflect the performance of space-shape configurations of places and objects. This paper is the result of a research that seeks to contribute to design and architecture/urban planning discussions and projects with respect to these unforeseen choices in relation to the urban space. It is part of a form of indiscipline, which tells something about the social expectations regarding spaces in the city. In more specific terms, the indiscipline approached herein is related to the need for support that characterizes the informal trade in public streets. When making choices of use and appropriation of urban space elements are triggered that reflect the performance of space-shape configurations, a set of volumes and voids, places and objects. The combination of these elements is an essential parameter for projects in these areas. The question addressed here is about society, space and materiality today. The quality of infusing order and transformation in the social environment inherent to architecture and design artifacts justifies the choice for carrying out this research.

Keywords: design, architecture, urban configuration, indiscipline, Brasília 


\section{RESUMEN}

Dentro del universo de posibilidades para soluciones integradas en el espacio urbano, abordar la indisciplina nos permite comprender la lógica subyacente al comportamiento de los individuos anónimos. Como parte de la colectividad, ellos se recrean, se repropian y rehacen su cotidiano de forma simple, frecuente e innovadora. A través de la comprensión de estas prácticas en la apropiación del espacio urbano, esta investigación contribuye al debate sobre la relación entre el diseño y la arquitectura. Tratase de entender la lógica detrás de esta conducta disruptiva en relación con lo que se ofrecía en los lugares abiertos de las ciudades en términos de configuración espacio-forma. Usar el espacio urbano es tomar decisiones acerca de un camino, es escoger un banco de plaza, un sitio más iluminado, más arbolado o más frecuentado. En estas decisiones se activan conjuntamente varios elementos que reflejen el desempeño de las configuraciones espacio-forma de los lugares y objetos. Este trabajo es el resultado de una investigación que busca contribuir con reflexiones y proyectos de diseño y arquitectura/planificación urbana con respecto a estas actitudes no previstas en relación al espacio urbano. Ella hace parte de una especie de indisciplina que habla de las expectativas sociales con respecto a los lugares de la ciudad. Más específicamente, la indisciplina abordada aquí se relaciona con la necesidad de mantenimiento que caracteriza el comercio informal en la calle. En las decisiones de uso y apropiación del espacio urbano son añadidos elementos que reflejen el desempeño de la configuraciones de espacio-forma, conjunto de volúmenes y vacíos de los lugares y los objetos. La combinación de estos elementos es un parámetro esencial para proyectos en estas áreas. La pregunta que se plantea aquí es acerca de la sociedad, del espacio y de la importancia relativa de hoy. La propiedad característica de los artefactos de arquitectura y diseño de establecer orden y transformación en el entorno social justifica la decisión de desarrollar esta investigación.

Palabras clave: diseño, arquitectura, configuración urbana, indisciplina, Brasília 


\section{LISTA DE FIGURAS}

\section{INTRODUÇÃO}

Figura i.1 imagens do comércio de frango assado localizado em uma das pontas do CLN 208, Asa Norte - Plano Piloto. Fonte: autora.

Figura i.2 esquema que apresenta o foco da pesquisa no design como resultado.

\section{PARTE I}

\section{CAPÍTULO 1}

Figura 1.1 esquema da tríade de âmbitos do objeto de pesquisa CONTEXTO/INTERFACE/ATIVIDADE.

Figura 1.2 esquema sobre as bifurcações e escolhas na conceituação de Arquitetura Sociológica, por Holanda. Fonte: HOLANDA, 2011.

Figura 1.3 esquema do movimento natural. Fonte: MEDEIROS, 2006, p. 103.

Figura 1.4 entrequadras norte $208 / 209$ - os caminhos feitos por pedestres no gramado. Fonte: Google Earth.

Figura 1.5 a imagem à esquerda é divulgada em um jornal da cidade, quatro anos depois, mostrando que os camelôs voltaram a atuar no Setor Comercial Sul; à direita uma imagem dos boxes (ainda fechados) oferecidos a estes comerciantes, no Shopping Popular, quatro anos antes. Fonte: Gustavo Moreno/Correio Braziliense/C.A Press (à esquerda) e Rafaela Felicciano/Jornal de Brasília (à direita).

Figura 1.6 comparação entre recursos de sobrevivência entre os Inuits e os camelôs: à esquerda um mapa inuit tridimensional de madeira Fonte: http://enciclopediavisual.blogspot.com.br/; à direita uma banca de camelô de frutas no Núcleo Bandeirante/DF - Fonte: Nana Ervilha.

Figura 1.7 exemplos de comércio informal de alimentos, no Brasil, retratados por Jean Baptiste Debret, no início do século XIX. Da esquerda para a direita: "Negras vendendo angu", "Negros vendendo carvão e milho" e "Negra tatuada vendendo caju". Fonte: www.dezenovevinte.net - reproduções do livro Voyage pittoresque et historique au Brésil, de Jean-Baptiste Debret (1768-1848).

Figura 1.8 ilustração/base para a explanação da ação de um ponto fictício de comércio de alimentos, dentro de uma quadra residencial no Plano Piloto - Brasília. Ilustração por Luisa Melo.

'Poltrona mole', exemplo de artefato considerado como sistema. Fonte: Instituto Sérgio Rodrigues.

Figura 1.9

Figura 1.10 ponto de comércio de frango grelhado, no Comércio Local Norte 207/208, exemplo de sistema por composição de vários artefatos e espaços de ação. Foto: autora. 
CAPÍTULO 2

Figura 2.1 gradação da coloração dos mapas de axialidade e de visibilidade indicativa dos níveis de integração dos trechos da área estudada.

Figura 2.2 trecho da superquadra SQN 315 representado pelos mapas de convexidade(destacando um dos espaços convexos determinados pela massa edilícia) e de axialidade.

Figura 2.3 os três mapas sequenciais instrumentais da variável integração visual de um trecho da SQN 315: (da esquerda para a direita) base cartográfica, barreiras e permeabilidades visuais (gerador) e integração visual (sintático).

Figura 2.4 croqui, de autoria de Lucio Costa, do Plano Piloto de Brasília, com a disposição das quadras residenciais ao longo do Eixo Rodoviário. Fonte: COSTA, 1991.

Figura 2.5 esboços de Lucio Costa na complementação do texto do Relatório do PPB sobre a questão residencial. Fonte: COSTA, 1991.

Figura 2.6 imagem do local apropriado para o ponto de comércio de tapioca, no interior da superquadra norte 113. Foto: Maya Macario.

imagem do local apropriado para o ponto de comércio de caldos, na entrada da superquadra norte 410. Foto: Maya Macario.

Figura 2.8 imagem do local apropriado para o ponto de comércio de churrasquinho no espeto, associado ao comércio local próximo à superquadra norte 408. Foto: Maya Macario.

Figura 2.9 imagem do local apropriado para o ponto de comércio de itens para café da manhã, na entrada da passagem subterrânea próxima a superquadra norte 209. Foto: Maya Macario.

PARTE II

CAPÍTULO 3

Figura 3.1 mapas do Plano Piloto (esquerda) e da Asa Norte (direita) com a localização dos pontos de comércio escolhidos para observação. Fonte: adaptado do Google Earth.

Figura 3.2 vista aérea do ponto em relação a quadra residencial de referência - SQN 408. Fonte: adaptado do Google Earth.

Figura 3.3 identificação do ponto de comércio relacionado à superquadra norte 408. Fonte: Maya Macario (esquerda); autora (direita).

Figura 3.4 gráfico sobre a renda, por número de salários mínimos, dos responsáveis por domicílios, da superquadra norte 408, na amostragem dos dados censitários do IBGE, de 2010.

Figura 3.5 mapa $(200 \mathrm{~m})$ dos espaços convexos do contexto imediato do ponto referente à SQN 408 e de sua inserção em um destes espaços.

Figura 3.6 quadro comparativo entre as medidas de integração máxima, média e mínima do Plano Piloto e da localização do ponto de comércio associado ao comércio local da SQN 408, no que se 
Figura 3.7 quadro comparativo entre as medidas de integração máxima, média e mínima do contexto imediato (área quadrada ao redor do ponto com $200 \mathrm{~m}$ de lado) e da localização do ponto de comércio referente à SQN 408, no que se refere à acessibilidade ao movimento de pedestres.

Figura 3.8 mapas de barreiras e permeabilidades ao movimento (gerador) (à esquerda) e de axialidade (à direita) para o ponto - SQN 408.

Figura 3.9 quadro comparativo entre as medidas de integração máxima, média e mínima da área do ponto de comércio (área quadrada ao redor do ponto com $20 \mathrm{~m}$ de lado) referente à SQN 408 e do seu ponto central, no que se refere à acessibilidade ao movimento de pedestres.

Figura 3.10 mapas de barreiras e permeabilidades (à esquerda) e axialidade (à direita) do ponto de comércio referente à SQN 408 (máscara quadrada de $20 \mathrm{~m}$ de lado ao redor do ponto).

Figura 3.11 quadro comparativo entre as medidas de integração visual máxima, média e mínima no contexto imediato (área quadrada ao redor do ponto com $200 \mathrm{~m}$ de lado) e da localização do ponto de comércio referente à SQN 408, no que se refere à acessibilidade à visão.

Figura 3.12 mapas de barreiras e permeabilidades à visão (gerador) (à esquerda) e de visibilidade (à direita) para o ponto - SQN 408.

Figura 3.13 quadro comparativo entre as medidas de integração visual máxima, média e mínima na área do ponto de comércio (área quadrada ao redor do ponto com $20 \mathrm{~m}$ de lado) referente à SQN 408 e do seu ponto central, no que se refere à acessibilidade à visão.

Figura 3.14 mapas de barreiras e permeabilidades à visão (à esquerda) e de visibilidade (à direita) do ponto de comércio referente à SQN 408 (máscara quadrada de $20 \mathrm{~m}$ de lado ao redor do ponto).

Figura 3.15 mapa de isovistas a partir do ponto - SQN 408.

Figura 3.16 imagens sobre as condições para a permanência no ponto de comércio referente à SQN 408. Fotos: autora (acima) e Maya Macario (abaixo).

Figura 3.17 imagens dos arredores do local do ponto de comércio referente à SQN 408 para ilustrar atividades ao redor. Fotos: Maya Macario.

Figura 3.18 mapa de espaço convexo determinado pelos elementos físicos com a arquitetura do ponto de comércio referente à SQN 408.

Figura 3.19 mapas comportamentais sobre a distribuição de pessoas no
ponto de comércio referente à SQN 408, nos dois dias observados.

Figura 3.20 planta baixa do ponto de comércio referente à SQN 408, com a especificação dos elementos físicos envolvidos na atividade.

$\begin{aligned} & \text { Figura } 3.21 \text { imagens dos elementos físicos na atividade do ponto de comércio } \\ & \text { referente à SQN 408. Fotos: autora (fotos a e b } \text { ); Maya Macario }\end{aligned}$ (fotos $\underline{\mathrm{c}}, \underline{\mathrm{d}}, \underline{\mathrm{e}}$ ef $\mathrm{f}$ ).

Figura 3.22 planta baixa do ponto de comércio referente à SQN 408 com identificação dos espaços da atividade (clientes e comerciante), da interface (passantes) e do contexto. 
Figura 3.23 vista aérea do ponto em relação a quadra residencial mais próxima (SQN 209). Fonte: adaptado do Google Earth.

Figura 3.24 identificação do ponto de comércio relacionado à superquadra norte 209. Foto: autora.

Figura 3.25 gráfico sobre a renda, por número de salários mínimos, dos responsáveis por domicílios, da superquadra norte 209, na amostragem dos dados censitários do IBGE, de 2010.

Figura 3.26

mapa $(200 \mathrm{~m})$ dos espaços convexos do contexto imediato do ponto referente à SQN 209 e de sua inserção em um destes espaços.

Figura 3.27 quadro comparativo entre as medidas de integração máxima, média e mínima do Plano Piloto e do ponto de comércio localizado na entrada da passagem subterrânea associada à SQN 209, no que se refere à acessibilidade ao movimento de veículos.

Figura 3.28 quadro comparativo entre as medidas de integração máxima, média e mínima do contexto imediato (área quadrada ao redor do ponto com $200 \mathrm{~m}$ de lado) e da localização do ponto de comércio referente à SQN 209, no que se refere à acessibilidade ao movimento de pedestres.

Figura 3.29 mapas de barreiras e permeabilidades ao movimento (gerador) (à esquerda) e de axialidade (à direita) para o ponto - SQN 209.

Figura 3.30

quadro comparativo entre as medidas de integração máxima, média e mínima da área do ponto de comércio (área quadrada ao redor do ponto com 20m de lado) referente à SQN 209 e do seu ponto central, no que se refere à acessibilidade ao movimento de pedestres.

Figura 3.31 mapas de barreiras e permeabilidades (à esquerda) e axialidade (à direita) do ponto de comércio referente à SQN 209 (máscara quadrada de $20 \mathrm{~m}$ de lado ao redor do ponto).

Figura 3.32 quadro comparativo entre as medidas de integração visual máxima, média e mínima no contexto imediato (área quadrada ao redor do ponto com $200 \mathrm{~m}$ de lado) e da localização do ponto de comércio referente à SQN 209, no que se refere à acessibilidade à visão.

Figura 3.33 mapas de barreiras e permeabilidades à visão (gerador) (à esquerda) e de visibilidade (à direita) para o ponto - SQN 209.

Figura 3.34 quadro comparativo entre as medidas de integração visual
máxima, média e mínima na área do ponto de comércio (área quadrada ao redor do ponto com $20 \mathrm{~m}$ de lado) referente à SQN 209 e do seu ponto central, no que se refere à acessibilidade à visão.

Figura 3.35 mapas de barreiras e permeabilidades à visão (à esquerda) e de visibilidade (à direita) do ponto de comércio referente à SQN 209 (máscara quadrada de $20 \mathrm{~m}$ de lado ao redor do ponto). mapa de isovistas a partir do ponto - SQN 209. imagens sobre condições para permanência no ponto de comércio referente à SQN 209. Foto: autora. 
Figura 3.39 mapa de espaço convexo determinado pelos elementos físicos com a arquitetura do ponto de comércio referente à SQN 209.

Figura 3.40 mapas comportamentais sobre a distribuição de pessoas no ponto de comércio referente à SQN 209, nos dois dias observados.

Figura 3.41 planta baixa do ponto de comércio referente à SQN 209, com a especificação dos elementos físicos envolvidos na atividade.

Figura 3.42 imagens dos elementos físicos na atividade do ponto de comércio referente à SQN 209. Fotos: autora.

Figura 3.43 planta baixa do ponto de comércio referente à SQN 209 com identificação dos espaços da atividade (clientes e comerciante), da interface (passantes) e do contexto.

Figura 3.44 vista aérea do ponto em relação a quadra residencial mais próxima (SQN 113). Fonte: adaptado do Google Earth.

Figura 3.45 identificação do ponto de comércio relacionado à SQN 113 . Fotos: Maya Macario (esquerda); autora (direita).

Figura 3.46 gráfico sobre a renda, por número de salários mínimos, dos responsáveis por domicílios, da superquadra norte 113, na amostragem dos dados censitários do IBGE, de 2010.

Figura 3.47

mapa $(200 \mathrm{~m})$ dos espaços convexos do contexto imediato do ponto referente à SQN 113 e de sua inserção em um destes espaços.

Figura 3.48 quadro comparativo entre as medidas de integração máxima, média e mínima do Plano Piloto e da localização do ponto de comércio associado ao comércio local da SQN 113, no que se refere à acessibilidade ao movimento de veículos.

Figura 3.49 quadro comparativo entre as medidas de integração máxima, média e mínima do contexto imediato (área quadrada ao redor do ponto com $200 \mathrm{~m}$ de lado) e da localização do ponto de comércio referente à SQN 113, no que se refere à acessibilidade ao movimento de pedestres.

Figura 3.50 mapas de barreiras e permeabilidades ao movimento (gerador) (à esquerda) e de axialidade (à direita) para o ponto - SQN 113.

quadro comparativo entre as medidas de integração máxima,

Figura 3.51 média e mínima da área do ponto de comércio (área quadrada ao redor do ponto com $20 \mathrm{~m}$ de lado) referente à SQN 113 e do seu ponto central, no que se refere à acessibilidade ao movimento de pedestres.

Figura 3.52 mapas de barreiras e permeabilidades (à esquerda) e axialidade (à direita) do ponto de comércio referente à SQN 113 (máscara quadrada de $20 \mathrm{~m}$ de lado ao redor do ponto).

Figura 3.53 quadro comparativo entre as medidas de integração visual máxima, média e mínima no contexto imediato (área quadrada ao redor do ponto com $200 \mathrm{~m}$ de lado) e da localização do ponto de comércio referente à SQN 113, no que se refere à acessibilidade à visão.

Figura 3.54 mapas de barreiras e permeabilidades à visão (gerador) (à esquerda) e de visibilidade (à direita) para o ponto - SQN 113.

Figura 3.55 quadro comparativo entre as medidas de integração visual máxima, média e mínima na área do ponto de comércio (área 
quadrada ao redor do ponto com $20 \mathrm{~m}$ de lado) referente à SQN 113 e do seu ponto central, no que se refere à acessibilidade à visão.

Figura 3.56 mapas de barreiras e permeabilidades à visão (à esquerda) e de visibilidade (à direita) do ponto de comércio referente à SQN 113 (máscara quadrada de $20 \mathrm{~m}$ de lado ao redor do ponto).

Figura 3.57

Figura 3.58

Figura 3.59

Figura 3.60

Figura 3.61

Figura 3.62

Figura 3.63

Figura 3.64

Figura 3.65

Figura 3.66

Figura 3.67

Figura 3.68

Figura 3.69

Figura 3.70

Figura 3.71

Figura 3.72

Figura 3.73 mapa de isovistas a partir do ponto - SQN 113.

imagens sobre as condições para a permanência no ponto de comércio referente à SQN 113. Fotos: Maya Macario (acima), autora (abaixo).

imagens dos arredores do local do ponto de comércio referente à SQN 113 para ilustrar atividades ao redor. Fotos: Maya Macario. mapa de espaço convexo determinado pelos elementos físicos com a arquitetura do ponto de comércio referente à SQN 113.

mapas comportamentais sobre a distribuição de pessoas no ponto de comércio referente à SQN 113, nos dois dias observados.

planta baixa do ponto de comércio referente à SQN 113, com a especificação dos elementos físicos envolvidos na atividade.

imagens dos elementos físicos na atividade do ponto de comércio referente à SQN 113. Fotos: Maya Macario.

coincidência entre as linhas integradas do mapa de acessibilidade ao movimento de pedestres na SQN 113 e as trilhas feitas pelos passantes.

planta baixa do ponto de comércio referente à SQN 113 com identificação dos espaços da atividade (clientes e comerciante), da interface (passantes) e do contexto.

vista aérea do ponto em relação a quadra residencial - SQN 410. Fonte: adaptado do Google Earth.

identificação do ponto de comércio relacionado à SQN 113. Foto: Maya Macario.

gráfico sobre a renda, por número de salários mínimos, dos responsáveis por domicílios, da superquadra norte 410, na amostragem dos dados censitários do IBGE, de 2010.

mapa $(200 \mathrm{~m})$ dos espaços convexos do contexto imediato do ponto referente à SQN 410 e de sua inserção em um destes espaços.

quadro comparativo entre as medidas de integração máxima, média e mínima do Plano Piloto e da localização do ponto de comércio associado ao comércio local da SQN 410, no que se refere à acessibilidade ao movimento de veículos.

quadro comparativo entre as medidas de integração máxima, média e mínima do contexto imediato (área quadrada ao redor do ponto com $200 \mathrm{~m}$ de lado) e da localização do ponto de comércio referente à SQN 410, no que se refere à acessibilidade ao movimento de pedestres.

mapas de barreiras e permeabilidades ao movimento (gerador) (à esquerda) e de axialidade (à direita) para o ponto - SQN 410.

quadro comparativo entre as medidas de integração máxima, 
média e mínima da área do ponto de comércio (área quadrada ao redor do ponto com $20 \mathrm{~m}$ de lado) referente à SQN 410 e do seu ponto central, no que se refere à acessibilidade ao movimento de pedestres.

Figura 3.74 mapas de barreiras e permeabilidades (à esquerda) e axialidade (à direita) do ponto de comércio referente à SQN 410 (máscara quadrada de $20 \mathrm{~m}$ de lado ao redor do ponto).

Figura 3.75 quadro comparativo entre as medidas de integração visual máxima, média e mínima no contexto imediato (área quadrada ao redor do ponto com $200 \mathrm{~m}$ de lado) e da localização do ponto de comércio referente à SQN 410, no que se refere à acessibilidade à visão.

Figura 3.76 mapas de barreiras e permeabilidades à visão (gerador) (à esquerda) e de visibilidade (à direita) para o ponto - SQN 410.

Figura 3.77 quadro comparativo entre as medidas de integração visual máxima, média e mínima na área do ponto de comércio (área quadrada ao redor do ponto com $20 \mathrm{~m}$ de lado) referente à SQN 410 e do seu ponto central, no que se refere à acessibilidade à visão.

Figura 3.78 mapas de barreiras e permeabilidades à visão (à esquerda) e de visibilidade (à direita) do ponto de comércio referente à SQN 410 (máscara quadrada de $20 \mathrm{~m}$ de lado ao redor do ponto).

Figura 3.79 mapa de isovistas a partir do ponto - SQN 410. imagens sobre as condições para a permanência no ponto de comércio referente à SQN 410. Fotos: Maya Macario.

Figura 3.80

Figura 3.81 imagens dos arredores do local do ponto de comércio referente à SQN 410 para ilustrar atividades ao redor. Fotos: Maya Macario.

Figura 3.82 mapa de espaço convexo determinado pelos elementos físicos com a arquitetura do ponto de comércio referente à SQN 209.

Figura 3.83 mapas comportamentais sobre a distribuição de pessoas no ponto de comércio referente à SQN 410, nos dois dias observados.

Figura 3.84 planta baixa do ponto de comércio referente à SQN 410, com a especificação dos elementos físicos envolvidos na atividade.

Figura 3.85 imagens dos elementos físicos na atividade do ponto de comércio referente à SQN 410. Fotos: Maya Macario.

Figura 3.86 planta baixa do ponto de comércio referente à SQN 410 com identificação dos espaços da atividade (clientes e comerciante), da interface (passantes) e do contexto.

Figura 3.87 mapa axial do Plano Piloto, Integração global (Rn). Fonte: Grupo DIMPU.

CAPÍTULO 4

Figura 4.1 espaços convexos dos quatro pontos de comércio observados (máscara quadrada 200m lado).

Figura 4.2 espaços convexos dos quatro pontos de comércio observados (máscara quadrada $20 \mathrm{~m}$ lado).

Figura 4.3 mapas axiais (movimento de pedestres - 200m) dos quatros pontos de comércio referentes às SQN 408, SQN 209, SQN 113 
e SQN 410.

Figura 4.4 mapas axiais (movimento de pedestres - 20m) dos quatros pontos de comércio referentes às SQN 408, SQN 209, SQN 113 e SQN 410.

Figura 4.5 mapas de visibilidade (conexão visual - 200m) dos quatros pontos de comércio referentes às SQN 408, SQN 209, SQN 113 e SQN 410.

Figura 4.6 mapas de visibilidade (conexão visual $-20 \mathrm{~m}$ ) dos quatros pontos de comércio referentes às SQN 408, SQN 209, SQN 113 e SQN 410.

Figura 4.7 mapas de isovistas dos quatro pontos observados.

Figura 4.8 quantidade de total de pessoas, classificadas por gênero (homem/mulher) e crianças, nos dois dias de levantamento, nos pontos comerciais das quadras $113 \mathrm{~N}, 209 \mathrm{~N}, 408 \mathrm{~N}$ e $410 \mathrm{~N}$.

Figura 4.9 quantidade total de pessoas, classificadas por faixa etária (criança, jovem, adulto e idoso), nos dois dias de levantamento, nos quatro pontos de comércio. 


\section{LISTA DE TABELAS}

\section{PARTE I}

\section{CAPÍTULO 2}

Tabela 2.1 variáveis, variabilidade e técnicas/ferramentas do nível analítico Características socioeconômicas.

Tabela 2.2 variáveis, variabilidade e técnicas/ferramentas do nível analítico Padrões espaciais.

Tabela 2.3 variáveis, variabilidade e técnicas/ferramentas do nível analítico Sistema de encontros e esquivanças.

Tabela 2.4 variáveis e técnicas/ferramentas do nível analítico Sistema de elementos físicos.

Tabela 2.5 composição do sistema da atividade nos sistemas social e morfológico, seus elementos de entrada e correspondentes níveis analíticos.

PARTE II

CAPÍTULO 3

Tabela 3.1 Total pessoas - permanência $=100$ : total crianças $=5$; total homens $=68$; total mulheres $=27$. Total pessoas - passagem $=$ 80. Total pessoas (SQN 408) $-1^{\circ}$. dia $=180$

Tabela 3.2 Total pessoas - permanência $=100$ : total crianças $=5$; total homens $=74$; total mulheres $=21$. Total pessoas - passagem $=$ 102. Total pessoas $(S Q N 408)-2^{\circ}$. dia $=202$

$\begin{aligned} & \text { Tabela } 3.3 \text { Total pessoas }- \text { permanência }=200 \text { : total crianças }=10 \text {; total } \\ & \text { homens }=142 \text {; total mulheres }=48 \text {. Total pessoas }- \text { passagem }=\end{aligned}$ 182. TOTAL PESSOAS - SQN $408=382$

Tabela 3.4 Total pessoas - permanência $=57$ : total crianças $=1$; total homens $=23$; total mulheres $=33$. Total pessoas - passagem $=$ 165. Total pessoas (SQN 209) $-1^{\circ}$. dia $=222$

Tabela 3.5 Total pessoas - permanência $=46$ : total crianças $=1$; total homens $=15$; total mulheres $=30$. Total pessoas - passagem $=$ 175. Total pessoas $(S Q N 209)-2^{\circ}$. dia $=221$

Tabela 3.6 Total pessoas - permanência $=103$ : total crianças $=2$; total homens $=38$; total mulheres $=63$. Total pessoas - passagem $=$ 340. TOTAL PESSOAS - SQN $209=443$

Tabela 3.7 Total pessoas - permanência $=49$ : total - crianças $=5$; total homens $=21$; total - mulheres $=23$. Total pessoas - passagem $=$ 86. Total pessoas (SQN 113) $-1^{\circ}$. dia $=135$

Tabela 3.8 Total pessoas - permanência $=46$ : total crianças $=4$; total homens $=20$; total mulheres $=22$. Total pessoas - passagem $=$ 100. Total pessoas (SQN 113) $2^{\circ}$. dia $=146$

Tabela 3.9 Total pessoas - permanência $=95$ : total - crianças $=9$; total - 
homens $=41 ;$ total - mulheres $=45$. Total pessoas - passagem $=$ 186. TOTAL DE PESSOAS - SQN = 281

Tabela 3.10 Total pessoas - permanência $=78$ : total - crianças $=2$; total homens $=32$; total - mulheres $=44$. Total pessoas - passagem $=$ 73. Total pessoas $-1^{\circ}$. dia $=151$

Tabela 3.11 Total pessoas - permanência $=54$ : total - crianças $=5$; total homens $=15$; total - mulheres $=34$. Total pessoas - passagem $=$ 71. Total pessoas $-2^{\circ}$. dia $=125$

Tabela 3.12 Total pessoas - permanência $=132$ : total - crianças $=7$; total homens $=47$; total - mulheres $=78$. Total pessoas - passagem $=$ 144. TOTAL DE PESSOAS - SQN = 276.

\section{CAPÍTULO 4}

Tabela 4.1 resumo comparativo dos dados dos quatro pontos de comércio observados sobre Características socioeconômicas.

Tabela 4.2 áreas dos espaços convexos em que estão inseridos cada ponto de comércio observado.

Tabela 4.3 acessibilidade ao movimento motorizado no Plano Piloto e nos quatro pontos de comércio observados.

Tabela 4.4 valores de integração máxima, média, mínima e no centro dos

Tabela 4.4 valores de integração máxima, média, mínima e no centro dos
locais de cada ponto de comércio com relação à acessibilidade ao movimento de pedestres.

Tabela 4.5 valores de integração visual máxima, média, mínima e no centro dos locais de cada ponto de comércio com relação à acessibilidade à visão - conexão visual.

Tabela 4.6 valores de área, perímetro e compacidade dos contextos de cada ponto de comércio com relação ao campo visual.

Tabela 4.7 condições para permanência (níveis de estado de conservação e conforto) dos quatro pontos de comércio observados. 
SUMÁRIO

INTRODUÇÃO - 23

PARTE I - Refletir para recortar e abordar

10 COMÉRCIO INFORMAL E SUAS REPERCUSSÕES - 42

1.1 Os contextos da atividade -44

1.1.1 O lugar escolhido, o contexto imediato -44

1.1.2 Dos desempenhos, o sociológico - 52

1.1.3 Espaço urbano, o contexto global -58

1.1.4 A cidade e o comércio em via pública: origens comuns - 61

1.20 comércio em via pública - 64

1.2.1 A indisciplina - uma postura social - 65

1.2.2 Entre as atividades no espaço urbano - 76

1.2.3 O comércio de alimentos - um sistema - 80

1.3 As implicações do design na atividade - 87

1.3.1 O aspecto social do design e os não designers -88

1.3.2 Interface - artefato do design ou da arquitetura? - 91

1.3.3 A composição do ponto de comércio - uma 'abordagem ecológica' - 95

Conclusão do capítulo - 99

\section{MÉTODO E APRESENTAÇÃO DO CAMPO - 101}

2.1 Níveis de análise, variáveis e técnicas/ferramentas - 104

2.1.1 Características socioeconômicas - 106

2.1.2 Padrões espaciais - 109

2.1.3 Sistemas de encontros e esquivanças -118

2.1.4 Sistema de Elementos Físicos - SEF - 121 
2.2 Para analisar as informações - 124

2.2.1 Subsistema do tipo social - agentes e ações - 125

2.2.2 Subsistema do tipo morfológico - lugar e elementos físicos - 127

2.3 Em Brasília, no Plano Piloto, na Asa Norte - o campo - 129

2.3.1 Apresentação geral - 129

2.3.2 Os aspectos morfológicos e sociais da escala residencial - 131

2.3.3 A tipologia de incidência de apropriação dos lugares - 136

Conclusão do capítulo - 139

\section{PARTE II - Abordar para aprender e projetar}

3 O TRABALHO DE CAMPO - 141

\subsection{Estudos de caso - 141}

3.1.1 Ponto de comércio relacionado à superquadra norte 408 - SQN 408 - 142

3.1.1.1 Identificação - SQN 408 - 142

3.1.1.2 Categorias analíticas - SQN $408-143$

3.1.1.3 Análise do ponto como um sistema - SQN 408 - 162

3.1.2 Ponto de comércio relacionado à superquadra norte 209 - SQN 209 - 164

3.1.2.1 Identificação - SQN 209 - 165

3.1.2.2 Categorias analíticas - SQN $209-166$

3.1.2.3 Análise do ponto como um sistema - SQN $209-182$

3.1.3 Ponto de comércio relacionado à superquadra norte 113 - SQN $113-185$

3.1.3.1 Identificação - SQN 113 - 185

3.1.3.2 Categorias analíticas - SQN $113-186$

3.1.3.3 Análise do ponto como um sistema - SQN 113 - 203

3.1.4 Ponto de comércio relacionado à superquadra norte 410 - SQN 410 - 207

3.1.4.1 Identificação - SQN 410 - 207

3.1.4.2 Categorias analíticas - SQN $410-208$

3.1.4.3 Análise do ponto como um sistema - SQN 410 - 225 
Conclusão do capítulo - 228

\section{ANÁLISE DO TRABALHO DE CAMPO - 229}

4.1 Análise comparativa entre os pontos de comércio observados - 229

4.1.1 Características socioeconômicas - 230

4.1.2 Padrões espaciais - 235

4.1.3 Sistema de encontros e esquivanças -248

4.1.4 Sistema de elementos físicos -251

4.2 Aspectos a serem considerados - os ensinamentos da indisciplina - 252

Conclusão do capítulo - 257

CONCLUSÃO - 259

BIBLIOGRAFIA E REFERÊNCIAS BIBLIOGRÁFICAS - 265

ANEXOS - 273 


\section{INTRODUÇÃO}

Volta e meia nos arrebatam questionamentos sobre a contribuição da área profissional para com a sociedade. Estamos contribuindo, de maneira coerente, no atendimento às expectativas de uma sociedade urbana marcada por forte diferenciação social e em constante processo de mudança? Que tipo de exercício reflexivo pode ser feito diante de tal questão, ainda tão ampla?

Em mais um exercício contra a indiferença e o conformismo ${ }^{1}$, adiciono a esses questionamentos, a necessidade profissional e pessoal de abordar a prática do design, com foco no que é usufruído em espaços públicos, em que a relação das pessoas com artefatos e ambiente é pautada na plena diversidade de sujeitos, atividades, espaços e atuações no tempo. Nesta relação, o modo de apropriação do espaço e o sistema de encontros estabelecidos pelas variadas atividades exercidas pelas pessoas, caracterizam o que entendo por aspecto social na reflexão sobre o espaço urbano.

$\mathrm{Na}$ época da graduação, em passagens quase diárias pelo centro da cidade do Rio de Janeiro, entre a moradia, na Zona Sul, e a universidade, na llha do Fundão/llha do Governador, me surpreendia curiosa sobre a condição do comerciante informal em relação à própria atividade. Ao passar por barracas montadas nas calçadas, praças e outros lugares oportunos, assistia, como pedestre e às vezes como cliente, artigos de toda sorte: relógios, calculadoras, óculos de sol, roupas, pares de pás para para-brisas, roupas etc. - expostos e sendo vendidos com sucesso. Percebia e concluía que aqueles comerciantes não dispunham de serviços de profissionais de design para projetarem seus postos de trabalho. Era instigante observar a capacidade daqueles comerciantes em resolver seus problemas práticos de exposição e transporte dos produtos, montagem e desmontagem fáceis e rápidas e outras características que um comércio em via pública demanda para o seu funcionamento.

\footnotetext{
${ }^{1}$ BONSIEPE, 2011, p. 36. O autor discorre sobre a necessidade da intelectualidade no design na cultura do projeto, como "antídoto a uma aceitação conformista".
} 
O resgate destes questionamentos e observações, anos depois, me trazem ao tema desta tese desenvolvida para instrumentar a discussão sobre o desempenho das soluções, escolhas e atuações dos comerciantes informais no espaço urbano, no que diz respeito à vida social. Procuro assim, contribuir com as áreas do conhecimento vinculadas ao projeto de artefatos urbanos - design e arquitetura considerando, primordialmente, a primeira como foco, a segunda como contexto e a interface entre elas no tratamento do tema.

O comércio em via pública abrange um conjunto de elementos físicos e espaciais, que são matéria concernente ao trabalho de ambas as áreas. Dependendo da apropriação e do uso atribuídos, estes elementos assumem funções diferentes em situações e momentos diversos. Reunidos - lugar eleito, produtos à venda e suportes - atuam na atividade que permite a experiência específica do comércio e, consequentemente, a participação dos envolvidos na vida social local.

Dentro do universo de possibilidades de soluções inseridas no espaço urbano, abordar a prática destes comerciantes permite entender a lógica subjacente no comportamento de indivíduos anônimos. Como parte do coletivo, eles recriam, se reapropriam e refazem seu cotidiano de uma maneira simples, frequente e inovadora, que caracteriza o que chamo aqui de indisciplina. $O$ estabelecido no espaço urbano, em termos de sua configuração e destinação de uso, é modificado e complementado pelos comerciantes em prol de um melhor aproveitamento do lugar apropriado para a atividade.

O objeto de estudo, então, caracteriza-se como um sistema, que na sua efemeridade em uma ação total no tempo, coaduna os elementos físicos (design), por um lado, e os volumes edificados e os espaços entre eles (arquitetura), por outro.

Por uma questão de ordem e especificidades, as duas áreas são comumente separadas no mercado e, principalmente, na academia. Além disso, a complexidade que caracteriza a diversidade de demandas no espaço urbano determina que cada uma destas atividades tenha uma especialização profissional para o seu exercício. 
Contudo, a abordagem por meio da conjugação destas áreas se apresentou imprescindível diante do sistema que caracteriza o objeto da pesquisa.

Com base nos estudos desenvolvidos nas duas áreas, a delimitação do objeto constitui um sistema dividido em três âmbitos: o contexto representado pela arquitetura do local escolhido, a atividade pelos elementos físicos envolvidos e a interface entre eles. Para abordar e entender a repercussão da configuração dos artefatos de ambas as áreas no espaço urbano, são considerados dois dos oito aspectos que definem arquitetura, segundo taxonomia proposta por Holanda (2010, p. 26$)^{2}$, que estendo para o design, nessa parceria: o sociológico e o funcional.

Os aspectos sociológicos dizem respeito à configuração do espaço arquitetônico, definida pela relação entre cheios e vazios, a implicar

\begin{abstract}
maneiras desejáveis de indivíduos e grupos (classes sociais, gênero, gerações, etnias) se localizarem nos lugares e se moverem por eles, e consequentemente condições desejadas para encontros e esquivanças interpessoais e visibilidade do outro. Tipo, quantidade e localização relativa das atividades que impliquem desejáveis padrões de utilização dos lugares, no espaço e no tempo. (op. cit., p. 140)
\end{abstract}

A quantidade e o tipo de espaços disponibilizados no atendimento à demanda de ordem prática para desenvolvimento das atividades cotidianas dizem respeito aos aspectos funcionais da arquitetura (op. cit., p. 139). Estes dois aspectos permeiam toda a análise da configuração dos lugares dos pontos de comércio observados.

A viabilidade da parte empírica foi possível a partir da definição de lugares específicos do Plano Piloto de Brasília para o desenvolvimento do trabalho de campo. Essa escolha foi pautada na facilidade de acesso aos mapas e documentação referentes a esta região e ao trabalho de observação e tomada de informações junto aos comerciantes.

Além do aspecto da facilidade de acesso às informações, a escolha por lugares de Brasília como campo é decorrente do intuito de também contribuir com o trabalho

\footnotetext{
${ }^{2}$ Em Brasilia - cidade moderna, cidade eterna, Holanda atualiza a taxonomia proposta em Espaço de Exceção (2002). Os oito aspectos são: funcionais, bioclimáticos, econômicos, sociológicos, topoceptivos, afetivos, simbólicos e estéticos.
} 
que vem sendo realizado no grupo de pesquisa voltado para estudos na área de morfologia urbana, da Faculdade de Arquitetura da Universidade de Brasília FAU/UnB. Nos anos 1980, DIMPU - Dimensões Morfológicas do Processo de Urbanização foi criado para investigar questões morfológicas no âmbito da cidade. A produção, disponibilizada em dissertações, teses e artigos, ampliou-se para questões do espaço arquitetônico e tende a abarcar a escala da paisagem natural. Em 2013, o grupo ganha o status de laboratório, nomeado Config.Arq - Laboratório de Configuração Arquitetônica ${ }^{3}$.

Neste estudo, o comércio em via pública é considerado como uma das modalidades de apropriação do espaço urbano, entre outras como: caminhos criados por pedestres, moradias improvisadas por indigentes e espaços tomados como estacionamento. É uma atividade que persiste desde a origem da cidade.

A documentação investigada no Sistema Integrado de Normas Jurídicas do Distrito Federal - SINJ-DF integra a lei 4.457/2009 - que "dispõe sobre o licenciamento e o funcionamento de atividades econômicas e atividades sem fins lucrativos no âmbito do Distrito Federal" - e a 4.257/2008 - que "estabelece normas para utilização de áreas públicas do Distrito Federal, por mobiliários urbanos do tipo quiosque e trailer, bem como similares a estes, para o exercício de atividades econômicas". Nelas, como previsto, encontram-se itens que abordam classificação de atividades, licenciamentos, funcionamento, procedimentos, documentação, infrações e penalidades, instalação de mobiliário, plano de ocupação de áreas, entre outras. Na busca por outros documentos, não foram encontrados os que contemplassem fomento para benfeitorias por parte da política pública do Governo do Distrito Federal, concernentes a atividade em questão.

Nesse contexto, o homem sem formação profissional em projeto se apropria de lugares específicos no tecido urbano, aciona mecanismos criativos para solucionar problemas de ordem prática e compõe o time de vendedores no cotidiano de uma

\footnotetext{
${ }^{3}$ As informações sobre a formação dos grupos de pesquisa DIMPU e Config.Arq foram extraídas do documento que deu origem ao Config.Arq, redigido, submetido e aprovado pelo colegiado do PPGFAU, no primeiro semestre de 2013.
} 
cidade. Desapercebido, forma uma constante resistência à omissão daqueles que planejam o espaço urbano.

A carência de reflexão e análise crítica sobre o desempenho das soluções em design e arquitetura, no que tange ao comportamento e expectativas na vida em sociedade, persiste tanto no desenvolvimento de políticas públicas e projetos em arquitetura, urbanismo e design, quanto na formação acadêmica nessas áreas.

A abordagem teórica sobre este tema ainda é pouco significativa, apesar de o último Documento de Área consultado apontar que a Área de Arquitetura, Urbanismo e Design passou por uma evolução importante, com repercussão internacional, inclusive (CAPES, 2013). O Documento de Área anterior (CAPES, 2009), entre outras informações e de maneira estatística, mostra a necessidade da migração da concentração na área de projeto para a área teórica na maioria dos cursos de formação no Brasil, seja em arquitetura e urbanismo, ou em design. Afirma ainda que os problemas decorrentes da falta de pesquisa nessa área repercutem na capacidade de contribuição do design na resolução de problemas sociais e na inovação tecnológica do país. Apesar de perceber maior atenção voltada para este tema no meio acadêmico, em poucos anos, intervalo de tempo entre um documento e outro, é pouco provável que este quadro tenha se modificado.

A problemática apresentada, constatada na defasagem de comprometimento com o tema da tese por parte da política pública e da formação acadêmica, leva à hipótese de que designers e arquitetos podemos retirar lições por meio da análise desta atividade para melhor apoiá-la, bem como a outras atividades que ocorrem no espaço urbano. Deste ponto de partida, busco responder a questão principal que emerge para a orientação do olhar da pesquisa. Em que condições, de que maneira e mediante quais atributos de configuração da forma-espaço o sistema de elementos físicos envolvidos, o contexto da atividade e a interface entre eles favorecem a interação social?

A ampliação da acuidade do olhar sobre as situações cotidianas da cidade, como por exemplo a venda de frango assado na esquina de um comércio local do Plano 
Piloto de Brasília (Figura i.1), proporciona uma proximidade de arquitetos e designers com a realidade vivida no espaço urbano.
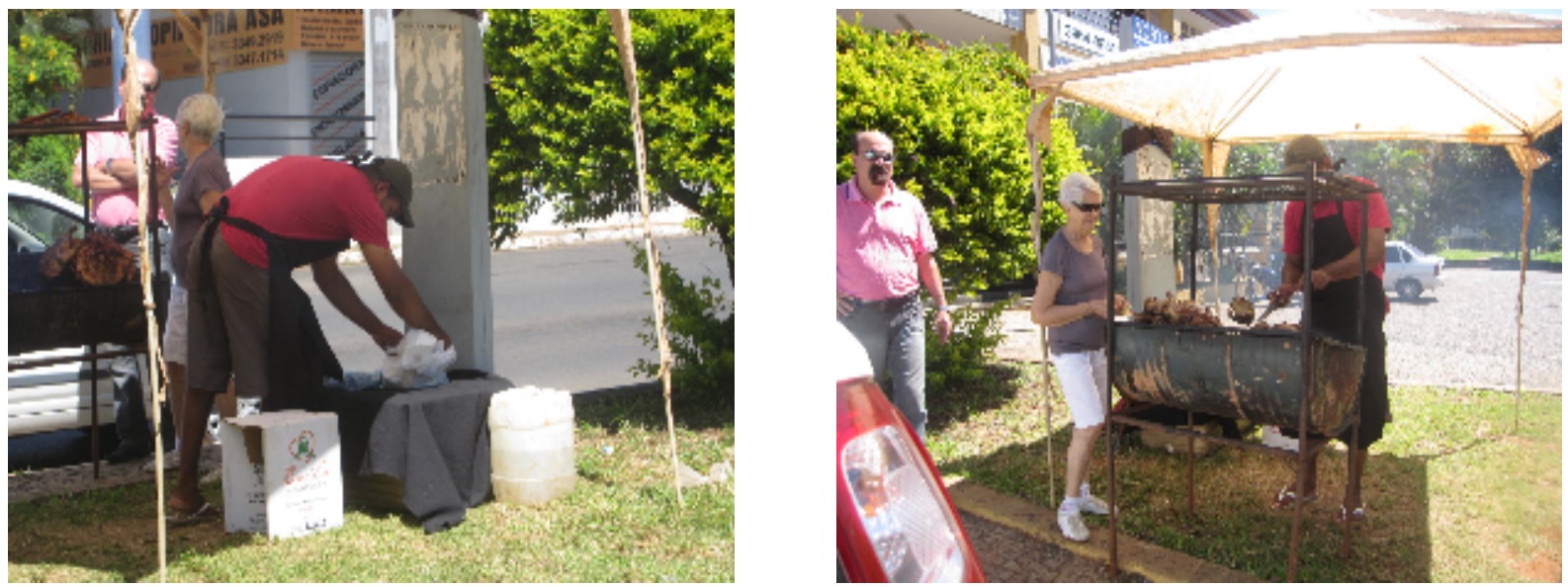

Figura i.1 - imagens do comércio de frango assado localizado em uma das pontas do CLN 208, Asa Norte - Plano Piloto. Fonte: autora.

Assim, parto do pressuposto de que para tratar este tema de maneira mais abrangente devo olhá-lo sob as lentes de duas parcerias:

- entre áreas do conhecimento - arquitetura e design construindo pontes com conteúdos de áreas como sociologia e psicologia e

- entre os níveis de conhecimento - inconsciente (ou tácito) e de consciência discursiva (Holanda, 2002).

Para chegar a própria formulação sobre níveis de conhecimento, Holanda dialoga com duas classificações, sendo uma delas, a de Giddens, que se baseia na distinção entre a ação no mundo espaço-temporal e a sua representação em planos de ordem simbólica. Três níveis constituem esta classificação: o da consciência prática, o da consciência discursiva e o do inconsciente (GIDDENS, 1986 apud HOLANDA, 2002). Holanda compara estes três níveis com os propostos por Hillier e Hanson - conhecimento social e conhecimento científico.

Ao analisá-los e compará-los, ele constata uma nebulosidade na distinção entre os níveis da consciência prática e do inconsciente, de Giddens, e a ausência de distinção entre o conhecimento social e o nível da consciência prática. Esta comparação possibilitou a sugestão de uma classificação mais ordenada e completa 
dos níveis de conhecimento, por Holanda (2002, p. 64): o inconsciente (ou tácito) e o de consciência discursiva.

No nível inconsciente de conhecimento, ele resume os conjuntos abstratos de ideias não verbalizadas, utilizadas nas ações concretas. A consciência discursiva é definida por ele como aquela que procura explicar o mundo espaço-temporal e que pode se dar nos níveis especulativo, empírico e científico. ${ }^{4}$

\begin{abstract}
... há um nível inconsciente de conhecimento, que é objetivo, e usamos no dia-a-dia, e ao qual não faz sentido aplicar as categorias de "verdadeiro" ou "falso": ele simplesmente "existe"; ele corresponde, por exemplo, à sintaxe de uma língua, e é diferente em espécie de ideias "falsas" com as quais também pensamos; ele constitui conjuntos abstratos de ideias que não verbalizamos e utilizamos implicitamente ao desempenhar nossas ações concretas; ... (HOLANDA, 2002, p. 64).
\end{abstract}

Localizo o fazer do comerciante no nível inconsciente da classificação de Holanda. São aproximações, ou identificação de similitudes entre a situação analisada e esta classificação teórica sobre níveis de conhecimento. Compreendo e diferencio a atuação deste ente social, como designer de sua própria situação. Sendo assim, um dos principais esforços da tese é traduzir o nível inconsciente do conhecimento utilizado pelos comerciantes observados em consciência discursiva científica para alimentar o arcabouço de conhecimento sobre design.

A pesquisa é desenvolvida com o objetivo geral de alcançar a compreensão da atividade do comércio informal praticado no espaço urbano, na relação entre seus aspectos de configuração e sociais. E por meio desta abordagem, discutir o desempenho do design e da arquitetura, no que se refere ao espaço urbano. Tratase da compreensão da lógica social que subjaz às soluções encontradas pelo comerciante em relação ao que foi oferecido nos espaços abertos das cidades, em termos de configuração de espaço-forma. Configuração é entendida aqui como a "maneira pela qual as partes do objeto se relacionam entre si" e espaço-forma ${ }^{5}$ a "consideração simultânea de cheios e vazios enquanto arquitetura" (MEDEIROS, 2006, p.38).

\footnotetext{
${ }^{4}$ Todo o detalhamento da análise das classificações em que se baseou (Giddens, Hillier e Hanson) e da proposta da própria classificação podem ser encontrados no livro/tese de Holanda (2002).

5 'Espaço-forma' é termo emprestado de Holanda (2002) e utilizado em teses e dissertações, no âmbito da Sintaxe Espacial.
} 
Em decorrência disso, objetivo especificamente:

- identificar e delimitar os tipos de espaços abertos escolhidos pelos comerciantes para a atividade;

- levantar os elementos físicos utilizados na atividade do comércio em via pública, bem como seus locais de incidência, para identificar uma padronização de soluções geradas pelos comerciantes;

- identificar os fatores ordenadores e reguladores desta atividade no espaço urbano como, por exemplo, a especialização funcional, não como causa, mas como ponto de partida da indisciplina;

- levantar a situação socioeconômica dos lugares eleitos para trabalho de campo;

- estabelecer relações entre aspectos de configuração, sociais e funcionais da atividade;

- propor aspectos a serem considerados em projetos de design para o espaço urbano, no sentido de contribuir com o aporte teórico neste tema.

\section{Um pouco sobre o objeto}

O setor informal no Brasil tem a sua primeira delimitação conceitual nas unidades econômicas que o constituem. Segundo pesquisa realizada pelo Instituto Brasileiro de Geografia e Estatística - IBGE, compõem este setor as unidades econômicas não-agrícolas que produzem bens e serviços - exceto aqueles para autoconsumo com o intuito de gerar emprego e renda para os envolvidos. Ainda como fator delimitador, entendem a unidade econômica como unidade de produção, cujos fatores no setor informal são produção em pequena escala, baixo nível de organização e inexistência de separação entre capital e trabalho (IBGE, 2003).

Com base nessas e em outras delimitações mais específicas, o IBGE chega ao que denomina operacionalização estatística, em que define a composição do setor informal como sendo "todas as unidades econômicas de propriedade de trabalhadores por conta própria e de empregadores com até cinco empregados, moradores de áreas urbanas, sejam elas a atividade principal de seus proprietários ou atividades secundárias." (IBGE, 2003). Segundo este documento, o comércio 
informal quanto ao "local de funcionamento" pode ser classificado como atividade que acontece em "via pública", "só fora do domicílio", ou "no domicílio e fora do domicílio". Quanto a classificação por "grupo de atividade", ele está inserido em "comércio e reparação". Estas informações foram reunidas para localizar esta atividade no contexto socioeconômico brasileiro, com repercussão no seu entendimento sob o ponto de vista cultural.

Quanto às modalidades de inserção do comércio em via pública, a Secretaria de Estado da Ordem Pública do Distrito Federal - SEOPS, estabelece que "o vendedor ambulante é aquele que comercializa produtos em trânsito pelas áreas públicas e o camelô pode ser definido como o vendedor que ocupa espaço público com uma barraca ou banca fixa." (GDF, 2009). O recorte da pesquisa delimita o objeto de estudo como sendo o comércio informal praticado em um lugar específico do espaço urbano, cotidianamente, durante determinado período de tempo, o que o aproxima da classificação 'camelô'.

Cobrança de elevado número de impostos, excesso de burocracia, legislação trabalhista que iguala micro e pequenas empresas às médias e grandes, grandes índices de desemprego, monopólios estatais e reserva de mercado são os principais fatores que restringem o acesso ao mercado formal. Independente destas e outras motivações, a atividade do comércio informal foi eleita objeto de estudo por proporcionar a análise dos aspectos morfológicos dos lugares apropriados em função de seus aspectos sociais.

Sobre as áreas de conhecimento envolvidas

A consolidação de cada área, em separado, é condição crucial para o diálogo entre elas. Contudo, a atuação em conjunto é o escopo desta pesquisa. A conjunção, necessária para o desempenho mais efetivo das contribuições de arquitetura e design para o espaço urbano, ainda é um aspecto pouco abordado em pesquisa e um recurso quase nunca utilizado na atuação profissional de ambas as áreas.

Para conceituá-las e traçar uma parceria entre elas na reflexão sobre o espaço urbano, optei por abranger seus aspectos comuns e distintos, como premissa, em 
termos de: terminologia; classificação de produção intelectual, no Brasil (determinado por um "Documento de Área", desenvolvido bianualmente pela Diretoria de Avaliação - DAV da Coordenação de Aperfeiçoamento de Pessoal de Nível Superior - CAPES); e conceituação.

Projeto, plano, modelo, desenho, esboço e propósito são traduções para o português do termo design com origem na língua inglesa ${ }^{6}$. Em um dicionário da língua portuguesa o termo é utilizado para designar "a concepção de um produto (máquina, utensílio, mobiliário, embalagem, publicação etc.) especialmente no que se refere à sua forma física e funcionalidade; (...) e por extensão DESENHO INDUSTRIAL, DESENHO DE PRODUTO e PROGRAMAÇÃO VISUAL." (HOUAISS \& VILLAR, 2009). A versão para o português foi feita para denominar a profissão de design exercida no Brasil. Em 1977, foi publicado um trabalho por Joaquim Redig denominado por ele como um Projeto de Conceituação do então, ainda, Desenho Industrial. Ali, nas premissas, a questão da nomenclatura é colocada de maneira a esclarecer parcialmente o uso do termo design neste trabalho.

\begin{abstract}
Se o Desenho Industrial é uma profissão nova e desconhecida, o problema começa na pouca identidade que the confere seu nome, pela impressão de seu significado. Trata-se originalmente de um problema de tradução, cuja barreira a língua não consegue transpor completamente, ou seja, Desenho Industrial não é Industrial Design porque Desenho não é Design. Enquanto Desenho é uma técnica de representação, Design é uma atividade que usa esta técnica. Se Desenho indica um objeto, Design indica um objetivo. Os designers franceses, italianos, alemães, por exemplo, têm o mesmo problema, que curiosamente não existe na língua espanhola, na qual se usa Dibujo e Diseño, como em inglês Drawing e Design. A palavra DESIGN tende portanto a se internacionalizar, e é nossa tendência também adotá-la, para identificar a atividade em estudo. (REDIG, 1977, p. 11).
\end{abstract}

A "tendência" da adoção do termo design se concretizou no Brasil, segundo a prospecção de Redig. Design é um termo inglês que significa projeto de arquitetura, de produto ou gráfico, sendo assim mais abrangente do que a sua versão em português que se restringe ao Desenho Industrial (de produto) ou Programação Visual. Destaco e utilizo tanto a abrangência, ou pontos comuns, quanto as especificidades das definições (em inglês - origem, e em português) dos termos

\footnotetext{
${ }^{6}$ Entre as definições encontradas a escolhida foi a do "English-Portuguese / Português-Inglês Dictionary", de WHITLAM et al, 2001.
} 
arquitetura e design para traçar a interface e a distinção entre as áreas, no que se refere à nomenclatura.

Apesar de serem duas áreas autônomas, a CAPES vem considerando a produção intelectual em arquitetura/urbanismo e design $(A U+D)$ como integrando uma única área de conhecimento. $A U+D$ apresentam intersecções epistemológicas que permitem uma classificação em áreas de concentração comuns: projeto; teoria, história e crítica; tecnologias de avaliação de desempenho do espaço e dos artefatos; interação do homem com o espaço e com os artefatos; representação e modelagem do espaço e dos artefatos; e produção e gestão do espaço e dos artefatos (CAPES, 2009). Nesse documento essas áreas são unidas por suas características técnicas, sobretudo enquanto disciplinas de projeto com desdobramentos teóricos e históricos.

$\mathrm{Na}$ revisão da conceituação de design e arquitetura, busco interpretar alguns conceitos julgados relevantes sob a ótica do recorte definido. Essa interpretação é pautada na maior abrangência de significação dos termos, consideradas as especificidades de cada área, e na atualização no que se refere à vida social contemporânea. Esse exercício de amplificação da abrangência de significação e conceituação dos elementos que compõem o universo da tese, em um primeiro momento, tende a sobrevoar o objeto, enxergando-o como um todo.

Resgato assim, o "espírito do começo" para o propósito inicial das duas atividades, assim como fez Louis Kahn na reflexão sobre a origem e o estabelecimento do processo ensino/aprendizagem como temos hoje - as escolas.

... o começo de qualquer atividade estabelecida do homem é o seu melhor momento. Porque é ali que habitam todo o espírito e toda a engenhosidade, dos quais devemos constantemente extrair nossas inspirações para as necessidades presentes. (KAHN, 2010:10).

Arquitetura e design são atividades oriundas do atendimento às necessidades decorrentes da relação do homem com seu habitat. A transformação do ambiente e dos artefatos é a origem comum a ambas. Transformação é o termo escolhido para 
melhor abranger criação, fabricação, apropriação, uso, interação e todas as ações que propiciam as relações humanas com o meio.

Na conceituação de Vitruvius para arquitetura, cunhada há dois milênios, moradia, dispositivos para deslocamento e objetos que cumprem diversas funções para a sobrevivência humana foram reunidos como demanda para uma única atividade atender (Encyclopaedia Brittanica apud HOLANDA, 2002, p. 65). O leque das funções da arquitetura, então, ia do projeto de um relógio ao de uma praça.

O pensamento de Ruskin e Morris e de seus sucessores reunia as duas atividades como artes da "construção e da decoração", no que Pevsner (1980) denomina desenho moderno. A forma, o desenho, mesmo que separados por idealismos contrários ou favoráveis à nova era técnica, unia os artistas em uma "arte aplicada" às questões cotidianas.

O esforço aqui é o de me colocar anterior à divisão entre arquitetura e design para, primeiramente, entendê-las ampla e originalmente como uma única área e, com isso utilizá-la para trabalhar o meu objeto. Mas a divisão é fato! Devo aproveitá-la e enfrentá-la! Comecei imaginando o ideal da atividade de arquitetura de Vitruvius nos dias de hoje. Com a gama de funções que a atividade abarcaria, em quantos anos faríamos uma graduação em arquitetura/design?

O aumento da complexidade no âmbito tecnológico, a caminho de uma especificidade cada vez maior de cada área e dentro delas, levou inevitavelmente a uma divisão de seus saberes e atuações, repercussão da diferenciação social, uma das principais componentes da modernização.

Para atingir o objetivo de relacionar os aspectos de configuração do comércio informal praticado no espaço urbano com os respectivos aspectos sociais e funcionais, é importante esclarecer o cunho das conceituações de cada área. "Funções do fazer e funções do usar" é a abordagem de Holanda (2002, p. 73) que discrimina a arquitetura entre processo da atividade, uma prática e o resultado desta atividade - a edificação em si, por exemplo. Estendo este entendimento da arquitetura para o design, por tratar da repercussão da configuração das soluções 
encontradas/criadas pelos comerciantes. Busco, então, conceituações que tratam de seus resultados e não de seus processos como atividades projetuais (Figura i.2).

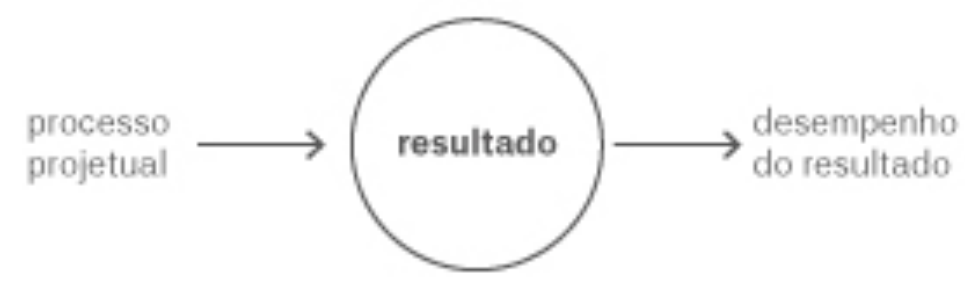

Figura i.2 - esquema que apresenta o foco da pesquisa no design como resultado.

Inicio as conceituações pela área contexto - a arquitetura. A busca por uma conceituação abrangente, atualizada e com caráter no resultado da atividade me levou às conceituações de Frederico Holanda para arquitetura. Digo conceituações porque, neste caso, elas estão sempre sendo atualizadas conforme as pesquisas deste autor. São três até o momento e uma não substitui a outra, a meu ver. Em nome da completude apresento as três, que foram e são caras para o entendimento desta área por uma designer. Principalmente com base nos conceitos de arquitetura de Vitruvius, Lucio Costa, Bill Hillier, Evaldo Coutinho e Carlos Antônio Leite Brandão, Frederico Holanda conceitua arquitetura.

O primeiro conceito é cunhado pelo próprio autor como sendo uma "definição relacional" em que "arquitetura é uma relação que as pessoas estabelecem com o espaço, por meio da apropriação ou da transformação deste, com o objetivo de satisfazer expectativas funcionais, de copresença, bioclimáticas, econômicas, topoceptivas, emocionais e simbólicas, em função de valores ecológicos, éticos e estéticos historicamente determinados". Mais detalhada e inclusiva, esta definição é dividida cuidadosamente nos termos, natureza e valores determinantes da relação entre seus elementos formadores: espaços natural e artificial como fenômeno arquitetônico, desempenho dos lugares em função das expectativas humanas quanto ao espaço ocupado e os valores que determinam cada tipo de expectativa humana (HOLANDA, 2002, p. 83-84). 
Ainda com vistas a abordar os tipos de desempenho, com a evolução de copresença para sociológico e a mudança de ângulo de visão sobre os valores que norteiam as relações dentro da arquitetura, um outro conceito é desenvolvido: "arquitetura é lugar usufruído como meio de satisfação de expectativas funcionais, bioclimáticas, econômicas, sociológicas, topoceptivas, afetivas, simbólicas e estéticas, em função de valores que podem ser universais, grupais ou individuais." (HOLANDA, 2010a, p. 28).

"Veja na arquitetura uma propriedade dos lugares" é o primeiro dos dez mandamentos da arquitetura desenvolvidos pelo autor em "10 mandamentos da Arquitetura" (2013). O mandamento traduz a conceituação atualizada que prima pela síntese e pela abrangência. "Arquitetura é uma propriedade de edifícios, conjuntos edificados, ruas, bairros, cidades, sítios naturais, que afeta corpos e mentes." (HOLANDA, 2013, p. 22).

Com isso, temos em Holanda uma evolução do conceito em que arquitetura é, concomitantemente, uma relação estabelecida pelas pessoas com o espaço, um lugar usufruído por elas e uma propriedade deste lugar. Conhecer este processo foi primordial para buscar ou formular a conceituação de design mais adequada para a tese.

Antes de chegar a esta conceituação, necessito relembrar a origem do uso do termo design na história dos artefatos. O que antes era concentrado na figura do artífice, é separado com o surgimento do sistema de fábricas, entre meados do século XVIII e fins do século XIX. O processo de separação entre projeto e execução de objetos culmina com a Revolução Industrial, em que um modelo de definição de design é assumido como a 'elaboração de projetos para a produção em série de objetos por meios mecânicos'. Porém, temos alguns exemplos na história de produção em série, que antecedem este modelo, com a moldagem de cerâmica e a fundição de metais, já na Antiguidade, e a utilização da imprensa com tipos móveis, na Europa do século XV (LUCIE-SMITH, 1984 apud DENIS, 2000). 
A separação fica mais patente com o surgimento do termo designer para o trabalhador responsável por uma parte específica do processo produtivo mecânico de artefatos.

\begin{abstract}
Esse período corresponde à generalização da divisão intensiva de trabalho, que é uma das características mais importantes da primeira Revolução Industrial, sugerindo que a necessidade de estabelecer o design como uma etapa específica do processo produtivo e de encarregá-la a um trabalhador especializado faz parte da implantação de qualquer sistema industrial de fabricação. Tanto do ponto de vista lógico quanto do empírico, não resta dúvida de que a existência de atividades ligadas ao design antecede a aparição da figura do designer. (DENIS, 2000, p. 18).
\end{abstract}

"Era a infância da sociedade de consumo" e o design veio para por ordem na bagunça do mundo industrial ${ }^{7}$. De lá para cá a indústria seguiu com o paradigma da produção em massa, sendo que hoje "caminha em direção à produção flexível, com cada vez mais setores buscando segmentar e adaptar seus produtos para atender à demanda por diferenciação" (CARDOSO, 2011), e o processo de design, mais do que nunca, à frente disso.

A definição de Joaquim Redig, apesar do tempo de formulação, mantém a atualidade por conceituar design como "o equacionamento simultâneo de fatores ergonômicos, perceptivos, antropológicos, tecnológicos, econômicos e ecológicos, no projeto dos elementos e estruturas físicas necessárias à vida, ao bem estar e à cultura do homem." (REDIG, 1977). Complemento esta definição com a do The International Council of Design Societies - ICSID:

\footnotetext{
Design é um processo estratégico de resolução de problemas que impulsiona a inovação, constrói o sucesso do negócio e leva a uma melhor qualidade de vida por meio de produtos inovadores, sistemas, serviços e experiências. (ICSID, 2016) ${ }^{8}$.
}

Apesar de tomá-las como as mais abrangentes e atuais definições de design, elas não contemplam o sentido de design como o resultado da prática. Nesse sentido, a criação de uma definição própria se fez necessária. Discuto o produto do design. Analiso o resultado de um processo que engloba basicamente a busca por uma

\footnotetext{
${ }^{7}$ Assim Rafael Cardoso retoma a história do design em "Design para um mundo complexo".

8 "Industrial Design is a strategic problem-solving process that drives innovation, builds business success and leads to a better quality of life through innovative products, systems, services and experiences." (Tradução livre).
} 
solução para um problema de ordem prática, o planejamento ou projeto para atender a esta demanda e a concretização da solução encontrada. Por sua abrangência conceitual, escolho o termo artefato, como utilizado por Hillier e Hanson (1984), para designar e tratar o cume de um processo que tem a sua origem na necessidade de aporte material que auxilia, ou mesmo viabiliza, atividades da vida cotidiana.

Com base no processo de Holanda para a definição de arquitetura, revendo a origem do termo na história e com foco no resultado e não no processo, concluo que design é o resultado de uma concepção - projeto e fabrico - que traduz elementos físicos, artificiais ou naturais, conjugados entre si e com o espaço envolvente, em soluções volumétricas móveis para o atendimento de expectativas das mais diversas, na escala das relações humanas diretas.

As definições de arquitetura e design apresentadas partem do princípio da contemplação de expectativas humanas e do impacto dos artefatos na natureza e na sociedade. Guardando as devidas especificidades e com base nestas definições, arquitetura e design têm como função atender a essas expectativas ${ }^{9}$ em suas reflexões e prática.

Outro aspecto a ser explicitado e que complementa as conceituações das áreas apresentadas é o da "configuração formal-espacial", termo proposto por Holanda (2007). Resultado da prática das áreas, a configuração dos artefatos traça a interface entre arquitetura e design. O termo define, quanto a relações formais, o conjunto de artefatos com os quais estamos em contato, sendo a configuração do espaço resultado da arquitetura e a configuração da forma dos artefatos resultado da prática do design. A contribuição aqui implica considerar a volumetria não somente das edificações, mas também dos artefatos de menor escala que equipam o espaço público como, por exemplo, mobiliário urbano e aparatos de iluminação e sinalização. No caso do objeto de estudo, estes aparatos são aqueles que dão suporte à atividade e os próprios produtos à venda.

\footnotetext{
${ }^{9}$ Expectativas é o termo escolhido por Holanda em sua definição de arquitetura e abrange as questões "Do que as pessoas realmente precisam" e "O que as pessoas realmente querem", colocadas por Vitor Papanek. Este termo é adotado aqui por abranger necessidades e desejos das pessoas.
} 
Sobre as teorias que embasam

Além das duas áreas principais, conhecimentos gerados nas áreas das ciências sociais e da psicologia foram acionados na pesquisa, o que reúne quatro teorias estudadas para embasar o desenvolvimento da tese: Teoria das Práticas Cotidianas, Teoria da Sintaxe Espacial, Teoria da Abordagem Ecológica (Affordance) e Teoria Geral dos Sistemas.

A Teoria das Práticas Cotidianas define a dualidade estratégia e tática como um modelo de estudo sobre a lógica subjacente às práticas do cotidiano, o que auxilia a compreensão do comportamento de indisciplina por parte do comerciante. A Teoria Geral dos Sistemas, por compreender os fenômenos da maioria das áreas e campos do conhecimento como relações de elementos entre si e com o meio, propicia a compreensão da atividade e seu contexto como um sistema, de nível de complexidade significativo, composto por elementos de cunhos material e social. A Teoria da Affordance (ou da abordagem ecológica), contribui com a tese por trazer a reflexão sobre um tipo de percepção do ambiente que o relaciona diretamente em termos utilitário/funcional com o seu observador. Por fim, a Teoria da Sintaxe Espacial relaciona a configuração do espaço com o seu desempenho social e, por isso, embasa a análise da capacidade do contexto da atividade, em termos morfológicos, de possibilitar ou restringir a vida social do local escolhido.

Além destas teorias, utilizo a classificação sugerida e consolidada por Holanda sobre os níveis de conhecimento inconsciente e o de consciência discursiva. Associo o primeiro àquele utilizado pelo comerciante na criação e execução das soluções utilizadas em via pública, para assim trazê-lo ao nível do segundo. A partir destas associações inicio o estudo sobre o design praticado pelos comerciantes informais no espaço urbano. E como parte da análise dos estudos de caso, traço um paralelo entre habilidades oriundas do conhecimento tácito e do discursivo para projetar e fabricar artefatos.

Para o desenvolvimento da parte empírica da tese, a escolha por estudar alguns pontos de comércio informal, na Asa Norte do Plano Piloto de Brasília, se deu, entre 
outros fatores, pela forte presença de uma dualidade caracterizada pela resistência dos comerciantes destes pontos a uma formalidade imposta pela configuração e pelo planejamento desta região. $\mathrm{E}$, ainda, destaco o valor desta atividade por claramente propiciar a copresença entre os agentes envolvidos, qualificando os lugares e a vida social da cidade.

O texto da tese é estruturado em duas partes, cada uma com dois capítulos. $\mathrm{Na}$ primeira parte, o capítulo 1 apresenta a revisão bibliográfica e documental feita em torno do objeto de estudo e suas repercussões. O comércio informal praticado em via pública é abordado sob a ótica das teorias apresentadas. O capítulo 2 traz as questões sobre o método, as técnicas e ferramentas que utilizo para desenvolver a etapa empírica da pesquisa. No capítulo 3 , os estudos de caso são apresentados e descritos pelas variáveis detalhadas no método. A análise dos resultados e um balanço sobre as variáveis são discutidos no capítulo 4 . 


\section{PARTE I}

Refletir para recortar e abordar 


\section{1 | o COMÉRCIO INFORMAL E SUAS REPERCUSSÕES}

Enxergar a indisciplina como um sintoma de fenômenos sociais para pensar a construção do espaço urbano é o principal ponto de partida desta pesquisa, do qual decorrem outros de cunho relacional. A atitude da indisciplina pressupõe a correlação entre algo estabelecido e uma contrapartida. Espraiada em vários lugares e momentos do cotidiano de qualquer cidade, esta postura, reforço, de caráter social, é matéria que coloca em questionamento o que tem sido feito em termos morfológicos quanto à produção do espaço urbano e às atividades que recebe.

Sob este prisma, situo este trabalho no grande tema do design do e para o espaço urbano, respectivamente considerando vazios e cheios como artefatos de um mesmo sistema, a cidade. Deste universo, retiro o meu objeto de estudo: o subsistema representado por uma atividade específica, o comércio informal em via pública. Deste ponto, trato o objeto como um (sub)sistema constituído de três âmbitos: CONTEXTO - INTERFACE - ATIVIDADE (Figura 1.1).

\section{espaço urbano}

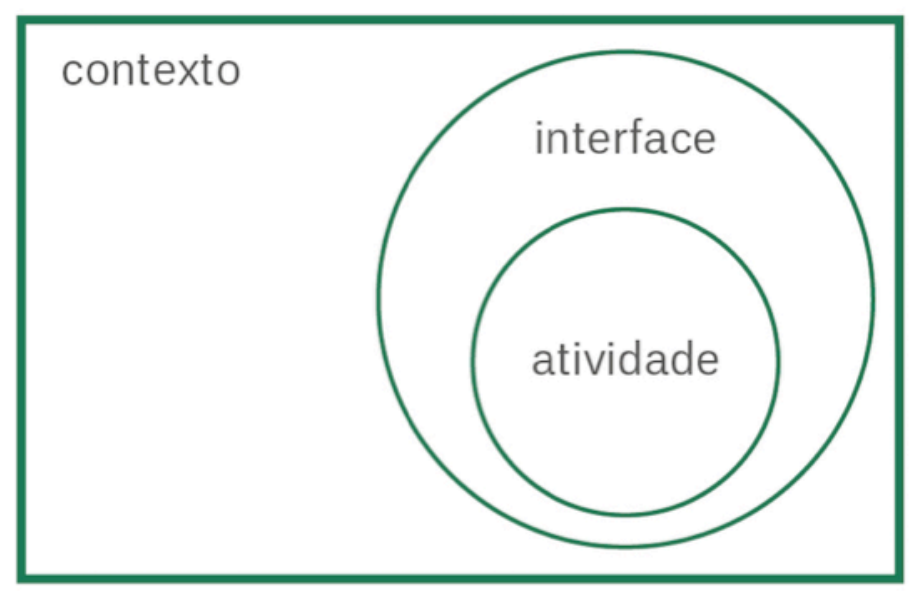

Figura 1.1 - esquema da tríade de âmbitos do objeto de pesquisa CONTEXTO/INTERFACE/ATIVIDADE

A particularidade do recorte neste sistema conduziu a pesquisa a um referencial teórico que aborda estes três âmbitos na relação entre a configuração dos artefatos resultado da prática das áreas envolvidas e os aspectos sociais que a atividade implica. A arquitetura representa o contexto da atividade que, por sua vez é 
subsidiada pelas soluções de design encontradas pelo comerciante. De maneira isolada, contexto e atividade vêm sendo abordados por algumas áreas do conhecimento. Nesta tese, o esforço pelo ineditismo está no traçado da interface entre estes dois âmbitos, sob o viés de quem projeta para o espaço urbano.

O comércio informal é comumente abordado nas áreas da economia e das ciências sociais, mas ainda pouco explorado na esfera acadêmica do design, da arquitetura e do planejamento urbano. O vendedor e seus clientes não são usuários comumente contemplados em projetos de design, tampouco são previstas e apoiadas intervenções como a desta atividade nos espaços definidos pela massa edilícia. Sua riqueza de aspectos sociais e de configuração, especificamente, propicia um estudo aprofundado das possibilidades de atuação mais efetiva no espaço urbano das áreas do conhecimento que desenvolvem reflexão e projeto de artefatos, aqui envolvidas.

O tipo de comércio informal escolhido como objeto de estudo, independente da classificação adotada pela legislação revisada, a qual não sigo para definí-lo, é aquele destinado predominantemente aos pedestres, especializado em comida preparada na hora ou previamente pelo comerciante. Ele se fixa por um determinado intervalo de tempo, em uma área específica escolhida pelo comerciante, que aguarda a aproximação dos clientes. Outra particularidade definida para o objeto é que o ponto de comércio não possuísse de maneira regulamentar, nenhum de seus aparatos neste local para funcionar. O que, a princípio, nos leva a pensar que o comerciante leva e monta tudo o que não é parte da arquitetura e da paisagem e, ao final do expediente, desmonta, retira e os leva de volta.

Reviso a literatura sobre o tema com início nas questões sobre o envolvimento da arquitetura como contexto da atividade, no que esta área contribui para o entendimento da relação entre a prática do comércio em via pública e o espaço urbano.

Sobre a atividade em si, começo pelo seu estopim, o comportamento da indisciplina. Sigo com a sua apresentação pela descrição dos aspectos funcionais, dos 
elementos físicos envolvidos e de sua composição no espaço, encarando-os como um sistema.

O design é revisado de forma particular por não ser comum, na bibliografia consultada, a abordagem sobre desdobramentos do resultado de projetos, tampouco daqueles oriundos de não profissionais específicos desta área. Busco autores que se debruçam sobre as questões sociais do design de modo geral, com especificidades no cotidiano.

\subsection{Os contextos da atividade}

A maior parte da abordagem do contexto da atividade é feita com base em uma leitura específica do espaço urbano voltada para a sua configuração. Para isso, começo revisando o conceito de arquitetura. Dentro do conceito mais geral desta área, interessam seus aspectos sociais, que são foco da arquitetura sociológica, termo cunhado por Holanda para a subdisciplina que considera como realidade empírica as relações lugar $x$ sistema de encontros e esquivanças (2010, p. 31). A teoria que embasa esta leitura é a da Sintaxe Espacial, que orienta, também, boa parte do método trabalhado no núcleo empírico. Faço um breve passeio sobre as origens tanto da cidade quanto do comércio em via pública para ensejar, então, a parte em que discorro sobre esta atividade, propriamente dita.

\subsubsection{O lugar escolhido, o contexto imediato}

O que faz de um espaço físico um lugar? Que características o tornam uma entidade significativa? Diz respeito àquele que dele desfruta? Considerar lugar como "parte delimitada de um espaço" (Houaiss) inicia o delineamento sobre o estudo do contexto imediato da atividade. Considero que a delimitação do espaço, nesta conceituação básica, advenha de uma construção elaborada pelo sujeito que desfruta de qualquer espaço físico. E, segundo o tipo de interferência entre espaço e sujeito, esta construção pode se dar de modo físico ou (somente) idealizado por transferência de significado. 
Tanto uma via quanto a outra - espaço afetando o sujeito ou sujeito delimitando o espaço (construindo lugares) - dizem respeito ao conceito de arquitetura. Quando Holanda conceitua, em seu primeiro mandamento, arquitetura como "uma propriedade de edifícios, conjuntos edificados, ruas, bairros, cidades, sítios naturais, que afeta corpos e mentes" (2013, p.22), reúne, critica, amplia e sintetiza outros conceitos do mesmo termo ${ }^{10}$. E nesta conceituação considera arquitetura como o que ali está. Diz respeito à primeira via - o espaço delimitado afetando o sujeito.

Por outro lado, a delimitação do espaço, toca na questão da "intencionalidade", um dos aspectos abordados por Holanda, que por conta da amplitude de sua conceituação, considera a construção do espaço pelo sujeito oriunda tanto de processos mentais conscientes, quanto inconscientes, ou seja, por conhecimento "reflexivo", ou por reprodução "inconsciente" de padrões (p. 27, grifos do autor), respectivamente. "Quaisquer realizações humanas são providas de intencionalidade porque têm fenômenos mentais subjacentes que lhes dão origem - inclusive vontades, valores, teorias." (p. 28).

Sejam quais forem as motivações, o sujeito constrói seus lugares, interferindo no espaço por meio do propósito, da ideia, matéria e tecnologia. Trata-se da arquitetura como artefato, quando, a partir da aplicação de significados sobre uma paisagem natural, temos a construção do espaço pela ideação, somente. Estes processos de significação ou ressignificação têm como ponto de partida os atributos do lugar em questão. É o fazer arquitetura da paisagem, por exemplo.

\footnotetext{
Cada um dos lugares implica peculiares atributos de luz/sombra, ruído/silêncio, calor/frio, aromas, dimensões, formas, possibilidades ou restrições ao movimento dos corpos, fazendo dos lugares mais ou menos fáceis para o encontro e a conversa, confortáveis, emocionantes, belos, memoráveis. São atributos arquitetônicos do lugar porque são atributos dos seus espaços entendidos como arquitetura, atributos que afetam nosso corpo e nossa mente; atributos de espaços naturais, sim, mas classificáveis da mesma maneira como você classifica e lista os atributos do espaço de sua sala de estar. (HOLANDA, 2013, p.38)
}

\footnotetext{
${ }^{10}$ HOLANDA, 2013, p. 40. Vale aprofundar na construção deste conceito que contradiz as conceituações de: Lucio Costa, sobre intenção estética; Bill Hillier, sobre tipos de conhecimento na produção do espaço; Evaldo Coutinho, na limitação do termo em relação a somente espaços internos; Carlos Brandão, sobre o status desta área; e de generalizações sobre arquitetura como somente artefato.
} 
No contexto da atividade identifico o tipo de construção do ambiente por ideação, uma vez que o comerciante se apropria de um local que já está construído. Sua interferência se dá com a inserção de artefatos menores, chegando no máximo à montagem de um toldo em época de chuva e à utilização de um automóvel para guardar/transportar o material. Por hipótese, deduzo que o comerciante escolhe o lugar por atributos identificados por ele, intuitivamente, que podem potencializar o desempenho da composição dos aparatos montados para o desenrolar da atividade.

Tratamos com a composição em que são relacionadas diferentes escalas de artefatos, o que implica na divisão e especificidades profissionais que atuam em seus projetos. Em relação ao tempo, as edificações são mais estáveis e os artefatos menores são, por natureza e definição, normalmente, rearranjados de modo contínuo. Como o recorte do trabalho empírico da tese está sobre a composição que é, majoritariamente, montada no local escolhido e desmontada assim que o período de vendas termina, trata-se, então, de uma composição temporária.

Parto do princípio que, assim que a composição é montada, existe uma qualificação direta do local, seja de que grau for, e este é um dos pontos analisados no trabalho de campo: os desdobramentos e grau desta qualificação, que suponho ser mútua. Se a escolha do lugar informa sobre algumas de suas características funcionais e sociais, os elementos físicos compostos informam sobre outras tantas, como por exemplo, uma das inúmeras possibilidades de apropriação e uso do local em questão.

A análise da interação destas escalas se dá em duas situações: o local escolhido sem a montagem dos elementos físicos que dão suporte a atividade e o mesmo local com toda a composição montada e a atividade em pleno funcionamento. Neste trecho da análise o foco está na interface. Assim como

os aparelhos qualificam um espaço doméstico, (...) O mesmo acontece na escala urbana. Em vez de móveis, abrigos e construções temporárias ou portáteis. A ironia é que é a dimensão transitória do espaço urbano que lhe permite a sobrevida. Isto é, na medida em que o ajuste fino é dado por elementos móveis, a estrutura global - edifícios, grandes vãos, ruas - pode ser mantida por sucessivas alterações e atualizações desse estrato mais "fluido" e perecível, sem necessitar sua contínua demolição e reconstrução. (PAZ, 2012) 
O caráter efêmero da ocupação do posto de trabalho da atividade em um local específico da cidade desperta para uma característica desejável em um espaço desta natureza: condições de uso mais gerais, ou melhor, sua capacidade de abarcar múltiplos usos, ou atividades diversas. O lugar, então, como ente do sistema da atividade, assume diversas "personalidades", mas com os mesmos atributos.

O conceito de sinomorfia, em psicologia ambiental, fundamentado por Roger Barker, traduz essa "fusão" entre o lugar e qualquer atividade que ele recebe. Todos os elementos envolvidos na atividade, desde os mais estáveis como calçadas ou empenas cegas de edifícios, aos móveis como engradados de refrigerante ou uma banqueta auxiliar, são partícipes de uma mesma estrutura espacial e de comportamento.

\begin{abstract}
Sinomórfica significa similar em estrutura: descreve uma característica essencial da relação entre meio e comportamento [behavior setting]. A sinomorfia dos limites de um comportamento e dos limites de um meio é impressionante e fundamental: os limites de um campo de futebol são os limites do jogo; o começo e o fim de uma partitura de uma escola de música demarca os limites de um padrão de comportamento musical. (BARKER, 1968, apud PAZ, 2012 - tradução do segundo autor).
\end{abstract}

Em uma abordagem sobre a efemeridade da arquitetura, são identificados dois perfis de meios que recebem transformações temporárias: meio 'agreste' e meio "construído"11. Tratamos aqui do segundo, sendo que Paz (2012) o subdivide ainda em áreas planejadas ou apropriadas. Nas planejadas existe o propósito em sua construção de abrigar tais atividades temporárias. Nas áreas apropriadas, caso da indisciplina praticada pelos comerciantes, a "tomada" dos espaços acontece "à revelia da intenção original" (op. cit.).

A opção por um ou outro tipo, lugares planejados ou apropriados para atividades diversas do cotidiano, faz parte de discussões no âmbito do planejamento urbano e condiz com a existência ou níveis de liberdade, condições e regulamentações para o uso do espaço urbano pelos sujeitos. Os lugares apropriados o são por seus

\footnotetext{
${ }^{11} \mathrm{PAZ}, 2012$. Em seu artigo "O lugar evanescente: características da arquitetura efêmera no sítio", Daniel Paz identifica, basicamente, estes dois meios em que o 'agreste' se caracteriza por ser composto por elementos em sua maioria naturais. O 'apropriado' é o meio dos elementos "inanimados".
} 
atributos mais ou menos condizentes com o que se espera do rendimento da atividade naquele local. Por isso, interessa aqui a sua repercussão como artefato, possuidor de uma configuração específica, resultado da arquitetura.

Pelo benefício da relação da configuração do espaço com a questão social, concentrei-me em buscar uma conceituação de espaço que permitisse reflexão e análise pertinentes. Antes de lá chegar, destaco dois autores que visitei com o intuito de neles encontrar, também, pensamentos neste sentido: Milton Santos e Lucrécia D’Aléssio Ferrara.

Preocupado com uma definição clara e com o papel do espaço no processo social, Milton Santos ressalta a importância de coerência e operacionalidade dos conceitos e instrumentos de análise no âmbito das ciências sociais (SANTOS, 2012, pp. 1921) e reflete sobre a relação da realidade com a sua estratificação pela ciência. Isso parece apontar para a pertinência da atenção nos focos das disciplinas sociais parceiras, quando nas conceituações de termos que as interligam.

\footnotetext{
O mundo é um só. Ele é visto através de um dado prisma, por uma dada disciplina, mas, para o conjunto de disciplinas, os materiais constitutivos são os mesmos. É isso, aliás, o que une as diversas disciplinas e o que, para cada uma, deve garantir, como uma forma de controle, o critério da realidade total. Uma disciplina é uma parcela autônoma, mas não independente, do saber geral. (p. 20)
}

Contudo, sua conceituação de espaço, apesar de ser o espaço geográfico, não toca na questão de sua configuração topológica (o que poderia promover interface entre geografia e arquitetura/urbanismo): "O espaço é formado por um conjunto indissociável, solidário e também contraditório de sistemas de objetos e de sistemas de ações,..." (p. 63). Ele discute as relações entre tempo e espaço, técnica e espaço e outras, mas nada é tocado quanto à configuração do espaço e este como entidade atuante e não somente receptor de ações, técnicas, cultura, história etc. Digo, o espaço em si e na forma que ele se apresenta.

De modo inverso, sua conceituação de lugar reúne reflexões das diversas áreas que tratam sobre este tema, inclusive faz alusão à repercussão da configuração do lugar, trecho que destaco com grifo: 
No lugar - um cotidiano compartido entre as mais diversas pessoas, firmas e instituições - cooperação e conflito são a base da vida em comum. Porque cada um exerce uma ação própria, a vida social se individualiza; e porque a contiguidade é criadora de comunhão, a política se territorializa, com o confronto entre organização e espontaneidade. O lugar é o quadro de uma referência pragmática ao mundo, do qual lhe vêm solicitações e ordens precisas de ações condicionadas, mas é também o teatro insubstituível das paixões humanas, responsáveis, por meio da ação comunicativa, pelas mais diversas manifestações da espontaneidade e da criatividade. (p. 322)

Além desta reunião de características, ele atrela a noção de lugar à dialética das ordens global e local. Segundo ele, cada uma age de modo a formar o lugar, resultado de fatores externos e internos. Enquanto os parâmetros da ordem global são a "razão técnica e operacional, o cálculo de função, a linguagem matemática. A ordem local funda a escala do cotidiano, e seus parâmetros são a copresença, a vizinhança, a intimidade, a emoção, a cooperação e a socialização com base na contiguidade." (p. 339).

Relacionar o conceito de lugar com esta dialética aponta para a importância de se analisar um mesmo local escolhido pelo comerciante sob estes dois ângulos. Isto auxilia posicioná-lo em relação ao seu contexto maior imediato, ao mesmo tempo em que se tem a noção do que ele é internamente. Este seria um dos meios para se analisar a interface entre a atividade e seu contexto.

Enquanto Milton Santos atrela seu conceito sobre espaço às questões geográficas sua busca por definir espaço geográfico - Ferrara constrói seu conceito de espaço sobre o de informação, que seria, basicamente, a produção de conhecimentos novos com respeito à realidade, provocadores de aprendizado e mudanças de comportamento, por meio de inferências (FERRARA, 1993, p. 151).

A partir desta conceituação de informação, mais uma vez o espaço vem como aquele que, tão somente, recebe a informação sem nenhuma repercussão sobre este processo: "Espaço de informação é aquele ambiente físico, social, econômico e cultural que agasalha um tipo de comportamento decorrente de um modo de vida, um modo de produção. Esses comportamentos revelam-se através de uma linguagem que tem como signos usos e hábitos." (op. cit., meu grifo). 
No entanto, acredito estar entrelinhas algo sobre a repercussão do espaço na produção das informações, em outro trecho de "Olhar Periférico":

\begin{abstract}
Espaço e informação são elementos interdependentes, visto não ser possível conceber, apreender um espaço senão através de usos e hábitos decorrentes do modo de produção que os caracteriza. Por outro lado, não é possível haver informação senão a partir de um estímulo físico, social ou cultural, produzido por diferentes tipos de vida que geram novos aprendizados e outros comportamentos. Espaço e informação fazem-se mutuamente, ou seja, é possível prever alterações espaciais sempre que um novo estímulo provoca novo aprendizado e consequentemente mudança de comportamento. (op. cit.,p. 151)
\end{abstract}

A mutualidade de repercussão é fato entre espaço e vida social. O foco, no caso do que defende Ferrara, está no que permeia a informação em si. O ponto de partida da autora está na informação como processo. O enfoque semântico na conceituação do espaço não nos permite enxergá-lo de modo mais nítido, explicativo quanto à sua repercussão como contexto participativo. Considera-se, então, mais as forças que atuam sobre ele do que vice versa. Deriva desta tendência o conceito de lugar de Ferrara entendido como uma "estrutura organizada, na qual ocorrem influências econômicas, comunicativas, associativas e culturais, consideradas cada uma delas como participantes de uma só instância: informacional." (p. 154).

Esta é a dimensão semântica da arquitetura que vem sendo explorada há mais tempo que a sintática. "A tradição da pesquisa em arquitetura tem muitas facetas, mas há predominâncias. [...] a tradição foca a semântica da arquitetura mais que a sintaxe, ênfase acentuada com a importância recente e crescente conferida à subjetividade. (HOLANDA, 2013, p. 164. Grifos do autor). Neste trabalho, a dimensão semântica é considerada fator relevante, porém, como o foco aqui está na repercussão da configuração do contexto, as implicações da sintaxe dos lugares escolhidos e apropriados é o que nos interessa no momento.

Retomo a questão sobre o que faz de um espaço um lugar que, dentre tantos outros na cidade, é escolhido para se permanecer com uma atividade durante um período significativo e intenso do dia (ou da noite). Dado o recorte nas implicações sintáticas, viso as condições físicas dos lugares que o fazem propícios para apropriação, mesmo que temporária, cotidiana. 
Um lugar é o espaço em que se pode ter a sensação de pertencimento. É onde se sente que se faz parte. Apesar de ser em um espaço externo e público, um lugar passa uma espécie de impressão de fechamento.

Ao discorrer em sua tese sobre o caráter das atividades na cidade, Tenório (2012) destaca entre outros o trabalho de Alexander et al (1997, p. 517-523), no item específico sobre "Espaço exterior positivo", que trata da configuração de espaços públicos. Espaços exteriores, na concepção dos autores, são aqueles que se encontram entre os edifícios e podem ser negativos ou positivos. Espaços negativos são caracterizados como resultados disformes de sobras (left over) entre os edifícios, enquanto os positivos são os que têm a forma distinta e definida como a de um cômodo e tão importante quanto a forma dos edifícios que a circundam (op. cit., p. 518).

Quanto à formação destes espaços, eles trabalham com os conceitos de convexidade e delimitação de modo complementar: o segundo complementando o primeiro. Destaco a pertinência da observação e correção feita em relação à parceria entre estes conceitos.

\footnotetext{
Outra forma de distinguir um espaço exterior positivo de um negativo é pelo seu grau de convexidade e seu grau de delimitação. Aqui há uma pequena incorreção, já que um espaço não pode ser definido por seu "grau" de convexidade. Em matemática, um espaço convexo é aquele que permite que se vá de qualquer parte para qualquer parte dele sem sair de suas fronteiras. Sendo assim, não há graus de convexidade: ou um espaço é convexo ou não é. Um espaço exterior positivo, então, segundo os autores, seria aquele que poderia ser representado por um polígono convexo.

Ocorre que qualquer espaço pode ser decomposto em polígonos convexos, por mais amorfo que ele seja. A questão é como estes polígonos resultantes são percebidos espacialmente. Provavelmente por isso os autores trouxeram o conceito de delimitação. (TENÓRIO, 2012, p. 130).
}

A complementação do conceito de convexidade pelo de delimitação estaria, então, sendo trabalhada conforme a Lei de Fechamento da Gestalt, em que, neste caso, "a delimitação só pode ocorrer em um espaço convexo, e que sua gradação está vinculada à contiguidade de seus limites" (op. cit., p. 131).

Alexander et al, na busca de um respaldo maior sobre a hipótese da convexidade para espaço exterior positivo, citam as propriedades das praças bem sucedidas, 
segundo a análise de Camilo Sitte ${ }^{12}$ : elas costumam ser parcialmente fechadas e interligadas a outros pequenos espaços como estes. A ideia do recinto é muito forte neste sentido, pois o conforto e a sensação de segurança que os ambientes parcialmente fechados transmitem derivam dos nossos instintos mais primitivos (ALEXANDER et al, 1977, p. 520).

É a ambiência que passa a sensação de segurança e conforto ao espaço, tornandoo um lugar para se estar e permanecer. Escolho o termo ambiência por ser a qualidade deste lugar que, delimitado parcialmente por elementos diversos edifícios, vias, arbustos, cercas etc., torna-se, justamente por sua configuração, um meio apropriado para o exercício de atividades humanas. Atividades que incrementam a vida social destes lugares e dos interligados a ele. O conceito de ambiência permeia boa parte da análise do contexto da atividade.

\subsubsection{Dos desempenhos, o sociológico}

O exercício da arquitetura e do design é a configuração de artefatos no esforço da tradução dos seus desempenhos dentro dos respectivos programas. Interessa, então, analisar o objeto da pesquisa sob o prisma de quem projeta, ou melhor, estudar o meio material que envolve e suporta a atividade do comércio informal no que diz respeito ao seu desempenho na vida social local em que ele acontece.

Além disso, a contribuição para a melhoria de qualidade da vida urbana é uma das motivações da pesquisa e, nesse sentido, me apoio nos conceitos de formalidade e urbanidade, propostos por Holanda (2002, pp. 125-6). Trata-se, resumidamente, de uma polaridade que descreve, na relação entre espaço e vida social, o intervalo entre o que é formal, oficial ou regulamentado de um lado, e o que é, em termos da vida urbana, o comportamento na relação entre os cidadãos entre si e com o meio, pautado em respeito e contínua negociação (HOLANDA, 2002, p. 125). Tanto um quanto outro conceito podem ser detectados nas escolhas de configurações arquitetônicas do espaço urbano, que seguem determinados padrões. Padrões compreendidos como

${ }^{12}$ SITTE, 1965. City Planning According to Artistic Principles. 
o modo de organização de qualquer sistema a partir da configuração das relações dos elementos deste sistema, o que define as características essenciais que o tornam semelhantes ou distintos de outros. (MEDEIROS, 2006, p. 91).

A Teoria da Sintaxe Espacial propõe uma leitura específica desses padrões, em que são privilegiadas as relações entre as partes na formação do todo. Hillier e Hanson, fundadores da teoria, iniciam seu argumento com o resgate dos estudos de Piaget sobre as primeiras ideias de espaço aprendidas pelas crianças. Ele observa que o desenvolvimento delas por meio da manipulação do mundo e os respectivos objetos é do tipo topológica, por aprenderem primeiro noções de proximidade, separação, sucessão espacial, recinto e contiguidade, conceitos inerentes a área da topologia (HILLIER e HANSON, 1984, p. 47).

Esses conceitos são apreendidos na abstração do mundo artificial por meio de uma linguagem baseada em estruturas formais, que os autores denominam 'linguagem mórfica' (morphic language). Baseada em sintaxes - estruturas combinatórias, desdobradas em famílias de padrões que tornam reconhecível a ordem interna do mundo artificial - "uma linguagem mórfica é qualquer conjunto de entidades que são ordenadas em diferentes arranjos pela sintaxe de forma a constituir elementos sociais reconhecíveis"13 (op. cit., p. 48).

Eles concluem que qualquer conjunto de entidades artificiais que utiliza a sintaxe, pode ser chamado de 'linguagem mórfica'. Assim como o espaço é uma linguagem mórfica, as relações sociais também o são, pois "cada sociedade vai construir padrões de encontro característicos para os seus membros, variando desde o mais estruturado ao mais aleatório." (op. cit.).

A Teoria da Sintaxe Espacial descreve os padrões físicos do espaço organizado com base em duas premissas: 1) a organização espacial humana é o estabelecimento de padrões de relações compostos essencialmente por barreiras e permeabilidades de vários tipos e 2) apesar de haver infinitas possibilidades de relações espaciais no mundo real, são finitos os geradores de complexidade na

\footnotetext{
13 "A morphic language is any set of entities that are ordered into different arrangements by syntax so as to constitute social knowables."
} 
organização espacial humana e é dentro desta restrição que o espaço é manipulado e adaptado para os propósitos sociais (p. 54).

O conhecimento gerado por Hillier, Leaman, Hanson e Holanda (no Brasil), a partir do que denominam "relação sociedade-espaço", embasa a formulação dessa teoria para introduzir o conceito de uma ordem do espaço, criada pelas edificações, que repercute na vida social (HILLIER \& HANSON, 1984). Os autores apontam que o principal impedimento para projetos mais efetivos para o espaço urbano é a falta de entendimento da natureza da relação entre a organização espacial e a vida social. Contudo, ao apontar esta falta, os autores se detêm às implicações sintáticas da arquitetura, que dizem respeito a configuração dos lugares. O equilíbrio e a completude na compreensão e prática da arquitetura estão em considerá-la em suas implicações sintáticas e, também, semânticas (HOLANDA, 2013, p. 163). A sobreposição de valores e convenções de uma sociedade, grupos, ou indivíduos "ressemantizam" os lugares, independentemente de suas configurações, que se apresentam como campo de possibilidades para novos significados, apropriações, usos. $^{14}$

Enquanto o conceito de cultura de Claude Lévi-Strauss (1908-2009) está vinculado à convenção da norma, o de Leslie White (1900-1975) tem base na geração de símbolos pelo homem (LARAIA, 1986, p. 54). "Todo comportamento humano se origina no uso de símbolos. Foi o símbolo que transformou nossos ancestrais antropoides em homens e fê-los humanos. (...) Toda cultura depende de símbolos." (WHITE, 1955 apud LARAIA, 1986). Esta linha de conceituação de cultura atrela, necessariamente, o símbolo a uma forma física, porque entende que somente assim ele pode ser assimilado na experiência humana. As teorias mais recentes sobre cultura a entendem como

sistemas de padrões de comportamento socialmente transmitidos que servem para adaptar as comunidades humanas aos seus embasamentos biológicos. Esse modo de vida das comunidades inclui tecnologias e modos de organização econômica, padrões de estabelecimento, de agrupamento social e organização política, crenças e práticas religiosas, e assim por diante. (KEESING, 1974 apud LARAIA, 1986).

\footnotetext{
${ }^{14}$ Em seu "sexto mandamento" Holanda (2013, p. 162) aponta a importância de se considerar ambas as implicações da arquitetura: sintáticas e semânticas, igualmente, apesar de na arquitetura sociológica, sua disciplina de pesquisa, voltar o foco para as questões sintáticas.
} 
As inúmeras conceituações de cultura passam por tipos de sistemas como adaptativos, cognitivos, estruturais, instrumentais, simbólicos. Cada um destes tipos com o foco em um modo de comportamento do homem na relação com seu meio, sempre na busca de seu entendimento, ordenação e controle. A concepção da configuração dos lugares é carregada de significação, assim como seus diferentes usos. As transformações dos lugares no sentido do hibridismo de apropriações e usos, nos revelam significativamente sobre os costumes da comunidade que os usufrui.

\begin{abstract}
As formas dos artefatos não possuem um significado fixo, mas antes são expressivas de um processo de significação - ou seja, a troca entre aquilo que está embutido em sua materialidade e aquilo que pode ser depreendido delas por nossa experiência. Por um lado, as formas concretizam os conceitos por trás de sua criação. Para empregar um termo corrente hoje, os artefatos obedecem a uma "lógica construtiva", a qual é a soma das ideias contidas em seu projeto com seus materiais e condições de fabricação. Por outro lado, formas e artefatos são passíveis de adaptação pelo uso e sujeitos a mudanças de percepção pelo juízo. (CARDOSO, 2012, p. 35)
\end{abstract}

Mas, se busco a relação entre uma atividade e seu contexto físico, encontro uma referência conceitual na lógica do espaço como o conjunto de padrões morfológicos complexos que incorporam e são incorporados por manifestações culturais. (HILLIER, 2005). Por meio da Teoria da Sintaxe Espacial a função social da arquitetura é clareada e a partir dela analiso a repercussão da configuração do espaço construído na escolha de cada lugar para a atividade do comércio informal.

Necessidade e expressão são os principais fatores de motivação e escolhas no uso cotidiano da cidade pelas pessoas. "A Sintaxe Espacial explica que preferimos certos lugares ou certos percursos, na vida rotineira, por serem mais acessíveis e mais integrados fisicamente ao todo urbano." (HOLANDA, 2010, p. 127).

Por estabelecer relações entre atributos de organização do espaço para fins humanos e estrutura social (MEDEIROS, 2006, p. 115), a Sintaxe Espacial referencia teoricamente a Arquitetura sociológica, conceito proposto por Holanda referente a uma das subdisciplinas da arquitetura, que aborda o seu desempenho sociológico. Do amadurecimento da ideia sobre o encontro entre arquitetura e 
ciências sociais, o autor denomina "pensadores reflexivos morfológicos" os pesquisadores de ambas as áreas, que sob pontos de vista particulares, analisam as implicações da forma arquitetônica (HOLANDA, 2002, p. 68). Por abarcar este tipo de análise, a Arquitetura sociológica é o referencial teórico eleito para intermediar a arquitetura com o recorte no design a ser tratado. Nesta linha de pensamento, analiso o contexto para o entendimento das soluções em design projetadas para atender a atividade do comércio informal no espaço urbano.

Ao desenvolver o conceito de Arquitetura sociológica, Holanda identifica duas bifurcações, nas quais faz duas escolhas (Figura 1.2). A primeira bifurcação diz respeito a relação de causa e efeito entre arquitetura e meio socionatural, que resulta em arquitetura como variável dependente ou independente, respectivamente, a que é influenciada pelo meio ou a que influencia o meio. A primeira escolha foi pela arquitetura como variável independente, que pode implicar o ambiente natural ou as pessoas. A segunda foi pelo impacto da arquitetura sobre as pessoas.

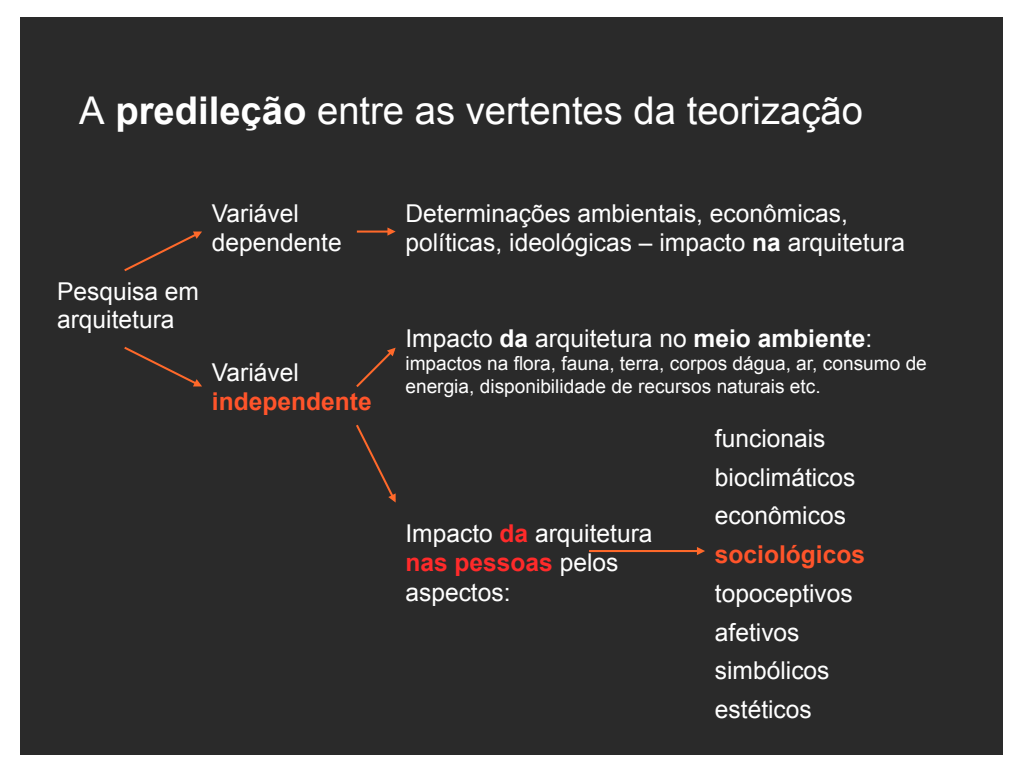

Figura 1.2 - esquema sobre as bifurcações e escolhas na conceituação de Arquitetura Sociológica, por Holanda. Fonte: HOLANDA, 2011.

Arquitetura sociológica, então, por meio da Sintaxe Espacial (SE), estuda os efeitos do espaço sobre a sociedade e o entende como um sistema que é descrito, em termos de sua ordem topológica, pelos atributos: proximidade, circunscrição, continuidade ou descontinuidade, contiguidade, separação, integração e segregação, opacidade e transparência (op. cit., p. 96). 
Os efeitos da arquitetura sobre o comportamento social não são considerados como um determinismo arquitetônico, que confere "à arquitetura superpoderes para transformar corpos e mentes" (HOLANDA, 2013, p. 115), mas constituindo "um campo de possibilidades e um campo de restrições, possibilidades que podem (ou não) ser exploradas, restrições que podem (ou não) ser superadas (p. 130). Assim, os sistemas de encontros e esquivanças compõem o eixo da arquitetura sociológica, no estudo das relações entre comportamentos sociais e estruturas urbanas.

$\mathrm{Na}$ abstração feita sobre o espaço das cidades pela SE, a decomposição analítica do sistema de espaços abertos pode ser descrita em termos de espaços 'convexos' e 'axiais'. Ambos são registrados por mapas específicos. O lugar é representado pelo espaço convexo em pequena escala, como visto, também, em Alexander et al.

\footnotetext{
Ao caminhar pelo espaço aberto da cidade, sabemos intuitivamente que sempre cruzamos transições (invisíveis) entre dois lugares (entre dois espaços convexos) ao dobrarmos uma esquina, ao adentrarmos numa praça. A técnica da convexidade permite explicitar essa intuição: as fronteiras invisiveis entre esses lugares transformam-se em segmentos de linha reta no mapa de convexidade. (op. cit., p. 97)
}

Enquanto os espaços convexos são unidades bidimensionais, os axiais são lineares por constituírem os eixos de deslocamento que organizam unidades de espaço convexo. Compõem um sistema de espaços abertos em que todas as barreiras estão obrigatoriamente separadas por linhas axiais. Outra maneira de entender o espaço urbano é por meio de seus atributos locais e globais. Nos locais são observados os elementos propriamente ditos, como por exemplo o tamanho de um espaço convexo. Os atributos globais dizem respeito à relação dos lugares com a cidade (op. cit., p. 99).

A diferenciação entre um e outro lugar se dá pela composição interna específica de cada um (convexidade). Na lógica da arquitetura sociológica e da Sintaxe Espacial, os espaços da cidade devem ser configurados para a permanência e não só para a passagem. 
Além da convexidade, a estrutura e ordenação dos trechos menores no grande espaço da cidade auxilia no entendimento da integração que estes lugares têm interna e externamente, que se acredita repercutir na escolha deles para se permanecer, utilizar, desenvolver atividades.

\subsubsection{Espaço urbano, o contexto global}

Qual seria a relação entre cada lugar escolhido pelo comerciante com o restante da cidade? Isso importa? No exercício crítico às visões teóricas sobre o desenho urbano, John Peponis (1989) identifica duas tendências equivocadas, limitadas: a defesa do desenho das cidades como uma "agregação de localidades mais ou menos autocontidas" e o grau secundário de importância dada ao aspecto cultural da estrutura do espaço urbano.

A maior parte das teorias revisadas e citadas por ele criticam o planejamento urbano moderno, contudo não chegam a identificar o que na arquitetura repercute no modo como se utiliza o espaço urbano e, ainda, elas se abstêm de discutir sobre "as propriedades projetuais e configurativas das cidades que são integradas espacialmente numa escala global, sem que se comprometa a diferenciação e o caráter distinto de suas partes." (PEPONIS, 1989).

A análise do ponto de comércio em si, com relação ao respectivo contexto imediato constitui somente parte do estudo sobre a atividade e sua repercussão social. Próximo a cada ponto, existe uma diversidade de outros lugares e atividades que de alguma maneira, física e socialmente, estão relacionados a ele. O desenho dos espaços que os interligam nos informa não somente sobre suas existências, mas principalmente como as interrelações se dão. "O que confere às cidades seu caráter distintivo não é meramente a variedade e natureza de diferentes tipos, mas a maneira pela qual estes se encontram relacionados." (op. cit.)

Infere-se que os espaços urbanos possuem propriedades relacionais que organizam, em si, a presença e a distribuição de pessoas. A apreensão dessas propriedades se dá pela inteligibilidade do espaço urbano, que não depende de conhecimento explícito prévio (HILLIER et al., 1987 apud PEPONIS, 1989). É uma 
captação do espaço por intermédio do que Peponis compara com o conceito de habitus de Bourdieu: "princípio gerador de práticas objetivamente classificáveis e, ao mesmo tempo, sistema de classificação de tais práticas." (BOURDIEU, 2011, p. 162). Toda a lógica da inteligibilidade do espaço urbano gira em torno da detecção de padrões, tanto da configuração do espaço, quanto do comportamento das pessoas em relação e a partir dele. Habitus é a base da 'lógica prática', expressão cunhada por Bourdieu, que norteia decisões e escolhas não sistemáticas, ou racionalizadas, no uso do espaço urbano, e tem como resultado o padrão de copresença (1980 apud PEPONIS, 1989).

A configuração do conjunto de vias de acesso entre os variados espaços da cidade repercute de maneira a permitir ou restringir o movimento, seja por veículos ou pedestres. "O movimento ao longo das ruas de uma malha viária é mais influenciado pela posição de cada rua dentro do complexo urbano como um todo, do que por qualidades imediatamente locais daquela rua" (MAJOR et al, 1997, p. 42.01 apud MEDEIROS, 2006, p. 102-103).

Movimento natural foi um conceito cunhado por Hillier et al (1993), para o movimento gerado por efeito da configuração. Nesta conceituação eles convergem em uma mesma situação a configuração, o movimento e a atração. Atração, neste caso, é considerada como a propriedade ou elementos que certas vias ou lugares possuem de concentrar movimento ou permanência de pessoas. Nesta tríade, a configuração tem preponderância de efeito sobre os outros dois aspectos.

Por meio do esquema da Figura 1.3, Medeiros (2006) interpreta a lógica do movimento natural representada por um ciclo fechado em que

a configuração da malha viária, por sua forma de articulação, estabelece a hierarquia do movimento definindo áreas com maior e menor concentração de fluxo: equivale ao efeito primário. Áreas com maior concentração de fluxo tendem a atrair certos usos que se beneficiam deste movimento, como o comercial e de serviço: corresponde ao efeito secundário de convergência de atratores. Estes atratores, por sua natureza, atraem novos fluxos e mais movimento, resultando no efeito terciário, e também podem alterar a configuração do espaço construído, correspondente ao efeito quaternário, fechando o ciclo. (MEDEIROS, 2006, p. 103) 


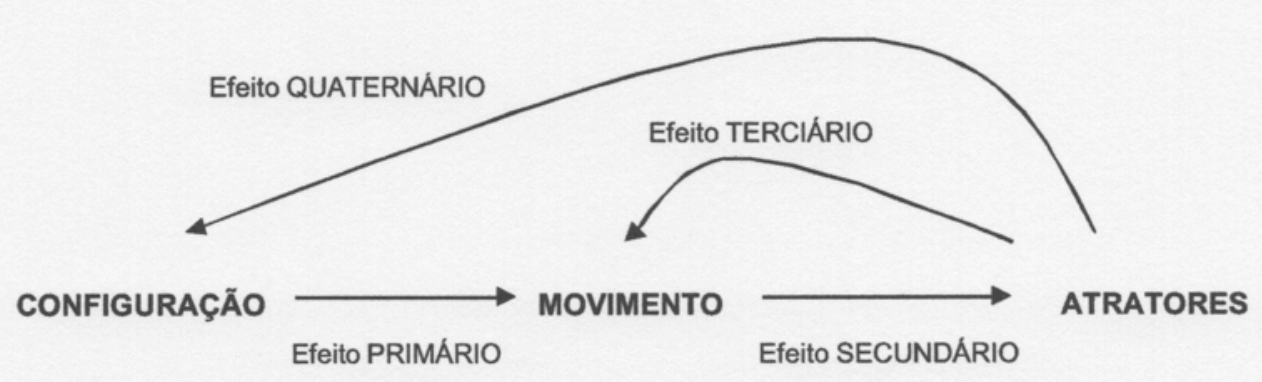

Figura 1.3 - esquema do movimento natural. Fonte: MEDEIROS, 2006, p. 103.

$\mathrm{Na}$ análise da estrutura local e global do conjunto das vias no espaço urbano, a Sintaxe Espacial se utiliza do conceito do movimento natural para evidenciar a relação entre configuração e movimento nas cidades.

No âmbito metodológico da Sintaxe Espacial, a medida de integração informa sobre os níveis de integração entre as partes de uma região que está sendo analisada. O conjunto de vias que interliga estas partes é analisado em sua configuração. Esta medição é feita por intermédio de mapas axiais (lineares) e pode se dar de duas maneiras: entre uma porção da cidade e o seu todo e entre uma determinada linha axial e o lugar onde está inserida (HOLANDA, 2002, p. 102). Por ser de natureza topológica e não geométrica, a medição neste caso

\begin{abstract}
...é obtida em razão de quantas linhas axiais, abstraídas do sistema de espaços abertos, temos minimamente de percorrer para ir de uma dada posição, na cidade, a outra posição, e não em virtude dos metros lineares de percurso que separam minimamente essas posições. Em outras palavras, num sistema muito integrado, temos de dobrar um número pequeno de esquinas para ir, em média, de uma rua para qualquer outra do lugar. O contrário se dá num sistema menos integrado. (HOLANDA, 2002, p. 102-3)
\end{abstract}

O trânsito entre os aspectos global e local dos lugares, passível de ser analisado por meio do estudo das técnicas da convexidade e da axialidade, possibilita a compreensão da interface entre os contextos e a atividade em si, no sentido da diferenciação e da integração, na sua relação com o entorno próximo, bem como com o todo da cidade. 


\subsubsection{A cidade e o comércio em via pública: origens comuns}

A cidade, contexto original do comércio informal, remonta mais de 5.000 anos acolhendo e atuando com esta atividade entre outras no cotidiano das pessoas. Uma das vertentes históricas sobre a origem das cidades descreve um incremento na população das aldeias do Oriente Próximo, principalmente de especialistas artesãos, mercadores, guerreiros e sacerdotes - o que resultou na necessidade da produção de um excedente de alimentos. O estabelecimento e a manutenção destes especialistas, com funções diferentes daqueles que cultivavam a terra, caracterizou a organização social que, junto à invenção da escrita, estabeleceram o advento da cidade nas civilizações oriental e ocidental (BENEVOLO, 2011, p. 10).

Desde então, os mercadores estão presentes nas ruas, inclusive como responsáveis pela formação desta estrutura social. O comércio é uma das principais atividades humanas, e está na base da organização social disposta em funções de subgrupos especializados de um coletivo. A complexidade das atividades de subsistência vai aumentando com a caracterizada vida em sociedade nas cidades. $O$ incremento por meio da especialização aconteceu como nas outras atividades, mas o complexar da atividade de mercador, base da formação burguesa, não retira completamente esta atividade das ruas. O comércio se subdivide por meio de seus atores: os que mantêm a origem nas ruas e os que ascendem dentro de uma organização social que os distingue.

Na Idade Média, um processo de ressurgimento das cidades se inicia e com ele os mercadores se tornam maioria, assim como os artesãos. Vivem às margens da organização feudal e refugiam-se nas cidades, por não encontrarem trabalho nos campos. Fatores como escassez dos meios, raridade de técnicos especialistas, falta de cultura artística organizada, urgência da necessidade de defesa e sobrevivência levaram a uma adaptação dessas pessoas ao ambiente natural, de maneira liberta e confiante, em que simplificaram, deformaram e estabeleceram novas instalações, sem o respeito ao que ali havia previamente - ruínas ou paisagens (op. cit., p. 255).

Aumento da população e da complexidade das atividades para dar suporte à vida de um modo geral são fatores que baseiam comportamentos que observamos até hoje, 
no seio de qualquer cidade. A indisciplina como reação ao estabelecido, consequentemente, está presente desde o início.

Apesar da liberdade de concepção formal que as cidades medievais apresentavam, por orientação cultural, eram previstos espaços destinados ao comércio e outras atividades em via pública.

\begin{abstract}
As ruas não são todas iguais, mas existe uma gradação contínua de artérias principais e secundárias; as praças não são recintos independentes das ruas, mas largos ligados estreitamente às ruas que para elas convergem. Somente as ruas secundárias são simples passagens: todas as outras se prestam a vários usos: ao tráfego, à parada, ao comércio, às reuniões. (BENEVOLO, 2011, p. 269).
\end{abstract}

Nem sempre as atividades prosaicas do cotidiano das ruas de uma cidade foram ignorados. Em meio àquela formação irregular, a ordem vigente contemplava alguns usos. Poderia até dizer que se tratava de uma incipiente setorização, que respeitava a diversidade de ações possíveis no espaço urbano.

Com a Revolução Industrial, a rapidez das transformações e suas repercussões na vida social foram tão intensas que os problemas decorrentes começam a aparecer e com eles as possíveis "soluções". As classes "dominantes" são aconselhadas a investirem no campo imobiliário, aproveitando-se da iniciativa privada e, ao mesmo tempo, da "desordem urbana sem sofrer-Ihe as consequências." (op. cit., p. 552).

Com o intuito comum de sanar os problemas oriundos das transformações desenfreadas das cidades industriais, representantes de grupos que começavam a se distinguir socialmente, buscam soluções calculadas por meio de reformas setoriais, ou pela idealização, na teoria, de setores habitacionais completamente novos. Mas, tratava-se de uma situação que se aprofundava cada vez mais em seu perfil de estratificação social, com repercussão na configuração das cidades.

De ambientes puramente naturais a construídos, passando pela formação de aldeia, a origem de uma cidade se caracteriza por um incremento da complexidade de formas de trabalho para atender a uma população crescente. Neste processo, a diferenciação entre as pessoas, pelos papéis que exercem nesta estrutura de 
atividades é um dos principais traços. Segundo Benevolo, dois tipos básicos de grupos de pessoas emergem desta diferenciação.

\footnotetext{
Nasce, assim, o contraste entre dois grupos sociais, dominantes e subalternos: mas, entrementes, as indústrias e os serviços já podem se desenvolver através da especialização, e a produção agrícola pode crescer utilizando estes serviços e estes instrumentos. A sociedade se torna capaz de evoluir e de projetar a sua evolução. (BENEVOLO, 2011, p. 23).
}

A diferenciação em apenas dois grupos - "dominantes e subalternos" - talvez possa suprir uma análise sobre a vida social daquele tempo, porém, rapidamente, esta classificação se torna insuficiente e esconde os diversos matizes que o aumento das relações entre indivíduos, grupos e ambientes cria na vida social das cidades, com a "evolução", citada pelo autor.

O modelo de cidade pós-liberal, estabelecido após as revoluções de 1848, repercute até hoje no tipo de organização que temos nas cidades. O limite fixado entre administração pública e propriedade privada torna-se mais definido, acarretando na dependência da determinação de um ou de outro, para a utilização dos espaços urbanizados. O desenho da cidade é formado pelas linhas de limite entre os espaços público e privado e esta organização, que acontece do centro para a periferia, encarece o custo da moradia e desloca os itens necessários ao funcionamento da cidade (armazéns, indústrias etc.) para o subúrbio e com eles a classe mais pobre.

Em relação aos problemas causados por este modelo, como grande densidade no centro e carência de moradias acessíveis economicamente, são tomadas medidas paliativas, como construções de parques públicos e casas populares. Quanto à forma, um misto de destruição de itens antigos e manutenção de monumentos, ruas e praças principais, caracterizou as medidas neste sentido. A ordem para efetivar as transformações necessárias para a resolução dos problemas da cidade vem de forma que a diferenciação entre técnicos e artistas se torna cada vez maior, sendo que aqueles devem executar as medidas impostas e torná-las aceitáveis, e estes devem trabalhar somente sobre os aspectos exteriores da cidade (op. cit., p. 573$586)$. 
Estes fatores dizem respeito à situação da maior parte das cidades ocidentais europeias, na segunda metade do século XIX, mas parece que estamos falando sobre cidades contemporâneas, de modo geral, guardando as devidas especificidades e atualizações.

Industriais, liberais, pós-liberais, modernas, contemporâneas (pós-modernas ou hipermodernas), ao longo da evolução, as cidades guardam algumas dicotomias sociais - dominantes-dominados, público-privado, individual-coletivo - como traço inerente. A atividade do comércio informal nasce com e permanece na cidade. Os aspectos que a formam são de base universal.

Sirvo-me destes breves aspectos e momentos da história da cidade, para trazer à pesquisa as origens da situação atual, que há muito é marcada pela distinção entre diversos grupos e seus interesses, no que se refere ao oferecido, de moradias a serviços públicos.

\subsection{0 comércio em via pública}

Historicamente, o comércio em via pública ocorre desde o nascimento da própria cidade. Algumas características se mantêm desde então e, a partir delas e da variedade de mudanças que aconteceram no âmbito das cidades como um todo, trabalho o meu objeto, dentro das especificidades morfológica e social.

Considero que o comportamento da indisciplina desencadeia a postura do comerciante como cidadão, trabalhador e, porque não, designer. A Teoria das Práticas Cotidianas é acionada para o embasamento do estudo sobre este tipo de postura em relação ao que é oferecido no espaço urbano e às reais necessidades e expectativas dos comerciantes informais.

A escolha por esta atividade, em específico, entre tantas outras, se deu pelo fato de o comércio apresentar várias facetas de análise da atuação das áreas abordadas arquitetura e design - no espaço urbano. O grau de complexidade que logo no início o estudo da atividade em seu contexto apresentou, levou a opção por abordá-la 
como um sistema, dentro dos princípios da Teoria Geral dos Sistemas. Segue, então, o objeto da pesquisa.

\subsubsection{A indisciplina - uma postura social}

Se considero a indisciplina, parto do pressuposto da existência de uma regra, de uma ordem estabelecida, ou de, no mínimo, um delineamento. No caso do objeto da tese, dois fatores delimitam as motivações ou restrições que referenciam a indisciplina aqui considerada: a regulamentação de uso do espaço público e o seu desenho, sua configuração. O primeiro fator é considerado porque informa sobre o raciocínio da ordem estabelecida, porém, devido à abordagem da pesquisa ser morfológica, com foco nos aspectos funcionais da atividade e sua repercussão na vida social do local escolhido, ele não influencia na análise do objeto. Isso faz do segundo, o fator determinante da indisciplina praticada pelo comerciante, sob o ponto de vista da escolha e apropriação do local e seu uso.

O embate silencioso e cotidiano entre as forças da ordem e da indisciplina, que (não) enxergamos na vida social de uma cidade é tão antigo quanto o seu nascimento. Antigo e perene, esse embate é um dos principais traços no que diz respeito à apropriação dos lugares no espaço urbano. A repercussão dessa indisciplina é o que interessa aqui, no que ela devolve ao estabelecido na produção e apropriação do espaço urbano, em que valem, também, as práticas produzidas por não profissionais. Trato deste tipo de produção.

Esses não profissionais estariam localizados alguns na classe social trabalhadores manuais e outros na pequena burguesia, duas das cinco classes propostas por Holanda $^{15}$. Seu trabalho de síntese, com base na classificação de Anthony Giddens (proprietários de meios de produção; detentores de qualificação técnica ou educacional e detentores de força de trabalho manual) e em dados atualizados ${ }^{16}$, contribuiu com uma classificação baseada na 'divisão técnica do trabalho' e não na faixa de renda, ou no tipo de ocupação (HOLANDA, 2013, p. 140-142). Os

\footnotetext{
${ }^{15}$ As cinco classes são: trabalhadores manuais, classe média, pequena burguesia, burguesia e grande burguesia. Esta última foi inserida na classificação de Holanda, após atualização no processo de "identificação empírica" do contexto brasileiro.

${ }^{16}$ Dados que foram retirados do banco de dados do Observatório das Metrópoles.
} 
comerciantes informais são donos do próprio negócio e, se organizados, podem ser inscritos como autônomos ou empreendedores individuais, no contexto legislativo trabalhista brasileiro. Estar em pelo menos duas classes, neste caso, parece ser inevitável. Um exemplo disso é a atualização de sua classificação junto aos dados do Observatório das Metrópoles, em que Holanda se deparou com esta questão em relação aos agricultores.

\begin{abstract}
Também trabalhadores manuais são os agricultores, embora alguns deles devam ser considerados como pequena burguesia - mas, pelas informações disponíveis, é impossível discriminá-los como tal dentre os agricultores em geral. Contudo, como temos a categoria pequenos empregadores, admito que essa 'pequena burguesia rural' esteja contemplada aqui, e não entre os agricultores como trabalhadores manuais. (HOLANDA, 2013, p. 141).
\end{abstract}

A evolução rápida e significativa dos fatores que regem os posicionamentos dos indivíduos e grupos na sociedade coloca em questão as classificações conhecidas. François Ascher (2010, p. 25) denomina terceira modernidade este momento em que um dos processos de base é a diferenciação social, marcada por funções diversificadas. O autor concorda que sua força motriz está na divisão técnica e social do trabalho, que repercute na dinâmica da economia de mercado e no aumento das especializações em uma sociedade, por isso, cada vez mais complexa.

As ações cotidianas discutidas aqui têm base na complexidade oriunda desta diferenciação crescente. O aumento de elementos agentes e de relações de interação que caracteriza o momento presente define o contexto do objeto, de modo geral.

"Desobediência, insubordinação, violação de regras ou ordens impostas..." são algumas das definições (HOUAISS, 2009) encontradas para o comportamento da indisciplina. Trabalho com este contraponto nas duas dimensões sociais identificadas por Michel de Certeau: a estratégia e a tática. A cidade é um constante dueto entre estratégias e táticas. São preto e branco cujos cinzas vêm da complexidade de suas imbricações. A estratégia, como âmbito de uma posição social estruturante e estruturada, de amplitude macro, pode ser entendida como um lugar social e historicamente definido. É a dimensão em que a ação se baseia nos 
estatutos derivados das estruturas definidas ou definidoras. O status quo ou establishment seriam o foco ou objetivo nessa dimensão de ação ${ }^{17}$.

A configuração e a regulamentação sobre funcionamento e uso dos espaços delimitados pela arquitetura e pela paisagem, podem ser considerados, em conjunto, como um dos tipos de estratégia articulados na cidade. O modus operandi desta estrutura estabelecida é pautado na lógica da estratégia.

\begin{abstract}
Chamo de estratégia o cálculo (ou a manipulação) das relações de forças que se torna possível a partir do momento em que um sujeito de querer e poder (uma empresa, um exército, uma cidade, uma instituição científica) pode ser isolado. A estratégia possui um lugar suscetível de ser circunscrito como algo próprio e ser a base de onde se podem gerir as relações com uma exterioridade de alvos ou ameaças (os clientes ou os concorrentes, os inimigos, o campo em torno da cidade, os objetivos e objetos da pesquisa etc.). (CERTEAU, 2009, p. 93).
\end{abstract}

O estabelecido é este lugar próprio da estratégia definida pelo autor. Ali, o sujeito delimita seu poder e querer próprios em que a conquista do lugar de onde controla, vence e é independente do tempo que é campo do que as circunstâncias inevitavelmente variam. A configuração deste lugar permite que seu próprio esteja, também, no poder da visão, para efeito de controle, previsão, antecipação - o 'panóptico'18. E, finalmente, o próprio se dá pelo poder do saber apropriado para a conquista de seu lugar (aquele que vence o tempo) ${ }^{19}$. Neste ciclo ele se fecha, delimita a si e o que e como pode ser feito em seu território por outros que não compartilham deste poder - os que se utilizam da tática, ou o 'homem ordinário' de Certeau.

... chamo de tática a ação calculada que é determinada pela ausência de um próprio. Então nenhuma delimitação de fora the fornece a condição de autonomia. A tática não tem por lugar senão o do outro. E por isso deve jogar com o terreno que lhe é imposto tal como o organiza a lei de uma força estranha. (CERTEAU, 2009, p. 94)

\footnotetext{
${ }^{17}$ Esta é a síntese da definição de estratégia, por Evandro Renato Perotto, em discussões no âmbito do ETHOS - Grupo de estudos sobre Design, Cultura e Sociedade, do Departamento de Design DIN/UnB, no segundo semestre de 2015.

${ }^{18} \mathrm{Em}$ a 'A microfísica do poder', são reunidos textos em que Foucault analisa um tipo de poder peculiar do meio social e que não é o exercido pelo Estado. É um 'micro-poder' de cunho disciplinar que reúne quatro características básicas interrelacionadas: organização do espaço; controle do tempo; vigilância contínua e extensiva a todos os espaços (com referência no Panopticon de Bentham); e registro contínuo de conhecimento. (FOUCAULT, 2011, p. XVIII).

${ }^{19}$ CERTEAU (2009, p. 94). O autor explicita nestas três características básicas, o lugar próprio do que define como estratégia.
} 
Assim como são três as características básicas do 'próprio' da estratégia, são três os tipos de lugar de que ela se apodera: lugar de poder, lugar teórico e lugar físico ${ }^{20}$. $\mathrm{O}$ aspecto das relações espaciais, então, vem como consequência deste processo de delimitação de poder. Das práticas do cotidiano descritas e pesquisadas por Certeau - como ler, falar, cozinhar, habitar e caminhar, me interessam, no momento, aquelas praticadas no espaço urbano. Estas práticas não dispõem deste poder, ou propriedade de lugares em que as regras (se) valem. A tática, o contraponto à estratégia, usa a arte de 'fazer com'21 o que ali já está e que não lhe pertence. A estratégia trabalha com o lugar, o fixo, o controlável, ao passo que a tática trabalha com o tempo que permite um trânsito fluido por um lugar que não é seu. Esta dimensão tem sua ação nos espaços entre as estruturas da dimensão estratégica. Articula objetivos e espaços sociais que não os estruturais.

O material da tática está no contexto em que ela trabalha de forma circunstancial. As opções são curtas, sem grandes perspectivas. Invisibilidade é outra característica, pois quem se utiliza da tática não possui e não controla o lugar em que atua e a ação é o seu principal instrumento. Em um momento o tático está ali e em outro, não. Porém, com a repetição característica do cotidiano deixam marcas que de tão comuns, se tornam, também, invisíveis.

Adoto os conceitos de estratégia e tática de Certeau como tipos de oportunidade de ação, mas é necessário ir além, digo, nas imbricações entre estes dois tipos, para entender o comércio informal e outras atividades no espaço urbano. Considero-os, então, como ponto de partida para identificar entre suas várias conjugações, as que dizem respeito à atividade objeto da tese.

Uma das críticas à proposição teórica de Certeau se dá de modo superficial à limitação das dicotomias de suprirem análises sobre modos de consumo. "As maneiras pelas quais os sujeitos se apropriam dos produtos culturais implicam em uma certa dimensão estratégica, ou seja, na ocupação de um lugar que eles tomam

\footnotetext{
${ }^{20}$ Ibidem (p. 96).

21 "Fazer com" é a expressão utilizada por Certeau durante praticamente todo o texto de $A$ invenção do cotidiano, para se remeter às táticas.
} 
para si." 22 Tomam para si, mas que não lhes pertence. Ora, esta apropriação da característica de identificação do outro já seria aqui identificada como uma das primeiras variações/imbricações das duas dimensões e não um limite da teoria. Imbricações como a que acontece entre o perito e o filósofo, em que suas posições são muito próximas na mediação entre o saber e a sociedade. O perito como especialista na vastidão das decisões sociopolíticas e o filósofo como detentor de uma técnica própria para os questionamentos mais gerais sobre a vida (CERTEAU, 2009 , p. 63). Transitam com tanta constância entre o específico e o geral, que se confundem em suas posições.

Estratégias e táticas são dimensões tão abrangentes e, por isso, formadoras, que grupos ou mesmo indivíduos podem empreender ações tanto em uma, quanto na outra. Elas "permitem" que tenhamos várias camadas concomitantes (estratégicas ou táticas) de atuação social no espaço urbano, sendo as oportunidades a orientarem a posição em uma ou em outra dimensão.

As práticas do cotidiano no espaço urbano começam com o caminhar, com a passagem. Aparentemente é um ato simples, sem muitas implicações. Mas, já aí, são acionadas intuitiva ou intencionalmente, maneiras de agir que envolvem escolhas, ou, de modo mais amplo, envolvem modalidades de relação do pedestre com o percurso escolhido. Certeau classificou essa relação, em que esgota esse conceito no que concerne aos valores que o pedestre dá às suas escolhas, em três modalidades. São elas as "aléticas", em que é atribuído o valor de verdade ao percurso (necessário, impossível, possível, ou contingente); as "epistêmicas", cujo valor atribuído é o cognitivo (certo, excluído, plausível, ou contestável); e as "deônticas", referentes ao valor do "dever-fazer" (obrigatório, proibido, permitido, facultativo $)^{23}$.

O jogo entre a estratégia e a tática no ambiente da cidade se caracteriza pela construção do espaço próprio da ordem por quem planeja e a manipulação por parte de quem o utiliza, pois "o espaço geométrico dos urbanistas e dos arquitetos parece

\footnotetext{
${ }^{22}$ Faria Pereira e Sarti (2010). Estes autores reduzem estratégia e tática a categorias de análise

${ }^{23}$ No capítulo de 'Invenções do Cotidiano' em que o autor discorre sobre as práticas cotidianas na cidade, ele inicia com as caminhadas como prática introdutória no espaço, ou, como ele denomina, de "enunciação".
} 
valer como 'sentido próprio' construídos pelos gramáticos e pelos linguistas visando dispor de um nível normal e normativo ao qual se podem referir os desvios e variações do figurado" (CERTEAU, 2009, p. 167). Os caminhos pavimentados oferecidos são utilizados, mas na medida em que as relações com estes caminhos estabelecidos se modificam, sejam de que ordem for (uma ou mais modalidades de valor atuando), os pedestres fazem seus próprios caminhos, talvez mais coerentes, mais práticos, funcionais, agradáveis etc., com a coincidência de escolhas que mais parece uma construção coletiva consciente (Figura 1.4).

Da mesma forma, a utilização do espaço por aqueles que fazem da permanência o meio de com ele interagir, funciona pelos mesmos princípios. Além da 'simples' circulação que já carrega seus valores, a permanência em um lugar no espaço urbano, também, ou mais ainda, é uma atitude de relação com o ambiente repleta daqueles valores e de um tipo de condição oferecida pela ordem que estabelece. São "falhas no sistema", ou vazios criados pela ordem que abrem, inevitavelmente, oportunidade para a criação de espaços de criação. Criação das práticas cotidianas.

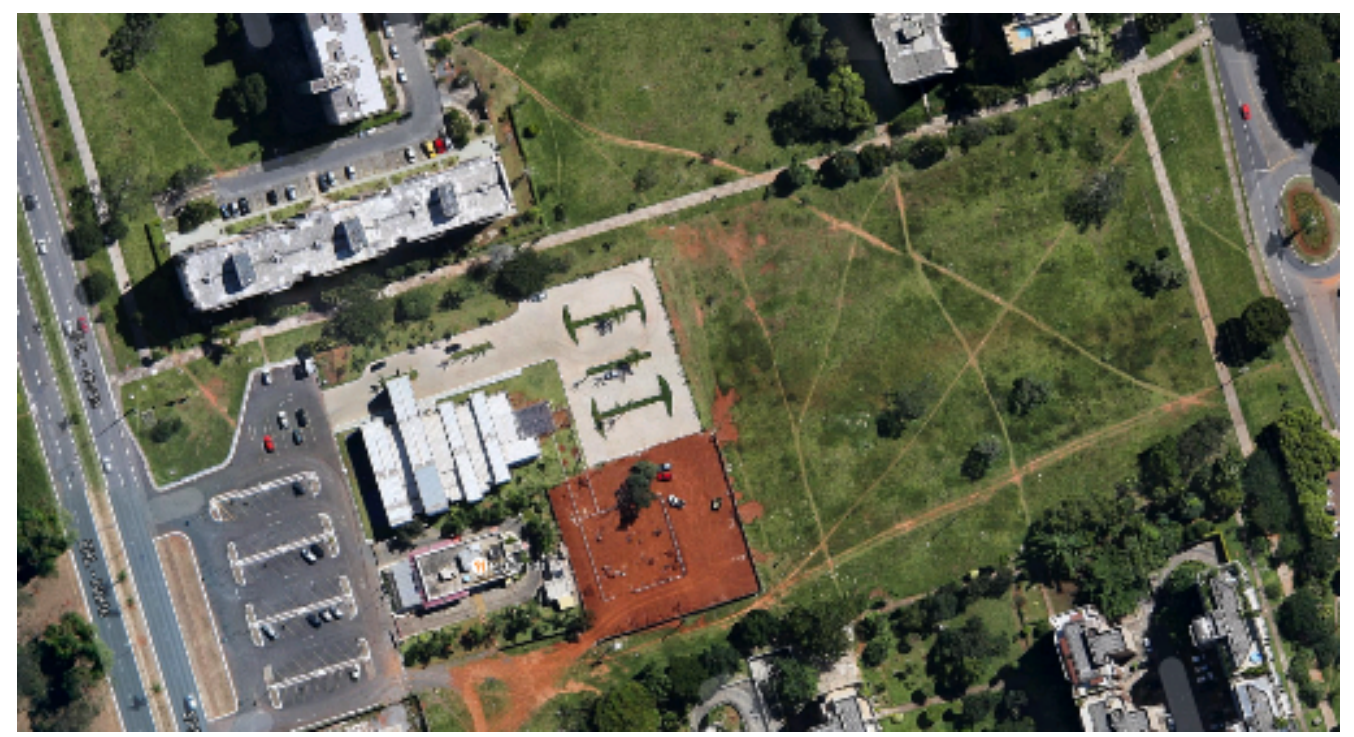

Figura 1.4 - entrequadras norte 208/209 - os caminhos feitos por pedestres no gramado. Fonte: Google Earth.

"Palimpsesto" foi um termo que me intrigou desde o início da leitura de "A invenção do cotidiano", mas que faz algum sentido quando pensamos nas atividades "invisíveis" praticadas no espaço urbano, todos os dias. É como se, de fato, fossem raspadas dali, para serem desenhadas em outro lugar, enquanto ali se desenham 
outras práticas. São camadas superpostas, cada uma com sua lógica própria de relação com o espaço que ali está. São lógicas que possuem modos diferentes de funcionamento, a princípio excludentes, por não possuírem instrumentalidade suficiente para estruturar ou estabelecer os meios do outro de funcionar. Porém, são exatamente estas lógicas e outras decorrentes destas que, em conjunto, faz funcionar o que parece caótico, a cidade.

Através da lente da teoria das práticas cotidianas de Certeau, visualizo o sujeito do meu objeto - o comerciante informal, na condição de homem ordinário, praticante do espaço urbano. Toda a atividade, desde a sua concepção e articulação até a desmontagem no final do turno e retorno para casa, considero como uma das táticas que se multiplicam na cidade. O início da pesquisa teve como referência alguns fatos que se destacaram entre observações e leituras mais gerais.

Sobre a atividade específica do comércio informal no espaço urbano, uma experiência no Plano Piloto de Brasília, chamou a atenção dos leitores dos jornais locais e dos que transitam e fazem parte do cotidiano do Setor Comercial Sul (SCS), do Plano Piloto, nos anos de 2008 e 2009. Em um processo claro de higienização social, os camelôs e ambulantes praticantes deste setor da cidade (porque esta cidade é dividida em setores), foram "convidados" a deslocarem seus negócios para o Shopping Popular, localizado a quilômetros dali, ao lado da extinta rodoferroviária.

É claro, neste exemplo, o embate entre os estratégicos e os táticos. Os espaços cobertos (sob pilotis entre um edifício e outro) e descobertos (calçadas e praças) desse setor têm trechos generosos para circulação de pedestres. Funcionalmente, o setor abriga instituições públicas e privadas que empregam uma diversidade de pessoas, oriundas de outras regiões administrativas, do entorno e da própria região (Plano Piloto). Essa situação é duplamente vista como oportunidade de apropriação por este tipo de comerciante.

Quatro anos depois do deslocamento para o Shopping Popular, alguns comerciantes são vistos, novamente, no local de onde foram retirados (Figura 1.5). 


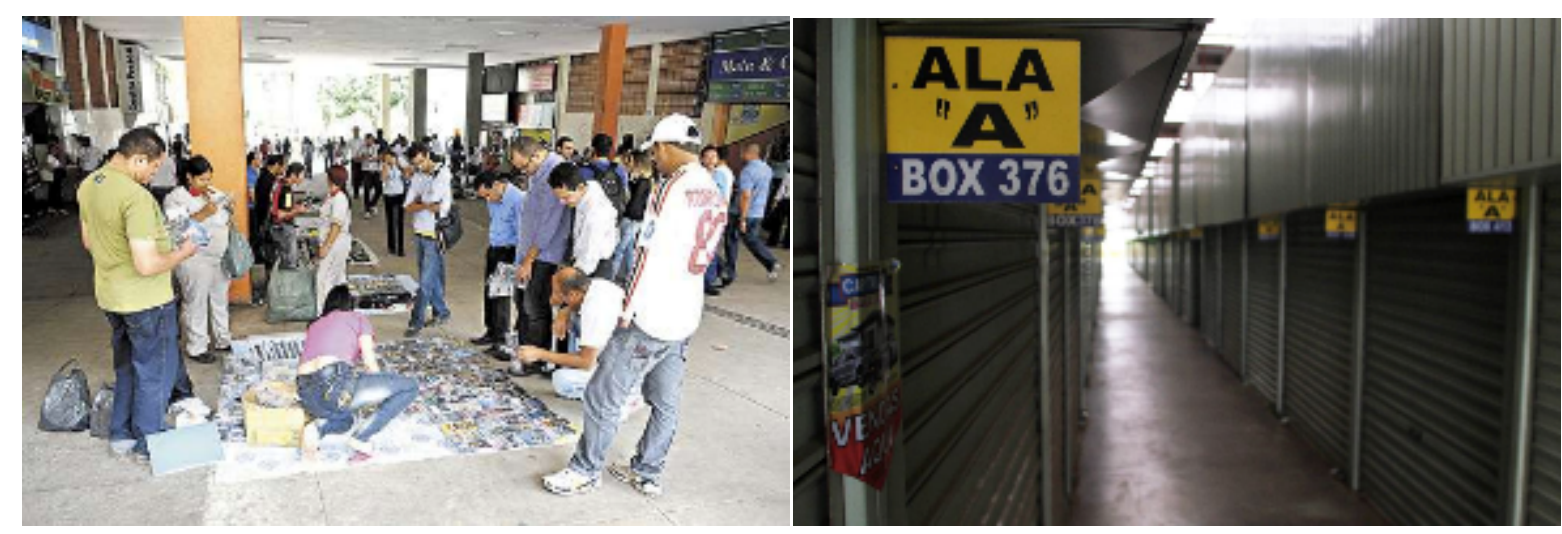

Figura 1.5 - a imagem à esquerda é divulgada em um jornal da cidade, quatro anos depois, mostrando que os camelôs voltaram a atuar no Setor Comercial Sul; à direita uma imagem dos boxes (ainda fechados) oferecidos a estes comerciantes, no Shopping Popular, quatro anos antes. Fonte: Gustavo Moreno/Correio Braziliense/C.A Press (à esquerda) e Rafaela Felicciano/Jornal de Brasília (à direita).

Se voltaram àquele local é porque a remoção claramente não os beneficiou: eles têm a garantia de clientes no SCS, pela quantidade de pessoas que passam ali diariamente e estão isolados de condições mínimas para o funcionamento de seus negócios, no Shopping Popular. Por outro lado, este retorno prejudica aos que tem comércio formalizado e, também, a paisagem da cidade, dizem os jornais e reclamam os prejudicados.

\footnotetext{
"Para o governo, a solução era a mais adequada para acabar com o comércio irregular, acusado de alterar a paisagem da área central de Brasília, tombada como patrimônio histórico e cultural da humanidade, além de interferir na escala monumental idealizada pelo urbanista Lucio Costa." ${ }^{24}$
}

Oportunidade pela configuração e pela função para uns, e prejuízo nos mesmos dois aspectos para outros. Sem entrar em juízo de valor, a análise breve que pode ser feita desta experiência, que ainda ocorre neste e em tantos outros casos nesta e em outras cidades brasileiras, soluções paliativas, que visam somente um lado dos envolvidos, continuarão a fracassar se não for respeitada, principalmente, a questão da diversidade que permeia os aspectos sociológicos e funcionais deste tipo de ambiente. Em termos de configuração, a oportunidade já é dada. Os comerciantes informais com suas práticas, demonstram isso.

\footnotetext{
${ }^{24}$ Este é o trecho de uma matéria do jornal Correio Brasiliense, publicada no dia 17/1/2012, sobre o retorno dos camelôs ao Setor Comercial Sul, cuja manchete foi "Camelôs voltam a invadir Setor Comercial Sul após ganharem shoppings populares". Eu ainda faria uma correção na escala a que o repórter se refere: no caso do foco da matéria não se trata da escala "monumental", mas da "gregária".
} 
Nesse sentido, a indisciplina também se manifesta contra a descontinuidade física e a especialização de uso. Dois problemas identificados por Holanda (2010, cap. 2) na cidade de Brasília, onde a setorização de serviços transformou as atividades funcionais em "ilhas". Para compensar essa especialização, busca-se "naturalmente" a diversificação da oferta de serviços.

A prática constante e disseminada da indisciplina denuncia as iniciativas de reurbanização que Jacobs aponta como tão frequentes em grandes cidades há muito desgastadas socioeconomicamente, que mais estigmatizam e excluem as pessoas da vida cotidiana do espaços públicos do que as integram e os revitalizam. Como uma das práticas no espaço urbano, a indisciplina praticada pelo comércio informal é sintoma da "necessidade que as cidades têm de uma diversidade de usos mais complexa e densa, que propicie entre eles uma sustentação mútua e constante, tanto econômica quanto social." (JACOBS, 2009, p. 13).

Em design, aborda-se com frequência a inovação como requisito básico, senão primeiro, de projetos. A indisciplina também é um exercício de constante inovação, considerando-se a capacidade encontrada neste tipo de comportamento para transcender o que foi prescrito ou imposto. Ela testemunha a capacidade e a sensibilidade dos indivíduos e dos grupos de enxergar outras possibilidades de uso da natureza, dos lugares e dos objetos.

A indisciplina, pensada no âmbito da prática do fabricar/produzir os próprios artefatos (anterior ao design), é um dos recursos usados pelos indivíduos na busca pela sobrevivência, cujos níveis de garantia são extremamente variáveis em função das sociedades. Tomando como exemplo os Inuit - "os melhores designers do mundo" - Papanek compara as culturas civilizadas com os povos ditos "primitivos" na questão da sobrevivência:

\footnotetext{
À exceção das ameaças representadas por acidentes termonucleares e um meio ambiente cada vez mais poluído, os chamados povos civilizados desfrutam de tantas proteções incorporadas, e estão a tal ponto perdidos nas preocupações rotineiras da vida do dia-a-dia, que a questão da sobrevivência é ignorada. Mas para os povos que vivem a nível mais "primitivo", a sobrevivência é uma questão cotidiana. (PAPANEK, 2007, p. 249-50).
} 
A sobrevivência como urgência de bens essenciais - alimentação, roupa, abrigo, utensílios - iguala os Inuits aos chamados povos civilizados, para os quais esta questão passa desapercebida, por disporem de inúmeros sistemas implícitos de proteção no dia a dia. Por viverem em um nível mais "primitivo", a questão da sobrevivência é cotidiana para os Inuits. Comparo, grosso modo, os comerciantes com os Inuits. Guardando as devidas especificidades, uns e outros têm como preocupação diária a questão da sobrevivência, o que os move a solucionar e atender, por eles mesmos, seus problemas, necessidades, expectativas (Figura 1.6).
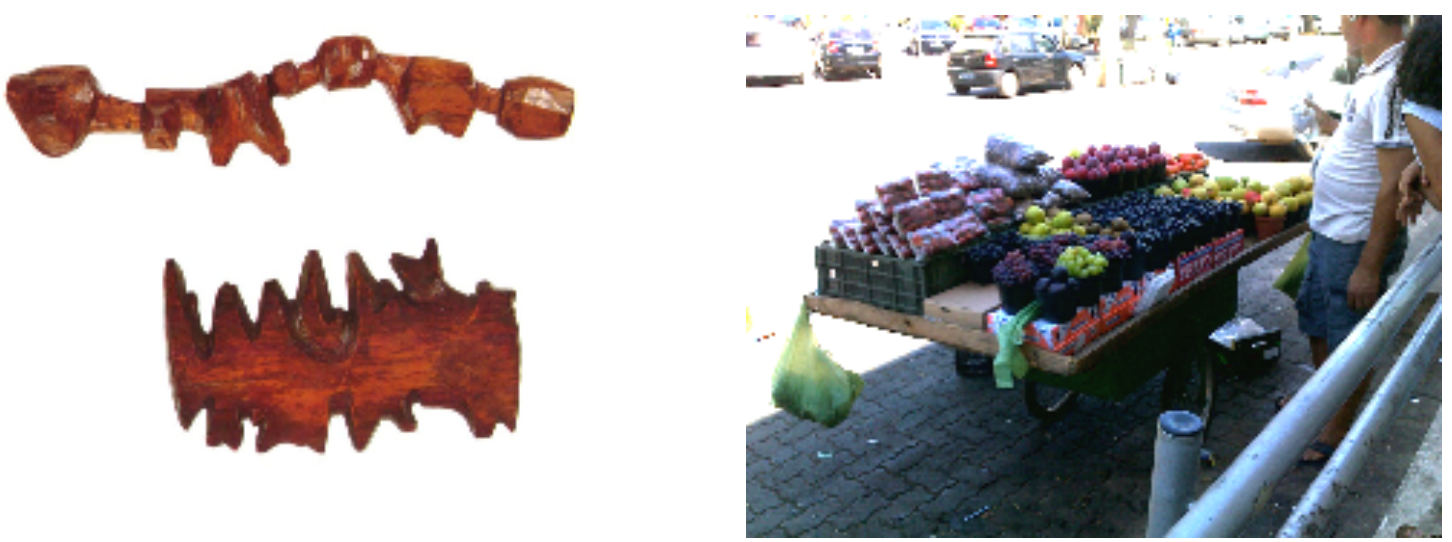

Figura 1.6 - comparação entre recursos de sobrevivência entre os Inuits e os camelôs: à esquerda um mapa inuit tridimensional de madeira - Fonte: http://enciclopediavisual.blogspot.com.br/; à direita uma banca de camelô de frutas no Núcleo Bandeirante/DF - Fonte: Nana Ervilha.

Os diferentes níveis de garantia de sobrevivência também podem ser constatados no interior de cada sociedade e numa mesma cidade. Membros de diferentes classes sociais estabelecidas ou emergentes, interagem no dia-a-dia e se diferenciam nos níveis de garantia de sobrevivência que possuem. São soluções em atividades diárias muito simples, que ora utilizam os mesmos lugares, ora circulam por pontos diferentes da cidade. Algumas são perenes, outras passageiras, mas todas buscam o interesse e a necessidade das pessoas por seus produtos, serviços e, porque não, pela troca social que estas atividades acarretam.

Sob o ponto de vista econômico e do trabalho, a indisciplina tratada aqui é a praticada pelos incluídos no setor informal. O setor se caracteriza, de modo geral, pela inserção no mercado de trabalho dos empregos sem contrato firmado e do 
trabalho por conta própria ${ }^{25}$. Neste último modo estão os comerciantes que atuam nos lugares abertos das cidades e em um espaço econômico diretamente relacionado às formas da produção capitalista que se movimentam numa dimensão de espaço-tempo. Por isso, este setor é comumente analisado como sendo constantemente recriado conforme a situação geral da economia em que está inserido, especialmente, no contexto urbano (SOUZA, 1982, p. 108). O termo setor informal, tem a sua conceituação baseado em características com foco na organização da produção do trabalho não assalariado ${ }^{26}$ :

(1) O produtor direto é o possuidor dos instrumentos de trabalho e/ou de estoque de bens para a realização de seu trabalho e se insere na produção sob a forma simultânea de patrão e empregado. (2) Ele emprega a si mesmo e pode lançar mão de trabalho familiar ou de ajudantes como extensão do seu próprio trabalho; obrigatoriamente, participa diretamente da produção e conjuga essa atividade com aquela de gestão. (3) O produtor direto vende seus serviços ou mercadorias e recebe um montante de dinheiro que é utilizado, principalmente, para consumo individual e familiar e para manutenção da atividade econômica. (4) A atividade é dirigida pelo fluxo de renda que a mesma fornece ao trabalhador e não por uma taxa de retorno competitiva, e é desta renda que se retira os salários dos ajudantes ou empregados que possam existir. (5) Nesta forma de produzir não existe vínculo impessoal e meramente de mercado entre os que trabalham - entre estes se encontra, com frequência, mão de obra familiar. (6) $O$ trabalho pode ser fragmentado em tarefas, mas isso não impede ao trabalhador aprender todo o processo que origina o produto ou serviço final.

A autora aborda o tema para além das questões puramente econômicas. Preocupase com as limitações das conceituações que alocam, por exemplo, os trabalhadores deste setor no grupo dos que alcançam baixos níveis de renda, enquanto fazem parte, também, os alocados no setor formal. Ela relativiza as origens deste setor em três aspectos básicos que, comumente, são colocados de modo bastante taxativo: atribuição à necessidade de sobrevivência do excedente de mão-de-obra; relação da produção, manutenção e permanência do setor para atender às demandas de grupos mais pobres e caracterização pelo grau elevado de competição (op. cit., p. 40).

\footnotetext{
${ }^{25}$ SOPLA (2010:71). Estas são duas das três posições na ocupação dos trabalhadores, que são: emprego com contrato firmado, emprego sem contrato firmado e trabalho por conta própria. No caso das posições do setor informal, segundo o trabalho desenvolvido pela fundação citada, nenhuma delas é regida por uma legislação trabalhista específica. Porém, desde dezembro de 2008 , temos no Brasil a Lei complementar no. 128, em que foi criada a figura do Microempreendedor Individual - MEI, que condiz e atende à situação do trabalhador por conta própria.

${ }^{26}$ Estas são as características que Souza (1982, p. 27) utiliza como base de sua tese. (Itens transcritos com adaptações).
} 
A abrangência devida com que deveria ser tratado o setor informal envolve tópicos que o defendem como oportunidade de emprego não somente para aqueles que não são absorvidos pelo mercado de trabalho formal, mas para os que desejam seguir por esta opção. Ela constata ainda que as atividades informais não necessariamente concorrem com as formais e que não é intrínseco a elas suprir somente demandas de camadas mais pobres do meio urbano. Existe um espaço econômico que permite a exploração deste tipo de setor e "a configuração de um setor informal numa dimensão espaço-temporal específica, absorvendo elevados contingentes de trabalhadores com baixa qualidade de força de trabalho e propiciando baixos níveis de renda a seus integrantes, pode estar expressando a debilidade não do setor informal em si, mas do processo e padrão de desenvolvimento capitalista em marcha, refletido por um perfil do setor formal" (op. cit., p. 108).

Destaco, da tese de Souza, a abordagem e escolha por tratar o setor informal como parte integrante da economia, sem a postura reducionista de tratá-lo como o "problema da informalidade", mas entendê-lo e conceituá-lo com base no mais próximo da realidade e aportá-lo como a qualquer outra atividade econômica e de trabalho. As peculiaridades da organização deste tipo de trabalho devem ser consideradas pelos que se ocupam do planejamento e projeto das cidades. "Aprender a trabalhar e manter-se no setor informal exige liderança, criatividade, desembaraço e até agressividade em determinadas circunstâncias." (op. cit. 39). São características que em alguns traços diferem do trabalho nos moldes formalizados, pois são menos burocráticos, mais dinâmicos, com alguma rotina, mas descontínuos, dependendo da situação. Perfis diferentes que formam o todo da estrutura produtiva. O formal, inevitavelmente, abre lacunas para o informal, assim como as estratégias e táticas.

\subsubsection{Entre as atividades no espaço urbano}

As atividades no espaço urbano, de modo geral, passaram por transformações significativas, ao longo da história. Aconteceram de modo intenso na época da cidade industrial, em que a maior parte das trocas comerciais aconteciam em lugares públicos. Apesar das condições precárias dos ambientes em que ocorriam, eram característica marcante das ruas daquele tempo. 
Na verdade, o espaço público - mal dimensionado, precário, insalubre - era o que os habitantes mais humildes da cidade industrial tinham de seu. Estavam todos ali, expondo sua miserável condição, facilmente captada por quem percorresse ruas e praças, mas também e fundamentalmente estavam, das formas possíveis, apropriando-se da cidade. (TENORIO, 2012, p. 40).

O impacto desta situação nos que se ocupavam das questões da cidade foi majoritariamente negativo, o que deu origem a projetos com o objetivo principal de expurgá-la. O urbanismo, no início do século XX, como uma área interdisciplinar atuante sobre o espaço da cidade, é acionado para a especificidade de contornar este quadro de desordem. Com certa ortodoxia, seus primeiros profissionais procuravam estabelecer, em seus projetos, modos padronizados de uso das cidades, limitando, reduzindo e homogeneizando a população, como se assim pudessem determinar a vida no espaço público (op. cit., p. 42).

A partir da principal reação à situação das cidades industriais - a cidade-jardim, de Ebenezer Howard - as atividades em via pública começam a ser consideradas de modo diferente. Três são os fatores principais que levam a isso: padronização nos tipos de moradia; separação drástica de funções (o que já começava a ocorrer nas cidades industriais) e transformação gradual da função da rua. Estes dois últimos fatores foram mantidos e estabelecidos no movimento moderno, em que se somou o início da setorização do espaço público para atender atividades específicas (op. cit., p.47-56).

A rua, então, tem a sua função transformada em passagem e entidade que separa, não mais congrega, outros espaços e funções na cidade. Neste contexto, as atividades que antes eram o motim da vida pública, passam a ser marginalizadas como tudo o que se tentou eliminar com o urbanismo moderno: o insalubre, a desordem, o convívio, pelo que as cidades de outrora ofereciam como espaço urbano de plena socialização espontânea.

A preocupação com os efeitos negativos destas medidas na qualidade da vida pública dos espaços da cidade, gera estudos no âmbito da arquitetura e do urbanismo, que nesta tese, se expande para a área do design. 
O comércio informal em via pública é apenas um dos diversos tipos de atividade que ocorrem no cotidiano de uma cidade. Com relação a essa diversidade e as respectivas condições físicas favoráveis, Jan Gehl, em seus estudos sobre o incremento da qualidade da vida das pessoas no espaço "entre edifícios", chega a uma categorização em que as atividades podem ser necessárias, opcionais e sociais (GEHL, 2006, p. 09).

Segundo o autor, o mínimo grau de demanda para ser executada, faz a atividade ser categorizada como necessária. As atividades opcionais envolvem vontade de executá-las, ou melhor, de desfrutá-las. E, finalmente, para uma atividade ser categorizada como social, ela precisa, no mínimo, da presença de pessoas em um mesmo lugar.

Alguns exemplos podem ser citados dentro de cada categoria dessas, porém, como observo o pequeno sistema em que quem vende está ali por necessidade, quem compra está ali por opção e ambos podem desfrutar de relações sociais em decorrência das anteriores, não tomo esta categorização de modo a desvincular uma categoria da outra em toda e qualquer atividade. O autor chega a concluir que algumas (categorias) levam às outras. Estas categorias estão tão imbricadas na maioria das atividades que seria desnecessário encará-las como tal.

Categorizamos quando podemos isolar em grupos os itens com as mesmas características. No caso da atividade específica do comércio em via pública (e acredito que em muitas outras), as três categorias estariam presentes, concomitantemente. Vender é uma necessidade; comprar pode ser uma necessidade ou opcional; vender, comprar, ou passar pela atividade é um ato social. Acredito que ser necessárias, opcionais ou sociais são modos de analisar as atividades e não categorias. Parecem categorias ao primeiro contato com a atividade, mas analisando-a com profundidade, pode-se descobrir outros espectros além daquele percebido inicialmente.

Com esta correção de ponto de vista, utilizo, também, o trabalho do autor na construção do método e na análise dos estudos de caso, mais ainda quando ele 
trata das condições físicas do espaço para as atividades, em que esmiúça praticamente todas as possibilidades.

Em sua discussão sobre os equívocos dos processos de reurbanização, Jane Jacobs nos alerta (na verdade, é um incisivo convite) para emergência da aventura pelo mundo real das cidades, de maneira mais próxima, despretensiosa e aberta aos fatos mais comuns. Nesta trilha, tento localizar o comércio informal entre a variedade de atividades que se pode observar no espaço urbano, desde as mais triviais até o próprio comércio, que tem um grau de complexidade, entre outras atividades, significativo.

Diversidade é um atributo natural às grandes cidades e, por isso, a combinação dos usos é um dos principais pontos de partida para se compreender a lógica das cidades como meio social (op. cit., p. 157). A proximidade de diversos tipos de serviços e produtos, que permitem o funcionamento da vida diária, é uma organização que atende às demandas de naturezas, também diversas, das várias regiões e núcleos de uma cidade. Em termos econômicos, para grandes e pequenos empreendedores, de segurança e, principalmente, de incremento da vida social, a diversidade é condição essencial para a garantia de cada um destes aspectos básicos.

Das quatro condições para gerar diversidade no espaço urbano, segundo Jacobs ${ }^{27}$, destaco duas em relação as quais o comércio informal seria beneficiado e, de certa forma, beneficiaria. A primeira diz respeito à necessidade de usos combinado do espaço de maneira que, em diferentes períodos do dia, haja a garantia da presença de pessoas circulando. A atividade em questão seria beneficiada no que tange ao fluxo de pessoas que passa por ela, o que potencializaria as vendas. A outra condição fala sobre a necessidade de concentração de usos no espaço urbano. Diversificação por usos combinados e por concentração. As escolhas dos lugares para a localização do ponto de comércio, com certeza passam por estas oportunidades.

\footnotetext{
${ }^{27}$ As quatro condições são: "a necessidade de usos principais combinados; a necessidade de quadras curtas; a necessidade de prédios antigos e a necessidade de concentração" (JACOBS, 2009, p. 165).
} 


\subsubsection{O comércio de alimentos - um sistema}

Entre os pontos de comércio observados para a análise do trabalho empírico da tese $^{28}$, me deparei com diversos tipos de produtos colocados a venda. De acessórios pessoais a móveis, podem ser encontrados tapetes, roupas, frutas, balas e doces, coco/água de coco, alimentos revendidos e (pré)preparados, entre outros. Como compartilho da constatação de que as atividades incrementam e retomam historicamente a saúde da vida pública das cidades, escolhi aquela cujo tipo de produto vendido propicia maior permanência das pessoas no local de venda. Assim, os pontos previamente observados, cujos produtos eram alimentos (pré)preparados foram os escolhidos. "Se você quer alimentar um lugar com atividade, ofereça alimento" $^{29}$ (WHITE, 2009, p. 50).

Atividades, de modo geral, são magnetos e as que se encarregam da alimentação têm capacidade significativa de atrair e manter alguma permanência de pessoas em determinado local no espaço urbano. Podem ser consideradas, então, como um dos diversos atratores dentro do espaço urbano que sofrem efeito da configuração dos lugares em que se encontram, assim como o movimento, segundo o conceito do movimento natural. Como tal, também podem repercutir no movimento de pessoas no lugar em que estão localizadas.

Necessidade e prazer, aliados ou não, movem a busca por alimentos nas ruas. De refeições mais completas a petiscos, os alimentos (pré)preparados geralmente são vendidos em lugares que são um misto de passagem e lugar de estar, ou melhor, lugares que foram projetados para passagem, mas que são transformados pela atividade em um ambiente para permanecer.

White chega a considerar o sucesso de uma praça observada, a um vendedor que lá está cotidianamente, há anos (op. cit.). Por sua vez, os pontos de comércio informal que se mantêm durante tempo considerável no lugar escolhido e apropriado e

\footnotetext{
${ }^{28}$ Foram feitas várias visitas aos lugares e vias do Plano Piloto e do centro de Taguatinga, para a escolha da região onde seria feito o trabalho de campo.

29 "If you want to seed a place with activity, put out food" (Tradução livre).
} 
conquista uma clientela fidelizada podem ser considerados empreendimentos de sucesso, igualmente. Pode-se constatar que existe uma mutualidade de repercussão entre o lugar e o ponto de comércio, no que diz respeito ao sucesso de cada um. Um lugar bem sucedido no espaço urbano é aquele que apresenta um potencial considerável de condições de passagem e permanência, o que irá repercutir de modo favorável para a inserção de pontos de comércio. Estes, por sua vez, são atratores de movimento para o local em que estão. Depreende-se, do que White destaca sobre o comércio de alimentos no espaço urbano, que o sucesso dos pontos de comércio pode ser medido pelo tempo de apropriação do lugar em que estão e pela popularidade entre os consumidores ${ }^{30}$, chegando a uma fidelização espontânea.

Comidas típicas são um chamariz pelo apelo cultural. Se elas têm origem longe dali, começam a fazer parte do cotidiano do lugar e da vida das pessoas que as consomem (Figura 1.7).
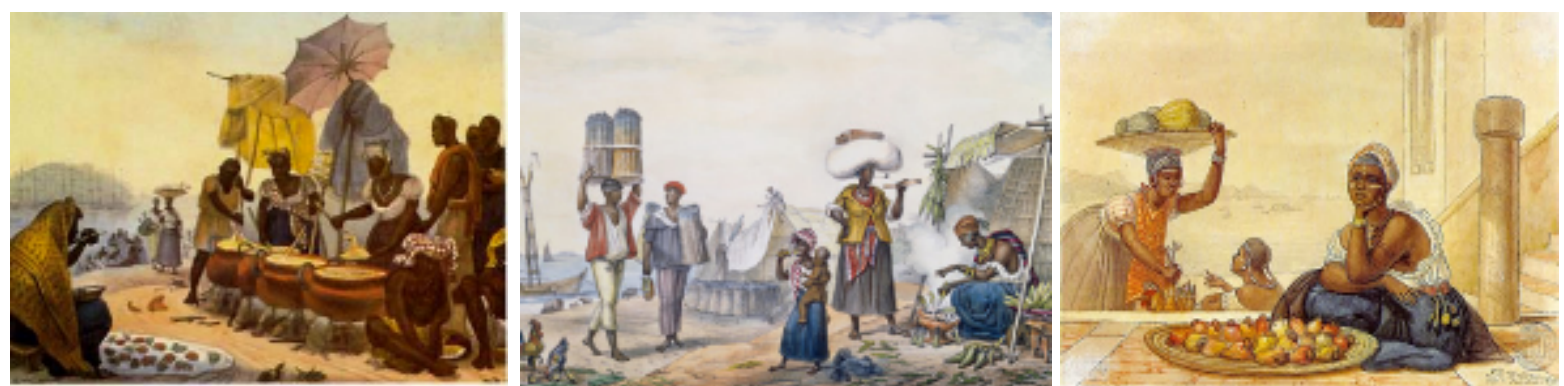

Figura 1.7 - exemplos de comércio informal de alimentos, no Brasil, retratados por Jean-Baptiste Debret, no início do século XIX. Da esquerda para a direita: "Negras vendendo angu", "Negros vendendo carvão e milho" e "Negra tatuada vendendo caju". Fonte: www.dezenovevinte.net reproduções do livro Voyage pittoresque et historique au Brésil, de Jean-Baptiste Debret (1768-1848).

Pontos de venda de comida (pré)preparada são magnetos de: pessoas, outros pontos com produtos similares, ou complementares (como bebidas) e outras atividades. A oportunidade encontrada pelos vendedores informais, nos espaços abertos da cidade, está na demanda constante, por parte dos pedestres (e motorizados), que os estabelecimentos comerciais regulares não conseguem

\footnotetext{
30 "Food attracts people who attract more people." (Comida atrai pessoas que atraem mais pessoas) (WHITE, 2009, p. 52)
} 
atender $^{31}$. Um exemplo disso, são os trabalhadores que tomam café da manhã na rua, em um destes pontos, porque não têm condições financeiras de frequentar uma padaria, todos (ou quase todos) os dias da semana. Existem consumidores para ambos os tipos de comércio.

A medida oficial de fiscalizar e retirar das ruas os pontos desta atividade em específico, vai além da questão da apropriação e do uso indevido do local escolhido pelo vendedor. O aspecto sanitário também é fiscalizado, porque parte-se do princípio de que, por ser na rua, o alimento vendido é insalubre, herança de tempos remotos, como podemos constatar no histórico das cidades e da atividade.

Para além do aspecto gastronômico, a venda de alimento (pré)preparado, impulsiona a copresença e a permanência de várias pessoas em um mesmo local. Sem dúvida, se este tipo de comércio não é o de maior potencial de incremento da vida social, é um dos principais. E o que isso mobiliza? Um entre vários núcleos de sociabilização da cidade, pelo prazer do consumidor em estar ali, suprindo a necessidade da alimentação combinado com a confiança/segurança alcançada tanto por parte do ponto de comércio, quanto por parte do lugar/ambiente.

A atividade mobiliza, também, elementos de naturezas diferentes que, relacionados de modo específico, permitem o seu desenvolvimento. Deste modo, trata-se do (sub)sistema que ela acarreta, que tem como camadas principais o contexto imediato, a atividade em si e a interface entre eles, apresentado anteriormente. $\mathrm{O}$ encontro de áreas diferentes do conhecimento e a interrelação de suas camadas conduz o estudo desta atividade no espaço urbano ao ponto de vista sistêmico.

A contextualização do objeto - a atividade do comércio - de modo local e global, ou em relação ao lugar escolhido e à cidade, respectivamente, e a complexidade determinada pelas diversas relações entre elementos da atividade, do lugar e as pessoas envolvidas, definem a abordagem da pesquisa também pela Teoria Geral

\footnotetext{
${ }^{31}$ William White, em sua pesquisa registrada em "The Social Life of Small Urban Spaces", estabelece a relação inversamente proporcional entre estabelecimentos comerciais regulares e pontos de comércio informal, em relação às demandas de consumo de alimento no ambiente urbano.
} 
dos Sistemas. A consideração de fenômenos como entidades constituídas de partes em interação é a matéria desta teoria que coloca em questão a ciência clássica.

As questões tratadas no âmbito das ciências sociais aplicadas, caso desta pesquisa, apresentam uma demanda de análise e síntese que a ciência desenvolvida sobre esquemas conceituais de caráter monolítico não atende adequadamente.

\begin{abstract}
A ideia de sistema conserva seu valor mesmo quando não pode ser formulada matematicamente ou permanece uma "ideia diretriz" mais do que uma construção matemática. Por exemplo, não podemos ter conceitos satisfatórios de sistemas em sociologia. A simples compreensão de que as entidades sociais são sistemas e não somas de átomos sociais, ou de que a história consiste em sistemas (embora mal definidos) chamados civilizações, que obedecem aos princípios gerais dos sistemas, implica a reorientação desses campos. (BERTALANFFY, 2015, p. 47).
\end{abstract}

$\mathrm{Na}$ reflexão sobre a evolução da ciência moderna, Bertalanffy constata o crescimento da especialização, resultado da soma de dados, da complexidade das técnicas e das estruturas teóricas de cada campo que, em consequência disso, se tornam cada vez mais encapsulados. Apesar e além disso, muitos desses campos diferentes entre si, têm problemas e concepções semelhantes e apresentam grandes possibilidades de se unirem em regiões de princípios mais gerais (p. 54).

A reboque desta teoria está o conceito de complexidade que, como toda vítima de modismos, é "consumida" como uma novidade de mercado. "Por isso, é importante termos presente que, apesar de a estarmos tomando como uma das dimensões do novo paradigma da ciência, não é a complexidade que é nova, mas é o seu reconhecimento pela ciência que é muito recente." (VASCONCELOS, 2012, p. 104).

Assimilada como uma propriedade que deve ser abordada em diversas disciplinas, não somente nas primeiras demandantes - biológicas e sociais - constata-se, atualmente, que a complexidade é parte integrante da análise de grande variedade de fenômenos.

Segundo Edgar Morin (2003), a questão da complexidade está na demanda de se conhecer qualquer objeto de estudo necessariamente ligando-o ao seu contexto, por 
meio da mobilização e congregação de saberes. Trata-se do trânsito entre as partes e o todo.

\begin{abstract}
Vivemos numa realidade multidimensional, simultaneamente econômica, psicológica, mitológica, sociológica, mas estudamos estas dimensões separadamente, e não umas em relação com as outras. O princípio da separação nos torna talvez mais lúcidos sobre uma pequena parte separada do seu contexto, mas nos torna cegos ou míopes sobre a relação entre a parte e o seu contexto. (MORIN, 2003, p. 15)
\end{abstract}

O primeiro de sete princípios para pensar a complexidade é o princípio sistêmico ou organizacional (MORIN, 2003, p. 27-30) ${ }^{32}$. Este princípio traduz a essência do pensamento complexo de integrar as partes que já são estudadas separadamente, complementando a postura da simplificação que separa objetos ou fenômenos que estão no foco do estudo. "Em vez de se concentrar nos elementos ou substâncias básicas, a abordagem sistêmica enfatiza princípios básicos de organização." (CAPRA, 2012, p. 260). Inevitavelmente, a separação do problema em elementos constituintes é necessária, mas este tipo de análise deve ser seguido da interrelação entre estes elementos estudados de modo separado. O entendimento não se confirma sem essa outra metade do estudo de qualquer objeto.

O propósito principal da Teoria Geral dos Sistemas é o de integrar as várias ciências, inclusive as sociais, alcançando para elas uma teoria mais definida, por meio de princípios que as unificam e atravessam, em busca de uma interrelação entre campos e áreas, há muito necessária na educação científica (BERTALANFFY, 2015, p. 60). E, ainda segundo o autor, em relação às ciências biológicas e sociais, em específico, existe uma exigência de generalização de conceitos básicos da ciência, no processo de assimilação desses campos pela tecnologia moderna, que implica novas categorias do pensamento científico (p. 131).

Matéria das ciências sociais, o estudo de grupos humanos, dos menores (famílias) aos maiores (nações), os abarca como sistemas. As relações de interdependência não se restringem aos elementos materiais das atividades praticadas por estes grupos. Os sistemas sociais abrangem alguns tantos aspectos de natureza imaterial

\footnotetext{
32 Toda a relação consiste nos princípios: sistêmico, hologramático, do anel retroativo, do anel recursivo, de auto-eco-organização, dialógico e da reintrodução.
} 
(p. 251). Ao analisarmos uma atividade como a do objeto de estudo em questão, é abarcada uma diversidade considerável de entidades, entre materiais e imateriais.

A referência teórica neste tipo de abordagem se pauta na busca por um tratamento da atividade do comércio no espaço urbano, considerado em suas três camadas, como um todo organizado e empenhado em seu potencial funcional e social, em que todas as suas partes são previstas e trabalham para o seu melhor desempenho neste sentido.

Uma das diversas características dos sistemas é a hierarquia no modo em que são trabalhados. São (sub)sistemas dentro de sistemas maiores. Aqui, o ponto de comércio é considerado um subsistema dentro de um outro subsistema que pode ser um dos trechos específicos da Asa Norte, que por sua vez está inserido no subsistema representado pelo Plano Piloto e assim por diante. Um subsistema tem interação com os outros por meio de entradas e saídas de elementos entre eles.

Entre os modelos de sistema existentes, o que interessa aqui são os sistemas abertos, justamente por caracterizarem a troca entre o que ele encerra e o ambiente que o cerca (outro sistema). Originalmente encarados como "complexos de elementos em interação", os sistemas podem ser físicos ou conceituais que, como já mencionado, abarcam respectivamente entidades materiais e imateriais. Para a análise do objeto desta pesquisa, foi necessário sobrepor estes dois tipos, por se tratar do desempenho da configuração dos lugares em relação aos aspectos sociais e funcionais da atividade.

Em termos físicos, para a atividade do comércio em lugares públicos, é mobilizado um conjunto de aparatos que podem ser descritos de modo mais geral. A apropriação do lugar se dá no momento em que o comerciante chega com alguns artefatos, incluindo os produtos a serem vendidos, e os compõem em conjunto com os do lugar (arquitetura ou paisagem). De modo geral, no comércio de alimentos (pré)preparados, os comerciantes se utilizam de tendas; mesas (para clientes e auxiliares); cadeiras; fogareiro, churrasqueira ou rechaud; pequenas estantes; caixotes (ou engradados) de madeira; caixas térmicas (de isopor); objetos menores de cozinha e mesa, como toalha de mesa, vasilhames, pratos, talheres, copos, 
garrafas térmicas, guardanapo, temperos etc. Contam, também, com elementos que já estão no local como suportes de sinalização; mobiliário urbano como bancos de alvenaria; latas de lixo; muros; calçadas; postes; árvores, arbustos, cercas vivas e canteiros etc. (Figura 1.8).

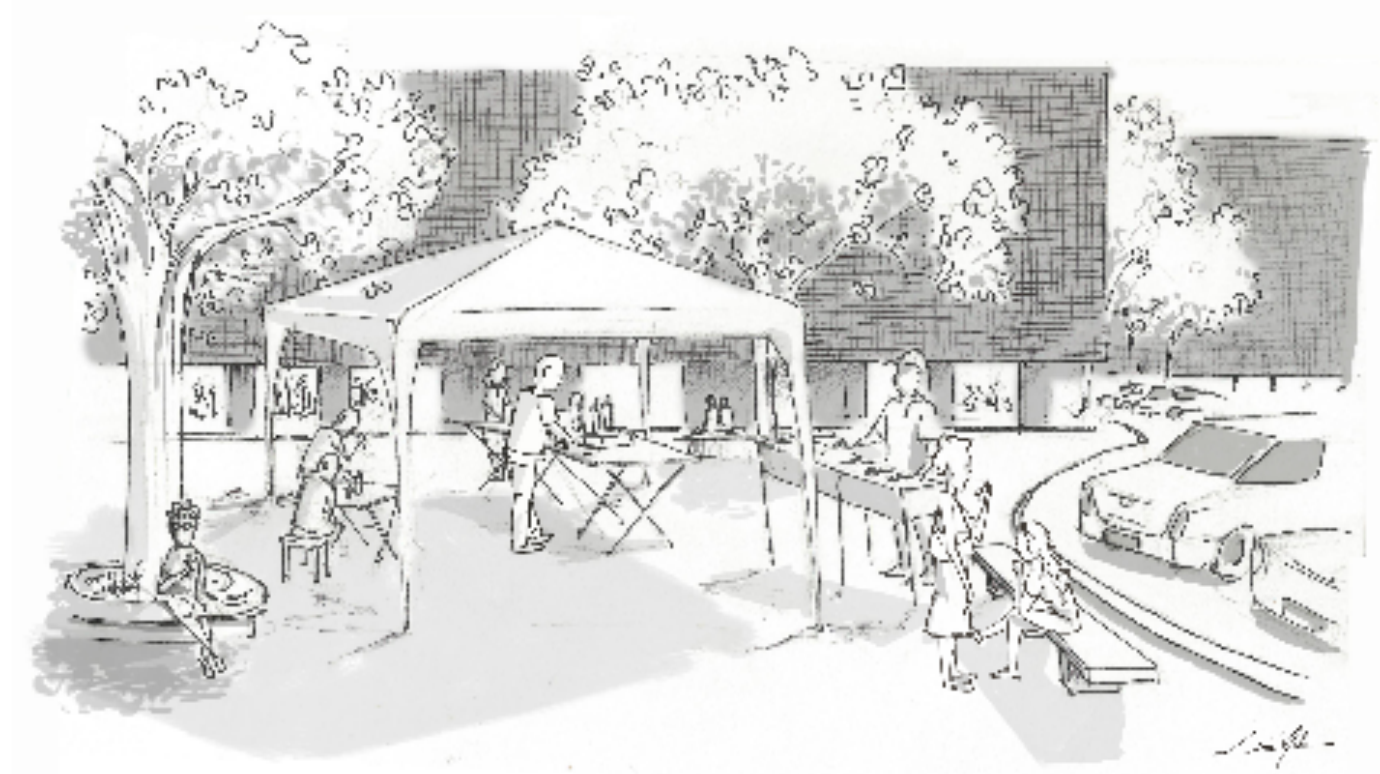

Figura 1.8 - ilustração/base para a explanação da ação de um ponto fictício de comércio de alimentos, dentro de uma quadra residencial no Plano Piloto - Brasília. Ilustração por Luísa Melo.

A caracterização da atividade como um sistema se dá na medida em que estes elementos interagem entre si e com os agentes - comerciante(s), clientes e passantes - nas ações entre e por intermédio deles. Obviamente, estas ações acontecem nos espaços delimitados por estes elementos físicos e pela massa edilícia ao redor. As entradas e saídas deste sistema, neste caso, são não somente dos produtos a serem vendidos, mas dos próprios elementos dispostos no local, das ações que consistem da compra/venda dos produtos, dos produtos em si, das pessoas envolvidas. Este subsistema interage de modo hierárquico com o subsistema imediatamente maior - o lugar escolhido para a montagem do ponto.

O que seria e como identificar a complexidade no sistema que caracteriza a atividade do comércio observada? Por envolver um grande número de elementos e a interrelação entre todos eles, a complexidade desta atividade é consideravelmente 
alta, incluindo o fato de dois sistemas de naturezas distintas se fundirem em um mesmo evento.

A dificuldade de apreensão das diversas relações de interdependência entre os elementos de um sistema conduz, inevitavelmente, ao trabalho de captá-lo por partes. Niklas Luhmann (1998) distingue elementos e relações como os dois fatores primordiais em um sistema e dois conceitos que o embasam - o da operacionalidade e o da observação. Diz que "a complexidade impõe a seleção". A qualificação de seus elementos/relações está na necessidade de selecioná-los tanto para a operacionalização do sistema, quanto para observá-lo. Se entre diversos elementos e relações, seleciona-se alguns, isto quer dizer que estes são importantes, ou prioritários no funcionamento daquele sistema. O autor, então, define complexidade com base na medida da falta de informação que um sistema possibilita, ou nas incertezas de conclusões que se tem em sua observação (p. 2627). Concluo que, diante da atividade como um todo, quanto maior a necessidade de selecionar seus elementos e relações, maior é a complexidade que ela apresenta como sistema.

\subsection{As implicações do design na atividade}

Os recortes da pesquisa nortearam sua visualização sob o ponto de vista do design de modo que os aspectos sociais encabeçam este item. Em seguida, é discutida a parceria entre as áreas envolvidas, por meio da interface entre atividade e contexto. As premissas do Design de Interação são acionadas e comparadas à situação em estudo. Acesso alguns conhecimentos e princípios desta disciplina específica dentro do design, que vem crescendo em estudos e práticas, por acreditar na amplitude de sua abordagem, que não se restringe ao universo digital.

Para a compreensão da composição do ambiente tomo como base a pesquisa desenvolvida pela Teoria da Abordagem Ecológica (Affordance), que tem como premissa a complementaridade entre o homem e o meio. A partir daí, considero cada ponto de comércio, uma composição constituída, também, por um conjunto de affordances. 


\subsection{1 $O$ aspecto social do design e os não designers}

Philip Pacey (1992) retoma o período um pouco anterior à industrialização e, por conseguinte, à profissionalização da atividade de projetar artefatos e relaciona a emergência da profissão de design com a remoção da dupla de habilidades projetar e fabricar do espaço público para lugares privados. O autor constata que esta remoção se deu no sentido de permitir que fossem desenvolvidas as habilidades e o conhecimento de certas categorias de atividade para atender a um maior número de pessoas. A produção de um artefato deixa de ser feita para benefício próprio, em baixa escala, ou em peça única para ser fabricada por repetição. Esta mudança facilitou a produção de uma escala maior de artefatos para atender a um público também maior. Este fato transfere para um público anônimo o atendimento de expectativas, a partir deste momento, grupais ou mesmo universais, o que confere à profissionalização desta e de outras atividades, a causa deste tipo de dependência entre os indivíduos de uma sociedade.

Diante desta "dependência", são duas as lentes pelas quais enxergo o aspecto social do design, não somente na atividade do comércio informal em via pública, mas em todo e qualquer produto oriundo desta prática profissional. A primeira, e necessariamente nesta ordem, é a abordagem do artefato como ente intrinsecamente social e a segunda, consequência da primeira, é a atenção sobre a responsabilidade social do design.

Retomo a perspectiva social do design de interação, de Saffer, para destacar a visão sobre a condição inerente de qualquer artefato de ser social, na medida em que compõe com e um ambiente, permite ações e conecta pessoas.

Segundo Abraham Moles (1989), os artefatos podem ser distinguidos de três maneiras diferentes, com base na relação entre os aspectos do ambiente e os indivíduos que interagem com eles: objetos individuais, ambientes domésticos e sistemas de larga escala (ambientes urbanos e de trabalho). Eles variam conforme tamanho e proporção no universo material das pessoas (p. 78). O artefato é, naturalmente, o resultado da tradução de valores e expectativas humanas em formas. $O$ ato da interpretação das possibilidades e limitações funcionais de uma 
atividade qualquer é intrínseco a quem projeta, em maior ou menor grau, dependendo do envolvimento com a realidade do que se está projetando.

Os artefatos em uma atividade são tão importantes quanto os agentes e a própria ação. Não considero nenhum dos elementos de entrada do sistema da atividade como elemento mediador de outros mais importantes. Victor Margolin (1995, p. 122) elege o termo "product milieu" que, em sua concepção, agrega os objetos, atividades, serviços e ambientes como partes da "vida do mundo" ${ }^{33}$. Assim considerando, os artefatos já são concebidos com implicações sociais intrínsecas. Fator este que alinha as abordagens sobre espaço e elementos físicos, pois a grande contribuição da Sintaxe Espacial é considerar os espaços, construídos ou naturais, por suas implicações sociais intrínsecas. Este tipo de implicação dos artefatos conduz à responsabilidade social do design, sobre a qual Papanek discorre.

No "Design for the real world", ele fala sobre necessidades reais e especiais, ética, pobreza do "Terceiro Mundo" e outras questões que permearam e permeiam a vida material e social humana. Denuncia omissões e inconsistências em projetos, condutas, posturas, cultura dentro do design, mundo afora, pelos mais variados motivos como incremento do consumismo, obsolescência forçada, projetos para uma minoria privilegiada. Como designer e antropólogo, o autor pode se debruçar sobre a diversidade de expectativas humanas - que variam de acordo com códigos universais, grupais, ou individuais. Suas reflexões sobre a própria experiência em diversos países continuam sendo um norte para questões sociais atuais que envolvem o design.

Atualizações da realidade no que se refere "a explosão do mundo digital" são muito bem-vindas e reconhecem a constância dos problemas colocados por Papanek, anos atrás.

O 'mundo real' de Papanek já não é mais o mesmo: sobretudo, porque a explosão do meio digital nos últimos anos tem transformado de modo

\footnotetext{
33 "Vida do mundo" é tradução de "lifeworld", termo utilizado por Alfred Schultz, um dos teóricos sociais (os outros: George Herbert Mead, Max Weber, Talcott Parsons, Thomas Luckmann e Alain Touraine) de quem Margolin "reclama" uma teoria da ação social relacionada com produtos.
} 
profundo a paisagem econômica, política, social e cultural. (...) Não que o 'mundo real' tenha deixado de existir! Os problemas apontados por Papanek, de miséria e exploração, violência e degradação, são mais reais do que nunca. Aliás, se examinarmos os dados estatísticos, muitos deles estão piores do que quatro décadas atrás. Apenas foi acrescentada à realidade material uma camada a mais, que tudo envolve e tudo permeia. (CARDOSO, 2012, p. 19-20)

A prática do design ainda é restrita a um tipo de público e ao mercado consumidor. Problemas que não têm vínculo direto com o consumo não são comumente tratados por designers, inclusive e principalmente, os de cunho social.

Papanek diz que "O conteúdo telesic de um projeto deve refletir os tempos e as condições que deram origem a ele e deve ser conjugado com a ordem socioeconômica humana em geral em que está inserido." ${ }^{34}$ (1984, p. 17). É o que interpreto como a busca por uma proximidade com o que de fato acontece socialmente. No caso do tema aqui abordado, a observância de vivências e práticas cotidianas no espaço urbano elucidaria variadas questões há muito não resolvidas, tão pouco detectadas.

Nesta linha de raciocínio, por ser parte ativa principal desta realidade cotidiana do espaço urbano, o comerciante informal é o designer das questões de sua própria atividade de trabalho. Aqui está no centro o produto do processo de design deste trabalhador. Na definição "design é o esforço consciente e intuitivo para impor ordem significativa”" ${ }^{35}$, Papanek resume um pensamento abrangente sobre esta atividade:

Todos os seres humanos somos designers. Tudo o que fazemos, quase todo o tempo, é design, por ser a base para toda a atividade humana. $O$ planejamento e a padronização de qualquer ação em direção a um objetivo previsível e desejado é um processo de design. (1984, p. 03)

A ação não especializada dos comerciantes informais, na maioria das vezes, tem como base a bagagem de conhecimento adquirido com a conjunção de estudo (muito pouco, às vezes) e, principalmente, com a experiência de vida, guiada por necessidade de sobrevivência, ambição, idealização, enfim, motivações de toda

\footnotetext{
34 "The telesic content of a design must reflect the times and conditions that have given rise to it and must fit in with the general human socioeconomic order in which it is to operate." (Tradução livre)

${ }^{35}$ Tradução da autora
} 
sorte. Eles compõem relações, por meio do que conhecem suficientemente sobre cada um dos elementos acionados na composição da atividade.

\subsubsection{Interface - artefato do design ou da arquitetura?}

A primeira implicação do design, na análise de uma atividade que ocorre em um espaço construído, externo ou interno, é o usufruto dos artefatos pelas pessoas. Em decorrência disso, a relação entre design e arquitetura se traduz na interface entre os artefatos de ambas as áreas. Busco, então, identificar os artefatos destas áreas na situação da atividade analisada. É fato que elas se distinguem em muitos aspectos, apesar de compartilharem de processos projetuais, como cunho da prática profissional, no atendimento de expectativas na relação homem/meio.

Além de se distinguirem como atividades "utilitárias", na visão do esteta Evaldo Coutinho (2010), arquitetura e design são diferenciadas como gêneros artísticos. Ele evidencia a distinção entre as artes, ou "a autonomia do gênero artístico" pela escolha da "matéria" em cada um dos gêneros. Matéria é o que traduz a identidade de cada gênero artístico, ou a base norteadora em sua categorização, dentro das artes. A arquitetura tem em comum com a escultura "a parte construtiva, plástica, figurativa (...), o volume palpável” (COUTINHO, 2010) e o que diferencia um gênero do outro é a matéria espaço, exclusiva da arquitetura.

Sinalização e elementos de propaganda, bancas de revista, dispositivos de iluminação e mobiliário urbanos são alguns exemplos de resultados de projeto de design para o espaço urbano, os quais Evaldo Coutinho denomina elementos escultóricos na arquitetura. Neste caso, os artefatos do design seriam comparados às obras da escultura em termos de matéria utilizada.

O autor considera que os artefatos de ambas as áreas se diferem no tipo de volume que geram, dentro da conceituação "matéria palpável" e "matéria espaço" (COUTINHO, 2010). Segundo esta mesma conceituação, a arquitetura se caracteriza pela utilização dos dois tipos de matéria, estabelecendo a relação entre vazios e cheios, para a formação de espaços, sua matéria fim. O design por sua vez, igualado à escultura, tem o seu fim na matéria palpável, na concepção de seus 
artefatos. Com isso, poderíamos constatar que a distinção entre as duas áreas, por meio dos tipos de artefato que projetam, está na afirmação de que arquitetura projeta espaços e, design, volumes.

O borrar das áreas está no borrar de seus artefatos - espaços em escalas diversas delimitados por massa edilícia pela arquitetura e artefatos pelo design. Um dos aspectos da interface entre atividade e contexto é ser um espaço específico criado e delimitado por projetos oriundos tanto da arquitetura quanto do design. Espaço em que agentes, ações, elementos físicos e a própria forma deste lugar interagem entre si em prol da atividade e da vida social local.

A interface, então, deve ser definida mediante variáveis morfológicas. Por meio da forma delimitada pelos três âmbitos - contexto, atividade e interface - identifico dois tipos de interface: a de permanência e a de passagem. Imediatamente a partir dos elementos físicos, a interface de permanência é aquela em que tomam lugar as ações de atendimento, consumo, compra/venda do alimento para viagem, ou mesmo um bate papo por quem não consome o produto ali vendido. A interface de passagem começa onde termina a de permanência, mas não toma todo o lugar da área do contexto. Dependendo da configuração do lugar, definida por barreiras como massa edilícia e elementos físicos da atividade, esta interface tem a sua definição ao redor da atividade, na permeabilidade ao movimento de pedestres.

A interação entre elementos é um princípio comum em qualquer projeto de design, com foco em um ou outro aspecto, desde a concepção formal (interação entre partes de um produto) à tradução entre linguagens (interação entre conceitos e matéria). Contudo, o conceito de interação vem adjetivando a prática do design desde os anos de 1990, quando Bill Moggridge denominou design de interação (interaction design) a disciplina do design que reúne conhecimentos de design de produto, comunicação e ciência da computação, basicamente, para tratar da interação entre pessoas, sistemas e dispositivos digitais. (SAFFER, 2010, p. 3).

Dan Saffer expõe quatro abordagens de trabalho nesta área: 'design centrado no usuário'; 'design centrado na atividade'; 'design de sistemas' e 'design de gênio'. 
Destaco a abordagem "design de sistemas", corroborando a ideia de que devo tratar o meu objeto como tal.

\begin{abstract}
Design de sistemas é uma forma muito analítica de abordar problemas de projeto; se utiliza de arranjo de componentes para criar soluções em design. Considerando que, no design centrado no usuário, o usuário é como o centro do processo de design, aqui um sistema - conjunto de entidades que atuam uns sobre os outros - o é. Um sistema não é, necessariamente, um computador, embora possa ser. Sistemas também podem consistir de pessoas, equipamentos, máquinas e objetos. Os sistemas podem variar do simples ao muito complexo. Design de sistemas é uma abordagem de projeto estruturada, rigorosa, excelente para resolver problemas complexos e oferece uma visão holística para a concepção. Design de sistemas não descartam objetivos e necessidades do usuário - eles podem ser usados para definir o objetivo do sistema. ${ }^{36}$ (p. 38)
\end{abstract}

É possível considerar como sistema tanto um artefato sozinho, quanto um conjunto de artefatos integrados em uma ação. Um único artefato é concebido para cumprir uma determinada função que envolve um número de sub-funções. Por exemplo, uma poltrona, artefato único, cumpre a função de assento com significativo conforto para compor ambientes de estar ou espera. Para isso, tem como elementos o próprio assento, o encosto e suportes para braços, todos a certa altura do chão. Esta composição não deixa de ser um sistema, uma vez que todos os elementos foram compostos e integrados com foco no cumprimento da função principal da poltrona, projetada para a ação simples de sentar com conforto (figura 1.9) ${ }^{37}$.

Da mesma forma, a atividade do comércio em via pública, com seus elementos integrados e voltados para uma ação principal, constituem um sistema tanto quanto a poltrona. A diferença está na interligação entre os elementos. Neste caso, são os espaços de ação os conectores dos elementos. Todo o ambiente com seus suportes, produtos para venda etc. compostos são o artefato, o sistema (Figura 1.10).

\footnotetext{
36 "Systems design is a very analytical way of approaching design problems; it uses an established arrangement of components to create design solutions. Whereas in user-centered design, the user is as the center of the design process, here a system - a set of entities that act upon each other - is. A system isn't necessarily a computer, although it can be. Systems can also consist of people, devices, machines and objects. Systems can range from the simple to enormously complex. Systems design is a structured, rigorous design approach that is excellent for tackling complex problems and offers a holistic approach to designing. Systems design doesn't discount user goals and needs - they can be used to set the goal of the system." (Tradução livre)

${ }^{37}$ A escolha deste artefato em específico é uma homenagem a Sérgio Rodrigues, arquiteto que conheci na época de minha formação, em um evento no IAB/RJ, e que faleceu no decorrer do meu doutoramento.
} 


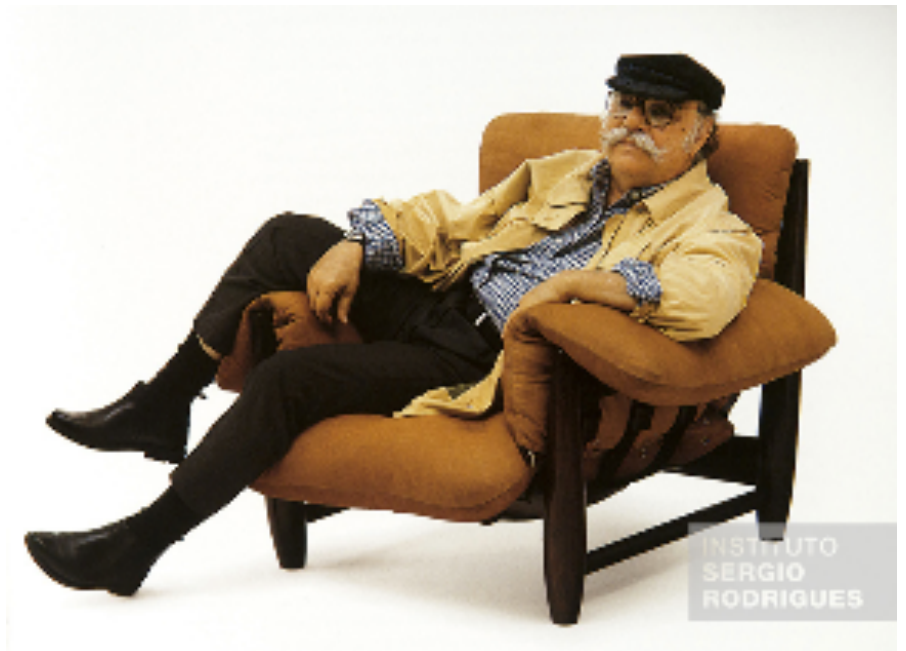

Figura 1.9 - 'Poltrona mole', exemplo de artefato considerado como sistema. Fonte: Instituto Sérgio Rodrigues

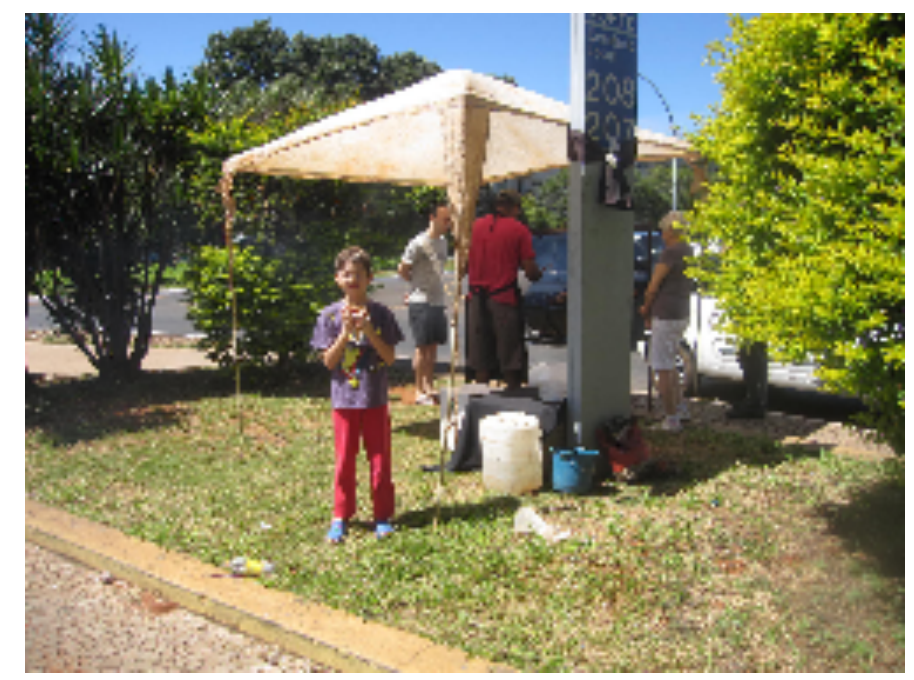

Figura 1.10 - ponto de comércio de frango grelhado, no Comércio Local Norte 207/208, exemplo de sistema por composição de vários artefatos e espaços de ação. Fonte: autora.

Além disso, no cerne do conceito de sistema está a questão do comportamento de pessoas e sistemas em relação ao funcionamento dos produtos resultantes. No estudo sobre design de interação como disciplina, são três as maneiras ou visões de abordá-la: a centrada na tecnologia, a behaviorista e a chamada design de interação social. Essa última visão é a que mais contribui com a análise da interface da atividade em questão por ser inerentemente social, por ter como foco a facilitação da comunicação entre as pessoas por meio dos artefatos (SAFFER, 2010, p. 5). 
Desta maneira, a interface entre o contexto e a atividade, representada pela intersecção entre os espaços delimitados pelos elementos físicos da arquitetura e do design, possibilitam o desempenho da atividade, bem como as relações entre as pessoas nela envolvidas.

\subsubsection{A composição do ponto de comércio - uma 'abordagem ecológica'}

Para abordar o aspecto social do design na atividade em questão, analiso os efeitos da composição dos elementos físicos sobre seus agentes, na medida da satisfação de suas expectativas. Parto, então, do que lá está, em cada ponto de comércio observado, como variável independente.

Antes da análise de qualquer ocorrência dentro do design como um fenômeno, estudá-lo em sua completude é observar duas fases importantes de sua existência. A primeira diz respeito ao processo pelo qual o fenômeno foi gerado. Uma vez concebido, a atuação em si, representada pelo seu uso, e a interação com o meio espaço e outros objetos - completam o fenômeno como um sistema. O design como um fenômeno encerra em qualquer um de seus resultados a interface entre sua geração e atuação.

O resultado de design observado e analisado, é fruto do trabalho do comerciante e engloba todo o sistema descrito nos três âmbitos principais: contexto, atividade e interface. O processo de concepção deste sistema, resumidamente, se dá em primeiro lugar, pela escolha do lugar e, a partir disso, pela composição dos aparatos para o funcionamento da atividade, relacionando-os com o lugar e com o que lá já está, em termos de elementos físicos.

$\mathrm{Na}$ análise da atividade, o ponto de partida é a configuração geral da situação, no que tange aos atributos dos três âmbitos identificados, que possibilitam copresença, permanência e ações do desenrolar da atividade. Com isso, analiso a conjunção dos elementos físicos e do espaço, o que me auxilia entender o efeito da forma resultante desta conjugação nos agentes e ações da atividade. 
Antes de interagirem como um sistema, os elementos físicos são dispostos no espaço por meio de uma composição. No campo do design, temos o conceito de composição como o artefato, ou conjunto de artefatos dispostos e integrados como um todo, resultado do ato projetual. É crucial o entendimento do efeito da composição formal do ponto de comércio como um todo no sistema de encontros do lugar em que se insere. Este é um dos aspectos, ou variáveis, que falam sobre a qualidade do ponto de comércio, atendendo a sua função básica de venda de produtos e, subsequente ou consequentemente, como promotor de vida social. Com um mesmo espaço, a composição pode ser feita de várias maneiras diferentes. A interpretação de quem compõe e a variação da disposição dos elementos distinguem a composição e isso interfere sobremaneira no contexto da atividade.

Busco seguir uma sequência hipotética de procedimentos por parte do comerciante como designer, quando da escolha do lugar para a composição de seu próprio posto de trabalho. A ambiência decorre das propriedades do lugar que serão percebidas pelo comerciante. Ali é um bom lugar para se estar e montar o seu ponto. Para a composição dos elementos físicos que dão suporte à atividade, um outro tipo de percepção é acionada. É um olhar mais direcionado para o que o ambiente proporciona, além de ser bom para se estar. Estão em jogo as propriedades do que faz parte daquele ambiente e que beneficiam o funcionamento da atividade. $O$ que dali ele pode aproveitar para, a partir disso, iniciar a sua composição?

O entendimento da estrutura da composição em termos visuais se mantém na seara das investigações sobre a percepção humana, com diversas linhas de pensamento, que de certa forma se complementam em suas divergências. A Teoria da Affordance, traduzida para o português como Teoria da Abordagem Ecológica, defende a percepção animal humana como aquela que envolve de modo inseparável um dado ambiente e seu observador. James Jerome Gibson tem no conceito de ecologia a referência para a defesa desta teoria e nega a sua abordagem como fenomenológica ou física (GIBSON, 1986).

A peculiaridade de proporcionar (afford em inglês) mutuamente benefícios (ou prejuízos), na relação dos seres entre si e com o meio em que vivem, levou Gibson a cunhar o termo affordance para denominar a teoria por ele fundamentada. Para 
isso, conceitua ambiente como os arredores daquele que o percebe e nele exerce determinado comportamento, o animal/humano (Ibidem). Fisicamente, define ambiente como o conjunto de superfícies que separam substâncias do meio em que vivemos, animais e humanos. Diz que a composição e o leiaute destas superfícies, possivelmente, constituem o que elas possibilitam, oferecem.

Utiliza, também, o conceito de nicho, no embasamento de sua teoria, como um conjunto de affordances, referindo-se não ao lugar onde vivem mas como vivem os animais/humanos neste lugar. "Em ecologia um nicho é uma configuração de características ambientais que são adequados para um animal, no qual ele se encaixa metaforicamente." (Ibidem) ${ }^{38}$

Affordance é o que pode ser percebido nos objetos e no espaço que compõem o ambiente e, por isso, uma unidade relativa a quem a percebe. É uma relação direta funcional entre o animal/humano e seu meio. Trata-se de distinguir as qualidades do meio para perceber o que ele oferece e aprender a usá-lo. E este conceito é estendido, por Gibson, para a questão social quando considera a relação entre humanos. "Comportamento proporciona comportamento, e todo o assunto da psicologia e das ciências sociais pode ser pensado como uma elaboração deste fato básico." (Ibidem $)^{39}$. Esta constatação é de grande relevância na análise do sistema da atividade, uma vez que as posições que as pessoas envolvidas ocupam e como o fazem na composição do ponto de venda, diz muito sobre a operacionalidade da composição e seu desempenho social. A percepção que o cliente, por exemplo, tem do comportamento do vendedor ou de seu ajudante implicará em seu próprio comportamento durante a sua estada ali.

Uma affordance pode ser natural ou mesmo construída e é sempre invariante, pois está sempre lá para ser percebida. O que mudam são as expectativas e necessidades humanas. Por se tratar da relação direta entre meio e observador, as informações tanto de um quanto do outro se complementam na formação de um ambiente ocupado, utilizado. O que o observador perceber como affordance no meio

\footnotetext{
${ }^{38}$ In ecology a niche is a setting of environmental features that are suitable for an animal, into which it fits metaphorically. (Tradução livre)

${ }^{39}$ Behavior affords behavior, and the whole subject matter of psychology and of the social sciences can be thought of as an elaboration of this basic fact. (Tradução livre)
} 
em que está, vai dizer muito sobre ambos. Gibson resume, assim, a Teoria da Affordance como uma nova abordagem da psicologia que envolve a noção de propriedades invariantes do meio que relacionam dois extremos: as necessidades de um observador às superfícies que o ambiente oferece (Ibidem).

A preocupação com o modo como as pessoas interagem com os artefatos do cotidiano, levou Donald Norman a adotar os princípios da affordance no campo do design. Contudo, como sua pesquisa anterior se voltava para o estudo dos erros cometidos por parte do design e da engenharia, no projeto e fabricação de objetos ineficientes, ou excluídos da categoria do bom design, sua apropriação da teoria aconteceu de maneira redirecionada ou adaptada para o fazer design.

Para muitos pesquisadores, defensores da teoria da affordance original, Norman se apropriou dela de maneira equivocada. Enquanto o conceito original versa sobre uma percepção do meio por parte do observador, uma relação direta indicando a possibilidade e como usá-lo, Norman acredita

\begin{abstract}
que as affordances dependem da nossa interpretação mental dos objetos, e consequentemente do conhecimento e experiências anteriores de cada indivíduo. (...) Essa visão é coerente com a teoria dos modelos mentais, uma vez que pressupõe um sistema cognitivo capaz de gerar representações dos objetos e de processar mentalmente as informações do ambiente. (SANT'ANNA, 2013, p. )
\end{abstract}

Em sua adaptação, Norman insere, ou modifica o modo como as affordances acontecem. Desta vez, elas são construídas cognitivamente. Pode-se fazer, então, uma comparação do tipo: affordance pela percepção de Gibson e affordance pela cognição de Norman. Tanto uma quanto a outra, dependendo do que se vai analisar, são de extrema importância no campo do design, especificamente. Concluo, então, que existem dois modelos de affordance, o de Gibson e o de Norman, e não uma apropriação equivocada da teoria do primeiro pelo segundo.

O modelo de affordance de Norman se aplica a problemas cujo foco principal é o "design apropriado e centrado no humano" (NORMAN, 2006, p. 15). Para ele, não existe erro humano, mas objetos mal projetados que levam ao uso equivocado, ou simplesmente, mau uso. Em seu estudo, affordance é um dos quatro princípios de 
design, entre modelos conceituais, feedback (ou retorno de informações) e restrições; está em um nível que avançou para a sua aplicação em projetos, "para que designers se certifiquem de que seus produtos sejam compreendidos e usáveis" (opus cit, p. 11). Acredito que aí reside a diferença entre os dois modelos de affordance.

Contudo, mesmo sendo a tese desenvolvida também e principalmente sob o viés do design, a apropriação da Teoria da Abordagem Ecológica se dá aqui sobre o modelo de Gibson. Avalio o quanto o que está disponível no contexto, no lugar escolhido, proporciona à atividade e como é percebido e apropriado pelo comerciante. Apesar de utilizar o que foi percebido, não considero que houve um acionamento de bagagem de conhecimento específica e significativa para tal. Este modelo se aproxima do nível inconsciente, cunhado por Holanda, montando um perfil de atuação do comerciante, no que diz respeito à composição que possibilita o funcionamento da atividade.

\section{Conclusão do capítulo}

O estudo da atividade do comércio informal no espaço urbano conduziu a um recorte referencial em que foram visitadas obras e textos nas áreas de arquitetura, design, psicologia (percepção), sociologia e "ciência dos sistemas".

Uma das primeiras delimitações do problema foi encarar a atividade como um sistema constituído de três âmbitos: atividade, contexto e interface (entre ambos). A organização deste sistema foi motivada, primeiramente, pelos aspectos do lugar, no que se refere à forma do espaço escolhido para a atividade. Para entender esta lógica, me apoiei nos princípios da Teoria da Sintaxe Espacial. Por intermédio desta teoria entrei em contato com os conceitos de lugar (convexidade) e de possibilidades de movimento e visibilidade (axialidade) pela configuração do espaço urbano, que são caros na análise da repercussão do contexto de cada ponto de comércio observado nos aspectos sociológicos e funcionais do exercício da atividade.

Outros aspectos de natureza física são os desencadeados pelos elementos da arquitetura, que suportam a atividade em conjunto com os levados e montados pelo 
comerciante. Parti da Teoria Geral dos Sistemas, com base na qual tracei as relações de complexidade entre lugar, elementos físicos e seus agentes. Foi possível, a partir daí, proceder com o desenvolvimento do estudo sobre a hipótese do sistema atividade/interface/contexto.

Com base na Teoria das Práticas Cotidianas, o comportamento da indisciplina foi esmiuçado, resultando na compreensão de que o comerciante age por meio de táticas para driblar as condições materiais e sociais a ele colocadas pelas estratégias de quem as oferece. $\mathrm{Na}$ análise ele é conjugado com o sistema material que engloba lugar, elementos físicos da arquitetura e paisagem e artefatos envolvidos.

A pesquisa sobre percepção ecológica, com base na Teoria da Abordagem Ecológica (Affordance) referencia as soluções dos comerciantes na montagem de seus postos de trabalho, na medida em que se beneficiam dos atributos de configuração do lugar escolhido para completar a composição, com os elementos que leva para montar.

A partir deste referencial teórico, pela conjugação das quatro teorias abordadas, parto para a descrição e explicação do método que a complementa, além de possibilitar e nortear o trabalho de campo desenvolvido. 


\section{2 | MÉTOdO E APRESENTAÇÃO DO CAMPO}

O tipo de pesquisa desenvolvida neste trabalho, pode ser classificado como social, por fazer parte do objetivo geral o entendimento da lógica social que respalda as soluções do comerciante na concepção de seu posto de trabalho, com relação à configuração de espaço-forma do lugar eleito no espaço urbano.

Por ter este perfil, o trabalho desenvolvido demandou itens instrumentais da pesquisa exploratória. Os pesquisadores sociais, com foco na atuação prática, comumente realizam pesquisas exploratórias em conjunto com a descrição dos fenômenos, procedimento inerente a qualquer pesquisa (GIL, 2002). Além da pesquisa bibliográfica e documental, utilizo o formato de estudos de caso, ambos itens da pesquisa exploratória. O caráter exploratório da pesquisa se dá por meio de: questionário junto aos comerciantes; conversas informais com comerciantes e respectivos clientes; observação sistêmica da atividade em cada ponto observado; registros fotográficos para complementação da observação in loco; mapeamento dos lugares no que tange às ferramentas de análise dos padrões espaciais e sistema de encontros e esquivanças. Ademais, a análise não tem o cunho quantitativo, mas qualitativo, em que as variáveis são descritas e tratadas de modo discursivo.

A construção do método reúne como alicerces os recortes teóricos apresentados no capítulo anterior. A atividade como um todo, em seu funcionamento e relações e, consequentemente, a sua abordagem nesta pesquisa estão amparadas pelos princípios do pensamento sistêmico, no âmbito de sua origem na Teoria Geral dos Sistemas. Os procedimentos gerais do trabalho de campo reúnem, basicamente, descrição, qualificação e relação dos elementos que compõem a atividade. Por meio desta sequência é detectada a complexidade sistêmica de cada ponto e como este fator repercute no contexto em que se insere.

A Teoria das Práticas Cotidianas respalda o entendimento do comportamento do comerciante em se apropriar de espaços abertos com destinações mais gerais ou, mesmo, outras diferentes daquela para a qual ele se apropria, ou seja, os lugares apropriados não foram projetados para a atividade do comércio em via pública. $O$ 
entendimento deste comportamento enseja o estudo sobre os atributos do contexto que recebe cada ponto de comércio informal observado.

Para trabalhar com os três âmbitos do objeto de estudo - contexto, atividade e interface - na formação das categorias de análise, conjugo parte da linhagem temática e metodológica desenvolvida dentro da Teoria da Sintaxe Espacial e da arquitetura sociológica, com os princípios da Teoria da Abordagem Ecológica Affordance.

As principais obras, desenvolvidas na esfera do Config.Arq, que norteiam o percurso metodológico a ser apresentado são: Espaço de Exceção (HOLANDA, 2002), Ao desocupado em cima da ponte. Brasília, arquitetura e vida pública, (TENORIO, 2012) e Habitar, trabalhar, recrear e circular: possibilidades e limitações nas superquadras de Brasília, (RIBEIRO, 2013).

A essência metodológica da pesquisa tomo de Holanda (2002), que no livro, fruto de sua tese, prima por conceituar e analisar a especificidade do fenômeno socioespacial de lugares isolados nas dimensões superestruturais de Brasília ${ }^{40}$. A lógica social do espaço traduzida na Teoria da Sintaxe Espacial, além de toda uma pesquisa histórica, o levou a três níveis de análise destes lugares, naquele momento denominados: padrões espaciais, vida espacial e vida social. A relação bem estruturada entre os conceitos primordiais e estes níveis analíticos, vasculhados na pesquisa em sua fase empírica, foi imprescindível em todos os momentos de construção e aplicação do método desta pesquisa.

A tese Ao desocupado em cima da ponte. Brasília, arquitetura e vida pública (TENORIO, 2012) descortinou um conjunto de variáveis a serem consideradas nas pesquisas sobre o espaço urbano de Brasília, no que tange à sua apropriação em diferentes tipos de atividades. Ela revisa de modo crítico e organiza os meios recomendados por diversos autores na leitura do espaço urbano, além da análise do potencial das áreas por ela pesquisada, sob a lógica social. É um norte didático que facilitou a busca por procedimentos condizentes com o recorte definido.

\footnotetext{
${ }^{40}$ Assim é apresentado o trabalho de Holanda em Espaço de Exceção, por Pasqualino Romano Magnavita.
} 
Além de compartilhar do foco na área residencial de parte do Plano Piloto de Brasília, a adoção de mapas comportamentais, como todo o percurso metodológico da dissertação Habitar, trabalhar, recrear e circular: possibilidades e limitações nas superquadras de Brasília (RIBEIRO, 2013) orientam e motivam este trabalho empírico. O recorte do trabalho de campo da tese aqui apresentada, de certa forma, é um aprofundamento em uma das atividades detectadas nesta dissertação. A autora relaciona a configuração dos espaços de algumas superquadras do Plano Piloto de Brasília, nas Asas Sul e Norte, com os respectivos padrões de uso. Aqui, parto de uma das atividades observadas por ela - a do comércio informal em via pública, elejo a região das superquadras, incluindo imediações (comércios locais, passagens subterrâneas, pontos de ônibus etc.) e traço o mesmo paralelo entre configuração dos locais escolhidos pelos comerciantes e suas características de utilização, além de discutir os aspectos referentes aos elementos físicos envolvidos da atividade em sua interface com o contexto, assunto específico desta pesquisa, que a difere das anteriores citadas.

Os três níveis de análise utilizados em Espaço de Exceção foram utilizados no método construído, com as devidas adaptações. Padrões espaciais, vida espacial e vida social, naquela obra, correspondem na tese a padrões espaciais, sistemas de encontros e esquivanças e características socioeconômicas, respectivamente. Estes três níveis analisam todos os aspectos das camadas do contexto e da interface.

Para a camada da atividade, introduzo um quarto nível analítico - sistema de elementos físicos. Norteiam a construção deste nível, os conceitos da Teoria Geral dos Sistemas e os princípios da Teoria da Abordagem Ecológica (Affordance). Sob a lente desta última teoria, na composição dos elementos físicos é considerado o que ela proporciona para a atividade e para a copresença e permanência dos envolvidos.

Neste capítulo, subsequente à apresentação detalhada dos níveis de análise, é explicitado a maneira pela qual é executada a análise das informações coletadas por intermédio das variáveis. 
Com base na literatura e nas observações empíricas, Brasília é abordada na medida do que dela preciso, objetivamente. Levanto suas características gerais, traços socioculturais e aspectos morfológicos peculiares, relacionados ao comércio em via pública nela praticado, na região escolhida. Como cumprimento da exigência de um dos objetivos específicos traçados no início deste trabalho, foi detectada a tipologia de incidência de apropriação dos lugares pelos comerciantes. Concomitantemente às visitas exploratórias e à detecção da tipologia, as variáveis de análise foram sendo calibradas em um teste realizado com um dos pontos. Com base nesta tipologia, foi possível escolher os pontos como estudos de caso e, assim, iniciar o trabalho de campo, propriamente dito.

\subsection{Níveis de análise, variáveis e técnicas/ferramentas}

Dentro de cada nível analítico, apresento, descrevo e justifico o uso dos conceitos, oriundos do referencial teórico, com as respectivas categorias analíticas, ou variáveis. Conceitual e operacionalmente, todas elas são relacionadas ao problema. As ferramentas são explicitadas dentro das técnicas pertinentes, sempre com o intuito de clarear o entendimento do percurso metodológico. Para a visualização da relação entre níveis, variáveis, técnicas e ferramentas, apresento uma tabela no início do item referente a cada nível analítico, com o intuito de melhor orientar a leitura. A apresentação dos níveis segue a ordem do mais abrangente ao mais específico, no que tange aos âmbitos contexto / interface / atividade, resultando na sequência: características socioeconômicas, sistema de elementos físicos, padrões espaciais e sistemas de encontros e esquivanças.

Faz-se necessário explicitar, previamente à apresentação dos níveis de análise e suas variáveis, algumas informações gerais sobre as técnicas e ferramentas utilizadas no trabalho de campo, o que não dirime de apresentá-las de modo específico em cada um dos níveis, mais adiante.

Sobre a importância da observação em uma pesquisa que tem a vida pública um de seus itens de levantamento, Tenorio (2012) destaca Jane Jacobs e Donald Appleyard como autores que primam por esse meio de conhecimento da realidade do cotidiano das pessoas no espaço urbano. Nenhum destes autores oferece 
técnicas para o levantamento da vida pública, mas promovem a observação como meio significativo para a obtenção deste tipo de informação.

Jacobs defende a observação atenta, livre de expectativas e próxima da realidade urbana, para que na "aventura de investigar o mundo real" possamos relacionar seus fatos mais prosaicos na busca de uma entendimento do comportamento das cidades (JACOBS, 2007, p. 12-13).

A observação, mais do que entrevistas sistematizadas e conversas informais com comerciantes e consumidores, foi um dos principais meios para o alcance do entendimento da atividade do comércio em via pública, em seus vários aspectos de relação com o contexto direto. As inúmeras visitas feitas a cada ponto estudado permitiram que diferentes informações fossem coletadas para o amadurecendo da visão sobre as respectivas interfaces contexto/atividade. A primeira visita, de caráter introdutório e comum aos pontos estudados, consistiu na apresentação do trabalho de pesquisa ao comerciante. As visitas seguintes variaram na sequência de acontecimento de acordo com cada ponto estudado e foram destinadas aos registros fotográficos, entrevistas, conversas informais com o comerciante e seus clientes, levantamento sistematizado feito por meio de contagem de passantes e clientes dos comércios observados, identificação e tomada de medidas do ambiente acolhedor e próximo e dos elementos físicos envolvidos na atividade e, finalmente, à captação da ambiência do local escolhido pelo comerciante.

O levantamento das características socioeconômicas foi direcionado sobre dois perfis: o do comerciante e o do público que mora e trabalha na região próxima ao comércio eleito. As características socioeconômicas do comerciante foram detectadas por meio de um questionário constituído de perguntas simples e diretas. As características da clientela foram captadas por uma questão formulada ao comerciante no questionário e por observação e as informações sobre o público da região circundante ao ponto, foram levantados na base de dados do Instituto Brasileiro de Geografia e Estatística - IBGE.

A Sintaxe Espacial, como método de análise dos padrões espaciais, demanda a construção de mapas específicos para avaliar as relações entre morfologias locais e 
padrões globais. Para construir os mapas que medem as variáveis sintáticas dos lugares, é preciso que sejam desenhados - o que chamo aqui de - mapas geradores. São mapas cujas informações são retiradas de mapas cadastrais, ou melhor, da base cartográfica do lugar em questão. Esta informações são elementos gráficos que traduzem o que se necessita detectar da base para ser analisado na variável. (ex.: barreiras e permeabilidades à visibilidade do pedestre). Dos mapas geradores, que geralmente são trabalhados em um programa de CAD, irão resultar os mapas que serão analisados no âmbito da Sintaxe Espacial. Estes, por sua vez, são confeccionados pelo DepthmapX, programa utilizado para executar análise de rede espacial, na busca pela compreensão dos processos sociais dentro do ambiente analisado. Suas especificidades são explicitadas dentro de cada variável.

Para operar com as informações sobre o sistema de encontros e esquivanças, pela Sintaxe Espacial, pode-se proceder de dois modos: mapeamento por meio do número e das características das pessoas que se encontram no local observado, ou amostragem da população envolvida na atividade, com o auxílio de questionários para detectar os respectivos grupos sociais (HOLANDA, 2002, p. 107). Pelo caráter exploratório do trabalho empírico, mais condizente foi a escolha por observar, contar e registrar as características dos que passavam pelo ponto de comércio em questão para, então, fazer o mapeamento deste sistema, referente a cada estudo de caso.

\subsubsection{Características socioeconômicas}

A abordagem com foco nos sistemas de encontros, no âmbito do espaço urbano, conduz à busca pelo entendimento do objeto, primeiramente, por suas características socioeconômicas. Estas características dizem respeito às diferenças de oportunidade entre as classes sociais na apropriação e uso dos lugares observados. A utilização deste nível analítico se justifica pela necessidade deste tipo de contextualização que antecede a questão morfológica do ambiente.

No processo de análise de cada estudo de caso, inicio identificando-os pela localização e pela categoria dentro dos tipos dos lugares em que incidem. Em seguida, contextualizo-os socioeconomicamente, com a aplicação das variáveis deste nível, cujas informações são concernentes ao comerciante e aos moradores e 
trabalhadores da região, que potencialmente são clientes do ponto de comércio observado. Em relação aos últimos, o estudo do objeto sob o ponto de vista socioeconômico é levantado junto à base de dados do IBGE, sobre a região em que o ponto em questão se estabelece.

Por meio de observação, entrevista e conversas informais com o comerciante e alguns dos respectivos clientes, detecto a relação dos agentes da atividade com o contexto, em primeiro lugar, socioeconômico, para depois compreender a relação dos mesmos agentes com o contexto arquitetônico.

A Tabela 2.1 condensa as variáveis com as respectivas técnicas e ferramentas como panorama completo deste nível e parcial do trabalho de campo.

Tabela 2.1 - variáveis, variabilidade e técnicas/ferramentas do nível analítico Características socioeconômicas.

\begin{tabular}{|c|c|c|c|}
\hline & VARIÁVEIS & VARIABILIDADE & FERRAMENTAS \\
\hline 01 & $\begin{array}{l}\text { Apresentação geral: gênero, faixa } \\
\text { etária, naturalidade, grau de } \\
\text { instrução }\end{array}$ & $\begin{array}{l}\text { gênero: }(\mathrm{F}) /(\mathrm{M}), \text { faixa etária: } \\
(20-30) ; \quad(30-40) ; \quad(40-50) ; \\
(50-60) ;(>60)\end{array}$ & \multirow{6}{*}{ Entrevista } \\
\hline 02 & $\begin{array}{l}\text { Local de moradia e modo de } \\
\text { deslocamento }\end{array}$ & lugares do DF & \\
\hline 03 & $\begin{array}{l}\text { A atividade é a única ocupação } \\
\text { remunerada? Dias da semana de } \\
\text { que se ocupa com a atividade. }\end{array}$ & $\begin{array}{l}\text { Única remuneração? (S); (N) } \\
\text { Dias da semana: }\left(2^{a} .\right) ;\left(3^{a} .\right) ; \\
\left(4^{a} .\right) ;\left(5^{a} .\right) ;\left(6^{a} .\right) ;(\text { sábado })\end{array}$ & \\
\hline 04 & $\begin{array}{l}\text { Renda mensal adquirida pela } \\
\text { atividade }\end{array}$ & $\begin{array}{l}\text { quantidade de salários } \\
\text { mínimos }\end{array}$ & \\
\hline 05 & $\begin{array}{l}\text { Razão da escolha por este local } \\
\text { para o ponto de comércio }\end{array}$ & resposta livre & \\
\hline 06 & Quem é o seu público/cliente? & moradores; trabalhadores & \\
\hline 07 & $\begin{array}{l}\text { Dados censitários sobre renda dos } \\
\text { moradores }\end{array}$ & $\begin{array}{l}\text { (pobres); (classe média } \\
\text { baixa); (classe média média); } \\
\text { (classe média alta); (ricos); } \\
\text { (sem remuneração). }\end{array}$ & $\begin{array}{l}\text { Banco de dados } \\
\text { do IBGE }\end{array}$ \\
\hline
\end{tabular}

\section{Variáveis}

1) Apresentação geral: gênero, faixa etária, naturalidade e grau de instrução

O conhecimento básico sobre o comerciante observado o apresenta à pesquisa como indivíduo e cidadão.

2) Local de moradia e modo de deslocamento para o ponto da atividade 
Detecção do quanto e como se dá o deslocamento e se o comerciante faz parte da classe social de morador ou de trabalhador que mora em cidade "dormitório" (satélite). Este é um dos itens sobre sua condição socioeconômica.

3) O comércio informal é a única ocupação remunerada? Dias da semana de que se ocupa com a atividade

Por meio destas perguntas detecto a importância da atividade para o comerciante. Conheço o quanto a atividade tem lugar na sua vida diária, social e financeira.

4) Renda mensal adquirida pela atividade

Juntamente com a informação sobre o local de moradia e o modo de deslocamento, esta variável informa sobre a condição socioeconômica do comerciante em questão.

5) Razão da escolha pelo local como ponto de comércio

As motivações para a escolha do local podem estar vinculadas aos atributos do espaço, como por exemplo, a proximidade com outras atividades. Esta informação pode reforçar, ou não, estes atributos na análise do local do ponto.

6) Quem é o seu público/cliente?

A resposta a esta pergunta complementa as observações feitas para detectar o tipo de cliente que o ponto de comércio em questão recebe, em termos de classificação social.

7) Dados censitários sobre renda dos moradores

Este item informa sobre a predominância de que classes sociais habitam as regiões que abarcam os lugares observados, por meio da detecção da renda dos responsáveis de cada unidade familiar entrevistada. Apesar de, em alguns pontos de comércio observados, ter sido constatado que os consumidores não 
necessariamente são os moradores dos arredores, esta variável tem sua importância para o acesso ao conhecimento da relação social do lugar com a região observada, isto é, nos permite fazer a relação entre as classes das pessoas que moram e das que trabalham na região em questão. Se não são moradores, são trabalhadores que atendem à região, seja dentro das residências, seja no comércio local, ou equipamentos. Neste estudo, as classes de renda são estipuladas conforme classificação (NUNES, 2003 apud Holanda, 2010), em que pobres: $\leq 2$ salários mínimos (SM); classe média inferior: $2 \mathrm{SM}<\mathrm{x} \leq 5 \mathrm{SM}$; classe média-média: $5 \mathrm{SM}<\mathrm{x} \leq 10 \mathrm{SM}$; classe média superior: $10 \mathrm{SM}<\mathrm{x} \leq 20 \mathrm{SM}$; classe rica: > 20 SM.

\subsubsection{Padrões espaciais}

$\mathrm{Na}$ análise do espaço urbano como contexto da atividade do comércio informal, pelas premissas da Sintaxe Espacial, o nível padrões espaciais aborda o contexto imediato de cada ponto analisado, de modo local e global.

Das categorias especificadas por Holanda (2002, pp. 95-107), dentro do nível analítico padrões espaciais, necessito de duas para analisar a interface entre o lugar escolhido e as especificidades da atividade: convexidade e axialidade. Além delas, utilizo a correspondente ao campo visual, ou isovistas. As três categorias são representações dos aspectos "de como as pessoas experimentam e usam o espaço: as pessoas movem-se ao longo de linhas (representação linear), agrupam-se em espaços convexos (espaços convexos) e dominam um campo visual a partir de qualquer ponto determinado (isovistas)." (MEDEIROS, 2006, p. 124).

Estou tratando da apropriação de lugares em espaços públicos e nos termos da Sintaxe Espacial, para tratar da ambiência destes lugares, recorro ao conceito de convexidade: um dos dois tipos de abstração, ou decomposição do sistema de espaços abertos de uma cidade. Um espaço convexo é a tradução do "lugar" dentro da sistematização desta teoria/método. Em um mapa de convexidade, os vários espaços convexos que formam os espaços abertos de um trecho, ou de uma cidade, são visualizados por meio da separação em segmentos de linha reta. A compreensão está em dizer "que é possível caminhar em linha reta entre quaisquer pontos que estejam dentro de um mesmo espaço convexo, e dá a ideia, para as 
pessoas que estão nele, de estar efetivamente num lugar determinado." (HOLANDA, 2002, p. 98).

O outro tipo de decomposição analítica dos espaços públicos, que complementa o conceito de convexidade, está no conceito de integração ou axialidade. A ligação, ou a sequência de deslocamentos entre espaços convexos se dá por meio de eixos, traduzidos em linhas retas, ou linhas axiais, pela Sintaxe Espacial. Nesta leitura, todas as barreiras, necessariamente, estão separadas por linhas axiais (HOLANDA, 2002, p. 99). No caso da análise feita aqui, a integração deve ser medida em um nível mais local em que cada linha é calculada com relação às linhas inseridas no local de raio definido previamente.

\begin{abstract}
A utilidade da medida de integração é imensa no que se refere a espaços públicos, pois trata de sua localização. Não é uma mera questão de endereçamento, mas de acessibilidade, pois ela se relaciona estreitamente com a integração. Os lugares mais integrados de uma cidade tendem também a ser os que são mais facilmente acessíveis de todos os seus pontos. Locais mais acessíveis costumam ser destinos ou trajetos comuns a muitas pessoas. Destinos ou trajetos comuns a muitas pessoas viabilizam transporte de massa. Espaços públicos em locais integrados têm, assim, grande potencial para atrair e reter vida pública. (TENÓRIO, 2012, p. 172)
\end{abstract}

Ambiência do ponto e sua integração, em termos de acessibilidade, com o entorno compõem um perfil de configuração espacial do lugar que nos informa sobre o seu potencial de atração, fluxo e permanência de pessoas. Isto pode ser visualizado na Figura 2.2, em que utilizo um trecho da superquadra SQN 315.

A coloração que vai do azul escuro ao vermelho diz respeito ao nível de integração, tanto no mapa de axialidade, quanto no de visibilidade, sendo que os trechos azuis escuros são os menos integrados e os vermelhos os mais integrados. Entre eles a gradação indica a variabilidade entre estes extremos (Figura 2.1).

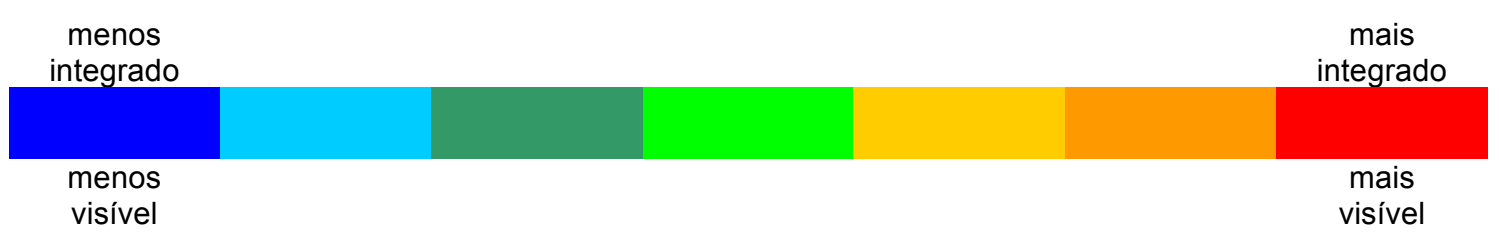

Figura 2.1 - gradação da coloração dos mapas de axialidade e de visibilidade indicativa dos níveis de integração dos trechos da área estudada. 

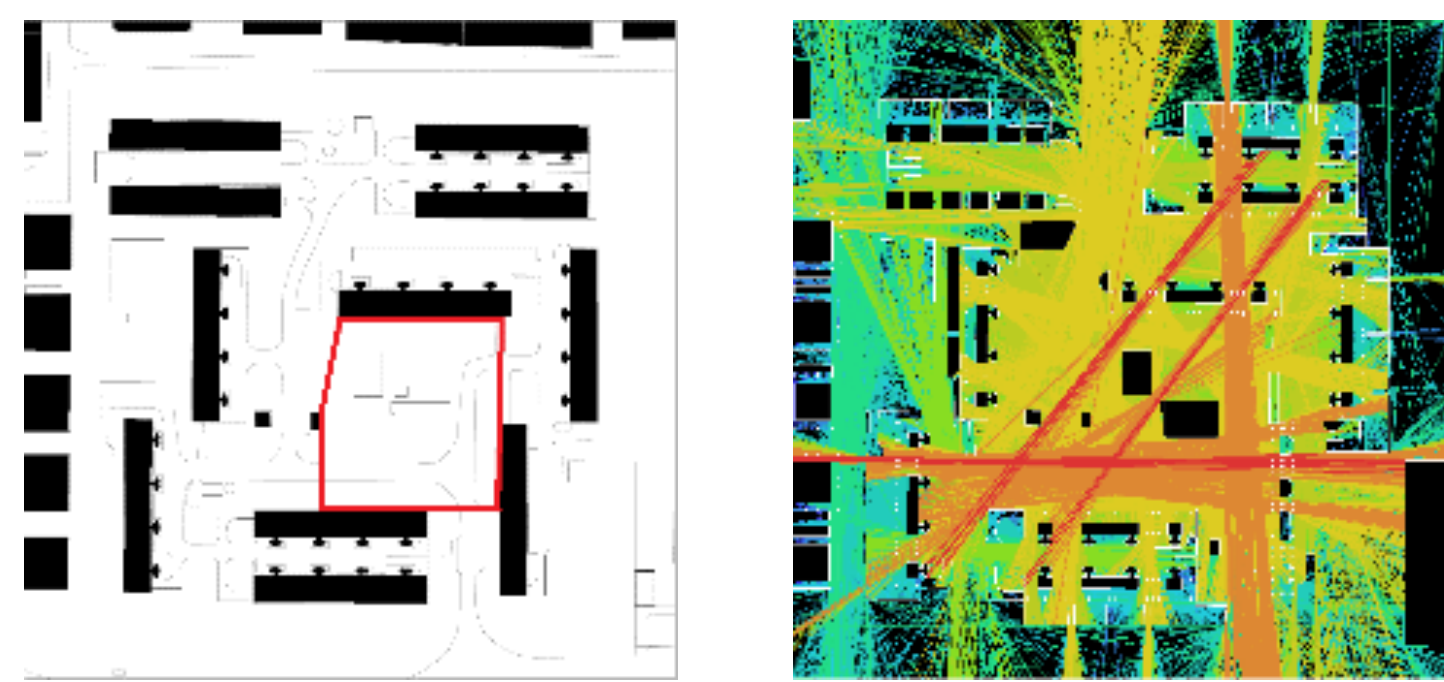

Figura 2.2 - trecho da superquadra SQN 315 representado pelos mapas de convexidade (destacando um dos espaços convexos determinados pela massa edilícia) e de axialidade.

É importante, também, detectar o campo visual dos que estão em cada ponto de comércio observado. Para isso, utilizo as isovistas como representação bidimensional de tudo que, a partir dali, pode ser visualizado. A reciprocidade é igualmente válida, isto é, importa aqui que o ponto seja acessível visualmente por uma maior quantidade de pontos possível, ao seu redor.

Conforme a sua localização, delimito um espaço quadrado, com 200 metros de lado, ao redor do ponto de comércio em estudo, para detectar suas informações sobre ambiência, acessibilidades ao movimento (motorizado e de pedestre) e à visão, campo visual, além das condições para permanência, traduzidas em seu estado de conservação e conforto e das atividades que existem ao redor. Todos os mapas produzidos estão delimitados por esta "máscara" de vazado quadrado, que tem o ponto de comércio estudado como centro.

Justifico a escolha e definição deste nível por ele permitir que a interface seja clareada quanto a maneira de inserção formal e funcional do ponto em seu contexto imediato. $\mathrm{Na}$ apresentação a seguir, as cinco primeiras das sete variáveis deste nível, dizem respeito à repercussão da configuração, em seus atributos locais, no que tange aos aspectos sociológicos e funcionais da atividade do comércio do ponto estudado. 
As técnicas utilizadas neste nível são a da convexidade, axialidade e isovistas, por meio dos mapeamentos específicos da Sintaxe Espacial, no que tange aos aspectos de formação e uso de lugares, ou espaços convexos, de integração e de campo visual. Mapas de convexidade, axiais e de isovistas, por meio de seus mapas geradores - mapas de cheios e vazios e mapas de barreiras e permeabilidades integram as ferramentas destas técnicas. Observação e registros textual e fotográfico permitiram o trabalho com as outras variáveis deste nível, na detecção das condições para permanência do local (estado de conservação e conforto) e das atividades ao redor do ponto.

As variáveis, com as respectivas técnicas e ferramentas, são apresentadas como panorama completo deste nível, na Tabela 2.2.

Tabela 2.2 - variáveis, variabilidade e técnicas/ferramentas do nível analítico Padrões espaciais.

\begin{tabular}{|c|c|c|c|}
\hline & VARIÁVEIS & VARIABILIDADE & FERRAMENTAS \\
\hline 08 & $\begin{array}{l}\text { Espaços convexos - ambiência } \\
\text { física para e a partir do ponto }\end{array}$ & $\begin{array}{l}\text { áreas de espaço convexo } \\
\text { médio }\end{array}$ & $\begin{array}{l}\text { mapa de } \\
\text { convexidade }\end{array}$ \\
\hline 09 & $\begin{array}{l}\text { Acessibilidade ao movimento de } \\
\text { veículos }\end{array}$ & medida de integração global & \multirow{3}{*}{$\begin{array}{l}\text { mapa de } \\
\text { axialidade }\end{array}$} \\
\hline 10 & $\begin{array}{l}\text { Acessibilidade ao movimento do } \\
\text { pedestre }\end{array}$ & medida de integração local & \\
\hline 11 & $\begin{array}{l}\text { Acessibilidade à visão - conexão } \\
\text { visual }\end{array}$ & medida de conexão visual & \\
\hline 12 & Isovistas - campo visual & $\begin{array}{l}\text { medida da área do campo } \\
\text { visual }\end{array}$ & $\begin{array}{l}\text { mapa de } \\
\text { isovistas }\end{array}$ \\
\hline 13 & $\begin{array}{l}\text { Condições para permanência - } \\
\text { estado de conservação e conforto }\end{array}$ & $\begin{array}{l}\text { elementos da arquitetura ou } \\
\text { paisagem que disponibilizam } \\
\text { as condições }\end{array}$ & $\begin{array}{l}\text { observação e } \\
\text { registro }\end{array}$ \\
\hline 14 & $\begin{array}{l}\text { Atividades ao redor do ponto de } \\
\text { comércio }\end{array}$ & $\begin{array}{l}\text { quantidade e variedade de } \\
\text { atividades }\end{array}$ & fotográfico \\
\hline
\end{tabular}

Variáveis

08) Espaço convexo que abarca o ponto - ambiência física

A convexidade determinada pela massa edilícia ao redor do ponto é o que, em primeiro lugar, informa sobre a sua ambiência física. São trechos de ruas, calçadas, praças, que podem variar de tamanho e formato, detectados pelos comerciantes como favoráveis à composição dos elementos físicos da atividade. Segundo Tenório (2012), um lugar tem seus limites claros e dimensões condizentes com suas características quando, em termos sintáticos, ele é representado por um mínimo de 
espaços convexos e sua percepção in loco apresenta grande correspondência com sua representação num mapa de convexidade (p. 192). Expressa em metros quadrados, essa categoria informa sobre dois tipos de utilização dos lugares, segundo Holanda: "Lugares convexos menores têm sido historicamente identificados com utilização secular, enquanto lugares convexos maiores com utilização simbólica." (HOLANDA, 2002, p. 100) ${ }^{41}$. Clareza nos elementos tridimensionais, contiguidade e dimensionamento pertinentes com a população que ali frequenta são pontos a serem observados.

A verificação desta variável é feita, primeiro, por meio da confecção do mapa gerador de cheios e vazios do local do ponto, como centro da máscara de $200 \mathrm{~m}$ de lado. Neste mapa os "cheios" representam todos os blocos edilícios do local. Por meio dele é gerado, então, o mapa de convexidade que apresenta a forma convexa, com o respectivo perímetro, do contexto que abarca o ponto. Uma vez detectados o espaço convexo, é analisado o grau de ambiência do contexto imediato para cada ponto observado, por sua medida de espaço convexo médio e pela relação entre sua localização e o espaço convexo em que está inserido. Ao conjugar este dois aspectos a ambiência física pode ser baixa, média ou alta.

09) Acessibilidade ao movimento de veículos

Cada ponto de comércio é acessado tanto via automóvel, quanto a pé. Dependendo da distância, ou do meio de transporte utilizado, muitos clientes saem motorizados, ou a pé de seus locais de trabalho, param no ponto, permanecem enquanto consomem, ou somente enquanto o produto é embalado para viagem. Apesar de o acesso ao pedestre ser considerado principal na análise deste nível, o acesso motorizado repercute de maneira significativa na atividade e na escolha do local. Esta é uma medida global do ponto, que informa sobre sua conectividade com todo o Plano Piloto, recorte maior, limite do campo trabalhado.

\footnotetext{
${ }^{41}$ Utilização secular e utilização simbólica são termos criados por Holanda. Utilização simbólica perpassa todo o Espaço de Exceção e restringe a utilização "superestrutural", em suas palavras. Trata-se da utilização para a reprodução de valores, ideias e crenças. Por outro lado, a utilização secular, que é a que trata a presente pesquisa, é aquela para a reprodução da vida prática, rotineira, cotidiana, econômica (ainda, segundo comunicação verbal do autor).
} 
Neste caso, para a leitura sintática, utiliza-se o mapa de barreiras e permeabilidades ao movimento de veículos, que interpreta tudo o que não é via como barreira. Este mapa gera, então, o mapa axial para medir a acessibilidade aos locais observados e revelar o respectivo sistema de integração, vias mais ou menos integradas e o ponto mais integrador da região medida. Com isso, por meio do mapa axial ao movimento motorizado, nesta variável considero os índices de axialidade máximo, mínimo e do local em que o ponto de comércio em questão se insere, para efeito de comparação interna ao ponto e entre os pontos estudados. A região medida nesta variável engloba todo o Plano Piloto.

10) Acessibilidade ao movimento do pedestre

Permitir movimento ou passagem é uma das funções do espaço urbano, além da ocupação ou permanência. Na Sintaxe Espacial, possibilidades de movimentos são reduzidas a linhas acessíveis que cobrem os espaços convexos em um mapa - as linhas axiais - representadas por redes em suas relações de adjacência ${ }^{42}$.

Esta variável tem repercussão direta e significativa no desempenho da atividade, tanto funcional, quanto socialmente. Por hipótese, se o vendedor escolheu aquele local é porque, intuitivamente, percebeu o seu potencial de acessibilidade a um fluxo maior de pedestres. O mapa axial, neste caso, mostra o quanto o local é acessível ao movimento de pedestre, no raio delimitado pela máscara quadrada para esta aferição. Para a análise do grau de acessibilidade ao movimento de pedestres dos quatro pontos observados, foram feitas duas medições: uma na área do contexto imediato à atividade (máscara quadrada ao redor do ponto com $200 \mathrm{~m}$ de lado) e outra na área menor que cobre suficientemente a composição de seus elementos físicos (máscara quadrada ao redor do ponto com $20 \mathrm{~m}$ de lado).

A variável em questão identifica esta percepção, além de medi-la. Seu mapa gerador é o de barreiras e permeabilidades ao movimento desta vez de pedestres, em que são barreiras: edifícios, elementos da paisagem mais altos que um gramado (árvores, arbustos, canteiros etc.), cercas, caixas de eletricidade, enfim, tudo o que

${ }^{42}$ Al_Sayed, K., Turner, A., Hillier, B., lida, S., Penn, A., 2014. 
impede o pedestre (ou o faça desviar) de circular pelo local. Assim, como na variável anterior, o mapa de axialidade apresenta os índices de axialidade (ao movimento do pedestre) máximo, mínimo e do local em que o ponto está. Eles são considerados nesta variável, para efeito de comparação.

11) Acessibilidade à visão - conexão visual

Da mesma forma que a acessibilidade aos movimentos motorizado e de pedestre, a acessibilidade à visão, ou conexão visual, permite verificar o quanto o local escolhido é acessível visualmente. Com a utilização da mesma máscara quadrada, de $200 \mathrm{~m}$ de lado, e da base cartográfica de cada ponto, é gerado o mapa de barreiras e permeabilidades à visão do pedestre, em que são consideradas barreiras todo e qualquer elemento fixo com altura acima de $1,50 \mathrm{~m}$ (edifícios e seus pilotis, postes, árvores etc.). A partir daí, é gerado o mapa de visibilidade, em que são considerados os índices de visibilidade máximo, mínimo e do ponto de comércio analisado, assim como os mapas axiais das variáveis anteriores.

A sequência de operações, ou feitura de mapas, para se chegar à análise sintática dos locais dos pontos de comércio é explicitada na sequência da Figura 2.3, em que são apresentados os três tipos de mapas citados de um trecho da quadra SQN 315, como exemplo.

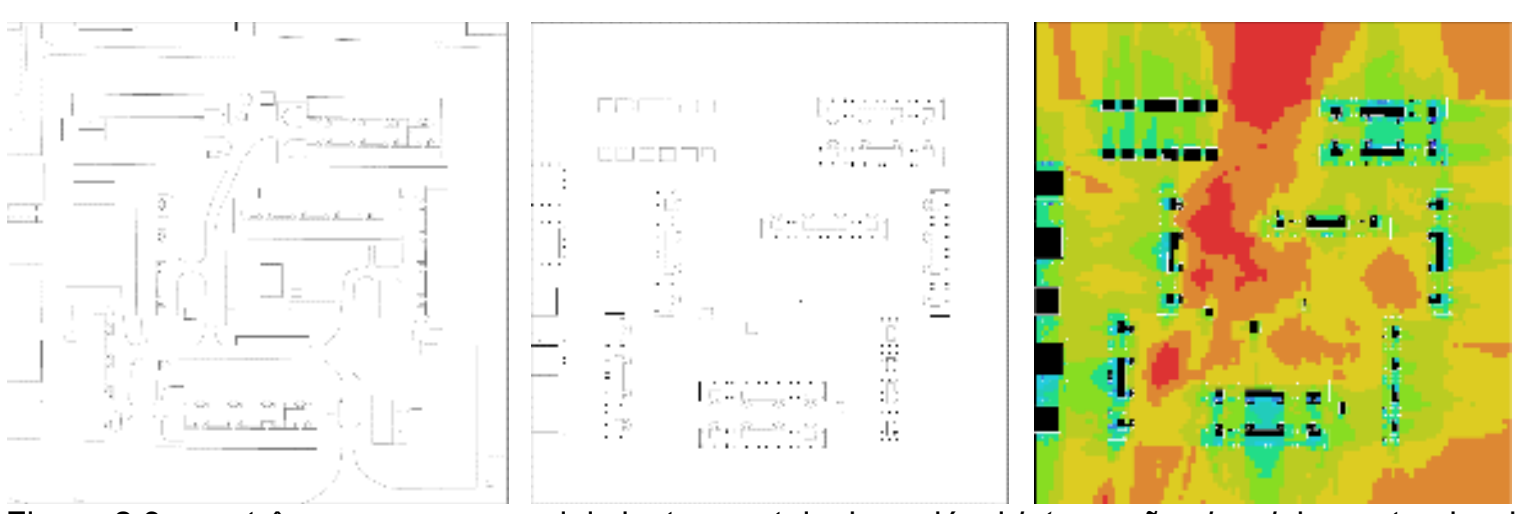

Figura 2.3 - os três mapas sequenciais instrumentais da variável integração visual de um trecho da SQN 315: (da esquerda para a direita) base cartográfica, barreiras e permeabilidades visuais (gerador) e integração visual (sintático). 
12) Isovistas - campo visual

Esta variável detecta a área do espaço diretamente visível a partir de um determinado ponto. É a ligação visual entre este ponto e todos os outros dentro de um mesmo ambiente. Sua representação está relacionada às propriedades de um ambiente construído, no que diz respeito a cognição espacial de uma posição situada. A compreensão deste tipo de percepção auxilia na detecção das possibilidades de visibilidade dentro de um lugar, a partir desta posição. As isovistas são representadas graficamente por um polígono fechado e, por isso, têm propriedades geométricas, como área e comprimento do perímetro (AL_SAYED et al, 2014, p. 29).

A técnica utilizada na detecção das isovistas segue os mesmos procedimentos utilizados para o trabalho com as variáveis de convexidade e axialidade, sendo que se difere no mapa gerado dentro do programa DepthmapX, em que é escolhido um ponto de onde partirá a ligação com todos os outros pontos acessíveis visualmente, isto é, não interrompidos por nenhuma barreira à visão. A área do polígono formado é constituída deste conjunto de inúmeras linhas que partem do ponto escolhido.

13) Condições para permanência - estado de conservação e conforto

Esta é uma variável síntese em que são congregados os aspectos físicos que informam sobre o estado de conservação e conforto do ambiente para cada ponto de comércio ali instalado. Parto da hipótese de que tanto o estado de conservação quanto o conforto são considerados pelo comerciante na escolha do lugar para a montagem do ponto de comércio e, também, pelos clientes.

Como nas pesquisas de Tenorio (2012) e Ribeiro (2013), o estado de conservação aqui é considerado sobre o nível de cuidado, limpeza e manutenção dos equipamentos e do espaço público em que o local do ponto se insere. A detecção do nível de conforto é restringida a oferta de lugares para sentar e de áreas com sombra ou boa iluminação, no caso dos pontos de comércio com funcionamento noturno. 
A verificação é feita por meio de observação in loco e de fotografias, identificando e contabilizando os elementos que determinam a preocupação com o lugar por parte do planejamento e pela importância dada a este quesito, pelo comerciante. Para avaliar esta variável, são determinados três níveis de atendimento a este quesito: ruim, mediano, bom.

14) Atividades ao redor do ponto de comércio

A diversidade e concentração de atividades em pequenas áreas do espaço urbano são magnetos de pessoas. Quanto maior for a diversidade de usos, maior será o número de pessoas atraídas por um lugar, pela reunião de expectativas diferentes que isso acarreta (JACOBS, 2007; WHITE, 2009; HOLANDA, 2002; TENORIO, 2012, RIBEIRO, 2013). Cada lugar escolhido pelo comerciante, por sua localização em relação à quadra residencial próxima e outras características, tem maior ou menor número de atividades ao redor. Isso influenciará diretamente no desempenho sociológico e funcional do ponto de comércio.

A partir do conceito de solidariedade (HOLANDA, 2002, p. 112), investigo a atuação direta e indireta da atividade na organização dos encontros sociais que acarreta. Da lista de variáveis especificadas por Holanda (p. 113), "variedade de rótulos" norteia a formulação desta variável. O conceito de rótulo congrega os tipos de atividades exercidas nos espaços fechados ao redor do espaço aberto observado, com as respectivas categorias de pessoas que as desenvolvem (p. 107).

A contabilização e o registro das atividades ao redor do ponto de comércio dentro da área de seu contexto imediato, previamente delimitado, permite a verificação da atuação do ponto estudado junto às outras atividades na construção da estrutura social do espaço em questão. Pode-se verificar o grau de qualificação mútua entre as atividades, rótulos e o ponto de comércio. Observação in loco e registros fotográficos, identificação, contagens e registros textuais permitem a detecção dos dados sobre as atividades ao redor do ponto de comércio estudado e as respectivas correlações. 


\subsubsection{Sistemas de encontros e esquivanças}

Uma vez analisados sintaticamente, os padrões espaciais que repercutem diretamente no desempenho da atividade, neste nível de análise são consideradas as variáveis relacionadas aos sistemas de encontros entre os sujeitos que, direta (que permanecem) ou indiretamente (em movimento), interessam ao bom andamento da atividade comercial observada e, consequentemente, à vida social do local. Desta vez, as categorias desvendam a passagem da análise entre os padrões espaciais e os de copresença, clareando um dos aspectos da interface entre o contexto e a atividade. Naquele nível é indicada a potencialidade dos encontros, que neste nível são constatados ${ }^{43}$. As variáveis deste nível são meios para a obtenção de informações sobre a passagem e, principalmente, a permanência de pessoas nos pontos de comércio observados.

As técnicas para o levantamento da vida pública formuladas por Jan Gehl, foram revisadas e utilizadas por Tenorio (2012) em sua tese, bem como Ribeiro (2013) em sua dissertação. Seguindo esta linhagem, no âmbito da pesquisa sobre arquitetura sociológica em Brasília, lanço mão destas técnicas com as devidas adaptações, por conta das especificidades do objeto de pesquisa.

As técnicas utilizadas para o levantamento do fluxo e atividades das pessoas (...) seguem sendo utilizadas nas consultorias que seu escritório presta para prefeituras ao redor do mundo (...) que têm interesse em obter mais urbanidade em áreas consolidadas, normalmente centros urbanos. (...) Consistem principalmente em identificar o tráfego de pedestres e as atividades estacionárias ocorridas em locais selecionados. São levantamentos simples, mas que demandam tempo de observação. (...) Para o tráfego de pedestres, os locais são escolhidos previamente, bem como são definidos os detalhes que se deseja obter: idade e sexo dos passantes, direção, lado da rua. A contagem é feita no inverno e no verão, em países onde estas duas estações são muito diferenciadas, de dia e à noite, em um dia da semana típico (normalmente de terça a quinta), e em um dia de fim de semana (normalmente sábado). Conta-se o número de pedestres que passam por um determinado ponto, por 10 minutos consecutivos, a cada hora. (...) O resultado obtido é matéria prima para várias informações derivadas. (...) A saída mais comum são gráficos que

\footnotetext{
43 Holanda (2002:110), apresentando o conceito de comunidade virtual de Hillier, que o sintetiza como "campo de encontros prováveis", clareia a interrelação entre os níveis Padrões espaciais e Sistemas de encontros e esquivanças. No primeiro, a análise é direcionada ao potencial da configuração do lugar, para que no segundo, sejam comprovados, ou não, os índices de copresença apontados nos mapas de integração. Esta correlação é descrita na categoria denominada predictibilidade.
} 
apresentam a intensidade do fluxo de pedestres e sua variação ao longo das horas do dia. (TENORIO, 2012, p. 127-128)

As adaptações feitas se devem ao fato de que o objeto de estudo é uma atividade específica, que já tem seu lugar de ocorrência estabelecido. Não se aplica, então, identificar "atividades estacionárias ocorridas em locais selecionados". Em relação aos que estão de passagem, é feita somente a contabilização, sem considerar idade, sexo, direção, ou mesmo, lado da rua. Como são o foco do estudo, os que permanecem no ponto de comércio, para consumir, ou não, são contabilizados levando-se em conta suas características, como gênero e faixa etária. Ademais, é registrado o comportamento destas pessoas, no que diz respeito à distribuição no local e no tempo.

Outra especificidade do objeto de estudo que leva a adaptações às técnicas de Gehl é a limitação de funcionamento dos pontos de comércio aos dias úteis da semana (na maior parte dos observados) e a determinados turnos do dia e não o dia inteiro. Devido a isso, para as variáveis sobre comportamento, observações sistematizadas foram feitas, levando-se em consideração o tempo que cada atividade de comércio permanece no local. Estas observações foram feitas em intervalos intercalados de tempo: 15 minutos contabilizando, 15 minutos não.

Este mapeamento é constituído, então, de características básicas (gênero e faixa etária) e comportamentais (localização de permanência) das pessoas - informações para serem confrontadas com os mapas e dados dos níveis anteriores e do nível seguinte.

Tabela 2.3 - variáveis, variabilidade e técnicas/ferramentas do nível analítico Sistemas de encontros e esquivanças.

\begin{tabular}{|c|c|c|c|}
\hline & VARIÁVEIS & VARIABILIDADE & FERRAMENTAS \\
\hline 15 & $\begin{array}{l}\text { Quantidade de pessoas }- \\
\text { passagem e permanência }\end{array}$ & quantidade de pessoas & \multirow{2}{*}{$\begin{array}{l}\text { observação } \\
\text { sistematizada: } \\
\text { contabilização } \\
\text { intercalada }\end{array}$} \\
\hline 16 & $\begin{array}{l}\text { Variedade de pessoas na } \\
\text { permanência: gênero e faixa etária }\end{array}$ & $\begin{array}{l}\text { quantidade de pessoas } \\
\text { distribuída em (F); (M) e } \\
\text { Quantidade de pessoas } \\
\text { distribuídas em (crianças); } \\
\text { (adolescentes); (20-30); (30- } \\
\text { 40); (40-50); (50-60); (>60) }\end{array}$ & \\
\hline 17 & $\begin{array}{l}\text { Distribuição de pessoas no tempo e } \\
\text { no espaço }\end{array}$ & $\begin{array}{l}\text { posições das pessoas } \\
\text { contabilizadas no espaço da } \\
\text { atividade }\end{array}$ & $\begin{array}{l}\text { mapeamento } \\
\text { comportamental }\end{array}$ \\
\hline
\end{tabular}


Variáveis

15) Quantidade de pessoas - passagem e permanência

Esta variável indica basicamente a intensidade de utilização do local em que o ponto de comércio se insere, pelos sujeitos. Está diretamente ligada à variável que informa sobre proximidade de atividades em relação ao ponto. Relacionada com outras variáveis, físicas inclusive, ela indica se o lugar estudado tem potencial de sucesso para o comércio informal. Os que passam e os que permanecem são contabilizados de modo separado, lembrando que, em relação aos que passam é contabilizada somente a quantidade, enquanto a variedade - gênero e faixa etária - dos sujeitos é detectada somente nos que permanecem. Para esta variável, dentro do respectivo nível analítico, são feitas as contagens intercaladas e, com base nestes registros, os mapas comportamentais são montados.

16) Variedade de pessoas na permanência

Quanto maior a variedade da clientela do ponto de comércio, melhor é o seu desempenho. Diversas são as características que descrevem esta variedade, porém gênero e faixa etária são as representativas e detectáveis por observação que interessam neste nível para indicar a variedade dos sujeitos.

\footnotetext{
Um espaço público bem sucedido deve permitir a copresença de pessoas diferentes: homens e mulheres com diferentes idades, de diferentes origens, de distintas condições físicas, financeiras, culturais, educacionais, em diferentes fases da vida, que morem em diferentes lugares, possuam ocupações e interesses diversos. A variedade de pessoas deve refletir a sociedade onde o espaço se insere, devendo incluir moradores da área. (TENORIO, 2012, p. 182)
}

17) Distribuição de pessoas no tempo e no espaço

Atrelada à variedade, a distribuição das pessoas no tempo e no espaço completa o que busco no comportamento daqueles que, de uma forma ou de outra, entram em contato com o ponto de comércio. A detecção da quantidade das pessoas que permanecem, por meio da variável anterior é feita com base nesta distribuição. É desejável que durante todo o período de tempo em que o ponto de comércio ocupa 
um determinado lugar, haja pessoas passando. O fluxo de sujeitos deve ser bem distribuído durante este período. Em relação à passagem, é importante a quantidade das pessoas e não as direções de deslocamento na proximidade ou dentro do espaço convexo em que o ponto se encontra. Isto se explica pela importância dada ao contato dos sujeitos com o ponto de comércio, e não de onde eles vêm ou para onde vão. As posições de permanência variam muito, pois as pessoas circulam pelos espaços determinados pelos elementos físicos do ponto de comércio com o ambiente, enquanto permanecem ali. São marcadas, então, somente as posições das pessoas quando são contabilizadas.

A variável indica o grau de aproveitamento destes espaços pelos sujeitos que ali passam ou permanecem para a compra e o consumo dos produtos vendidos, o que repercute sobremaneira na vida social do espaço ocupado pelo ponto de comércio e arredores.

O mapeamento comportamental constitui a técnica utilizada e o intercalar dos períodos de 15 minutos é distribuído no tempo em que o comércio permanece no local apropriado pelo comerciante. Os mapas utilizados são os de cheios e vazios determinados pelos elementos físicos envolvidos na atividade entre si e com o espaço em que se insere.

\subsubsection{Sistema de Elementos Físicos - SEF}

A composição espacial constituída da interação dos elementos físicos entre si e com o meio, na atividade do comércio é o foco do nível analítico Sistema de Elementos Físicos - SEF. Organizo os elementos em duas categorias:

a) elementos portados pelo comerciante, que englobam tendas, mobiliário (mesas, cadeiras, estantes), churrasqueira (fogareiro ou rechaud), caixotes (ou engradados), caixas térmicas (de isopor) e objetos menores de cozinha e mesa, em conjunto com o(s) produto(s) para ser(em) vendido(s): tipo quanto à origem/fabricação (revenda, fabricado pelo comerciante em casa, fabricado pelo comerciante no local); diversidade (1, 2, 3 ou mais tipos de produto); 
quantidade em relação ao tamanho e ao tempo de permanência no local para a venda (quantidade exposta é igual ao estoque).

b) elementos do local, ou da arquitetura ou da paisagem, aproveitados pela atividade: suportes de sinalização; calçadas; muros; postes; mobiliário urbano (bancos, mesas); latas de lixo; árvores, arbustos, cercas vivas e canteiros.

Neste nível, analiso a atividade em si e a repercussão formal/sintática de sua inserção no espaço convexo em que está inserida. Analisar o SEF nas variáveis descritas a seguir, permite conhecer a contribuição dos aspectos da interface formal da atividade em seu desempenho social.

Como técnica básica deste nível, é confeccionado um mapa mais detalhado, na escala da atividade, em que os cheios são os seus elementos físicos. Após a análise de cada mapa em suas informações relevantes, este mapa e o de convexidade são sobrepostos para a análise da interface gerada, em termos funcionais e sociológicos, por meio da inserção do ponto naquele local específico. Além da análise destes mapas do local e da atividade separadamente e da relação entre eles, a verificação é feita por meio de observação in loco e fotografias, com o intuito de complementação da detecção das informações no âmbito desta variável.

Tabela 2.4 - variáveis e técnicas/ferramentas do nível analítico Sistemas de elementos físicos.

\begin{tabular}{|c|c|c|c|}
\hline & VARIÁVEIS & VARIABILIDADE & FERRAMENTAS \\
\hline 18 & $\begin{array}{l}\text { Complexidade: descrição, atributos } \\
\text { e relações }\end{array}$ & $\begin{array}{l}\text { diversidade de elementos } \\
\text { utilizados, suas funções e } \\
\text { qualidades individuais e } \\
\text { relações e integração }\end{array}$ & \multirow{2}{*}{$\begin{array}{l}\text { mapa detalhado } \\
\text { com elementos } \\
\text { da atividade; } \\
\text { observação in } \\
\text { loco e registro } \\
\text { fotográfico }\end{array}$} \\
\hline 19 & Aspectos funcionais & $\begin{array}{l}\text { itens de relação entre os } \\
\text { elementos e suas funções na } \\
\text { atividade }\end{array}$ & \\
\hline
\end{tabular}


Variáveis

18) Complexidade

Nesta variável síntese são observados três fatores em relação aos elementos físicos envolvidos na atividade como um sistema: descrição (o quê), atributos (qualidades) e relações (como interagem).

Na descrição, os elementos são posicionados em uma das categorias citadas acima, antes de serem descritos: elementos portados ou elementos do local. O que são, a quantidade e o tamanho (pequeno, médio, grande) dos elementos interessam nesta etapa, que prepara para o conhecimento de suas funções e relações, nas subvariáveis seguintes.

As qualidades e funções de cada elemento são destacadas na segunda etapa desta variável, complementando sua descrição. Neste momento, já começam a ser detectadas as affordances dos elementos e da composição como um todo, cuja observação se completa na etapa seguinte, a das relações entre os elementos físicos da atividade.

Massa edilícia, mobiliário urbano, sinalização, paisagem etc. são integrados em um todo que compõe o ambiente e fornece subsídios para o comércio. Ao estabelecer as relações dentro do sistema de elementos físicos, portados ou do local, é possível detectar o nível de integração entre eles: quanto maior for a utilização do que já está no local, maior a integração entre o SEF e o lugar utilizado, em termos de aproveitamento físico. Os princípios da affordance são acionados na concepção e utilização desta variável. A detecção desta integração, por meio das relações entre os elementos, subsidia o entendimento sobre a percepção do comerciante em relação às possibilidades funcionais dos elementos físicos existentes no lugar por ele escolhido, em termos de sua configuração. Os resultados desta variável auxiliam na análise sobre o nível de qualificação entre o lugar e o conjunto de elementos físicos. 
19) Aspectos funcionais - relações entre elementos físicos e as práticas

Este nível trata das condições para o funcionamento que o conjunto de elementos físicos proporciona a atividade. Ainda neste nível, é importante verificar se estes elementos cumprem outras funções como transporte, exposição, armazenamento etc. e de que maneira, no sentido de otimizar a atividade naquele local.

Somam, assim, dezenove variáveis distribuídas em quatro níveis analíticos, algumas compostas por subvariáveis, que foram criadas para abordar a atividade como um sistema.

\subsection{Para analisar as informações}

Conforme o recorte da pesquisa, interpreto a atividade como a conjugação de dois tipos de sistema: um social e outro morfológico, em que cada um deles é composto por dois elementos de entrada no sistema como um todo. Existe uma correspondência entre os quatro elementos de entrada com os níveis analíticos do método construído, conforme mostra a Tabela 2.5. A opção por esta correspondência é mostrar que antes de ser abordada pelas teorias, a atividade é considerada como um sistema. Na linha da tabela "ELEMENTOS DE ENTRADA", a atividade é apresentada de modo mais geral, como um sistema formado por dois subsistemas, um prenúncio de como a estou analisando. Na linha seguinte "NÍVEIS ANALÍTICOS CORRESPONDENTES" - ela é apresentada como o mesmo sistema, sendo que analisado pelo ponto de vista das Teorias da Sintaxe Espacial e da Abordagem Ecológica (Affordance).

Tabela 2.5 - composição do sistema da atividade nos sistemas social e morfológico, seus elementos de entrada e correspondentes níveis analíticos.

\begin{tabular}{c|l|l|l|l}
\hline \multicolumn{1}{c|}{ SISTEMA } & \multicolumn{3}{|c}{ O sistema da atividade } \\
\hline TIPOS DE SUBSISTEMA & \multicolumn{2}{|c}{ Sistema social } & \multicolumn{1}{c}{ Sistema morfológico } \\
\hline $\begin{array}{c}\text { ELEMENTOS DE } \\
\text { ENTRADA }\end{array}$ & $\begin{array}{l}\text { agentes - } \\
\text { comerciante, } \\
\text { clientes e } \\
\text { passantes } \\
\text { (clientes em } \\
\text { potencial) }\end{array}$ & $\begin{array}{l}\text { ações - a } \\
\text { ocorrência da } \\
\text { atividade em } \\
\text { si: compra e } \\
\text { venda, } \\
\text { permanência e } \\
\text { passagem }\end{array}$ & $\begin{array}{l}\text { lugar - } \\
\text { espaço } \\
\text { escolhido, } \\
\text { apropriado e } \\
\text { utilizado }\end{array}$ & $\begin{array}{l}\text { elementos } \\
\text { físicos - } \\
\text { arquitetura e } \\
\text { paisagem, } \\
\text { produtos e } \\
\text { suportes }\end{array}$ \\
NIVEIS ANALITICOS & $\begin{array}{l}\text { Características } \\
\text { Socioeconômicas }\end{array}$ & $\begin{array}{l}\text { Sistemas de } \\
\text { encontros e } \\
\text { esquivanças }\end{array}$ & $\begin{array}{l}\text { Padrões } \\
\text { espaciais }\end{array}$ & $\begin{array}{l}\text { Sistemas de } \\
\text { Elementos } \\
\text { Físicos - SEF }\end{array}$ \\
\hline
\end{tabular}


Todos os elementos contribuem para a formação e o funcionamento da atividade, mesmo o lugar que, normalmente é considerado ambiente do sistema, é parte significativa, assim como os outros. O sistema é formado, então, por quatro elementos básicos de entrada: agentes, ações, lugar e elementos físicos. Neste caso, o conjunto de regiões residenciais da Asa Norte, com seus diversos pontos de comércio em via pública, constitui o ambiente imediatamente maior e, por isso, recebedor do sistema da atividade. A formação original do sistema em três âmbitos - CONTEXTO | INTERFACE | ATIVIDADE - colocada anteriormente, se mantém para efeito de conceituação, análise e estrutura geral. Os elementos e suas interrelações são introduzidos, com base nestes âmbitos, a medida que avanço na reflexão e formação do sistema da atividade.

Faço, a seguir, uma breve descrição dos quatro elementos de entrada, para o melhor entendimento da base teórica concernente ao envolvimento da arquitetura e do design, que vem respectiva e subsequentemente, nas teorias da Sintaxe Espacial e da Abordagem Ecológica (Affordance).

\subsubsection{Subsistema do tipo social - agentes e ações}

As pessoas envolvidas, a quem nesta situação são comumente denominadas agentes $^{44}$, e as ações por elas empreendidas são os elementos de entrada que compõem o sistema do tipo social. As características socioeconômicas, tanto dos agentes da atividade, quanto dos que vivem (moram e trabalham) próximos aos pontos de comércio observados, informam sobre o perfil deste contingente no que diz respeito à sua base econômica. Associado a isso, considero parte integrante do sistema social da atividade o comportamento socioespacial destes agentes na permanência e passagem pelo local do ponto de comércio.

O comerciante desencadeia toda a atividade e, por isso, tem relação causal com todos os outros elementos. Ele inicia as ações pela escolha do lugar para

\footnotetext{
44 “... pessoa ou algo que produz ou desencadeia ação ou efeito" (HOUAISS, 2009). Escolho agente pela definição afinada com o conceito de atividade: "faculdade ou possibilidade de agir, de se mover, de fazer, empreender coisas" (ibidem).
} 
apropriação temporária e instalação do ponto. Elege, transporta e compõe todos os elementos físicos que suportam a atividade, complementando o lugar escolhido. Prepara e disponibiliza os produtos para a venda; serve, atendendo a demanda dos clientes. E, finalmente, desmonta, tira e transporta para fora do lugar os elementos físicos que levou.

Os clientes, agentes tão importantes quanto o comerciante, podem ser os de primeiro contato - aqueles que estão consumindo no ponto pela primeira vez -, os de contato eventual ou os de contato assíduo. Em qualquer um dos tipos de cliente, são pessoas que se direcionam para o ponto com o intuito primeiro de consumir. Este fato, caracterizaria a atividade como principalmente necessária, segundo Jan Gehl.

Ela é opcional a partir da constatação de que os potenciais clientes têm outros pontos de comércio informais, ou estabelecimentos comerciais formais próximos para a compra dos produtos. O encontro entre clientes e comerciantes, seus ajudantes, outros clientes e passantes caracteriza a atividade como social. O comerciante desencadeia, também, o caráter social da atividade, mas são os clientes que o potencializam.

Os passantes, como clientes potenciais, compõem o quadro social da atividade pelo fato da simples copresença com comerciante e clientes, além de indicarem que o lugar em questão propicia, funcional e formalmente, fluxo de pedestres.

Anterior à questão das ações específicas da atividade do comércio em via pública, a copresença é o fator primordial de qualquer atividade de cunho social no espaço urbano. O compartilhar físico e sensorial do mesmo ambiente caracteriza o princípio da socialização. A partir deste primeiro (cont)ato todas as outras ações podem acontecer, o que permite o desenrolar das inúmeras atividades que, normalmente, ocorrem no espaço urbano.

A ocorrência da atividade engloba uma diversidade de pequenas ações que são consideradas em sua composição como parte integrante do sistema social, além dos agentes. Ações que vão desde a eleição do local pelo comerciante até a 
desmontagem dos aparatos de venda, passando pela venda dos produtos, permanência de clientes e passagem de pedestres, próximo ao ponto. A atividade é o próprio sistema em pleno funcionamento e sua razão de ser. Um dos magnetos do espaço urbano.

Agentes e suas ações são como um único ente neste subsistema. Completamente imbricados, eles impulsionam e mobilizam o outro tipo de subsistema que compõe a atividade: o sistema material.

\subsubsection{Subsistema do tipo morfológico - lugar e elementos físicos}

O subsistema do tipo morfológico é composto pelo lugar escolhido pelo comerciante e pelos elementos físicos que dão suporte à atividade. Este lugar é o resultado dos espaços delimitados pela massa edilícia ao redor do ponto e é escolhido por reunir e apresentar qualificações específicas, que proporcionam a ambiência adequada à atividade em questão. São os atributos formais de que trata a Sintaxe Espacial, que permitem, por exemplo, fluxo significativo de pedestres, visibilidade do ponto a uma distância considerável e delimitação do espaço pela arquitetura resultando em um ambiente acolhedor, que conduzem a escolha do comerciante por determinado lugar.

Os elementos físicos são compostos conforme a configuração do lugar. Por isso, a composição formal do todo da atividade engloba todas as suas escalas, passando pelo contexto, a interface e os elementos da atividade, propriamente dita. São dispostos de maneira que a atividade cumpra o seu propósito da melhor forma possível, segundo o planejamento do comerciante. A forma do lugar e dos elementos físicos menores da arquitetura e da paisagem (parapeitos, calçadas, arbustos etc.) informam e orientam o comerciante na composição dos elementos levados.

A interface, tanto física quanto social, entre contexto e atividade, acontece na intersecção dos espaços delimitados pela arquitetura e pelos elementos físicos da atividade. 
As interrelações entre os quatro elementos são aqui analisadas nos pontos de comércio observados, na medida em que cada elemento suporta e qualifica o outro. São iluminadas as relações de troca entre cada dupla. E com a descrição de cada elemento inserido em seu respectivo tipo de sistema, chego a um modelo próprio do sistema da atividade, para embasar a formação do método e, consequentemente analisar os estudos de caso. As relações se dão entre os níveis analíticos que representam os elementos do sistema que cada ponto de comércio encerra.

A seguir, sintetizo o tipo de relação entre os pares formados pelo quatro elementos, ou níveis analíticos. Esta síntese serve de roteiro para a análise de cada ponto como um sistema, após a sua descrição, no capítulo 3. Os níveis analíticos assim são relacionados:

. Padrões Espaciais + Características Socioeconômicas - a escolha e a apropriação (a indisciplina) do espaço pelo comerciante, envolvendo as pessoas que ali frequentam.

. Padrões Espaciais + Sistema de Encontros e Esquivanças - o potencial do espaço do contexto revelado pelo comportamento (movimento + permanência) observado.

- Padrões Espaciais + Sistema de Elementos Físicos - repercussão mútua no potencial das configurações do contexto e do ponto de comércio observado.

. Sistema de Elementos Físicos + Características Socioeconômicas - a escolha dos elementos físicos e do arranjo pelo comerciante, envolvendo as pessoas que ali frequentam.

. Sistema de Elementos Físicos + Sistema de Encontros e Esquivanças - o potencial do espaço da atividade revelado pelo comportamento (movimento + permanência) observado.

- Características Socioeconômicas + Sistema de Encontros e Esquivanças - a demonstração do grau de sucesso das escolhas pelo comerciante (do espaço, dos elementos físicos e do arranjo) revelado pelo comportamento (movimento e permanência) observado. 
A comparação entre cada ponto de comércio observado é feita no capítulo 4, tomando-se como base as categorias analíticas. $O$ intuito é comparar para levantar aspectos positivos e negativos de cada escolha de lugar, cada composição de elementos e suas repercussões para então formular o que foi aprendido e trazido para a reflexão e o exercício do projeto para o espaço urbano. Ademais, as variáveis são avaliadas em seu funcionamento e suas relações no âmbito da análise do objeto de estudo

\subsection{Em Brasília, no Plano Piloto, na Asa Norte - o campo}

O foco da pesquisa no cotidiano, direcionou a escolha do campo para a região residencial de Brasília, por acreditar ser aí uma fonte bastante significativa de costumes da vida brasiliense. Não bastou estar morando nesta cidade (ou melhor, região administrativa) por quase 20 anos, tive que apreendê-la com os pés ${ }^{45}$ de forma mais cuidadosa, desta vez. Quando motorizada, assim que avistava um ponto de comércio informal, estacionava próximo e ia conhecer de perto, o que repetidas vezes passou desapercebido. A princípio, visitei pontos localizados nas asas Norte e Sul do Plano Piloto de Brasília ${ }^{46}$.

O critério utilizado para a escolha da Asa Norte como região estudada no trabalho de campo se deu pela proximidade ao campus da Universidade de Brasília - UnB. Isto favoreceu a dinâmica da pesquisa e facilitou sobremaneira o desenvolvimento do trabalho de campo.

\subsubsection{Apresentação geral}

Sobre Brasília, impressões vão de um extremo ao outro. Críticas e elogios são tecidos por parte dos habitantes e de estudiosos do tema. Tanto numa quanto noutra situação ela é comparada a outras cidades planejadas ou tradicionais brasileiras e

\footnotetext{
${ }^{45}$ Holanda (2010) inicia o Brasília - cidade moderna, cidade eterna assim, no capítulo 1 - Apreender com os pés. Uma das primeiras dicas sobre como conhecer uma cidade e, também Brasília, por mais árduo que possa parecer.

${ }^{46}$ O Plano Piloto de Brasília, projeto de Lucio Costa, compreende o cruzamento em formato de cruz dos eixos Rodoviário e Monumental. No sentido norte-sul, o Eixo Rodoviário é composto pelas asas Norte e Sul e pela parte central, onde se localiza a Rodoviária do Plano Piloto.
} 
estrangeiras. Esta cidade, apesar de passar por problemas e êxitos de toda sorte, comuns a outras cidades, tem peculiaridades socioespaciais que devem ser ressaltadas logo no início de qualquer discussão acadêmica em que ela é tema ou região para trabalho de campo.

Uma das maneiras que comumente Brasília é debatida recai sobre a relação entre seus modos de vida e organização espacial. É comprovado, principalmente dentro da arquitetura sociológica, que os fatores morfológicos, para além dos políticos e ideológicos da capital, são responsáveis por traços importantes da vida social de seus habitantes. "O modo de vida 'brasiliense' passa, assim, a ser totalmente explicado pela morfologia espacial e tudo então se torna típico, exclusivo e específico de Brasília." (MACHADO, MAGALHÃES, 2010, p. 285).

Holanda (2010b, p. 200) explica esta questão por meio do estudo das relações entre urbanismo, definido como a conjunção da morfologia física da cidade e a estrutura locacional de suas inúmeras funções, e os modos de apropriação do espaço urbano. É Brasília estudada sob a lente da Sintaxe Espacial, em que "os atributos de caráter relacional, como de proximidade ou distância, continuidade ou contiguidade, enclausuramento, obstrução ou permeabilidade, separação ou agregação, são os que interessam fundamentalmente para a análise." (p. 201).

Estes aspectos específicos de configuração, caracterizam o urbanismo moderno, berço conceitual dos ideais de concepção da capital brasileira. Foi a idealização que interligou três pilares: 1) uma nova capital, 2) com uma nova organização do espaço e 3) para uma nova sociabilidade urbana. A receita da utopia. Isso em oposição ao considerado "caos urbano", oriundo da repercussão da industrialização capitalista sobre as cidades e a sociedade em si.

\footnotetext{
Brasília é filha integral do urbanismo moderno do final do século XIX que exigia não mais a "reforma" parcial das cidades, mas o projeto e a construção de uma cidade concebida como um todo. Brasília é toda uma cidade nascida diretamente de uma prancheta e implantada no vazio do cerrado. (MACHADO, MAGALHÃES, 2010, p. 287).
}

E para atender essa nova sociedade de modo "salubre", harmônico e homogêneo na busca de um 'equilíbrio entre o homem e seu meio', o partido urbanístico foi o de 
separar espacialmente as funções básicas de uma cidade em unidades de habitação, trabalho, agrárias, circulação etc. (LE CORBUSIER, 1971 apud MACHADO, MAGALHÃES, 2010).

\subsubsection{Os aspectos morfológicos e sociais da escala residencial}

Em linhas gerais, citei o binômio 'formalidade' e 'urbanidade', no capítulo 1, para indicar uma das bases da arquitetura sociológica. Retomo-os para entender Brasília, quanto à sua configuração, dentro destes paradigmas. Verifica-se que em seus estudos sobre Brasília, Holanda elucida a origem de suas peculiaridades sobre os aspectos morfológicos de fragmentação, densidade, dispersão, excentricidade e segregação socioespacial (HOLANDA, 2010a, p. 47). Estes aspectos posicionam Brasília, na régua descrita entre os paradigmas da urbanidade e da formalidade, mais perto do último. E "espaços formais, (...), implicam um sobre-esforço do povo para superar as restrições impostas pela configuração." (p. 42).

A fragmentação é um dos aspectos que mais marca Brasília, morfologicamente, por possuir um tecido urbano descontínuo, isto é, partes de configurações diversas da cidade são separadas por vazios. Como mencionado, "a medida refere-se à maior ou menor acessibilidade interpartes de uma cidade, com base no número mínimo de inflexões de percurso entre um ponto e outro. (...) se dobramos mais esquinas, a cidade é mais fragmentada; se dobramos menos, ela é mais integrada." (p. 51). As maiores vias, como os eixos Rodoviário e Monumental e as W3 e L2 facilitam a mobilidade e a apreensão global do Plano Piloto, mas no nível das superquadras residenciais, região do trabalho de campo, isso se torna mais difícil pela grande bifurcação, dado o sistema viário "em árvore" ${ }^{47}$. É normal, até para quem já conhece o sistema das superquadras, perder-se, principalmente, na saída da parte mais profunda de uma delas em direção à entrada.

A densidade, ou o número de habitantes por hectare $\left(10.000 \mathrm{~m}^{2}\right.$ de área), é outro aspecto que em Brasília a média é baixa. Porém, na região das superquadras, pelo tratamento dado, como por exemplo, intensa arborização e calçadas que as

\footnotetext{
${ }^{47}$ Em termos de integração média, Brasilia pode ser comparada à integração média das cidades brasileiras tipicamente fragmentadas (BARROS, 2009 apud HOLANDA, 2010a).
} 
interligam, a utilização do espaço urbano é mais intensa, aumentando assim a densidade média desses locais. (p. 54).

A distância média entre habitantes e centro urbano, ou o índice de dispersão em Brasília é consideravelmente grande em relação a outras cidades. Isso aponta para a dificuldade, em termos de tempo gasto e custos com passagem, dos que se deslocam cotidianamente das satélites para o centro, Plano Piloto. (p. 55). Estas grandes distâncias são agravadas com a localização em pontos diferentes e distantes entre si, no Plano, dos centros funcional, demográfico e morfológico ${ }^{48}$. A coincidência ou quase entre eles diminuiria consideravelmente esses esforços de deslocamento.

Em decorrência destes aspectos, a segregação socioespacial ocorre com o desenvolver da cidade, desde os seus primórdios e apesar do que Lucio Costa pretendia. Das quatro escalas que formam Brasília ${ }^{49}$, a residencial reflete bastante 0 intuito do urbanista de, com o projeto das superquadras, promover o convívio das diferentes faixas socioeconômicas da população. Mas não foi o que ocorreu. A separação entre as camadas menos favorecidas e as de maior poder aquisitivo acontece como em outras cidades, em que as primeiras são mantidas distanciadas em termos de moradia.

A região residencial do Plano Piloto foi originalmente projetada ao longo do Eixo Rodoviário e subdividida, simetricamente, nas Asas Norte e Sul, com uma fileira a leste (superquadras 200) e duas a oeste (superquadras 100 e 300) (Figura 2.4).

\footnotetext{
${ }^{48}$ HOLANDA (2010a): 'centro funcional' é o ponto em torno do qual se concentra a maioria dos empregos e serviços; 'centro demográfico' corresponde ao local de moradia, ou "centro de massa" populacional e 'centro morfológico' é o mais acessível fisicamente, em relação ao sistema viário.

${ }_{49}$ As escalas que diversificam o projeto de Lucio Costa, por ele estipuladas, são: monumental, gregária, residencial e bucólica.
} 


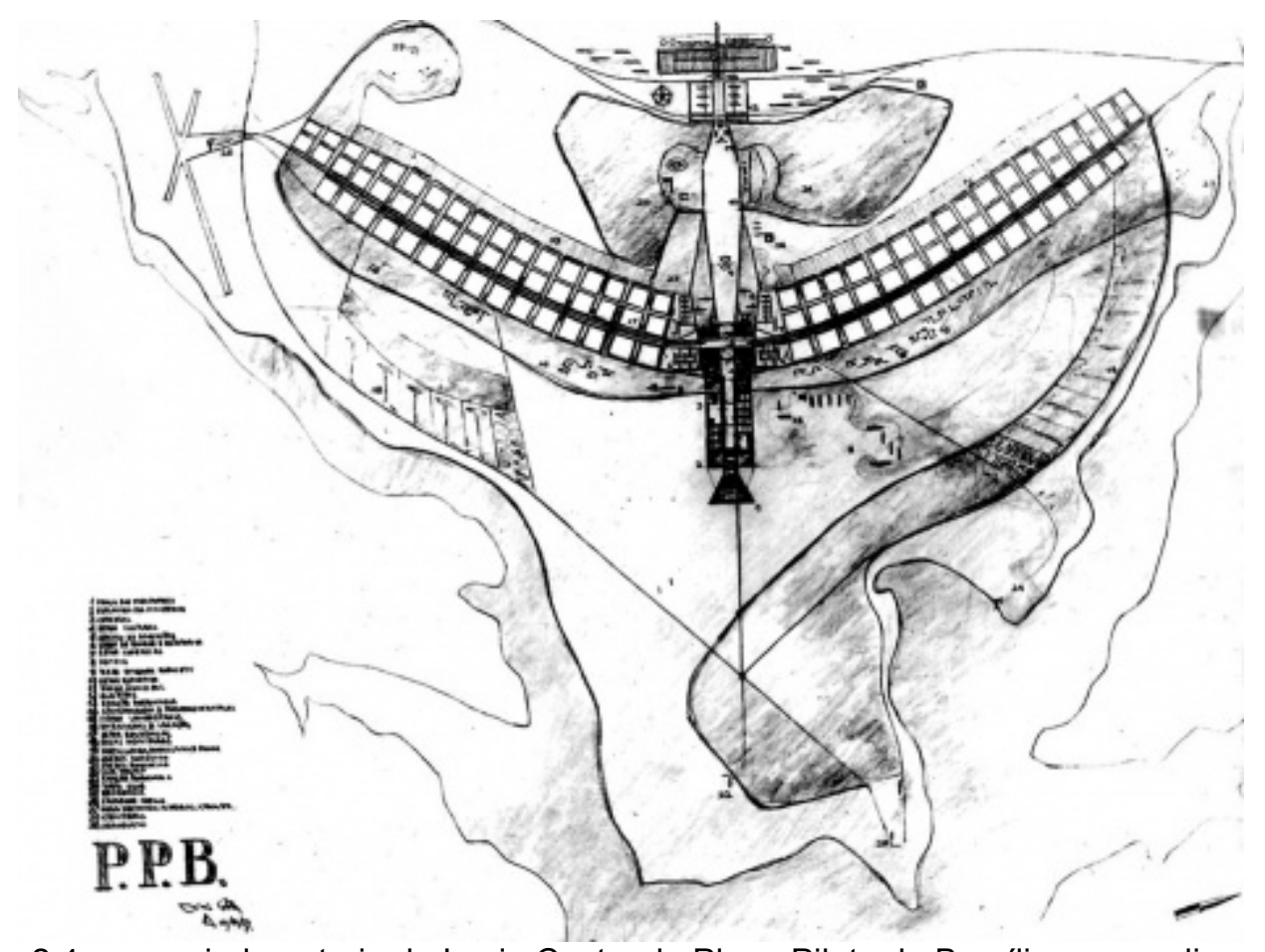

Figura 2.4 - croqui, de autoria de Lucio Costa, do Plano Piloto de Brasília, com a disposição das quadras residenciais ao longo do Eixo Rodoviário. Fonte: COSTA, 1991.

Lucio Costa segue os princípios modernistas, também, no projeto da área residencial. Com inspiração nas unidades de vizinhança, de Clarence Perry ${ }^{50}$, Costa busca reunir entre e ao redor das habitações - edifícios com gabarito de seis andares - os serviços voltados a esta função principal da cidade. ${ }^{51}$ (BENEVOLO, 2011; RIBEIRO, 2013).

O urbanista descreve esta região, em linhas gerais, quanto à forma de cada quadra e quanto à disposição de pequenos conjuntos delas, para formar a Unidade de Vizinhança.

\begin{abstract}
Quanto ao problema residencial, ocorreu a solução de criar-se uma sequência contínua de grandes quadras dispostas, em ordem dupla ou singela, de ambos os lados da faixa rodoviária, e emolduradas por uma larga cinta densamente arborizada, árvores de porte, prevalecendo em cada quadra determinada espécie vegetal, com chão gramado e uma cortina suplementar intermitente de arbustos e folhagens, a fim de resguardar melhor, qualquer que seja a posição do observador, o conteúdo das
\end{abstract}

\footnotetext{
${ }^{50}$ Como Le Corbusier, Lucio Costa toma como base o conceito de unidade de vizinhança para projetar a região residencial do Plano Piloto. Voltado para Nova York, em 1929, Perry idealizou as Unidades de Vizinhança (UV) com vistas a "resgatar as relações de vizinhança existentes nas cidades tradicionais, por meio da criação de áreas residenciais autônomas." (RIBEIRO, 2013, p. 42).

${ }^{51}$ As quatro funções da cidade, segundo Le Corbusier: habitar, trabalhar, cultivar o corpo e o espirito e circular. A função habitar é prioritária e são considerados inseparáveis os serviços que a complementam. (BENEVOLO, 2011, p. 630).
} 
quadras, visto sempre num segundo plano e como que amortecido na paisagem. Disposição que apresenta a dupla vantagem de garantir a ordenação urbanística mesmo quando varie a densidade, categoria, padrão ou qualidade arquitetônica dos edifícios, e de oferecer aos moradores extensas faixas sombreadas para passeio e lazer, independentemente das áreas livres previstas no interior das próprias quadras. (COSTA, 1991, p. 30).

No relatório do Plano Piloto de Brasília (COSTA, 1991), ele continua essa descrição morfológica e funcional expandindo para a área de serviços com o detalhamento dos respectivos equipamentos. A figura 2.5 mostra dois esboços de Costa, à esquerda exemplificando a possibilidade de disposição dos edifícios e vias de circulação de uma quadra; à direita, a conjugação de quatro quadras na formação da UV.
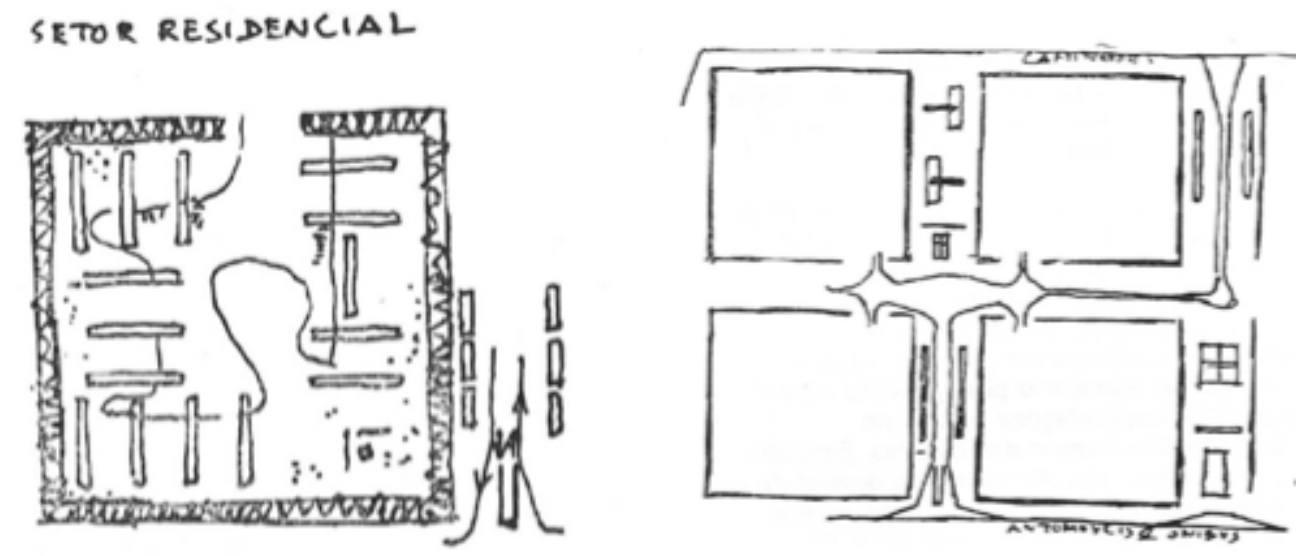

Figura 2.5 - esboços de Lucio Costa na complementação do texto do Relatório do PPB sobre a questão residencial. Fonte: COSTA, 1991.

Contudo, Lucio Costa somente se inspirou na UV tradicional, pois alterou seu conceito ao tirar do interior das superquadras os comércios locais, que constituem as áreas de serviços, e no projeto do urbanista estão na periferia das quadras. Isso repercute e possibilita, de modo significativo, o fluxo de pessoas nesta parte da unidade: "Isso torna o comércio local facilmente acessível, não apenas aos habitantes mas também ao morador da cidade em geral." (HOLANDA, 2010b, p. 325). Em um dos casos estudados mostrados adiante, verifica-se esta repercussão.

Apesar de a população das superquadras utilizar espaços públicos com frequência, não o faz na vizinhança, traço típico da classe média (MACHADO e MAGALHÃES, 2010; HOLANDA, 2010a). O público observado neste trabalho de campo, formado por comerciantes, clientes e moradores dos locais dos pontos, é distinguido entre as 
classes médias e populares, residentes tanto no Plano Piloto quanto nas cidades do entorno.

Machado e Magalhães (2010) denominam "cidade-espaço" e "cidade grande" as representações de Brasília para as classes médias e populares, respectivamente, quanto ao uso de seu espaço urbano. Segundo as autoras, para as classes médias, Brasília, como qualquer outra cidade, é um espaço que deve servir como recurso ou instrumento para a realização de um projeto individual (e familiar) previamente delineado.

\footnotetext{
Os segmentos médios voltam-se para o espaço urbano; não para a sociabilização mais ampla que poderia haver no uso de uma área coletiva por excelência, mas para a busca individualista de suas funções. É assim que o modo individualista de inserção no espaço urbano vai definir a representação, o uso e a leitura desse espaço. (MACHADO, MAGALHÃES, 2010, p. 295).
}

Para as classes populares, Brasília é "cidade grande" porque o uso do seu espaço urbano é uma constante busca pela expansão das relações que têm dentro das redes de parentes e de vizinhos. Estas classes têm a rede de parentesco "regida pelo código da reciprocidade e da hierarquia capaz de circunscrever, sob as mesmas regras, a rede de vizinhança e amizade." (p. 302) Com um outro perfil de sociabilidade, as classes populares se utilizam destas redes como instrumentos para conseguir o que as classes médias fazem de maneira individualizada. Contudo, essa rede de relações vai além do cunho instrumental, pois é "um fim em si mesma: 'viver bem' numa cidade supõe estabelecer e manter relações com parentes, transformar amigos em compadres e considerar vizinhos como "parentes'” (p. 303, grifos das autoras).

Nos espaços da região estudada, usos diversos por perfis diferenciados acontecem diariamente e não se restringem aos segmentos citados de modo ortodoxo. Os perfis das classes médias e populares se mesclam resultando em múltiplas maneiras de apropriação, uso e produção do espaço urbano.

De modo geral, o projeto das superquadras baseado na UV proporciona nível significativo de urbanidade aos seus espaços, principalmente em sua periferia. Isso 
se deve aos pontos negativos apontados em relação ao interior da superquadra. Isso reflete nas escolhas dos pontos de comércio quanto à localização (no interior ou na periferia).

\begin{abstract}
A posição das escolas, muito distantes da entrada, é inadequada, dado o incômodo provocado (...) pelo fluxo veicular no início e no final dos turnos (...). Proliferam barreiras no espaço interno da quadra, o que dificulta o fluxo de passagem de pedestres ou ciclistas (...). As relações da quadra com o entorno, principalmente com o comércio local e com a parada de ônibus, são inadequadas: a disposição dos blocos comumente impede um acesso mais franco a esses pontos. Os espaços internos das quadras são pouco diferenciados e mal definidos, prejudicando a legibilidade. (HOLANDA, 2010a, p. 116).
\end{abstract}

Com base na configuração do projeto de Lucio Costa para a área residencial do Plano Piloto e nas observações exploratórias feitas no início do trabalho de campo, busquei detectar um padrão na escolha dos lugares pelos comerciantes/designers para apropriação e uso na atividade. Cheguei a uma tipologia que é apresentada a seguir.

\title{
2.3.3 A tipologia de incidência de apropriação dos lugares
}

Por meio das visitas exploratórias, busquei conhecer se havia algum padrão nas escolhas dos locais para apropriação e utilização pelos comerciantes. Foram detectados quatro tipos de lugar que comumente são utilizados para a atividade do comércio na região observada: interior de superquadra; entrada de superquadra; associado a comércio local; associado à passagem subterrânea.

Inevitavelmente, conjectura-se sobre o potencial de cada lugar desta tipologia em oferecer condições que possibilitem a movimentação e a copresença de pessoas, possíveis clientes do comércio.

Do ponto no interior de superquadra espera-se uma clientela somente local, moradores da quadra, ou no máximo, das quadras vizinhas. Com isso, a movimentação pode ou não ser alta, devido a reserva do local, isto é, longe das principais vias de acesso da cidade, em que a probabilidade de diversidade de pessoas é maior. Com relação a este tipo de lugar apropriado, elegi para estudo de 
caso o ponto de comércio de tapioca, no interior da superquadra norte 113 (Figura 2.6).

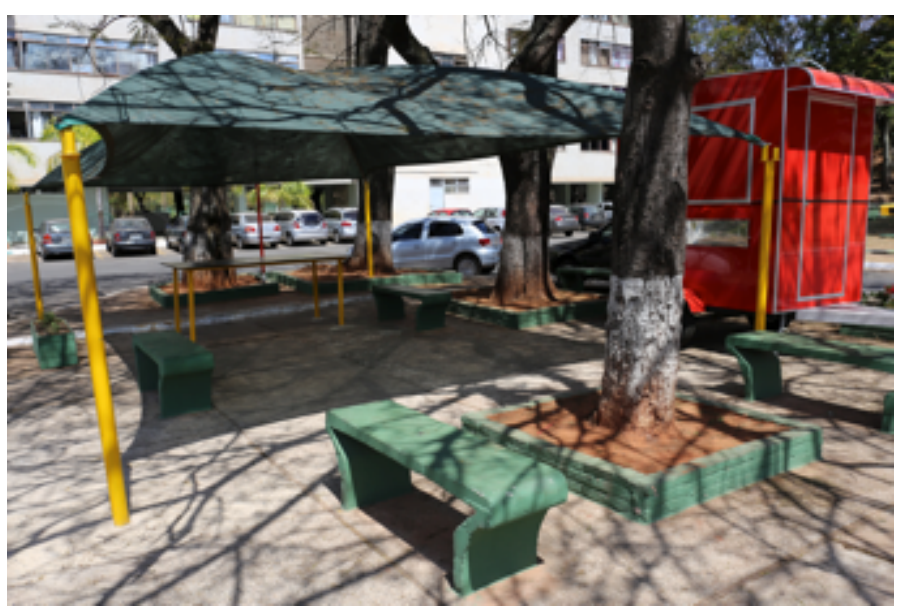

Figura 2.6 - imagem do local apropriado para o ponto de comércio de tapioca, no interior da superquadra norte 113. Foto: Maya Macario.

A situação do ponto em entrada de superquadra já fica mais clara quanto ao seu potencial, pois este local está ligado diretamente a vias de acessos principais e quadras de comércio. O ponto de comércio de caldos localizado na entrada da superquadra norte 410 foi o observado neste tipo de apropriação (Figura 2.7).

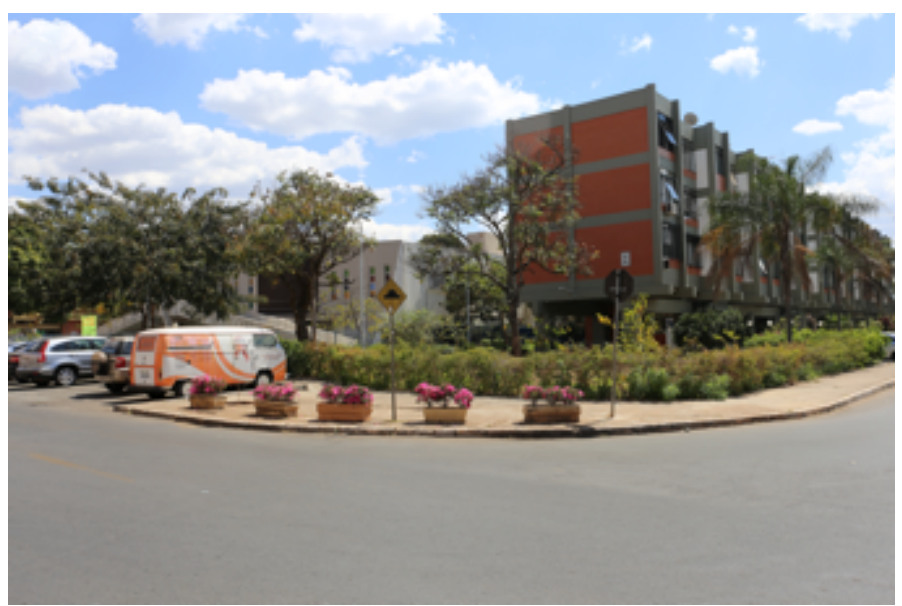

Figura 2.7 - imagem do local apropriado para o ponto de comércio de caldos, na entrada da superquadra norte 410. Foto: Maya Macario.

O ponto associado a comércio local, transmite fortemente a impressão de estar em um lugar com alto fluxo de pedestres, bem como de motorizados. O próprio comércio formal, com sua variedade de lojas, reúne características muito favoráveis a este tipo de apropriação, que é representada como estudo de caso nesta pesquisa 
pelo ponto de comércio de churrasquinho no espeto, associado ao comércio local próximo à superquadra norte 408 (Figura 2.8).

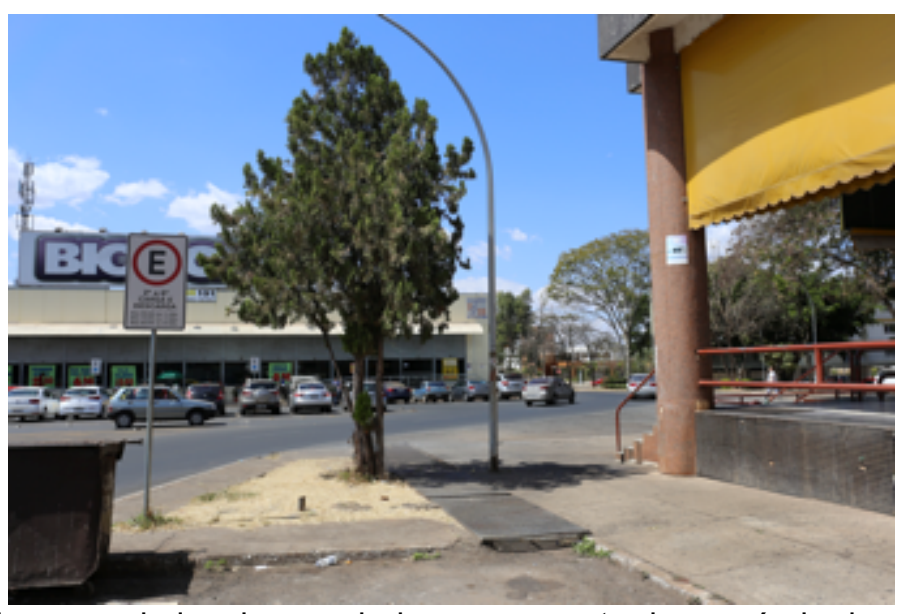

Figura 2.8 - imagem do local apropriado para o ponto de comércio de churrasquinho no espeto, associado ao comércio local próximo à superquadra norte 408. Foto: Maya Macario.

Um comércio de itens para café da manhã, na entrada da passagem subterrânea próxima a superquadra norte 209 (Figura 2.9) representa o tipo de lugar apropriado pontos próximos ou em passagens subterrâneas. Este tipo apresenta potencial considerável de fluxo de pedestres nos horários de ingresso e saída de trabalho, que se deslocam a pé ou de ônibus.

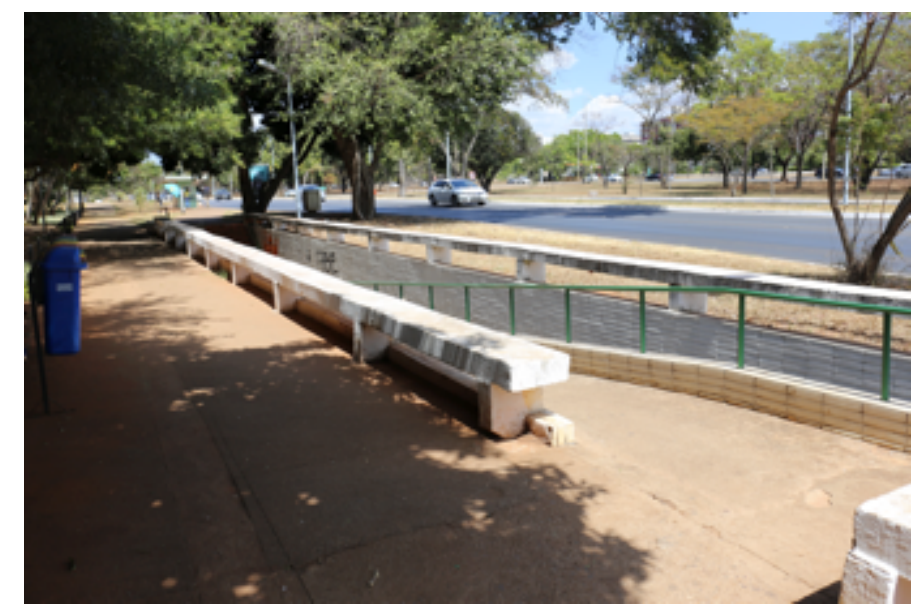

Figura 2.9 - imagem do local apropriado para o ponto de comércio de itens para café da manhã, na entrada da passagem subterrânea próxima a superquadra norte 209. Foto: Maya Macario. 
A tipologia da configuração de cada ponto é apresentada no capítulo 3, no nível padrões espaciais. E as hipóteses levantadas na detecção de cada tipo de lugar apropriado são consideradas e confrontadas na análise de cada ponto.

\section{Conclusão do capítulo}

Procurei compor os níveis analíticos, com as respectivas categorias, buscando abranger todo o arcabouço do referencial teórico com objetividade. Como em um sistema, o conteúdo destes níveis são, então, relacionados na análise.

As descrições dos pontos de comércio observados, dentro de cada categoria analítica acima explicitada, são feitas de modo individual, ponto por ponto, no capítulo 3. Todos eles são descritos na sequência da apresentação feita neste capítulo. A conjugação do preenchimento das variáveis com o perfil esperado de cada lugar detectado na tipologia de incidência de apropriação é o primeiro cruzamento feito entre as informações sistematizadas na análise, subsequente a descrição do trabalho de campo.

No capítulo 4, inicio com a análise comparativa entre os pontos observados, dentro de cada categoria analítica e com o balanço das variáveis, o que me permite partir para os aspectos a serem considerados em projeto para o espaço urbano, sobre a relação do contexto com a atividade - a interface - e sua repercussão, em termos morfológicos, na vida social dos lugares em questão. 


\section{PARTE II}

Abordar para aprender e projetar 


\section{3| O TRABALHO DE CAMPO}

O núcleo empírico da pesquisa se deu em duas fases, sendo a primeira um piloto que abrangeu contatos exploratórios feitos por intermédio de circulações motorizadas e a pé, o que propiciou a deteç̧ão de alguns pontos e breves aproximações para observação, algumas perguntas e registros fotográficos. Ainda nesta fase, e como cumprimento da exigência de um dos objetivos específicos, foi detectada a tipologia de incidência de apropriação dos lugares pelos comerciantes. Concomitantemente às visitas exploratórias e à detecção da tipologia, as variáveis de análise foram sendo calibradas em um teste realizado com um dos pontos.

\subsection{Estudos de caso}

Este capítulo apresenta cada estudo de caso por meio de sua identificação, descrição pelas categorias analíticas e análise como um sistema. Os pontos de comércio escolhidos foram os localizados nas proximidades (ou dentro, dependendo do tipo) das superquadras norte 408, 209, 113 e 410. Apresento-os, primeiramente, em suas localizações em relação ao contexto maior, a Asa Norte. (Figura 3.1).
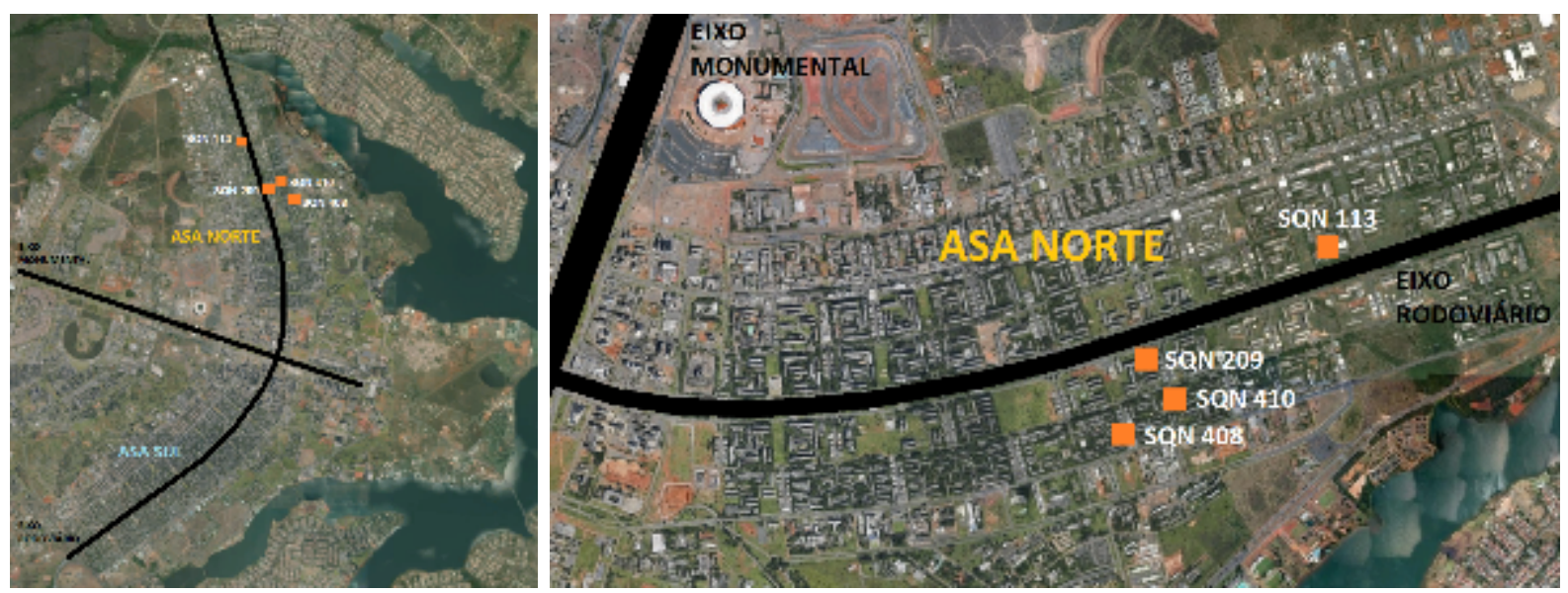

Figura 3.1 - mapas do Plano Piloto (esquerda) e da Asa Norte (direita) com a localização dos pontos de comércio escolhidos para observação. Fonte: adaptado do Google Earth. 
O ponto de comércio relacionado à superquadra norte 408 foi o primeiro a ser observado, por isso tornou-se o piloto entre os quatro estudos de caso do trabalho de campo. Seguem a identificação, a apresentação nas categorias analíticas e a análise deste ponto como um sistema.

\subsubsection{Identificação - SQN 408}

O ponto de comércio relacionado à superquadra norte 408 , representa a categoria associado a comércio local (Figura 3.2). Este ponto se especializou no preparo e venda de churrasquinho no espeto de carnes variadas, refrigerantes e cervejas. Seu funcionamento acontece de segunda-feira a sexta-feira, no horário de 17 h00 às 22h00 (Figura 3.3).

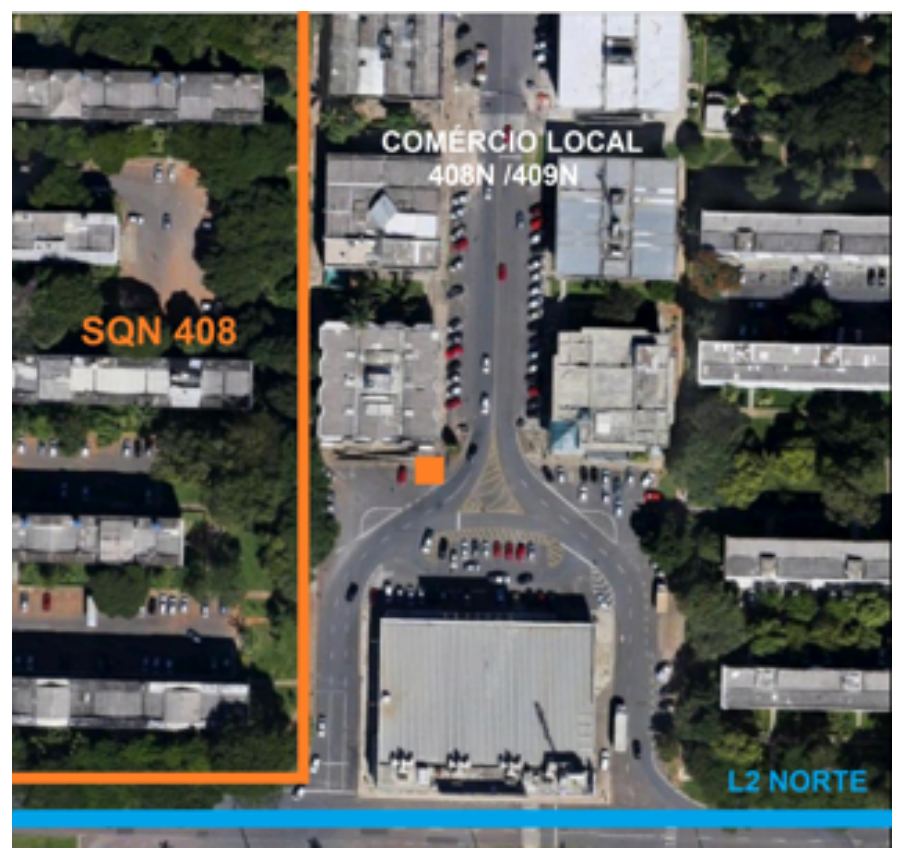

Figura 3.2 - vista aérea do ponto em relação a quadra residencial de referência - SQN 408. Fonte: adaptado do Google Earth. 

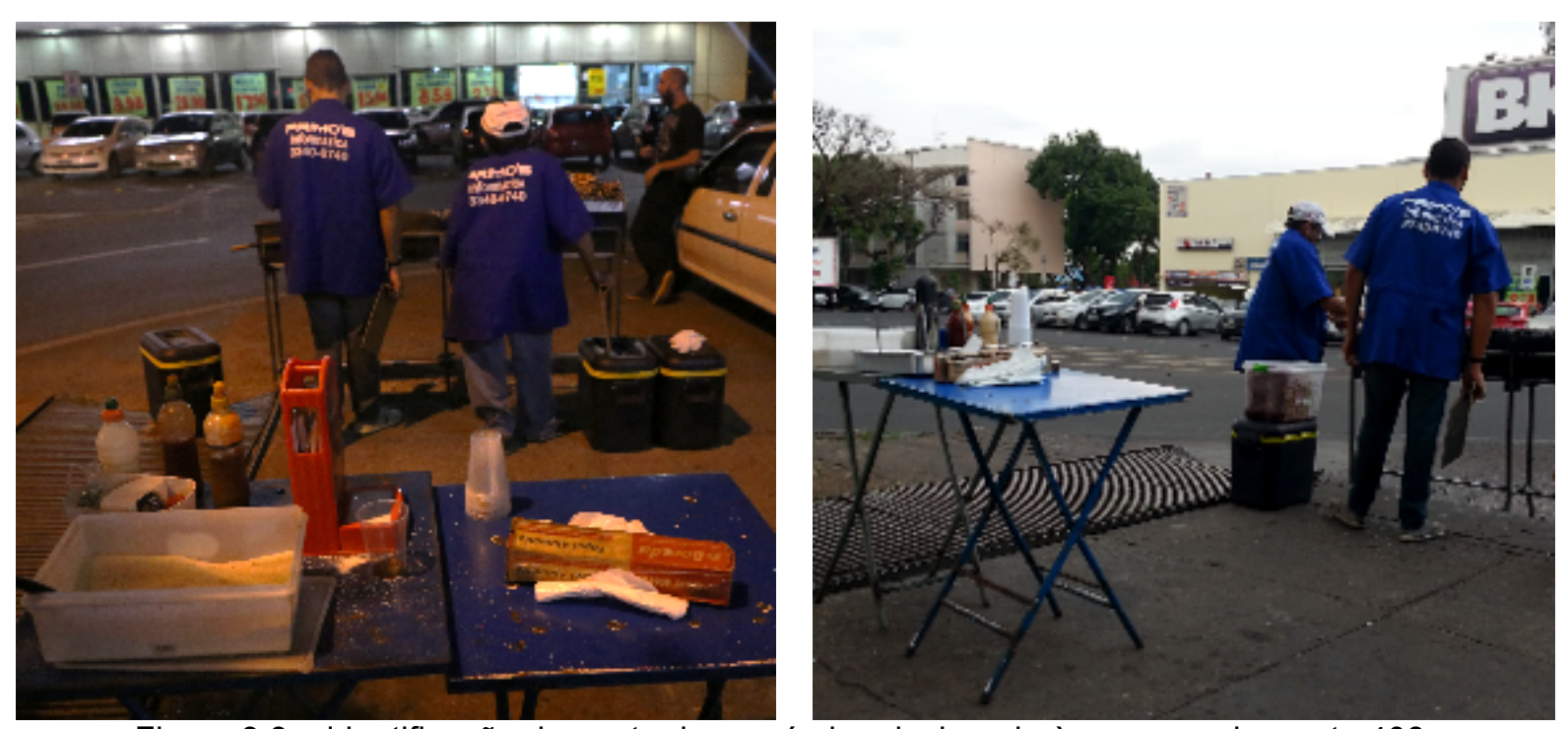

Figura 3.3 - identificação do ponto de comércio relacionado à superquadra norte 408. Fonte: Maya Macario (esquerda); autora (direita).

\subsubsection{Categorias analíticas - SQN 408}

\section{Características socioeconômicas}

1) Apresentação geral: gênero; faixa etária, naturalidade e grau de instrução.

2) Local de moradia e modo de deslocamento.

3) A atividade é a única ocupação remunerada? Dias da semana de que se ocupa com a atividade.

4) Renda mensal adquirida pela atividade.

5) Razão da escolha por este local para o ponto de comércio.

6) Quem é o seu público/cliente?

7) Dados censitários sobre renda dos moradores.

Sr. Domingos, natural do Piauí, tem idade entre 40 e 50 anos. Ele mora em Planaltina - DF, de onde vem com seu sobrinho, que o ajuda em todos os dias de trabalho no ponto. O deslocamento deles é por meio de uma pick up adaptada/ampliada para transportar boa parte dos elementos físicos de que necessitam para a atividade. Sua instrução parou nos primeiros anos do ensino fundamental. O comércio na rua é sua única ocupação remunerada, com rendimento líquido mensal em torno de $\mathrm{R} \$ 5.000,00$. Insiro o comerciante, pelas características apresentadas, na classe média baixa. 
A razão da escolha pelo local do ponto se deu pela sua proximidade com o local de trabalho anterior ao negócio com comércio de alimento. Na verdade, Sr. Domingos "herdou" o ponto em questão do irmão que trabalhava como zelador, em um bloco na quadra residencial próxima, que identifica este ponto (SQN 408). Faz mais de quinze anos que o irmão detectou esta oportunidade e iniciou este tipo de negócio nesta esquina do comércio local correspondente a quadra em que trabalhava. $O$ restaurante localizado no bloco E do Comércio Local Norte (CLN) 408, em frente ao ponto também é da família do Sr. Domingos.

Ao ser perguntado sobre quem é seu público alvo, ele responde que "tem de tudo um pouco!". Falou, primeiro, sobre os funcionários das lojas do comércio local e de instituições localizadas ao longo da via L2, que antes de irem para casa, passam por ali para consumir. Geralmente, os que se deslocam de ônibus, consomem no local e os motorizados, às vezes, pedem para embalar os espetinhos para viagem. Em seguida, contou que moradores são frequentadores há quase o mesmo tempo em que ele herdou o ponto do irmão, ou antes disso. Em suma, sua clientela varia entre moradores e não moradores, que podem trabalhar perto, ou se deslocaram até lá só para consumirem no ponto dele. Com base nos dados censitários sobre a superquadra em questão, a classe social predominante é a média (Figura 3.4).

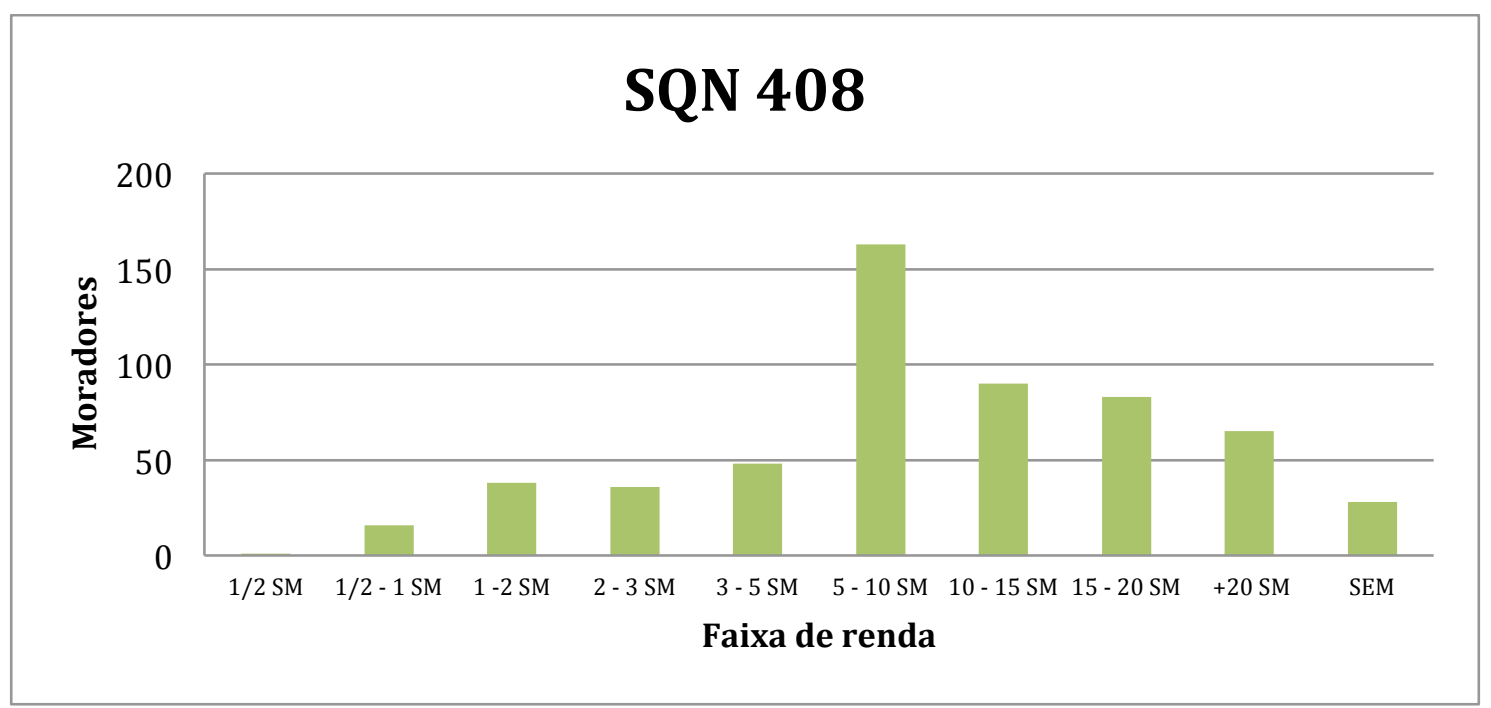

Figura 3.4 - gráfico sobre a renda, por número de salários mínimos, dos responsáveis por domicílios, da superquadra norte 408, na amostragem dos dados censitários do IBGE, de 2010. 
A observação sobre os que frequentam este ponto, condiz com a descrição feita pelo comerciante em questão e com os dados censitários. Conforme observado, incluo a classe média baixa, tanto de moradores quanto de trabalhadores no rol de clientes deste ponto.

\section{Padrões espaciais}

08) Espaço convexo que abarca o ponto - ambiência física

As áreas $\left(\mathrm{em} \mathrm{m}^{2}\right.$ ) dos espaços convexos do contexto imediato ao ponto de comércio referente a SQN 408 são $^{52}$ : 4246, 3068, 2677, 2194, 1969, 1816, 1812, 1804, 1635, 1478, 1012, 994, 894, 881, 836, 776, 736, 364, 352, 348, 343, 339, 298, 136. O espaço convexo que abarca este ponto possui a maior área entre os relacionados: $4.246 \mathrm{~m}^{2}$ (Figura 3.5).

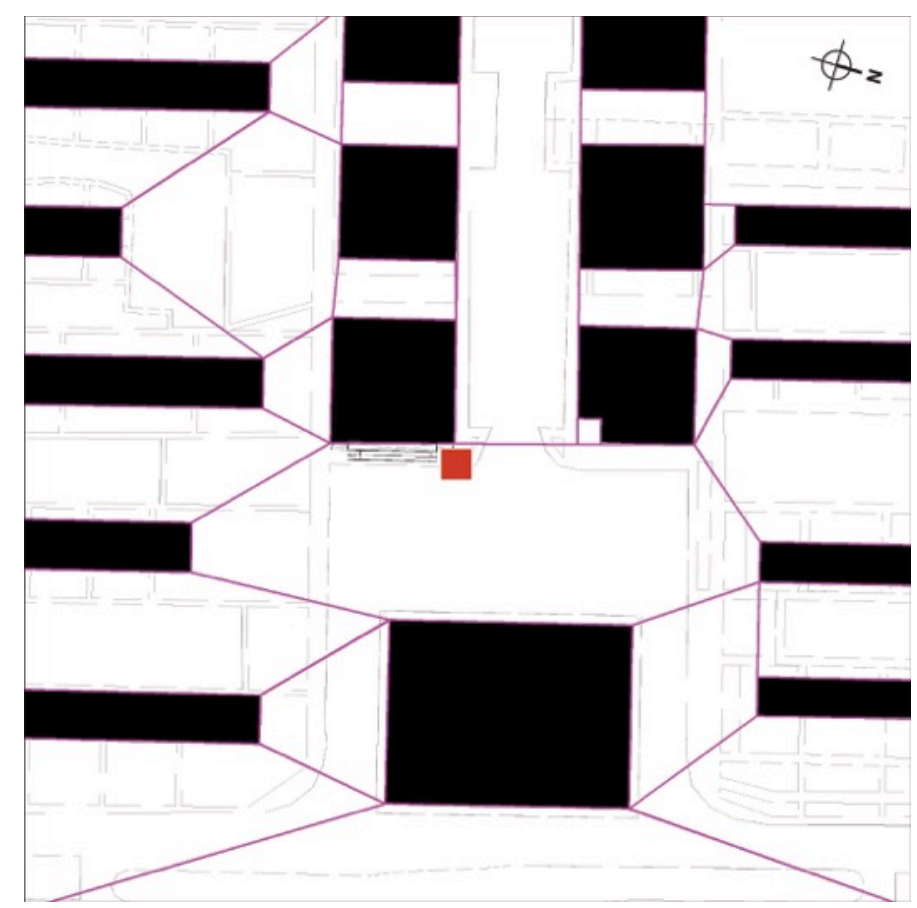

Figura 3.5 - mapa $(200 \mathrm{~m})$ dos espaços convexos do contexto imediato do ponto referente à SQN 408 e de sua inserção em um destes espaços.

É formado, basicamente, por edifícios localizados nos dois lados do comércio local, pela fachada do supermercado e, mais distante, por dois blocos residenciais: um da

\footnotetext{
${ }^{52}$ As áreas com medidas inferiores a $100 \mathrm{~m} 2$ não foram consideradas aqui e nos outros três pontos observados.
} 
SQN 409, outro da própria SQN 408. A composição do ponto está posicionada na interface entre o primeiro e o terceiro maiores espaços convexos deste contexto.

No que se refere a afirmação de que quanto menor o espaço convexo mais condizente ele é com o uso para atividades cotidianas e com relação às medidas das áreas dos espaços convexos em questão, poder-se-ia afirmar que a ambiência deste ponto é baixa. Porém, a demarcação por blocos altos de todos os lados e a posição do ponto bem próxima a um desses blocos confere ao ponto uma ambiência maior. Diante disso, considero média a ambiência física conferida pela medida do espaço convexo conjugada à posição do ponto.

09) Acessibilidade ao movimento de veículos

No que se refere à acessibilidade ao movimento de veículos, o valor do nível de integração do ponto de comércio associado ao comércio local da superquadra norte 408 é de 0,94 . Valor considerado médio se comparado aos valores máximo, médio e mínimo dos níveis de integração do Plano Piloto - 1,379, 0,847 e 0,349, respectivamente (Figura 3.6). Sua localização no início de uma das várias bifurcações diretas da via L2 norte propicia este valor. A L2 norte pode ser considerada uma das vias secundárias do Plano Piloto por ser a terceira paralela a leste do eixo rodoviário, nas Asa Norte e Asa Sul (Figura 3.87).

\begin{tabular}{|c|c|c|c|}
\hline $\begin{array}{c}\text { Integração máxima no } \\
\text { Plano Piloto }\end{array}$ & $\begin{array}{c}\text { Integração média no } \\
\text { Plano Piloto }\end{array}$ & $\begin{array}{c}\text { Integração mínima no } \\
\text { Plano Piloto }\end{array}$ & $\begin{array}{c}\text { Integração do ponto } \\
\text { SQN 408 }\end{array}$ \\
\hline 1,379 & 0,847 & 0,349 & 0,94 \\
\hline
\end{tabular}

Figura 3.6 - quadro comparativo entre as medidas de integração máxima, média e mínima do Plano Piloto e da localização do ponto de comércio associado ao comércio local da SQN 408, no que se refere à acessibilidade ao movimento de veículos.

10) Acessibilidade ao movimento do pedestres

A medida de integração do ponto de comércio referente à SQN 408 no contexto imediato é de 8,33 . Comparada às medidas de integração máxima, média e mínima desta área - 14,82, 7,76 e 3,20, respectivamente, a deste ponto pode ser considerada mediana (Figura 3.7). Para esta avaliação foram feitos os mapas de barreiras e permeabilidades ao movimento de pedestres e, a partir dele, o de 
axialidade (Figura 3.8). A posição do ponto na região de coloração amarelada confirma a medida do ponto em torno da média do contexto.

\begin{tabular}{|c|c|c|c|}
\hline $\begin{array}{c}\text { Integração máxima no } \\
\text { contexto imediato }\end{array}$ & $\begin{array}{c}\text { Integração média no } \\
\text { contexto imediato }\end{array}$ & $\begin{array}{c}\text { Integração mínima no } \\
\text { contexto imediato }\end{array}$ & $\begin{array}{c}\text { Integração no ponto - } \\
\text { SQN 408 }\end{array}$ \\
\hline 14,82 & 7,76 & 3,20 & 8,33 \\
\hline
\end{tabular}

Figura 3.7 - quadro comparativo entre as medidas de integração máxima, média e mínima do contexto imediato (área quadrada ao redor do ponto com $200 \mathrm{~m}$ de lado) e da localização do ponto de comércio referente à SQN 408, no que se refere à acessibilidade ao movimento de pedestres.
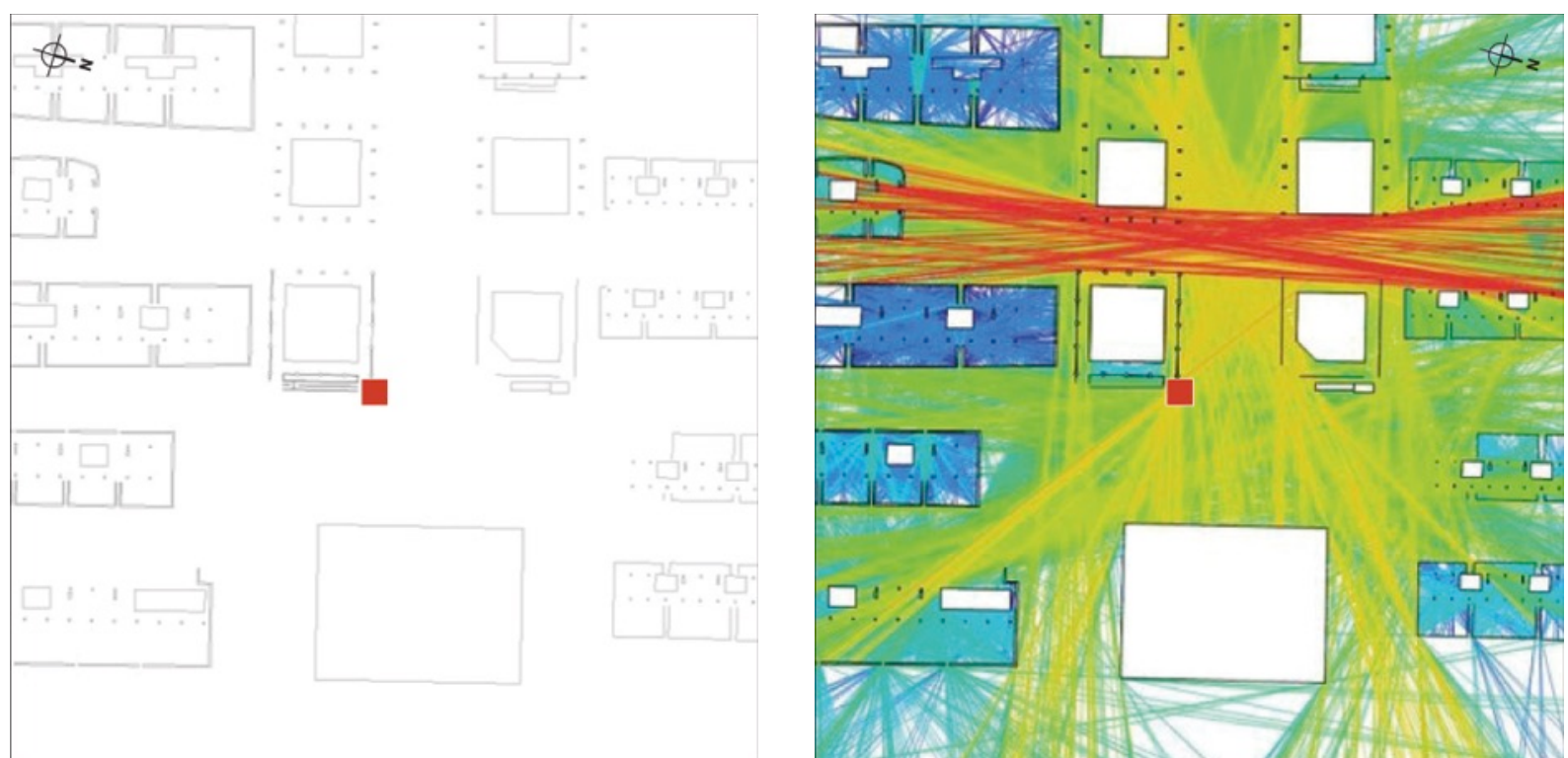

Figura 3.8 - mapas de barreiras e permeabilidades ao movimento (gerador) (à esquerda) e de axialidade (à direita) para o ponto - SQN 408.

Com relação à área quadrada que abarca a composição dos elementos da atividade, a medida de integração do seu centro é de 19,53. Esta medida está entre as média e máxima desta área delimitada (Figura 3.9). O mapa de barreiras e permeabilidades contém o mobiliário e equipamento levado pelo comerciante, assim como os elementos da arquitetura utilizados na atividade. O mapa de axialidade aponta uma predominância de coloração alaranjada, com algumas linhas vermelhas no centro da área da atividade, corroborando a medida significativamente alta de acessibilidade ao movimento de pedestres nesta área (Figura 3.10).

\begin{tabular}{|c|c|c|c|}
\hline $\begin{array}{c}\text { Integração máxima na } \\
\text { área da atividade }\end{array}$ & $\begin{array}{c}\text { Integração média na } \\
\text { área da atividade }\end{array}$ & $\begin{array}{c}\text { Integração mínima na } \\
\text { área da atividade }\end{array}$ & $\begin{array}{c}\text { Integração no ponto } \\
\text { central - SQN 408 }\end{array}$ \\
\hline 27,23 & 13,45 & 3,87 & 19,53 \\
\hline
\end{tabular}

Figura 3.9 - quadro comparativo entre as medidas de integração máxima, média e mínima da área do ponto de comércio (área quadrada ao redor do ponto com 20m de lado) referente à SQN 408 e do seu ponto central, no que se refere à acessibilidade ao movimento de pedestres. 


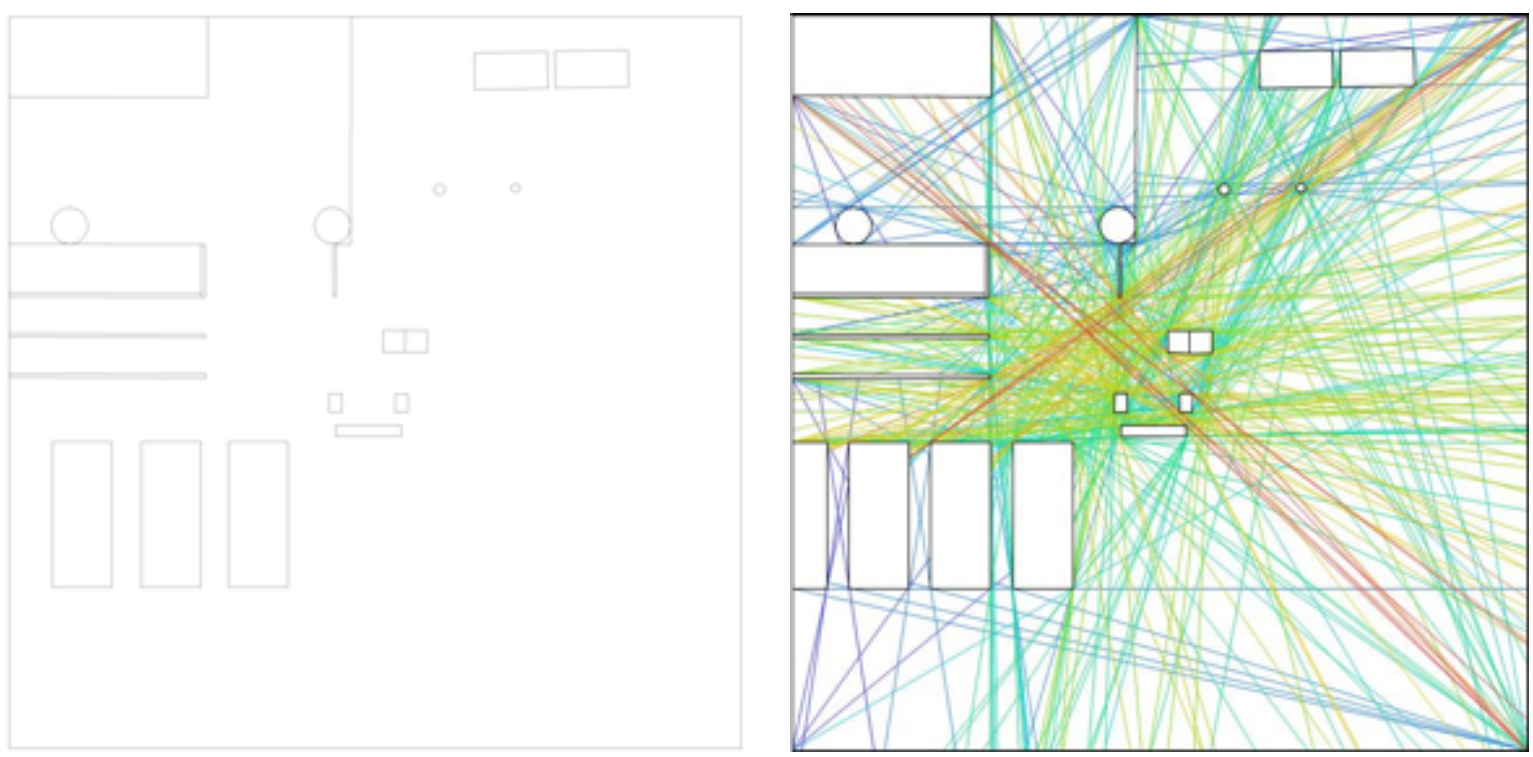

Figura 3.10 - mapas de barreiras e permeabilidades (à esquerda) e axialidade (à direita) do ponto de comércio referente à SQN 408 (máscara quadrada de $20 \mathrm{~m}$ de lado ao redor do ponto).

As medidas de integração deste ponto apontam para um bom aproveitamento do espaço quanto ao seu potencial para este tipo de integração. As escolhas pelo local e pela composição dos elementos físicos beneficiaram tanto a atividade, quanto o contexto imediato.

11) Acessibilidade à visão - conexão visual

A avaliação da integração de cada ponto se estende à acessibilidade a visão a partir e para cada ponto de comércio no âmbito do contexto imediato. Com relação ao ponto referente à SQN 408, sua medida de integração visual é de 18,16 , considerada alta em relação às medidas máxima, média e mínima no contexto de, respectivamente, 20,96, 15,28 e 7,56 (Figura 3.11). A coloração alaranjada do mapa na área apropriada para o ponto confirma o alto nível de integração visual que este ponto possui (Figura 3.12).

\begin{tabular}{|c|c|c|c|}
\hline $\begin{array}{c}\text { Integração visual } \\
\text { máxima no contexto }\end{array}$ & $\begin{array}{c}\text { Integração visual } \\
\text { média no contexto }\end{array}$ & $\begin{array}{c}\text { Integração visual } \\
\text { mínima no contexto }\end{array}$ & $\begin{array}{c}\text { Integração visual no } \\
\text { ponto - SQN 408 }\end{array}$ \\
\hline 20,96 & 15,28 & 7,56 & 18,16 \\
\hline
\end{tabular}

Figura 3.11 - quadro comparativo entre as medidas de integração visual máxima, média e mínima no contexto imediato (área quadrada ao redor do ponto com $200 \mathrm{~m}$ de lado) e da localização do ponto de comércio referente à SQN 408, no que se refere à acessibilidade à visão. 


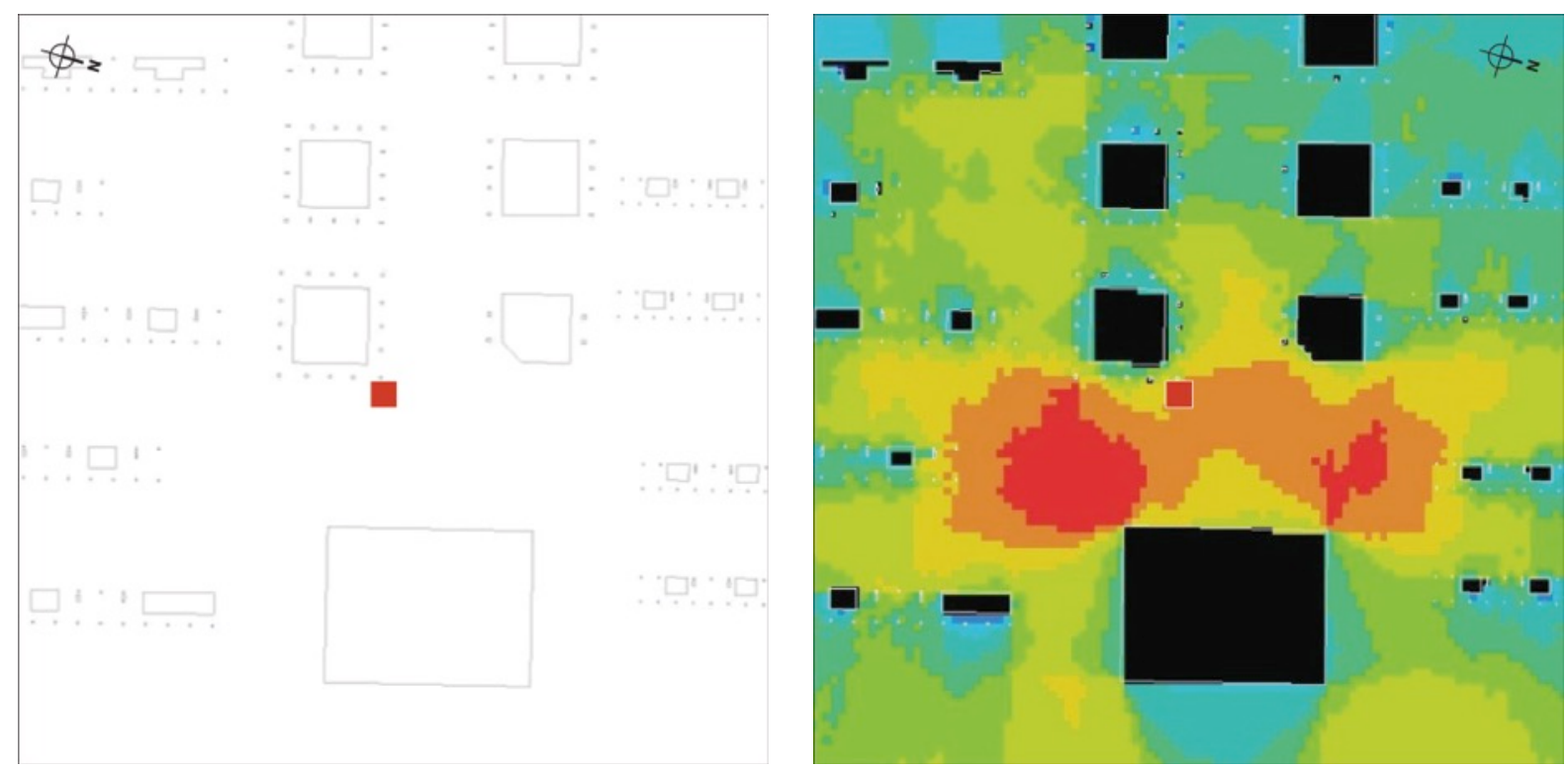

Figura 3.12 - mapas de barreiras e permeabilidades à visão (gerador) (à esquerda) e de visibilidade (à direita) para o ponto - SQN 408.

No caso da área menor ocupada pela composição de elementos físicos para a atividade, a medida de integração visual é de 68,84. Esta medida é considerada mediana quando relacionada às máxima $(112,28)$, média $(50,89)$ e mínima $(13,15)$ desta área (Figura 3.13). As colorações amarela e verde no centro do mapa de visibilidade desta área demonstra a aferição (Figura 3.14).

\begin{tabular}{|c|l|l|l|}
\hline $\begin{array}{l}\text { Integração visual } \\
\text { máxima na área da } \\
\text { atividade }\end{array}$ & $\begin{array}{l}\text { Integração visual } \\
\text { média na área da } \\
\text { atividade }\end{array}$ & $\begin{array}{l}\text { Integração visual } \\
\text { mínima na área da } \\
\text { atividade }\end{array}$ & $\begin{array}{l}\text { Integração visual no } \\
\text { ponto central }- \text { SQN } \\
408\end{array}$ \\
\hline 112,28 & 50,89 & 13,15 & 68,84 \\
\hline
\end{tabular}

Figura 3.13 - quadro comparativo entre as medidas de integração visual máxima, média e mínima na área do ponto de comércio (área quadrada ao redor do ponto com $20 \mathrm{~m}$ de lado) referente à SQN 408 e do seu ponto central, no que se refere à acessibilidade à visão.

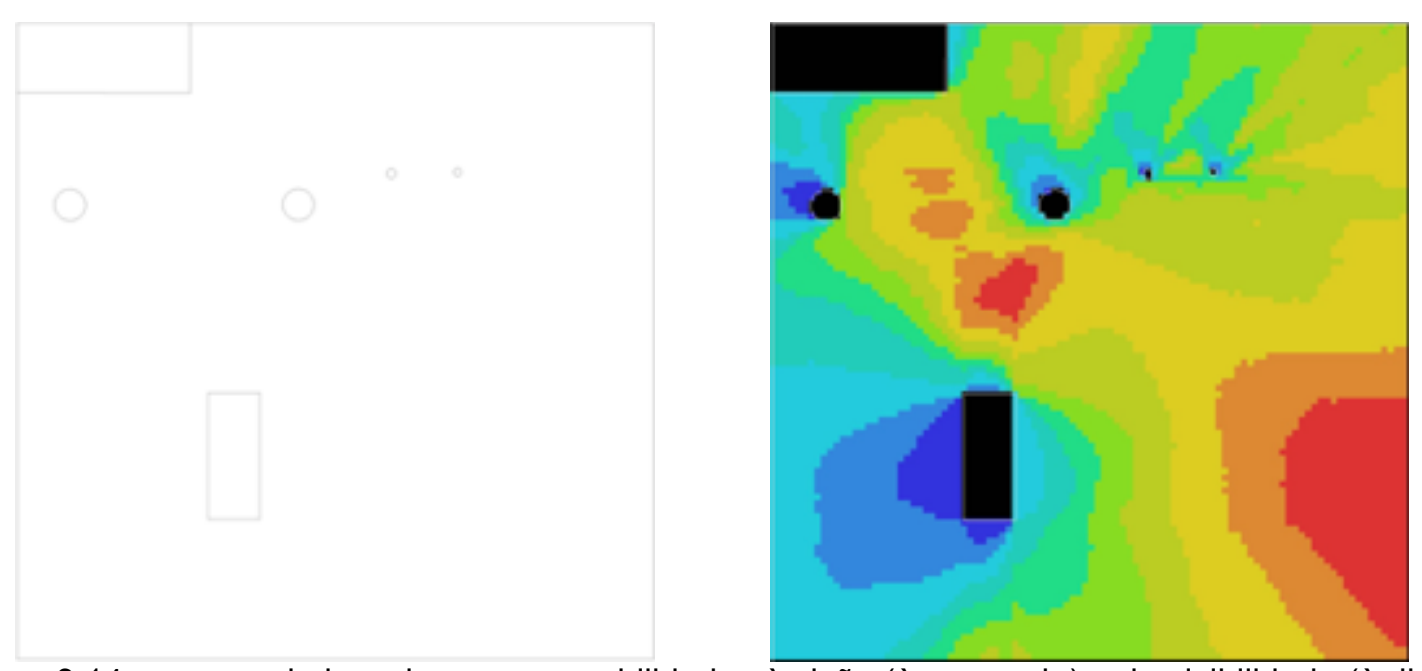

Figura 3.14 - mapas de barreiras e permeabilidades à visão (à esquerda) e de visibilidade (à direita) do ponto de comércio referente à SQN 408 (máscara quadrada de $20 \mathrm{~m}$ de lado ao redor do ponto). 
12) Isovistas - campo visual

Área, perímetro e compacidade foram as medidas destacadas do mapa de isovistas dos quatro pontos, para a análise do grau de ligação visual entre quem está no ponto e os pontos ao redor, dentro da área do contexto imediato. Tomou-se como origem o mapa de barreiras e permeabilidades para a visão (máscara de $200 \mathrm{~m}$ de lado), apresentado na categoria analítica anterior.

Com relação aos dados sobre as isovistas do ponto referente à SQN 408, as medidas são: área $=15.982 \mathrm{~m}^{2}$; perímetro $=3.505 \mathrm{~m}$ e compacidade $=0,02 \mathrm{Na}$ análise dos pontos de comércio como sistemas, a área das isovistas é comparada à área do espaço convexo em que cada ponto está inserido, para a averiguação de quanto a conexão visual extrapola este espaço, dentro do contexto imediato (Figura 3.15).

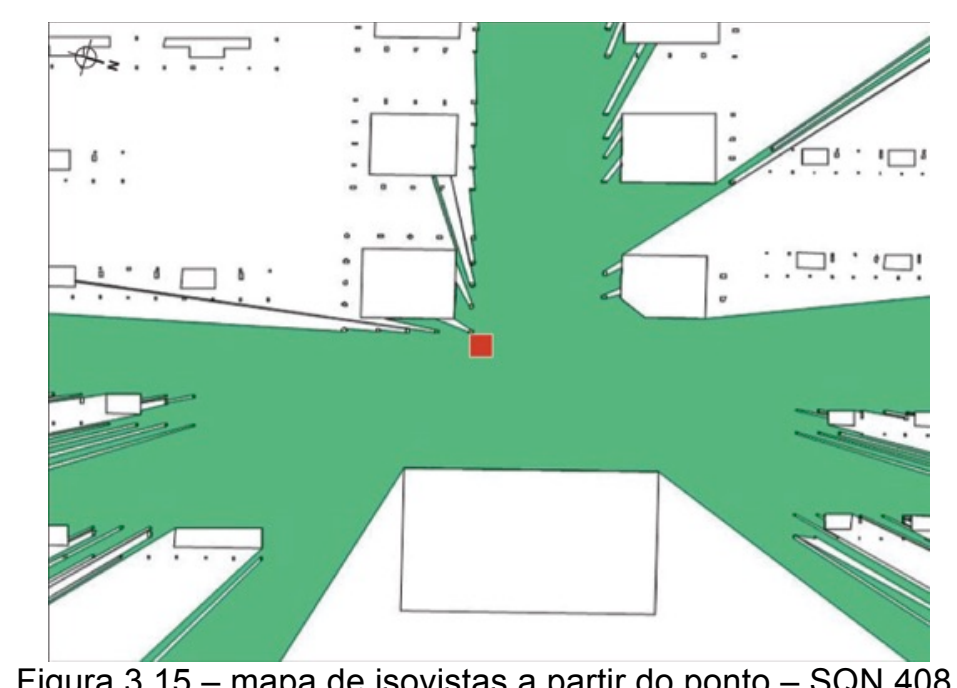

Figura 3.15 - mapa de isovistas a partir do ponto - SQN 408.

A medida de compacidade quanto mais próxima de 1 , mais compacta é a área de conexão visual a partir do ponto para todo o contexto imediato. Sendo assim, o valor da medida de compacidade do ponto de comércio referente à SQN 408 é considerado relativamente baixo. Isto é devido ao número considerável de barreiras à visão em relação a este ponto. $A$ área de isovistas é bem recortada. $A$ medida do perímetro acompanha e confirma o grau de compacidade da área de isovistas, isto é, quanto maior a compacidade (mais próximo de 1), menor o perímetro. 
13) Condições para permanência - estado de conservação e conforto

Nesta categoria são observados, no que se refere ao estado de conservação, os níveis de cuidado com limpeza e manutenção dos elementos que estão disponibilizados no local apropriado. O conforto é medido pela oferta ou não de lugares para sentar e de sombra, no caso de atividades diurnas, ou iluminação, no caso de noturnas.

No ponto de comércio referente à SQN 408, a limpeza da esquina apropriada é feita, porém, devido à grande frequência de passantes e consumidores do ponto, no final do expediente o local fica com lixo no chão, apesar das lixeiras que o comerciante coloca junto ao poste, ou à árvore que limitam o ambiente. Por causa do uso intenso desta esquina, o gramado que fica em um pequeno trecho da calçada está desgastado, visivelmente sem manutenção frequente. Além disso, a fiação do poste que delimita a área de uso deste ponto está exposta, sendo um item de risco para quem ali frequenta. $O$ calçamento está em boas condições e o gradeado que cobre a calha no piso está razoavelmente nivelada com o calçamento (Figura 3.16 acima).

O consumo do churrasquinho é feito primordialmente em pé. Os consumidores que se sentam, se apropriam dos degraus da escada que leva ao bloco A do CLN 408. Por ser noturno o funcionamento deste ponto, a necessidade é de iluminação apropriada. A parte da atividade iluminada pelo poste é a churrasqueira, o que não ajuda muito, pois o comerciante e seu ajudante ficam de costas para ela. A outra parte da atividade mais próxima ao poste e à árvore fica pouco iluminada (Figura 3.16 - abaixo).

Diante do apresentado, considero mediano o estado de conservação do local apropriado e baixo o seu nível de conforto para a permanência. 

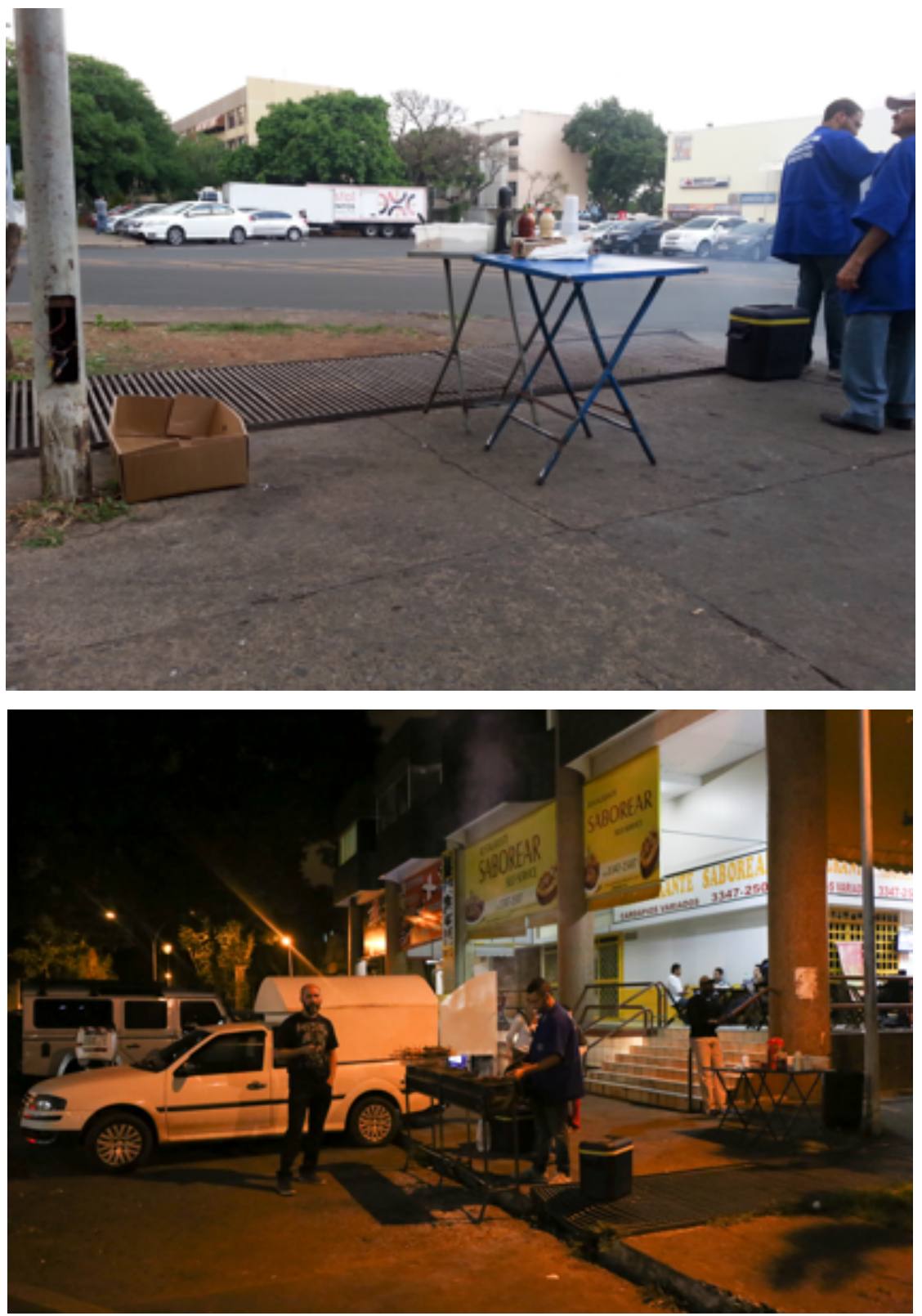

Figura 3.16 - imagens sobre as condições para a permanência no ponto de comércio referente à SQN 408. Fotos: autora (acima) e Maya Macario (abaixo).

14) Atividades ao redor do ponto de comércio

As atividades deste ponto são em sua maioria comerciais formais. O comércio local específico, em cuja esquina está o ponto, o CLN 408, tem muitos bares com funcionamento intenso no mesmo horário de funcionamento do ponto de comércio observado. Os estabelecimentos que não são bares, fecham ao mesmo tempo em que o comerciante arrumar os elementos físicos no local para funcionar. Além dos dois comércios locais - CLN 408 e CLN 409 - o ponto tem em frente um supermercado BIG BOX. 
A maior parte das atividades identificadas e em funcionamento noturno têm em comum com o ponto a atratividade pela função do lazer. Porém, não são excludentes. Quem vai a um dos bares, pode passar no churrasquinho antes para esperar o grupo de amigos. Ou o público que frequenta o churrasquinho não frequenta os bares. Dependendo da faixa etária, do gosto, do horário (cedo ou tarde da noite) etc. o público que ali frequenta é bastante numeroso, diversificado, consome em um lugar ou outro e assim, confere sucesso a vida social deste contexto. Não falta cliente para nenhum dos estabelecimentos formais e para o ponto de comércio informal em questão, como o observado (Figura 3.17).
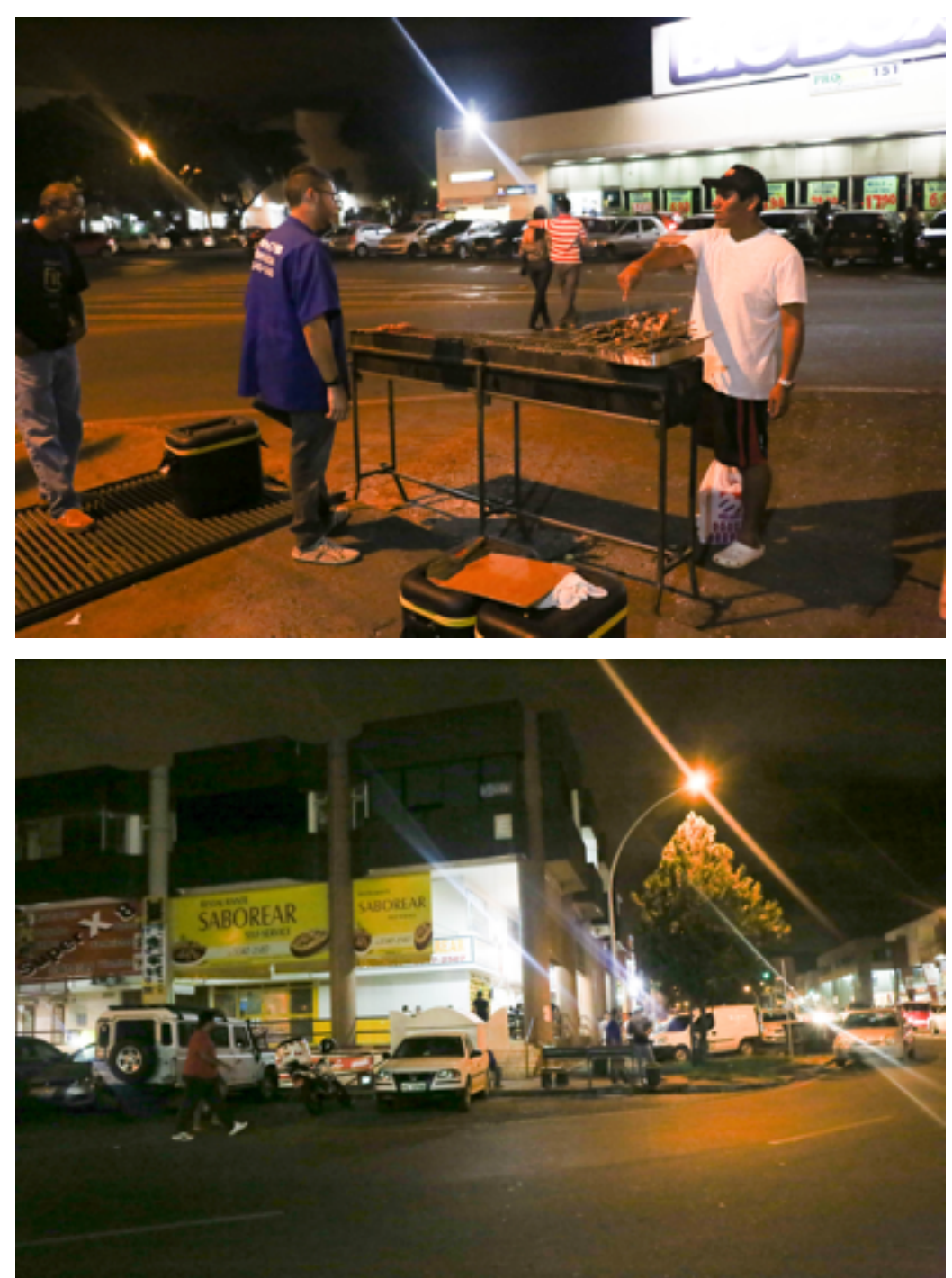

Figura 3.17 - imagens dos arredores do local do ponto de comércio referente à SQN 408 para ilustrar atividades ao redor. Fotos: Maya Macario. 
Sistemas de encontros e esquivanças

15) Quantidade de pessoas - passagem e permanência

16) Variedade de pessoas na permanência

A interdependência entre estas duas variáveis é grande. Enquanto iam sendo contabilizadas, o gênero e faixa etária das pessoas eram detectados, no caso das que permaneciam. Em relação aos quatro pontos, estas contagens foram feitas em dois dias de meses diferentes e períodos diversos dentro do mês. Segundo alguns comerciantes, o consumo no ponto é maior no início de cada mês, devido ao pagamento do salário da maioria dos consumidores, neste período.

No caso do ponto referente à SQN 408, os dados coletados podem ser conferidos nas Tabelas 3.1, 3.2 e 3.3. A prevalência de homens consumindo neste ponto é significativa. No primeiro dia, foram 68 homens para 27 mulheres contabilizados que permaneceram no ponto. No segundo dia, foram 74 homens para 21 mulheres. As crianças estiveram presentes nos dois dias de contagem, sendo 5 em cada um. Os idosos foram registrados em um número bem menor: 5 nos dois dias.

Tabela 3.1 - Total pessoas - permanência $=100$ : total crianças $=5$; total homens $=68$;

total mulheres $=27$. Total pessoas - passagem $=80$. Total pessoas $(S Q N 408)-1^{\circ}$. dia $=180$

\begin{tabular}{|c|c|c|c|c|c|c|c|c|c|}
\hline \multirow{2}{*}{$\begin{array}{l}1^{\circ} \cdot \text { dia } \\
\text { períodos }\end{array}$} & \multirow[t]{2}{*}{ passagem } & \multirow[t]{2}{*}{ gênero } & \multicolumn{6}{|c|}{ faixa etária } & \multirow{2}{*}{$\begin{array}{c}\text { total } \\
\text { gênero }\end{array}$} \\
\hline & & & $A / J^{53}$ & $20-30$ & $30-40$ & $40-50$ & $50-60$ & $>60$ & \\
\hline \multirow[t]{2}{*}{1} & \multirow[t]{2}{*}{5} & $\mathrm{H}$ & - & 2 & 3 & - & - & - & 5 \\
\hline & & $\mathrm{M}$ & - & 2 & 1 & - & - & - & 3 \\
\hline \multirow{2}{*}{$\begin{array}{c}2 \\
c=2\end{array}$} & \multirow[t]{2}{*}{11} & $\mathrm{H}$ & - & 4 & 9 & 4 & - & - & 17 \\
\hline & & $\mathrm{M}$ & - & 4 & 3 & 2 & - & - & 9 \\
\hline \multirow{2}{*}{$\begin{array}{c}3 \\
c=2\end{array}$} & \multirow[t]{2}{*}{9} & $\mathrm{H}$ & - & 6 & 6 & 1 & - & - & 13 \\
\hline & & $\mathrm{M}$ & - & 3 & 2 & 1 & - & 1 & 7 \\
\hline \multirow{2}{*}{$\begin{array}{c}4 \\
c=1\end{array}$} & \multirow[t]{2}{*}{16} & $\mathrm{H}$ & - & 3 & 1 & 3 & 2 & - & 9 \\
\hline & & $\mathrm{M}$ & - & - & - & - & - & - & - \\
\hline \multirow[t]{2}{*}{5} & \multirow[t]{2}{*}{8} & $\mathrm{H}$ & - & 7 & 5 & 2 & 1 & - & 15 \\
\hline & & $\mathrm{M}$ & - & 3 & 1 & - & 1 & - & 5 \\
\hline \multirow[t]{2}{*}{6} & \multirow[t]{2}{*}{31} & $\mathrm{H}$ & - & 5 & 1 & 3 & - & - & 9 \\
\hline & & $\mathrm{M}$ & 1 & - & 2 & - & - & - & 3 \\
\hline \multirow{3}{*}{ total } & \multirow{3}{*}{80} & $\mathrm{~T} / \mathrm{H}$ & - & 27 & 25 & 13 & 3 & - & 68 \\
\hline & & $\mathrm{T} / \mathrm{M}$ & 1 & 12 & 9 & 3 & 1 & 1 & 27 \\
\hline & & $\mathrm{T} / \mathrm{H}+\mathrm{M}$ & 1 & 39 & 34 & 16 & 4 & 1 & 95 \\
\hline
\end{tabular}

${ }^{53} \mathrm{~A} / \mathrm{J}=$ faixa etária que abarca adolescentes e jovens (pessoas entre 13 e 19 anos). 
Pessoas, principalmente homens, dentro das faixas etárias de 20 a 30 e de 30 a 40 anos foram as que predominaram no que diz respeito à permanência neste ponto de comércio. O número vai diminuindo conforme o avançar da faixa etária. É provável que as condições de conforto influenciem nestes números. Neste ponto de comércio, não são disponibilizados assentos para os que permanecem, tanto pelo local previamente, quanto pelo comerciante. O máximo que se tem por lá são os degraus da escada que dá acesso ao bloco E da CLN 408, como já apresentado.

Tabela 3. 2 - Total pessoas - permanência $=100$ : total crianças $=5$; total homens $=74$; total mulheres $=21$. Total pessoas - passagem $=102$. Total pessoas $(S Q N 408)-2^{\circ}$. dia $=202$

\begin{tabular}{|c|c|c|c|c|c|c|c|c|c|}
\hline \multirow{2}{*}{$\begin{array}{l}2^{\circ} . \text { dia } \\
\text { período }\end{array}$} & \multirow[t]{2}{*}{ passagem } & \multirow[t]{2}{*}{ gênero } & \multicolumn{6}{|c|}{ faixa etária } & \multirow{2}{*}{$\begin{array}{c}\text { total } \\
\text { gênero }\end{array}$} \\
\hline & & & $\mathrm{A} / \mathrm{J}$ & $20-30$ & $30-40$ & $40-50$ & $50-60$ & $>60$ & \\
\hline \multirow[t]{2}{*}{1} & \multirow[t]{2}{*}{29} & $\mathrm{H}$ & - & 2 & 4 & 2 & 2 & 1 & 11 \\
\hline & & $M$ & - & - & - & 1 & - & - & 1 \\
\hline \multirow[t]{2}{*}{2} & \multirow[t]{2}{*}{17} & $\mathrm{H}$ & 1 & 10 & 4 & 2 & 1 & 1 & 19 \\
\hline & & $\mathrm{M}$ & - & 1 & - & 1 & - & - & 2 \\
\hline \multirow{2}{*}{$\begin{array}{c}3 \\
c=2\end{array}$} & \multirow[t]{2}{*}{26} & $\mathrm{H}$ & - & 7 & 2 & 2 & 2 & 1 & 14 \\
\hline & & $M$ & 1 & 2 & 2 & - & 2 & - & 7 \\
\hline \multirow{2}{*}{$\begin{array}{c}4 \\
c=2\end{array}$} & \multirow[t]{2}{*}{8} & $\mathrm{H}$ & - & 11 & 3 & 2 & 1 & - & 17 \\
\hline & & $M$ & 1 & 2 & 3 & - & - & - & 6 \\
\hline \multirow{2}{*}{$\begin{array}{c}5 \\
c=1\end{array}$} & \multirow[t]{2}{*}{17} & $\mathrm{H}$ & - & 5 & 4 & 2 & 1 & 1 & 13 \\
\hline & & $\mathrm{M}$ & - & 4 & 1 & - & - & - & 5 \\
\hline \multirow[t]{2}{*}{6} & \multirow[t]{2}{*}{5} & $\mathrm{H}$ & - & - & - & - & - & - & - \\
\hline & & $\mathrm{M}$ & - & - & - & - & - & - & - \\
\hline \multirow{3}{*}{ total } & \multirow{3}{*}{102} & $\mathrm{~T} / \mathrm{H}$ & 1 & 35 & 17 & 10 & 7 & 4 & 74 \\
\hline & & $\mathrm{T} / \mathrm{M}$ & 2 & 9 & 6 & 2 & 2 & - & 21 \\
\hline & & $\mathrm{T} / \mathrm{H}+\mathrm{M}$ & 3 & 44 & 23 & 12 & 9 & 4 & 95 \\
\hline
\end{tabular}

Tabela 3.3 - Total pessoas - permanência $=200$ : total crianças $=10$; total homens $=142$; total mulheres $=48$. Total pessoas - passagem $=182$. TOTAL PESSOAS - SQN $408=382$

\begin{tabular}{|c|c|c|c|c|c|c|c|c|c|}
\hline \multirow{6}{*}{$\begin{array}{c}1^{\circ} \text {. dia } \\
+ \\
2^{\circ} \text {. dia }\end{array}$} & \multirow[t]{2}{*}{ passagem } & \multirow[t]{2}{*}{ gênero } & \multicolumn{6}{|c|}{ faixa etária } & \multirow{2}{*}{$\begin{array}{c}\text { total } \\
\text { gênero }\end{array}$} \\
\hline & & & $\mathrm{A} / \mathrm{J}$ & $20-30$ & $30-40$ & $40-50$ & $50-60$ & $>60$ & \\
\hline & \multirow{4}{*}{182} & $\mathrm{~T} / \mathrm{H}$ & 1 & 62 & 42 & 23 & 10 & 4 & 142 \\
\hline & & $\mathrm{T} / \mathrm{M}$ & 3 & 21 & 15 & 5 & 3 & 1 & 48 \\
\hline & & $\mathrm{T} / \mathrm{H}+\mathrm{M}$ & 4 & 83 & 57 & 28 & 13 & 5 & 190 \\
\hline & & criança & \multicolumn{7}{|c|}{10} \\
\hline
\end{tabular}

17) Distribuição de pessoas no tempo e no espaço

Para avaliar a distribuição das pessoas no local da atividade de cada ponto de comércio, apresento primeiro o mapa de espaço convexo delimitado pelos elementos físicos do ponto em questão, para depois mostrar os mapas comportamentais sobre a distribuição de pessoas no ponto, nos dois dias observados. O intuito é o de comparar a delimitação da área da atividade com a composição e o seu real uso. Verifico se extrapolam ou não a área delimitada, se a 
ocupam total ou parcialmente, se há concentração em algumas partes ou se as pessoas se distribuem de modo mais uniforme. Analiso, assim, o aproveitamento do espaço pelas pessoas em relação ao local da atividade e à interface com o contexto imediato.

A frequência de pessoas que permanecem no ponto referente à SQN 408 é alta. Os espaços disponíveis entre os elementos físicos são bem distribuídos, pois permitem o acesso do comerciante, auxiliar, clientes e passantes a todos os elementos (Figura 3.18). No primeiro dia de contagem de pessoas neste ponto não choveu. Por isso, sua distribuição extrapolou significativamente a área delimitada pelos elementos físicos do ponto. Isso já não ocorreu no segundo dia, pois choveu e a distribuição das pessoas se deu mais dentro da área delimitada, onde o comerciante monta uma tenda, neste caso.

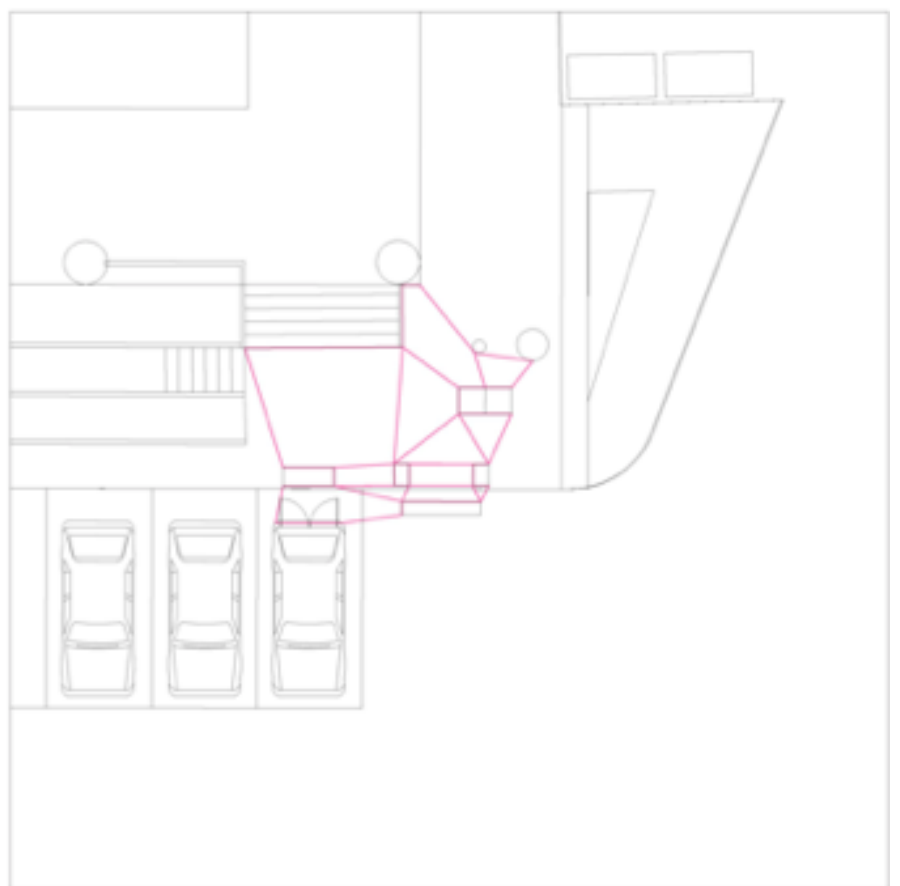

Figura 3.18 - mapa de espaço convexo determinado pelos elementos físicos com a arquitetura do ponto de comércio referente à SQN 408.

Existe uma concentração de pessoas, tanto em um dia quanto no outro, ao redor da churrasqueira, pelo tipo de atendimento feito no ponto. Com exceção da concentração ao redor da churrasqueira, o restante das partes do ponto é ocupado de modo relativamente uniforme, na maior parte das vezes (Figura 3.19). 


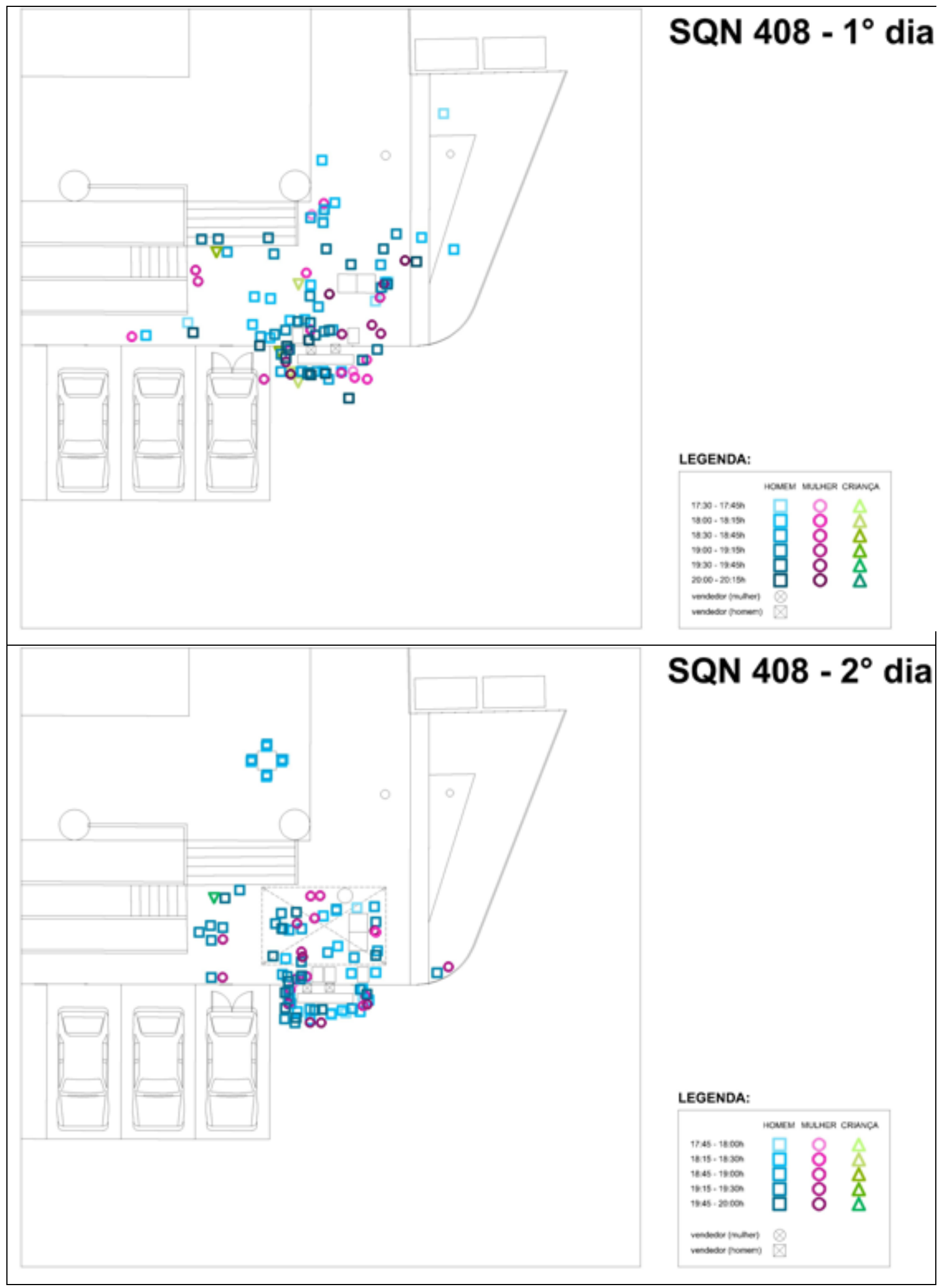

Figura 3.19 - mapas comportamentais sobre a distribuição de pessoas no ponto de comércio referente à SQN 408, nos dois dias observados. 
Neste ponto, observou-se que a distribuição dos elementos físicos permite não só a permanência, mas a passagem de pessoas por entre os elementos. A ocupação do lugar não obstruiu completamente o acesso aos passantes. A composição é permeável.

\section{Sistema de Elementos Físicos - SEF}

18) Complexidade

Esta é a variável síntese que engloba a descrição dos elementos físicos envolvidos na atividade - com a distinção entre os portados pelo comerciante e os disponibilizados no lugar escolhido - suas funções e a relação entre eles.

\section{Descrição}

São 11 os elementos físicos envolvidos na atividade do ponto de comércio referente à SQN 408 (Figura 3.20).
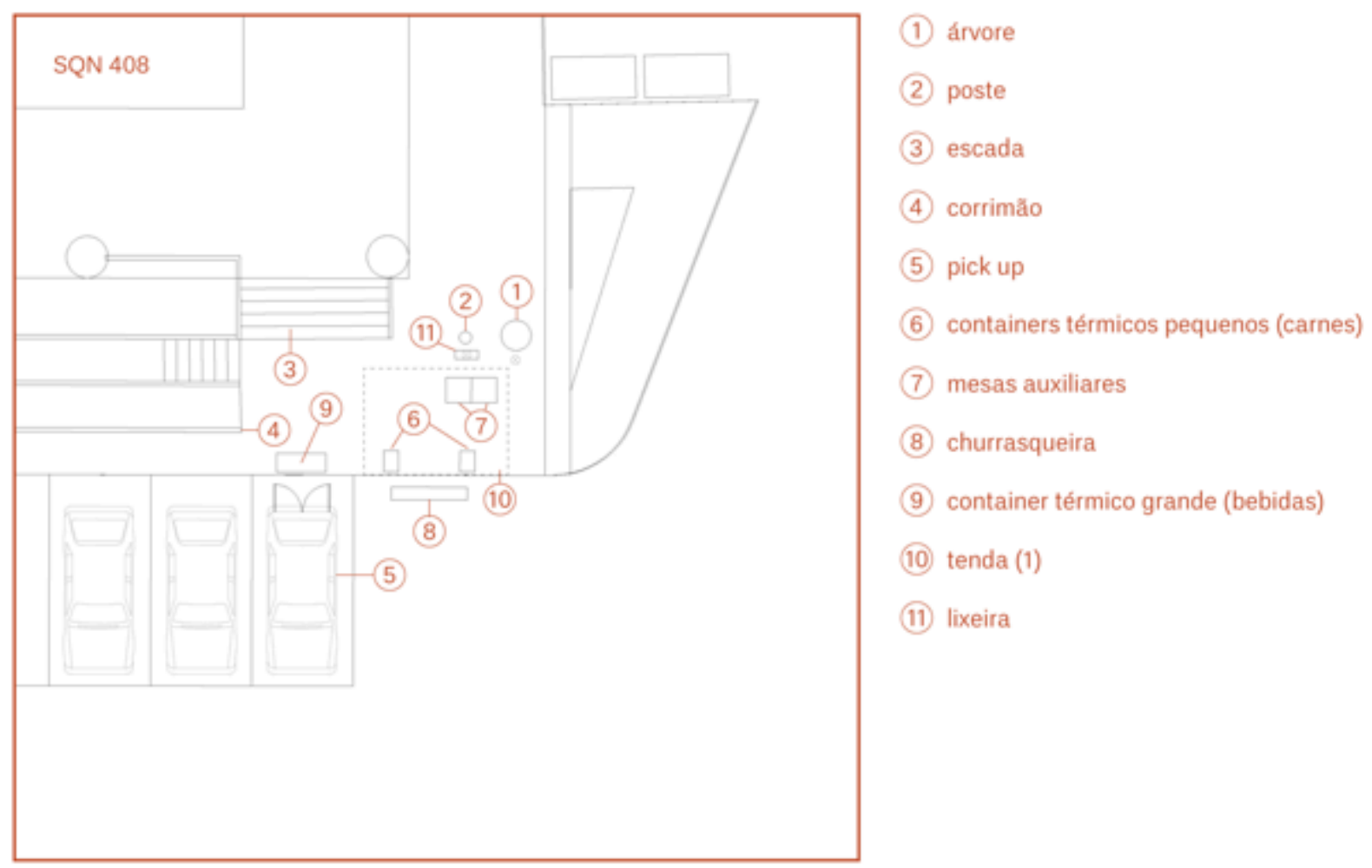

Figura 3.20 - planta baixa do ponto de comércio referente à SQN 408, com a especificação dos elementos físicos envolvidos na atividade. 
Os portados são em maior número do que os do local, o que aponta para um aproveitamento pequeno, porém significativo por suas funções na atividade.

. elementos portados - pick up, containers térmicos pequenos (para o acondicionamentos dos espetos de carne), mesas auxiliares, churrasqueira, container térmico grande (para o acondicionamento de bebidas), tenda, lixeira(s);

. elementos do local - árvore, poste de iluminação, escada, corrimão.

\section{Função dos elementos e suas relações}

Os 11 elementos descritos têm suas funções distintas, mas comuns no atendimento ao comércio de espetos de carne preparados na hora. Para isso, a pick up que fica sempre estacionada bem ao lado da churrasqueira tem a função de armário, além de transportar todos os elementos portados e montados pelo comerciante. A churrasqueira, além de sua função primária de assar a carne, serve de suporte para os espetos de carne que são previamente assados, ali no local mesmo. As duas mesas colocadas próximas (ou atrás, se considerarmos o posicionamento do comerciante e de seu ajudante) à churrasqueira dão suporte a acessórios como vasilhame de plástico aberto com farinha de mandioca, guardanapos, canudos, copos plásticos, sacos plásticos e temperos. O comerciante utiliza containers térmicos de tamanhos variados para acondicionar espetos com os pedaços de carne crua, previamente preparados (em casa), para serem assados no local. Dois ou três deles ficam dispostos junto à churrasqueira para também servir de apoio ao pano de prato e ao abanador. Outros dois containers, um pouco maiores que estes, ficam sempre dentro da pick up como uma reserva. Existe ainda um container maior que fica do lado de fora da pick up, sobre a calçada mesmo, que acondiciona as bebidas em lata. Para o lixo, eles disponibilizam uma caixa de papelão ou mesmo uma lixeira grande de plástico. A tenda é montada somente em época de chuva. Ela alcança as mesas auxiliares e o local onde ficam o comerciante e seu ajudante.

Os elementos disponibilizados no local são poucos, mas importantes em termos de delimitação do espaço e a oferta de algum conforto. O poste de iluminação e a árvore ao lado constituem um dos limites do espaço que este ponto de comércio ocupa e servem de referência para a disposição das lixeiras. A escada que leva ao bloco E do CLN 408 é o assento mais próximo da churrasqueira e das mesas, além 
de delimitar também este espaço. O corrimão delimita o espaço do ponto e serve de apoio às pessoas que consomem no local.

A ação principal na atividade deste ponto é executada na churrasqueira. Todos os outros elementos físicos dão apoio e continuidade ao que começa ali. Estão ligados por proximidade e formam os espaços convexos em que transitam e permanecem os comerciantes, seus clientes e até mesmo alguns pedestres que conseguem passar por entre estes elementos.

19) Aspectos funcionais - relações entre elementos físicos e as práticas

Apesar de chegarem no local por volta das $17 \mathrm{~h} 00$, para a montagem do posto de trabalho, a atividade começa pela manhã com a compra de carnes e bebidas. Eles preparam previamente os espetos com os pedaços de carne e os acondicionam em containers térmicos com gelo, que são levados na pick up e dispostos no local, ao lado da churrasqueira (Figura 3.21-d). Também são transportados containers, maiores que os dos espetos que dão apoio à atividade na churrasqueira. Eles servem tanto como reserva de mais espetos quanto para o acondicionamento das bebidas. São transportados e permanecem dentro da parte traseira da própria pick up, que é estacionada no lugar cativo, ao lado da atividade. As portas traseiras da pick up ficam abertas para que tanto os containers de reserva de carne, quanto o container das bebidas sejam acessados pelo Sr. Domingos e seu assistente e pelos clientes, no caso deste último (Figura 3.21-f).

O armazenamento das mesas e da lixeira fica por conta do restaurante da irmã, estabelecimento formal que é muito próximo a este ponto. As mesas juntas auxiliam quanto ao serviço de adição da farinha ao espeto, que é opcional e pode ser feito pelo cliente ou pelo comerciante. Sobre as mesas também estão os aparatos para a embalagem do(s) espeto(s) para viagem e o acesso a copos, canudos e guardanapos (Figura 3.21-d). A lixeira fica próxima ao poste ou à arvore. A tenda é guardada desmontada na parte de cima da pick up e só é montada em dias de chuva (Figura 3.21-b). 
Uma vez montados todos os elementos, eles acendem a churrasqueira e começam a assar os primeiros espetos de carne, para que os clientes possam, a partir das 18h, começar a escolher e se servir. O cliente assíduo se aproxima do ponto primeiro junto à churrasqueira, escolhe o(s) espeto(s) previamente assado(s) e o(s) põe na brasa. Aguarda ao redor da churrasqueira, conversando ou pegando uma bebida no container. Os clientes de primeira visita fazem seu pedido e são servidos (Figura 3.21-c). O movimento ao redor da churrasqueira, mesas auxiliares e pick up é intenso, por causa deste self service (Figura 3.21-e).

Com a disposição da churrasqueira, das mesas auxiliares e da lixeira uma atrás da outra, com um espaço de circulação entre elas, temos uma sequência linear de ações envolvendo estes elementos (Figura 3.21-a). A outra direção no espaço da atividade fica por conta do acesso à pick up para o consumo de bebidas e o apoio à atividade na churrasqueira. Assim, o movimento e a ocupação do espaço se dão no "L" que a esquina apropriada disponibiliza.

a

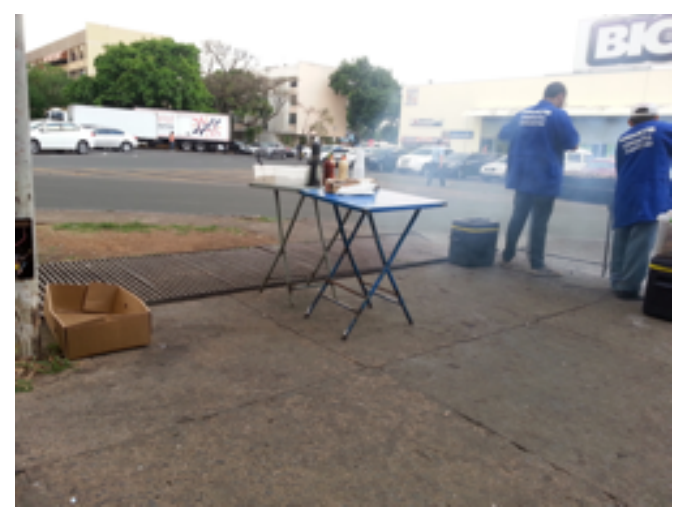

C

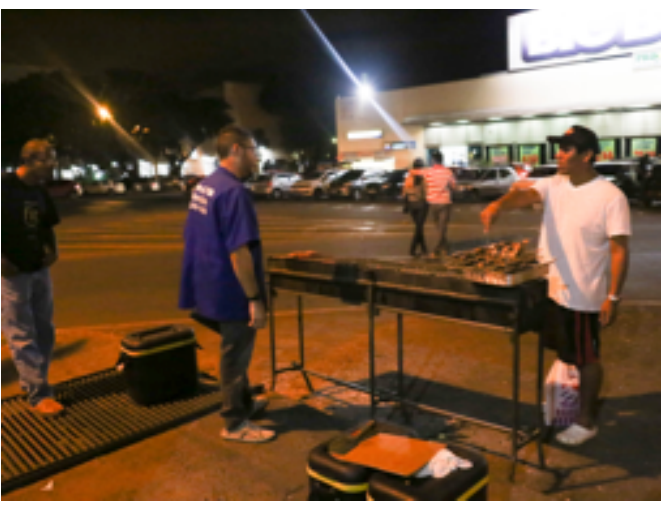

b

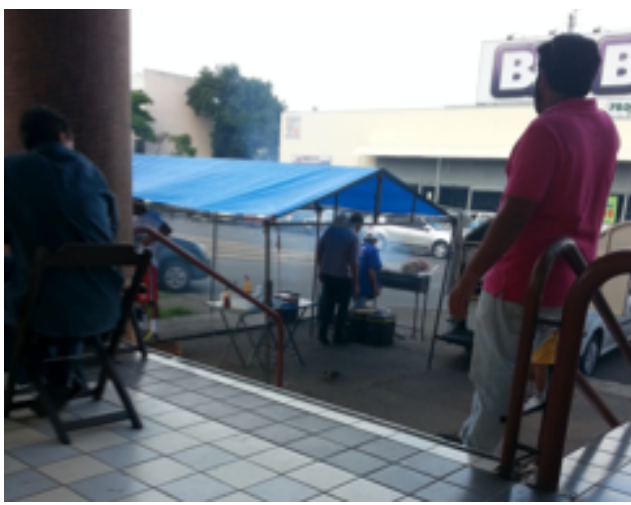

d

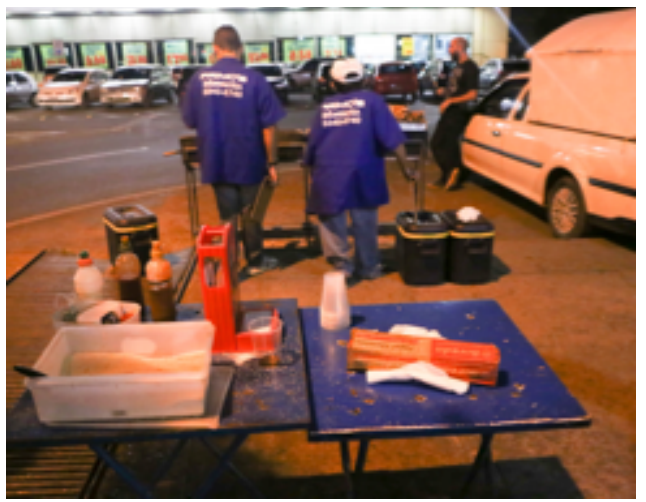



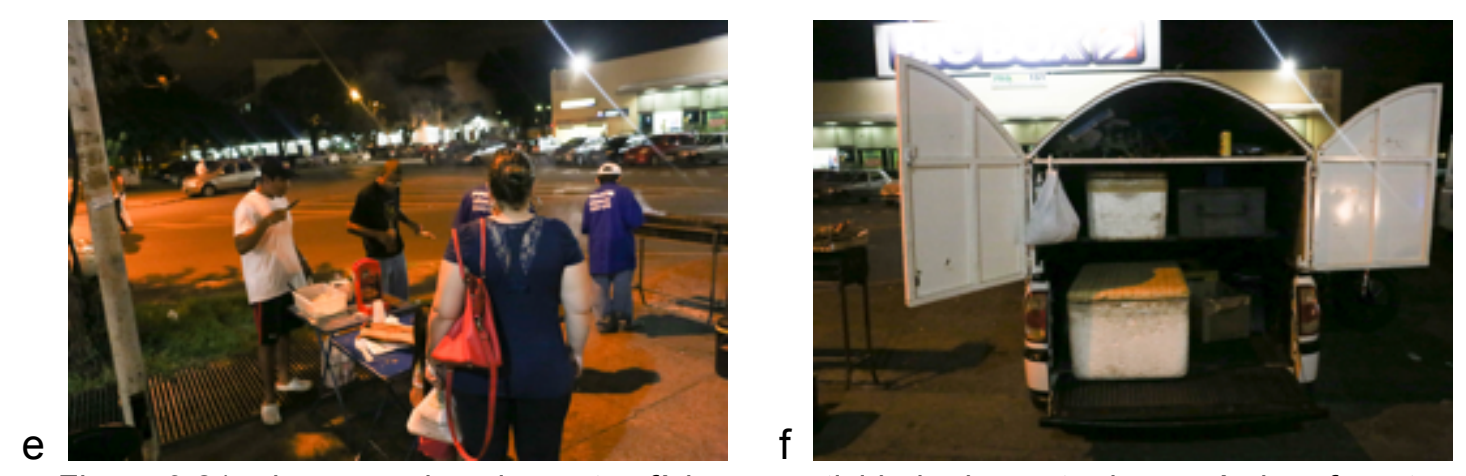

Figura 3.21 - imagens dos elementos físicos na atividade do ponto de comércio referente à SQN 408. Fotos: autora (fotos a e $\underline{b}$ ); Maya Macario (fotos $\underline{c}$, $\underline{d}$, e e $\underline{\text { f) }}$.

\subsubsection{Análise do ponto como um sistema - SQN 408}

\section{Padrões Espaciais + Características Socioeconômicas}

A classe social do comerciante e seu local de moradia condizem com pessoas que tendem à escolha por lugares que possibilitam maior urbanidade. A diversidade, em termos socioeconômicos, do público que frequenta este ponto também corrobora esta escolha. Estas informações conferem com os atributos favoráveis à urbanidade que reúne o lugar escolhido pelo irmão de Seu Domingos, há mais de quinze anos: aspectos de ambiência física média; níveis de acessibilidade ao movimento de veículos e de pedestres no contexto médios; acessibilidade alta em relação ao movimento do comerciante, de clientes e até passantes dentro da área do ponto; alta acessibilidade no que tange à conexão visual no contexto e mediana em relação à área da atividade; campo visual com área que extrapola consideravelmente o espaço convexo em que o ponto se encontra $\left(15.982 \mathrm{~m}^{2}\right.$ para $\left.4.246 \mathrm{~m}^{2}\right)$, apesar de sua baixa compacidade; condições medianas (estado médio de conservação e pouco conforto) para a permanência; beneficiamento da atividade do ponto pela proximidade com um número considerável de atividades.

\section{Padrões Espaciais + Sistema de Encontros e Esquivanças}

Os dados sobre ambiência e integração dos espaços do contexto e da atividade apresentados, são confirmados quanto ao potencial de urbanidade pelos números e diversidade de pessoas contabilizadas na passagem e permanência no local deste ponto de comércio. Em dois dias de contagem, entre os que passaram e 
permaneceram, homens, mulheres, crianças e idosos, foram 382 pessoas contabilizadas neste ponto de comércio.

\section{Padrões Espaciais + Sistema de Elementos Físicos}

O número, o arranjo e as relações entre os elementos físicos envolvidos na atividade deste ponto, bem como o seu funcionamento se beneficiaram de maneira considerável dos atributos de configuração do local escolhido. A interface entre a área do ponto e a do contexto imediato é bastante borrada. Uma extrapola a outra (Figura 3.22).
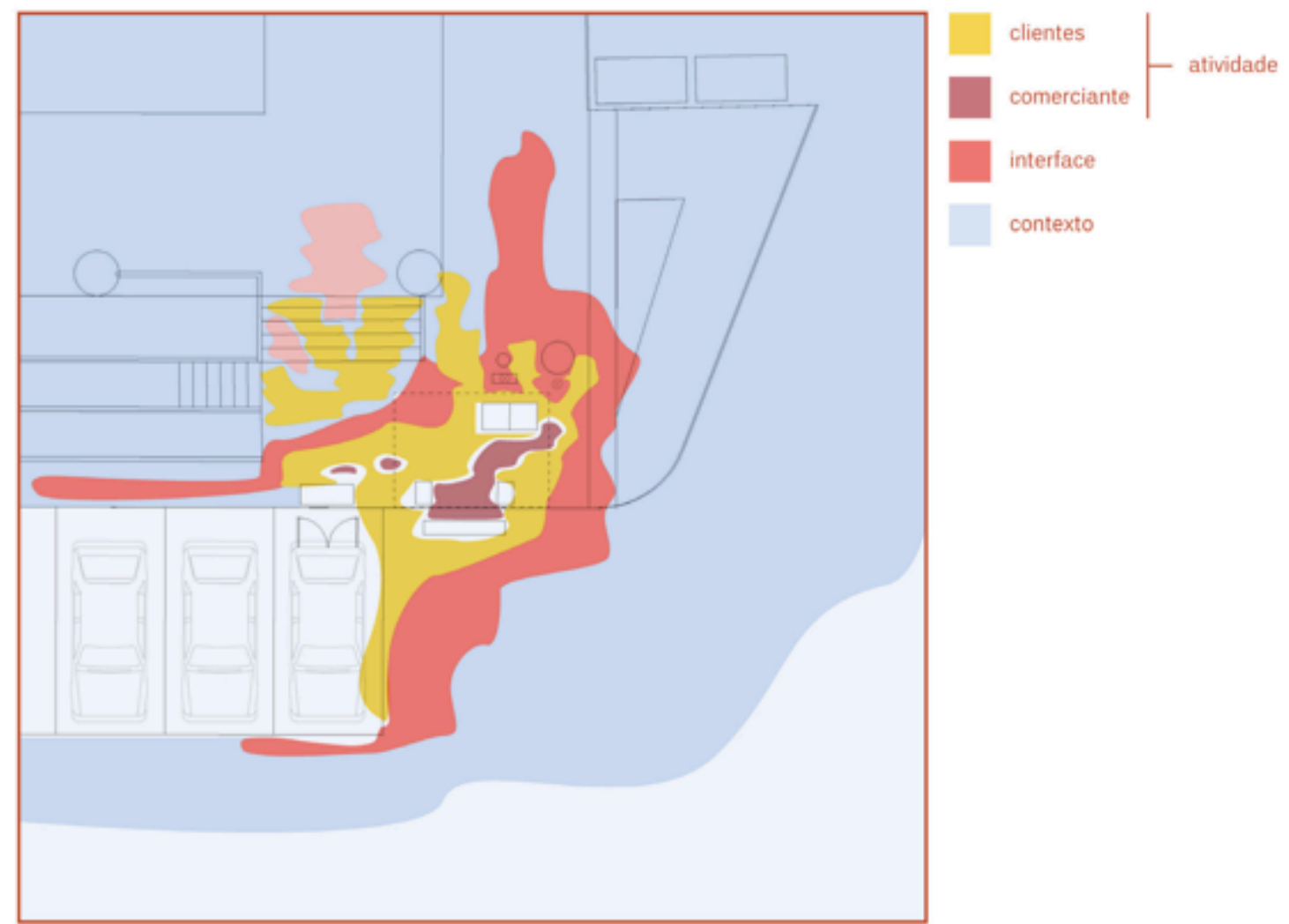

Figura 3.22 - planta baixa do ponto de comércio referente à SQN 408 com identificação dos espaços da atividade (clientes e comerciante), da interface (passantes) e do contexto.

As características do contexto beneficiam a atividade no ponto e este, por sua vez, pela composição de seus elementos físicos potencializa o grau de urbanidade que o espaço já possui por sua configuração. 
Sistema de Elementos Físicos + Características Socioeconômicas

O arranjo dos elementos neste ponto foi feito de maneira que a atividade possa ser executada quase que completamente tanto pelo comerciante, como pelo cliente. Os espaços deixados entre os elementos principais do ponto - churrasqueira, mesas auxiliares e pick up - possibilitam o serviço, ou auto serviço e a permanência para o consumo. As características socioeconômicas do comerciante e do cliente permitem que eles se "confundam", se mesclem em suas posições/funções na atividade. Este é outro aspecto que considero aumentar a urbanidade no ponto.

\section{Sistema de Elementos Físicos + Sistema de Encontros e Esquivanças}

O comportamento mais espontâneo das pessoas que transitam para além do espaço da atividade, entre o auto serviço e a permanência para o consumo, confirmam o sucesso do arranjo que estabelece espaços para este trânsito, bem como da relação funcional entre os elementos, neste ponto.

\section{Características Socioeconômicas + Sistema de Encontros e Esquivanças}

O perfil do comerciante e de seus clientes traduzidos em suas características socioeconômicas, neste ponto são bem representados por suas escolhas do espaço e dos elementos físicos. Isto repercute positivamente no comportamento das pessoas, que passam ou permanecem neste ponto, pelos atributos formais do contexto e da atividade. Esta última relação resume o sucesso do ponto de comércio referente à SQN 408, no que tange à mutualidade na promoção de urbanidade entre o contexto e a atividade.

\subsubsection{Ponto de comércio relacionado à superquadra norte 209 - SQN 209}

Entre os quatro pontos de comércio observados, o relacionado à superquadra norte 209 é o único que tem funcionamento diurno, pela manhã. Identificação, apresentação nas categorias analíticas e análise deste ponto como um sistema são apresentados a seguir. 


\subsubsection{Identificação - SQN 209}

Este ponto relaciona-se à superquadra norte 209 e representa a categoria associado à passagem subterrânea (Figura 3.23). É especializado no preparo e venda de itens para café da manhã: café, sucos, bolos e salgados. Seu funcionamento acontece de segunda a sexta-feira, de 06h00 até 09h40, quando, geralmente, todos os itens são vendidos (Figura 3.24).

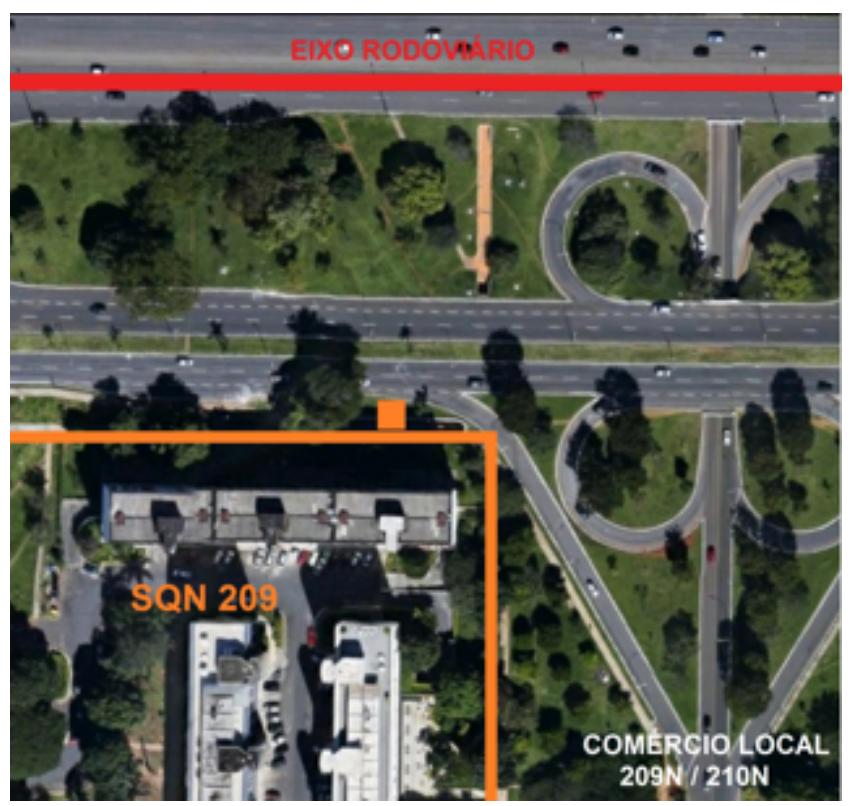

Figura 3.23 - vista aérea do ponto em relação a quadra residencial mais próxima (SQN 209). Fonte: adaptado do Google Earth.
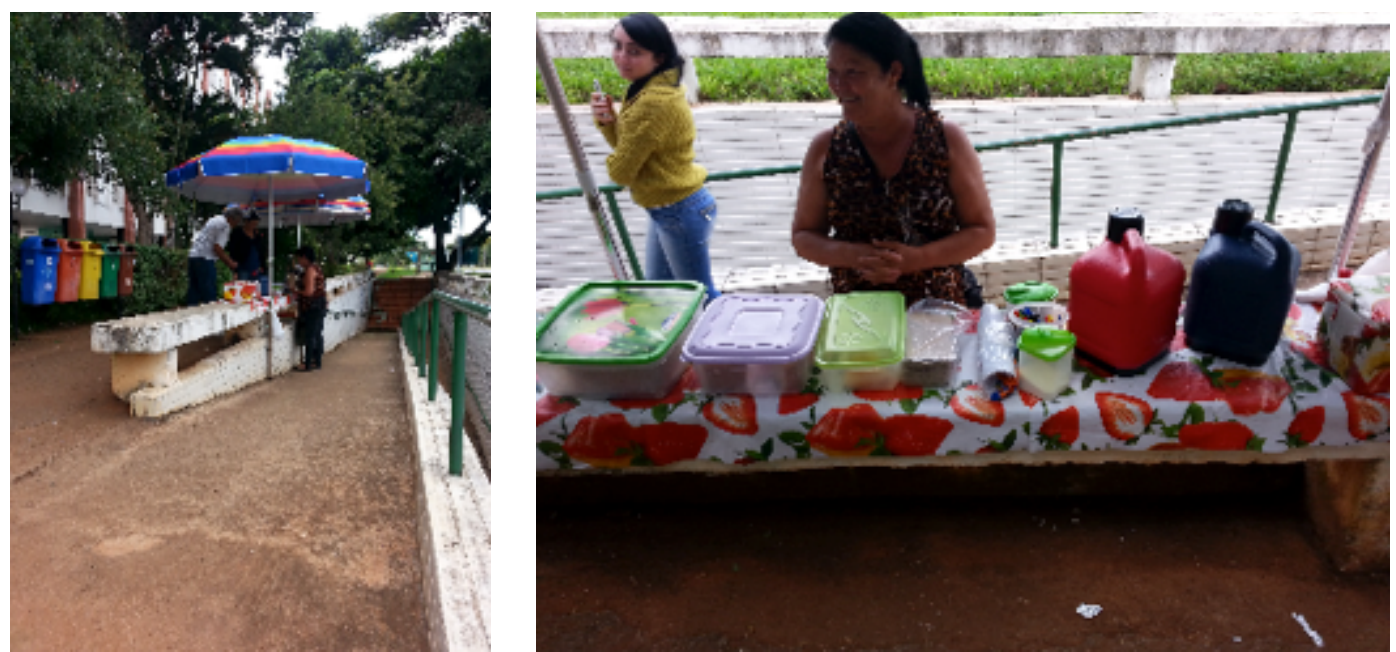

Figura 3.24- identificação do ponto de comércio relacionado à superquadra norte 209. Fonte: autora. 


\subsubsection{Categorias analíticas - SQN 209}

\section{Características socioeconômicas}

1) Apresentação geral: gênero; faixa etária, naturalidade e grau de instrução.

2) Local de moradia e modo de deslocamento.

3) A atividade é a única ocupação remunerada? Dias da semana de que se ocupa com a atividade.

4) Renda mensal adquirida pela atividade.

5) Razão da escolha por este local para o ponto de comércio.

6) Quem é o seu público/cliente?

7) Dados censitários sobre renda dos moradores.

Dona Aparecida é natural de Minas Gerais e tem idade entre 50 e 60 anos. Mora com a família em Planaltina - DF, de onde vem com a filha mais nova, sua ajudante na parte financeira da atividade. As duas se deslocam de casa para o ponto com o filho mais velho de Dona Aparecida, que é motorista de táxi. O carro, além de transportar as duas, leva três bolsas grandes com os itens a serem vendidos e alguns outros artefatos que dão suporte à atividade, como toalha de mesa, copos e pratos descartáveis, guardanapos etc. Em época de chuvas, dois guarda-chuvas. Quando não se deslocam por meio do táxi, elas vêm de ônibus, mesmo. Seu grau de instrução corresponde, também, aos primeiros anos do ensino fundamental. $O$ comércio na rua não é sua única ocupação remunerada, pois duas vezes por semana ela complementa sua renda como diarista em casa de família. Sua renda mensal obtida com o ponto de comércio é em torno de $R \$ 1.800,00$.

Ela não escolheu o local onde tem o ponto de comércio, mas o "herdou" de um conhecido que ali tinha o seu ponto. Para não perder o lugar, ela começou a ocupálo em seguida à saída do comerciante anterior. Ela vende café da manhã ali faz três anos e, quando falta, os clientes "reclamam" depois. Ela conta com a boa vontade dos porteiros do Bloco I da SQN 209, próximo ao ponto, para usar a vassoura deles, de vez em quando, e o toalete dos aposentos da zeladoria deste bloco. 
Sobre quem são seus clientes, a comerciante responde que a grande maioria é constituída de pessoas que trabalham em residências, como diaristas; em equipamentos, como escolas e nos estabelecimentos do comércio local próximo ao ponto (CLN 209/210). A observação feita confere com o que Dona Aparecida relatou, pois foram muito poucos os moradores da superquadra de referência observados consumindo naquele ponto. Destaco um senhor que parou no ponto porque conhecia a comerciante. Ele consumiu um café, mas a atividade que, de fato, o levou fora de casa a passar por ali foi o passeio matinal de seu cão.

Apesar dos dados censitários apontarem como classe social predominante dos moradores da superquadra norte 209 a classe rica, constatou-se que a grande parte dos clientes do comércio local em questão está inserida nas classes média inferior e pobre (Figura 3.25).

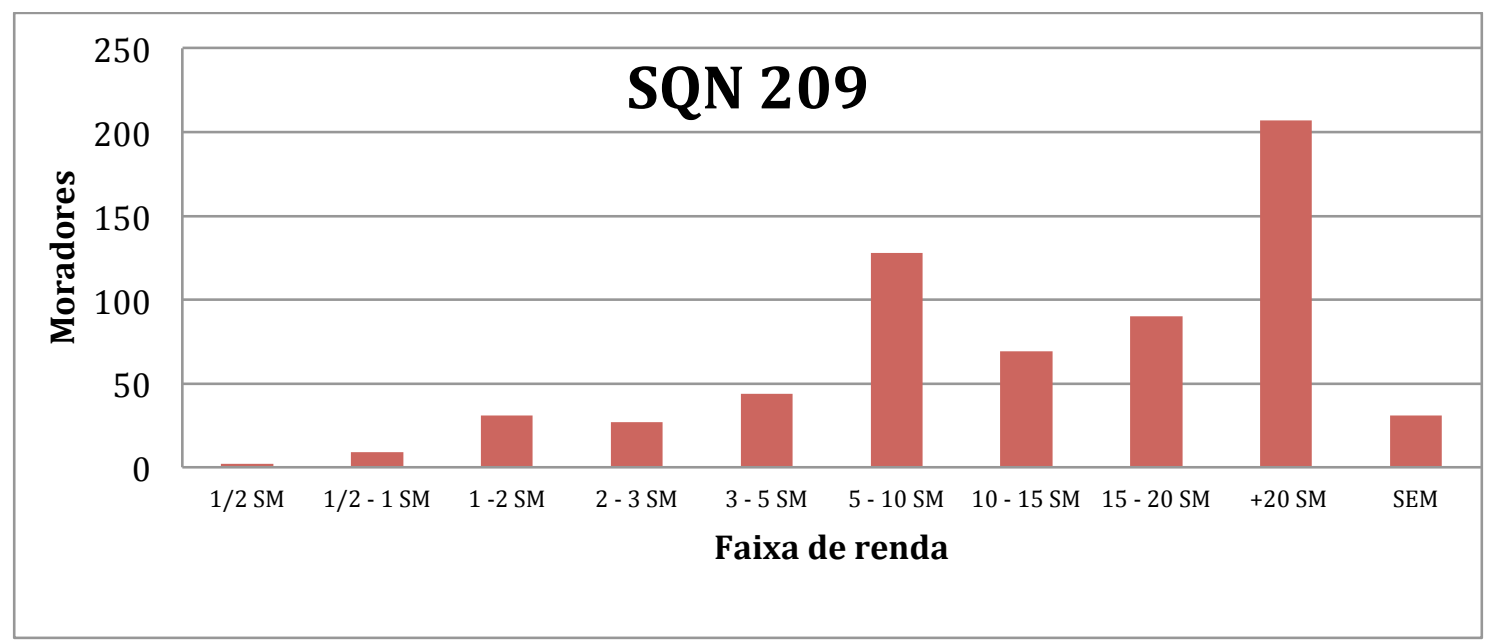

Figura 3.25 - gráfico sobre a renda, por número de salários mínimos, dos responsáveis por domicílios, da superquadra norte 209, na amostragem dos dados censitários do IBGE, de 2010.

\section{Padrões espaciais}

08) Espaço convexo que abarca o ponto - ambiência física

As áreas dos espaços convexos considerados no contexto imediato ao ponto de comércio referente a SQN 209 são: 5444, 3072, 2790, 1991, 1989, 1225, 1053, 993, $860,846,845,840,826,813,731,666,629,285,240,177,164,162,143,113$. A medida da área do espaço convexo em que o ponto em questão está inserido está entre as oito maiores (é a quinta maior) relacionadas: $1989 \mathrm{~m}^{2}$ (Figura 3.26). Este 
espaço é basicamente retangular, delimitado pela fachada do bloco I da superquadra norte 209, em sua extensão. A delimitação oposta à fachada se dá pela ERL Norte, uma barreira não visual, mas virtual devido ao seu grande fluxo de motorizados.

Por ser retangular, a forma do espaço convexo aproxima qualquer ponto inserido nele do bloco tridimensional delimitador (o bloco I da superquadra referência). Além disso, o ponto está localizado em uma das extremidades do espaço convexo. A proximidade com o bloco da quadra, a posição do ponto dentro do espaço convexo e a medida deste espaço, apesar de estar entre as maiores do contexto, conferem uma ambiência física alta para ponto de comércio referente à SQN 209.

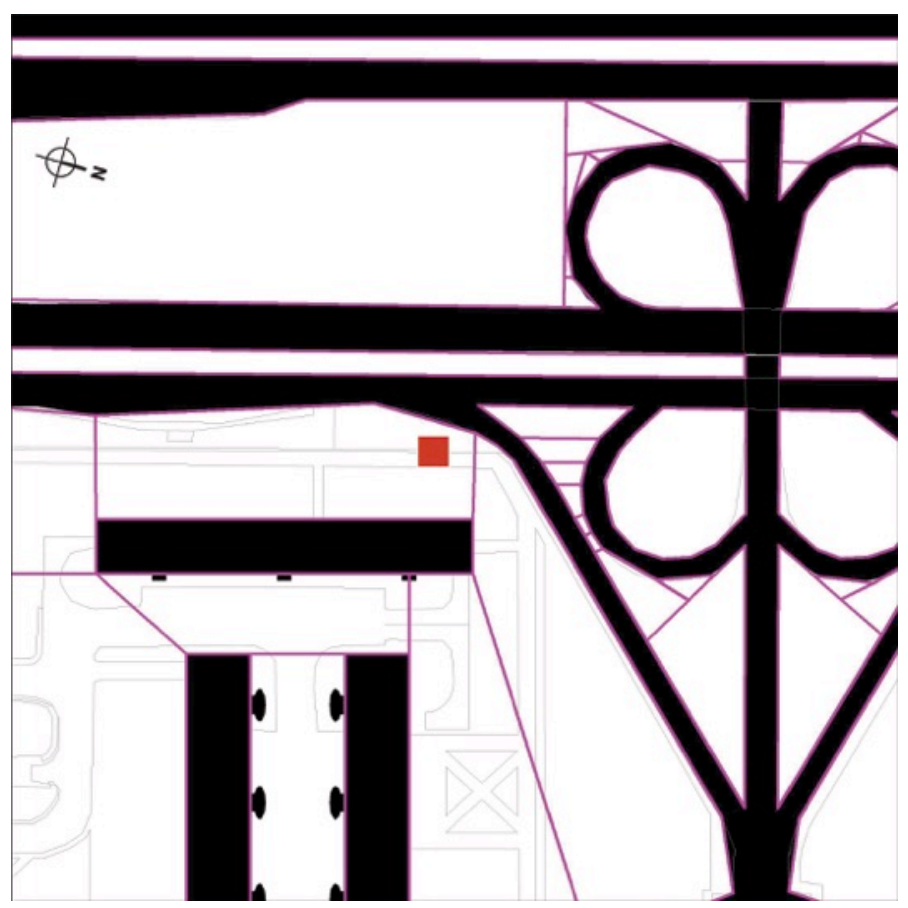

Figura 3.26 - mapa $(200 \mathrm{~m})$ dos espaços convexos do contexto imediato do ponto referente à SQN 209 e de sua inserção em um destes espaços.

09) Acessibilidade ao movimento de veículos

O ponto de comércio localizado na entrada da passagem subterrânea associada à superquadra norte 209 , tem o valor de seu nível de integração de 1,083. Com relação aos valores máximo, médio e mínimo de integração, no que se refere à acessibilidade ao movimento de veículos, este valor está situado entre os níveis de integração média e máxima do Plano Piloto - de 0,847 e 1,379, respectivamente 
(Figura 3.27). Considerado razoavelmente alto este valor é devido ao ponto de comércio estar localizado ao longo do eixo $L$, diretamente paralelo ao eixo rodoviário do Plano Piloto, uma de suas principais e maiores vias, que interliga todas as superquadras residenciais, das Asa Norte e Asa Sul (Figura 3.87).

\begin{tabular}{|c|c|c|c|}
\hline $\begin{array}{c}\text { Integração máxima no } \\
\text { Plano Piloto }\end{array}$ & $\begin{array}{c}\text { Integração média no } \\
\text { Plano Piloto }\end{array}$ & $\begin{array}{c}\text { Integração mínima no } \\
\text { Plano Piloto }\end{array}$ & $\begin{array}{c}\text { Integração do ponto } \\
\text { SQN 209 }\end{array}$ \\
\hline 1,379 & 0,847 & 0,349 & 1,083 \\
\hline
\end{tabular}

Figura 3.27 - quadro comparativo entre as medidas de integração máxima, média e mínima do Plano Piloto e do ponto de comércio localizado na entrada da passagem subterrânea associada à SQN 209, no que se refere à acessibilidade ao movimento de veículos.

10) Acessibilidade ao movimento do pedestres

O grau de acessibilidade ao movimento de pedestres do ponto de comércio referente à SQN 209 é de 6,82. Comparado às medidas de integração máxima $(18,94)$, média $(10,37)$ e mínima $(3,62)$ da área de seu contexto imediato, este valor é considerado baixo (Figura 3.28), devido a grande quantidade de barreiras ao movimento de pedestres que esta área possui.

\begin{tabular}{|c|c|c|c|}
\hline $\begin{array}{c}\text { Integração máxima no } \\
\text { contexto imediato }\end{array}$ & $\begin{array}{c}\text { Integração média no } \\
\text { contexto imediato }\end{array}$ & $\begin{array}{c}\text { Integração mínima no } \\
\text { contexto imediato }\end{array}$ & $\begin{array}{c}\text { Integração do ponto } \\
\text { SQN 209 }\end{array}$ \\
\hline 18,94 & 10,37 & 3,62 & $\mathbf{6 , 8 2}$ \\
\hline
\end{tabular}

Figura 3.28 - quadro comparativo entre as medidas de integração máxima, média e mínima do contexto imediato (área quadrada ao redor do ponto com $200 \mathrm{~m}$ de lado) e da localização do ponto de comércio referente à SQN 209, no que se refere à acessibilidade ao movimento de pedestres.

Grande parte dos eixos se concentra no interior da quadra, porém este ponto fica às margens de um dos percursos mais integrados, por ser ali entrada/saída de passagem subterrânea (Figura 3.29).

A medida de integração do centro da área (quadrada com $20 \mathrm{~m}$ de lado) que envolve a composição dos elementos físicos deste ponto é de 10,09. Com relação as medidas máxima $(14,05)$, média $(5,69)$ e mínima $(2,83)$ da área, a medida é considerada de média a alta (Figura 3.30). 

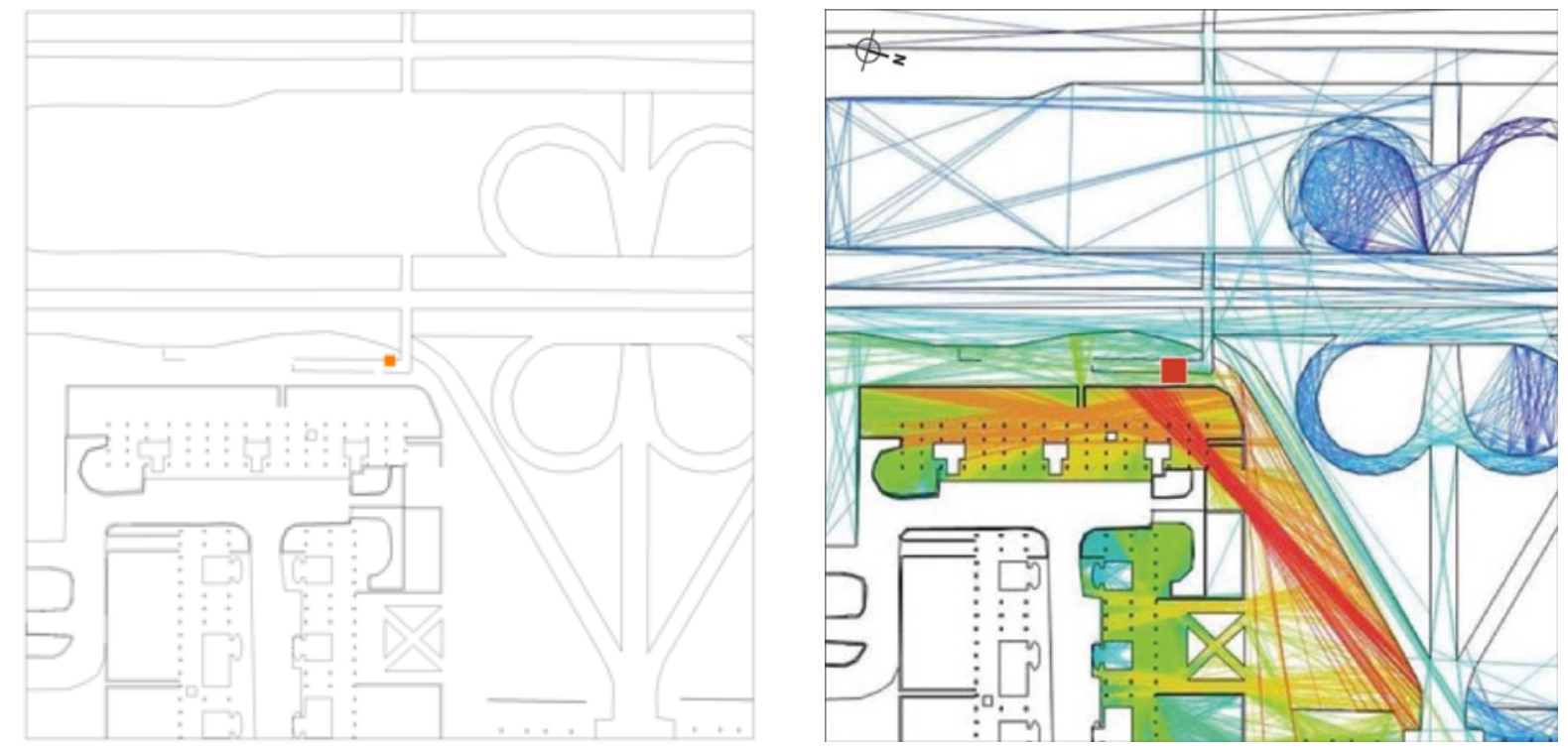

Figura 3.29 - mapas de barreiras e permeabilidades ao movimento (gerador) (à esquerda) e de axialidade (à direita) para o ponto - SQN 209.

\begin{tabular}{|c|c|c|c|}
\hline $\begin{array}{c}\text { Integração máxima na } \\
\text { área da atividade }\end{array}$ & $\begin{array}{c}\text { Integração média na } \\
\text { área da atividade }\end{array}$ & $\begin{array}{c}\text { Integração mínima na } \\
\text { área da atividade }\end{array}$ & $\begin{array}{c}\text { Integração do ponto } \\
\text { central - SQN 209 }\end{array}$ \\
\hline 14,05 & 5,69 & 2,83 & 10,09 \\
\hline
\end{tabular}

Figura 3.30 - quadro comparativo entre as medidas de integração máxima, média e mínima da área do ponto de comércio (área quadrada ao redor do ponto com $20 \mathrm{~m}$ de lado) referente à SQN 209 e do seu ponto central, no que se refere à acessibilidade ao movimento de pedestres.

A entrada e saída de pessoas da passagem subterrânea se dá bem ao lado da área apropriada pela comerciante. Isso pode ser constatado no mapa da Figura 3.31.

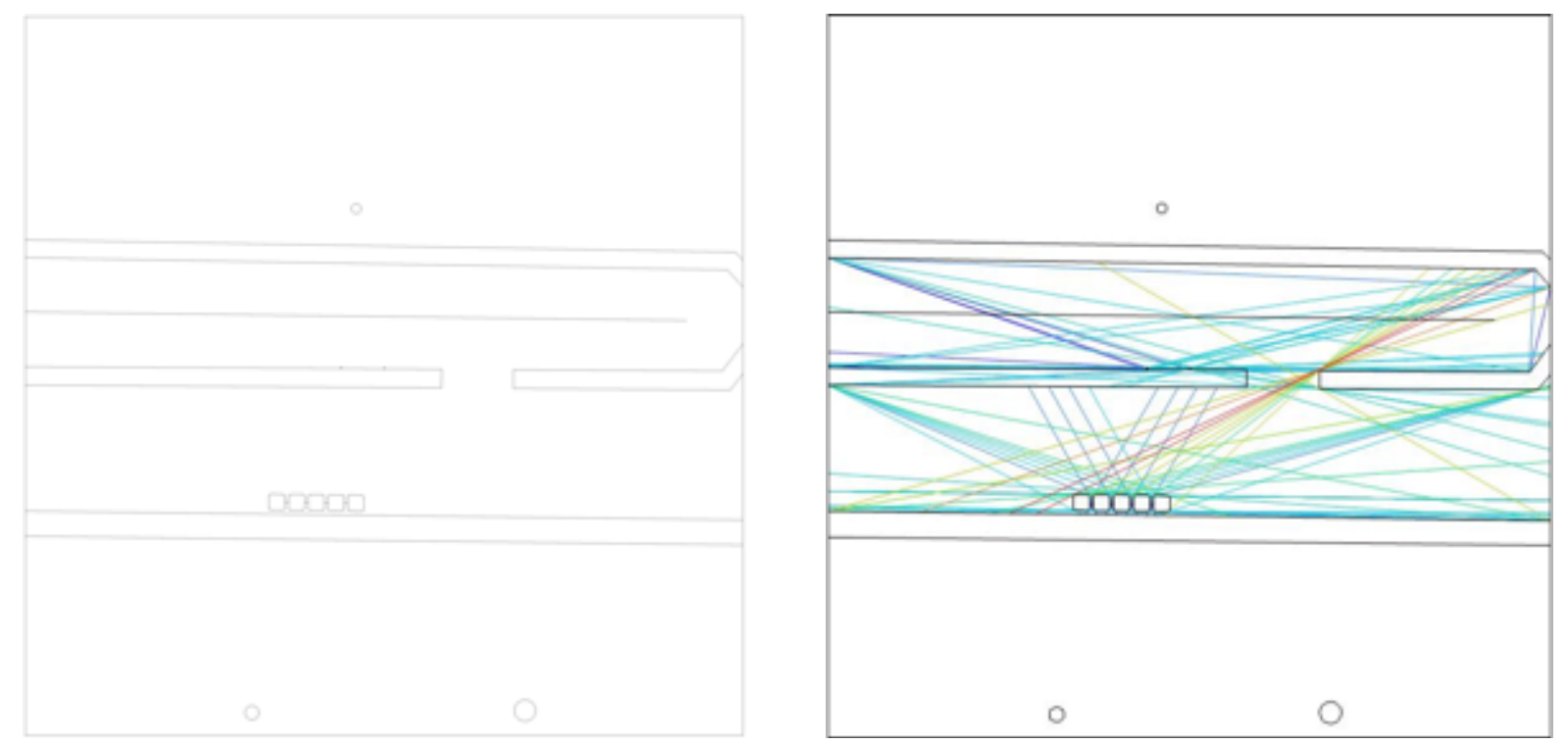

Figura 3.31 - mapas de barreiras e permeabilidades (à esquerda) e axialidade (à direita) do ponto de comércio referente à SQN 209 (máscara quadrada de $20 \mathrm{~m}$ de lado ao redor do ponto). 
11) Acessibilidade à visão - conexão visual

O ponto de comércio referente à SQN 209 possui um grau de visibilidade de 56,59, que está acima da média na comparação com as medidas máxima $(77,03)$, média $(46,66)$ e mínima $(5,97)$ deste tipo de integração na área de seu contexto imediato (Figura 3.32). Esta aferição pode ser confirmada com a localização do ponto entre as colorações verde claro e amarela no mapa de visibilidade (Figura 3.33).

\begin{tabular}{|c|c|c|c|}
\hline $\begin{array}{l}\text { Integração visual } \\
\text { máxima no contexto }\end{array}$ & $\begin{array}{l}\text { Integração visual } \\
\text { média no contexto }\end{array}$ & $\begin{array}{l}\text { Integração visual } \\
\text { mínima no contexto }\end{array}$ & $\begin{array}{l}\text { Integração visual no } \\
\text { ponto - SQN 209 }\end{array}$ \\
\hline 77,03 & 46,66 & 5,97 & 56,59 \\
\hline
\end{tabular}

Figura 3.32 - quadro comparativo entre as medidas de integração visual máxima, média e mínima no contexto imediato (área quadrada ao redor do ponto com 200m de lado) e da localização do ponto de comércio referente à SQN 209, no que se refere à acessibilidade à visão.

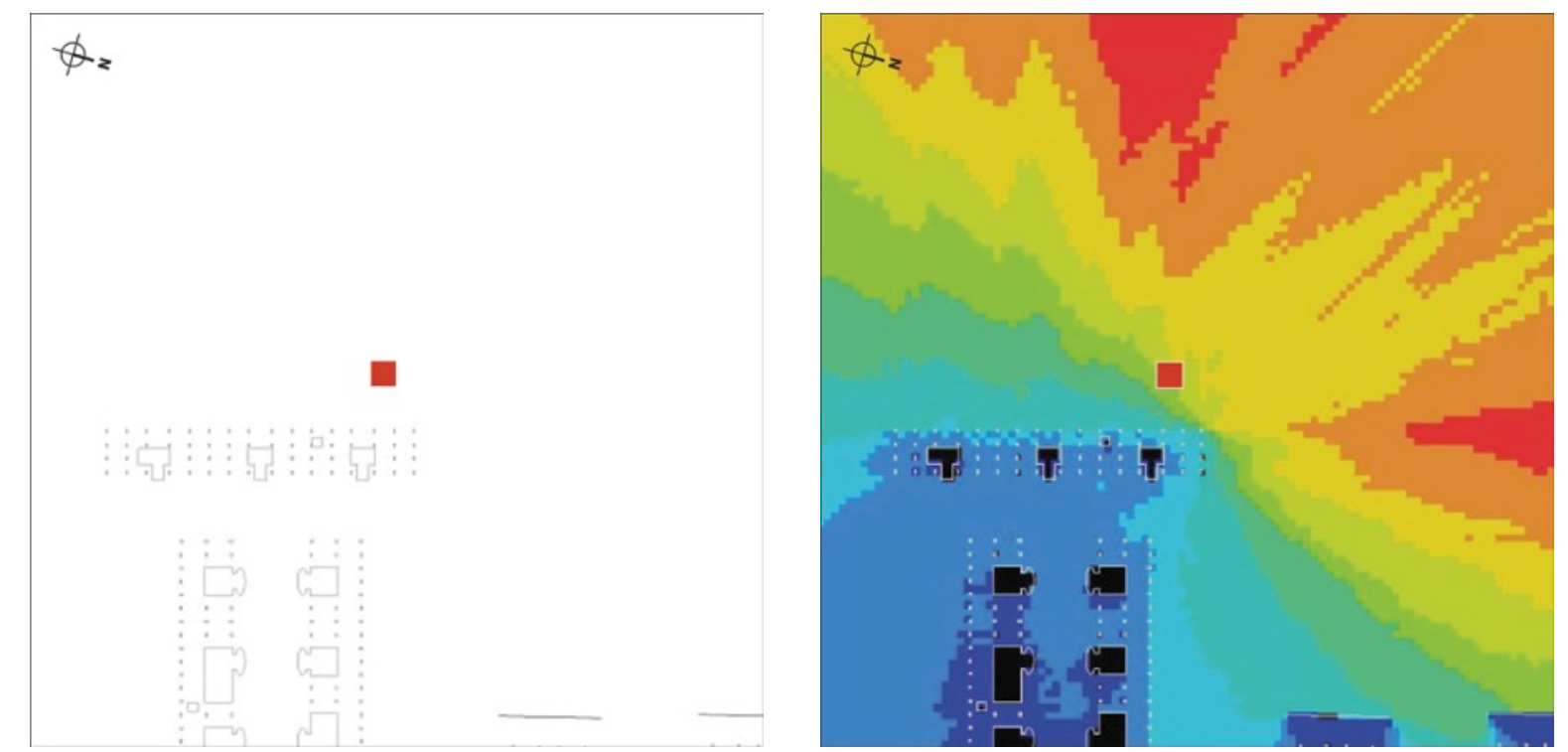

Figura 3.33 - mapas de barreiras e permeabilidades à visão (gerador) (à esquerda) e de visibilidade (à direita) para o ponto - SQN 209.

A área que abarca este ponto possui apenas a fila de lixeiras e alguns troncos de árvore como barreira à visão. Sua medida de integração de 90,43 , considerada mediana, se aproxima da média da área que é de 127, 65 (Figura 3.34).

\begin{tabular}{|c|c|c|c|}
\hline $\begin{array}{c}\text { Integração visual } \\
\text { máxima na área da } \\
\text { atividade }\end{array}$ & $\begin{array}{c}\text { Integração visual } \\
\text { média na área da } \\
\text { atividade }\end{array}$ & $\begin{array}{c}\text { Integração visual } \\
\text { mínima na área da } \\
\text { atividade }\end{array}$ & $\begin{array}{c}\text { Integração visual no } \\
\text { ponto central }- \text { SQN } \\
209\end{array}$ \\
\hline 408,13 & 127,65 & 10,46 & 90,43 \\
\hline
\end{tabular}

Figura 3.34 - quadro comparativo entre as medidas de integração visual máxima, média e mínima na área do ponto de comércio (área quadrada ao redor do ponto com $20 \mathrm{~m}$ de lado) referente à SQN 209 e do seu ponto central, no que se refere à acessibilidade à visão. 
No centro do mapa de visibilidade, onde se localiza a montagem do café da manhã pela comerciante, a coloração é azul clara e confirma a aferição (Figura 3.35).

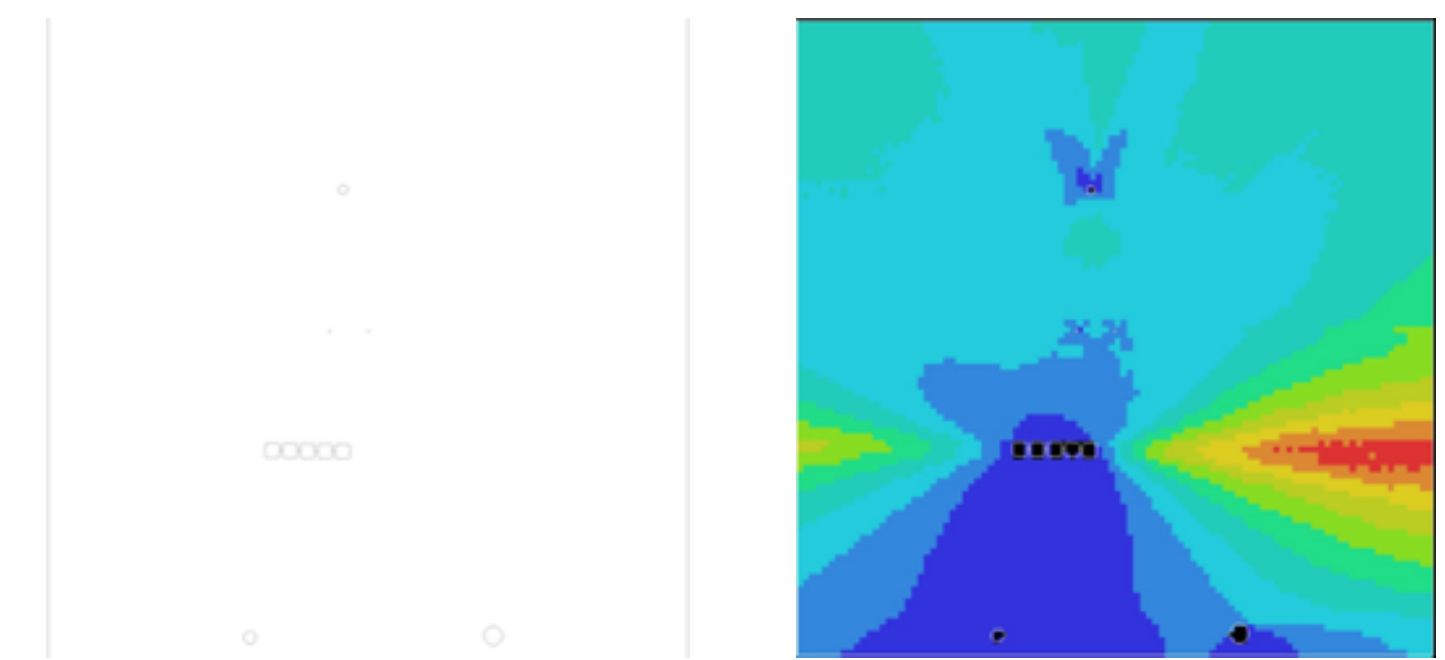

Figura 3.35 - mapas de barreiras e permeabilidades à visão (à esquerda) e de visibilidade (à direita) do ponto de comércio referente à SQN 209 (máscara quadrada de 20m de lado ao redor do ponto).

12) Isovistas - campo visual

Os dados considerados sobre as isovistas do ponto referente à SQN 209 são: área = $32.337 \mathrm{~m}^{2}$; perímetro $=2.707 \mathrm{~m}$ e compacidade $=0,06$. $\mathrm{O}$ valor da medida de compacidade deste ponto é considerado relativamente alto e isto se deve à localização do ponto ao longo da via ERL - Norte. Boa parte da área de isovistas não possui barreiras à visão (Figura 3.36).

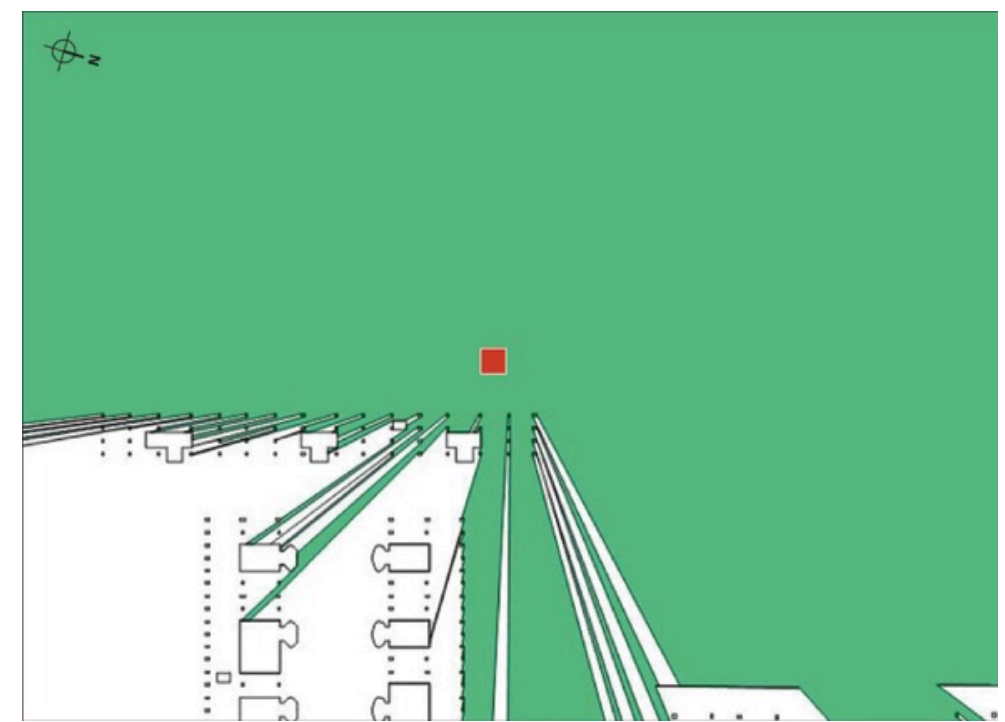

Figura 3.36 - mapa de isovistas a partir do ponto - SQN 209. 
13) Condições para permanência - estado de conservação e conforto

A limpeza da calçada e da passagem subterrânea em que se instala o ponto referente à SQN 209 é feita normalmente pelo Serviço de Limpeza Urbana (SLU), porém, como o local é via de passagem de muitos pedestres, logo fica com algum lixo no chão, apesar do grupo de lixeiras seletivas instaladas ali. $O$ calçamento se encontra em estado conservado (sem fissuras) e a mureta, onde a comerciante dispõem os produtos para o café da manhã, está com a pintura desgastada pela exposição às diversas condições climáticas, necessitando de manutenção com mais frequência.

Este ponto tem o seu funcionamento no turno matutino e, por sua localização, está protegido do sol pelo bloco I de sua superquadra referência, durante todo o período de atividade. $O$ consumo neste ponto também é feito praticamente em pé. Quem se demora mais no ponto para consumir ou conversar, senta na mureta em que é colocado o café da manhã (Figura 3.37).

Diante do exposto, considero medianas as condições para permanência neste ponto de comércio, tanto no que se refere ao estado de conservação, quanto ao conforto.
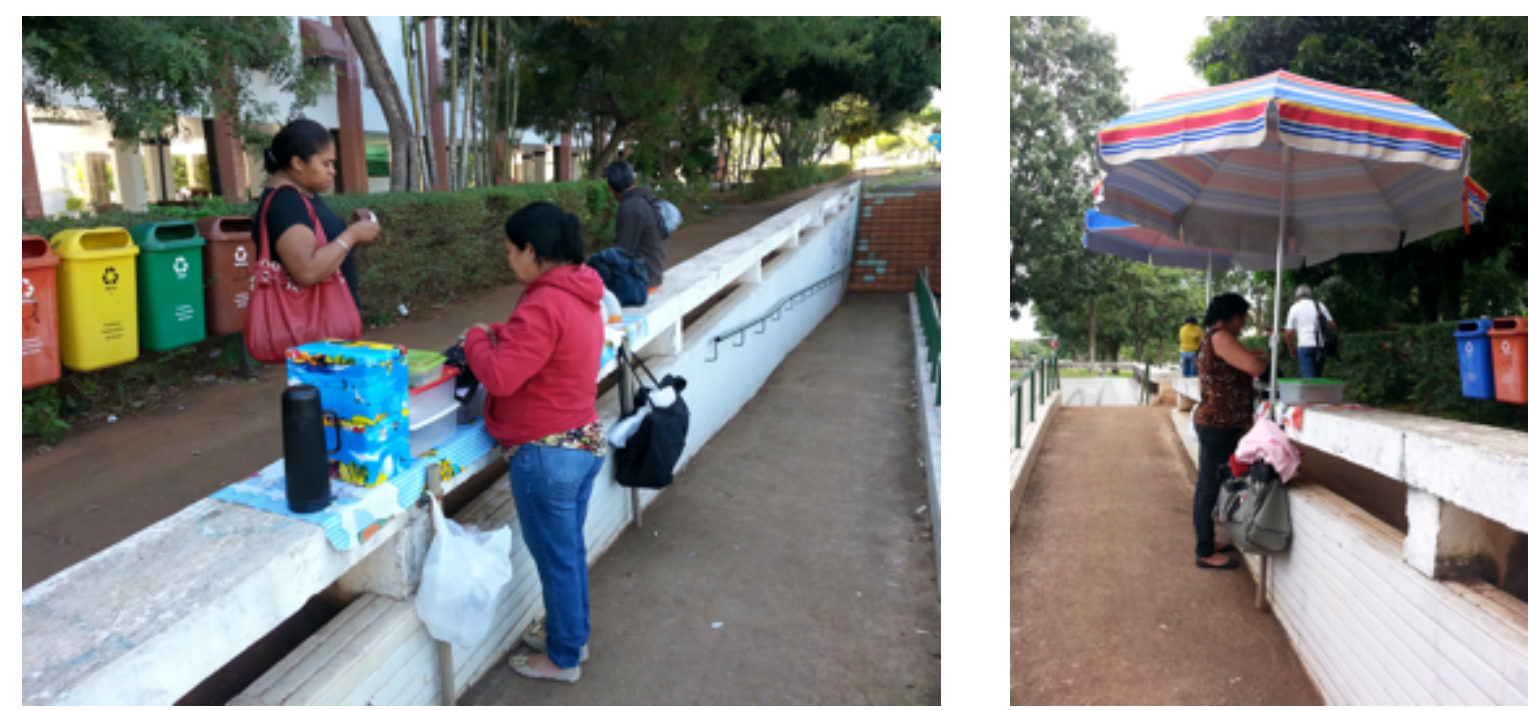

Figura 3.37 - imagens sobre condições para permanência no ponto de comércio referente à SQN 209. Fotos: autora. 
14) Atividades ao redor do ponto de comércio

Ao redor deste ponto de comércio, dentro da área do seu contexto imediato (máscara quadrada com 200m de lado), não existem estabelecimentos comerciais formais. O ponto está cercado por vias, pela passagem subterrânea, pelo bloco I da SQN 209, por um ponto de ônibus na mesma calçada, ainda na altura da superquadra referência. Somente este ponto de comércio desempenha o papel de atividade atratora neste contexto, principalmente no horário de seu funcionamento.

Apesar de não estar abarcado pela delimitação do contexto imediato deste ponto, vale destacar a existência de um outro ponto de comércio informal de café da manhã do outro lado da passagem subterrânea, ao longo da ERW - Norte. Acredito não serem concorrentes estes dois pontos, apesar da proximidade relativa, por causa dos destinos diferentes de seus clientes. Constata-se assim, que o sucesso do ponto de comércio referente à SQN 209 não se deve à proximidade com outras atividades (Figura 3.38).

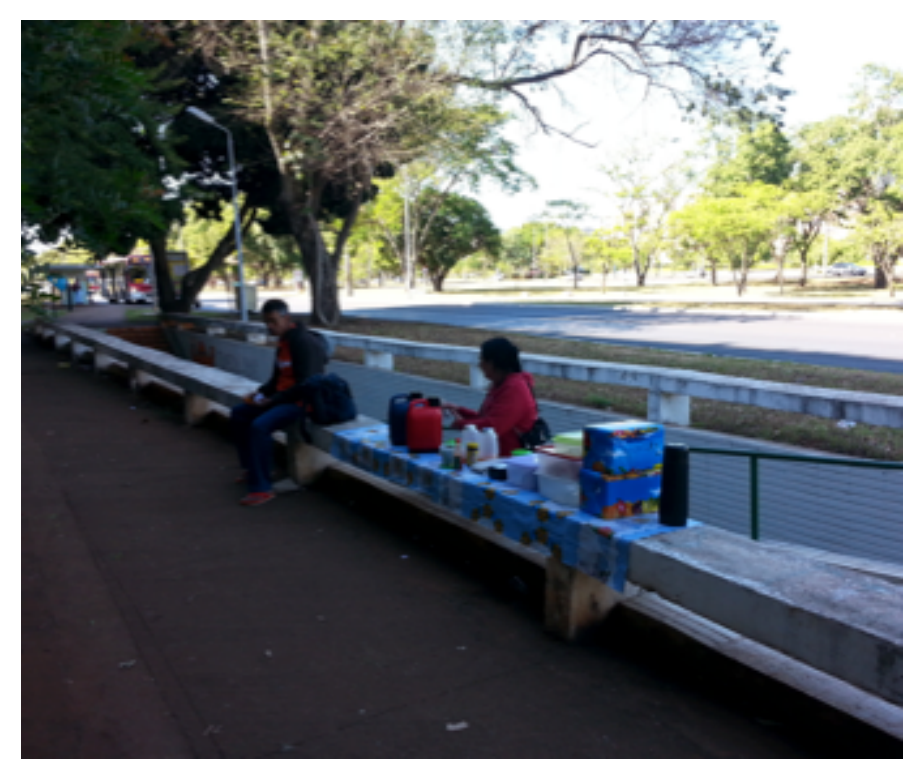




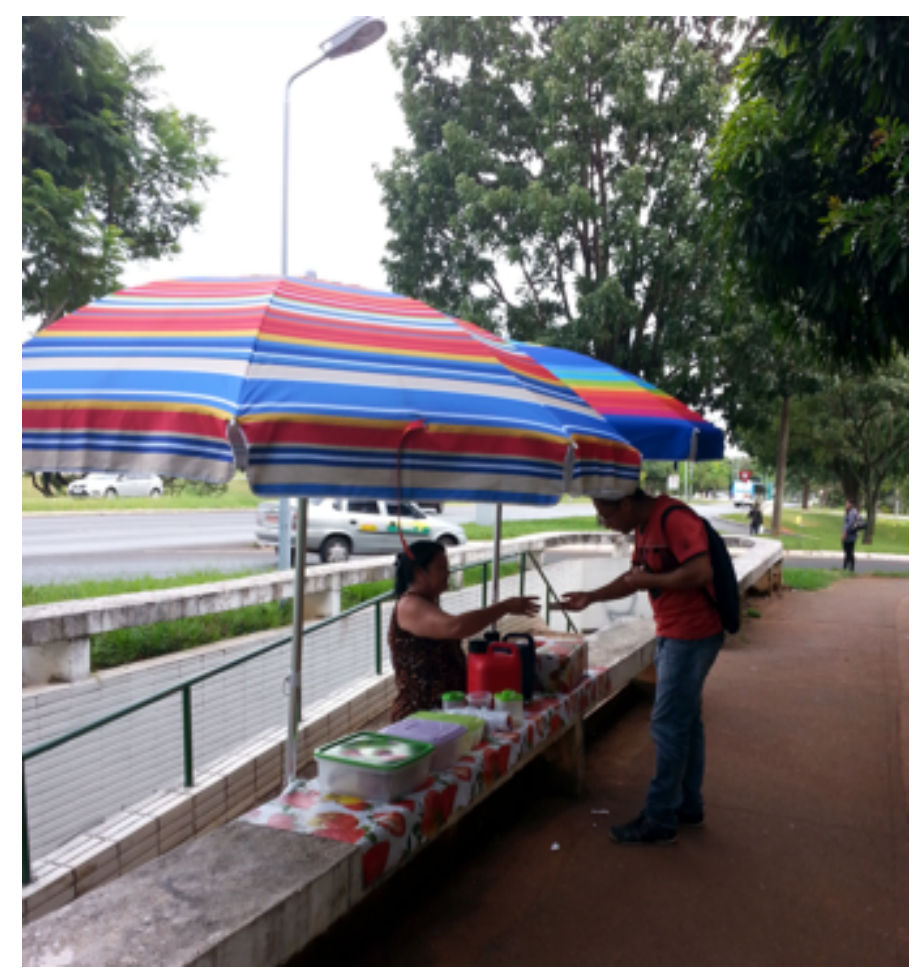

Figura 3.38 - imagens dos arredores do local do ponto de comércio referente à SQN 209 para ilustrar atividades ao redor. Fotos: autora.

Sistemas de encontros e esquivanças

15) Quantidade de pessoas - passagem e permanência

16) Variedade de pessoas na permanência

Ao contrário do que foi observado no ponto de comércio referente à SQN 408, neste ponto observou-se a predominância de mulheres permanecendo e consumindo. As Tabelas 3.4, 3.5 e 3.6 demonstram esta prevalência e a quase ausência de crianças: somente uma em cada dia de contagem. Poucos foram os adolescentes e jovens que permaneceram no ponto e não foi observada nenhuma pessoa com mais de 60 anos no local, durante as contagens no primeiro e no segundo dias. A concentração de pessoas nas faixas etárias de 20 a 30 e de 30 a 40 anos se explica pelo tipo de público que ali passa e frequenta. São trabalhadores pertencentes à classe baixa em sua maioria. 
Tabela 3.4 - Total pessoas - permanência $=57$ : total crianças $=1$; total homens $=23$; total mulheres $=33$. Total pessoas - passagem $=165$. Total pessoas $\left(\right.$ SQN 209) $-1^{\circ}$. dia $=222$

\begin{tabular}{|c|c|c|c|c|c|c|c|c|c|}
\hline \multirow{2}{*}{$\begin{array}{l}1^{\circ} . \text { dia } \\
\text { período }\end{array}$} & \multirow[t]{2}{*}{ passagem } & \multirow[t]{2}{*}{ gênero } & \multicolumn{6}{|c|}{ faixa etária } & \multirow{2}{*}{$\begin{array}{c}\text { total } \\
\text { gênero }\end{array}$} \\
\hline & & & $\mathrm{A} / \mathrm{J}$ & $20-30$ & $30-40$ & $40-50$ & $50-60$ & $>60$ & \\
\hline \multirow{2}{*}{$\begin{array}{c}1 \\
c=1\end{array}$} & \multirow[t]{2}{*}{42} & $\mathrm{H}$ & - & 2 & 6 & 2 & 1 & - & 11 \\
\hline & & $\mathrm{M}$ & - & 2 & 5 & 2 & 1 & - & 10 \\
\hline \multirow[t]{2}{*}{2} & \multirow[t]{2}{*}{52} & $\mathrm{H}$ & - & 3 & 1 & 1 & - & - & 5 \\
\hline & & $\mathrm{M}$ & - & 1 & 7 & - & 1 & - & 9 \\
\hline \multirow[t]{2}{*}{3} & \multirow[t]{2}{*}{29} & $\mathrm{H}$ & - & 1 & 3 & 1 & - & - & 5 \\
\hline & & $\mathrm{M}$ & - & - & 5 & 1 & 1 & - & 7 \\
\hline \multirow[t]{2}{*}{4} & \multirow[t]{2}{*}{42} & $\mathrm{H}$ & - & - & 2 & - & - & - & 2 \\
\hline & & $\mathrm{M}$ & - & 5 & 1 & 1 & - & - & 7 \\
\hline \multirow{3}{*}{ total } & \multirow{3}{*}{165} & $\mathrm{~T} / \mathrm{H}$ & - & 6 & 12 & 4 & 1 & - & 23 \\
\hline & & $\mathrm{T} / \mathrm{M}$ & - & 8 & 18 & 4 & 3 & - & 33 \\
\hline & & $\mathrm{T} / \mathrm{H}+\mathrm{M}$ & - & 14 & 30 & 8 & 4 & - & 56 \\
\hline
\end{tabular}

Tabela 3.5 - Total pessoas - permanência $=46$ : total crianças $=1$; total homens $=15$;

total mulheres $=30$. Total pessoas - passagem $=175$. Total pessoas $\left(\right.$ SQN 209) $-2^{\circ}$. dia $=221$

\begin{tabular}{|c|c|c|c|c|c|c|c|c|c|}
\hline \multirow{2}{*}{$\begin{array}{l}2^{\circ} . \text { dia } \\
\text { período }\end{array}$} & \multirow[t]{2}{*}{ passagem } & \multirow[t]{2}{*}{ gênero } & \multicolumn{6}{|c|}{ faixa etária } & \multirow{2}{*}{$\begin{array}{c}\text { total } \\
\text { gênero }\end{array}$} \\
\hline & & & $\mathrm{A} / \mathrm{J}$ & $20-30$ & $30-40$ & $40-50$ & $50-60$ & $>60$ & \\
\hline \multirow[t]{2}{*}{1} & \multirow[t]{2}{*}{41} & $\mathrm{H}$ & 1 & 2 & 1 & 2 & 1 & - & 7 \\
\hline & & $\mathrm{M}$ & - & 4 & 5 & 1 & - & - & 10 \\
\hline \multirow[t]{2}{*}{2} & \multirow[t]{2}{*}{46} & $\mathrm{H}$ & - & 3 & - & - & - & - & 3 \\
\hline & & $\mathrm{M}$ & - & 1 & 5 & 1 & - & - & 7 \\
\hline \multirow[t]{2}{*}{3} & \multirow[t]{2}{*}{74} & $\mathrm{H}$ & - & 3 & 1 & - & - & - & 4 \\
\hline & & $\mathrm{M}$ & - & 1 & 1 & 4 & - & - & 6 \\
\hline \multirow{2}{*}{$\begin{array}{c}4 \\
c=1\end{array}$} & \multirow[t]{2}{*}{14} & $\mathrm{H}$ & - & - & 1 & - & - & - & 1 \\
\hline & & $\mathrm{M}$ & - & 2 & 2 & 3 & - & - & 7 \\
\hline \multirow{3}{*}{ total } & \multirow{3}{*}{175} & $\mathrm{~T} / \mathrm{H}$ & 1 & 8 & 3 & 2 & 1 & - & 15 \\
\hline & & $\mathrm{T} / \mathrm{M}$ & - & 8 & 13 & 9 & - & - & 30 \\
\hline & & $\mathrm{T} / \mathrm{H}+\mathrm{M}$ & 1 & 16 & 16 & 11 & 1 & - & 45 \\
\hline
\end{tabular}

Tabela 3.6 - Total pessoas - permanência $=103$ : total crianças $=2$; total homens $=38$; total mulheres $=63$. Total pessoas - passagem $=340$. TOTAL PESSOAS - SQN $209=443$

\begin{tabular}{|c|c|c|c|c|c|c|c|c|c|}
\hline \multirow{6}{*}{$\begin{array}{c}1^{\circ} \cdot \text { dia } \\
+ \\
2^{\circ} \cdot \text { dia }\end{array}$} & \multirow[t]{2}{*}{ passagem } & \multirow[t]{2}{*}{ gênero } & \multicolumn{6}{|c|}{ faixa etária } & \multirow{2}{*}{$\begin{array}{c}\text { total } \\
\text { gênero }\end{array}$} \\
\hline & & & $\mathrm{A} / \mathrm{J}$ & $20-30$ & $30-40$ & $40-50$ & $50-60$ & $>60$ & \\
\hline & \multirow{4}{*}{340} & $\mathrm{~T} / \mathrm{H}$ & 1 & 14 & 15 & 6 & 2 & - & 38 \\
\hline & & $\mathrm{T} / \mathrm{M}$ & - & 16 & 31 & 13 & 3 & - & 63 \\
\hline & & $\mathrm{T} / \mathrm{H}+\mathrm{M}$ & 1 & 30 & 46 & 19 & 5 & & 101 \\
\hline & & criança & \multicolumn{7}{|c|}{2} \\
\hline
\end{tabular}

17) Distribuição de pessoas no tempo e no espaço

A simplicidade do arranjo do ponto referente à SQN 209 define e distingue claramente as partes da atividade. Como os artefatos para o café da manhã são dispostos sobre a mureta da passagem subterrânea, esta parte se estabelece como um divisor entre duas áreas: a rampa de acesso à passagem propriamente dita e a calçada adjacente à superquadra (Figura 3.39). 


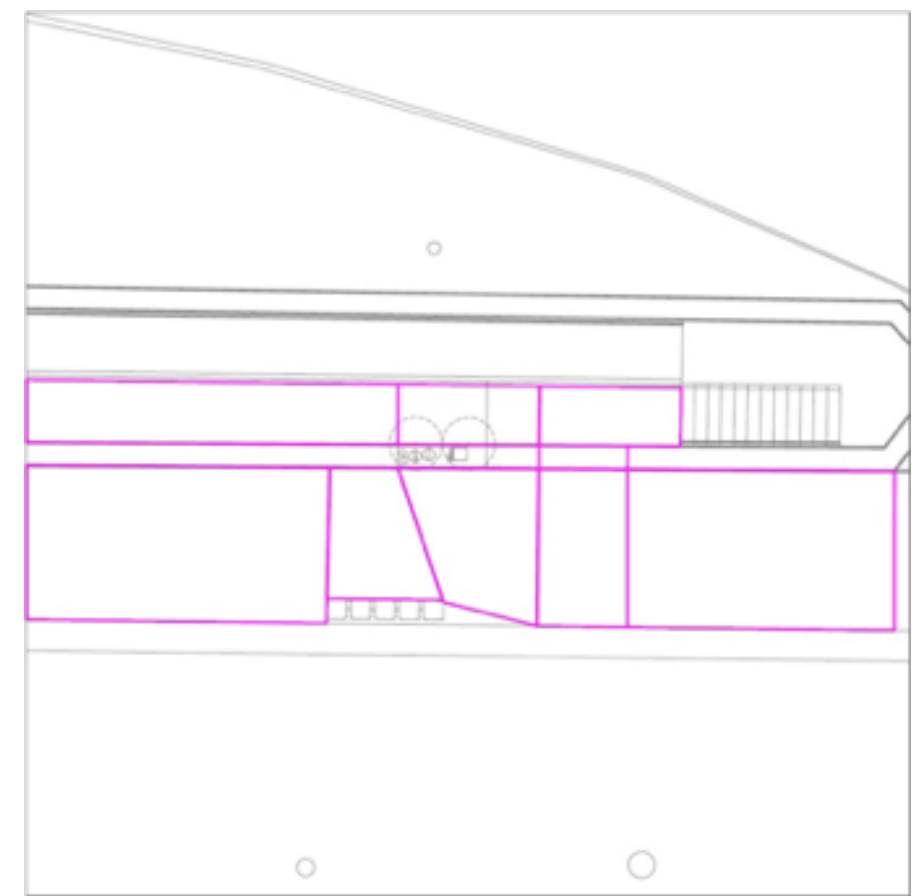

Figura 3.39 - mapa de espaço convexo determinado pelos elementos físicos com a arquitetura do ponto de comércio referente à SQN 209.

$\mathrm{Na}$ rampa ficam a comerciante e sua auxiliar. $\mathrm{Na}$ calçada ficam os clientes, que quando permanecem mais um pouco no local, utilizam a mureta como assento, de um lado ou de outro da toalha onde os artefatos estão dispostos. Porém, como pode ser visto na Figura 3.40 , outras pessoas permanecem na rampa com as comerciantes.

São pessoas conhecidas que, por causa da intimidade, permanecem "atrás do balcão com a dona do estabelecimento". É uma divisão social que é estabelecida pelo arranjo do ponto desta maneira. Foi verificado, também, que a passagem de pedestres pela rampa fica um pouco prejudicada com a presença das comerciantes ali, o que não acontece com a calçada por ser mais larga. A concentração de clientes próxima à mureta libera o restante da calçada, utilizada para quem vai para ou vem do ponto de ônibus próximo dali. 


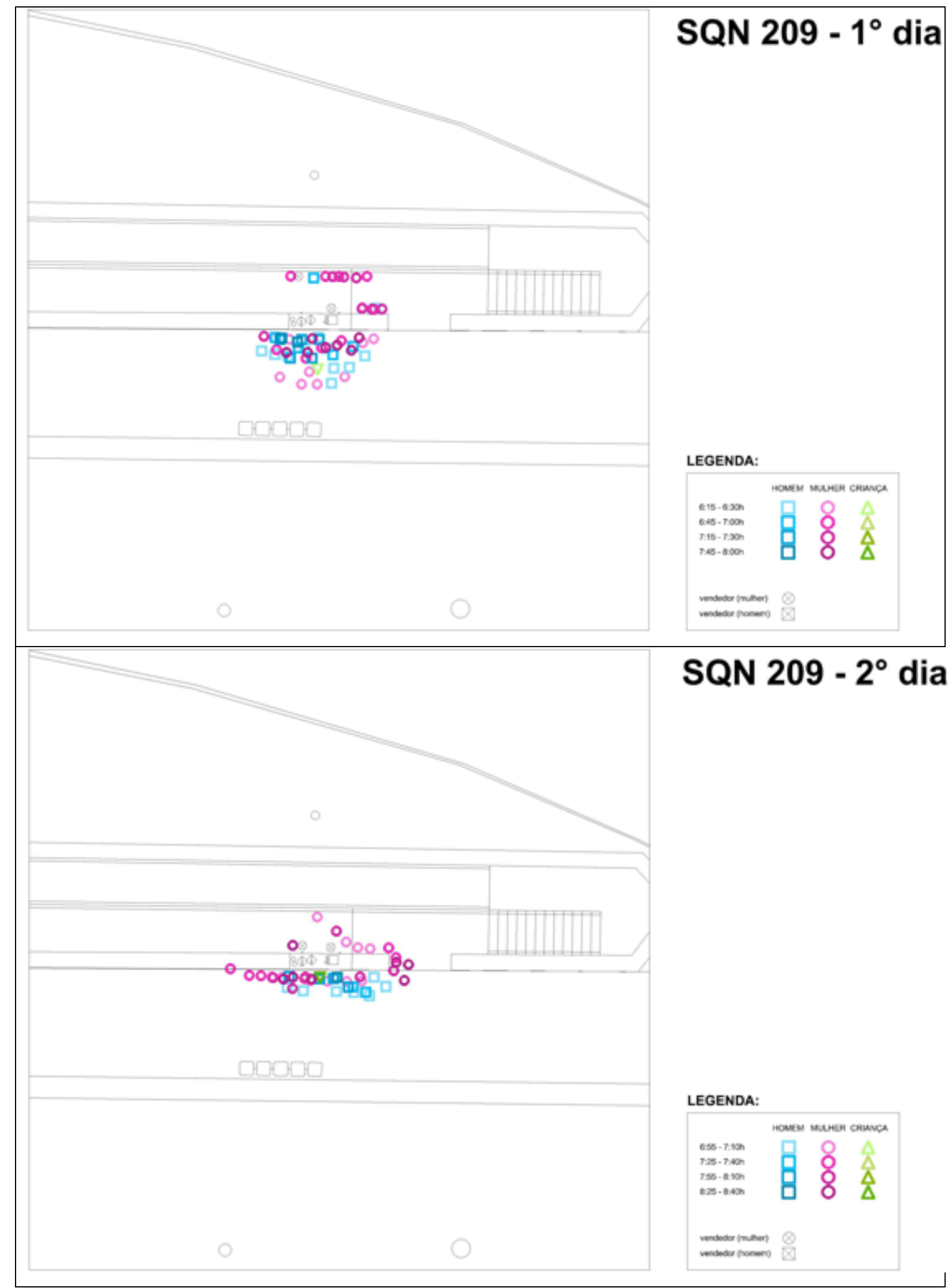

Figura 3.40 - mapas comportamentais sobre a distribuição de pessoas no ponto de comércio referente à SQN 209, nos dois dias observados. 
18) Complexidade

\section{Descrição}

Os elementos físicos envolvidos na atividade do ponto de comércio referente à SQN 209 (Figura 3.41) somam 8, a saber:

. elementos portados -2 toalhas de mesa, 2 garrafas térmicas de 5 litros cada, duas garrafas de 1 litro cada, vasilhames de tamanhos variados, 2 caixas de isopor pequenas, 2 guarda-chuvas grandes, lixeiras, bolsas grandes e pequenas;

. elementos do local - mureta, conjunto de lixeiras, 2 suportes (tubos de PVC) para guarda-chuvas.
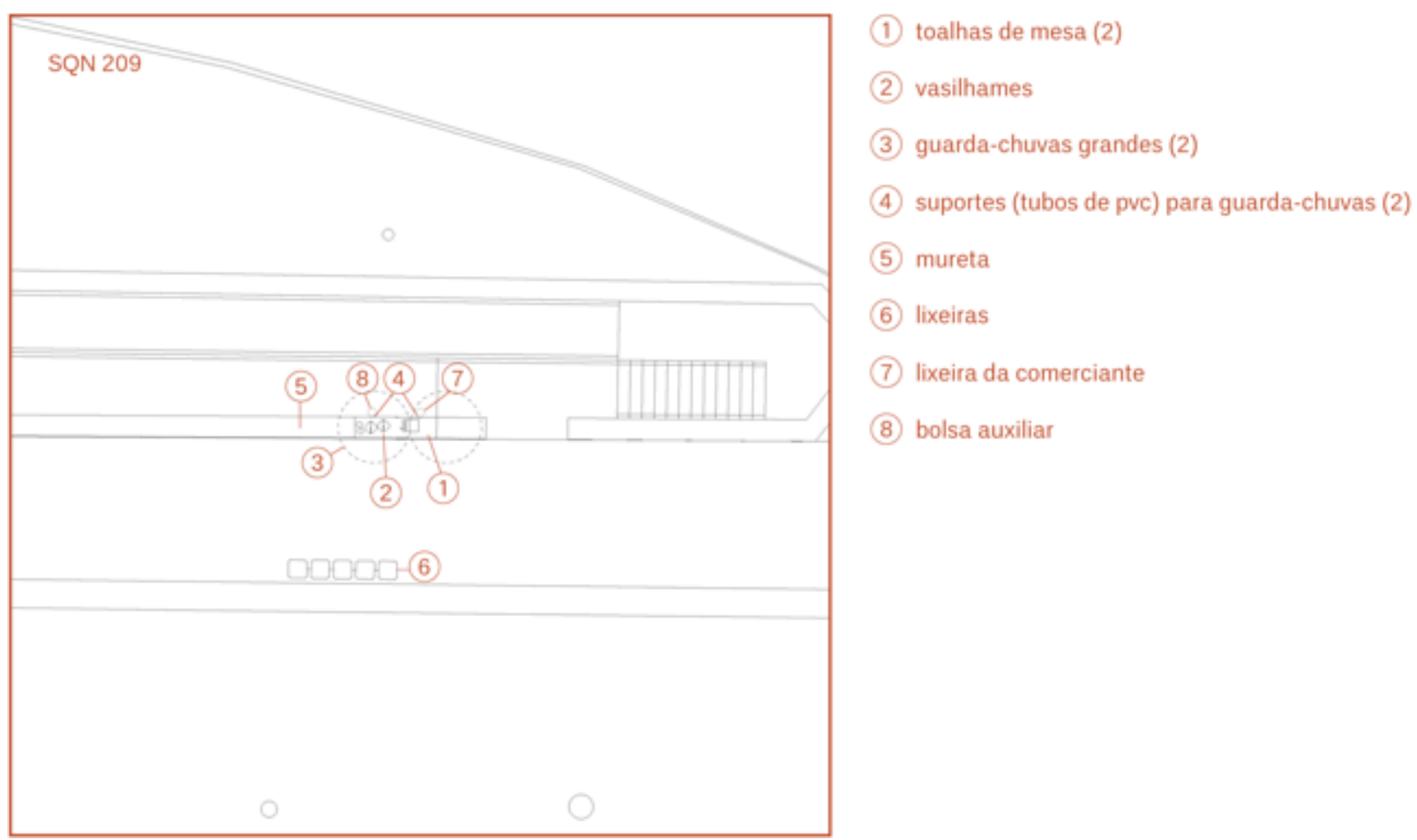

Figura 3.41 - planta baixa do ponto de comércio referente à SQN 209, com a especificação dos elementos físicos envolvidos na atividade.

Função dos elementos e suas relações

Os 8 elementos descritos estão envolvidos na atividade do comércio de produtos para café da manhã, preparados em casa pela comerciante, poucas horas antes de 
seu deslocamento para o local. A parte inicial (perto da entrada que dá acesso à passagem subterrânea) da mureta apropriada serve de suporte para a exposição dos produtos a serem vendidos, além de servir de assento. Essas duas funções ocorrem na parte superior da mureta, obviamente. Na parte vazada desta mureta com o piso, a comerciante guarda os vasilhames que esvaziam com o consumo (Figura 3.42-f). As lixeiras seletivas do local foram consideradas como elemento por serem utilizadas pelos clientes que permanecem na calçada enquanto consomem. Junto à comerciante, na mureta foram afixados dois tubos de PVC, com uma distância entre eles de 1,75m, para darem suporte a dois grandes guarda-chuvas, que só são utilizados para os dias de chuva mesmo, pois o local recebe sombra no período da manhã (Figura 3.42-c). Pendurados nestes tubos de PVC, ficam, de um lado, um saco plástico reutilizado como lixeira para a comerciante e, do outro, uma bolsa pequena auxiliar que guarda embalagens para acondicionar os produtos vendidos para viagem (Figura 3.42-d). As toalhas de mesa são sempre duas, colocadas lado a lado, para cobrir uma área suficiente que isole os vasilhames da superfície da mureta. Todos os vasilhames e embalagens colocados sobre as toalhas acondicionam os produtos/alimentos e acessórios para o café da manhã.

Com exceção das lixeiras seletivas, todos os elementos estão concentrados na parte da mureta apropriada. As relações entre eles são diretas, ou mesmo imbricadas. Os espaços que delimitam estão somente ao redor desta concentração. Todas as ações acontecem, então, na calçada, na rampa de passagem, ou nas pontas contiguas às toalhas de mesa colocadas.

19) Aspectos funcionais - relações entre elementos físicos e as práticas

Dona Aparecida relatou que acorda, de segunda à sexta, às 4 h00 da manhã, para preparar todos os itens que chegam completamente prontos ao local da venda. Acondiciona todas as bebidas (café puro, café com leite e dois tipos de suco) em garrafas térmicas de 1 e 5 litros. Os salgados e bolos de sabores variados, são transportados em vasilhames de plástico bem tampados (Figura 3.42-e). Todas estas embalagens são colocadas em bolsas grandes com zíper, juntamente com o material que dá suporte à atividade, que vão e voltam com ela para casa, ou de carro (táxi do filho), ou de ônibus (Figura 3.42-a). 
Ao chegar no local, verifica se está em condição de uso quanto à limpeza. Se não está, ela pega uma vassoura emprestada, com a zeladoria do bloco I da SQN 209, para então, começa a montar o ponto. Quando/depois de limpos o chão e a mureta, ela começa a organizar os elementos, estendendo as toalhas de vinil na mureta da passagem subterrânea. Em seguida, dispõe todos os vasilhames, garrafas e itens como guardanapo, açucareiro etc. (Figura 3.42-b). Mal termina de organizar o local, as vendas já se iniciam, pois os clientes passam cedo para tomar o café e logo ir para o trabalho.

Clientes na calçada e comerciante e ajudante na rampa da passagem, a atividade se desenvolve até os produtos acabarem. Os clientes não se servem neste ponto. Eles fazem o pedido, a comerciante serve e a ajudante recebe o pagamento.
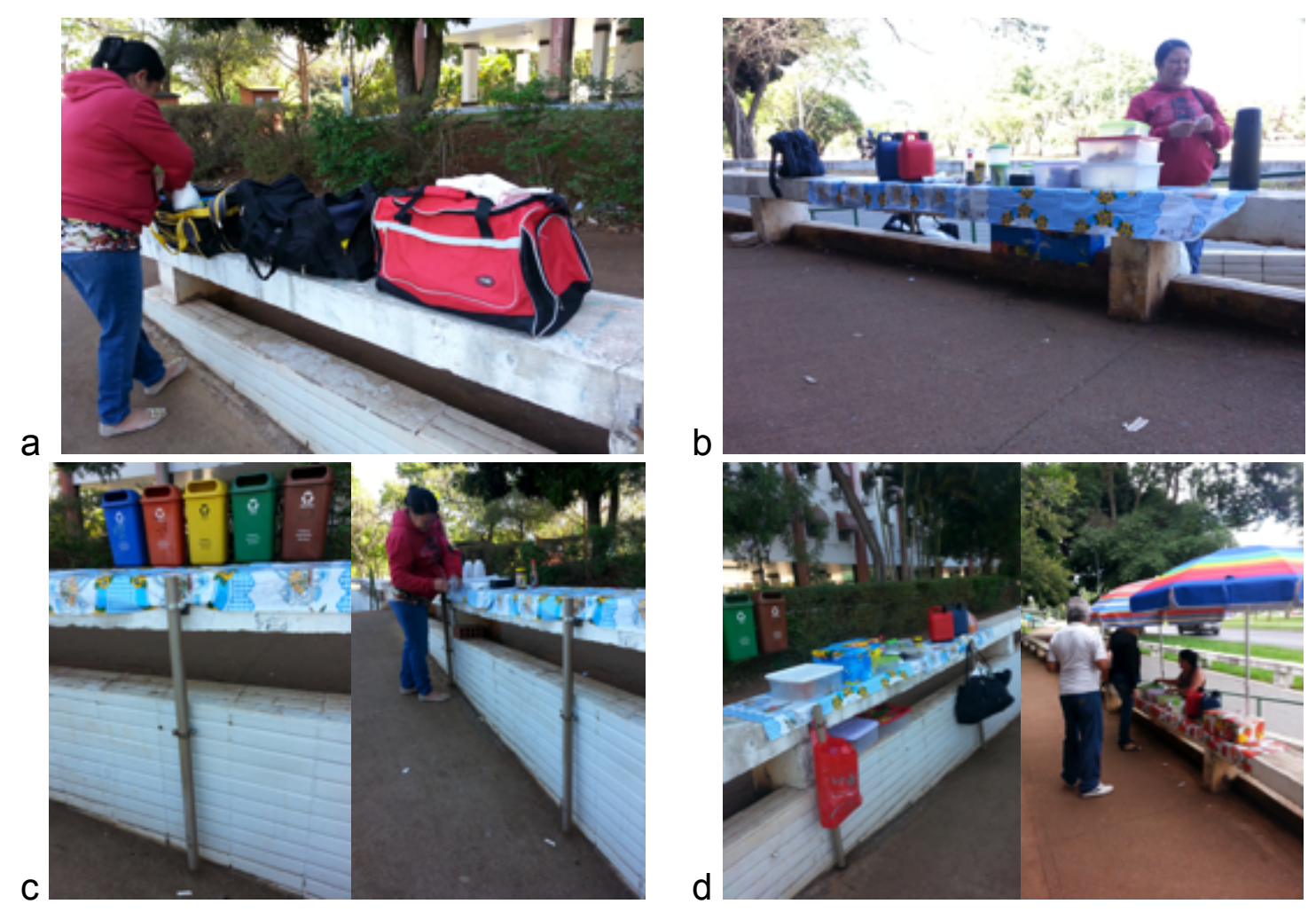


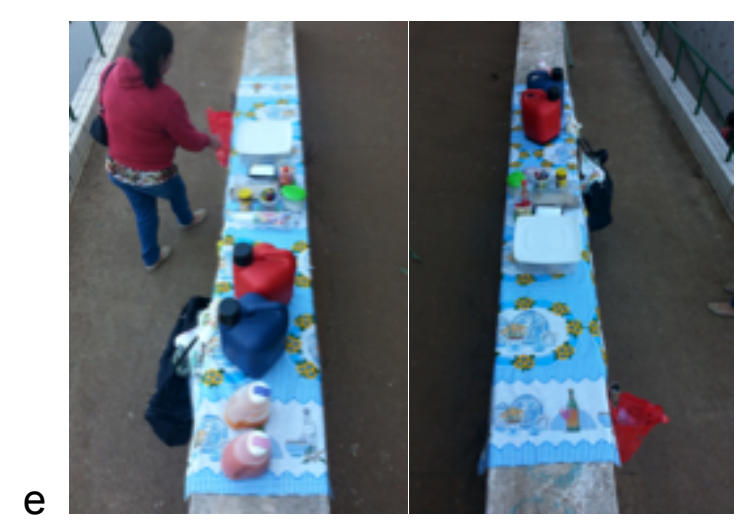

Figura 3.42 - imagens dos elementos físicos na atividade do ponto de comércio referente à SQN 209. Fotos: autora.

\subsubsection{Análise do ponto como um sistema - SQN 209}

\section{Padrões Espaciais + Características Socioeconômicas}

Neste caso, as características sociais da comerciante e de seus clientes, conferem com um perfil de escolha por lugares que reúnem atributos propícios à copresença e movimento de pessoas, assim como no estudo de caso relacionado à SQN 408. O espaço do contexto imediato ao ponto de comércio referente à SQN 209, possui aspectos de ambiência física alta; alto grau de acessibilidade ao movimento motorizado; potencial baixo de acessibilidade ao pedestre, porém com realidade contrária a essa medição pela localização do ponto próximo à entrada/saída de passagem subterrânea, o que confere um grau mais alto de acessibilidade ao pedestre na área do ponto; conexão visual acima da média em relação ao seu contexto e mediana dentro da área do ponto; campo visual, ou isovistas, com medidas altas de área e compacidade; condições medianas para permanência, mas condizentes com o tempo que os clientes ficam no ponto e nenhuma outra atividade que atrai pessoas além do próprio ponto, que é compensado pelo fluxo de pessoas que a passagem subterrânea acarreta.

\section{Padrões Espaciais + Sistema de Encontros e Esquivanças}

O potencial da configuração do contexto imediato deste ponto representado pelos atributos resumidos acima, é revelado pela observação e contabilização das pessoas que nele permaneceram e por ele passaram. O número dos passantes foi maior do que o dos que permaneceram, devido à proximidade com a passagem 
subterrânea. Porém, o número dos que permaneceram (103 nos dois dias de contagem) foi razoável para o período de tempo e o turno em que o ponto funciona.

\section{Padrões Espaciais + Sistema de Elementos Físicos}

Os valores altos de algumas variáveis dos padrões espaciais do contexto deste ponto de comércio não o beneficiam de maneira significativa. A acessibilidade por motorizados é alta, porém para o consumo neste ponto este dado não faz muita diferença, pois de modo geral seu público é outro e para o motorizado estacionar para consumir teria que fazê-lo um pouco distante dali e ir caminhando até o ponto. O potencial para movimento de pedestre é baixo na medição da axialidade do contexto, mas alto na área da atividade. A ambiência física é uma dos aspectos que acredito beneficiar o ponto que é muito celular. Os outros atributos não beneficiam de maneira significativa o ponto. O sistema de elementos físicos é bem concentrado, integrado à arquitetura e simples (Figura 3.43).

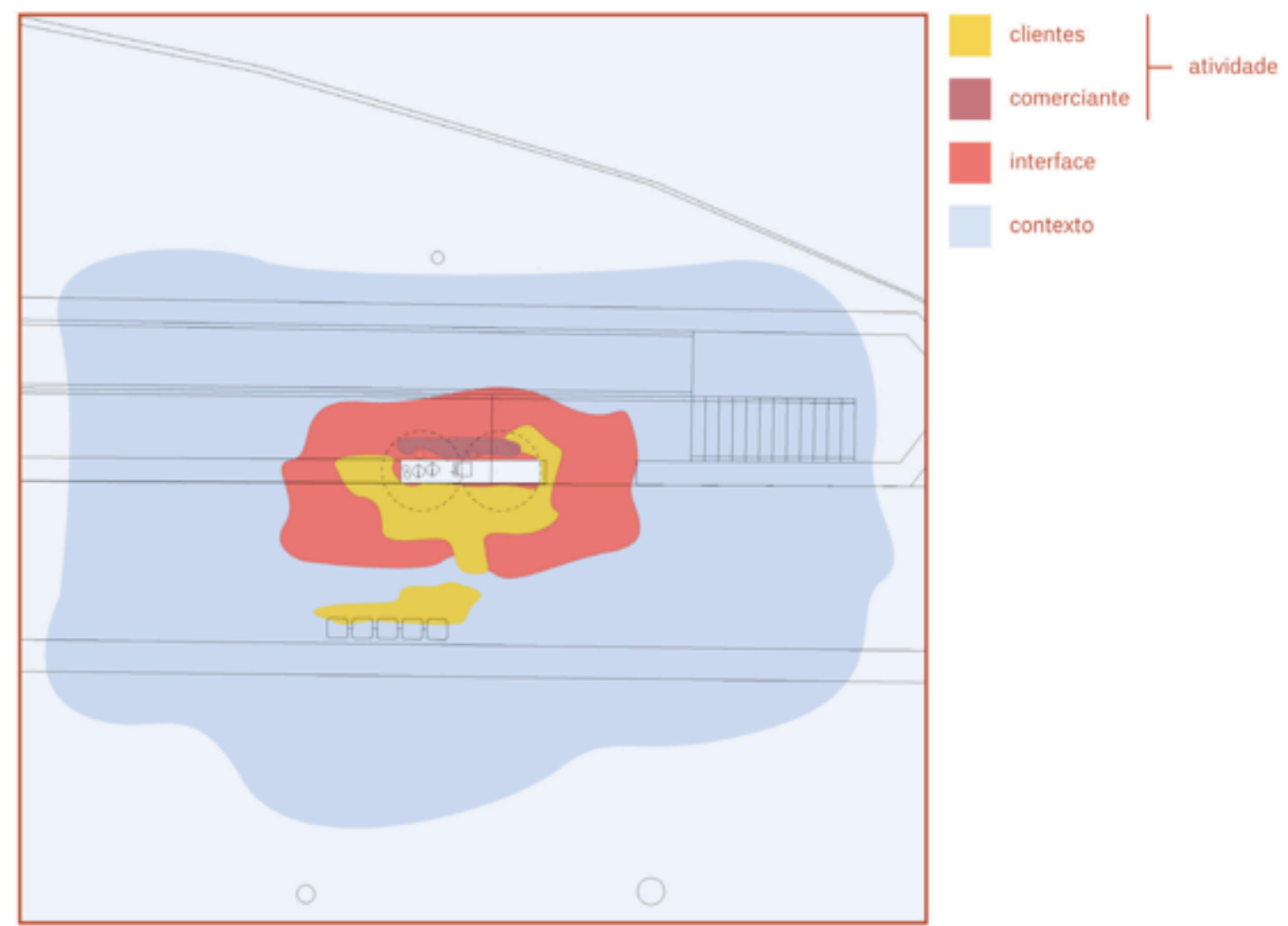

Figura 3.43 - planta baixa do ponto de comércio referente à SQN 209 com identificação dos espaços da atividade (clientes e comerciante), da interface (passantes) e do contexto. 
Delimita duas áreas retangulares pelo uso da mureta como "balcão de atendimento". O campo visual de quem está no ponto é muito maior com uma área em que só passam automóveis em alta velocidade. A conexão visual é mais importante na extensão da calçada dos dois lados. Acredito que o ponto se beneficia mais pela proximidade com a passagem subterrânea do que pela configuração do lugar apropriado pela comerciante.

\section{Sistema de Elementos Físicos + Características Socioeconômicas}

O aproveitamento máximo do local apropriado, isto é, poucos elementos portados e a simplicidade do arranjo condizem com o perfil socioeconômico tanto da comerciante, quanto de seus clientes. Ela conta com a mureta como balcão e assento, a sombra do bloco I da superquadra, o conjunto de lixeiras seletivas e até com a vassoura da zeladoria do bloco ao lado. Transporta o necessário para o ponto de comércio e não tem estoque, pois quando os produtos acabam ela vai embora. $O$ sistema de elementos físicos deste ponto em sua baixa complexidade de composição e funcionamento representa as classes sociais envolvidas.

\section{Sistema de Elementos Físicos + Sistema de Encontros e Esquivanças}

Por ser bastante concentrado o sistema de elementos principais envolvidos na atividade deste ponto acarreta em um comportamento ao seu redor também concentrado e definido. A definição se dá pela mureta, que pode ser considerada o principal elemento físico. Ela divide o espaço em duas áreas distintas: a do comerciante e a dos clientes. Com esta composição o ponto não deixa de ser um atrator do local. Sua concisão traduz a objetividade dos encontros que ocorrem ali.

\section{Características Socioeconômicas + Sistema de Encontros e Esquivanças}

Pode-se dizer que um dos aspectos de atratividade deste ponto está em sua simplicidade que é traço das classes sociais envolvidas. O comportamento das pessoas ao seu redor acompanha esta simplicidade ao mesmo tempo formal. 
Além de seguir os critérios de escolha dos pontos de comércio para observação, apresentados no início deste capítulo, este ponto foi escolhido por estar inserido em uma das quadras analisadas no trabalho de campo desenvolvido para a dissertação de Ribeiro (2013). Comparo algumas informações entre as duas pesquisas, corroborando algumas e refutando outras. Seguem a identificação, a apresentação nas categorias analíticas e a análise deste ponto como um sistema.

\subsubsection{Identificação - SQN 113}

A categoria interior de superquadra (Figura 3.44) é representada pelo ponto de comércio relacionado à superquadra norte 113. A especialidade deste ponto é o preparo na hora e venda de tapioca, em tamanhos e sabores de recheio variados. $O$ funcionamento deste ponto acontece de quinta-feira a sábado, no horário de 18 h00 às 23 h00 (Figura 3.45).

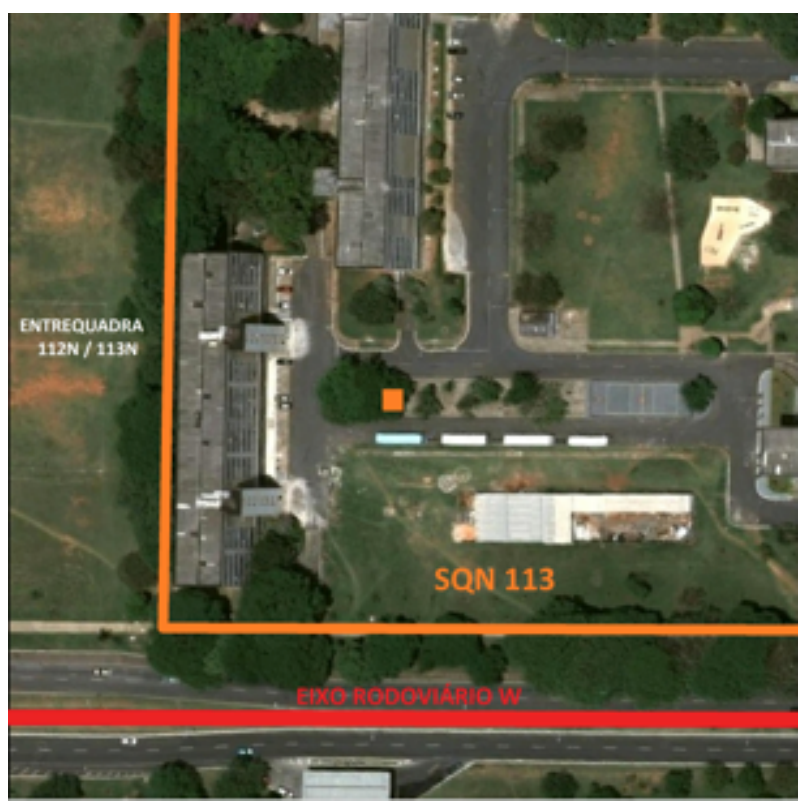

Figura 3.44 - vista aérea do ponto em relação a quadra residencial mais próxima (SQN 113). Fonte: adaptado do Google Earth. 

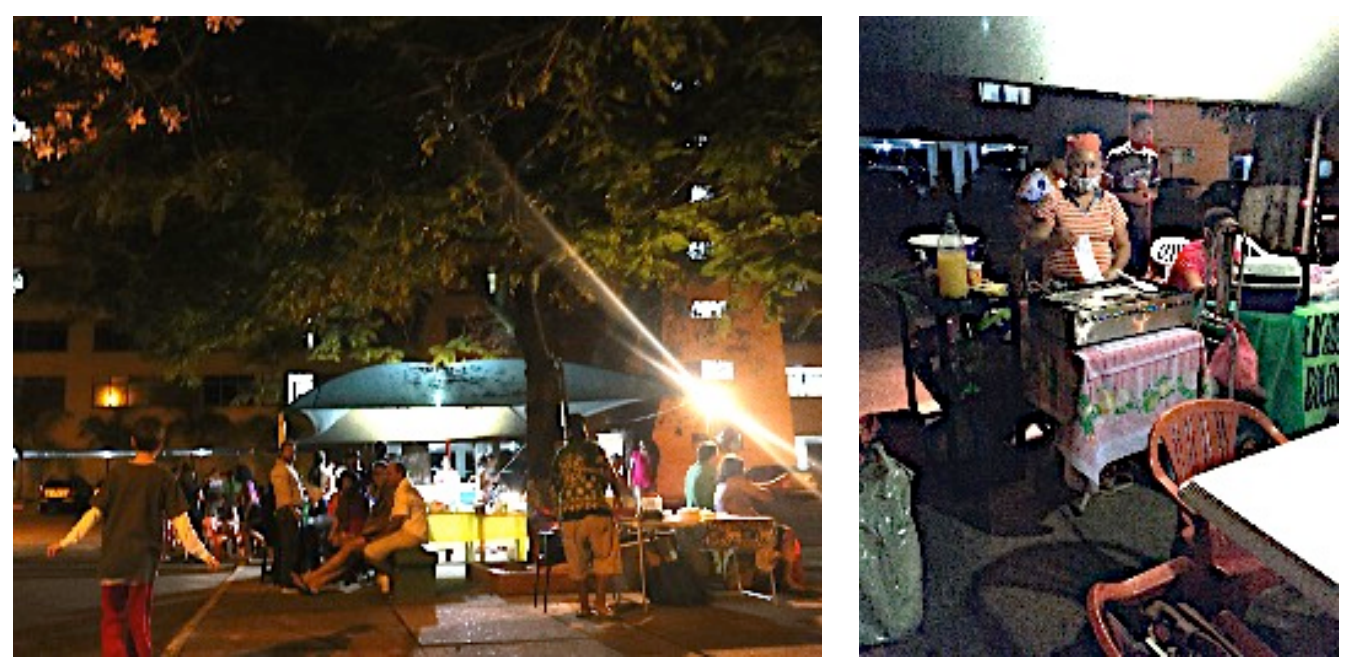

Figura 3.45 - identificação do ponto de comércio relacionado à SQN 113. Fotos: Maya Macario (esquerda); autora (direita).

\subsubsection{Categorias analíticas - SQN 113}

\section{Características socioeconômicas}

1) Apresentação geral: gênero; faixa etária, naturalidade e grau de instrução.

2) Local de moradia e modo de deslocamento.

3) A atividade é a única ocupação remunerada? Dias da semana de que se ocupa com a atividade.

4) Renda mensal adquirida pela atividade.

5) Razão da escolha por este local para o ponto de comércio.

6) Quem é o seu público/cliente?

7) Dados censitários sobre renda dos moradores.

Natural de Fortaleza, Solange reside na própria superquadra norte 113, há quase quatro anos. Ela tem entre 40 e 50 anos e o ensino médio completo. A renda mensal obtida com a venda de tapioca não foi informada. Na maioria das vezes seu filho adolescente a acompanha para ajudá-la com o transporte dos elementos para a atividade, no seu deslocamento a pé. No momento em que foi entrevistada, só tinha o comércio de tapioca como fonte de renda individual. Comentou que trabalhava em "outra coisa", antes, concomitantemente ao comércio no interior de sua quadra.

Ela começou a preparar e vender tapioca na quadra em que mora, desde que se mudou para lá. Porém, ocupava um lugar diferente do que está hoje: em frente ao 
seu bloco. Logo percebeu que o local era muito apertado para receber a quantidade de pessoas que viraram seus clientes. Mudou-se, então, para uma "praça" no interior da quadra, um lugar mais amplo, porém um pouco afastado do bloco onde mora.

Logo, outras moradoras começaram, também, a preparar e vender itens para lanche (salgados, doces, batata frita, pastel etc.) junto com Solange, no local que com o tempo foi sendo incrementado pela prefeitura da superquadra para receber estas e outras atividades. Por meio deste ponto, ela já conseguiu encomendas para preparar tapiocas para café da manhã em eventos de empresas em que seus clientes trabalham.

Segundo a comerciante, a maior parte do seu público é formada por moradores da própria quadra e das quadras vizinhas. Pessoas de outros lugares do Plano Piloto ali frequentam, convidados pelos moradores, mas não é o público mais significativo. Essa frequência aumenta quando essas mulheres que vendem lanche na própria quadra, como Solange, organizam no início de cada mês, uma feira gastronômica e de artesanato, no mesmo lugar em que Solange tem o seu ponto de comércio. $O$ depoimento de Solange foi corroborado com as observações nesse sentido. Foram feitas visitas em dias com e sem a feira. Além da observação, em conversa com alguns clientes, percebi que eles eram assíduos tanto no consumo da tapioca da Sol, cotidianamente, quanto nas visitas e consumo nos eventos, as feiras do início de mês.

A classe social significativamente predominante dos moradores e clientes do ponto de comércio observado no interior da superquadra norte 113 é a média, de acordo com os dados censitários referentes (Figura 3.46). Essa superquadra tem a particularidade funcional de reunir militares como residentes. 


\section{SQN 113}

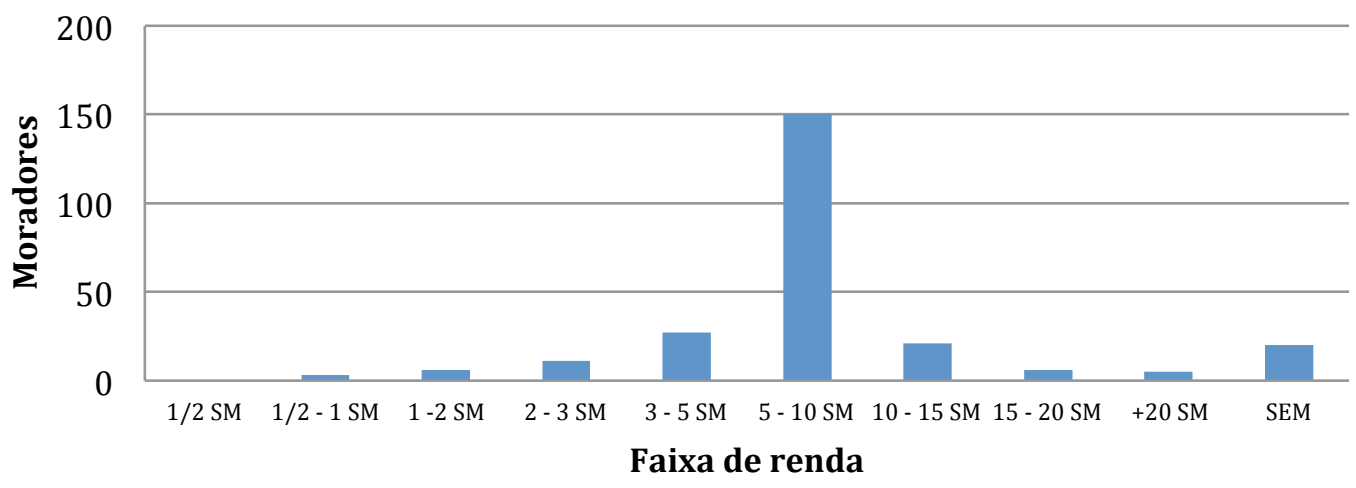

Figura 3.46 - gráfico sobre a renda, por número de salários mínimos, dos responsáveis por domicílios, da superquadra norte 113, na amostragem dos dados censitários do IBGE, de 2010.

\section{Padrões espaciais}

08) Espaço convexo que abarca o ponto - ambiência física para e a partir do ponto

Os espaços convexos do contexto imediato ao ponto de comércio referente a SQN 113 somam 13. Suas áreas, da maior para a menor, são: 10724, 5838, 5450, 5028, 2420, 2240, 1000, 798, 743, 633, 575, 215 e 110. Assim como no caso do ponto de comércio referente à SQN 408, o ponto de comércio no interior da SQN 113 está inserido no maior espaço dos relacionados: $10.724 \mathrm{~m} 2$.

O local apropriado para a atividade fica em uma espécie de praça no interior da superquadra, em um espaço convexo formado por poucos elementos tridimensionais e muito espaçados entre eles. O desenho da praça e a localização do ponto em uma de suas extremidades marcam mais o recinto para o ponto do que a sua localização em relação ao espaço convexo em que está inserido. A medida de área alta, a baixa clareza dos elementos tridimensionais delimitadores e a posição do ponto em relação aos limites do espaço convexo apontam uma baixa ambiência física para o ponto de comércio no interior da SQN 113 (Figura 3.47). 


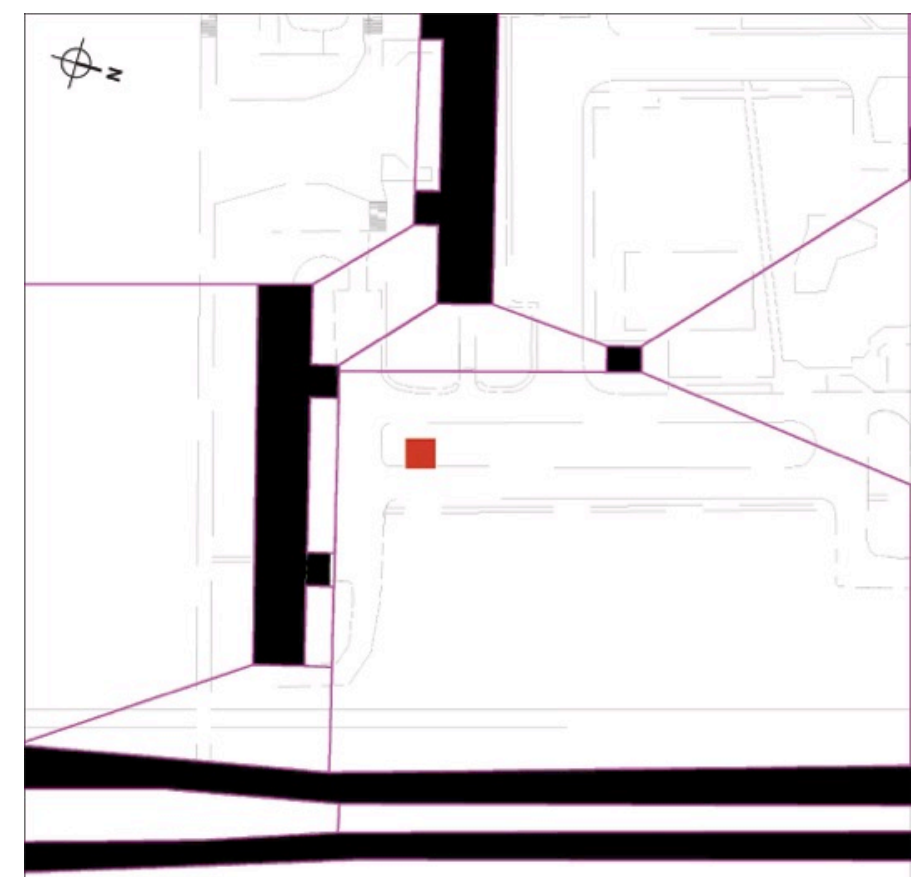

Figura 3.47 - mapa (200m) dos espaços convexos do contexto imediato do ponto referente à SQN 113 e de sua inserção em um destes espaços.

09) Acessibilidade ao movimento de veículos

O nível de integração do ponto de comércio localizado no interior da superquadra norte 113 é de 0,707 . Situada entre os níveis de integração mínima e média do Plano Piloto - de 0,349 e 0,847, respectivamente - este valor é considerado baixo, no que se refere à acessibilidade ao movimento de veículos no Plano Piloto (Figura 3.48). A localização no interior da quadra coloca este ponto de comércio em situação de alta profundidade no sistema "em árvore", da configuração da região residencial do Plano Piloto (Figura 3.87).

\begin{tabular}{|c|c|c|c|}
\hline $\begin{array}{c}\text { Integração máxima no } \\
\text { Plano Piloto }\end{array}$ & $\begin{array}{c}\text { Integração média no } \\
\text { Plano Piloto }\end{array}$ & $\begin{array}{c}\text { Integração mínima no } \\
\text { Plano Piloto }\end{array}$ & $\begin{array}{c}\text { Integração do ponto } \\
\text { SQN 113 }\end{array}$ \\
\hline 1,379 & 0,847 & 0,349 & 0,707 \\
\hline
\end{tabular}

Figura 3.48 - quadro comparativo entre as medidas de integração máxima, média e mínima do Plano Piloto e da localização do ponto de comércio associado ao comércio local da SQN 113, no que se refere à acessibilidade ao movimento de veículos.

10) Acessibilidade ao movimento do pedestre

A integração do ponto de comércio referente à SQN 113 mede 13,31 e é considerada alta, por estar próxima à medida de integração máxima da área do 
contexto, que é de 17, 30 (Figura 3.49). Esta medida se deve às linhas bem integradas que cruzam o interior da quadra, passando pelo ponto em questão, em direção, provavelmente, a pontos de ônibus localizados ao longo do eixo ERW Norte (Figura 3.50).

\begin{tabular}{|c|c|c|c|}
\hline $\begin{array}{c}\text { Integração máxima no } \\
\text { contexto imediato }\end{array}$ & $\begin{array}{c}\text { Integração média no } \\
\text { contexto imediato }\end{array}$ & $\begin{array}{c}\text { Integração mínima no } \\
\text { contexto imediato }\end{array}$ & $\begin{array}{c}\text { Integração do ponto } \\
\text { SQN 113 }\end{array}$ \\
\hline 17,30 & 8,63 & 3,20 & 13,31 \\
\hline
\end{tabular}

Figura 3.49 - quadro comparativo entre as medidas de integração máxima, média e mínima do contexto imediato (área quadrada ao redor do ponto com $200 \mathrm{~m}$ de lado) e da localização do ponto de comércio referente à SQN 113, no que se refere à acessibilidade ao movimento de pedestres.
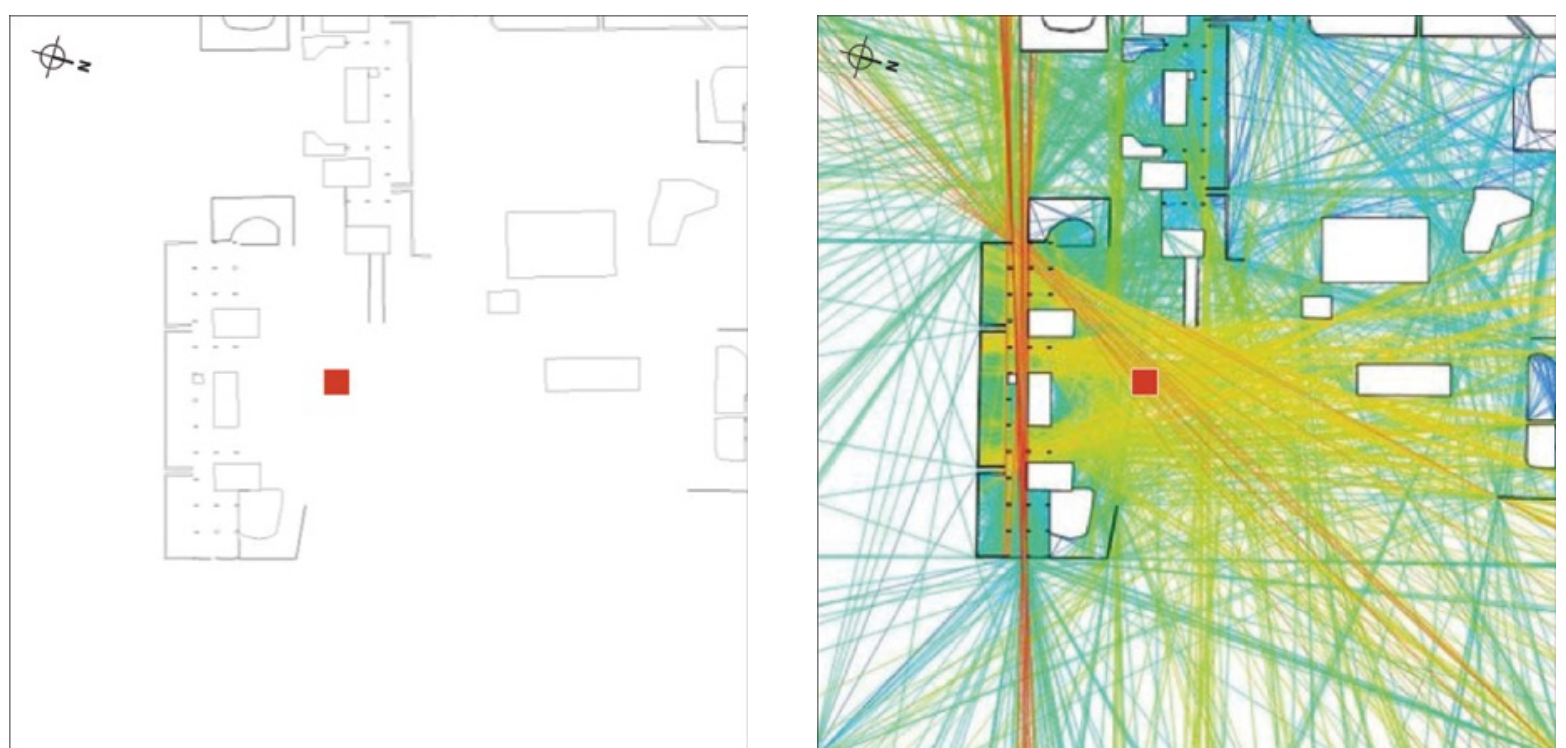

Figura 3.50 - mapas de barreiras e permeabilidades ao movimento (gerador)

(à esquerda) e de axialidade (à direita) para o ponto - SQN 113.

De acordo com o arranjo do mobiliário integrado ao que já é oferecido no lugar em termos de elementos físicos (bancos de alvenaria e canteiros), a acessibilidade ao movimento de pessoas se dá de modo mediano, com a medida de integração de 12,27, próxima à média da área restrita à atividade que mede 11,12 (Figura 3.51). Alguns poucos feixes bem integrados e concentrados passam pelo interior da composição de elementos físicos que, praticamente, cerca todo o seu centro (Figura 3.52).

\begin{tabular}{|c|c|c|c|}
\hline $\begin{array}{l}\text { Integração máxima na } \\
\text { área da atividade }\end{array}$ & $\begin{array}{l}\text { Integração média na } \\
\text { área da atividade }\end{array}$ & $\begin{array}{l}\text { Integração mínima na } \\
\text { área da atividade }\end{array}$ & $\begin{array}{l}\text { Integração do ponto } \\
\text { central }- \text { SQN 113 }\end{array}$ \\
\hline 27,94 & 11,12 & 5,85 & 12,27 \\
\hline
\end{tabular}

Figura 3.51 - quadro comparativo entre as medidas de integração máxima, média e mínima da área do ponto de comércio (área quadrada ao redor do ponto com $20 \mathrm{~m}$ de lado) referente à SQN 113 e do seu ponto central, no que se refere à acessibilidade ao movimento de pedestres. 


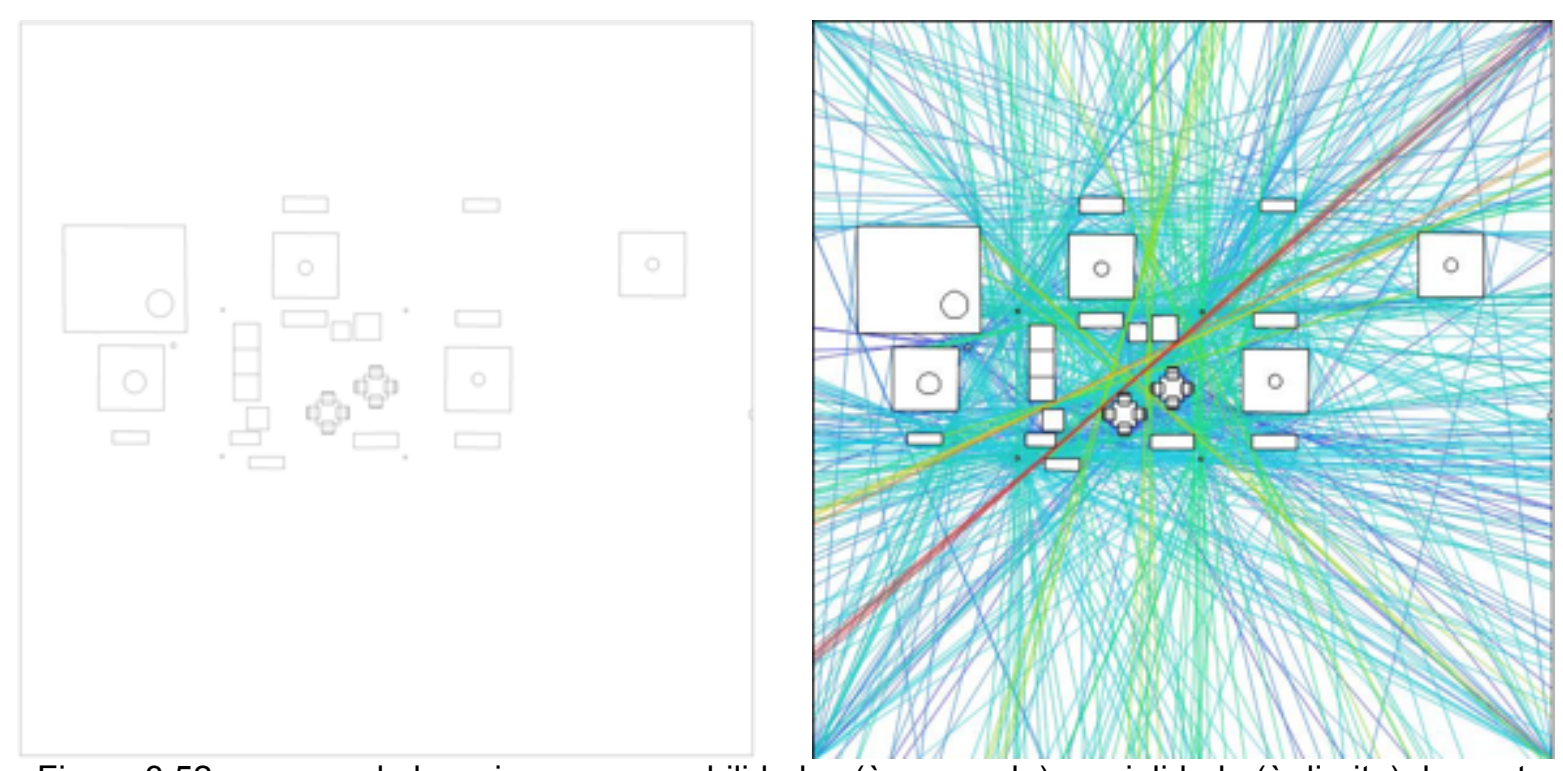

Figura 3.52 - mapas de barreiras e permeabilidades (à esquerda) e axialidade (à direita) do ponto de comércio referente à SQN 113 (máscara quadrada de $20 \mathrm{~m}$ de lado ao redor do ponto).

11) Acessibilidade à visão - conexão visual

No espaço interno da SQN 113 em que se encontra o ponto de comércio estudado as barreiras à visão são troncos de árvores que não interferem de maneira significativa neste sentido. A medida de visibilidade do ponto em questão é de 45,43 e é considerado mediano por estar entre as medidas média $(37,31)$ e alta $(68,47)$ do contexto (Figura 3.53). No mapa de visibilidade, a região que abarca o ponto tem coloração de verde escuro a verde claro, confirmando o valor (Figura 3.54).

\begin{tabular}{|c|c|c|c|}
\hline $\begin{array}{l}\text { Integração visual } \\
\text { máxima no contexto }\end{array}$ & $\begin{array}{l}\text { Integração visual } \\
\text { média no contexto }\end{array}$ & $\begin{array}{l}\text { Integração visual } \\
\text { mínima no contexto }\end{array}$ & $\begin{array}{l}\text { Integração visual no } \\
\text { ponto - SQN 113 }\end{array}$ \\
\hline 68,47 & 37,31 & 2,88 & 45,43 \\
\hline
\end{tabular}

Figura 3.53 - quadro comparativo entre as medidas de integração visual máxima, média e mínima no contexto imediato (área quadrada ao redor do ponto com $200 \mathrm{~m}$ de lado) e da localização do ponto de comércio referente à SQN 113, no que se refere à acessibilidade à visão. 


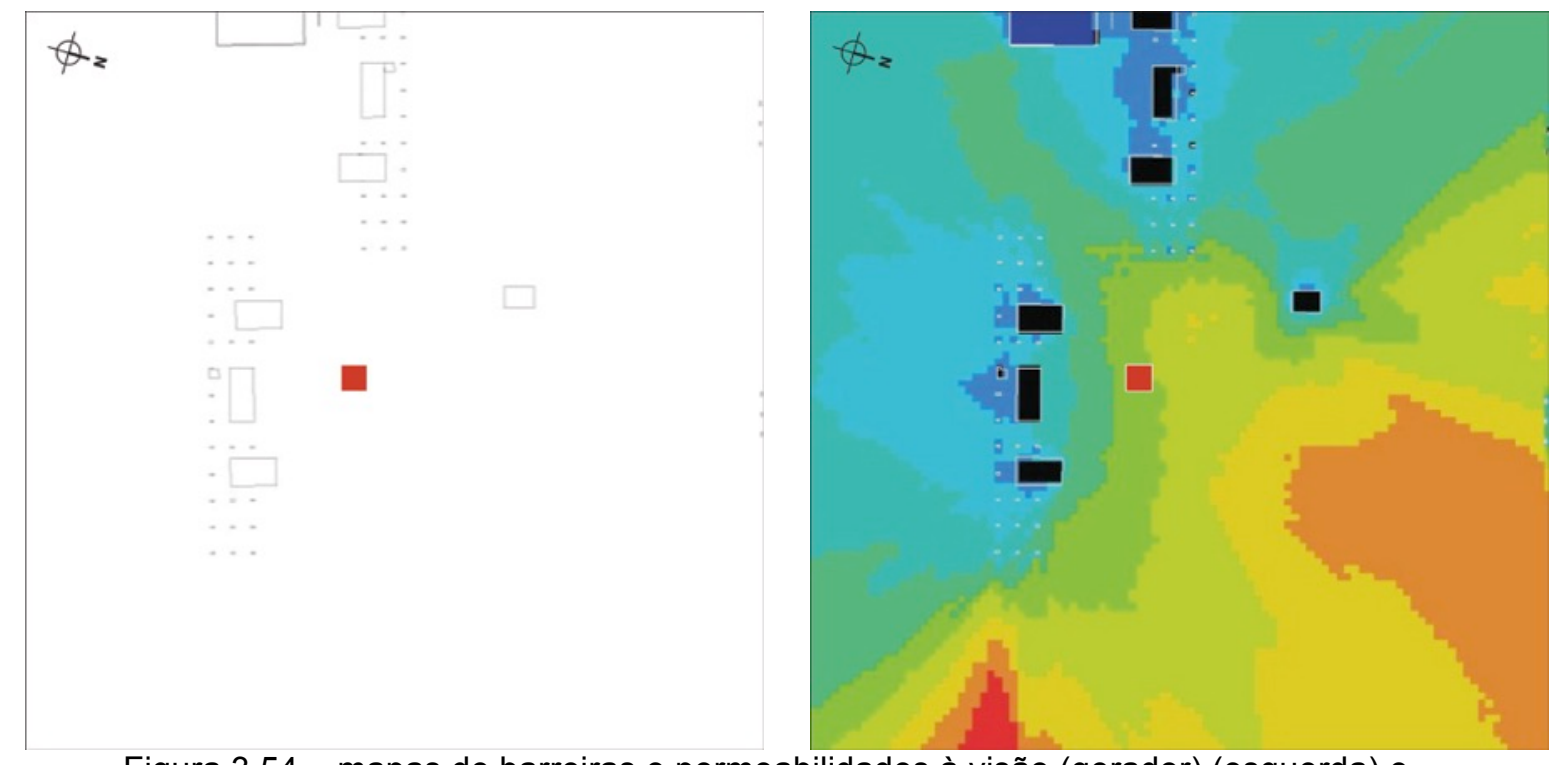

Figura 3.54 - mapas de barreiras e permeabilidades à visão (gerador) (esquerda) e de visibilidade (direita) para o ponto - SQN 113.

Dos elementos físicos e apropriados pela comerciante, nenhum apresenta barreira à visão do centro da área em que a composição está montada. A medida de visibilidade deste centro é de 151,53, considerada alta por estar entre as medidas alta $(195,74)$ e média $(124,13)$ desta área (Figura 3.55) e pela coloração amarelada indicada no mapa de visibilidade desta área (Figura 3.56).

\begin{tabular}{|c|c|c|c|}
\hline $\begin{array}{c}\text { Integração visual } \\
\text { máxima na área da } \\
\text { atividade }\end{array}$ & $\begin{array}{c}\text { Integração visual } \\
\text { média na área da } \\
\text { atividade }\end{array}$ & $\begin{array}{c}\text { Integração visual } \\
\text { mínima na área da } \\
\text { atividade }\end{array}$ & $\begin{array}{c}\text { Integração visual no } \\
\text { ponto central }- \text { SQN } \\
113\end{array}$ \\
\hline 195,74 & 124,13 & 10,91 & 151,53 \\
\hline
\end{tabular}

Figura 3.55 - quadro comparativo entre as medidas de integração visual máxima, média e mínima na área do ponto de comércio (área quadrada ao redor do ponto com 20m de lado) referente à SQN 113 e do seu ponto central, no que se refere à acessibilidade à visão.

Figura 3.56 - mapas de barreiras e permeabilidades à visão (à esquerda) e de visibilidade (à direita) do ponto de comércio referente à SQN 113 (máscara quadrada de 20m de lado ao redor do ponto). 
12) Isovistas - campo visual

O ponto de comércio referente à SQN 113, em relação aos dados de isovistas considerados, possui as medidas: área $=31.212 \mathrm{~m}^{2}$; perímetro $=4.287 \mathrm{~m} \mathrm{e}$ compacidade $=0,2$. A localização do ponto e os valores das medidas consideradas, estão representados graficamente pelo mapa de isovistas mostrado na Figura 3.57.

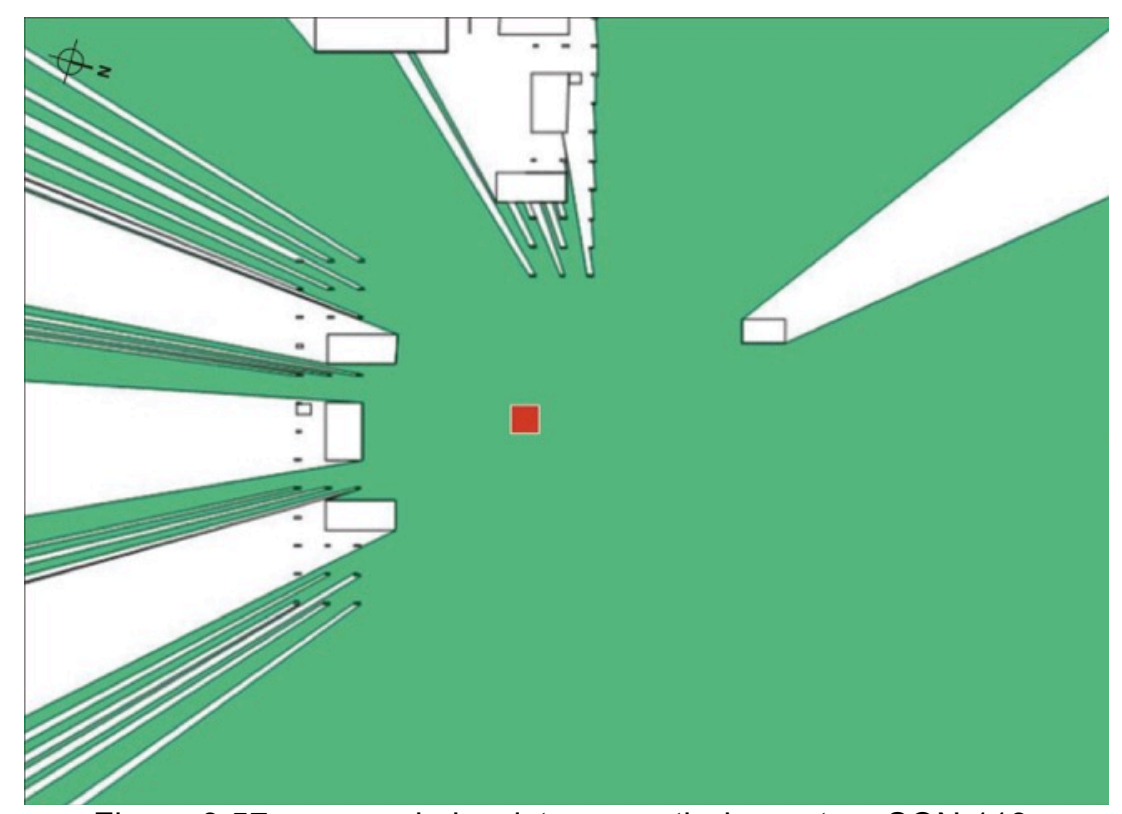

Figura 3.57 - mapa de isovistas a partir do ponto - SQN 113.

O valor baixo da medida de compacidade deste ponto se deve ao número significativo de barreiras à visão em boa parte do contexto imediato. A maioria destas barreiras é formada pelos pilotis dos blocos mais próximos ao ponto. Por isso a área ser parte estriada.

13) Condições para permanência - estado de conservação e conforto

Por ser localizado no interior da superquadra, o ponto de comércio referente à SQN 113 é muito bem cuidado no que tange às condições para a permanência. A limpeza do local é feita quase diariamente. A manutenção do que ali se encontra também é feita com certa frequência. Um exemplo disso é a pintura dos bancos de alvenaria. No período de um ano em que frequentei o local com certa assiduidade, percebi duas pinturas diferentes nesses assentos. Além da manutenção, o local apropriado 
pela comerciante, assim como todo o resto da superquadra, vem sendo equipado para propiciar melhor ambiente para a permanência dos moradores, pela prefeitura desta superquadra.

A atividade deste ponto acontece à noite. Apesar de a prefeitura da superquadra providenciar inúmeras melhorias, a comerciante teve que providenciar, por conta própria, a iluminação do local escolhido, por meio de um ponto de luz que ela obtém do bloco mais próximo. Ela paga ao condomínio do bloco, mensalmente, por este ponto de luz. Em termos de lugar para sentar, esta "praça" oferece alguns bancos de alvenaria, como citado, além dos canteiros para as árvores que ficam ao redor do ponto, que têm altura propícia para servir de assento (Figura 3.58). Diante do exposto, considero boas as condições para a permanência neste ponto de comércio.

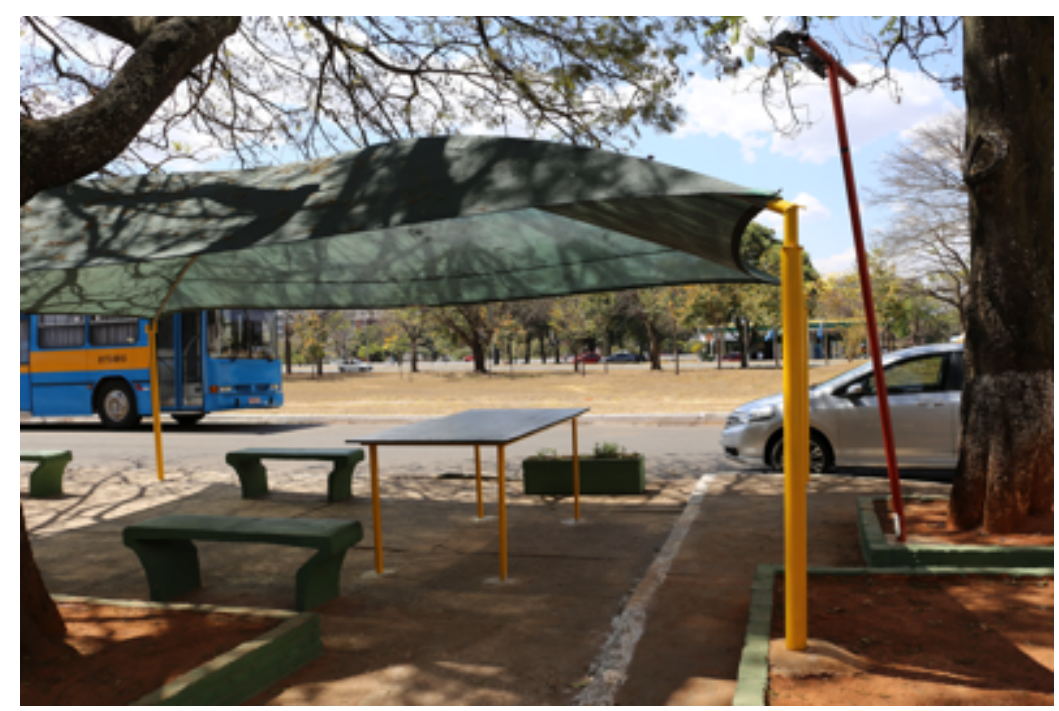




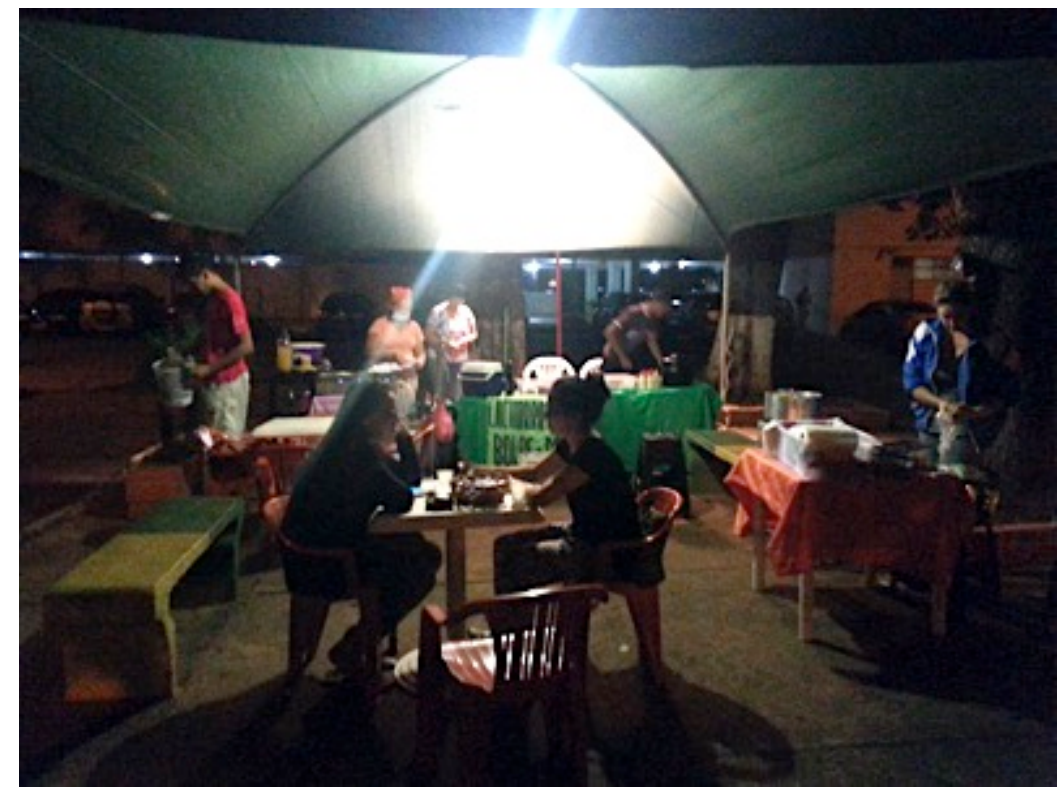

Figura 3.58 - imagens sobre as condições para a permanência no ponto de comércio referente à SQN 113. Fotos: Maya Macario (acima), autora (abaixo).

14) Atividades ao redor do ponto de comércio

A localização no interior da superquadra isola o ponto de comércio referente à SQN 113 das atividades comerciais formais localizadas no comércio local correspondente. Concomitante ao período de funcionamento deste ponto, as atividades observadas ao redor foram jogos de quadra por crianças e encontros para conversa entre pessoas de diferentes idades e gênero. Na maior parte, pela apresentação despojada, são moradores que depois da rotina de trabalho ou escola, descem ao interior da superquadra para um momento de lazer.

Outras atividades, além da exercida pelo ponto observado, são advindas de outros pontos de comércio informal que ali são montados, também. Porém, a maior assiduidade se dá por parte do estudo aqui. Por serem produtos diferentes, não são concorrentes. Existe uma congregação entre eles na oferta de uma variedade de opções para o lanche noturno (Figura 3.59). 

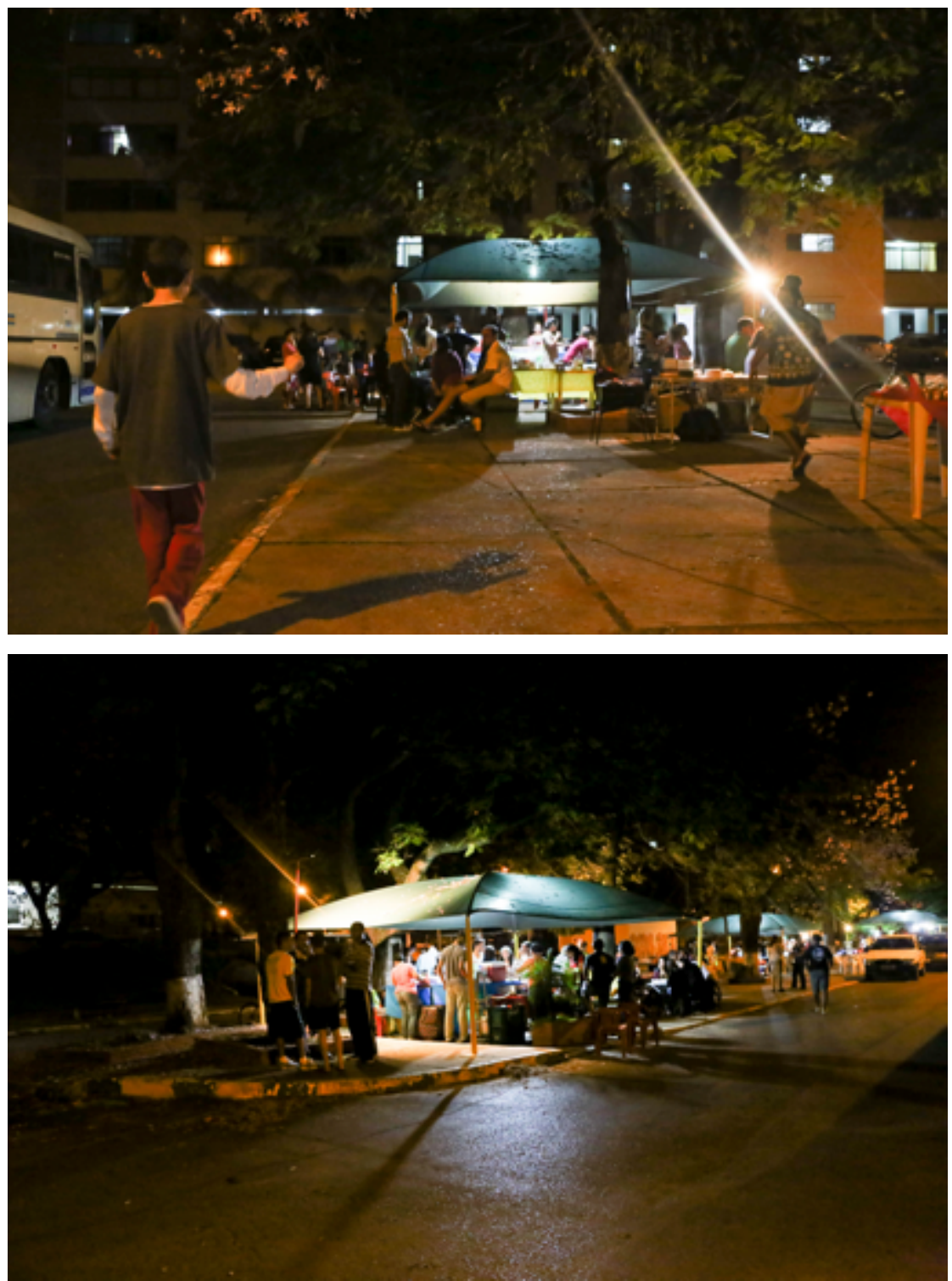

Figura 3.59 - imagens dos arredores do local do ponto de comércio referente à SQN 113 para ilustrar atividades ao redor. Fotos: Maya Macario.

\section{Sistemas de encontros e esquivanças}

15) Quantidade de pessoas - passagem e permanência

16) Variedade de pessoas na permanência

O público que frequenta o ponto referente à SQN 113 é mais variado em termos de gênero e faixa etária. $O$ total de homens e mulheres contabilizados nos dois dias se equilibram, praticamente: 41 homens e 45 mulheres. As crianças estão mais presentes neste tipo de lugar - interior de quadra com frequência predominante de moradores - totalizando 9. Notou-se uma presença maior, também, de adolescentes 
e jovens, porém foram muito poucos os idosos contabilizados (somente 1 nos dois dias). A concentração de pessoas nas faixas etárias de 20 a 30 e de 30 a 40 anos se repete neste ponto de comércio (Tabelas 3.7, 3.8 e 3.9).

Tabela 3.7 - Total pessoas - permanência $=49$ : total - crianças $=5$; total - homens $=21$; total - mulheres $=23$. Total pessoas - passagem $=86$. Total pessoas $(S Q N 113)-1^{\circ}$. dia $=135$

\begin{tabular}{|c|c|c|c|c|c|c|c|c|c|}
\hline \multirow{2}{*}{$\begin{array}{l}1^{\circ} \cdot \text { dia } \\
\text { períodos }\end{array}$} & \multirow[t]{2}{*}{ passagem } & \multirow[t]{2}{*}{ gênero } & \multicolumn{6}{|c|}{ faixa etária } & \multirow{2}{*}{$\begin{array}{c}\text { total } \\
\text { gênero }\end{array}$} \\
\hline & & & $\mathrm{A} / \mathrm{J}$ & $20-30$ & $30-40$ & $40-50$ & $50-60$ & $>60$ & \\
\hline \multirow{2}{*}{$\begin{array}{c}1 \\
c=3\end{array}$} & \multirow[t]{2}{*}{15} & $\mathrm{H}$ & 1 & - & - & 1 & - & - & 2 \\
\hline & & $\mathrm{M}$ & - & 3 & 1 & 1 & 1 & - & 6 \\
\hline \multirow{2}{*}{$\begin{array}{c}2 \\
c=1\end{array}$} & \multirow[t]{2}{*}{13} & $\mathrm{H}$ & 2 & 2 & 1 & - & - & - & 5 \\
\hline & & $\mathrm{M}$ & - & 2 & - & - & 1 & - & 3 \\
\hline \multirow{2}{*}{$\begin{array}{c}3 \\
c=1\end{array}$} & \multirow[t]{2}{*}{17} & $\mathrm{H}$ & 2 & 1 & 2 & - & - & - & 5 \\
\hline & & $\mathrm{M}$ & 1 & 1 & 1 & 1 & - & - & 4 \\
\hline \multirow[t]{2}{*}{4} & \multirow[t]{2}{*}{11} & $\mathrm{H}$ & - & - & 2 & 1 & - & - & 3 \\
\hline & & $\mathrm{M}$ & - & 2 & 2 & - & - & - & 4 \\
\hline \multirow[t]{2}{*}{5} & \multirow[t]{2}{*}{17} & $\mathrm{H}$ & 2 & - & - & 1 & - & - & 3 \\
\hline & & $\mathrm{M}$ & 1 & 2 & - & 1 & - & - & 4 \\
\hline \multirow[t]{2}{*}{6} & \multirow[t]{2}{*}{13} & $\mathrm{H}$ & - & 1 & 1 & 1 & - & - & 3 \\
\hline & & $\mathrm{M}$ & - & 1 & 1 & - & - & - & 2 \\
\hline \multirow{3}{*}{ total } & \multirow{3}{*}{86} & $\mathrm{~T} / \mathrm{H}$ & 7 & 4 & 6 & 4 & - & - & 21 \\
\hline & & $\mathrm{T} / \mathrm{M}$ & 2 & 11 & 5 & 3 & 2 & - & 23 \\
\hline & & $\mathrm{T} / \mathrm{H}+\mathrm{M}$ & 9 & 15 & 11 & 7 & 2 & - & 44 \\
\hline
\end{tabular}

Tabela 3.8 - Total pessoas - permanência $=46$ : total crianças $=4$; total homens $=20$; total mulheres $=22$. Total pessoas - passagem $=100$. Total pessoas $(S Q N 113) 2^{\circ}$. dia $=146$

\begin{tabular}{|c|c|c|c|c|c|c|c|c|c|}
\hline \multirow{2}{*}{$\begin{array}{l}2^{\circ} \cdot \text { dia } \\
\text { períodos }\end{array}$} & \multirow[t]{2}{*}{ passagem } & \multirow[t]{2}{*}{ gênero } & \multicolumn{6}{|c|}{ faixa etária } & \multirow{2}{*}{$\begin{array}{c}\text { total } \\
\text { gênero }\end{array}$} \\
\hline & & & $\mathrm{A} / \mathrm{J}$ & $20-30$ & $30-40$ & $40-50$ & $50-60$ & $>60$ & \\
\hline \multirow[t]{2}{*}{1} & \multirow[t]{2}{*}{11} & $\mathrm{H}$ & 1 & - & 1 & - & - & - & 2 \\
\hline & & $\mathrm{M}$ & 1 & - & - & - & - & - & 1 \\
\hline \multirow{2}{*}{$\begin{array}{c}2 \\
c=1\end{array}$} & \multirow[t]{2}{*}{16} & $\mathrm{H}$ & - & 3 & - & 2 & - & - & 5 \\
\hline & & $\mathrm{M}$ & - & 1 & 2 & 1 & - & - & 4 \\
\hline \multirow[t]{2}{*}{3} & \multirow[t]{2}{*}{17} & $\mathrm{H}$ & - & 3 & 1 & - & - & - & 4 \\
\hline & & $\mathrm{M}$ & - & 2 & 2 & - & - & - & 4 \\
\hline \multirow{2}{*}{$\begin{array}{c}4 \\
c=1\end{array}$} & \multirow[t]{2}{*}{20} & $\mathrm{H}$ & - & - & 1 & - & - & 1 & 2 \\
\hline & & $\mathrm{M}$ & - & 2 & 3 & 1 & - & - & 6 \\
\hline \multirow{2}{*}{$\begin{array}{c}5 \\
c=1\end{array}$} & \multirow[t]{2}{*}{21} & $\mathrm{H}$ & 1 & - & 1 & 2 & - & - & 4 \\
\hline & & $\mathrm{M}$ & - & - & 1 & 1 & - & - & 2 \\
\hline \multirow{2}{*}{$\begin{array}{c}6 \\
c=1\end{array}$} & \multirow[t]{2}{*}{15} & $\mathrm{H}$ & 1 & 1 & - & 1 & - & - & 3 \\
\hline & & $\mathrm{M}$ & 1 & 1 & 3 & - & - & - & 5 \\
\hline \multirow{3}{*}{ total } & \multirow{3}{*}{100} & $\mathrm{~T} / \mathrm{H}$ & 3 & 7 & 4 & 5 & - & 1 & 20 \\
\hline & & $\mathrm{T} / \mathrm{M}$ & 2 & 6 & 11 & 3 & - & - & 22 \\
\hline & & $\mathrm{T} / \mathrm{H}+\mathrm{M}$ & 5 & 13 & 15 & 8 & - & 1 & 42 \\
\hline
\end{tabular}

Tabela 3.9 - Total pessoas - permanência $=95$ : total - crianças $=9$; total - homens $=41$; total - mulheres $=45$. Total pessoas - passagem $=186$. TOTAL DE PESSOAS - SQN $=281$

\begin{tabular}{|c|c|c|c|c|c|c|c|c|c|}
\hline \multirow{6}{*}{$\begin{array}{c}1^{\circ} \text {. dia } \\
+ \\
2^{\circ} \text {. dia }\end{array}$} & \multirow[t]{2}{*}{ passagem } & \multirow[t]{2}{*}{ gênero } & \multicolumn{6}{|c|}{ faixa etária } & \multirow{2}{*}{$\begin{array}{l}\text { total } \\
\text { gênero }\end{array}$} \\
\hline & & & $\mathrm{A} / \mathrm{J}$ & $20-30$ & $30-40$ & $40-50$ & $50-60$ & $>60$ & \\
\hline & \multirow{4}{*}{186} & $\mathrm{H}$ & 10 & 11 & 10 & 9 & - & 1 & 41 \\
\hline & & $\mathrm{M}$ & 4 & 17 & 16 & 6 & 2 & - & 45 \\
\hline & & $\mathrm{H}+\mathrm{M}$ & 14 & 28 & 26 & 15 & 2 & 1 & 86 \\
\hline & & criança & \multicolumn{7}{|c|}{9} \\
\hline
\end{tabular}


17) Distribuição de pessoas no tempo e no espaço

Os espaços convexos no arranjo do ponto referente à SQN 113, são delimitados por muitos elementos físicos ao redor do preparo da tapioca. Isto porque observou-se que ali há um misto de tipos de encontro, por assim dizer. Os moradores, principalmente, ocupam o espaço apresentado na Figura 3.60 para conversar, levar os filhos para brincar, espairecer depois de um dia de trabalho e consumir a tapioca ou os produtos para lanche dos pontos adjacentes a este.

Apesar do espaço ser ocupado plenamente por estas pessoas, foram contabilizadas as que consumiram no ponto de comércio de tapioca, o escolhido para estudo de caso. Foram dois dias de contagem, sendo que no primeiro, outros pontos estavam vendendo seus produtos junto com o da tapioca. No segundo dia de contagem, o ponto observado estava funcionando sozinho no local. Curiosamente, as quantidades dos que permaneceram em um dia e no outro foram muito próximas. Isso demonstra a clientela cativa do ponto da tapioca, independente das outras atividades ao redor. Existe uma concentração de quem permanece no ponto, em frente à chapa de preparo da tapioca. Estas pessoas se sentam às mesas disponíveis, nos bancos de alvenaria, ou ficam em pé, próximas ao posto de trabalho da comerciante (Figura 3.61). Os que não permanecem, ou vão para seus blocos, ou se distanciam bastante do local do ponto, mas permanecem no interior da superquadra. 


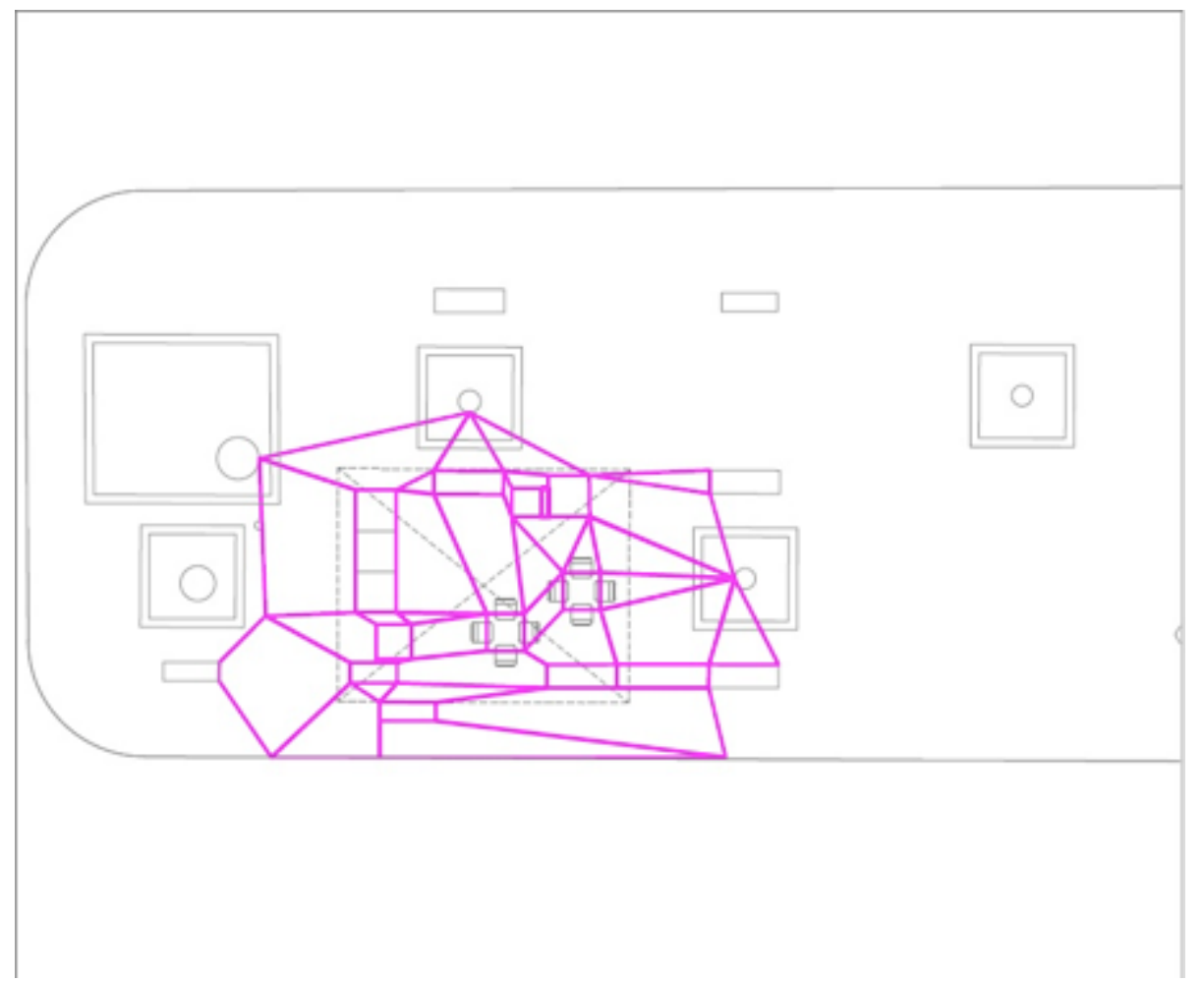

Figura 3.60 - mapa de espaço convexo determinado pelos elementos físicos com a arquitetura do ponto de comércio referente à SQN 113.

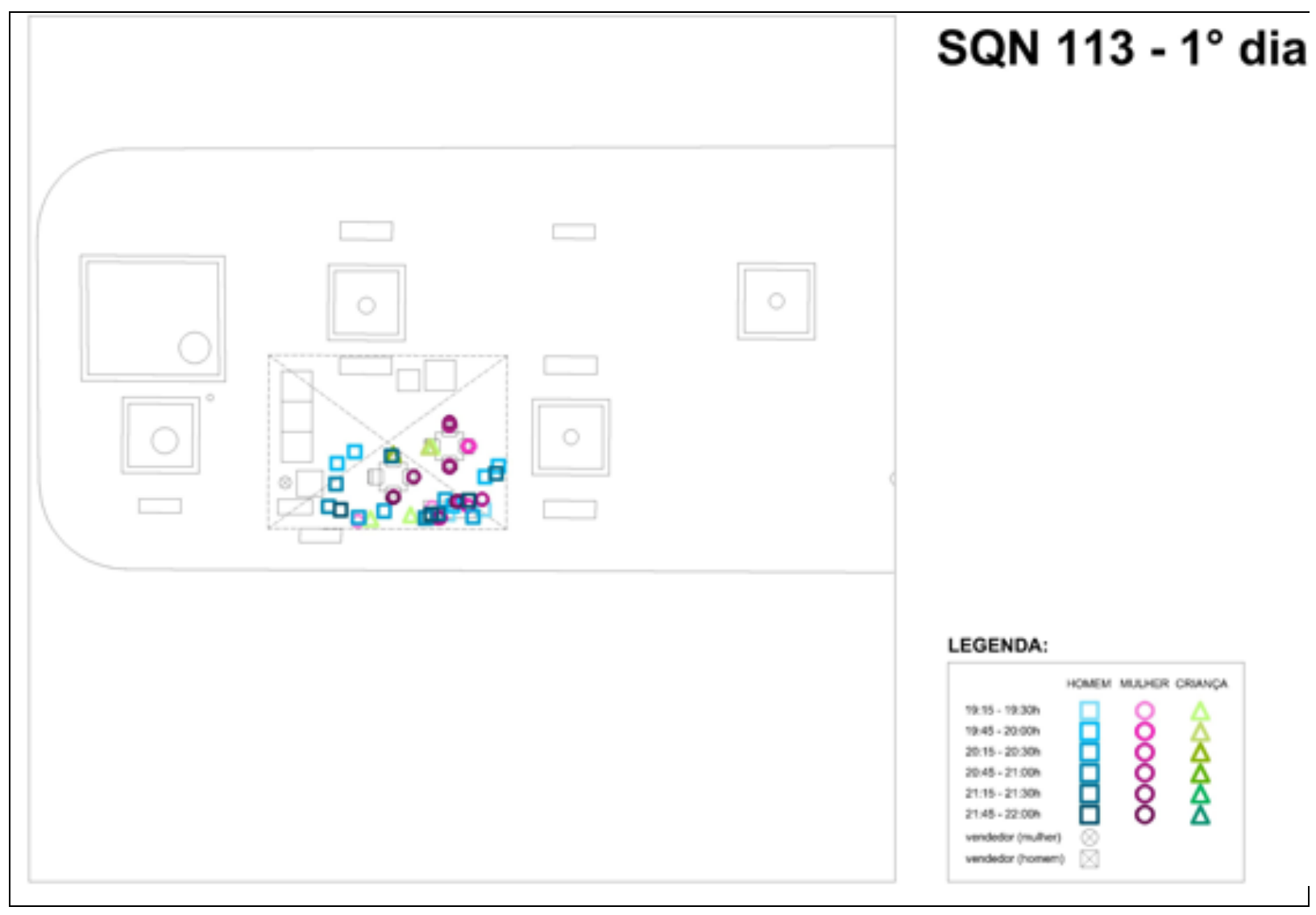




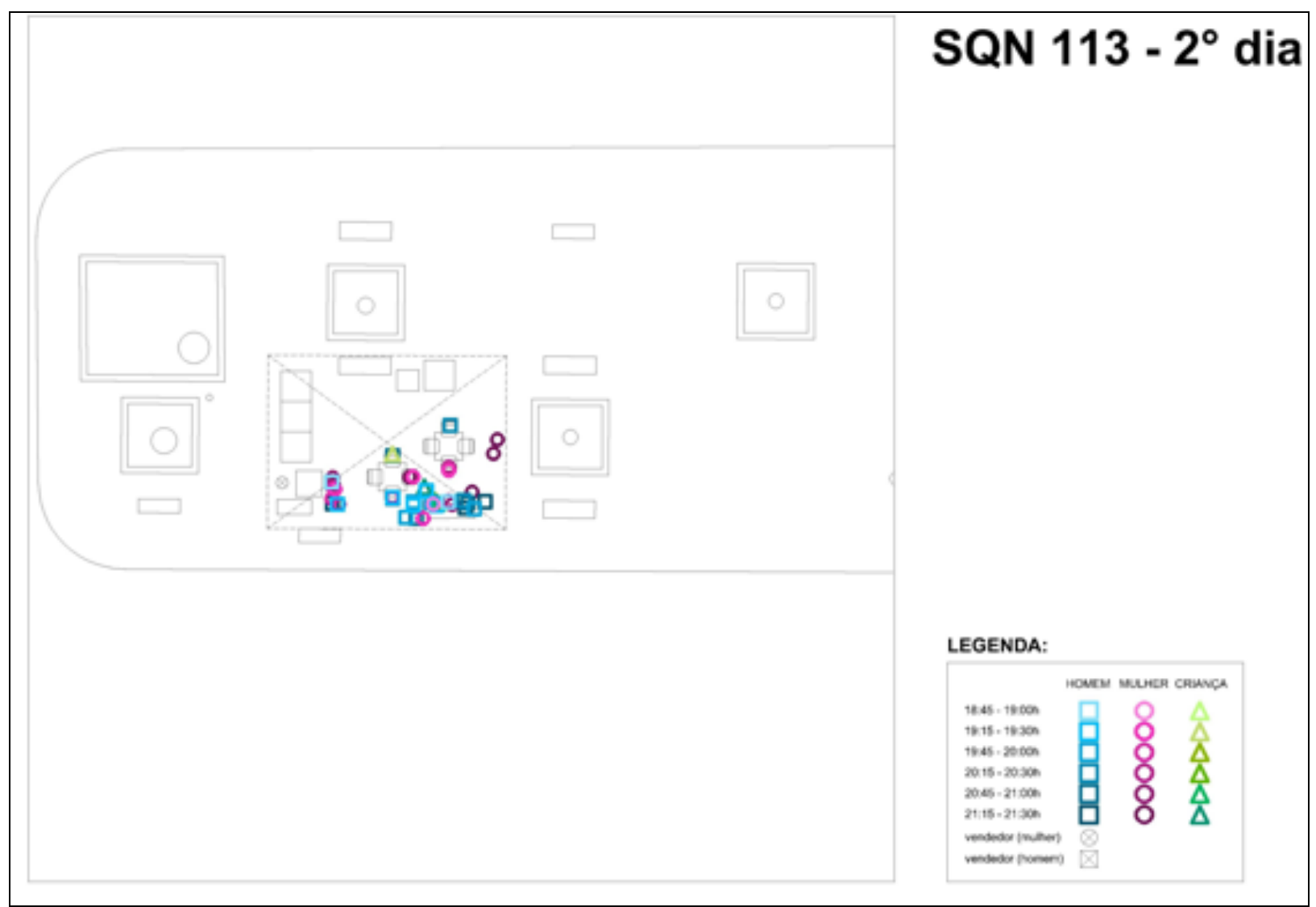

Figura 3.61 - mapas comportamentais sobre a distribuição de pessoas no ponto de comércio referente à SQN 113, nos dois dias observados.

Sistema de Elementos Físicos - SEF

18) Complexidade

\section{Descrição}

Os 13 elementos físicos envolvidos na atividade do ponto de comércio referente à SQN 113 (Figura 3.62) são:

. elementos portados - estante auxiliar, mesa pequena, 2 mesas médias, 8 cadeiras, botijão de gás (em um carrinho de carga próprio), engradado auxiliar, lixeira;

. elementos do local -5 bancos de alvenaria, tenda grande, canteiros, floreira, poste/ponto de iluminação. 


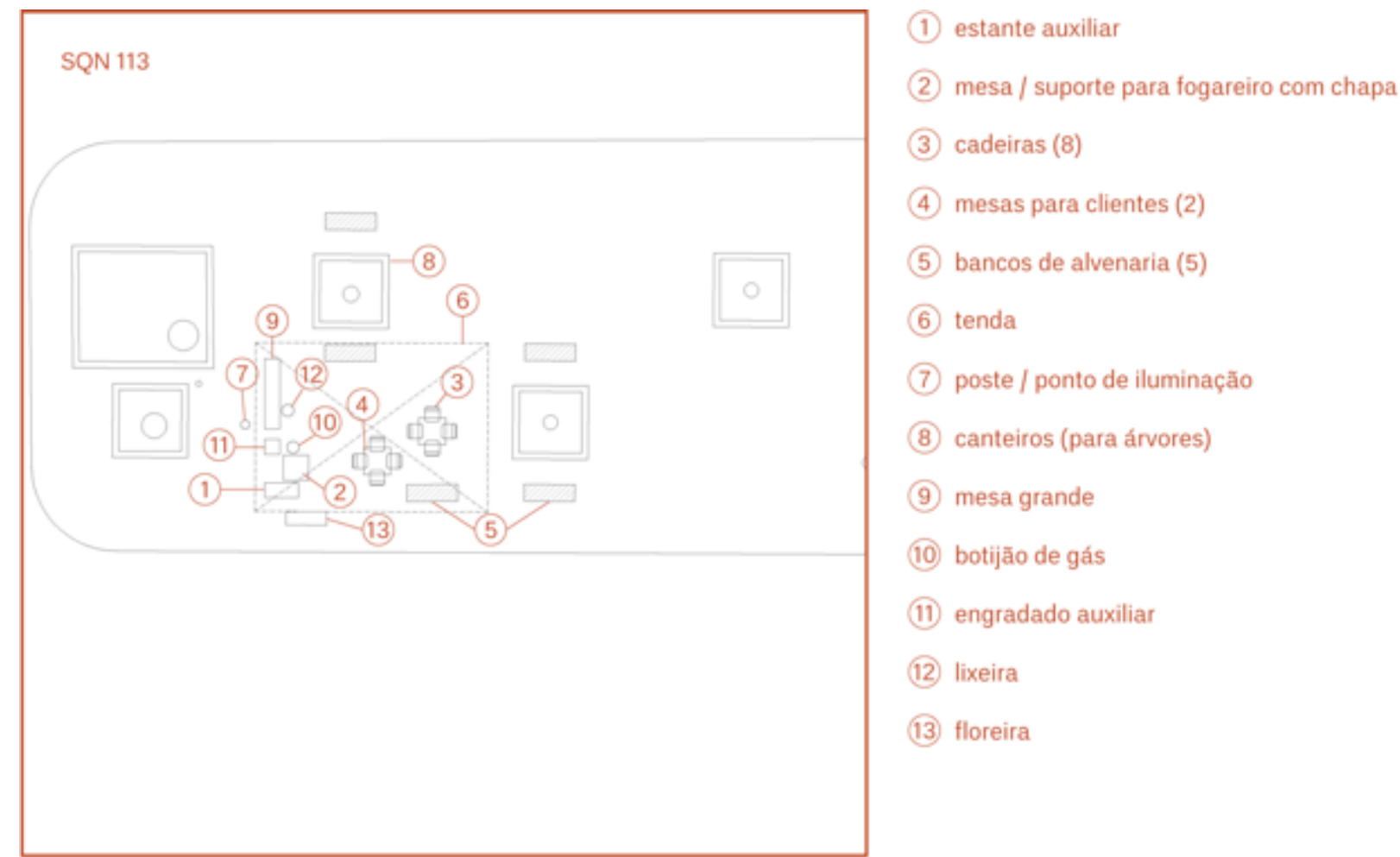

Figura 3.62 - planta baixa do ponto de comércio referente à SQN 113, com a especificação dos elementos físicos envolvidos na atividade.

Função dos elementos e suas relações

No ponto de comércio referente à SQN 113, foram considerados 13 elementos envolvidos no preparo e venda de tapioca. Disponibilizados no local, a atividade conta com uma floreira que serve de delimitador do espaço, bancos de alvenaria e alguns canteiros que cercam as árvores próximas que são utilizados como assento. Uma das árvores serve de suporte para a tabela de preços da comerciante (Figura 3.63-a). Está instalado ali, também, um poste para a iluminação do local. A tenda, que antes era montada por quem ali vende seus produtos, foi disponibilizada de modo permanente pela prefeitura da superquadra.

Envolvidos diretamente na atividade, são os elementos portados pela comerciante. Para o preparo da tapioca, é levada para o local uma chapa que, colocada sobre uma mesa, prepara até duas peças ao mesmo tempo. De um lado da comerciante fica uma estante auxiliar em que são guardados todos os ingredientes utilizados no preparo da tapioca. Do outro lado, é posicionado o botijão de gás acoplado ao seu carrinho, além de um engradado utilizado para guardar e disponibilizar o material que dá suporte à atividade. A comerciante muda os elementos de lugar, mas sempre 
dentro de uma pequena área em um dos cantos da tenda. É um pequeno quadrado delimitado pelo final da área coberta, de um lado, e do outro por uma mesa que hoje é fixa no local e serve a outro ponto de comércio informal, não tão assíduo quanto o da Solange com a tapioca. Em frente ao seu posto de trabalho e esta mesa ao lado, fica uma lixeira grande que atende aos dois pontos quando funcionam juntos (Figura 3.63-f).

Para a permanência e o consumo, além dos canteiros e bancos de alvenaria, as pessoas podem contar com duas mesas e oitos bancos de plástico, que ficam bem embaixo da tenda e em frente ao posto de trabalho da comerciante.

19) Aspectos funcionais - relações entre elementos físicos e as práticas

Quando foi entrevistada, Solange tinha como rotina ir para o curso onde terminava o ensino médio, pela manhã. Cuida da casa e da família à tarde e nas noites de quinta-feira a sábado, prepara e vende tapioca na sua vizinhança.

Por volta das $18 \mathrm{~h}$, ela se desloca de seu bloco até a "praça" que tem no interior da superquadra onde mora. Com a ajuda do filho, que é seu assistente, ela transporta a pé todo o material utilizado. Eles montam os elementos e aguardam os moradores que só começam a chegar de fato, às 19h, ou mais tarde (Figura 3.63-b). A disposição dos elementos principais da atividade - mesa com a chapa, estante auxiliar, engradado e botijão - é sempre em forma de "U", mesmo mudando os lugares destes elementos entre si. Na maior parte do tempo, ela fica em frente à chapa e utiliza as laterais para acionar ou a estante, ou o engradado. A estante dá suporte à chapa quando Solange pega ali a goma da tapioca e os ingredientes que formam os variados recheios (Figura 3.63-c). O engradado é acionado para momentos como o da embalagem da tapioca para viagem e o da limpeza da chapa entre um preparo e outro (Figura 3.63-d).

A comerciante não se desloca de seu posto, pois as pessoas escolhem a tapioca com o recheio específico, aguardam próximo à chapa e pegam quando o seu pedido está pronto. Preparo e atendimento são feitos num mesmo local (Figura 3.63-e). O restante do espaço sob a tenda e arredores é ocupado pelas pessoas que 
consomem tapioca ou algum produto de outros pontos, e por aqueles que permanecem ali somente para conversar ou, simplesmente, estar.
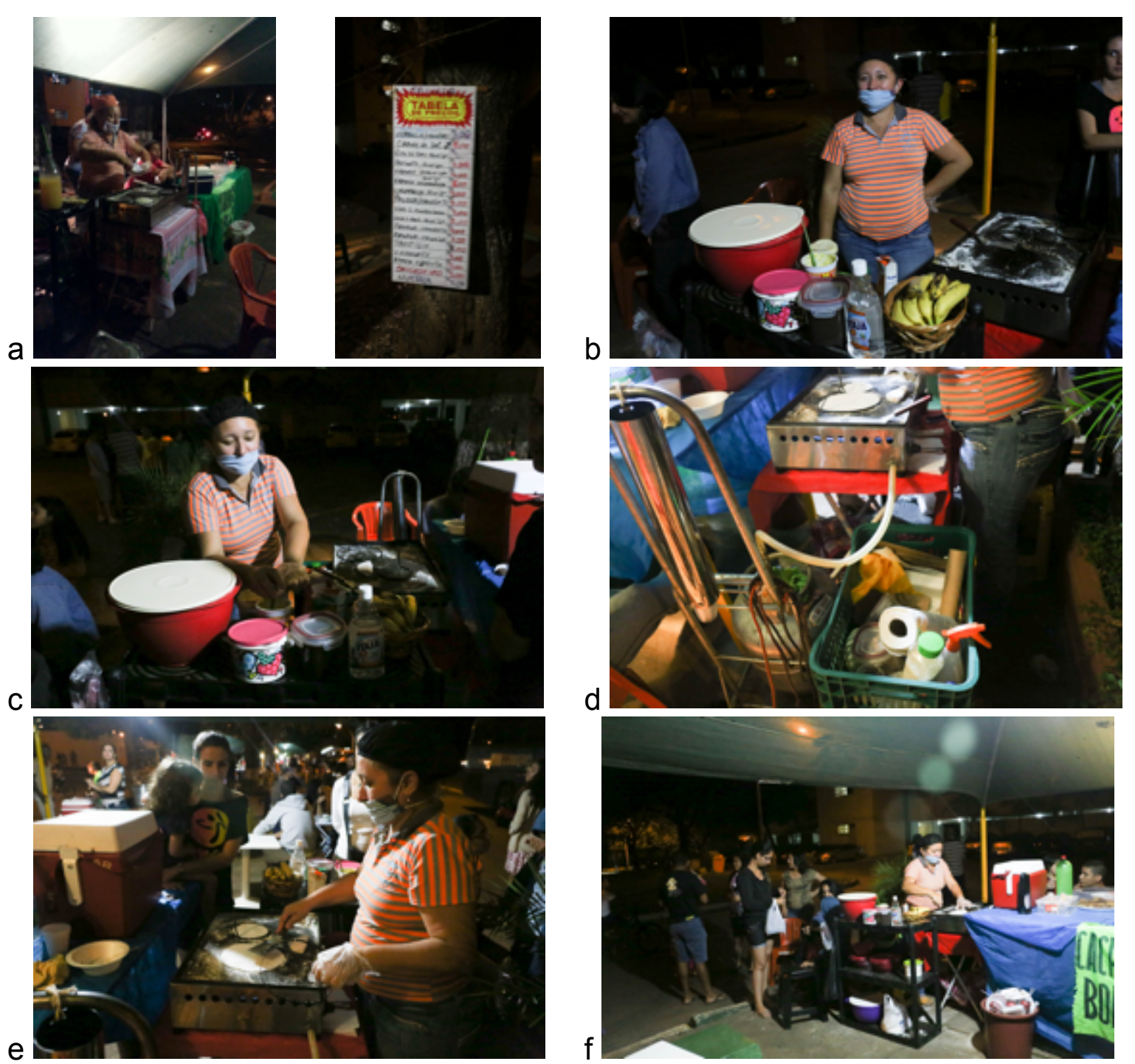

Figura 3.63 - imagens dos elementos físicos na atividade do ponto de comércio referente à SQN 113 . Fotos: Maya Macario.

\subsubsection{Análise do ponto como um sistema - SQN 113}

\section{Padrões Espaciais + Características Socioeconômicas}

Os atributos da configuração do lugar escolhido por Solange para vender tapioca são: baixa ambiência física, com uma grande área de espaço convexo igual a $10.724 \mathrm{~m}^{2}$; acessibilidade baixa ao movimento motorizado, por este ponto se localizar no interior da superquadra referência; acessibilidade ao movimento de pedestres alta no contexto e média no espaço da atividade (muitos elementos como 
barreira); conexão visual média no contexto e alta no espaço da atividade; campo visual com área de $31.212 \mathrm{~m}^{2}$, excedendo a área do espaço convexo em que o ponto está inserido $\left(10.724 \mathrm{~m}^{2}\right)$ e boas condições para permanência.

Os moradores desta superquadra, incluindo obviamente a comerciante, apesar de fazerem parte da classe média, têm hábitos mais próximos da urbanidade no que diz respeito ao uso do espaço urbano da vizinhança. O espaço apropriado pelo ponto de comércio observado e por outros que o seguiram, apesar da baixa ambiência possui os aspectos de acessibilidade ao movimento de pedestres e à visão altos. Estes são aspectos importantes para os frequentadores do ponto que parecem primar por certa vigilância do local do ponto em nome da segurança, principalmente. Afinal, estão no "quintal" de suas casas.

\section{Padrões Espaciais + Sistema de Encontros e Esquivanças}

Para uma frequência basicamente de moradores, o número de pessoas contabilizado nos dois dias foi razoável: 281 pessoas. Porém, quase o dobro dos que permaneceram foi o número dos passantes: 186 para 95. Este dado mostra que aquele centro de superquadra além de atrair seus moradores para lazer é um local de passagem importante para os que frequentam outros locais em sua unidade de vizinhança. Um exemplo disso pode ser visualizado na Figura 3.64, em que o mapa da esquerda mostra a acessibilidade ao movimento de pedestres da SQN 113 coincidente com as trilhas feitas pelas pessoas no interior desta superquadra. 

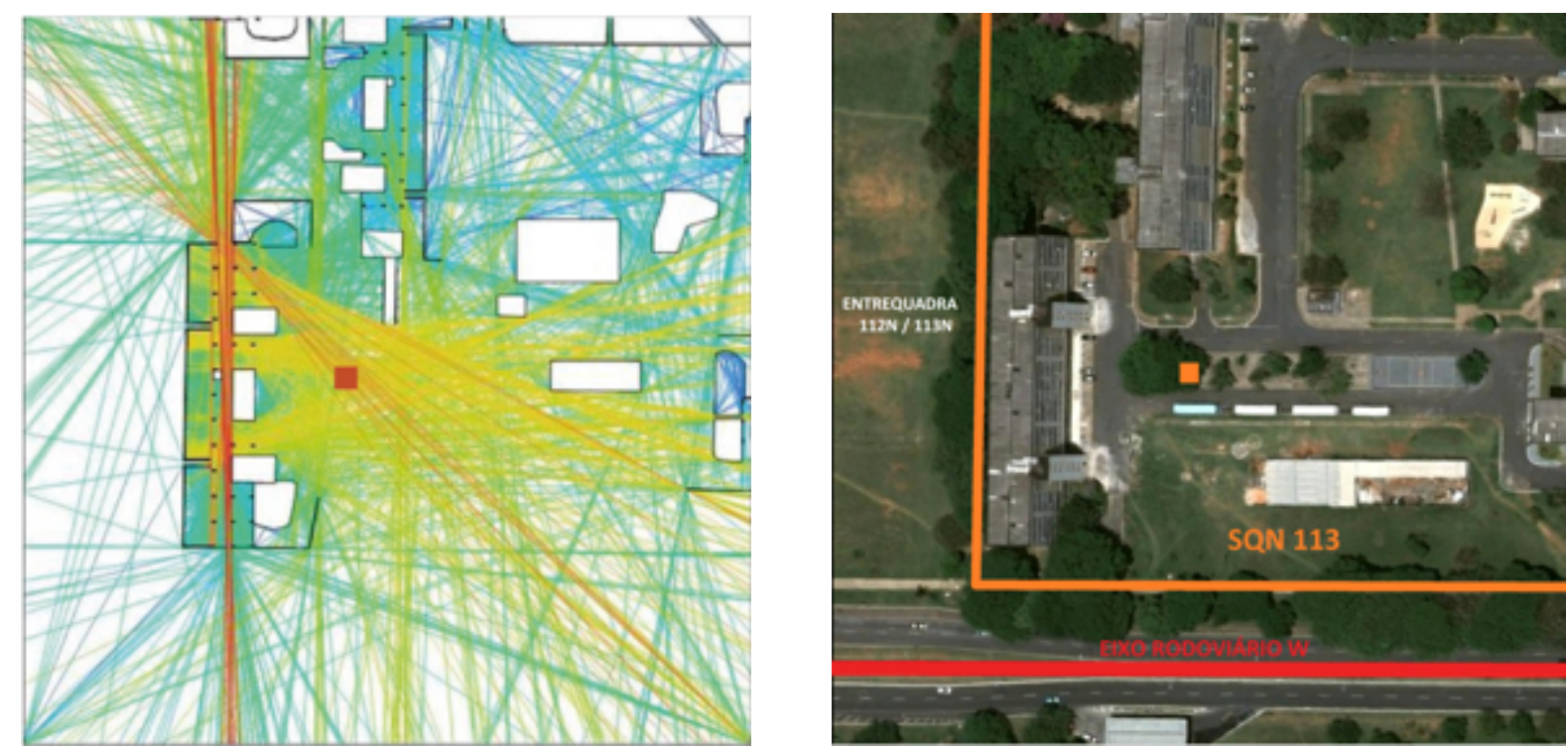

Figura 3.64 - coincidência entre as linhas integradas do mapa de acessibilidade ao movimento de pedestres na SQN 113 e as trilhas feitas pelos passantes.

\section{Padrões Espaciais + Sistema de Elementos Físicos}

Como visto, os aspectos positivos da configuração do contexto imediato deste ponto são a acessibilidade ao movimento de pedestre e à visão, o bom estado de conservação e conforto e a proximidade, mesmo que eventual, a outros pontos de comércio informal. Estes aspectos favorecem o ponto, que perde um pouco na permeabilidade ao movimento no espaço da atividade, pela relação física entre os elementos, que de certa forma cercam o local. Mas a área para a permanência é generosa e possibilita a interação entre as pessoas de modo misto e não direcionado somente a atividade observada. A interface entre a atividade e o contexto aqui se dá, também, de forma borrada (Figura 3.65). De modo geral, a composição dos elementos da atividade e a configuração de seu contexto se beneficiam mutuamente quanto à urbanidade no interior desta superquadra. 


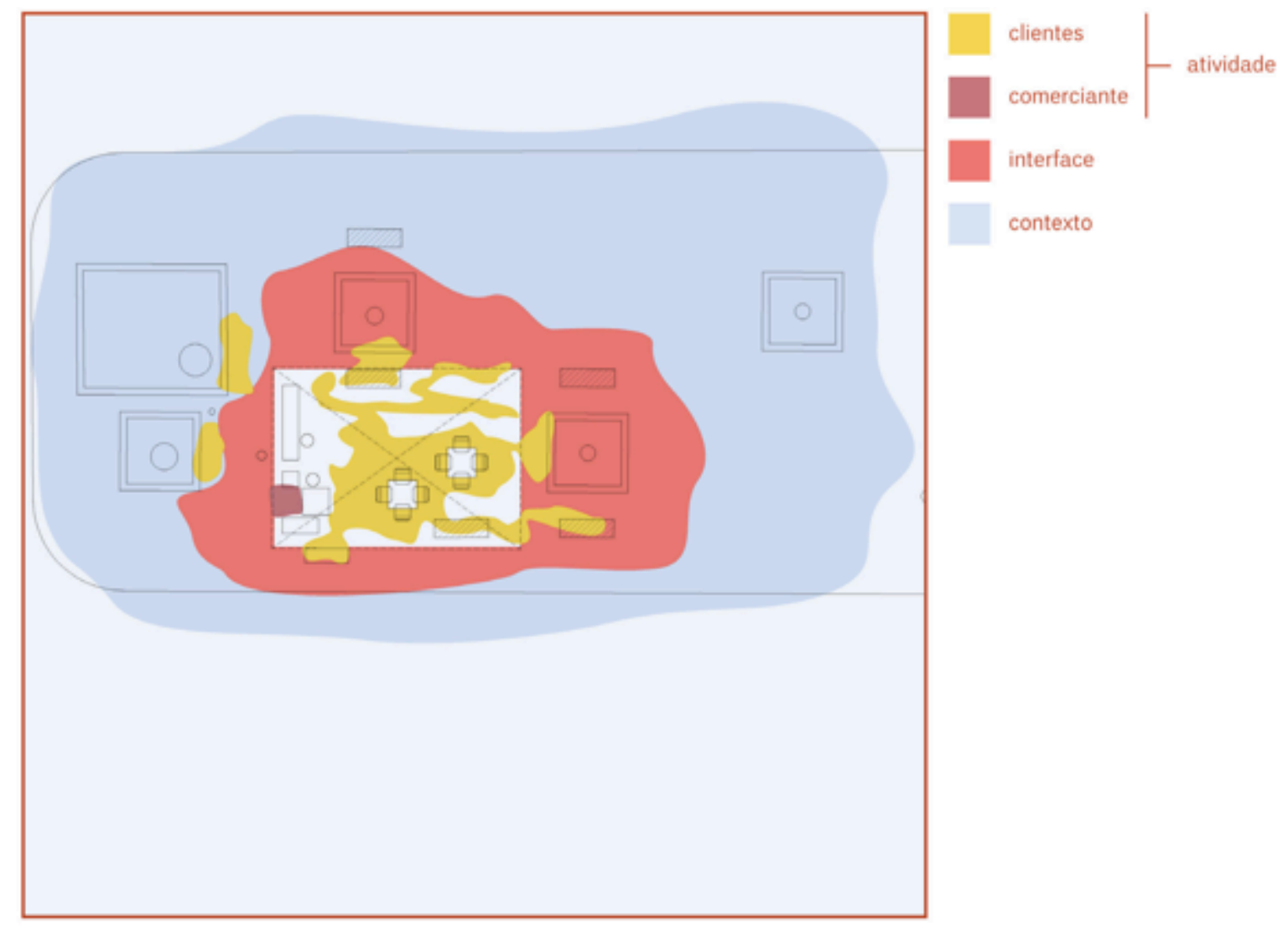

Figura 3.65 - planta baixa do ponto de comércio referente à SQN 113 com identificação dos espaços da atividade (clientes e comerciante), da interface (passantes) e do contexto.

\section{Sistema de Elementos Físicos + Características Socioeconômicas}

Os elementos portados pela comerciante não são em grande quantidade, porém os disponibilizados são providos por iniciativa dos próprios moradores que são frequentadores deste espaço. Observou-se neste caso, que existe parte desta classe social uma necessidade de formalizar a disponibilização dos elementos que atendem às atividades possíveis dentro da superquadra. Não só naquele local específico, mas em outras áreas desta superquadra foram instaladas outras tendas para o abrigo de mais atividades como a deste estudo de caso e outras.

\section{Sistema de Elementos Físicos + Sistema de Encontros e Esquivanças}

Quando Solange mudou o seu ponto de comércio para este local só haviam os canteiros das árvores e os bancos de alvenaria, que já acompanhavam o desenho do espaço da "praça". Ela se instalou em um dos cantos do recinto que os canteiros e bancos formam ali. Os outros pontos acompanharam o contorno deste recinto que 
abriga as pessoas em seus diversos tipos de interação: do consumo de tapioca ao bate-papo. Observou-se, também, que apesar desta área ter um tamanho considerável, a ocupação das pessoas a extrapola.

\section{Características Socioeconômicas + Sistema de Encontros e Esquivanças}

Apesar da classe média dos frequentadores e da comerciante ser a predominante, esta superquadra tem a peculiaridade de uma urbanidade mais intensa em seu espaço público interno. O sistema de encontros não se beneficia somente da configuração física do espaço favorável, mas deste perfil que prima pelo aproveitamento mais intenso dos espaços externos da vizinhança.

\subsubsection{Ponto de comércio relacionado à superquadra norte 410 - SQN 410}

Como último ponto analisado, o relacionado à superquadra norte 410 fechou o grupo de estudos de caso como sendo um dos mais populares entre os quatro observados. A seguir, são apresentadas a identificação, a apresentação nas categorias analíticas e a análise deste ponto como um sistema.

\subsubsection{Identificação - SQN 410}

O ponto de comércio que representa a categoria entrada de superquadra (Figura 3.66) é relacionado à superquadra norte 410 . O ponto é especializado no preparo e venda de caldos e refrigerantes. O funcionamento deste ponto acontece de segunda a sexta-feira, no horário de 17 h00 às 22 h00 (Figura 3.67). 


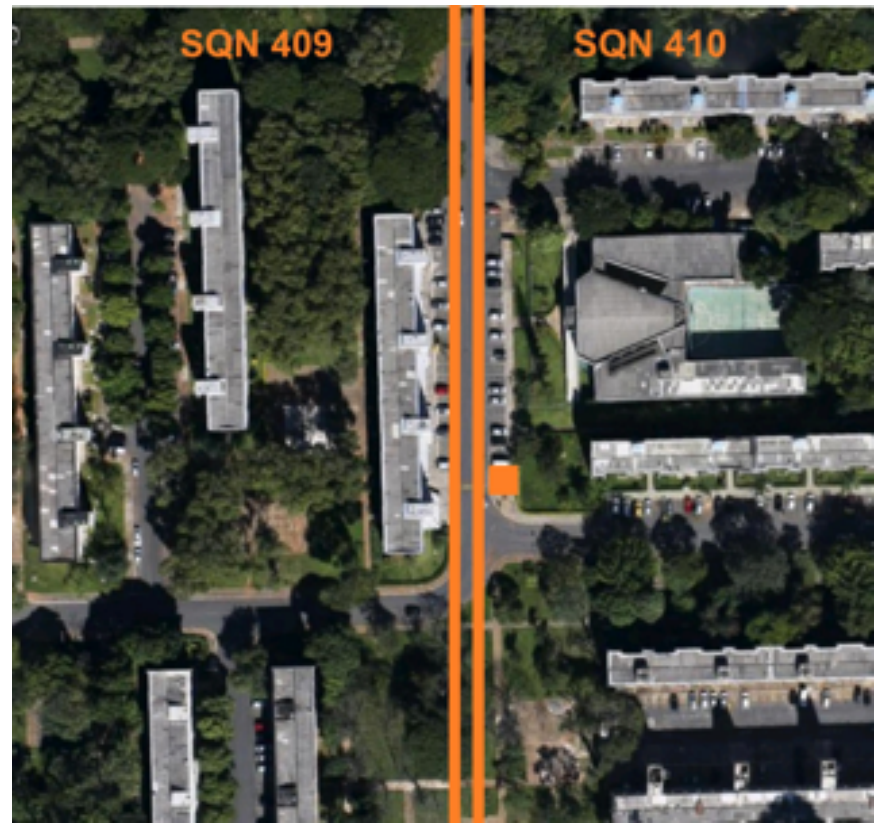

Figura 3.66 - vista aérea do ponto em relação a quadra residencial - SQN 410. Fonte: adaptado do Google Earth.

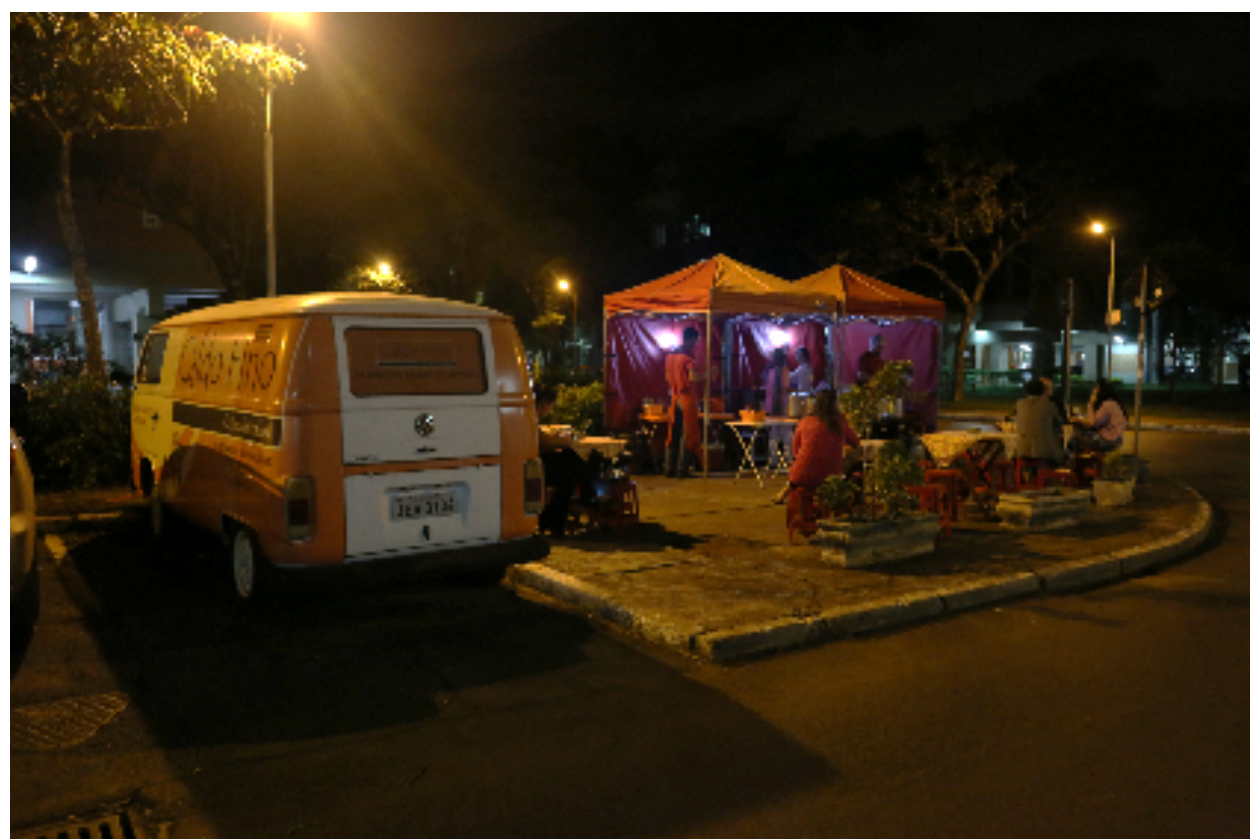

Figura 3.67 - identificação do ponto de comércio relacionado à SQN 113. Foto: Maya Macario.

\subsubsection{Categorias analíticas - SQN 410}

\section{Características socioeconômicas}

1) Apresentação geral: gênero; faixa etária, naturalidade e grau de instrução.

2) Local de moradia e modo de deslocamento. 
3) A atividade é a única ocupação remunerada? Dias da semana de que se ocupa com a atividade.

4) Renda mensal adquirida pela atividade.

5) Razão da escolha por este local para o ponto de comércio.

6) Quem é o seu público/cliente?

7) Dados censitários sobre renda dos moradores.

Renato tem idade entre 40 e 50 anos e é morador, também, da mesma superquadra em que tem o comércio de caldos, há mais de 10 anos. É natural do Rio de Janeiro e tem nível superior. Este negócio prosperou tanto, que ele abriu um pequeno restaurante em um comércio local a duas superquadras dali. Com isso, ele administra os dois negócios, sendo um extensão do outro. No ponto, ele mantém dois funcionários por noite e ainda conta com o auxílio de uma das irmãs, que também mora na mesma quadra, no bloco que fica em frente ao ponto. A presença dele é mais constante no restaurante, atualmente. Não foi informado o rendimento mensal que ele tem proveniente do ponto informal.

O deslocamento das grandes panelas de caldo é feito por uma multivan, que atende aos dois pontos de comércio, e que chega ao local do ponto informal, por volta das 18h40. O restante dos elementos para a atividade é guardado dentro de uma kombi, que fica estacionada, permanentemente, na lateral do ponto.

Ele conta que escolheu o local porque sempre o achara bonito, principalmente quando ainda havia uma árvore frondosa no canteiro que fica na parte posterior à montagem das barracas do seu ponto de comércio, que é bastante conhecido não só na Asa Norte. Sua popularidade é traduzida na diversidade de tipos de clientes. Ele conta que seu público é diverso dentro das classes média baixa, média e alta, com predominância da média e que tem reconhecimento por todo o Plano Piloto e além, inclusive pela imprensa de Brasília.

Os dados censitários da superquadra norte 410 confirmam as informações passadas por Renato bem como as observações feitas nas visitas ao ponto, durante seu funcionamento. A predominância nesta superquadra é da classe média-média, com um certo destaque, seguida da classe média inferior (Figura 3.68). 


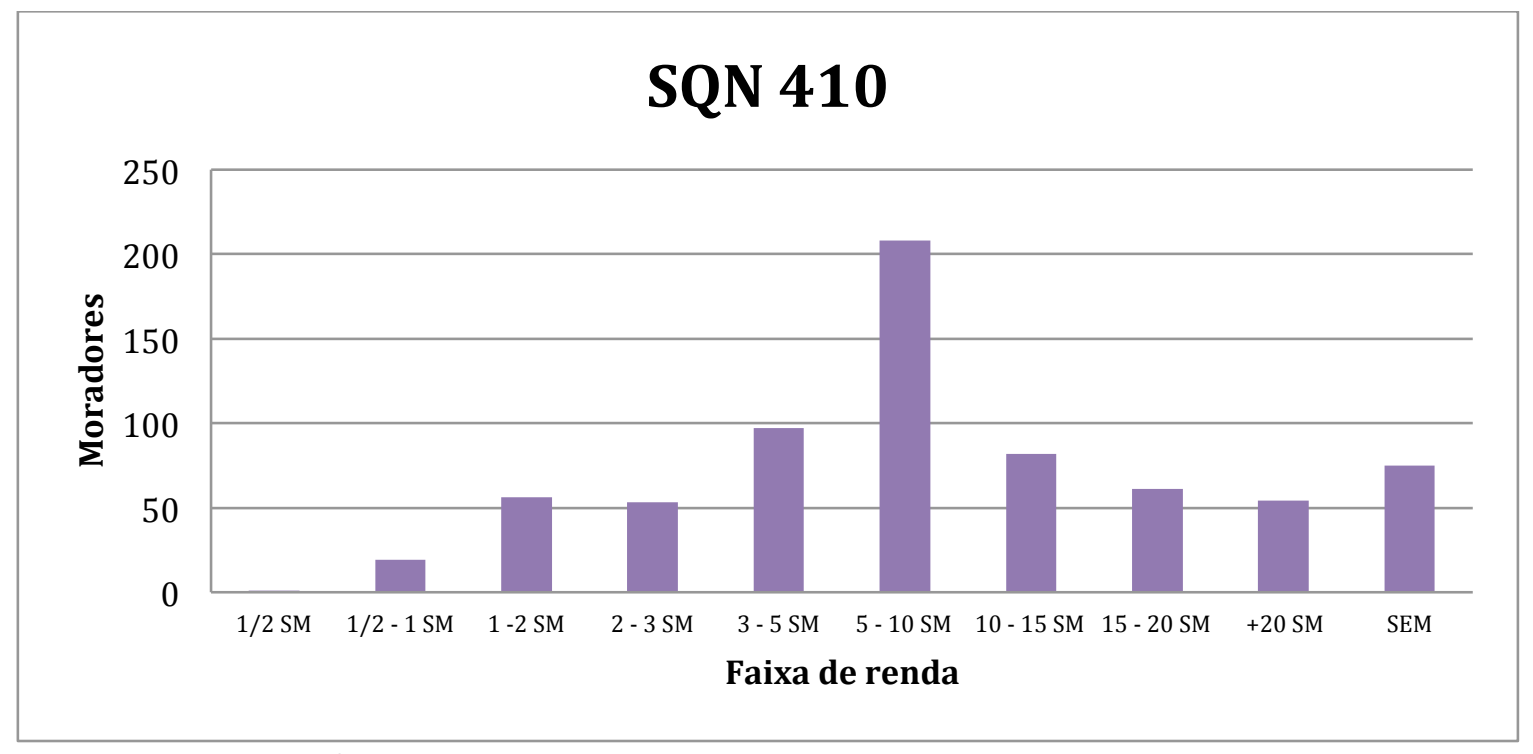

Figura 3.68 - gráfico sobre a renda, por número de salários mínimos, dos responsáveis por domicílios, da superquadra norte 410, na amostragem dos dados censitários do IBGE, de 2010.

\section{Padrões espaciais}

08) Espaço convexo que abarca o ponto - ambiência física para e a partir do ponto

Os espaços convexos considerados no contexto imediato do ponto de comércio na entrada da SQN 410 somam 20 e suas áreas são: 4391, 3149, 3121, 2623, 2455, 2443, 2436, 2254, 1954, 1463, 1443, 1333, 1236, 1042, 981, 620, 475, 463, 207 e 176. A área em que o ponto em questão está inserido é a terceira maior dos acima relacionados: $3.121 \mathrm{~m}^{2}$. A fachada do bloco A da entrada da SQN 409 tem papel importante como elemento tridimensional na formação deste espaço convexo. A extensão desta fachada também delimita as laterais do espaço. Apesar de ser um delimitador do espaço na parte traseira do ponto, o bloco A da SQN 410 tem a sua percepção por quem está no ponto amenizada pela cerca viva que o circunda parcialmente (Figura 3.69). Conjugadas a medida da área do espaço convexo com a localização do ponto de comércio em relação a ele mais ou menos central, considero média a ambiência física do contexto para este ponto. 


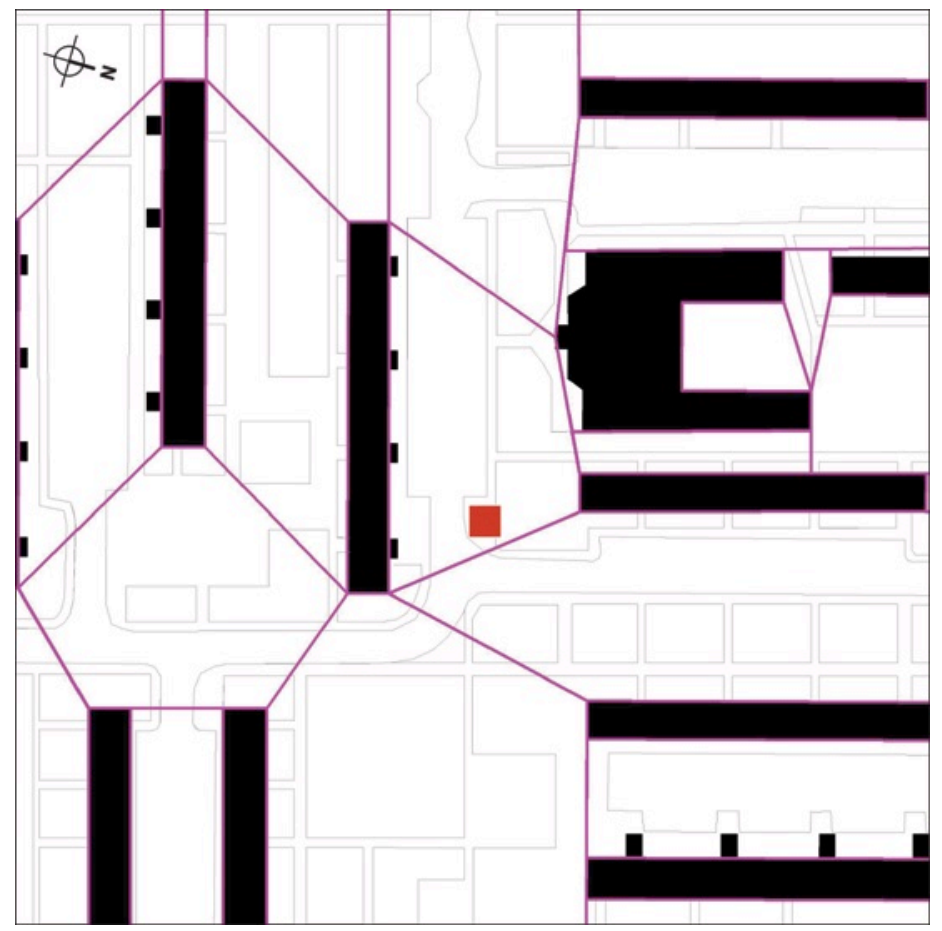

Figura 3.69 - mapa $(200 \mathrm{~m})$ dos espaços convexos do contexto imediato do ponto referente à SQN 410 e de sua inserção em um destes espaços.

09) Acessibilidade ao movimento de veículos

O nível de integração do ponto de comércio situado na entrada da superquadra norte 410 é de 1,135 (Figura 3.70). Este valor é consideravelmente próximo à integração máxima, no que se refere à acessibilidade ao movimento de veículos no Plano Piloto (Figura 3.87). Esta medida alta se deve à sua localização de baixa profundidade no sistema "em árvore", da configuração da região residencial do Plano Piloto.

\begin{tabular}{|c|c|c|c|}
\hline $\begin{array}{l}\text { Integração máxima no } \\
\text { Plano Piloto }\end{array}$ & $\begin{array}{l}\text { Integração média no } \\
\text { Plano Piloto }\end{array}$ & $\begin{array}{l}\text { Integração mínima no } \\
\text { Plano Piloto }\end{array}$ & $\begin{array}{l}\text { Integração do ponto } \\
\text { SQN 410 }\end{array}$ \\
\hline 1,379 & 0,847 & 0,349 & $\mathbf{1 , 1 3 5}$ \\
\hline
\end{tabular}

Figura 3.70 - quadro comparativo entre as medidas de integração máxima, média e mínima do Plano Piloto e da localização do ponto de comércio associado ao comércio local da SQN 410, no que se refere à acessibilidade ao movimento de veículos.

10) Acessibilidade ao movimento do pedestres

A medida de integração do ponto de comércio referente à SQN 410 é de 6,97 e posiciona-se entre as média e mínima da área de seu contexto - 9,03 e 3,98, respectivamente (Figura 3.71). Apesar de ter um grau relativamente baixo de 
integração, esta área é via de circulação significativamente intensa de pedestres, que por ali passam percorrendo trajetos entre equipamentos e pontos de ônibus situados na via L2 - Norte e as superquadras norte 209 e 210 e o comércio local entre elas. Outros trechos próximos, principalmente da SQN 409, são mais integrados do que aquele que abarca o ponto (Figura 3.72).

\begin{tabular}{|c|c|c|c|}
\hline $\begin{array}{l}\text { Integração máxima no } \\
\text { contexto imediato }\end{array}$ & $\begin{array}{l}\text { Integração média no } \\
\text { contexto imediato }\end{array}$ & $\begin{array}{l}\text { Integração mínima no } \\
\text { contexto imediato }\end{array}$ & $\begin{array}{l}\text { Integração do ponto } \\
\text { SQN 410 }\end{array}$ \\
\hline 17,41 & 9,03 & 3,98 & $\mathbf{6 , 9 7}$ \\
\hline
\end{tabular}

Figura 3.71 - quadro comparativo entre as medidas de integração máxima, média e mínima do contexto imediato (área quadrada ao redor do ponto com $200 \mathrm{~m}$ de lado) e da localização do ponto de comércio referente à SQN 410, no que se refere à acessibilidade ao movimento de pedestres.
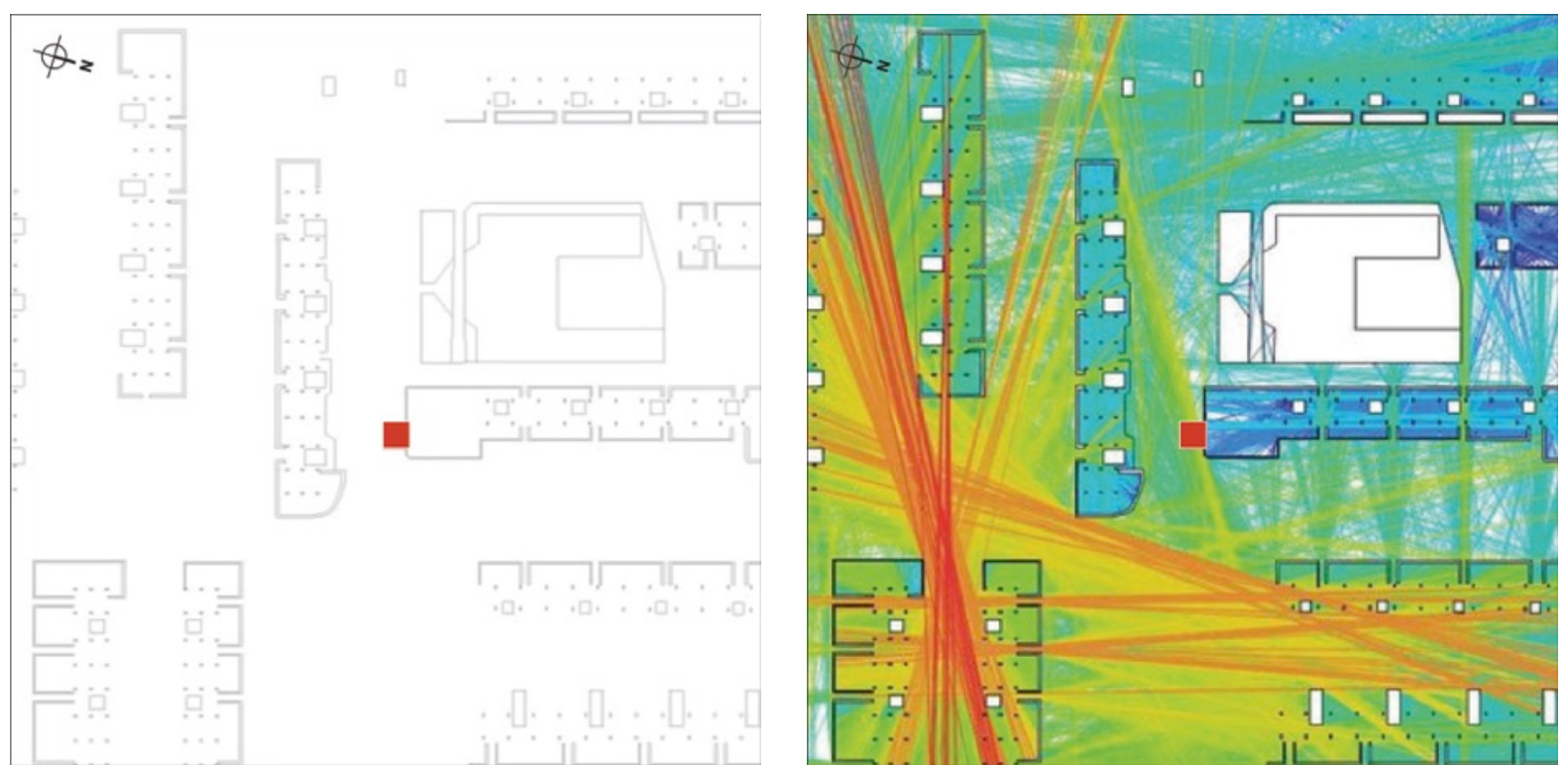

Figura 3.72 - mapas de barreiras e permeabilidades ao movimento (gerador) (à esquerda) e de axialidade (à direita) para o ponto - SQN 410.

A acessibilidade ao movimento de pessoas dentro do espaço da atividade é significativa, apesar da composição de elementos físicos cercar seu centro (Figura 3.74). A medida de 12,97 um pouco acima da média do local $(12,01)$ confirma esta verificação (Figura 3.73).

\begin{tabular}{|c|c|c|c|}
\hline $\begin{array}{l}\text { Integração máxima na } \\
\text { área da atividade }\end{array}$ & $\begin{array}{l}\text { Integração média na } \\
\text { área da atividade }\end{array}$ & $\begin{array}{l}\text { Integração mínima na } \\
\text { área da atividade }\end{array}$ & $\begin{array}{l}\text { Integração do ponto } \\
\text { central - SQN 410 }\end{array}$ \\
\hline 21,71 & 12,01 & 4,73 & 12,97 \\
\hline
\end{tabular}

Figura 3.73 - quadro comparativo entre as medidas de integração máxima, média e mínima da área do ponto de comércio (área quadrada ao redor do ponto com 20m de lado) referente à SQN 410 e do seu ponto central, no que se refere à acessibilidade ao movimento de pedestres. 


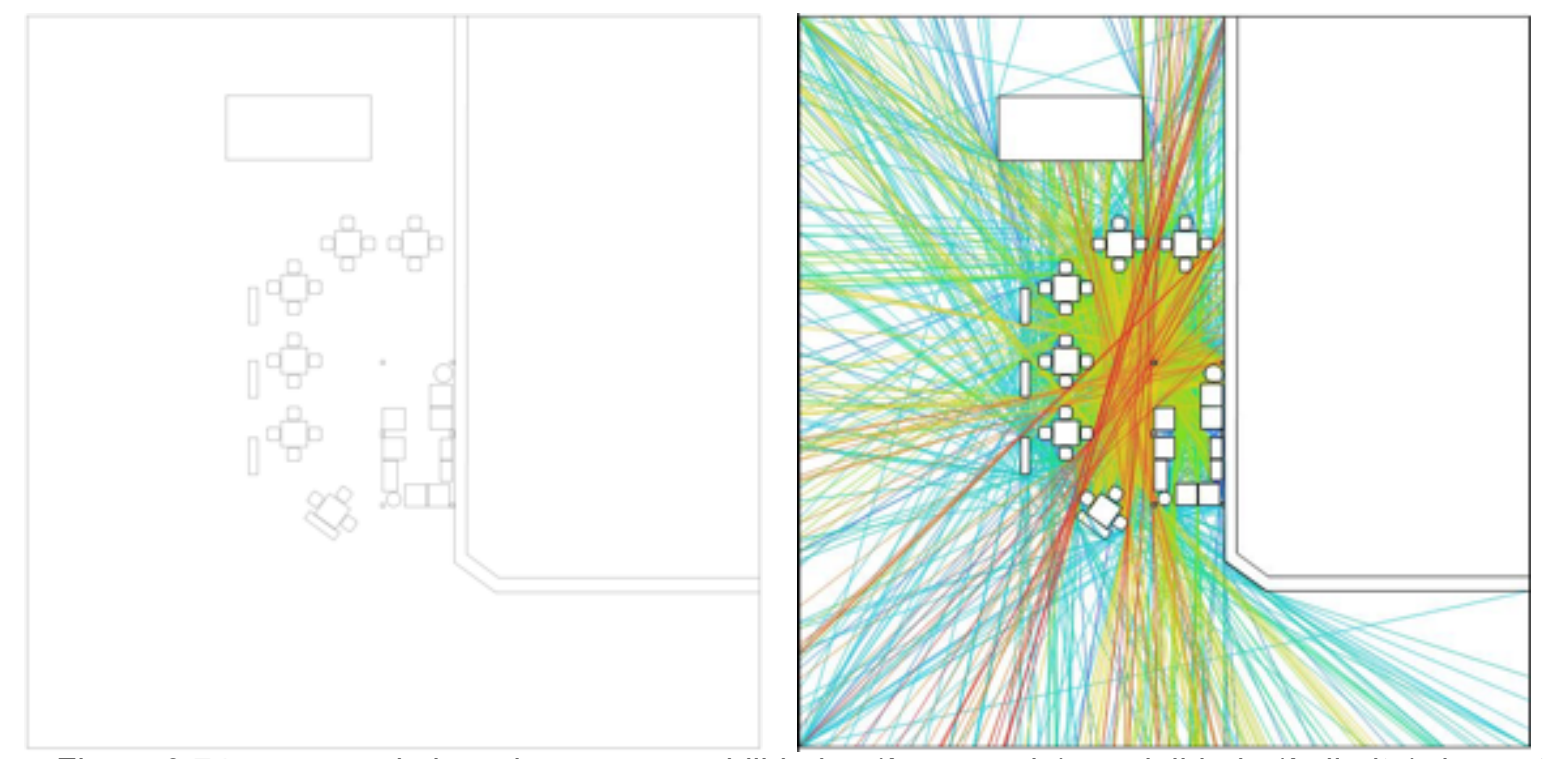

Figura 3.74 - mapas de barreiras e permeabilidades (à esquerda) e axialidade (à direita) do ponto de comércio referente à SQN 410 (máscara quadrada de $20 \mathrm{~m}$ de lado ao redor do ponto).

11) Acessibilidade à visão - conexão visual

A medida de 19,22 do ponto referente à SQN 410 em relação à visão é considerada alta, visto que as medidas de integração visual máxima, média e mínima no contexto imediato ao ponto são 24,74, 16,90 e 5,28, respectivamente (Figura 3.75). Sua posição na coloração laranja do mapa de visibilidade do contexto confirma a medida (Figura 3.76).

\begin{tabular}{|c|c|c|c|}
\hline $\begin{array}{l}\text { Integração visual } \\
\text { máxima no contexto }\end{array}$ & $\begin{array}{l}\text { Integração visual } \\
\text { média no contexto }\end{array}$ & $\begin{array}{l}\text { Integração visual } \\
\text { mínima no contexto }\end{array}$ & $\begin{array}{l}\text { Integração visual no } \\
\text { ponto }- \text { SQN 410 }\end{array}$ \\
\hline 24,74 & 16,90 & 5,28 & 19,22 \\
\hline
\end{tabular}

Figura 3.75 - quadro comparativo entre as medidas de integração visual máxima, média e mínima no contexto imediato (área quadrada ao redor do ponto com $200 \mathrm{~m}$ de lado) e da localização do ponto de comércio referente à SQN 410, no que se refere à acessibilidade à visão. 


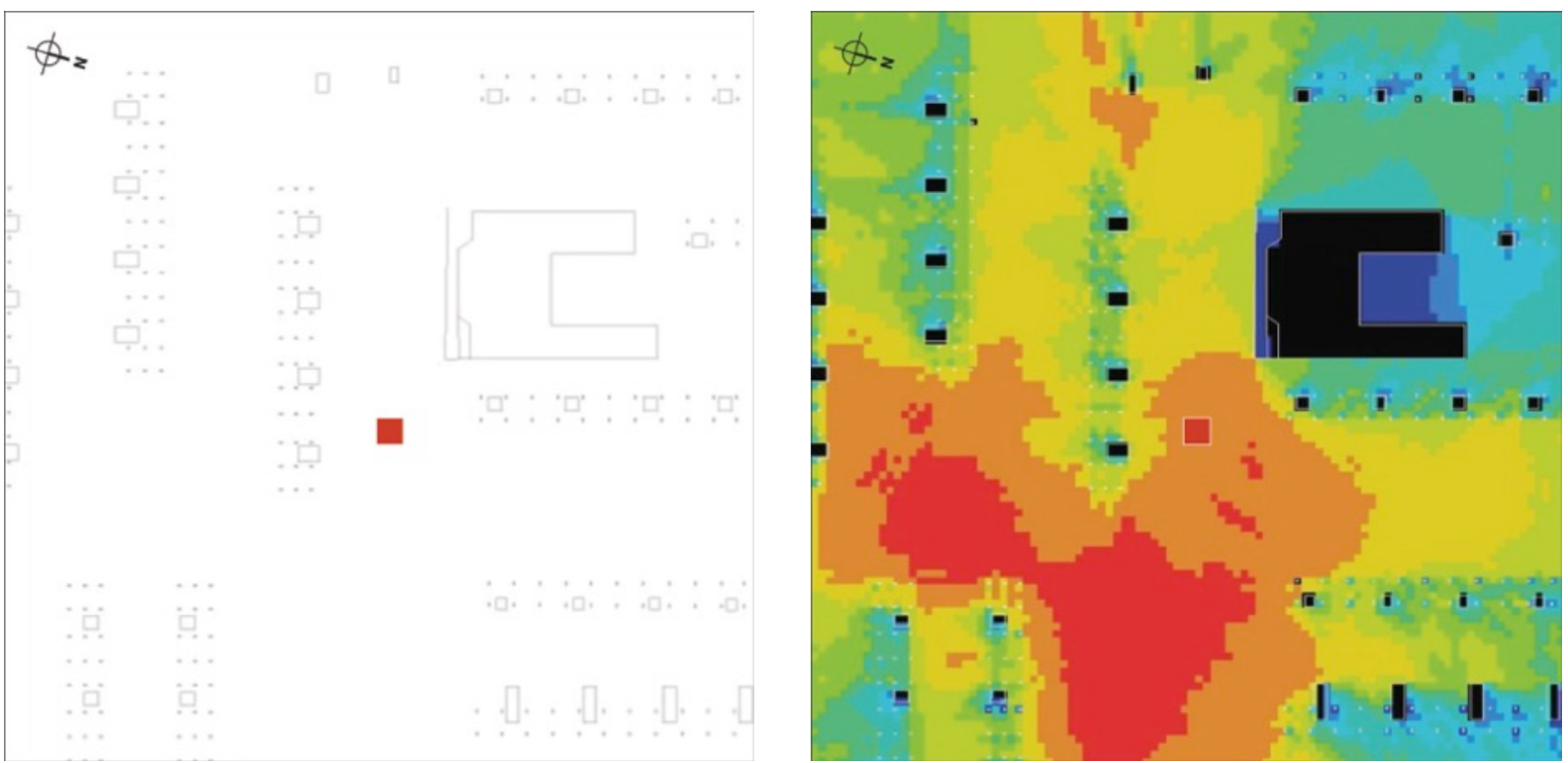

Figura 3.76 - mapas de barreiras e permeabilidades à visão (gerador) (à esquerda) e de visibilidade (à direita) para o ponto - SQN 410.

Como barreiras à visão este ponto possui a kombi permanentemente estacionada próxima à atividade e um toldo que cobre a parte posterior das tendas armadas sobre a área de trabalho do comerciante. A medida de visibilidade do centro desta atividade é de 67,05. Em relação as medidas de integração visual máxima $(90,52)$, média $(56,67)$ e mínima $(10,67)$ no contexto imediato ao ponto, seu grau de visibilidade é considerado médio (Figura 3.77). Esta medida é confirmada pela coloração azul clara do mapa de visibilidade (Figura 3.78).

\begin{tabular}{|c|l|l|l|}
\hline $\begin{array}{l}\text { Integração visual } \\
\text { máxima na área da } \\
\text { atividade }\end{array}$ & $\begin{array}{l}\text { Integração visual } \\
\text { média na área da } \\
\text { atividade }\end{array}$ & $\begin{array}{l}\text { Integração visual } \\
\text { mínima na área da } \\
\text { atividade }\end{array}$ & $\begin{array}{l}\text { Integração visual no } \\
\text { ponto central }- \text { SQN } \\
410\end{array}$ \\
\hline 90,52 & 56,67 & 10,67 & 67,05 \\
\hline
\end{tabular}

Figura 3.77 - quadro comparativo entre as medidas de integração visual máxima, média e mínima na área do ponto de comércio (área quadrada ao redor do ponto com 20m de lado) referente à SQN 410 e do seu ponto central, no que se refere à acessibilidade à visão. 


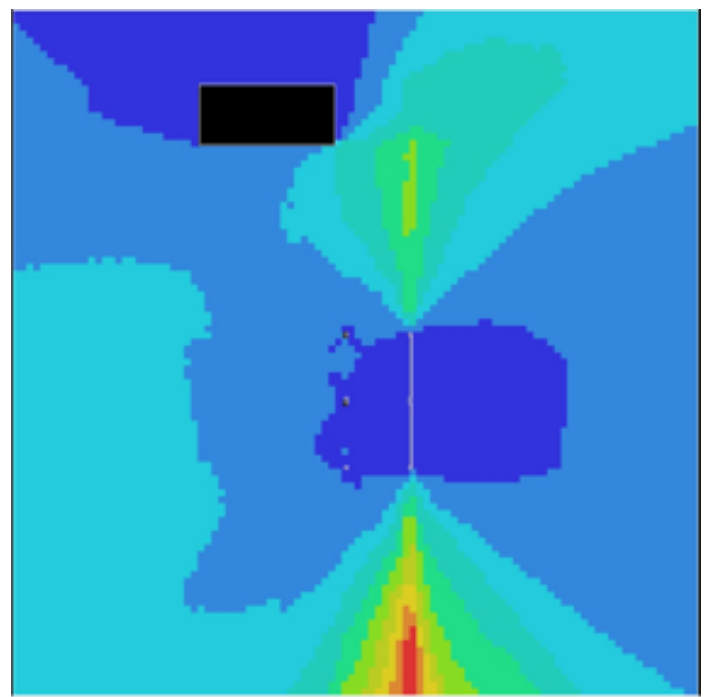

Figura 3.78 - mapas de barreiras e permeabilidades à visão (à esquerda) e de visibilidade (à direita) do ponto de comércio referente à SQN 410 (máscara quadrada de $20 \mathrm{~m}$ de lado ao redor do ponto).

12) Isovistas - campo visual

Os dados de isovistas considerados sobre o ponto de comércio referente à SQN 410, possui as seguintes medidas: área $=20.060 \mathrm{~m}^{2}$; perímetro $=6.438 \mathrm{~m} \mathrm{e}$ compacidade $=0,006$. A área de isovistas deste ponto para o seu contexto é bastante estriada, por isso o valor da medida de compacidade ser tão baixa (Figura 3.79).

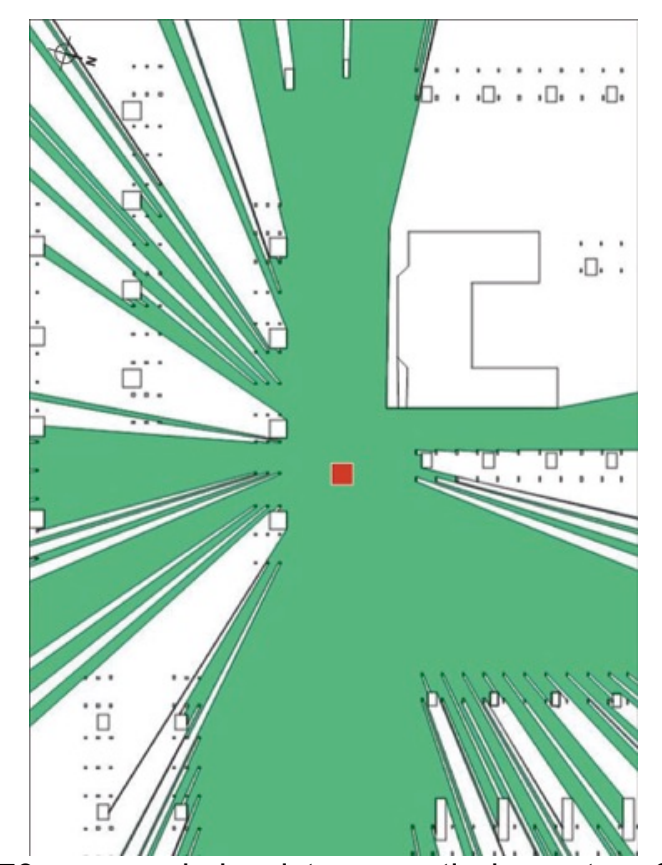

Figura 3.79 - mapa de isovistas a partir do ponto - SQN 410. 
As barreiras à visão são muitas e estão praticamente ao redor de todo o ponto. São formadas por pilotis e colunas de escadas que possuem os blocos das superquadras norte 409 e 410.

13) Condições para permanência - estado de conservação e conforto

As condições para a permanência neste ponto de comércio são consideradas boas. A limpeza é feita pela SLU, além de ser mantida por quem trabalha neste ponto. $O$ calçamento é uniforme e a cerca viva é cuidada pela zeladoria do bloco adjacente ao ponto. Foram colocadas floreiras que cercam todo o local apropriado. Elas recebem manutenção constante por parte do comerciante.

A atividade neste ponto aproveita a iluminação pública principalmente para a parte de atendimento às mesas. Para iluminar o interior da tenda, o comerciante instala um lampião. Sendo um lugar originalmente para passagem de pedestres, não é oferecido nenhum assento. O comerciante providencia mesas e bancos para a permanência de seus clientes no consumo dos caldos (Figura 3.80).

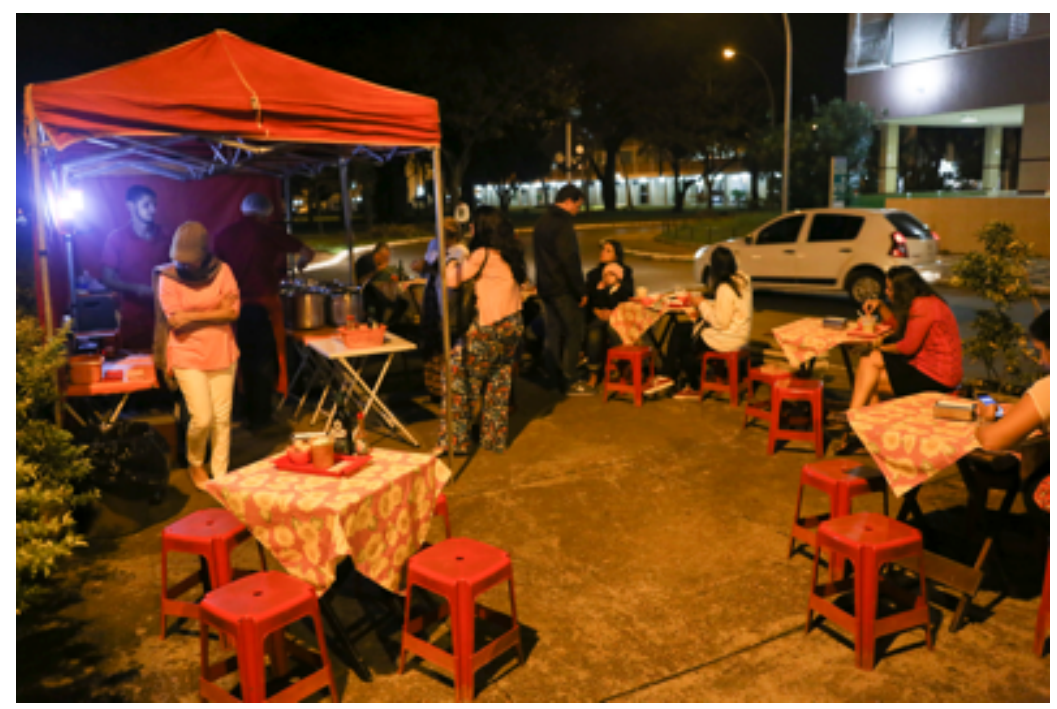




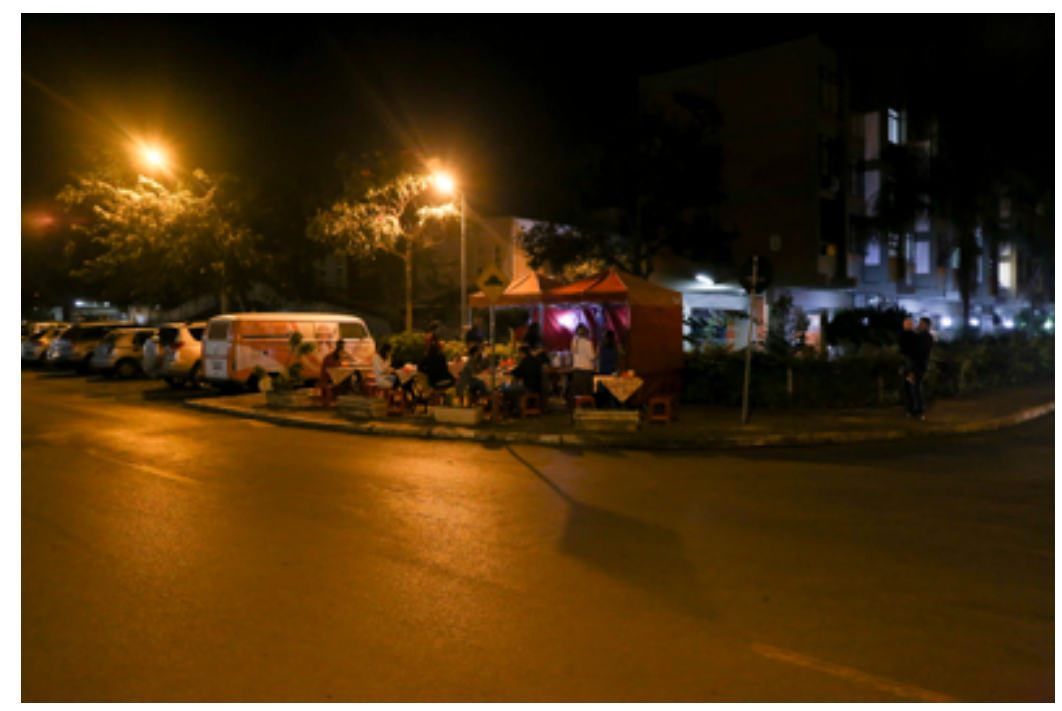

Figura 3.80 - imagens sobre as condições para a permanência no ponto de comércio referente à SQN 410. Fotos: Maya Macario.

14) Atividades ao redor do ponto de comércio

O ponto de comércio referente à SQN 410 tem dentro de seu contexto imediato poucas atividades ao redor: uma igreja, um ponto de táxi, uma banca de jornal e um outro ponto de comércio informal de alimentos. A banca de jornal fica fechada durante o horário de funcionamento do ponto. Nas visitas feitas não foram observados clientes que se deslocaram da igreja para o ponto. O outro ponto de comércio informal vende cachorro quente e, por isso, abrange um outro tipo de cliente. Não foi observada nenhuma interação entre os dois pontos, pois existe um distanciamento físico e de tipos de clientes visível. A atratividade e o sucesso deste ponto de comércio se deve a ele próprio (Figura 3.81). 

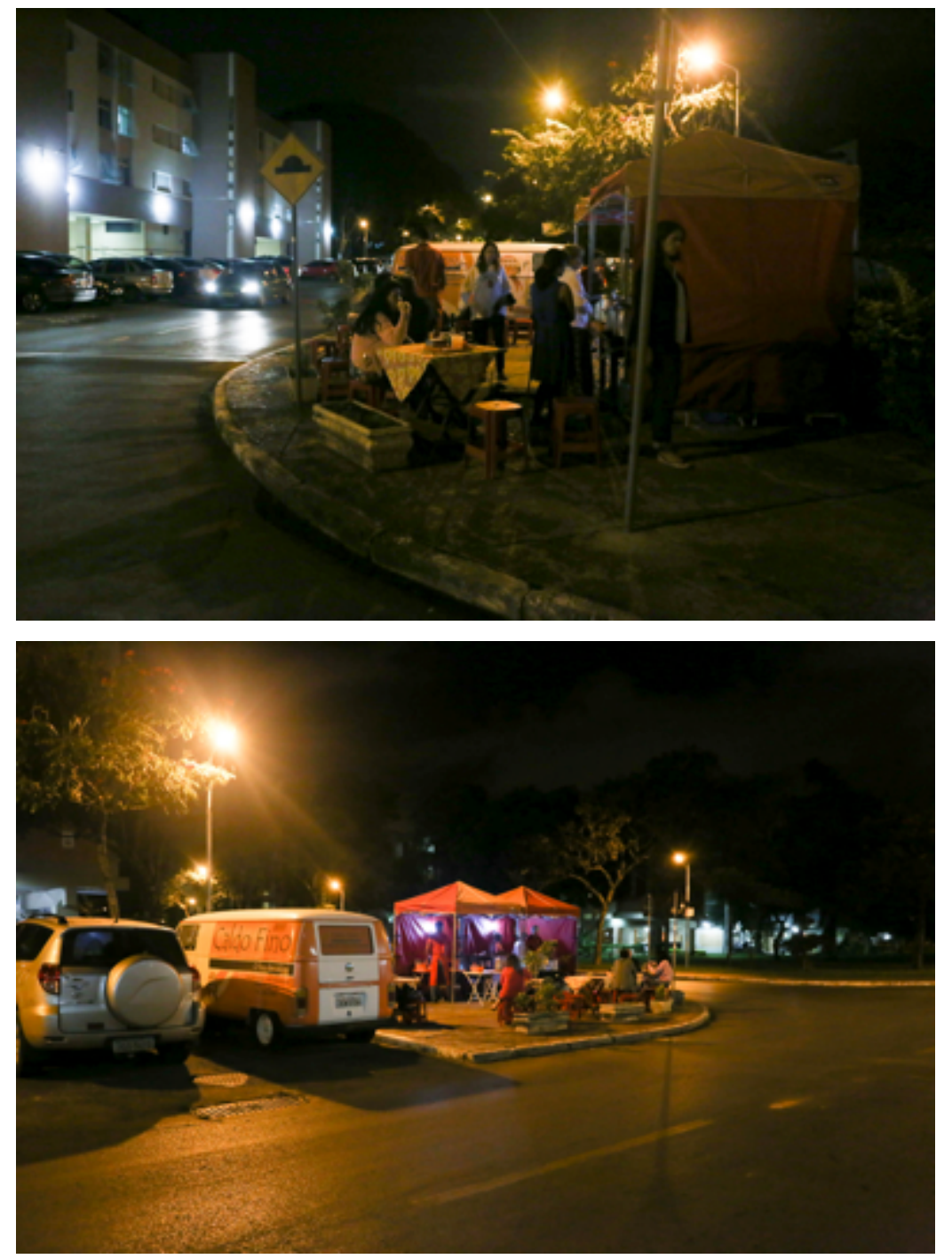

Figura 3.81 - imagens dos arredores do local do ponto de comércio referente à SQN 410 para ilustrar atividades ao redor. Fotos: Maya Macario.

Sistemas de encontros e esquivanças

15) Quantidade de pessoas - passagem e permanência

16) Variedade de pessoas na permanência

No ponto referente à SQN 410 a presença de mulheres também é bastante significativa. Nos dois dias foram contabilizadas 78 mulheres e 47 homens. A presença de adolescentes e jovens é muito baixa e a de idosos e crianças mais alta. Foram contabilizados ao todo 5 idosos, distribuídos equilibradamente entre os gêneros, e 7 crianças. A concentração de pessoas continua sendo, como nos outros pontos de comércio, nas faixas de 20 a 30 e de 30 a 40 anos (Tabelas 3.10, 3.11 e 3.12). 
Tabela $3.10-$ Total pessoas - permanência $=78$ : total - crianças $=2$; total - homens $=32$;

total - mulheres $=44$. Total pessoas - passagem $=73$. Total pessoas $-1^{\circ}$. dia $=151$

\begin{tabular}{|c|c|c|c|c|c|c|c|c|c|}
\hline \multirow{2}{*}{$\begin{array}{l}1^{\circ} . \text { dia } \\
\text { períodos }\end{array}$} & \multirow[t]{2}{*}{ passagem } & \multirow[t]{2}{*}{ gênero } & \multicolumn{6}{|c|}{ faixa etária } & \multirow{2}{*}{$\begin{array}{l}\text { total } \\
\text { gênero }\end{array}$} \\
\hline & & & $A / J$ & $20-30$ & $30-40$ & $40-50$ & $50-60$ & $>60$ & \\
\hline \multirow{2}{*}{$\begin{array}{c}1 \\
c=1\end{array}$} & \multirow[t]{2}{*}{9} & $\mathrm{H}$ & - & 2 & 2 & - & - & - & 4 \\
\hline & & M & - & 10 & 2 & - & - & 1 & 13 \\
\hline \multirow{2}{*}{$c=1$} & \multirow[t]{2}{*}{11} & $\mathrm{H}$ & - & - & 2 & 1 & - & 1 & 4 \\
\hline & & $M$ & - & 4 & 4 & - & 1 & 1 & 10 \\
\hline \multirow[t]{2}{*}{3} & \multirow[t]{2}{*}{17} & $\mathrm{H}$ & 1 & 3 & 3 & - & - & - & 7 \\
\hline & & $M$ & - & 4 & 4 & - & - & - & 8 \\
\hline \multirow[t]{2}{*}{4} & \multirow[t]{2}{*}{18} & $\mathrm{H}$ & - & 3 & 2 & 1 & - & - & 6 \\
\hline & & $M$ & - & 4 & 1 & 2 & - & - & 7 \\
\hline \multirow[t]{2}{*}{5} & \multirow[t]{2}{*}{10} & $\mathrm{H}$ & - & 1 & 2 & - & 2 & - & 5 \\
\hline & & $M$ & - & - & 1 & 2 & 1 & - & 4 \\
\hline \multirow[t]{2}{*}{6} & \multirow[t]{2}{*}{8} & $\mathrm{H}$ & - & 1 & 2 & 1 & 1 & 1 & 6 \\
\hline & & $M$ & - & - & 2 & - & - & - & 2 \\
\hline \multirow{3}{*}{ total } & \multirow[t]{3}{*}{73} & $\mathrm{~T} / \mathrm{H}$ & 1 & 10 & 13 & 3 & 3 & 2 & 32 \\
\hline & & $\mathrm{T} / \mathrm{M}$ & - & 22 & 14 & 4 & 2 & 2 & 44 \\
\hline & & $\mathrm{H}+\mathrm{M}$ & 1 & 32 & 27 & 7 & 5 & 4 & 76 \\
\hline
\end{tabular}

Tabela $3.11-$ Total pessoas - permanência $=54$ : total - crianças $=5$; total - homens $=15$;

total - mulheres $=34$. Total pessoas - passagem $=71$. Total pessoas $-2^{\circ}$. dia $=125$

\begin{tabular}{|c|c|c|c|c|c|c|c|c|c|}
\hline \multirow{2}{*}{$\begin{array}{l}\mathbf{2}^{\circ} . \text { dia } \\
\text { períodos }\end{array}$} & \multirow[t]{2}{*}{ passagem } & \multirow[t]{2}{*}{ gênero } & \multicolumn{6}{|c|}{ faixa etária } & \multirow{2}{*}{$\begin{array}{l}\text { total } \\
\text { gênero }\end{array}$} \\
\hline & & & $A / J$ & $20-30$ & $30-40$ & $40-50$ & $50-60$ & $>60$ & \\
\hline \multirow[t]{2}{*}{1} & \multirow[t]{2}{*}{8} & $\mathrm{H}$ & - & - & - & - & - & - & - \\
\hline & & M & - & 3 & - & - & - & 1 & 4 \\
\hline \multirow{2}{*}{$c=1$} & \multirow[t]{2}{*}{10} & $\mathrm{H}$ & - & - & 1 & - & 1 & - & 2 \\
\hline & & $M$ & - & - & 2 & - & - & - & 2 \\
\hline \multirow{2}{*}{$c=1$} & \multirow[t]{2}{*}{13} & $\mathrm{H}$ & - & 4 & 1 & - & - & - & 5 \\
\hline & & $M$ & - & 3 & 3 & - & - & - & 6 \\
\hline \multirow{2}{*}{$\begin{array}{c}4 \\
c=1\end{array}$} & \multirow[t]{2}{*}{14} & $\mathrm{H}$ & - & 1 & 2 & - & - & - & 3 \\
\hline & & $M$ & - & 5 & 2 & - & - & - & 7 \\
\hline \multirow{2}{*}{$\begin{array}{c}5 \\
c=2\end{array}$} & \multirow[t]{2}{*}{13} & $\mathrm{H}$ & - & 1 & - & 1 & - & - & 2 \\
\hline & & $M$ & 1 & 3 & 5 & - & - & - & 9 \\
\hline \multirow[t]{2}{*}{6} & \multirow[t]{2}{*}{13} & $\mathrm{H}$ & - & - & 3 & - & - & - & 3 \\
\hline & & $\mathrm{M}$ & - & 2 & 4 & - & - & - & 6 \\
\hline \multirow{3}{*}{ total } & \multirow[t]{3}{*}{71} & $T / H$ & - & 6 & 7 & 1 & 1 & - & 15 \\
\hline & & $T / M$ & 1 & 16 & 16 & - & - & 1 & 34 \\
\hline & & $\mathrm{H}+\mathrm{M}$ & 1 & 22 & 23 & 1 & 1 & 1 & 49 \\
\hline
\end{tabular}

Tabela $3.12-$ Total pessoas - permanência $=132$ : total - crianças $=7$; total - homens $=47$;

total - mulheres $=78$. Total pessoas - passagem $=144$. TOTAL DE PESSOAS - SQN $=276$

\begin{tabular}{|c|c|c|c|c|c|c|c|c|c|}
\hline \multirow{6}{*}{$\begin{array}{c}1^{\circ} \text {. dia } \\
+ \\
2^{\circ} \text {. dia }\end{array}$} & \multirow[t]{2}{*}{ passagem } & \multirow[t]{2}{*}{ gênero } & \multicolumn{6}{|c|}{ faixa etária } & \multirow{2}{*}{$\begin{array}{l}\text { total } \\
\text { gênero }\end{array}$} \\
\hline & & & $\mathrm{A} / \mathrm{J}$ & $20-30$ & $30-40$ & $40-50$ & $50-60$ & $>60$ & \\
\hline & \multirow{4}{*}{144} & $\mathrm{H}$ & 1 & 16 & 20 & 4 & 4 & 2 & 47 \\
\hline & & $M$ & 1 & 38 & 30 & 4 & 2 & 3 & 78 \\
\hline & & $\mathrm{H}+\mathrm{M}$ & 2 & 54 & 50 & 8 & 6 & 5 & 125 \\
\hline & & criança & & & & 7 & & & \\
\hline
\end{tabular}


17) Distribuição de pessoas no tempo e no espaço

Apesar de um número considerável de elementos físicos delimitando os espaços convexos do ponto de comércio referente à SQN 410, o arranjo é bem regular e fechado. A composição restringe o uso do espaço apropriado a quem lá permanece para consumo ou somente a compra do caldo para levar. A passagem de pedestres é dificultada com a disposição das floreiras e mesas no contorno da esquina em que se encontra o ponto (Figura 3.82).

Por formar quase um "recinto" fechado e disponibilizar um número considerável de assentos para a permanência e consumo dos caldos, a composição deste ponto leva a uma distribuição bem definida das pessoas e concentrada nos limites dos espaços convexos delimitados pelos elementos físicos da atividade. No interior das tendas ficam os assistentes do comerciante (os vendedores, conforme as legendas da Figura 3.83), preparando os caldos e servindo quem compra para viagem, que fica em pé em frente às tendas. Sentados às mesas ficam aqueles que consomem os caldos no local. Os vendedores se deslocam até as mesas para o atendimento a quem permanece. O comportamento da clientela deste ponto se assemelha ao de um restaurante pequeno.

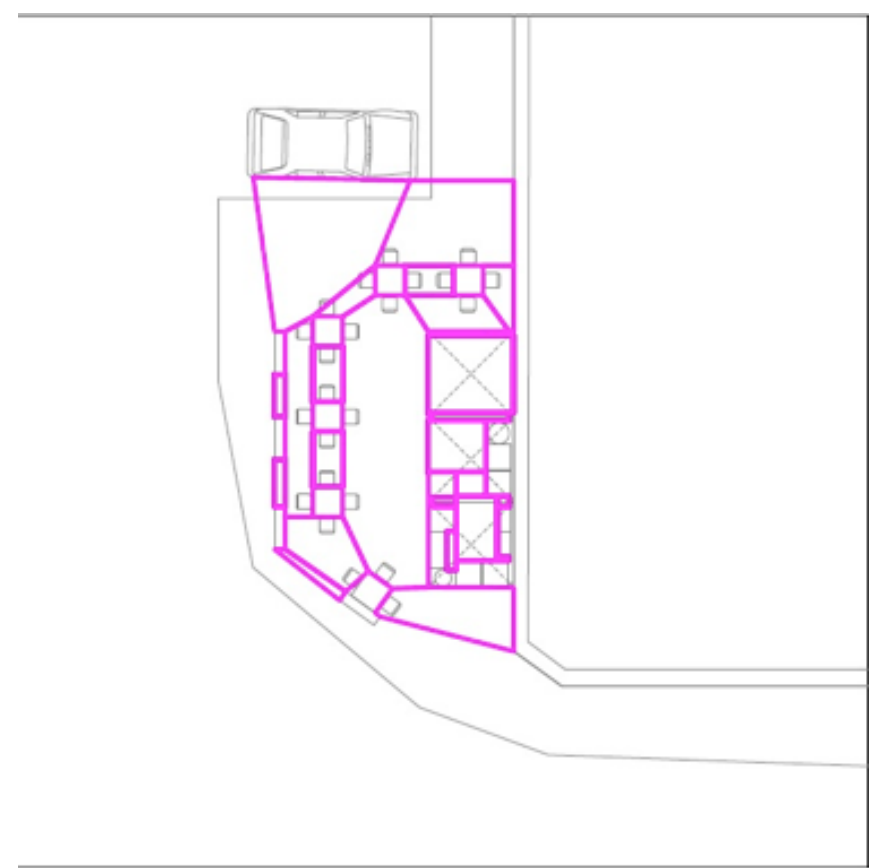

Figura 3.82 - mapa de espaço convexo determinado pelos elementos físicos com a arquitetura do ponto de comércio referente à SQN 209. 


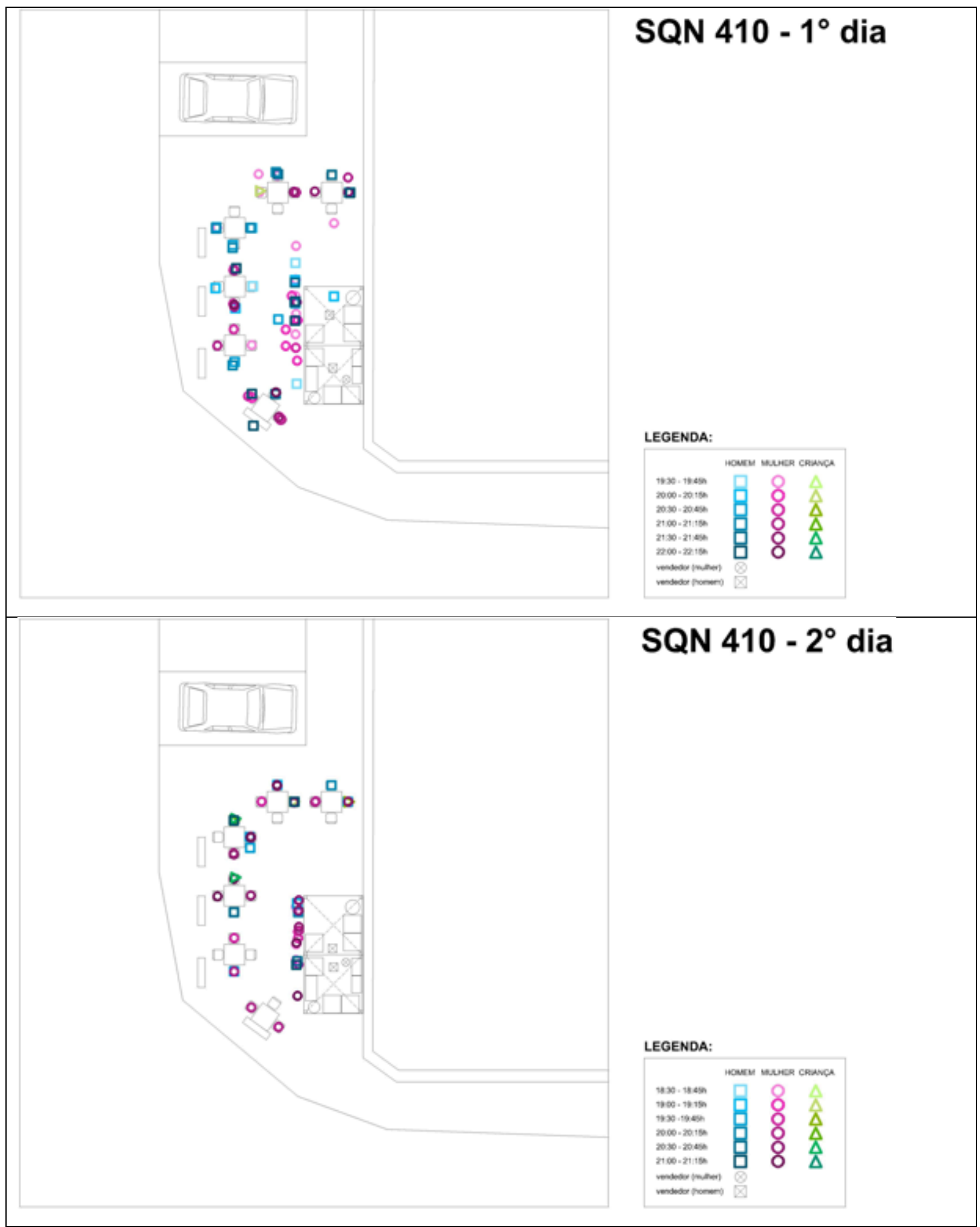

Figura 3.83 - mapas comportamentais sobre a distribuição de pessoas no ponto de comércio referente à SQN 410, nos dois dias observados. 
Sistema de Elementos Físicos - SEF

18) Complexidade

\section{Descrição}

Os 12 elementos físicos envolvidos na atividade do ponto de comércio referente à SQN 410 (Figura 3.84) são:

. elementos portados -23 bancos, 6 mesas médias, 2 tendas, botijão de gás, 7 mesas pequenas, lixeira;

. elementos do local - cerca viva, 5 floreiras, kombi.

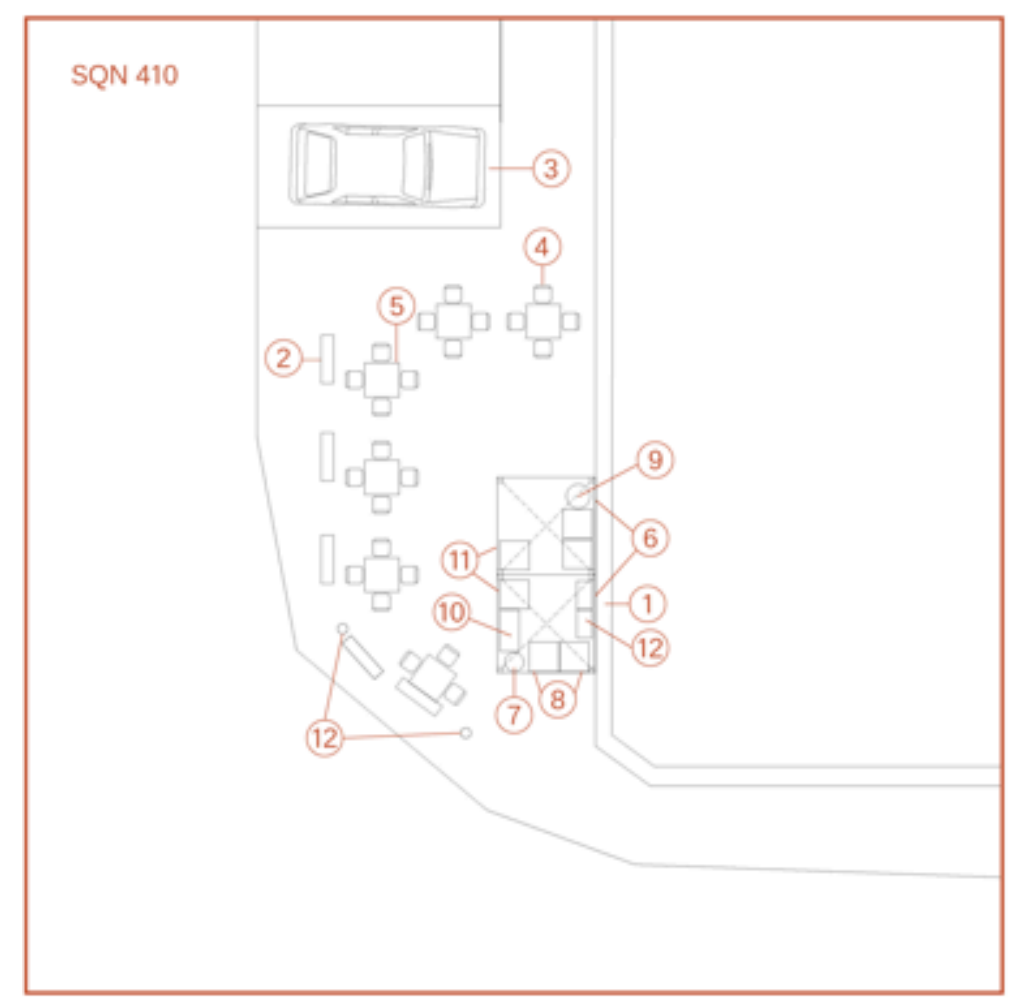

(1) cerca viva

(2) floreiras (5)

(3) kombi para o ponto

(4) bancos (23)

(5) mesas para clientes (6)

(6) tendas (2)

(7) botijão de gás

(8) mesas auxiliares (4)

(9) lixeira

(10) mesa / fogareiro

(11) mesas para panelas / exposiçăo (2)

(12) postes de sinalização

Figura 3.84 - planta baixa do ponto de comércio referente à SQN 410, com a especificação dos elementos físicos envolvidos na atividade.

Função dos elementos e suas relações

Os elementos descritos acima têm em comum o atendimento ao comércio de caldos. Eles compõem um ambiente bem definido e fechado na parte inicial da SQN 410. As floreiras, além de ornamentais, têm a função de delimitar o espaço do ponto, em uma composição que acompanha o desenho da esquina, em que ele está. Do local, 
a cerca viva foi aproveitada para delimitar o espaço, do lado oposto às floreiras. Ela funciona como uma parede em que são encostadas as tendas que abrigam os assistentes do comerciante. A terceira e última delimitação deste espaço fica por conta da kombi estacionada de modo transversal à cerca viva e, consequentemente, às tendas. Nela é guardado o material envolvido no ponto de comércio em funcionamento, como mesas dobráveis e bancos de plástico empilháveis (Figura 3.85-c). Mesas e bancos são utilizados para o atendimento aos clientes. Outras mesas servem de apoio ao trabalho executado embaixo das tendas, bem como um botijão de gás, uma lixeira e alguns engradados ou estantes de plástico.

19) Aspectos funcionais - relações entre elementos físicos e as práticas

Uma hora antes da chegada dos caldos, o ponto é montado pelos funcionários de Renato. O preparo dos caldos, inicialmente, era feito na casa de Renato. Depois que abriu o restaurante, passou a prepará-los lá. Renato não vai ao ponto com frequência mas monitora toda a sua movimentação por telefone, de segunda a sexta-feira. Nas noites em que foi observado, muitos carros estacionaram próximo ao ponto para que os clientes comprassem o caldo "para viagem", ou para que comessem no local, mesmo. Pessoas da vizinhança compraram e foram comer no pilotis de seus próprios blocos. Assim como o comércio de espetos de churrasco, o 'Caldo Fino' serve, geralmente, àqueles que saem do trabalho, ou pessoas com ou sem crianças, fazendo a refeição noturna.

O atendimento é bastante similar ao de um restaurante, pois disponibiliza mesas e cadeiras em número considerável para as pessoas permanecerem no local. Embaixo das tendas ficam os atendentes que se deslocam com alguma frequência entre as mesas para levar os caldos para quem permanece (Figura 3.85-a). Na parte frontal de uma das tendas fica um fogão de duas bocas, com o botijão ao lado para o aquecimento dos caldos, que já chegam prontos ao ponto (Figura 3.85-b). As panelas que não estão em aquecimento ficam expostas, lado a lado, para que os atendentes possam servir aos clientes (Figura 3.85-d). Estas grandes panelas são transportadas por um veículo do restaurante do comerciante. Ainda sob as tendas, são guardados os acessórios para servir os caldos com acompanhamentos e a lixeira (Figura 3.85-e). 
Sob as tendas somente os atendentes podem ficar. É raro um cliente adentrar este recinto. Entre as mesas e as tendas, transitam atendentes, clientes que permanecem e aqueles que somente compram para viagem. Estes últimos se colocam em frente às tendas, pedem, recebem, pagam e dali vão embora. São, então, três camadas distintas de trânsito neste espaço, delimitadas pelos elementos físicos, basicamente (Figura 3.85-f).

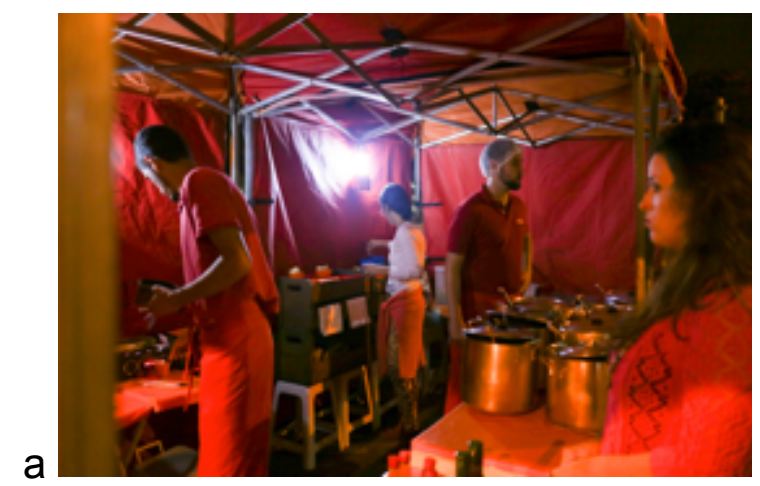

a

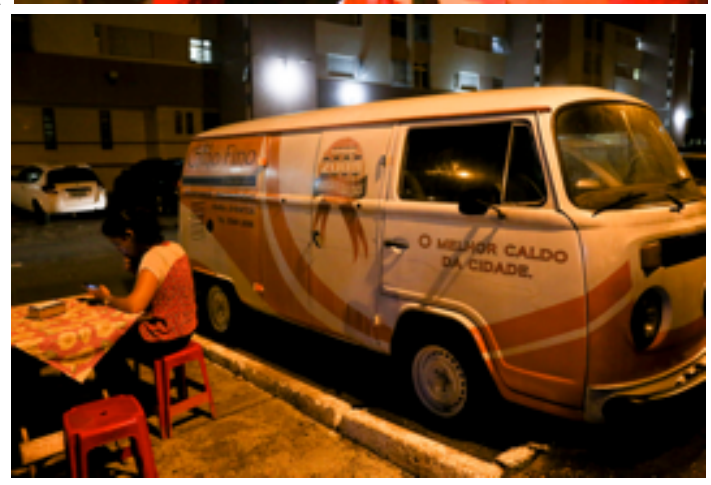

b
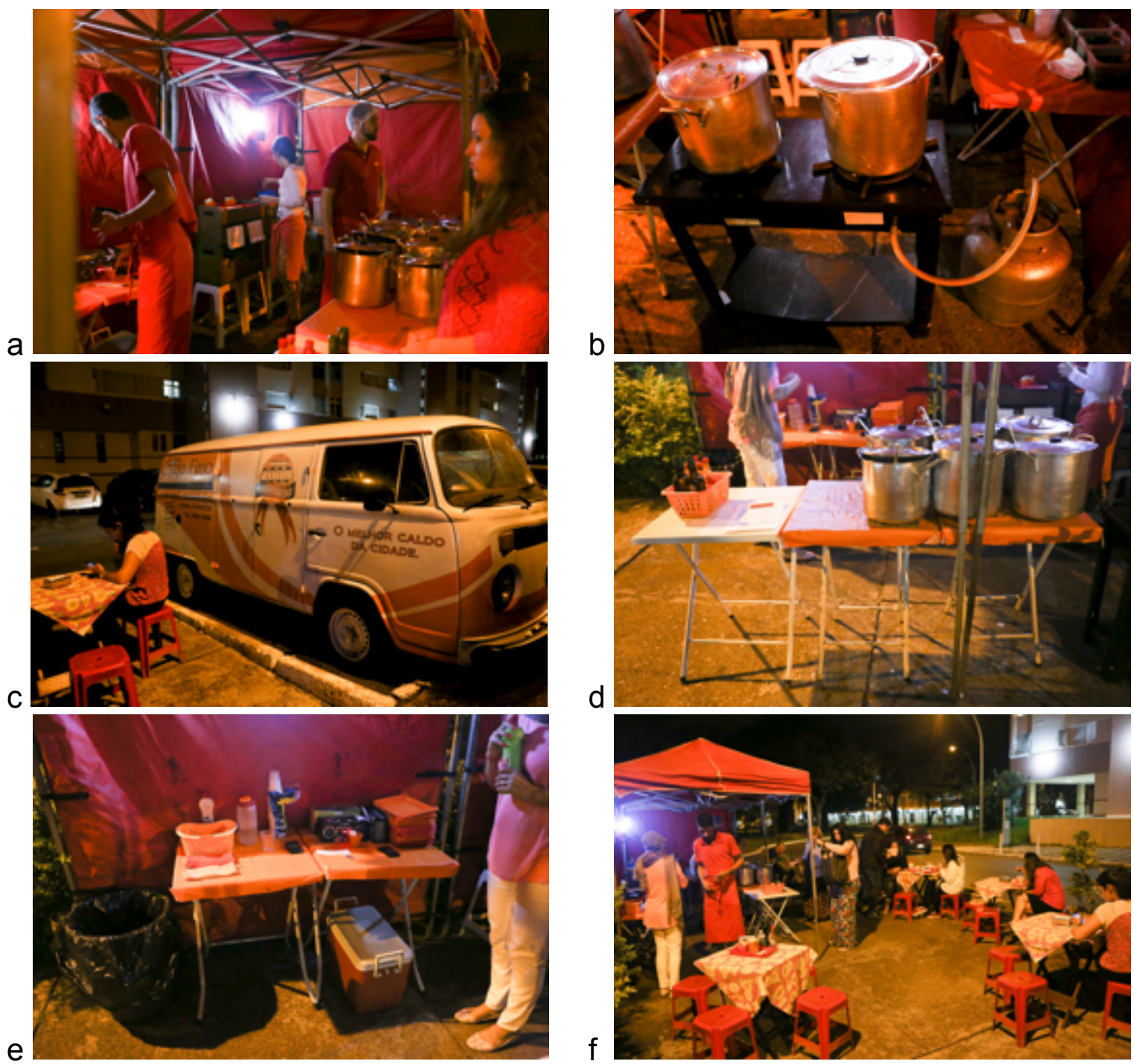

Figura 3.85 - imagens dos elementos físicos na atividade do ponto de comércio referente à SQN 410. Fotos: Maya Macario. 


\subsubsection{Análise do ponto como um sistema - SQN 410}

\section{Padrões Espaciais + Características Socioeconômicas}

São atributos do espaço (contexto e atividade) deste ponto de comércio: ambiência física média, com $3.121 \mathrm{~m}^{2}$ de área convexa (a terceira maior de seu contexto); acessibilidade alta ao movimento motorizado; acessibilidade mediana ao movimento de pedestres nos espaços do contexto imediato e da atividade; conexão visual alta no contexto e média na área da atividade; campo visual com área que extrapola a do espaço convexo em que o ponto se encontra, mas com baixa compacidade; boas condições de conservação e conforto e proximidade com outras atividades sem relevância. Este espaço reúne características favoráveis à atividade de comércio informal, que é bem aproveitada tanto pelo comerciante como por seus clientes, que fazem parte das classes média-média e média alta dos arredores e de toda a Asa Norte, pelo menos. A facilidade de acesso motorizado e lugares próximos para estacionar permite que pessoas de lugares diversos cheguem ao ponto da superquadra referência. O local é passagem para quem não consome os caldos (provavelmente os de classe média baixa ou baixa), mas que confere ao espaço possibilidade de boa circulação de pessoas.

\section{Padrões Espaciais + Sistema de Encontros e Esquivanças}

Nos dois dias de contagem, foram 276 pessoas ao todo que passaram (144) ou permaneceram (132) no ponto. Estes números revelam o potencial de urbanidade do contexto e da área da atividade, em quase todos os atributos de configuração e condições para permanência.

\section{Padrões Espaciais + Sistema de Elementos Físicos}

A composição dos elementos físicos acompanha a configuração da esquina em que se encontra o ponto. A curva da esquina é contornada internamente pelas floreiras e pelas mesas com os bancos. As tendas com fundo potencializam a função da cerca viva, que é uma barreira ao movimento e se torna, assim, barreira à visão, também. Por isso, o potencial do espaço do contexto é bem aproveitado e acompanhado pela 
atividade, que é bastante concentrada no espaço da esquina. A Figura 3.86 mostra a interface bem definida entre atividade e contexto e entre clientes e atendentes pela disposição dos elementos físicos.

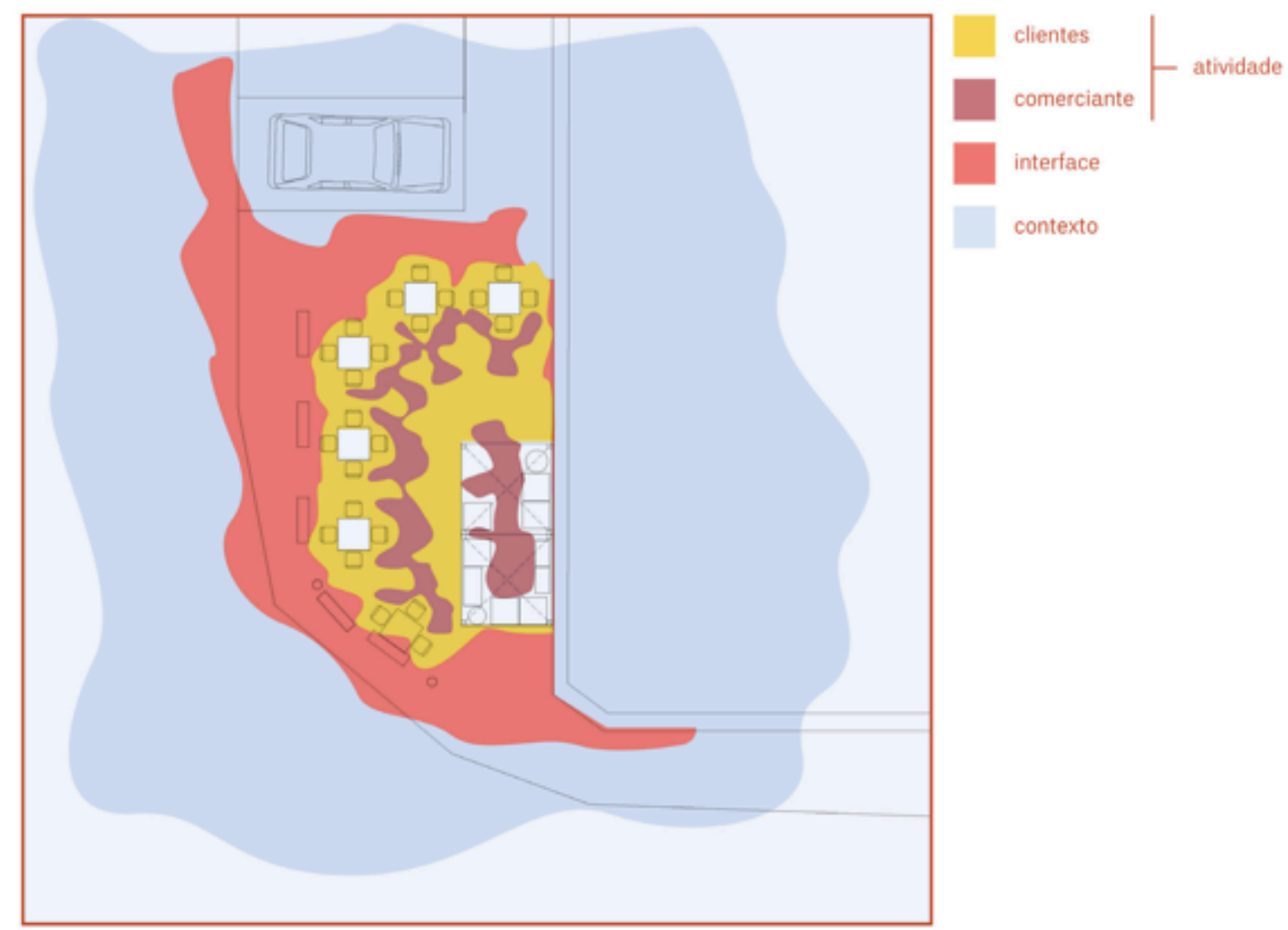

Figura 3.86 - planta baixa do ponto de comércio referente à SQN 410 com identificação dos espaços da atividade (clientes e comerciante), da interface (passantes) e do contexto.

\section{Sistema de Elementos Físicos + Características Socioeconômicas}

O número de elementos físicos disponibilizados no local são 3 , sendo 2 deles providenciados pelo comerciante (as floreiras e a kombi). A quantidade de elementos montados diariamente é grande, o que evidencia a possibilidade por parte do comerciante em prover seu negócio com tal estrutura. A composição mais formal escolhida, semelhante a de um restaurante, e o seu sucesso entre os clientes confirma a posição dos que frequentam o ponto nas classes sociais detectadas: média-média e média alta. 
O arranjo dos elementos portados com os disponibilizados no local, além de fechar um recinto, define bem a destinação dos espaços formados para atendentes, clientes que permanecem e clientes que compram para viagem. Ademais, esta composição restringe o acesso ao seu interior aos que por ali somente passam. As pessoas contabilizadas nos dois dias se alternaram de modo equilibrado entre passantes e consumidores e estes se posicionaram nas duas possibilidades dentro da área da atividade: às mesas ou em frente às tendas.

\section{Características Socioeconômicas + Sistema de Encontros e Esquivanças}

O comportamento no espaço da atividade dos que permanecem e passam por este ponto de comércio revela bem as características socioeconômicas tanto do comerciante como de seus clientes de uma tendência a privilegiar os aspectos funcionais da atividade à urbanidade daquele lugar no espaço urbano em questão.

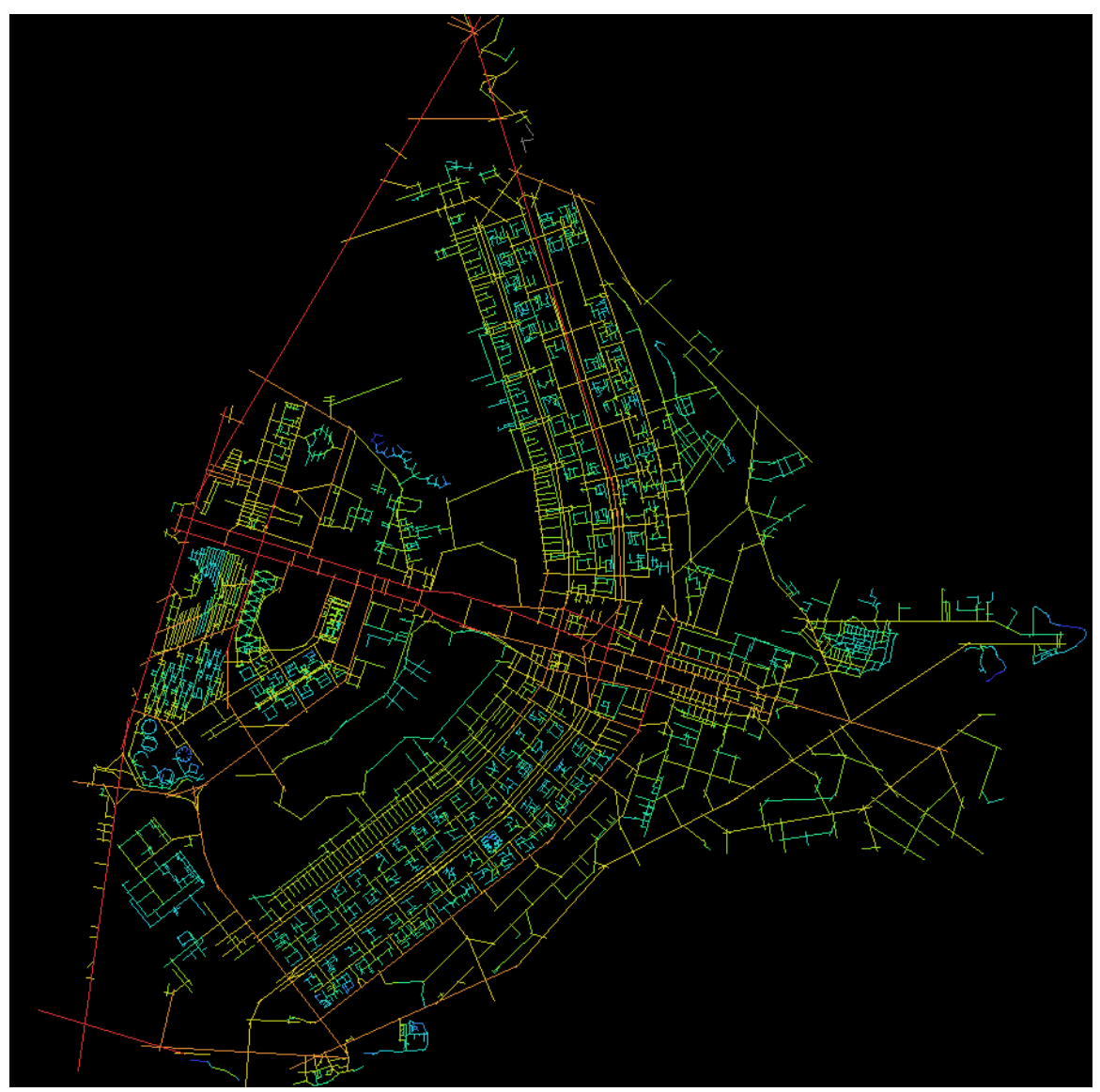

Figura 3.87 - mapa axial do Plano Piloto, Integração global (Rn). Fonte: Grupo DIMPU. 


\section{Conclusão do capítulo}

Os quatro pontos escolhidos, observados e analisados representam satisfatoriamente as categorias da tipologia de incidência de apropriação de lugares levantada.

Verifiquei que os horários de funcionamento dos quatro pontos condizem com a rotina de entrada e saída de trabalho e escola. Este aspecto é bem característico das práticas cotidianas não somente desta região do Plano Piloto, mas de toda e qualquer cidade. Este e outros aspectos demonstram a intensidade do uso do espaço urbano na vida social da região observada.

A escolha dos quatro estudos de casos não previu a coincidência da abordagem de dois deles serem de propriedade de moradores da própria quadra em que instalaram seus pontos, e os outros dois morarem fora do Plano Piloto. Isso possibilitou a análise da atividade e a composição dos respectivos elementos sob o ponto de vista de deslocamento e operacionalidade. Houve, também, a variabilidade em termos de gênero e grau de escolaridade, o que mostra os matizes entre as classes sociais praticando a mesma atividade no espaço urbano. Outra variabilidade encontrada foi em relação a ocorrência dos dias dos pontos na semana: três deles atendem os "dias úteis" e um o final de semana (o ponto da tapioca/Solange).

No capítulo 4, os estudos de caso serão comparados dentro de cada variável apresentada aqui. Por meio da comparação é possível detectar as diferenças entre eles e a partir delas, especificar os aspectos a serem considerados em projetos para o espaço urbano, ou melhor, detectar o conjunto de ensinamentos que as experiências dos pontos de comércio observados nos transmitem. 


\section{4 | ANÁLISE do TRABALHO dE CAMPO}

Os pontos de comércio observados foram descritos no capítulo 3 com relação às características socioeconômicas dos comerciantes e clientes, ao sistema dos elementos envolvidos na atividade, aos aspectos de configuração física dos lugares apropriados e ao sistema de encontros das pessoas no contexto imediato e no local de cada ponto. A partir disso, foi possível proceder com uma análise prévia de cada ponto como um sistema, considerando estes níveis de análise como elementos de entrada.

Neste capítulo, dou prosseguimento à análise do trabalho de campo com a comparação entre os pontos de comércio estudados, por meio dos atributos de análise. Com isso, busco reunir as diferenças entre eles que são encaradas aqui como possibilidades de apropriação e uso do espaço urbano por esta atividade. Essas diferenças, por sua vez, nos levam aos ensinamentos que as práticas desses comerciantes e clientes, consequentemente, nos dão sobre o aproveitamento do potencial da configuração física dos lugares conjugada a da composição dos elementos físicos envolvidos.

Ainda no âmbito de cada nível analítico, quando da comparação entre os pontos de comércio, busco fazer um balanço do trabalho de campo, no que tange à utilidade $e$ ao funcionamento das variáveis e ferramentas utilizadas.

\subsection{Análise comparativa entre os pontos de comércio observados}

Neste item, então, além de comparar a variabilidade dos atributos, o propósito com esta parte da análise é a verificação, lado a lado, de possibilidades diferentes de morfologia, apropriação e comportamento espaciais, além da composição material, apresentados nos quatro estudos de caso. 


\subsubsection{Características socioeconômicas}

As variáveis utilizadas neste nível foram escolhidas e organizadas com o intuito de conhecer o comerciante - o agente da indisciplina - de modo geral e com relação ao próprio negócio. Na aplicação destas variáveis, houve uma complementaridade entre elas no entendimento deste comerciante com relação à sua atividade, seu público e o cotidiano do lugar apropriado.

Os dados sobre as variáveis: 'apresentação geral', 'moradia e modo de deslocamento', 'única ocupação remunerada e dias de atividade' e 'renda com a atividade' informaram basicamente sobre o segmento social em que o comerciante entrevistado está inserido.

Com a variável 'razão pela escolha do lugar' busquei saber se havia alguma motivação de cunho espacial na sua escolha, isto é, se os atributos do espaço em questão o levaram àquela determinada escolha. Muito sutil quanto a esse aspecto foi a resposta de uma das comerciantes. As outras três respostas não auxiliaram muito na interconexão que eu buscava entre a motivação para a escolha e os padrões espaciais que detectaria em seguida. Muito subjetivas e pouco indicativas da escolha as respostas a esta pergunta/variável não acrescentaram muito na análise deste nível analítico.

Por meio das duas últimas variáveis deste nível - 'público cliente' e 'dados censitários sobre moradores' foi possível recolher informações básicas sobre o público frequentador e sobre os moradores da área do contexto imediato ao ponto, quanto à classe social e costumes no cotidiano do lugar. Essas informações foram tão gerais que foi necessário complementar com observações feitas nas diversas visitas a cada ponto.

De modo geral, as variáveis apresentadas na Tabela 4.1 possibilitaram que as primeiras abordagens aos pontos fossem eficazes no conhecimento dos traços socioeconômicos dos agentes envolvidos na atividade do comércio informal de alimentos, na região residencial estudada. 
Tabela 4.1 - resumo comparativo dos dados dos quatro pontos de comércio observados sobre Características socioeconômicas.

\begin{tabular}{|c|c|c|c|c|}
\hline \multirow[t]{2}{*}{ Variáveis } & \multicolumn{4}{|c|}{ Pontos de comércio } \\
\hline & SQN 408 & SQN 209 & SQN 113 & SQN 410 \\
\hline $\begin{array}{l}1 \text { - Apresentação } \\
\text { geral }\end{array}$ & $\begin{array}{l}\text { Homem; 40-50 } \\
\text { anos; } \\
\text { piauiense; } \\
\text { ensino fundam. } \\
\text { incompleto }\end{array}$ & $\begin{array}{l}\text { Mulher; } 50-60 \\
\text { anos; mineira; } \\
\text { ensino fundam. } \\
\text { incompleto }\end{array}$ & $\begin{array}{l}\text { Mulher; } 40-50 \\
\text { anos; } \\
\text { cearense; } \\
\text { ensino médio }\end{array}$ & $\begin{array}{l}\text { Homem; 40-50 } \\
\text { anos; carioca; } \\
\text { ensino superior }\end{array}$ \\
\hline $\begin{array}{l}2 \text { - Local de } \\
\text { moradia e modo } \\
\text { de deslocamento }\end{array}$ & $\begin{array}{l}\text { Planaltina; } \\
\text { carro (pick up) }\end{array}$ & $\begin{array}{l}\text { Planaltina; } \\
\text { carro (táxi do } \\
\text { filho) ou ônibus }\end{array}$ & $\begin{array}{l}\text { SQN 113; } \\
\text { caminhada }\end{array}$ & $\begin{array}{l}\text { SQN 410; } \\
\text { carro } \\
\text { (multivan) }\end{array}$ \\
\hline $\begin{array}{l}3 \text { - Única } \\
\text { ocupação } \\
\text { remunerada? } \\
\text { Dias de atividade }\end{array}$ & $\begin{array}{l}\text { Sim. } \\
2^{a} \text {. a } 6^{a} . \text { feira }\end{array}$ & $\begin{array}{l}\text { Não. } \\
2^{a} \text {. a } 6^{a} \text {. feira }\end{array}$ & $\begin{array}{l}\text { Sim. } \\
5^{\mathrm{a}} . \text { a sábado }\end{array}$ & $\begin{array}{l}\text { Não. } \\
2^{a} \text {. a } 6^{a} \text {. feira }\end{array}$ \\
\hline $\begin{array}{l}4 \text { - Renda com a } \\
\text { atividade }\end{array}$ & $\begin{array}{l}\text { Em torno de } \\
\mathrm{R} \$ 5.000,00\end{array}$ & $\begin{array}{l}\text { Em torno de } \\
\mathrm{R} \$ 2.000,00\end{array}$ & Não informado & Não informado \\
\hline $\begin{array}{l}5 \text { - Razão pela } \\
\text { escolha do lugar }\end{array}$ & $\begin{array}{l}\text { Fluxo de } \\
\text { pedestres } \\
\text { originalmente e } \\
\text { herança. }\end{array}$ & $\begin{array}{l}\text { Fluxo de } \\
\text { pedestres } \\
\text { originalmente e } \\
\text { herança. }\end{array}$ & $\begin{array}{l}\text { Maior espaço, } \\
\text { mais visível e } \\
\text { perto de casa. }\end{array}$ & $\begin{array}{l}\text { Lugar bonito, } \\
\text { visível e perto } \\
\text { de casa. }\end{array}$ \\
\hline 6 - Público cliente & $\begin{array}{l}\text { diverso: } \\
\text { funcionários de } \\
\text { instituições L2 } \\
\text { e comércio } \\
\text { formal, } \\
\text { moradores e } \\
\text { outros }\end{array}$ & $\begin{array}{l}\text { diaristas; } \\
\text { funcionários de } \\
\text { equipamentos } \\
\text { (escolas e } \\
\text { posto de } \\
\text { saúde) e do } \\
\text { comércio local } \\
\text { próximo }\end{array}$ & $\begin{array}{l}\text { moradores da } \\
\text { própria } \\
\text { superquadra e } \\
\text { de } \\
\text { superquadras } \\
\text { vizinhas, } \\
\text { convidados } \\
\text { dos moradores }\end{array}$ & $\begin{array}{l}\text { diverso: } \\
\text { moradores e } \\
\text { pessoas de } \\
\text { todo o Plano } \\
\text { Piloto entre os } \\
\text { três níveis da } \\
\text { classe média }\end{array}$ \\
\hline $\begin{array}{l}7 \text { - Dados } \\
\text { censitários dos } \\
\text { moradores }\end{array}$ & $\begin{array}{l}\text { predomina } \\
\text { classe média- } \\
\text { média }\end{array}$ & $\begin{array}{l}\text { predomina } \\
\text { ricos e classe } \\
\text { média-média }\end{array}$ & $\begin{array}{l}\text { predomina } \\
\text { classe média- } \\
\text { média }\end{array}$ & $\begin{array}{l}\text { predomina } \\
\text { classe média- } \\
\text { média }\end{array}$ \\
\hline
\end{tabular}

1) Apresentação geral: gênero; faixa etária, naturalidade e grau de instrução

A diversidade de gênero das pessoas envolvidas com este tipo de atividade no espaço urbano está bem representada neste estudo, pois entre os quatro pontos de comércio observados, dois têm mulheres como empreendedoras. Com exceção de uma delas, a faixa etária dos comerciantes entrevistados é entre 40 e 50 anos, fase ativa em termos de produtividade, que carrega certa experiência nesta e em outras atividades que a antecederam ou lhe são concomitantes.

Nenhum dos comerciantes em questão é natural de Brasília: alguns vieram quando crianças com suas famílias, outros chegaram com mais idade para tentar uma vida melhor na capital. Quanto ao grau de instrução, neste pequeno grupo temos dois 
comerciantes com ensino fundamental incompleto, uma com ensino médio completo (o que ocorreu durante o trabalho de campo desta tese) e um com ensino superior.

2) Local de moradia e modo de deslocamento

Temos, também, um equilíbrio na diversidade quanto ao local de moradia: dois comerciantes moram no Plano Piloto, nas superquadras em que têm seus pontos de comércio e os outros dois residem em cidades do entorno de Brasília (coincidentemente na mesma: Planaltina). Diante disso, os modos de deslocamento variam entre automóvel, transporte público e caminhada. Destaco a diferença do modo de deslocamento feito no ponto da SQN 410: o comerciante não se desloca para lá, mas os atendentes e a assistente que leva de multivan, as panelas de caldo do restaurante para o ponto. Trata-se de uma logística um pouco mais complexa que a dos outros pontos, por este ponto de comércio ter tido uma expansão como empreendimento.

3) A atividade é a única ocupação remunerada? Dias da semana de que se ocupa com a atividade

Dois dos comerciantes têm a atividade nos seus pontos de comércio como única ocupação remunerada. Os outros dois têm ocupações paralelas, mas por motivos diversos: um por necessidade de complementação de renda e o outro porque o próprio negócio do ponto prosperou a ponto de gerar uma ocupação formal: uma ampliação. Uma única comerciante não se ocupa desta atividade em todos os dias úteis da semana, porque privilegia um misto de dias da semana com final de semana, abrindo o seu ponto de quinta-feira a sábado. Os outros três cumprem presença em seus pontos, direta ou indiretamente, de segunda a sexta-feira, sendo dois no período noturno e um no matutino.

4) Renda mensal adquirida pela atividade

A renda mensal proveniente desta atividade não foi informada por dois dos comerciantes entrevistados: aqueles que são moradores das superquadras em que têm ponto de comércio. Foi informado pelos que responderam que o negócio com a 
venda de café da manhã rende de $R \$ 1.800,00$ a $R \$ 2.000,00$ mensais e o ponto que vende churrasquinho no espeto rende em torno de $\mathrm{R} \$ 5.000,00$ por mês. Por seus graus de instrução e possíveis renda mensais localizo os comerciantes nas seguintes classes sociais: a do ponto de café da manhã (SQN 209) na classe média baixa ou pobre; o do churrasquinho no espeto (SQN 408) na classe média-média; a da tapioca (SQN 113) na classe média-média e o dos caldos na classe média-média ou classe média alta.

5) Razão da escolha por este local para o ponto de comércio

Os pontos dos dois comerciantes não moradores do Plano Piloto foram apropriados por pessoas anteriores a eles, que enxergaram uma oportunidade de sucesso deste tipo de negócio nestes lugares, provavelmente pelo grande fluxo de pedestres facilmente detectável em ambos. Os comerciantes moradores das superquadras escolheram os lugares de seus pontos, em primeiro lugar, pela proximidade de casa e por motivos também condizentes com o tipo de espaço: um por ser na entrada da superquadra, localização de fácil visualização por motorizados e pedestres e porque achou o lugar "bonito" por causa da árvore frondosa que havia ali (SQN 410); a outra se deslocou para aquele lugar por achá-lo maior e mais visível dentro da superquadra (SQN 113).

\section{6) Quem é o seu público/cliente?}

A localização, o período e o tipo de alimento servido são aspectos que influenciam sobremaneira o tipo de público que cada ponto de comércio tem. Pela manhã ou à noite, dependendo também da rotina dos arredores dos lugares apropriados, o público pode ser de moradores, funcionários dos estabelecimentos comerciais e equipamentos, ou mesmo, pessoas que não compartilham a rotina destes lugares, mas se deslocam para consumir lá. Enquanto a clientela da SQN 113 tende a ser mais homogênea, constituída basicamente de moradores, a da SQN 410 tem uma diversidade considerável, reunindo ali pessoas de todo o Plano Piloto, por sua popularidade. 
7) Dados censitários sobre renda dos moradores.

Os dados censitários levantados são sobre os moradores das superquadras referentes aos quatro pontos observados. Nos pontos de clientela mais diversa SQN 408 e SQN 410 - os moradores são apenas uma parcela dos clientes. Isso não ocorre nos outros dois pontos de situações opostas. Enquanto no ponto da SQN 113 a clientela é constituída basicamente de moradores, o ponto da SQN 209 quase não tem morador como cliente. As classes sociais destes moradores foram confrontadas com o que se observou nesse sentido sobre as clientelas dos pontos. $O$ único ponto de situação diferente é o da SQN 209, que tem as classes rica e média-média predominantes em relação aos moradores e as classes média inferior e pobres representadas pelos clientes deste ponto. Os outros três pontos têm situação equilibrada entre moradores e público consumidor.

\section{Considerações sobre 'Características socioeconômicas'}

De modo geral, temos uma diversidade quanto às características socioeconômicas dos comerciantes e público dos arredores e frequentador de seus pontos. Mais constantes são a faixa etária entre 40 e 50 anos e a classe social predominante média-média. Os outros aspectos variam caso a caso e refletem o cotidiano dos lugares e arredores.

Os comerciantes moradores do Plano Piloto têm graus de instrução mais altos do que os dos comerciantes moradores do entorno. Contam com atrativos de empreendimento mais individualizados que coletivos. Se apropriam dos lugares com mais propriedade, pois estão em seu "território" e, por isso, têm mais controle e vigilância sobre estes pontos, além do período de uso.

Os moradores do entorno, por sua vez, contam mais com o potencial de urbanidade e outros atributos que os lugares apropriados proporcionam. Demonstram isso os focos no fluxo de trabalhadores que utilizam a passagem subterrânea junto à SQN 209 e o movimento de pessoas variadas que frequentam o Comércio Local Norte 408/409, por Dona Cida e Seu Raimundo, respectivamente. 


\subsubsection{Padrões espaciais}

A escolha pela 'ambiência física' pela convexidade, 'acessibilidade aos movimentos de veículos e pedestres', 'acessibilidade à visão', 'campo visual', 'condições para permanência' e 'atividades ao redor' se deu a partir da divisão do objeto de estudo nas suas três escalas: contexto, interface e atividade.

A convexidade tanto do contexto quanto do espaço da atividade informaram em conjunto sobre a ambiência e sobre o aproveitamento do espaço pela composição dos elementos físicos. Ambiência como potencial do espaço do contexto e aproveitamento pela composição como o que, de fato, foi feito com este potencial de ambiência. Os dados oriundos desta variável são essenciais para o início de conhecimento sobre o espaço escolhido para a permanência de pessoas na atividade.

Todas as variáveis de acessibilidade, tanto ao movimento quanto à visão, foram importantes para o conhecimento do potencial de cada lugar apropriado para o funcionamento de um ponto de comércio. A variável 'acessibilidade ao movimento motorizado' foi escolhida porque em três dos quatro pontos observados o acesso se dá, também, desta maneira. Porém, mais significativa é a que coleta dados sobre a acessibilidade ao movimento de pedestre. O potencial de permeabilidade ou barreira a este tipo de movimento abrange tanto os que passam quanto os que permanecem em suas ações na atividade. No âmbito do contexto e no da atividade é possível comparar e sobrepor este potencial dos espaços formados pela massa edilícia, vias e elementos físicos.

A conexão e o campo visuais se complementam na detecção de informações sobre a visibilidade e isovistas, para e a partir do ponto. Foi possível perceber, claramente, a interferência da composição dos elementos físicos no espaço escolhido, por meio da variável de acessibilidade à visão, pelos mapas de visibilidade tanto do contexto quanto da área da atividade.

As informações oriundas das variáveis não sintáticas deste nível, complementam o conhecimento sobre cada lugar apropriado. Dados sobre 'condições para a 
permanência', de certa forma, completam aqueles sobre ambiência física. Por meio da variável 'atividades ao redor do ponto' é possível detectar se o espaço do contexto imediato do ponto tem o potencial funcional de isolar ou congregar atividades diversas.

As sete variáveis deste nível apresentadas a seguir na comparação dos quatro pontos de comércio, foram cruciais para abordar os espaços dos contextos e das atividades, de modo configuracional e funcional.

08) Espaço convexo que abarca o ponto - ambiência física

As ambiências físicas dos quatro pontos de comércio são analisadas a partir da avaliação dos espaços convexos em que estão inseridos e dos espaços convexos que eles formam a partir da interação dos elementos físicos portados e montados com os pré-existentes. Vale lembrar que a delimitação dos espaços convexos maiores se deu não apenas pelos edifícios do entorno, mas também por barreiras virtuais existentes, como é o caso das vias de grande circulação de veículos.

Na figura 4.1 é apresentada a inserção dos pontos de comércio em espaços convexos. Nos casos das SQN 113 e SQN 209, tem-se o Eixo Rodoviário como uma das vias adjacentes e com poucos edifícios em seu entorno. Nos pontos referentes à SQN 408 e à SQN 410 há maior quantidade de edifícios ao redor, o que implica em boa ambiência.

No que se refere ao tamanho de área convexa, o ponto da SQN 209, seria o de maior ambiência pela menor área convexa $\left(1.989 \mathrm{~m}^{2}\right)$ apresentada entre os quatro. O ponto referente à SQN 410, por outro lado, é o de menor ambiência física por apresentar maior área convexa $\left(10.724 \mathrm{~m}^{2}\right)$, além de ter pouca tridimensionalidade percebida ao redor (Tabela 4.2). 


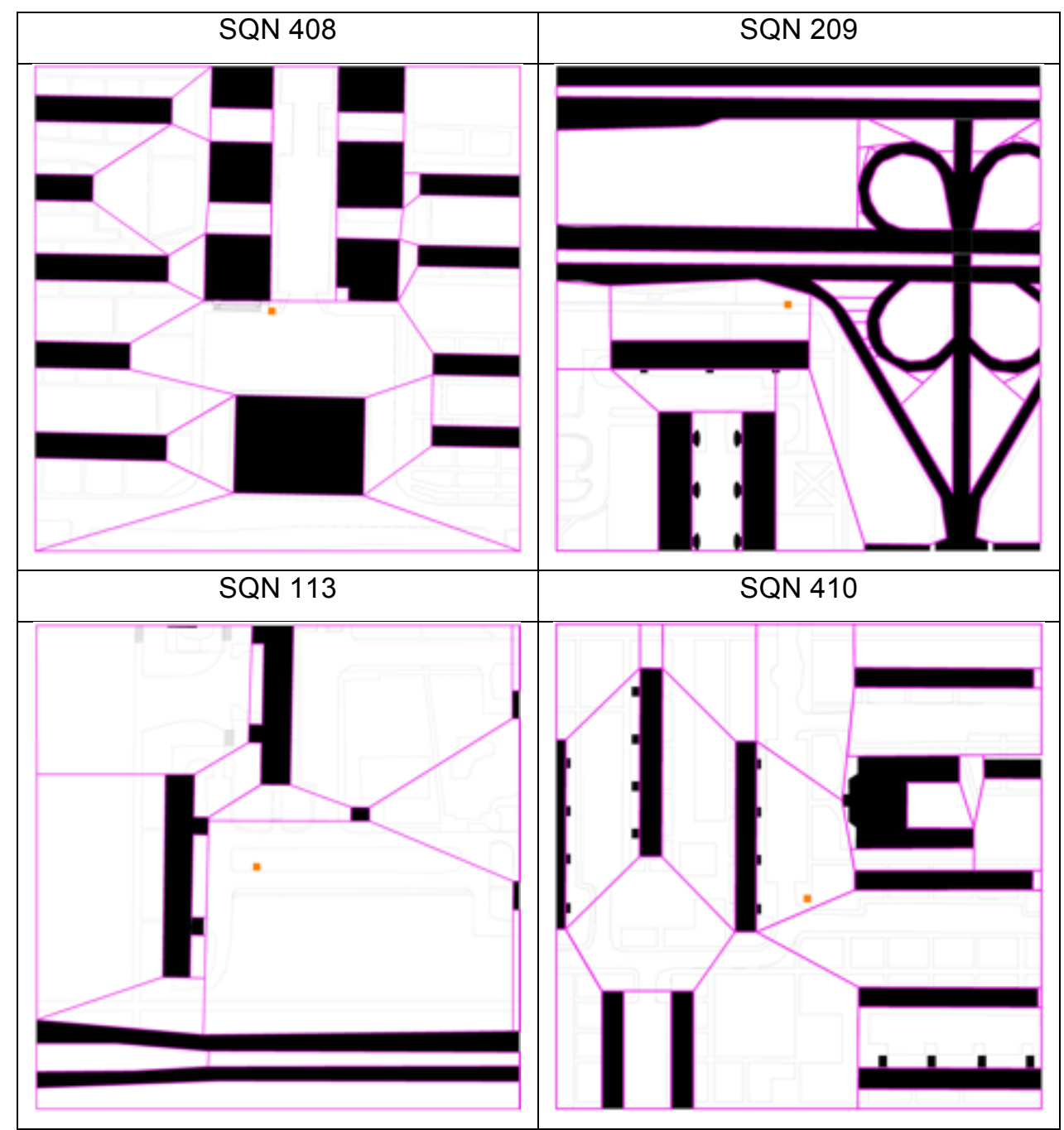

Figura 4.1 - espaços convexos dos quatro pontos de comércio observados (máscara quadrada 200 m lado).

Tabela 4.2 - áreas dos espaços convexos em que estão inseridos cada ponto de comércio observado.

\begin{tabular}{c|c|c|c|c}
\hline \multirow{2}{*}{ Convexidade } & \multicolumn{4}{|c}{ Pontos de comércio } \\
\cline { 2 - 5 } & SQN 408 & SQN 209 & SQN 113 & SQN 410 \\
\hline Área $\left(\mathrm{m}^{2}\right)$ & 4.246 & 1.989 & 10.724 & 3.121 \\
\hline
\end{tabular}

A figura 4.2 mostra os mapas com os espaços convexos de cada ponto de comércio (20m). Os pontos referentes às SQN 113 e SQN 410 geram maior número de pequenos espaços convexos em comparação aos pontos referentes à SQN 209 e à SQN 408, o que guarda grande relação com a quantidade de elementos utilizados pelos comerciantes. Quanto mais elementos, mais subespaços convexos gerados. E estes pontos com mais elementos portados e montados são aqueles que, quanto à tipologia de incidência de apropriação dos lugares, são instalados no interior e no início de superquadra, cujos donos são moradores do Plano Piloto. 


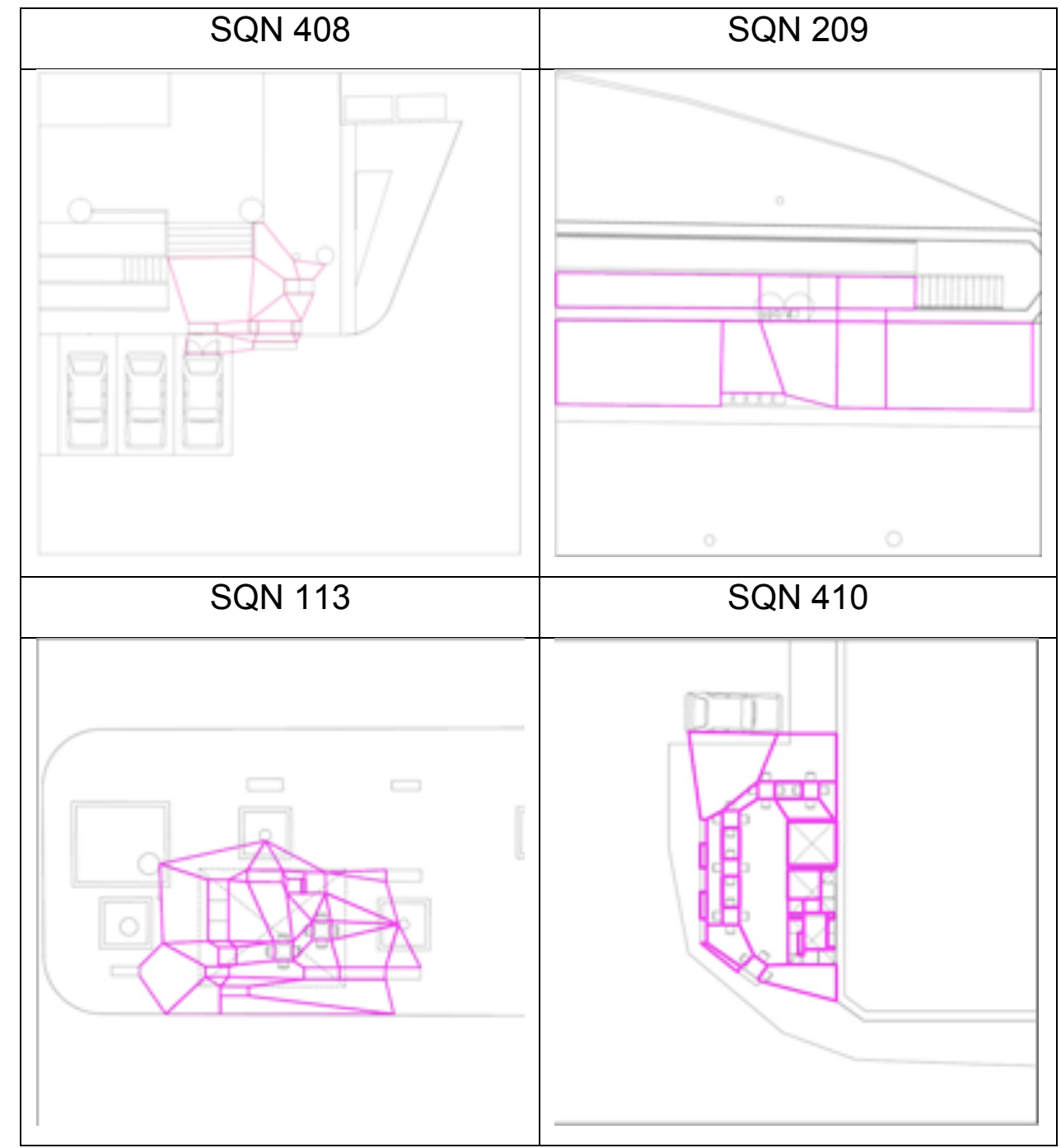

Figura 4.2 - espaços convexos dos quatro pontos de comércio observados (máscara quadrada $20 \mathrm{~m}$ lado).

09) Acessibilidade ao movimento de veículos

O mapa axial do Plano Piloto (Figura 3.87) foi a base para a avaliação desta variável. A partir dele, pode-se observar o valor de integração dos lugares que recebem os quatro pontos de comércio. Este instrumento possibilita verificar 0 potencial de circulação de motorizados por cada ponto.

Relembro que no mapa axial as linhas vermelhas identificam as vias de maior circulação, neste caso de veículos. O oposto passa por uma gradação até chegar à cor azul. O eixo Rodoviário na Asa Norte apresenta a coloração vermelha, o que 
indica um maior grau de integração em comparação à Asa Sul. Isso repercute no restante das vias direta ou indiretamente conectadas a este eixo.

O sistema viário em árvore das superquadras explica o valor de integração do ponto da superquadra $410 \mathrm{~N}$ ser mais alto (Tabela 4.3) por estar localizado na entrada da superquadra. Neste sistema as vias de entrada são mais integradas por estarem mais próximas das vias de maiores fluxos. Isso explica, também, o menor valor de integração ser atribuído ao da SQN 113, em comparação aos outros três pontos.

Por estarem os outros dois pontos com valores entre a média e o máximo de integração do Plano Piloto, acompanham o ponto da $410 \mathrm{~N}$, no que tange a acessibilidade ao movimento motorizado.

Tabela 4.3 - acessibilidade ao movimento motorizado no Plano Piloto e nos quatro pontos de comércio observados.

\begin{tabular}{c|c|c|c|c|c|c|c}
\hline \multirow{2}{*}{ Variável } & \multicolumn{3}{|c|}{ Pontos de comércio } & \multicolumn{3}{c}{ Plano Piloto } \\
\cline { 2 - 7 } & SQN 408 & SQN 209 & SQN 113 & SQN 410 & Máx. & Méd. & Mín. \\
\hline $\begin{array}{c}\text { Acessibilidade } \\
\text { ao movimento } \\
\text { de veículos }\end{array}$ & 0,94 & 1,083 & 0,707 & 1,135 & 1,379 & 0,847 & 0,349 \\
\hline
\end{tabular}

10) Acessibilidade ao movimento do pedestres

A figura 4.3 ilustra os quatro mapas axiais gerados a partir dos mapas de barreiras e permeabilidades ao movimento de pedestres $(200 \mathrm{~m})$, no entorno de cada ponto de comércio estudado. No mapa axial do ponto referente à SQN 113 temos os eixos mais integrados passando pelo pilotis de um dos prédios adjacentes, contudo o ponto de comércio está situado em um dos lugares mais integrados da área do seu contexto imediato. Este é o ponto de localização mais integrada no espaço de seu contexto imediato comparado aos outros pontos. O interior desta, como de outras superquadras, é passagem para pedestres que vão dos arredores para os pontos de ônibus ao longo do ERW Norte. Além disso, a área grande do espaço convexo em que este ponto está inserido é potencial e possibilidade real de permeabilidade a este tipo de movimento. Este aspecto compensaria a quase ausência de atividades atratoras junto as de comércio informal no interior desta quadra. 
Por outro lado, o mapa do ponto referente à SQN 209 possui grande quantidade de barreiras ao movimento de pedestres. Grande parte dos eixos se concentra no interior da quadra, porém o ponto de comércio fica às margens de um dos percursos mais integrados. Os pontos referentes às SQN 408 e SQN 410 são medianamente permeáveis ao movimento de pedestres, sendo aquele situado em posição mais estratégica, bem próximo aos eixos mais integrados, e este em área menos integrada.

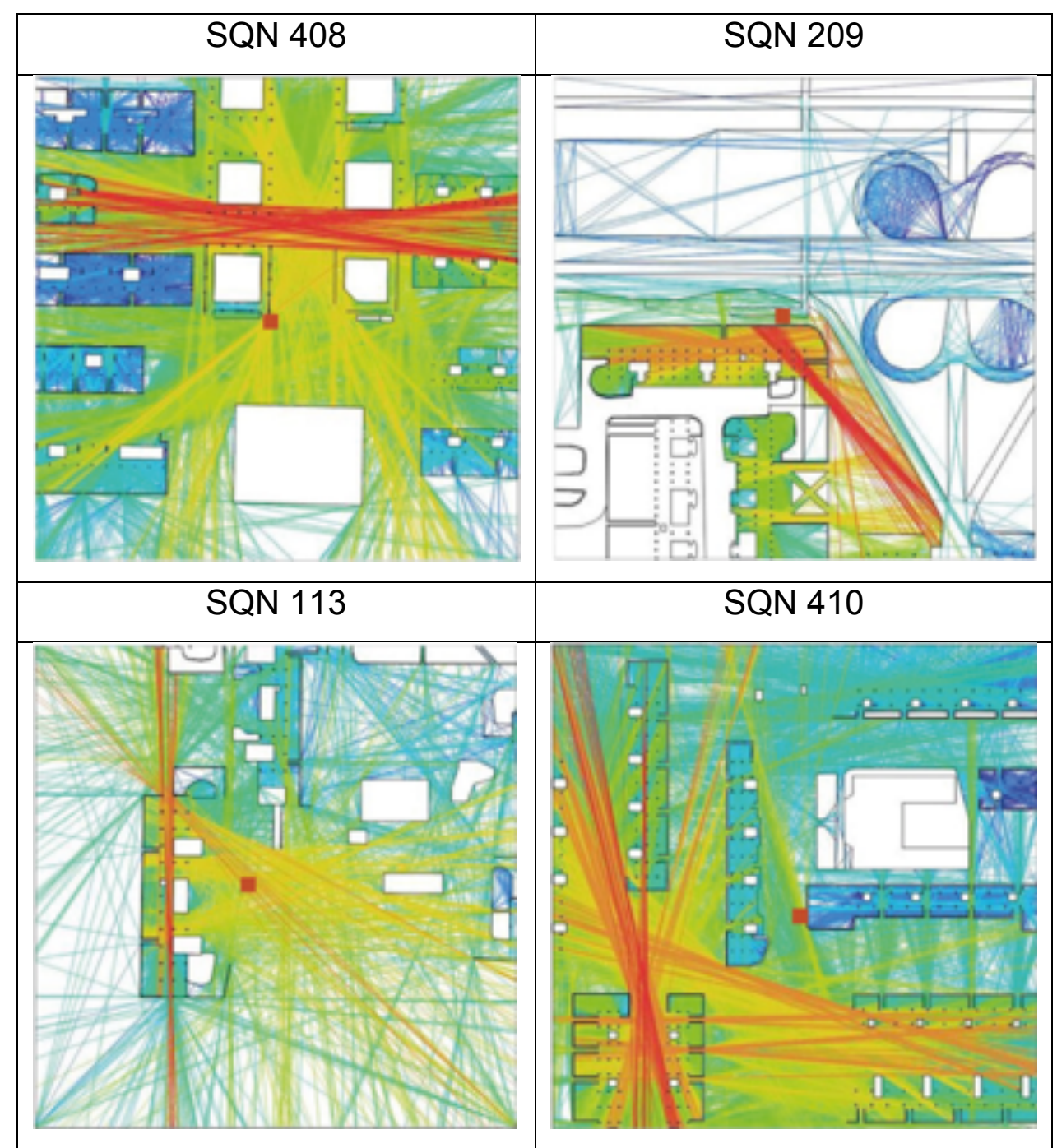

Figura 4.3 - mapas axiais (movimento de pedestres $-200 \mathrm{~m}$ ) dos pontos de comércio referentes às SQN 408, SQN 209, SQN 113 e SQN 410.

Os mapas axiais numa escala menor $(20 \mathrm{~m})$ são apresentados na Figura 4.4. O ponto de comércio referente à SQN 209, apesar de ser o com menor quantidade de mobiliário, é o que possui maior quantidade de barreiras ao movimento, gerando um mapa com poucos eixos. Nos demais, há grande quantidade de eixos que cruzam o 
espaço do ponto de comércio. Nos mapas da SQN 408 e SQN 410 nota-se que boa parte dos eixos mais integrados cruzam o layout estabelecido por cada comerciante.

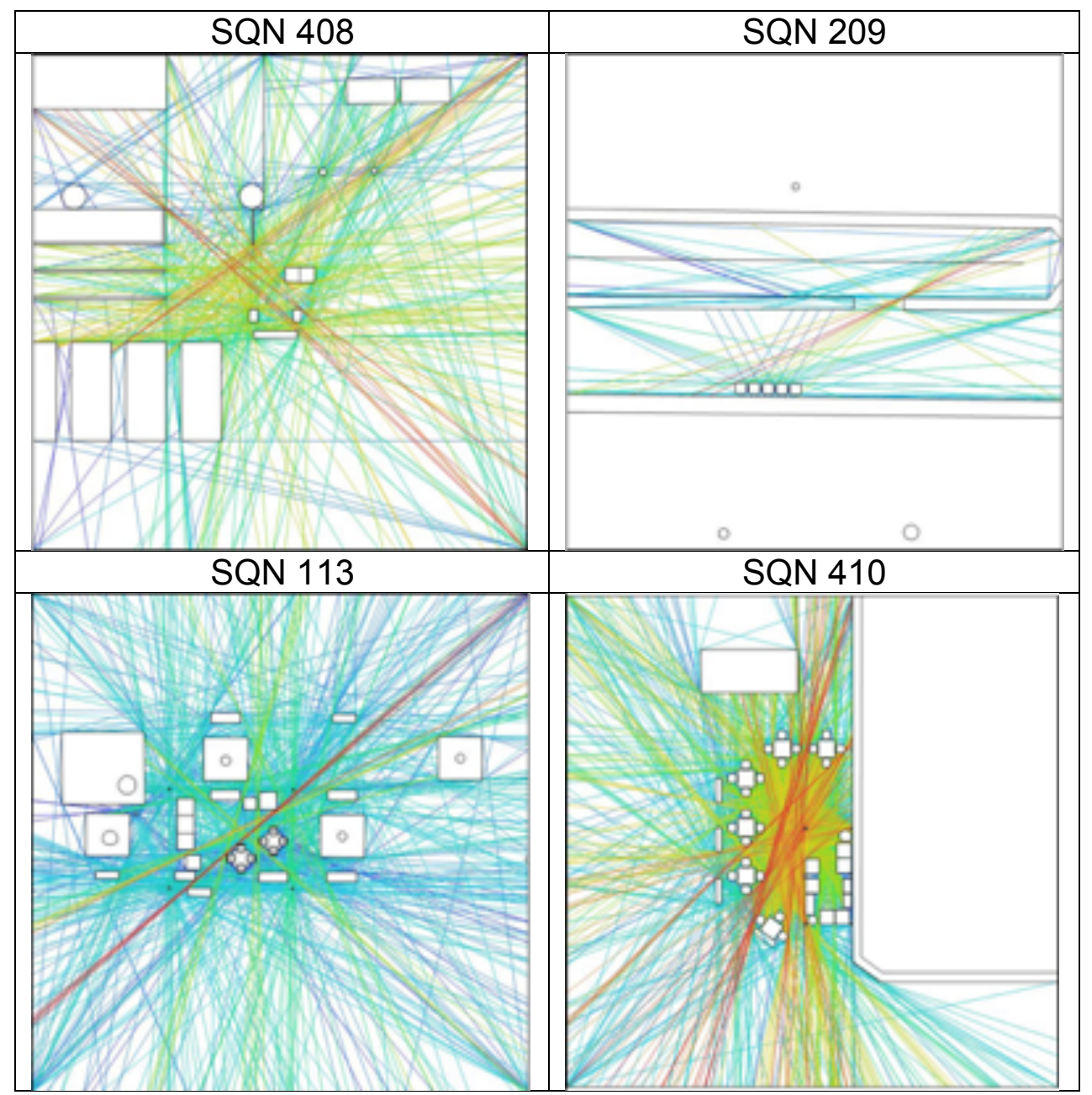

Figura 4.4 - mapas axiais (movimento de pedestres $-20 \mathrm{~m}$ ) dos pontos de comércio referentes às SQN 408, SQN 209, SQN 113 e SQN 410.

$\mathrm{Na}$ tabela 4.4 , observa-se que na escala maior $(200 \mathrm{~m})$ o ponto de comércio mais acessível ao movimento de pedestres é o referente à SQN 113, seguido dos pontos da SQN 408, SQN 410 e SQN 209, de forma decrescente. Na escala menor (20m), considerando os elementos físicos dos pontos comércio como barreiras ao movimento, temos o referente à SQN 408 como o mais acessível, seguido dos pontos da SQN 410, SQN 113 e SQN 209. Estes últimos dados, revelam como a existência e a composição dos elementos (portados e existentes no local) interfere no desempenho do espaço público, nesse caso, implicando no movimento de pedestres. 
Tabela 4.4 - valores de integração máxima, média, mínima e no centro dos locais de cada ponto de comércio com relação à acessibilidade ao movimento de pedestres.

\begin{tabular}{|c|c|c|c|c|c|c|}
\hline \multirow[b]{2}{*}{ Variável } & \multirow[b]{2}{*}{ Mapa gerador } & \multirow[b]{2}{*}{ Variável SE } & \multicolumn{4}{|c|}{ Pontos de comércio } \\
\hline & & & SQN 408 & SQN 209 & SQN 113 & SQN 410 \\
\hline \multirow{8}{*}{$\begin{array}{l}\text { Acessibilidad } \\
\text { e ao } \\
\text { movimento de } \\
\text { pedestres }\end{array}$} & \multirow{4}{*}{$\begin{array}{l}\text { Mapa barreiras } \\
\text { e } \\
\text { permeabilidades } \\
\text { movimento } \\
\text { pedestres: } \\
200 \mathrm{~m}\end{array}$} & Integr. máxima & 14,82 & 18,94 & 17,30 & 17,41 \\
\hline & & Integr. média & 7,76 & 10,37 & 8,63 & 9,03 \\
\hline & & Integr. mínima & 3,20 & 3,62 & 3,20 & 3,98 \\
\hline & & $\begin{array}{l}\text { Integr. no } \\
\text { ponto }\end{array}$ & 8,33 & 6,82 & 13,31 & 6,97 \\
\hline & \multirow{4}{*}{$\begin{array}{l}\text { Mapa barreiras } \\
\text { e } \\
\text { permeabilidades } \\
\text { movimento } \\
\text { pedestres: } 20 \mathrm{~m}\end{array}$} & Integr. máxima & 27,23 & 14,05 & 27,94 & 21,71 \\
\hline & & Integr. média & 13,45 & 5,69 & 11,12 & 12,01 \\
\hline & & Integr. mínima & 3,87 & 2,83 & 5,85 & 4,73 \\
\hline & & $\begin{array}{l}\text { Integr. no } \\
\text { ponto }\end{array}$ & 19,53 & 10,09 & 12,27 & 12,97 \\
\hline
\end{tabular}

11) Acessibilidade à visão - conexão visual

A figura 4.5 apresenta os mapas de integração visual no contexto imediato (área quadrada de $200 \mathrm{~m}$ ), a partir dos pontos de comércio observados. Nos quatro casos, de modo geral, cada ponto está situado em local de grande visibilidade dentro do seu contexto, com destaque para os referentes às SQN 408 e SQN 410, que estão não apenas próximos, mas inseridos nas áreas de maior visibilidade de seus contextos imediatos. A conexão visual do ponto da SQN 209 tem sua área mais integrada com uma boa parte do contexto em que não transitam pedestres. A integração visual é boa, mas pouco aproveitada por este ponto.

A Figura 4.6 ilustra a permeabilidade visual num raio de $20 \mathrm{~m}$ do ponto comercial de cada quadra. Os comerciantes praticamente não utilizam elementos que funcionam como barreira visual. No ponto da SQN 113 as barreiras visuais são os troncos das árvores existentes, que pouco interferem na visibilidade. No da SQN 209 as barreiras são lixeiras altas (para a posição da comerciante) e alguns troncos de árvores. Nos pontos da SQN 408 e SQN 410, os veículos utilizados pelos comerciantes como elementos obstruem a visão. Na $410 \mathrm{~N}$, além do automóvel estacionado, foi instalado na parte posterior do ponto uma lona que também desfavorece a permeabilidade visual. Com isso, estes pontos que são os mais favorecidos em termos de visibilidade em seus contextos, sofrem uma queda de integração visual nesse sentido, devido à determinadas disposições de alguns elementos físicos em suas composições. 


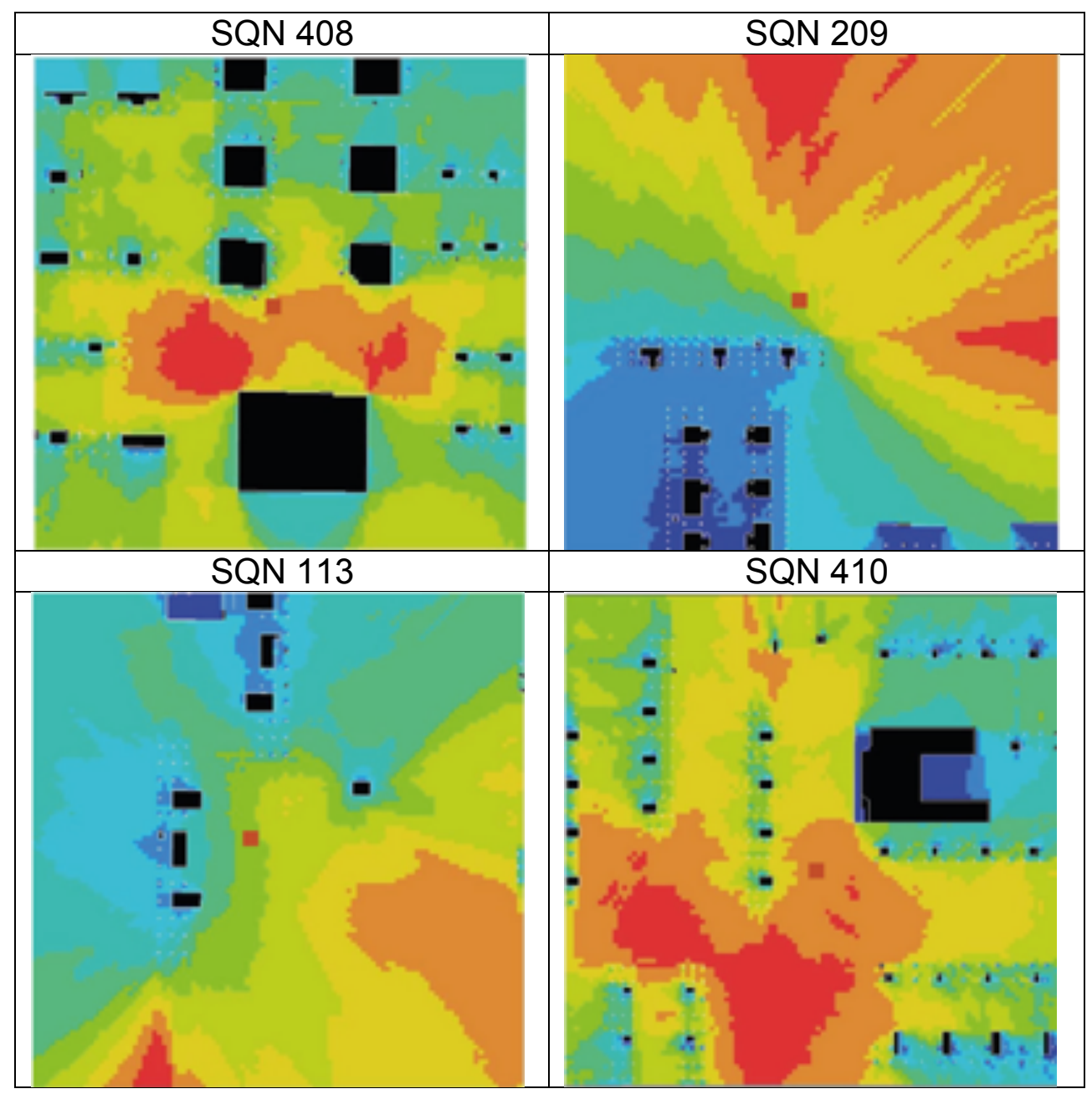

Figura 4.5 - mapas de visibilidade (conexão visual - 200m)dos pontos de comércio referentes às SQN 408, SQN 209, SQN 113 e SQN 410.

A Tabela 4.5 apresenta os valores de integração visual obtidos a partir dos mapas das Figuras 4.5 e 4.6. Quando saímos da escala maior da medição da visibilidade do lugar sem a composição dos elementos e partimos para a verificação desta mesma medição numa escala menor com a inserção dos elementos, a situação muda favorecendo ou desfavorecendo o ponto de comércio em questão, quanto à conexão visual no seu contexto imediato. Mas, apesar das barreiras inseridas nas composições a integração visual nos pontos das SQN 408 e SQN 410 ainda é maior, pois suas medidas, tanto na escala maior $(200 \mathrm{~m})$ quanto na menor $(20 \mathrm{~m})$ são as mais próximas da integração máxima correspondente. 


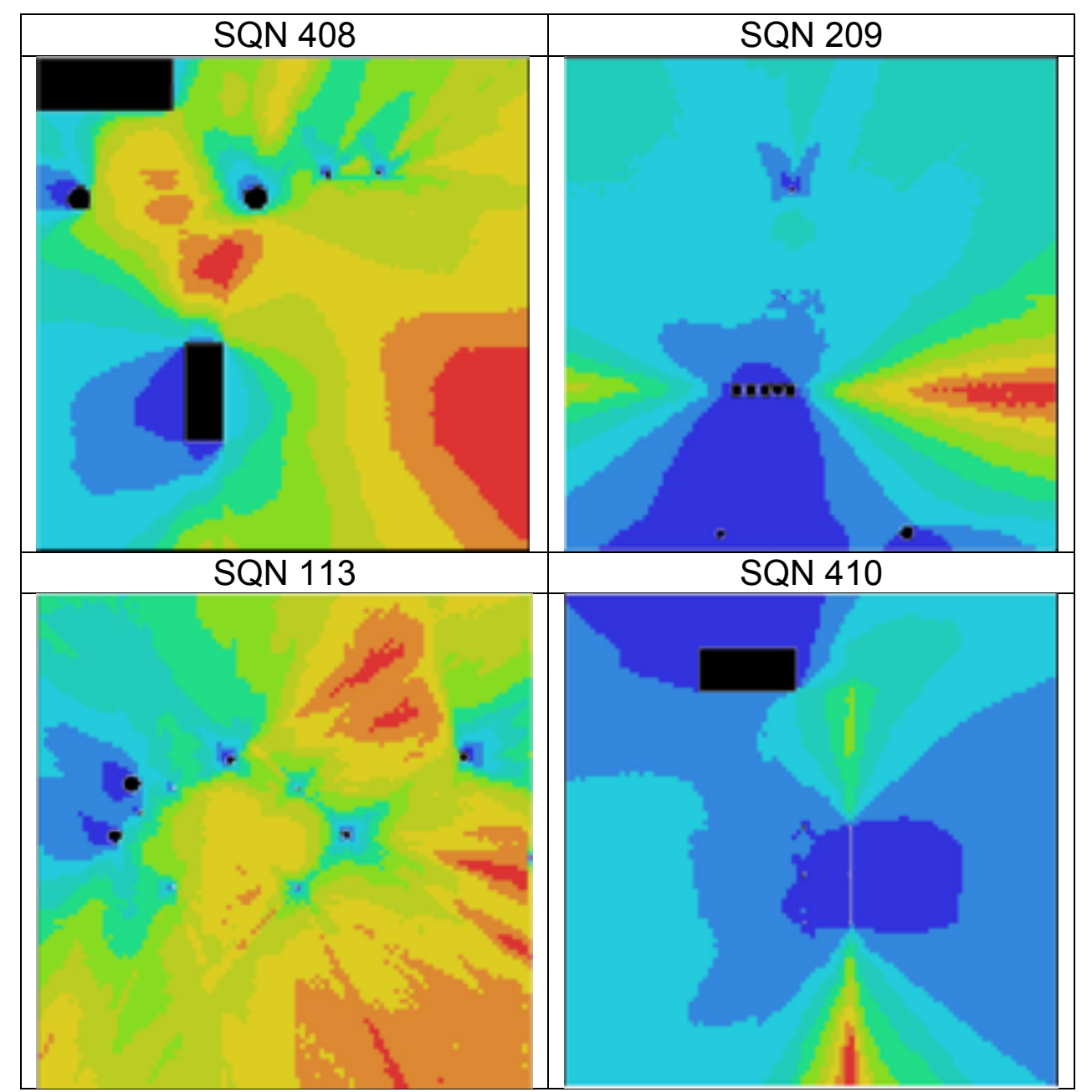

Figura 4.6 - quadro comparativo dos mapas de visibilidade (conexão visual - 20m) dos quatros pontos de comércio referentes às SQN 408, SQN 209, SQN 113 e SQN 410.

Tabela 4.5 - valores de integração visual máxima, média, mínima e no centro dos locais de cada ponto de comércio com relação à acessibilidade à visão - conexão visual.

\begin{tabular}{|c|c|c|c|c|c|c|}
\hline \multirow[b]{2}{*}{ Variável } & \multirow[b]{2}{*}{ Mapa gerador } & \multirow[b]{2}{*}{ Variável SE } & \multicolumn{4}{|c|}{ Pontos de comércio } \\
\hline & & & SQN 408 & SQN 209 & SQN 113 & SQN 410 \\
\hline \multirow{8}{*}{$\begin{array}{l}\text { Acessibilidad } \\
\text { e à visão }\end{array}$} & \multirow{4}{*}{$\begin{array}{l}\text { Mapa barreiras / } \\
\text { permeabilidades } \\
\text { à visão }-200 m\end{array}$} & Integr. máxima & 20,96 & 77,03 & 68,47 & 24,74 \\
\hline & & Integr. média & 15,28 & 46,66 & 37,31 & 16,90 \\
\hline & & Integr. mínima & 7,56 & 5,97 & 2,88 & 5,28 \\
\hline & & $\begin{array}{l}\text { Integr. no } \\
\text { ponto }\end{array}$ & 18,16 & 56,59 & 45,43 & 19,22 \\
\hline & \multirow{4}{*}{$\begin{array}{l}\text { Mapa barreiras / } \\
\text { permeabilidades } \\
\text { à visão }-20 m\end{array}$} & Integr. máxima & 112,28 & 408,13 & 195,74 & 90,52 \\
\hline & & Integr. média & 50,89 & 127,65 & 124,13 & 56,67 \\
\hline & & Integr. mínima & 13,15 & 10,46 & 10,91 & 10,67 \\
\hline & & $\begin{array}{l}\text { Integr. no } \\
\text { ponto }\end{array}$ & 68,84 & 90,43 & 151,53 & 67,05 \\
\hline
\end{tabular}

12) Isovistas - campo visual

As áreas das isovistas nos contextos dos pontos da SQN 209 e da SQN 113 são as maiores, sendo que a do ponto do café da manhã tem grande parte não aproveitada. Um trecho considerável de seu campo visual coincide com as vias de trânsito 
motorizado (Eixo Rodoviário, ERL e ERW norte), como já visto. Já o ponto de comércio dentro da superquadra se beneficia dessa grande área de isovistas com alto grau de compacidade. Os outros dois pontos, por estarem próximos de um maior número de edifícios, têm seus campos visuais com áreas menores e menos compactos (Figura 4.7).

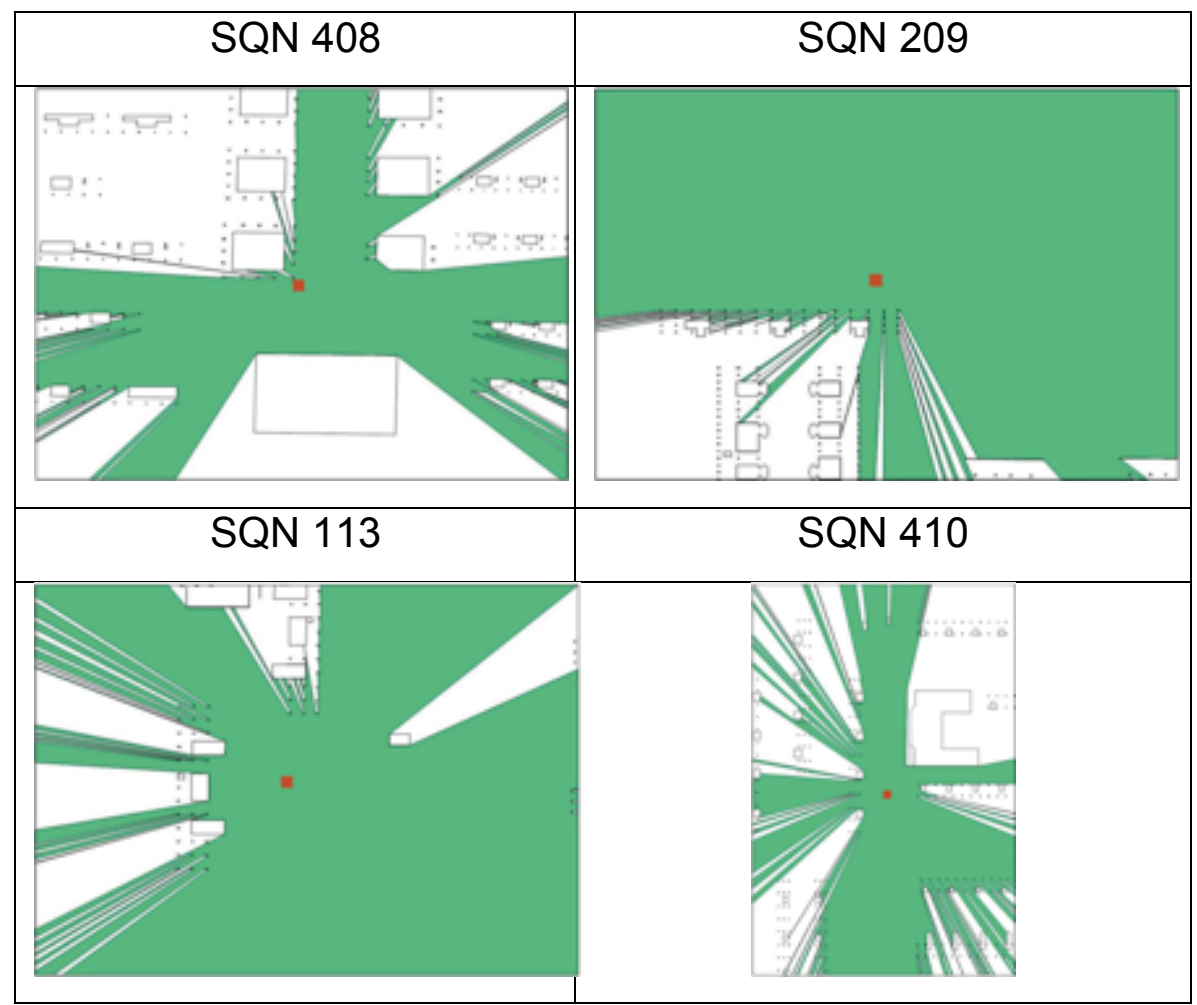

Figura 4.7 - mapas de isovistas dos quatro pontos observados.

O maior valor de área de isovistas do ponto da SQN 209, neste caso, é desconsiderado e o ponto da SQN 113, então, seria o de maior área de isovistas, com o maior nível de compacidade, corroborando as suas maiores medidas de área de espaço convexo e de grau de integração visual. Apesar da área de isovistas do ponto da SQN 410 ser maior do que o da SQN 408, seu nível de compacidade é muito pequeno, por sua área ser muito estriada. $\mathrm{Na}$ comparação de um com outro, as isovistas do ponto da SQN 408 estaria em vantagem em relação ao da SQN 410. Busco um equilíbrio entre as medidas de área e compacidade para analisar os resultados desta variável na comparação entre os pontos (Tabela 4.6). 
Tabela 4.6 - valores de área, perímetro e compacidade dos contextos de cada ponto de comércio com relação ao campo visual.

\begin{tabular}{l|c|c|c|c}
\hline \multirow{2}{*}{$\begin{array}{l}\text { Isovistas } \\
\text { medidas }\end{array}$} & \multicolumn{4}{|c}{ Pontos de comércio } \\
\cline { 2 - 5 } & SQN 408 & SQN 209 & SQN 113 & SQN 410 \\
\hline Área $\left(\mathrm{m}^{2}\right)$ & 15.982 & 32.337 & 31.212 & 20.060 \\
\hline Perímetro & 3.505 & 2707 & 4.287 & 6.438 \\
\hline Compacidade & 0,02 & 0,06 & 0,2 & 0,006 \\
\hline
\end{tabular}

13) Condições para permanência - estado de conservação e conforto

A Tabela 4.7 mostra que, com exceção do nível de conforto do ponto da SQN 408, as condições para permanência nos quatro pontos são de medianas a boas. Nos pontos referentes à entrada e ao interior das superquadras - SQN 410 e SQN 113, respectivamente - tanto o estado de conservação quanto o conforto são bons. Infiro que isso se deve a alguns fatores como: melhores condições financeiras dos comerciantes (moradores das superquadras em questão) para prover boas condições para funcionamento e consequentemente, permanência nestes pontos; menor movimento de pedestres nestes lugares em comparação com os que são externos às superquadras; e as prefeituras das superquadras incrementam os lugares internos como benfeitorias para os moradores.

No caso dos pontos de comércio referentes à passagem subterrânea e ao comércio local (SQN 209 e SQN 408), os lugares são de uso mais intenso e diversificado. Ademais, são apropriados por comerciantes de menor valor aquisitivo e de pouca ou nenhuma influência nas medidas de conservação do espaço público em que se inserem. Daí os níveis de estado de conservação e conforto serem medianos ou baixos.

Tabela 4.7 - condições para permanência (níveis de estado de conservação e conforto) dos quatro pontos de comércio observados.

\begin{tabular}{l|c|c|c|c}
\hline Condições para & \multicolumn{4}{|c}{ Pontos de comércio } \\
\cline { 2 - 5 } permanência & SQN 408 & SQN 209 & SQN 113 & SQN 410 \\
\hline $\begin{array}{l}\text { Estado de } \\
\text { conservação }\end{array}$ & mediano & mediano & bom & bom \\
\hline Conforto & baixo & mediano & bom & bom \\
\hline
\end{tabular}


14) Atividades ao redor do ponto de comércio

Com relação às atividades ao redor, os quatro pontos são bem diferentes uns dos outros. Relaciono essa diversidade à tipologia detectada destes lugares. O ponto de comércio da SQN 408, por ser aquele referente à comércio local, obviamente terá um maior número de atividades ao redor. Atividades atraem pessoas, que atraem mais atividades. É o ciclo do movimento natural comprovado. Os pontos da SQN 113 e da SQN 410, mesmo sendo relacionados diretamente à superquadra, guardam suas diferenças. No primeiro caso, as atividades são de lazer ou iguais ao do ponto, íntimas do seu público consumidor. No segundo, o ponto de comércio está praticamente sozinho como atividade, no horário em que funciona, apesar de ter ao redor um ponto de táxi, uma igreja, uma banca de jornal e um outro comércio informal. O ponto da SQN 209, também funciona sozinho, sendo que na área de seu contexto não tem nenhuma atividade ao redor detectada. Este ponto tem a particularidade de mais manter pessoas do que atrair, mesmo que por pouco tempo.

\section{Considerações sobre 'Padrões espaciais'}

Além de permitir conhecer as configurações dos espaços dos lugares apropriados em seus potenciais descritos, foi possível verificar as mudanças que as inserções dos pontos, pela composição dos elementos físicos, imprimiram nestes espaços. Executar as medições sintáticas no contexto e, também, no espaço da atividade possibilitou o início do delineamento da interface entre estas duas escalas. O quanto muda, se piora ou melhora aquele atributo, são avaliações possíveis de serem feitas na análise dos lugares qualificados pela atividade.

A análise dos pontos por comparação, neste nível analítico, não culmina na detecção de um ponto de comércio melhor ou pior que outro, em termos de configuração de lugar, mas se condizem com o restante das informações levantadas nos outros níveis analíticos. 


\subsubsection{Sistema de Encontros e Esquivanças}

As três variáveis deste nível analítico foram suficientes na comprovação dos atributos do nível 'Padrões espaciais', bem como os do nível 'Sistema de elementos físicos'. A relação entre esses níveis mostra como os espaços, tanto do contexto, quanto da atividade, são aproveitados individualmente e na interface entre essas escalas. Porém, o foco dado à permanência dos frequentadores de cada ponto talvez tenha restringido a avaliação das trocas sociais mais gerais ocorridas nestes lugares.

No princípio da pesquisa, achei ser suficiente somente contabilizar os de passagem, sem detectar as direções, gênero e faixa etária. Ao final, foi possível perceber que, principalmente a informação sobre a direção dos que passam era importante para corroborar os dados sobre acessibilidade ao movimento de pedestres. A interface entre o espaço da atividade e o do contexto abrange esse movimento.

Contudo, quantidade, variedade e distribuição das pessoas nos espaços formados pelos elementos físicos da atividade em conjunto com os que delimitam o contexto, revelaram a relação entre a análise da configuração do espaço repercutindo no comportamento das pessoas nos lugares apropriados para a atividade.

15) Quantidade de pessoas - passagem e permanência

A tabela 4.8 mostra a utilização desta variável em dois tipos de comparação: entre seus dados e os do nível de integração de cada ponto e desta correlação entre os pontos.

O ponto da SQN 408 reúne os dados da correlação entre quantidade de pessoas e níveis de integração mais favoráveis, além de ser o único que teve a quantidade de pessoas que permaneceram maior do que as que somente passaram pelo ponto. Este potencial foi revelado pelo maior nível de integração no local da atividade entre os quatro pontos $(19,53)$. Era esperado que este ponto fosse o de maior número de passantes e pedestres. Entre os quatro, não padece de questões de sazonalidade (épocas de chuva, férias escolares, final de mês etc.). A frequência neste ponto parece intocável no que diz respeito ao sucesso. 
Os outros três pontos estão praticamente equilibrados nesta aferição. Constata-se que os diretamente associados às superquadras - o ponto da SQN113 e o da SQN 410 - são os de menor frequência, apesar de nos estudos de Ribeiro (2013) a superquadra SQN 113 apresentar bom desempenho neste quesito.

Tabela 4.8 - correlação entre quantidade de pessoas e integração (axialidade - movimento de pedestres) dos quatro pontos de comércio

\begin{tabular}{l|c|c|c|c}
\hline \multirow{2}{*}{$\begin{array}{l}\text { Correlação entre } \\
\text { variáveis }\end{array}$} & \multicolumn{4}{|c}{ Pontos de comércio } \\
\cline { 2 - 5 } $\begin{array}{l}\text { Integração no } \\
\text { ponto (200m) }\end{array}$ & 8,33 & SQN 209 & SQN 113 & SQN 410 \\
\hline $\begin{array}{l}\text { Integração no } \\
\text { ponto (20m) }\end{array}$ & 19,53 & 6,82 & 13,31 & 6,97 \\
\hline $\begin{array}{l}\text { Quantidade de } \\
\text { pessoas - 2 dias }\end{array}$ & perm.>passagem & 10,09 & 12,97 \\
\hline
\end{tabular}

16) Variedade de pessoas na permanência

$\mathrm{Na}$ variabilidade por gênero, foi observada a predominância de homens na superquadra SQN 408. O inverso ocorre na SQN 410. Os outros dois pontos se equilibram em termos de quantidade de homens e mulheres. Crianças são menos frequentes no ponto da SQN 209, devido, provavelmente, ao horário e ao tipo de lugar (passagem subterrânea). A presença de crianças é uma constante em todos os pontos, mesmo que em menor número e mais naqueles de funcionamento noturno (Figura 4.8).

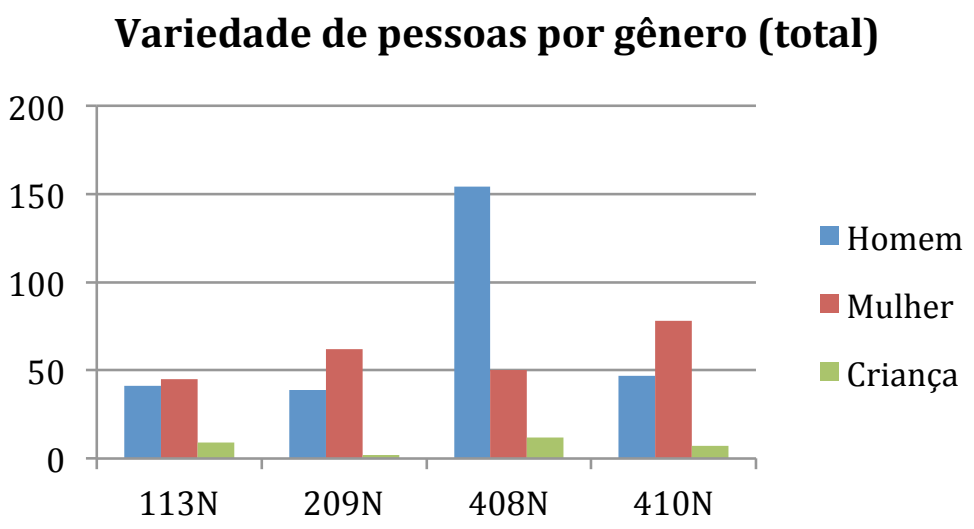

Figura 4.8 - quantidade de total de pessoas, classificadas por gênero (homem/mulher) e crianças, nos dois dias de levantamento, nos pontos comerciais das quadras $113 \mathrm{~N}, 209 \mathrm{~N}, 408 \mathrm{~N}$ e $410 \mathrm{~N}$. 
De modo geral, os adultos prevalecem na contagem de pessoas, em todos os pontos, dias e horários de observação, sendo o ponto da SQN 410 o que tem o maior número de adultos e idosos entre os quatro (Figura 4.9). Condizente com a medição da variabilidade por gênero, as crianças são em menor número no ponto da SQN 209. Vale ressaltar a soma da quantidade de crianças e jovens no ponto da SQN 113. Dos pontos é o único que apresenta esta característica, provavelmente por ser dentro da quadra, o que implica mais confiança e segurança dos pais de deixarem seus filhos circularem por ali.

Variedade de pessoas por faixa etária

(total)

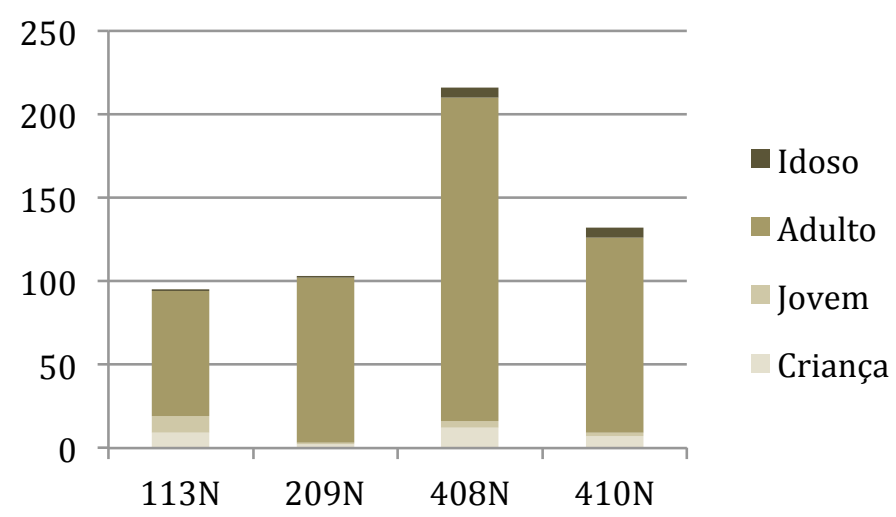

Figura 4.9 - quantidade total de pessoas, classificadas por faixa etária (criança, jovem, adulto e idoso), nos dois dias de levantamento, nos quatro pontos de comércio.

17) Distribuição de pessoas no tempo e no espaço

Dos quatro pontos o da SQN 408 foi o que permitiu melhor permeabilidade tanto para quem permaneceu quanto para quem passou. A composição dos elementos permitiu uma interface equilibrada entre as ações, a permanência e a passagem. Caso oposto se deu com a formalidade na composição do ponto da SQN 410, que restringiu a distribuição dos que permaneceram e evitou a passagem, apesar da medida de integração deste ponto ser a segunda mais alta (figura 4.4 e tabela 4.4). Os outros dois pontos se colocam entre estes opostos em seus arranjos.

Considerações sobre 'Sistema de Encontros e Esquivanças'

Nesta aferição, importou como as pessoas, que permaneceram no ponto, se movimentaram e se posicionaram nos pequenos espaços formados pelos elementos 
físicos e pela delimitação mais geral do espaço convexo em que o ponto se insere. Por meio desta avaliação é possível detectar o tipo de interação das pessoas com a atividade e com o espaço. Dependendo da composição e do que nela é oferecido, as pessoas se locomovem mais ou menos pelo espaço, cumprindo em maior ou menor grau com o ordenamento colocado por ela.

\subsubsection{Sistema de Elementos Físicos}

Por ter sido um nível analítico estranho à metodologia seguida neste trabalho, dentro da Sintaxe Espacial, as duas variáveis eleitas foram aplicadas de modo completamente experimental. 'Complexidade' é uma variável síntese por meio da qual foi possível conhecer e abordar a atividade em sua composição física. Antes de chegar na composição propriamente dita, enumerar seus elementos, detectar suas funções e relacioná-los foi uma sequência paulatina e didática de aproximação do objeto neste tipo de análise. Os dados extraídos desta variável só complementaram o que já estava sendo avaliado sobre as composições dos elementos físicos em outros níveis de análise. Aqui as composições estão sob a lente do conceito de sistema.

A parte funcional deste sistema, diretamente ligada ao ponto de comércio em ação foi coberta pela variável 'Aspectos funcionais', sempre subsequente à avaliação da composição como um sistema. Este dueto cobre, a princípio, a abordagem do objeto por seus elementos físicos.

18) Complexidade

Os pontos fora das superquadras - SQN 408 e SQN 209 - são os que envolvem menor número de elementos, sendo o que serve café da manhã o mais simples dos quatro. São esses dois que também aproveitam mais o que o local oferece do que os outros dois pontos. Verificou-se, assim, uma relação direta entre simplicidade e aproveitamento dos elementos do espaço. Uma affordance clara destes elementos, que foi percebida e apropriada pelos comerciantes destes pontos. Por meio da relação entre os elementos detectados, foi possível entender e avaliar cada 
composição como, também, campo de possibilidades e restrições ao movimento e às ações da atividade.

19) Aspectos funcionais - relações entre elementos físicos e as práticas

Nos quatro pontos de comércio pode-se observar exemplos de tipos diversos de funcionamento/atendimento. Temos desde um restaurante à la carte (SQN 410), até um self service (SQN 408), passando por um atendimento de balcão de lanchonete (SQN 209) e por uma barraquinha de feira (SQN 113). Em todos esses casos, ou perfis de atendimento, os elementos físicos em suas composições, atendem satisfatoriamente aos aspectos funcionais da atividade de comércio de alimentos no espaço urbano.

Considerações sobre 'Sistemas de Elementos Físicos'

Nas escolhas e arranjos dos elementos físicos para a atividade nos pontos, muito pode ser visto dos perfis socioeconômicos, além das questões de fundo configuracional. Como entendem e aproveitam o espaço por seus atributos em benefício da atividade, passa por questões de habitus inerente a cada segmento social. A importância da inserção deste nível analítico nos estudos sobre esta atividade no espaço urbano, está no esforço de uma aproximação necessária ao objeto, para melhor entendê-lo e atendê-lo.

\subsection{Aspectos a serem considerados - os ensinamentos da indisciplina}

Por simples oportunidade ou escolha mais direcionada, os espaços foram percebidos, apropriados e vêm sendo utilizados com sucesso pelos quatro pontos. Os contextos têm seus atributos como campos de possibilidades e restrições que permitiram o funcionamento dos pontos, além de promoverem encontros não só para o consumo de seus produtos. Estes atributos podem ser detectados de modo racionalizado, por meio da observação dos comerciantes informais, para a detecção de tipologias e proposta de outras. 
A tipologia detectada, sob o critério principal de integrar a região residencial da Asa Norte do Plano Piloto, reúne quatro tipos de lugar que evidenciam determinado potencial desta região para abarcar atividades do cotidiano como a do comércio de alimentos. Em termos gerais, os lugares observados apresentam boa ambiência, visibilidade e acessibilidade ao movimento.

Além desses aspectos, o tipo representado pelo comércio de churrasquinho no espeto - o associado à SQN 408 - por ser a esquina de um comércio local, congrega outros atributos favoráveis ao comércio, como grande proximidade com outras atividades e localização que atende a um público bastante diversificado, e a presença de moradores das quadras vizinhas e pessoas que só trabalham (não moram) perto do local, além das que se deslocam para o ponto somente para consumir.

O que mais caracteriza a entrada de passagens subterrâneas, tipo de lugar representado pelo estudo de caso da SQN 209, é o fluxo intenso de pedestres em horários específicos do dia (início e fim da jornada de trabalho, principalmente), pela natureza de sua destinação. Não oferece muito espaço além do corredor para a circulação de pedestres no interior da passagem. Compõe também este lugar a parte externa da passagem, a calçada que é mais larga que a circulação interna. Ambas as circulações são utilizadas nas apropriações por esse tipo de atividade.

Entradas de superquadras têm bom nível de integração em relação ao movimento motorizado, principalmente. O movimento de pedestres vai depender da quantidade de barreiras que, neste caso é considerável, pela proximidade de edifícios, cercas vivas e outros obstáculos. Porém, geralmente, são caminhos entre comércios locais e pontos de ônibus. Este tipo de lugar, geralmente, disponibiliza trechos mais largos de calçadas, o que permite melhor aproveitamento do espaço para a instalação dos pontos de comércio.

No interior de superquadra, várias são as possibilidades de escolha para a apropriação e, por isso, é o tipo de lugar que não tem um padrão morfológico repetitivo. Porém, o ponto em comum entre essas possibilidades é a baixa integração ao movimento motorizado, devido ao sistema viário em árvore que as 
superquadras apresentam. O estudo de caso que representa este tipo de lugar, ocupou dois lugares distintos dentro da SQN 113, sendo o primeiro pequeno e pouco visível em relação ao segundo.

A ambiência do ponto é uma conjunção equilibrada dos dados da convexidade do local com a composição dos elementos físicos. Na convexidade, mais do que a área do espaço convexo em que cada ponto se encontra, a tridimensionalidade dos componentes da arquitetura que o delimitam proporciona a sensação de ambiência. Esse aspecto pode ser conjugado à composição dos elementos físicos envolvidos na atividade, que determinam pequenos espaços de ações que complementam a ambiência do local apropriado. É como se a pessoa tivesse a sensação de ambiência pela constatação nos seguintes estágios: "Eu chego, permaneço/estou neste lugar (pela convexidade/arquitetura), participo da atividade social (copresença e troca) e funcionalmente (espaços específicos para funções específicas), como comerciante e cliente, preparando, vendendo, comprando, consumindo, conversando (pela composição dos elementos físicos)". Esta conjugação é um dos aspectos da interface entre o espaço da atividade e o do contexto.

A inserção dos elementos físicos qualificou os espaços escolhidos, alguns com melhor aproveitamento dos atributos do lugar do que outros. Todos os casos funcionaram como centros atratores ou fixadores de pessoas para os lugares escolhidos. Quando não oferecido pelo espaço, portam, instalam clandestina ou formalmente (no caso das prefeituras das superquadras) o que precisam para funcionar durante o período do dia em que acontece a atividade no local.

O movimento natural pode ser comprovado neste tipo de pesquisa, mas outros fatores, como os culturais, irão contribuir, em maior ou menor grau, com o sucesso do ponto de comércio em questão e, consequentemente, com o lugar em que está. Os contextos imediatos dos quatro pontos de comércio observados possuem em suas configurações atributos para atrair e concentrar movimento e permanência de pessoas. Os dados das categorias analíticas do nível Padrões Espaciais o comprovam. Contudo, em cada um deles pode ser observado que os fatores que compõem o habitus da região residencial escolhida para trabalho de campo também interferem no funcionamento da atividade. O período do dia em que o comércio é 
instalado e permanece é um deles. O cotidiano dessa área é marcado, nos dias úteis, pela circulação mais intensa nas saídas (ou chegadas) para o trabalho pela manhã e término desta jornada no início da noite. O ponto de comércio associado à SQN 209, contando com os atributos da configuração de seu contexto, não tem tanto sucesso em um horário diferente do que normalmente se instala. Foi observado e constatado que, a partir das 9 horas da manhã, o movimento de clientes começa a diminuir. O mesmo acontece com os pontos de funcionamento noturno: antes das 18 horas não tem movimento em nenhum dos três pontos observados nesse horário (os associados à SQN 408, SQN 113 e SQN 410).

O aproveitamento dos espaços e dos elementos do local corroboram os estudos desenvolvidos no âmbito da Sintaxe Espacial e da Affordance, respectivamente. Atuar com o que já existe foi uma característica marcante detectada nestes comerciantes. Os potenciais dos espaços foram comprovados nas apropriações dos lugares. Os outros usos, muitas vezes inéditos, dos elementos físicos, mostram que não é necessário muito para o aproveitamento dos locais. Exemplo disso são elementos como a escada que serve de assento, poste e árvore que delimitam o lugar e mureta que funciona como balcão (suporte para os produtos a serem vendidos e divisor do espaço entre área dos clientes e área do comerciante).

Quanto menos recursos o comerciante tem, maior o aproveitamento das possibilidades proporcionadas pelos elementos físicos disponibilizados no local. Os dados sobre as características socioeconômicas dos comerciantes informam que aqueles que não residem no Plano Piloto pertencem às classes sociais mais baixas. Os recursos dos comerciantes variam conforme a classe social a que pertencem. Com base nesses dados, constatou-se que a comerciante do ponto de comércio da SQN 209 é a que possui menos recursos dos quatro comerciantes observados. A simplicidade da composição dos elementos físicos de seu ponto reflete o fato.

Ao comparar os quatro pontos de comércio com relação ao número de elementos físicos portados e aproveitados do local, foi possível constatar que os relacionados a este ponto são em menor número: 8 contra 11, 12 e 13 dos contabilizados nos outros pontos. Só a mureta cumpre três funções: a de dar suporte aos produtos para a venda (balcão), de armazenar as bolsas em que ela transporta os produtos 
(estante) e a de assento para os clientes. Fora as lixeiras seletivas que também são usadas por quem ali consome. Os elementos portados são basicamente os que transportam os itens a serem vendidos.

Nas conversas com os comerciantes, não foi relatada interferência por parte de órgãos públicos no que se refere à fiscalização, apreensão de material, ou suporte para funcionamento da atividade. Nesse sentido, a regulamentação encontrada referente a esta atividade no espaço urbano versa sobre o que é, ou não, permitido no que se refere a licenciamento, instalação e funcionamento. O único incremento observado durante o trabalho de campo foi o promovido pela prefeitura da SQN 113, em que, a partir da observação do uso que seus habitantes fazem do espaço externo da quadra, foram instaladas tendas, mesas e assentos.

Por maior que seja o número de elementos físicos levados, montados ou aproveitados, os pontos de comércio necessitam de uma infraestrutura básica para o funcionamento. Nos estudos de caso em que houve aproveitamento do que tem no local de modo mais significativo, como os casos da SQN 209 e SQN 408, e o da SQN 113 em que foram sendo instalados recursos para as atividades no interior da superquadra por sua prefeitura, foram identificados os seguintes itens básicos a serem oferecidos no espaço urbano: iluminação, manutenção constante dos equipamentos, limpeza, lixeiras e assento. Eles compõem melhores condições em lugares diversos, como os detectados na tipologia apresentada, para o funcionamento desta e de outras atividades no espaço urbano.

Para o desenvolvimento de uma política governamental sobre o tema, seria recomendável a parceria entre as áreas envolvidas neste trabalho, junto ao setor de planejamento, primeiro para observar e fazer um levantamento dessas indisciplinas que reúnem informações valiosas sobre a qualificação mútua entre atividade e espaço urbano. Subsequente a essas observações, poderiam ser feitos mapeamentos sintáticos dos lugares apropriados, chegando-se a novas tipologias de apropriação. O aproveitamento dos elementos físicos e o que é portado aponta as necessidades reais do comerciante, da atividade, dos clientes. 
Enfim, proponho que além de regulamentar esta atividade, sejam implementadas e mantidas ações de cunho investigativo sobre a repercussão das diferentes posturas da indisciplina em relação ao espaço urbano, com o intuito de aproveitá-las em seu potencial social.

\section{Conclusão do capítulo}

O caráter exploratório desta pesquisa demanda a continuidade de sua aplicação. A comparação entre os pontos só é possível com o nível pormenorizado de descrição feita no capítulo 3. Outros entrelaçamentos entre os dados das variáveis podem ser feitos, na medida em que são calibradas.

A tipologia foi detectada e um caso de apropriação de cada tipo de lugar foi observado. Vale, ainda, fazer o levantamento de informações sobre a quantidade de pessoas que passam em situações sem o comércio, ou seja, em lugares do mesmo tipo que não foram utilizados como estudo de caso. A comparação entre as quantidades de pessoas entre os dois casos (com e sem o comércio) será um meio para a verificação do grau de atratividade e fixação de pessoas nos lugares em que existe um ponto de comércio.

Além da permanência das pessoas no ponto, que foi detectada por meio da localização e do período de tempo, questões como o que estão fazendo e como interagem possibilitarão uma exploração mais aprofundada dos mapas comportamentais como instrumentos de análise da atividade, no âmbito do nível analítico Sistema de Encontros e Esquivanças.

Os estudos de caso foram escolhidos após a detecção da tipologia e um dos critérios de seleção foi que os pontos para estudo passassem pela total montagem e desmontagem dos elementos portados pelo comerciante. Ao longo das visitas foi sendo identificado que todos eles tinham pelo menos um elemento fixado e deixado pelo comerciante no local, após o ponto ser desmontado. A assimilação desta quebra de critério serviu para considerar este fato como um sintoma da necessidade de condições básicas oferecidas pelo ambiente para o funcionamento da atividade, apesar de todo o trabalho de composição empreendido pelos comerciantes. 
Apesar do que ainda precisa ser complementado em termos de um melhor aproveitamento no tratamento dos dados levantados, o método construído para abordar o objeto nos quatro estudos de caso serviu para o início de um trabalho que efetivamente pode ser feito entre as duas áreas em questão. Aos níveis analíticos que já eram trabalhados dentro da Sintaxe Espacial - Padrões Espaciais, Sistemas de Encontros e Esquivanças e Características Socioeconômicas - foi somado o dos Sistemas de Elementos Físicos, por meio do qual pude me aproximar do objeto de modo pormenorizado com foco, neste momento, no aproveitamento do que era disponibilizado no espaço e no que os comerciantes precisavam transportar, ou complementar para o funcionamento da atividade. Com relação a este nível, o estudo deve ser aprofundado a partir das funções levantadas de cada elemento detectado e a relação entre eles, com o estabelecimento de outras classificações como por exemplo elementos de: delimitação, apoio, proteção, assento, socialização etc. Essa calibragem nas variáveis desse nível contribuirá para o conhecimento principalmente na área do design, em que comumente fazemos a análise da tarefa como etapa projetual de estações de trabalho.

Dois tipos de interface foram identificados logo no início do trabalho de campo: a interna à atividade que acontece entre o comerciante e os clientes nos pequenos espaços delimitados pela composição e a que ocorre entre o espaço da atividade e o contexto. Após a análise do trabalho de campo, no primeiro tipo de interface foram detectados tipos de arranjo de atendimento que podem ser comparados a arranjos existentes [lanchonete (SQN 209), restaurante (SQN 410), feira (SQN 113) e self service (SQN 408)], revelando a busca por alguma padronização na organização de seus espaços de trabalho pelos comerciantes. Na análise do segundo tipo de interface, foi possível identificar que apesar da composição também conferir ambiência e determinar o tipo da primeira interface, ela interfere pouco nos atributos do lugar quanto à acessibilidade ao movimento e à visão e ao campo visual, o que é considerado positivo, pois demonstra que os atributo são mantidos e aproveitados apesar e com a inserção do ponto. 


\section{CONCLUSÃO}

Ressalto a importância deste trabalho e de muitos outros desenvolvidos no âmbito da arquitetura sociológica e do design voltado para as questões sociais, pela reflexão e trabalho com o que aí está. Voltar a atenção para a repercussão dos artefatos na vida social das pessoas tem se mostrado um caminho mais consciente de se pensar as áreas envolvidas na materialidade que permeia as atividades do cotidiano urbano. Os usos e apropriações se libertam, de modos variados, dos propósitos projetuais e de planejamento e nos mostram o que em nenhuma sala de aula se ensina.

O que foi observado e analisado é de uma riqueza significativa de informação, no sentido da sua aplicação direta em projetos, sejam os que começam do zero, sejam aqueles que trabalham com espaços já construídos, principalmente. Além da conjugação de informações apresentadas aqui, como base para projetos e planejamento urbanos, o próprio trabalho de campo tem em seus procedimentos diretrizes para o cotidiano de quem projeta. Sair dos escritórios, salas, departamentos, setores e apreender a cidade com os pés deve ser conjugado com o primeiro rabiscar.

O design precisa (mais) fazer com! Os discursivos sobrevoamos as situações, os nossos objetos. O conhecimento não está somente na visibilidade (CERTEAU, 2009, p.158-9) deste objeto, mas no deixar de vê-lo e estar com ele, como pedestre, cliente, papeador. Fazer pesquisa é saber transitar entre os sobrevoos e as caminhadas.

Os espaços percebidos, concebidos e vividos ${ }^{54}$ de Brasília recebeu neste estudo mais um destes sobrevoos e caminhadas que são feitos por seus habitantes, acadêmicos, críticos e apaixonados. Isso, apesar e por causa de sua "racionalidade compreensível, de sua paisagem visual fortemente captável pelos sentidos" ${ }^{\prime \prime 5}$ e de seus problemas sociais, comuns a todas as cidades brasileiras.

\footnotetext{
${ }^{54}$ HOLANDA, 2013, p. 200.

55 op. cit., p. 198. (Grifos do autor)
} 
A conjunção dos atributos analíticos com base na teoria e no método da Sintaxe Espacial e nos princípios da Affordance, permitiu captar Brasília como campo contexto do objeto - sob a parceria da compreensão racional com a percepção sensível ${ }^{56}$.

Do objeto parti, ao objeto cheguei. O trabalho empírico foi feito antes de eu registrar o que assimilei dos autores que falaram, alguns mais tangenciais, outros bem mais em sintonia sobre o que eu buscava para abordar o objeto.

Das teorias consultadas, a Sintaxe Espacial, como base conceitual e metodológica sobre o contexto do objeto, é norte, também, de toda a pesquisa. Neste estudo sua limitação se dá por restringir sua análise ao nível topológico, o que contribuiu com o conhecimento dos atributos espaciais da atividade, mas que não perpassam a tridimensionalidade peculiar a camada de escala (menor) tratada pelo design. Porém, este fator não impossibilitou a busca pela sua conjunção com outras teorias que pudessem embasar as outras facetas do objeto.

O contato com o binômio táticas e estratégias, e o conceito de homem ordinário, no âmbito da Teoria das Práticas Cotidianas de Certeau, não só despertou para a escolha do comércio informal como objeto de estudo, mas embasou toda a parte da pesquisa sobre as igualdades e desigualdades sociais no uso e apropriação do espaço urbano. Aquela indisciplina! Apesar das críticas sobre a redução do comportamento, ou condição do homem social em uma dualidade apenas, pude partir dela para entender os matizes desse homem em suas relações sociais. Afinal, os cinzas são obtidos do binômio preto e branco.

Acessar a origem da Teoria da Abordagem Ecológica (Affordance) e compará-la ao seu uso ou vertente no design, mostrou o quanto ainda somos (designers) cegamente utilitaristas. Fico com a origem. Comparo o olhar para a materialidade

${ }^{56}$ op. cit., p. 199. 
pelo viés da percepção sensível com o apreender a cidade com os pés. Ambos potencializam a consciência no modo de apreensão pelo corpo do espaço vivido. ${ }^{57}$

A Affordance se mostrou como um campo de possibilidades e restrições em relação aos elementos físicos, assim como são encaradas as barreiras e permeabilidades no espaço arquitetônico, pela Sintaxe Espacial. Por intermédio da Affordance, pode-se constatar que os elementos da arquitetura e os naturais são mais comumente encarados como possíveis dispositivos de uso no espaço urbano do que se imagina. O atendimento a funções como servir de suporte, assento, delimitador de espaço, armazenador etc. revela as possibilidades que esses elementos proporcionam à essa atividade. As restrições, nesse caso, são consideradas aquelas funções que são demandadas pela atividade que não estão sendo atendidas pelo oferecido no local, tendo que ser, então, portado e montado pelo comerciante. As possibilidades e restrições no âmbito da Sintaxe Espacial são reveladas pelas categorias de análise discutidas nessa teoria: Padrões Espaciais e Sistema de Encontros e Esquivanças. Massa edilícia e elementos naturais são barreiras ao movimento e à visão, mas também podem delimitar espaços convexos. Tudo vai depender do que se está demandando e analisando. Esta comparação entre as duas teorias, no que se refere ao oferecido no espaço urbano em termos de vazios e volumetria como campos de possibilidades e restrições, revela uma afinidade de visão entre elas que foi sendo constatada no decorrer da análise do trabalho de campo. Ademais, este fator reforça a importância da parceria entre as áreas no estudo sobre o espaço urbano.

A união com a arquitetura só corroborou a ideia de que todo e qualquer artefato de design, isolado ou em seu contexto, é e compõe um sistema. A abordagem, nesse estudo, das teorias acima citadas antecedeu a da teoria geral dos sistemas. Ela veio como um elemento aglutinador entre os conceitos que recortaram o objeto, por sua complexidade.

Os lugares escolhidos pelos comerciantes dos quatro estudos de caso mostraram graus diferenciados dentro das variáveis observadas, mas têm em comum a escolha por uma ordem subjacente, explicada pelas sintaxes. Níveis de ambiência,

${ }^{57}$ Ibidem. 
integração, tratamento, equilíbrio, complexidade etc. informaram que a qualificação mútua entre elementos físicos e lugar se dá no ato da escolha, na composição da atividade que amplia a função do espaço de receber e repercutir no ir e vir e estar para o agir das pessoas. Elementos físicos também são pequenas barreiras e a permeabilidade possibilita as ações ao seu redor no desenvolvimento das diversas atividades que acontecem em um espaço.

A descontinuidade física e a especialização de uso são os dois principais aspectos ou problemas que caracterizam o espaço urbano de Brasília, posicionando-a mais próxima da formalidade do que da urbanidade. Contudo, na observação dos estudos de caso foi constatada que a apropriação daqueles lugares promove a diversidade de uso do espaço urbano em contrapartida àqueles problemas. Tanto os dois casos que se apropriam de lugares em superquadras (SQN 113 e SQN 410), quanto os que se instalam nos arredores (SQN 408 e SQN 209), contribuem com a promoção da qualificação dos espaços em questão no que se refere à interação social, aumentando a permanência de pessoas no lugar para além horário comercial, caso do ponto referente à SQN 408; conferindo identidade para o local, como faz o ponto da SQN 410; fixando os pedestres que passam pela passagem subterrânea, no ponto da SQN 209 e mostrando que no interior da SQN 113 as relações de vizinhança são beneficiadas por um comportamento de grupo.

A partir desta pesquisa, inicio a compreensão da lógica social que subjaz às soluções encontradas pelo comerciante em relação ao que foi oferecido nos espaços abertos das cidades, em termos de configuração de espaço-forma. Da apropriação de uma mureta como suporte para os aparatos de café da manhã e, ao mesmo tempo, para assento, à composição de um pequeno restaurante ao ar livre, foi observado que o comerciante procura estabelecer um conjunto de condições, a partir de um espaço apropriado, para o funcionamento de uma atividade que já é naturalmente social. Os atributos de integração e convexidade são assimilados intuitivamente, em maior ou menor grau, nas escolhas do lugar para a apropriação.

A questão principal da tese 'Em que condições, de que maneira e mediante quais atributos de configuração da forma-espaço o sistema de elementos físicos envolvidos, o contexto da atividade e a interface entre eles favorecem a interação 
social?' é respondida com a conjugação desses atributos do espaço assimilados pelos comerciantes com o aproveitamento dos elementos que nele estão para a composição dos aparatos da atividade. Esta conjugação acaba por ser a interface entre o contexto e a atividade em termos de forma-espaço que permite seu funcionamento e, consequentemente, a interação social no local.

A interface é a resposta para o que acontece com a vida social de um lugar quando seu espaço é multiplicado em sua repercussão. É estabelecida entre os limites da convexidade do contexto e os dos variados pequenos contornos dos objetos e, por isso, é um conjunto de espaços múltiplos, que por meio de suas formas possibilitam, em maior ou menor grau, as atividades, a copresença, o contato, a vida social.

Tal interface é melhor apreendida quando da parceria, em reflexão e ação, entre a arquitetura e o design. Com o desenvolvimento deste trabalho veio a constatação da relação muito estreita entre as duas áreas, que não é explorada nos projetos, tanto de uma quanto de outra.

O ineditismo da relação de ambas as áreas por meio do objeto de estudo, em específico, torna-se uma denúncia, ao final. Adianta continuarmos a tentar solucionar questões na realidade urbana, que mobilizam tantas áreas, sem ao menos nos unirmos aos que compartilham das mesmas linguagens?

Levo para a profissão e para a vida acadêmica o despertar, para o design, da dimensão espacial ao redor dos artefatos, resultado de seus projetos, e a correlação direta com eles pela mesma linguagem utilizada na observação e interferência em relação aos fenômenos, no nosso caso, sociais. Afinal, também projetamos espaços!

Concluo este trabalho constatando que o espaço, como ambiente social, é resultado conjunto das duas áreas, arquitetura e design. A apropriação e o uso dos espaços e a utilização da arquitetura e de elementos paisagísticos fazem parte das ações projetivas dentro do design para o espaço urbano.

Ações isoladas acabam por repercutir na subutilização do espaço urbano, cuja pequena parte de seu potencial busquei mostrar neste trabalho. No caso de Brasília, 
de fato, não é uma flor de estufa, como bem constatou Lucio Costa. "Na verdade, o sonho foi menor que a realidade. A realidade foi maior, mais bela." (COSTA, 1991). É esta realidade maior que permite, todos os dias, a apropriação dos lugares por pessoas como Dona Aparecida, Sr. Domingos, Solange e Renato.

Este trabalho abre questões sobre a relação entre a variedade e a natureza dos artefatos que dão suporte às atividades no espaço urbano. Pela experiência com essa pesquisa, recomendo o estudo sistemático que tem como base a observação de atividades no espaço urbano, que congregue profissionais e acadêmicos principalmente das áreas envolvidas aqui.

A constante "manutenção" do tipo de informação levantada neste estudo parece ser uma postura mais comprometida com as múltiplas realidades do espaço urbano. Seu ordenamento parece não prescindir deste olhar atento, mas ao mesmo tempo flexível e aberto. "... o que procuramos não é uma ordem definitiva, mas uma ordem aberta, passível de continuidade em seu desenvolvimento." (LYNCH, 2010, p. 7). 


\section{| BIBLIOGRAFIA E REFERÊNCIAS BIBLIOGRÁFICAS}

ADMINISTRAÇÃO REGIONAL DE BRASÍLIA - RA I. Governo do Distrito Federal. Disponível em: http://www.brasilia.df.gov.br/sobre-a-ra-i/conheca-brasilia-ra-i.html. Acesso em: 05/2014

ALEXANDER, C.; ISHIKAWA, S.; SILVERSTEIN, M. A Pattern Language. New York: Oxford University Press, 1977.

AL_SAYED, Kinda; TURNER, Alasdair; HILLIER, Bill; IIDA, Schinichi; PENN, Alan. Space Syntax Methodology. Bartlett School of Architecture, UCL: London, 2014.

ANDERSON, Stanford. A ficção da função. Anais do $4^{\circ}$. SEDUR - Seminário sobre Desenho Urbano no Brasil, Faculdade de Arquitetura e Urbanismo da Universidade de Brasília: Brasília, 1995.

ARANTES, Otília; VAINER, Carlos; MARICATO, Ermínia. A cidade do pensamento único: desmanchando consensos. Petrópolis, RJ: 2013.

ARGAN, Giulio Carlo. Projeto e destino. São Paulo: Editora Ática, 2004.

AUGÉ, Marc. Não lugares: introdução a uma antropologia da supermodernidade. Campinas: Papirus, 2012.

ASCHER, François. Novos Princípios do Urbanismo seguido de Novos Compromissos Urbanos. Um léxico. Lisboa: Livros Horizonte, 2010.

BARKER, Roger G. Ecological Psichology - concepts and methods for studying the environment of human behavior. California, Standford University Press, 1968.

BAUMAN, Zygmunt. Modernidade líquida. Rio de Janeiro: Zahar, 2001.

BENEVOLO, Leonardo. História da cidade. São Paulo: Perspectiva, 2011.

BERGER, Peter L., LUCKMANN, Thomas. A construção social da realidade: tratado de sociologia do conhecimento. Petrópolis: Vozes, 2009.

BERTALANFFY, Ludwig von. Teoria geral dos sistemas: fundamentos, desenvolvimento e aplicações. Petrópolis, RJ: Vozes, 2015.

BOGÉA, Marta. Cidade errante: arquitetura em movimento. São Paulo: Editora SENAC São Paulo, 2009.

BONSIEPE, Gui. Design, cultura e sociedade. São Paulo: Blucher, 2011.

BOURDIEU, Pierre. A distinção: crítica social do julgamento. Porto Alegre, RS: Zouk, 2011.

BUCHANAN, Richard; MARGOLIN, Victor. Discovering design: explorations in design studies. Chicago, USA: Chicago Press, 1995. 
CAPES - Coordenação de Aperfeiçoamento de Pessoal de Nível Superior. Documento da Área de Arquitetura e Urbanismo e Design (2009). Disponível em: http://www.capes.gov.br. Acesso em: 08/2010.

CAPES - Coordenação de Aperfeiçoamento de Pessoal de Nível Superior. Documento da Área de Arquitetura e Urbanismo e Design (2013). Disponível em: http://www.capes.gov.br. Acesso em: 09/2014.

CAPRA, Fritjof. O ponto de mutação. São Paulo: Cultrix, 2012.

CARDOSO, Rafael. Design para um mundo complexo. São Paulo: Cosac Naify, 2012.

CERTAU, Michel de. A invenção do cotidiano: 1. Artes de fazer. Petrópolis/RJ: Vozes, 2009.

CHASE, John, CRAWFORD, Margaret, KALISKI, John. Everyday urbanism. New York: The Monacelli Press, Inc., 1999.

COSTA, Lucio. Relatório do Plano Piloto de Brasília. Brasília: GDF, 1991.

COUTINHO, Evaldo. O espaço da arquitetura. São Paulo: Perspectiva, 2010.

DENIS, Rafael Cardoso. Uma introdução à história do design. São Paulo: Edgard Blucher, 2000.

ENCYCLOPAEDIA BRITTANICA. Chicago: William Benton Publisher, 1963.

FERRARA, Lucrécia D'Alessio. Design em espaços. (Coleção TextosDesign). São Paulo: Edições Rosari, 2002.

FERRARA, Lucrécia D'Alessio. Olhar Periférico: informação, linguagem, percepção ambiental. São Paulo: Editora da Universidade de São Paulo, 1993.

FLUSSER, Vilém. O mundo codificado. São Paulo: Cosac Naify, 2007.

FOUCAULT, Michel. Microfísica do poder. Rio de Janeiro: Edições Graal, 2011.

FOUCAULT, Michel; MISKOWIEC, Jay. Of other spaces. Diacritics, p. 22-27, 1986.

GDF - Governo do Distrito Federal. Lei N . 4.457, de 23 de dezembro de 2009.

Dispõe sobre o licenciamento para funcionamento de atividades econômicas e atividades sem fins lucrativos no âmbito do Distrito Federal. Diário Oficial da República Federativa do Brasil, Brasília, DF, 24/12/09. Disponível em: <http://www.seops.df.gov.br> Acesso em: 11/2012.

GDF - Governo do Distrito Federal. Lei N . 4.257, de 02 de dezembro de 2008. Estabelece critérios de utilização de áreas públicas do Distrito Federal por mobiliários urbanos do tipo quiosque e trailer para o exercício de atividades econômicas e dá outras providências. Diário Oficial da República Federativa do 
Brasil, Brasília, DF, 04/12/08. Disponível em: <http://www.seops.df.gov.br> Acesso em: 11/2012.

GEERTZ, Clifford. O saber local: novos ensaios em antropologia interpretativa. Petrópolis, RJ: Vozes, 1997.

GEHL, Jan. Life between buildings - using public space. Skive: The Danish Architectural Press, 2006.

GEHL, Jan. Cidades para pessoas. São Paulo: Perspectiva, 2013.

GIBSON, James J. The Ecological Approach to Visual Perception (livro digital). New York, USA: Psychology Press, 1986.

GIDDENS, Anthony. The constitution of society - outline of a theory of structuration. Cambridge: Polity Press, 1986.

GIL, Antônio Carlos. Como classificar as pesquisas. Como elaborar projetos de pesquisa, v. 4, p. 44-45, 2002.

GORDON, Charles C. A selection of sociologies: The sociology of work. In: INTERNATIONAL JOURNAL OF ENGINEERING EDUCATION, v. 19, n. 1, p. 9498, 2003.

GREENWOOD, Ernest; VILLEGAS, Óscar Uribe. Los Métodos de Investígación Empírica en Sociología. In: Revista Mexicana de Sociologia, p. 541-574, 1963.

GUNTHER, Hartmut. Mobilidade e 'affordance' como cerne dos Estudos PessoaAmbiente. In: Estudos de Psicologia, 8(2), p. 273-280, 2003.

HALL, Peter. Cidades do Amanhã: uma história intelectual do planejamento e do projeto urbanos no século XX. São Paulo: Perspectiva, 2013.

HARVEY, David. Espaços de esperança. São Paulo: Edições Loyola, 2013.

HILLIER, Bill. The art of place and the science of space. World Architecture 11/2005 185, Beijing, Special Issue On Space Syntax, 2005, p. 24-34 in Chinese, p. 96-102 in English.

HILLIER, B., PENN, A., HANSON, J., GRAJEWSKI, T., XU, J. Natural movement: or, configuration and attraction in urban pedestrian movement. In Environment and Planning B. Londres: Pion Publication, vol. 20, n. 1, p. 29-66, 1993.

HILLIER, B., BURDETT, R., PEPONIS, J., PENN, A. Creating life: or, does architecture determine anything? In Architecture et Comportment/Architecture and Behavior, vol. 3, n. 3, pp. 233-250, 1987.

HILLIER, B., HANSON, J. The Social Logic of Space. Cambridge: Cambridge University Press, 1984. 
HILLIER, B. and LEAMAN, A. The man-environment paradigm and its paradoxes. Architectural Design, 78 (8), 1973, p. 507-511.

HILLIER, B. and LEAMAN, A. How is design possible? Journal of Architectural Research, 3 (1), 1974, p. 4-11.

HOLANDA, Frederico de. O espaço de exceção. Brasília: Editora Universidade de Brasília, 2002.

HOLANDA, Frederico de. Arquitetura sociológica. Revista brasileira de estudos urbanos e regionais, vol. 9, n.1, p. 115-129. Associação Nacional de PósGraduação e Pesquisa em Planejamento Urbano e Regional, 2007.

HOLANDA, Frederico de. Be aware of local properties. In: INTERNATIONAL SPACE SYNTAX SYMPOSIUM, 6, 2007, Istambul. Proceedings, $6^{\text {th }}$ International Space Syntax Symposium. Istanbul: ITU Faculty of Architecture, 2007, p. 082-01082-13.

HOLANDA, Frederico de. Brasília - cidade moderna, cidade eterna. Brasília: FAU UnB, 2010a.

HOLANDA, Frederico de. A morfologia interna da capital. In PAVIANI, Aldo (org.). "Brasília, ideologia e realidade - espaço urbano em questão". São Paulo: Projeto, 2010b.

HOLANDA, Frederico de (org.). Arquitetura e Urbanidade. Brasília: FRBH Edições, 2011.

HOLANDA, Frederico de. Oscar Niemeyer: de vidro e concreto / of glass and concrete. Brasília: FRBH, 2011.

HOLANDA, Frederico de (org.). Ordem e desordem: arquitetura e vida social. Brasília: FRBH Edições, 2012.

HOLANDA, Frederico de. 10 mandamentos da arquitetura. Brasília: FRBH Edições, 2013.

HOUAISS, Antônio e VILLAR, Mauro de Salles. Dicionário Houaiss da língua portuguesa. Rio de Janeiro: Objetiva, 2009.

IBGE - Instituto Brasileiro de Geografia e Estatística. Economia Informal Urbana 2003. Disponível em: http://www.ibge.gov.br. Acesso em: 11/2012.

ICSID - The International Council of Design Societies. Disponível em: http://www.icsid.org/. Acesso em: 12/2012 e 01/2016.

JACOBS, Jane. Morte e vida de grandes cidades. São Paulo: Martins Fontes, 2009. 
JACQUES, Paola Berenstein. Estética da ginga: a arquitetura das favelas através da obra de Hélio Oiticica. Rio de Janeiro: Casa da palavra, 2011.

JACQUES, Paola Berenstein. Elogio aos errantes. Salvador: EDUFBA, 2012.

JOHNSON, Steven. Emergência - a dinâmica de redes em formigas, cérebros, cidades e softwares. Rio de Janeiro: Jorge Zahar Editor Ltda., 2003.

KAHN, Louis. Forma e design. São Paulo: Martins Fontes, 2010.

KEESING, Roger. Theories of Culture. Annual Review of Anthropology, vol. 3. Palo Alto, California, 1974.

KOHLSDORF, Maria Elaine. A apreensão da cidade. Brasília: Editora Universidade de Brasília, 1996.

LARAIA, Roque de Barros. Cultura: um conceito antropológico. Rio de Janeiro: Zahar, 1986.

LUCIE-SMITH, Edward. The Story of Craft: the Craftsman Role in Society. Nova York: Van Nostrand Reinhold, 1984.

LUHMANN, Niklas. Complejidad y modernidad: de la unidad a la diferencia. Madrid: Editorial Trotta, 1998.

LYNCH, Kevin. A imagem da cidade. São Paulo: Martins Fontes, 1997.

MACHADO, Lia Zanotta, MAGALHÃES, Themis Quezado. Imagens do espaço: imagens de vida. In PAVIANI, Aldo (org.). "Brasília, ideologia e realidade - espaço urbano em questão". São Paulo: Projeto, 1985.

MADDEN, Kathleen. How to Turn a Place Around - A Handbook for Creating Succesful Public Spaces. New York: Project for Public Spaces, 2005.

MAJOR, Mark David; PENN, Alan; HILLIER, Bill. Space Syntax: a theory with a toolkit. In: $1^{\text {st }}$ INTERNATIONAL SPACE SYNTAX SYMPOSIUM, 1997, Londres Inglaterra. Proceedings... Londres: Space Syntax Laboratory / The Bartlett School of Graduate Studies / University College London, 1997. v. 3, p. 42.01-42.07.

MARGOLIN, Victor. Design discourse: history, theory, cristicism. Chicago: The University of Chicago Press, 1989.

MARGOLIN, Victor; BUCHANAN, Richard. The idea of design. Massachusetts, USA: MIT Press, 1996.

MANZINI, Ezio. Design, when everybody designs: an introduction to design for social innovation. Massachusetts, USA: MIT Press, 2015.

MEDEIROS, Valério Augusto Soares de. Urbis Brasiliae, ou sobre as cidades do Brasil: inserindo assentamentos urbanos do país em configurações 
configuracionais comparativas. Tese (Doutorado em Arquitetura e Urbanismo). Faculdade de Arquitetura e Urbanismo, Universidade de Brasília, Brasília, 2006. MOLES, Abraham. The Comprehensive Guarantee: A new Consumer Value. In MARGOLIN, Victor (org.). "Design Diacourse: history, theory, criticism. Chicago: The University of Chicago Press, 1989. p. 77-90.

MONTEIRO, Circe M. G., CAVALCANTI, Rafaella. A face noturna da cidade: dinâmica sócio espacial, morfologia e segurança das atividades noturnas no bairro de Boa Viagem, Recife. In: Anais do $2^{\circ}$. ENAMPARQ - Encontro da Associação Nacional de Pesquisa e Pós-graduação em Arquitetura e Urbanismo, Faculdade de Arquitetura e Urbanismo da Universidade Federal do Rio Grande do Norte: Natal, 2012. Disponível em: http://www.anparq.org.br/dvdenanparq/simposios.

MORIN, Edgar. Da necessidade de um pensamento complexo. In MARTINS, Francisco Menezes, SILVA, Juremir Machado (org.). "Para navegar no século XXI - Tecnologias do Imaginário e Cibercultura". Porto Alegre: EDIPUCRS/Sulina, p. 13-36, 2003.

MORIN, Edgar. Os sete saberes necessários à educação do futuro. São Paulo:

Cortez; Brasília, DF: UNESCO, 2000.

NETTO, Vinícius. A urbanidade como devir do urbano. In: Anais do $1^{\circ}$. ENAMPARQ - Encontro da Associação Nacional de Pesquisa e Pós-graduação em Arquitetura e Urbanismo, Faculdade de Arquitetura e Urbanismo da Universidade Federal do Rio de Janeiro: Rio de Janeiro, 2010. Disponível em: http://www.anparq.org.br/dvd-enanparq/simposios

NORMAN, Donald A. O design do dia-a-dia. Rio de Janeiro: Rocco, 2006.

NORMAN, Donald A. O design do futuro. Rio de Janeiro: Rocco, 2010.

NUNES, Brasilmar Ferreira. A lógica social do espaço. In PAVIANI, Aldo, GOUVÊA, Luiz Alberto de (orgs.). Brasília: Controvérsias Ambientais. Brasília: Editora Universidade de Brasília, 2003, pp.76-102.

PACEY, Philip. 'Anyone Designing Anything?' Non-Professional Designers and the History of Design. Journal of Design History, Oxford University Press, Vol. 5, No. 3, 1992. Disponível em: http://www.jstor.org/stable/1315839. Acesso em: 03/2012. PAPANEK, Victor. Design for the real world - human ecology and social change. New York: Van Nostrand Reinhold, 2000. 
PAPANEK, Victor. The green imperative: ecology and ethics in design and architecture. Singapure: C. S. Graphics, 2003.

PAPANEK, Victor. Arquitetura e Design - Ecologia e Ética. Lisboa: Edições 70, 2007.

PAVIANI, Aldo (org.). Brasília, ideologia idade: espaço urbano em questão. Brasília: Editora Universidade de Brasília, 2010.

PAZ, Daniel. O lugar efervescente: características da arquitetura efêmera no sítio. In: Anais do $2^{\circ}$. ENAMPARQ - Encontro da Associação Nacional de Pesquisa e Pósgraduação em Arquitetura e Urbanismo, Faculdade de Arquitetura e Urbanismo da Universidade Federal do Rio Grande do Norte: Natal, 2012. Disponível em: http://www.anparq.org.br/dvd-enanparq/simposios

PEREIRA, Mateus Henrique de Faria, SARTI, Flávia Medeiros. A leitura entre táticas e estratégias? Consumo cultural e práticas epistolares. História da Educação, ASPHE/FaE?UFPel, Pelotas, v. 14, n. 31 p. 195-217, Maio/Ago 2010. Disponível em: http//fae.ufpel.edu.br/asphe. Acesso em: setembro/2015.

PEPONIS, John. Espaço, cultura e desenho urbano no modernismo tardio e além dele. Boletim do IA, no. 51. Brasília: IA-UnB, 1989.

PEVSNER, Nikolaus. Os pioneiros do desenho moderno: de William Morris a Walter Gropius. São Paulo: Martins Fontes, 1980.

PEVSNER, Nikolaus. Origens da arquitetura moderna e do design. São Paulo: Martins Fontes, 1981.

REDIG, Joaquim. Sobre Desenho Industrial. Rio de Janeiro: ESDI, 1977.

RIBEIRO, Manuela S. Habitar, trabalhar, recrear e circular: possibilidades e limitações nas superquadras de Brasília. Dissertação (Mestrado em Arquitetura e Urbanismo) - Faculdade de Arquitetura e Urbanismo, Universidade de Brasília, Brasília, 2013.

SAFFER, Dan. Designing for interaction: creating innovative applications and devices (livro digital). Berkeley, USA: New Riders, 2010.

SAHLINS, Marshall David. Cultura e razão prática. Rio de Janeiro: Zahar, 2003.

SANT'ANNA, Hugo Cristo. Design sem Designer (livro digital). Serra/Espírito Santo: Edição do autor, 2013.

SANTOS, Milton. A natureza do espaço: técnica e tempo, razão e emoção. São Paulo: Editora da Universidade de São Paulo, 2012. 
SANTOS, Milton. Técnica, espaço, tempo: globalização e meio técnico-científicoinformacional. São Paulo: Editora da Universidade de São Paulo, 2013.

SENNETT, Richard. O Artífice. Rio de Janeiro: Record, 2012.

SEOPS - Secretaria de Estado da Ordem Pública do Distrito Federal. Disponível em: http://www.seops.df.gov.br/. Acesso em: 10/2012.

SOPLA - Políticas Sociales en América Latina. Sector Informal y Políticas Públicas en América Latina. Rio de Janeiro: Konrad-Adenauer-Stiftung, 2010.

SOUZA, Maria Cristina Cacciamali. Um estudo sobre o setor informal urbano e formas de participação na produção. Tese (Doutorado em Economia) - Faculdade de Economia e Administração, Universidade de São Paulo, São Paulo, 1982.

SIU, K. W. M. Guerrilla wars in everyday public spaces: reflections and inspirations for designers. In: International Journal of Design, 1(1). 2007, p. 37-56.

TENÓRIO, Gabriela de Souza. Ao desocupado em cima da ponte. Brasília, arquitetura e vida pública. Tese (Doutorado em Arquitetura e Urbanismo) Faculdade de Arquitetura e Urbanismo, Universidade de Brasília, Brasília, 2012.

THACKARA, John. Plano B: o design e as alternativas viáveis em um mundo complexo. São Paulo: Saraiva: Versar, 2008.

TONKISS, Fran. Cities by Design - The Social Life of Urban Form. Cambridge: Polity Press, 2013.

VASCONCELOS, Maria José Esteves de. Pensamento sistêmico: o novo paradigma da ciência. Campinas, SP: Papirus, 2012.

VASSÃO, Caio Adorno. Metadesign: ferramentas, estratégias e ética para a complexidade. São Paulo: Blucher, 2010.

WHITE, Leslie. The Symbol: The Origin and Basis of Humans Behavior. In MORBEL, LENNINGS e SMITH (orgs.), Readings of Antropology. New York: McGraw-Hill Book Co., 1955.

WHITE, William H. The Social Life of Small Urban Spaces. New York: Project for Public Spaces, 2009.

WHITLAM, John et al. English - Portuguese / Português - Inglês Dictionary. São Paulo: Disal, 2001. 
ANEXOS 


\section{ANEXO 1 - Tabela geral dos níveis analíticos *}

\begin{tabular}{|c|c|c|c|c|}
\hline NÍVEIS & & VARIÁVEIS & VARIABILIDADE & FERRAMENTAS \\
\hline \multirow{7}{*}{ 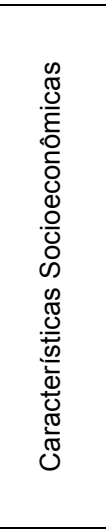 } & 01 & $\begin{array}{l}\text { Apresentação geral: gênero, faixa etária, } \\
\text { naturalidade, grau de instrução }\end{array}$ & $\begin{array}{l}\text { gênero: }(\mathrm{F}) /(\mathrm{M}) \text {, faixa etária: } \\
(20-30) ;(30-40) ;(40-50) ;(50- \\
60) ;(>60)\end{array}$ & \multirow{6}{*}{ Entrevista } \\
\hline & 02 & Local de moradia e modo de deslocamento & lugares do DF & \\
\hline & 03 & $\begin{array}{l}\text { A atividade é a única ocupação remunerada? } \\
\text { Dias da semana de que se ocupa com a } \\
\text { atividade. }\end{array}$ & $\begin{array}{l}\text { Única remuneração? (S); (N) } \\
\text { Dias semana: }\left(2^{\mathrm{a}} .\right) ;\left(3^{\mathrm{a}} .\right) ;\left(4^{\mathrm{a}} .\right) ; \\
\left(5^{\mathrm{a}} .\right) ;\left(6^{\mathrm{a}} .\right) ;(\text { sábado) }\end{array}$ & \\
\hline & 04 & Renda mensal adquirida pela atividade & $\begin{array}{l}\text { quantidade de salários } \\
\text { mínimos }\end{array}$ & \\
\hline & 05 & $\begin{array}{l}\text { Razão da escolha por este local para } \\
\text { o ponto de comércio }\end{array}$ & resposta livre & \\
\hline & 06 & Quem é o seu público/cliente? & moradores; trabalhadores & \\
\hline & 07 & $\begin{array}{l}\text { Dados censitários sobre renda dos } \\
\text { moradores }\end{array}$ & $\begin{array}{l}\text { (pobres); (classe média } \\
\text { baixa); (classe média média); } \\
\text { (classe média alta); (ricos); } \\
\text { (sem remuneração). }\end{array}$ & $\begin{array}{l}\text { Banco de dados } \\
\text { IBGE }\end{array}$ \\
\hline \multirow{7}{*}{ 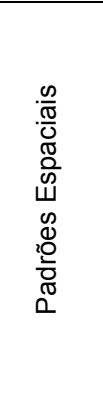 } & 08 & $\begin{array}{l}\text { Espaços convexos - ambiência física para e } \\
\text { a partir do ponto }\end{array}$ & $\begin{array}{l}\text { áreas de espaço convexo } \\
\text { médio }\end{array}$ & $\begin{array}{c}\text { mapa de } \\
\text { convexidade }\end{array}$ \\
\hline & 09 & Acessibilidade ao movimento de veículos & medida de integração global & \multirow{3}{*}{$\begin{array}{l}\text { mapa de } \\
\text { axialidade }\end{array}$} \\
\hline & 10 & Acessibilidade ao movimento do pedestre & medida de integração local & \\
\hline & 11 & Acessibilidade à visão - conexão visual & medida de conexão visual & \\
\hline & 12 & Isovistas - campo visual & $\begin{array}{l}\text { medida da área do campo } \\
\text { visual }\end{array}$ & $\begin{array}{l}\text { mapa de } \\
\text { isovistas }\end{array}$ \\
\hline & 13 & $\begin{array}{l}\text { Condições para permanência - estado de } \\
\text { conservação e conforto }\end{array}$ & $\begin{array}{l}\text { elementos da arquitetura ou } \\
\text { paisagem que disponibilizam } \\
\text { as condições }\end{array}$ & \multirow{2}{*}{$\begin{array}{l}\text { observação e } \\
\text { registro } \\
\text { fotográfico }\end{array}$} \\
\hline & 14 & Atividades ao redor do ponto de comércio & $\begin{array}{l}\text { quantidade e variedade de } \\
\text { atividades }\end{array}$ & \\
\hline \multirow{3}{*}{ 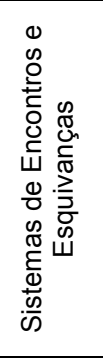 } & 15 & $\begin{array}{l}\text { Quantidade de pessoas - passagem e } \\
\text { permanência }\end{array}$ & quantidade de pessoas & \multirow[b]{2}{*}{$\begin{array}{l}\text { observação } \\
\text { sistematizada: } \\
\text { contabilização } \\
\text { intercalada }\end{array}$} \\
\hline & 16 & $\begin{array}{l}\text { Variedade de pessoas na permanência: } \\
\text { gênero e faixa etária }\end{array}$ & $\begin{array}{l}\text { quantidade de pessoas } \\
\text { distribuída em (F); (M) e } \\
\text { Quantidade de pessoas } \\
\text { distribuídas em (crianças); } \\
\text { (adolescentes); (20-30); (30- } \\
\text { 40); (40-50); (50-60); (> 60) }\end{array}$ & \\
\hline & 17 & $\begin{array}{l}\text { Distribuição de pessoas no tempo e no } \\
\text { espaço }\end{array}$ & $\begin{array}{l}\text { posições das pessoas } \\
\text { contabilizadas no espaço da } \\
\text { atividade }\end{array}$ & $\begin{array}{l}\text { mapeamento } \\
\text { comportamental }\end{array}$ \\
\hline \multirow{2}{*}{ 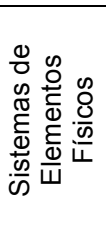 } & 18 & $\begin{array}{l}\text { Complexidade: descrição, atributos e } \\
\text { relações }\end{array}$ & $\begin{array}{l}\text { diversidade de elementos } \\
\text { utilizados, suas funções e } \\
\text { qualidades individuais e } \\
\text { relações e integração }\end{array}$ & \multirow{2}{*}{$\begin{array}{l}\text { mapa detalhado } \\
\text { com elementos } \\
\text { da atividade; } \\
\text { observação in } \\
\text { loco e registro } \\
\text { fotográfico }\end{array}$} \\
\hline & 19 & Aspectos funcionais & $\begin{array}{l}\text { itens de relação entre os } \\
\text { elementos e suas funções na } \\
\text { atividade }\end{array}$ & \\
\hline
\end{tabular}

* Os mapas de convexidade e axialidade, bem como seus geradores foram executados por Manuela Ribeiro. Os mapas de isovistas foram confeccionados por Vânia Loureiro. 
ANEXO 2 - Mapas comportamentais**

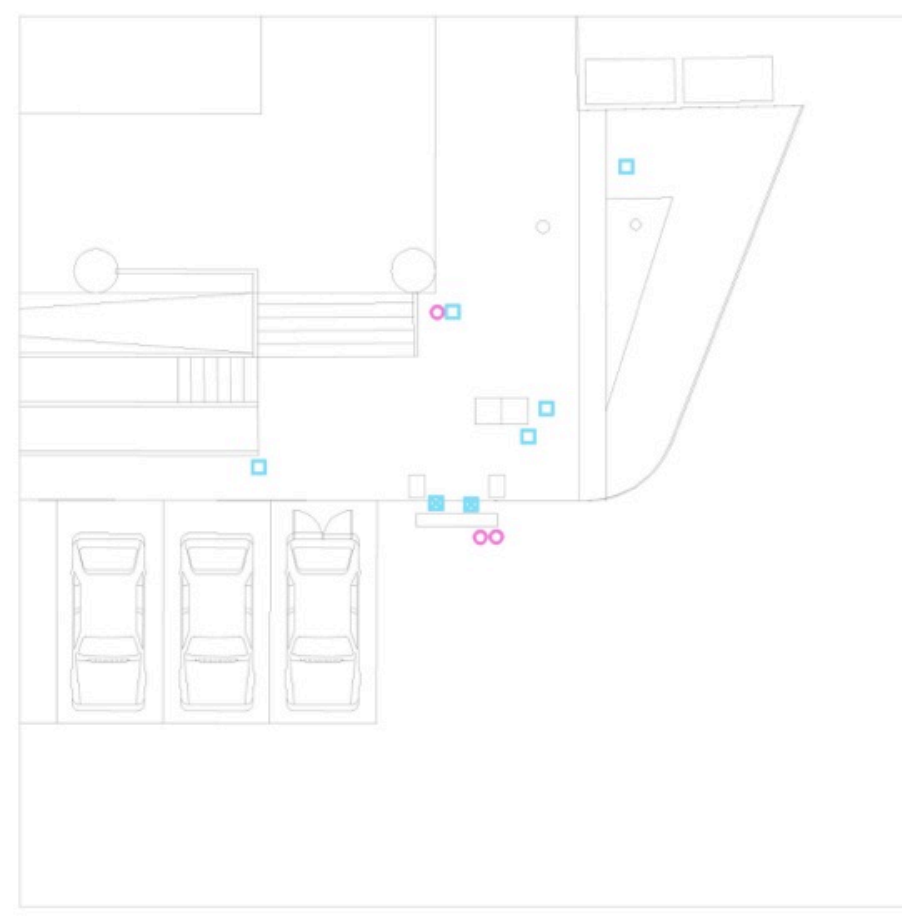

SQN $408-1^{\circ}$ dia

LEGENDA:
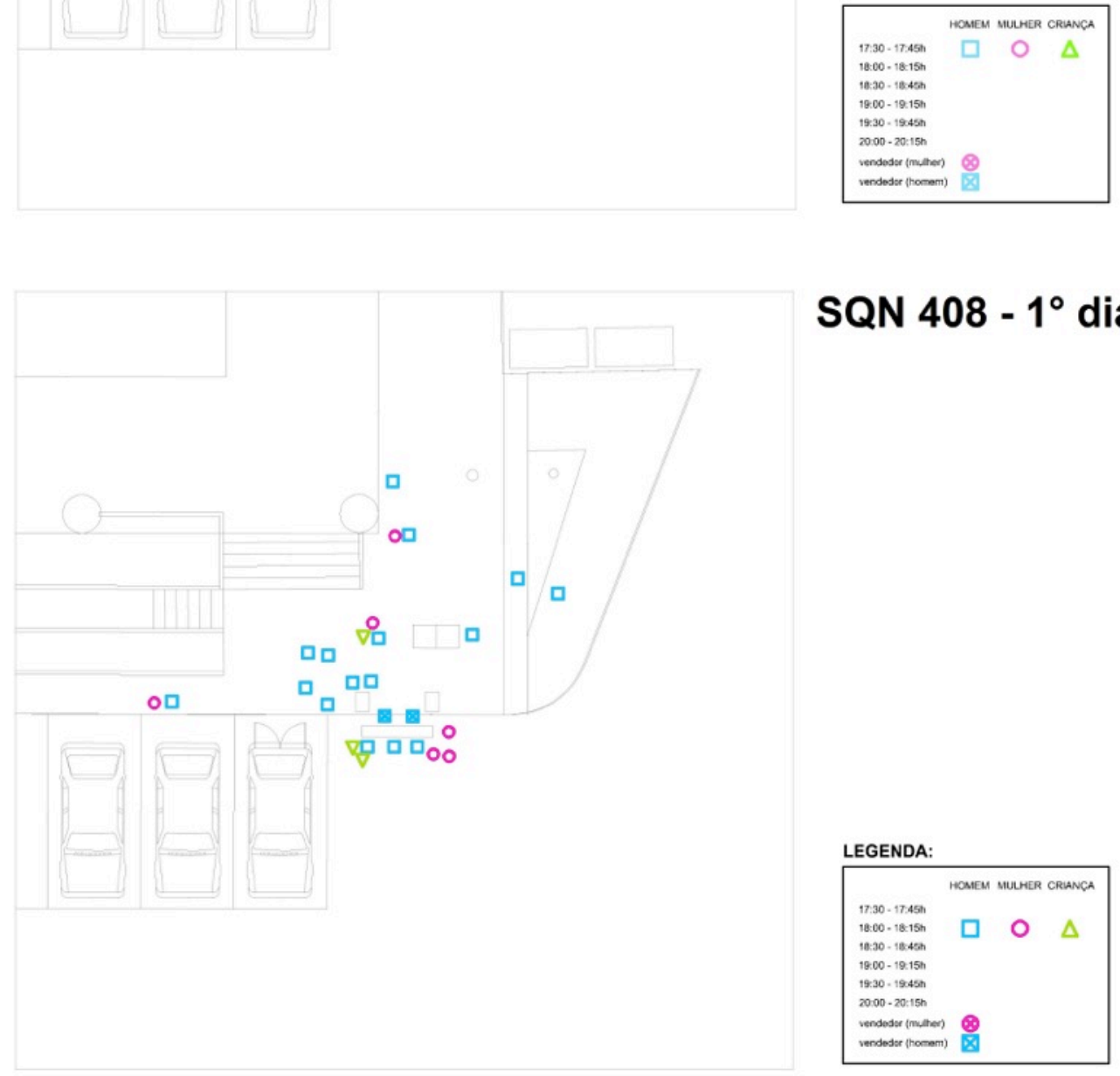

SQN $408-1^{\circ}$ dia

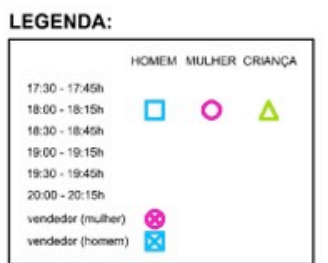

** Aqui são mostrados os mapas comportamentais detalhados (por intervalos de 15 minutos) do comércio associado à SQN 408, estudo de caso que foi o piloto do trabalho de campo. O mesmo tipo de registro foi feito para os outros pontos de comércio informal. A digitalização dos registros foi feita, também, por Manuela Ribeiro. 


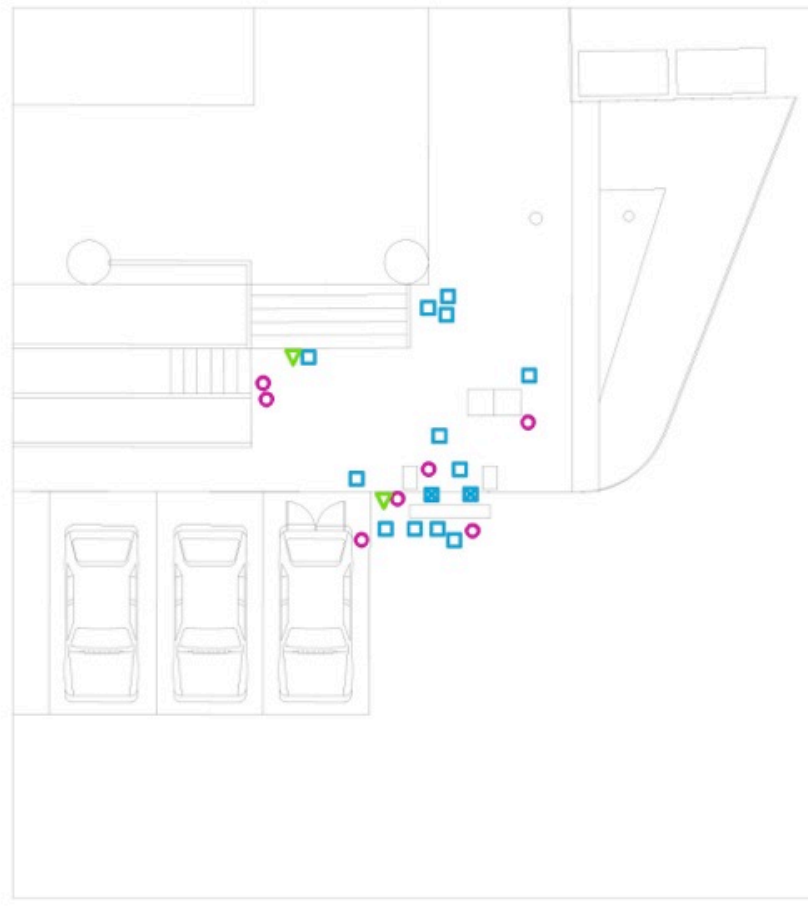

SQN $408-1^{\circ}$ dia
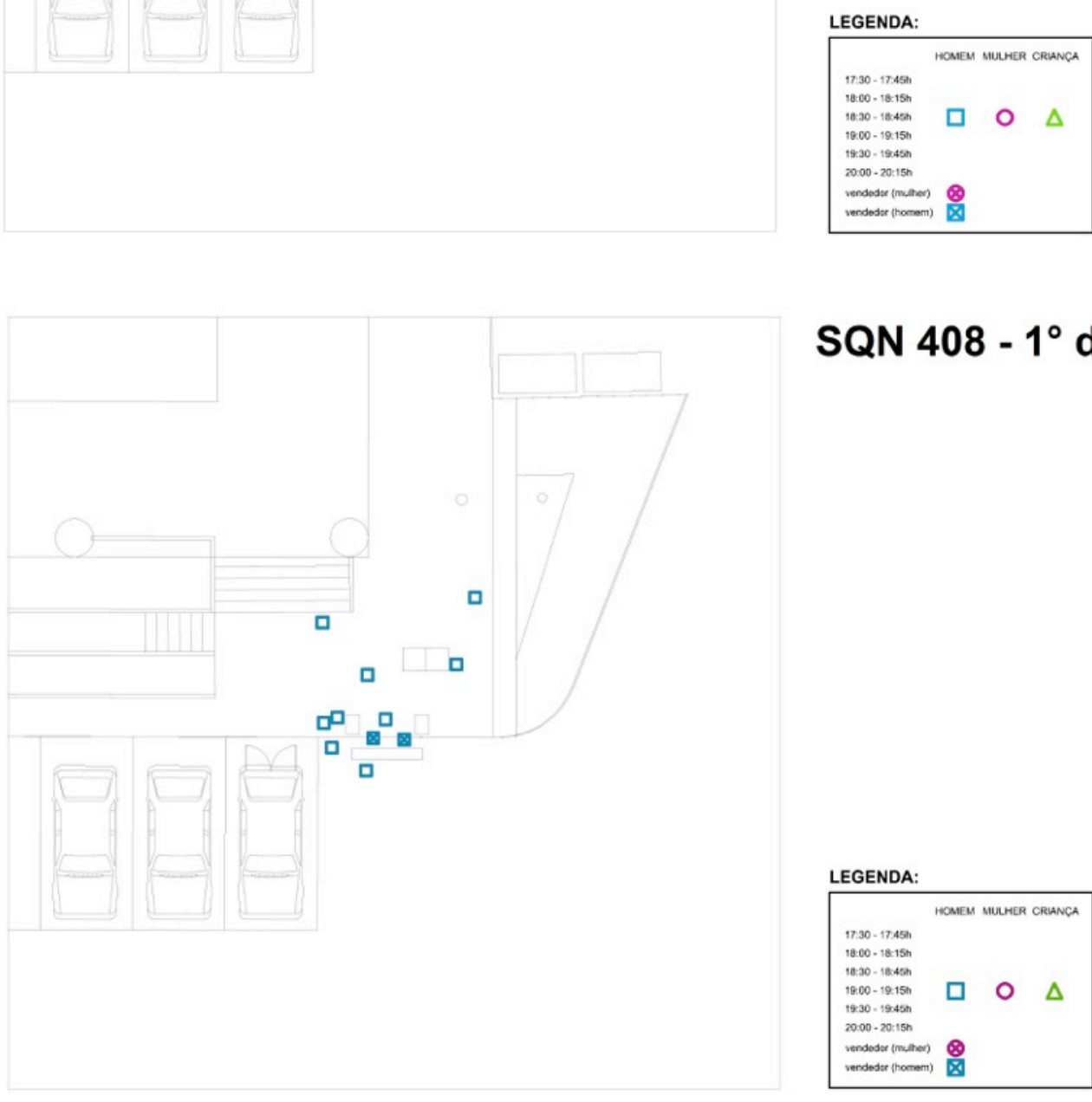

SQN $408-1^{\circ}$ dia

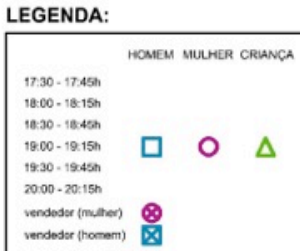


SQN $408-1^{\circ}$ dia

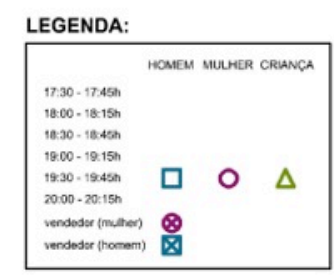

SQN $408-1^{\circ}$ dia

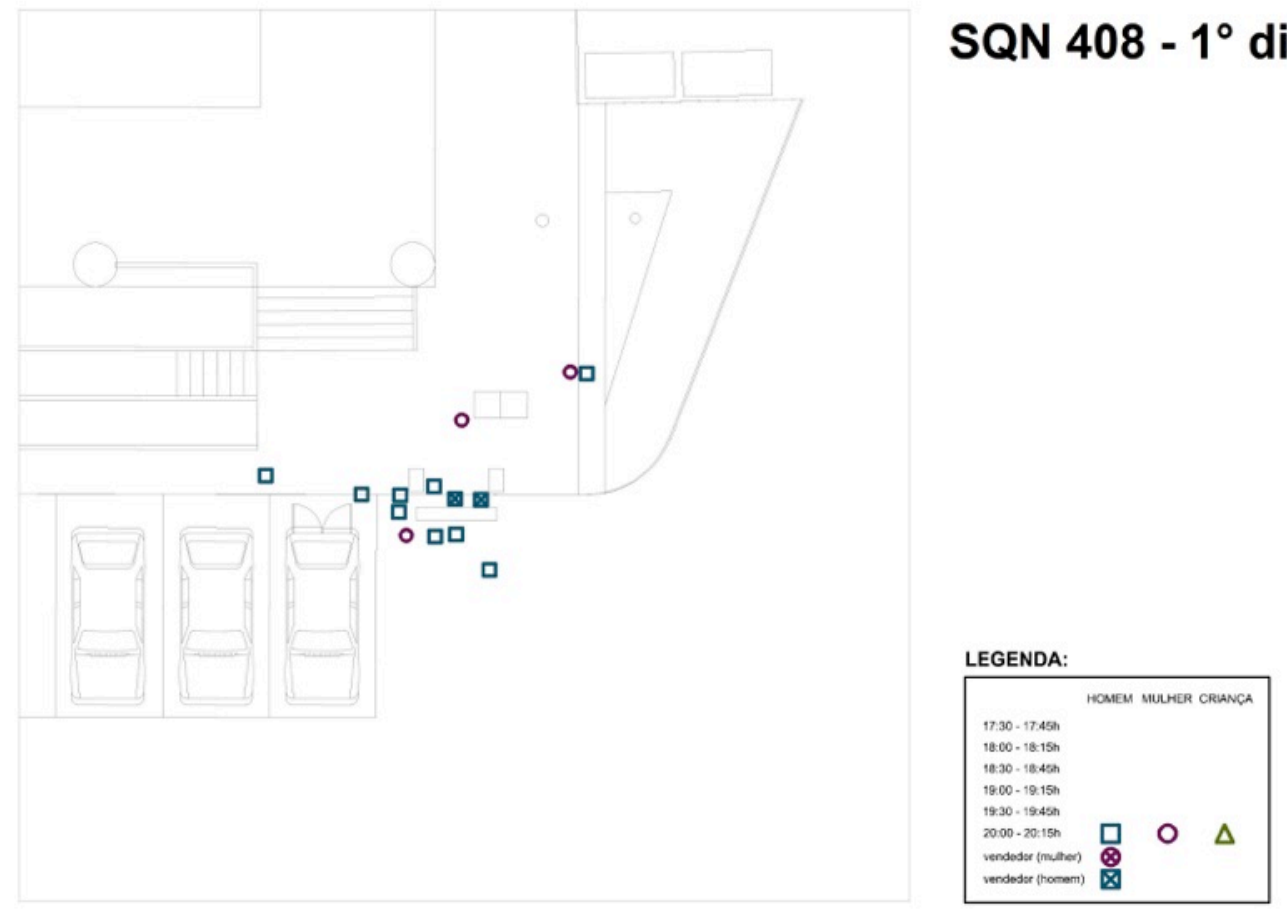




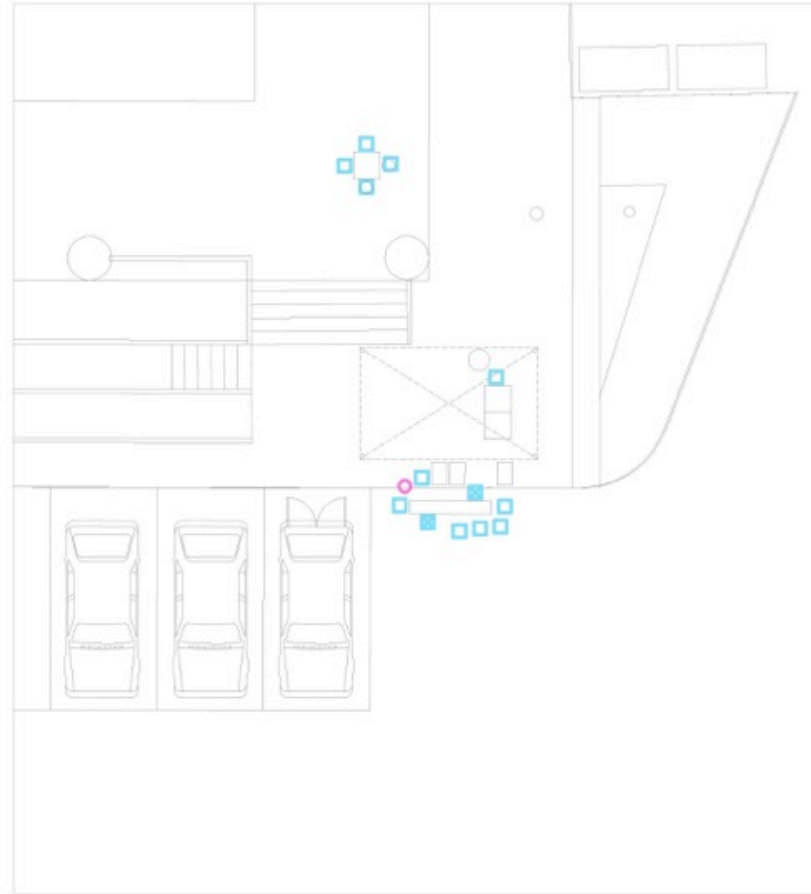

SQN $408-2^{\circ}$ dia
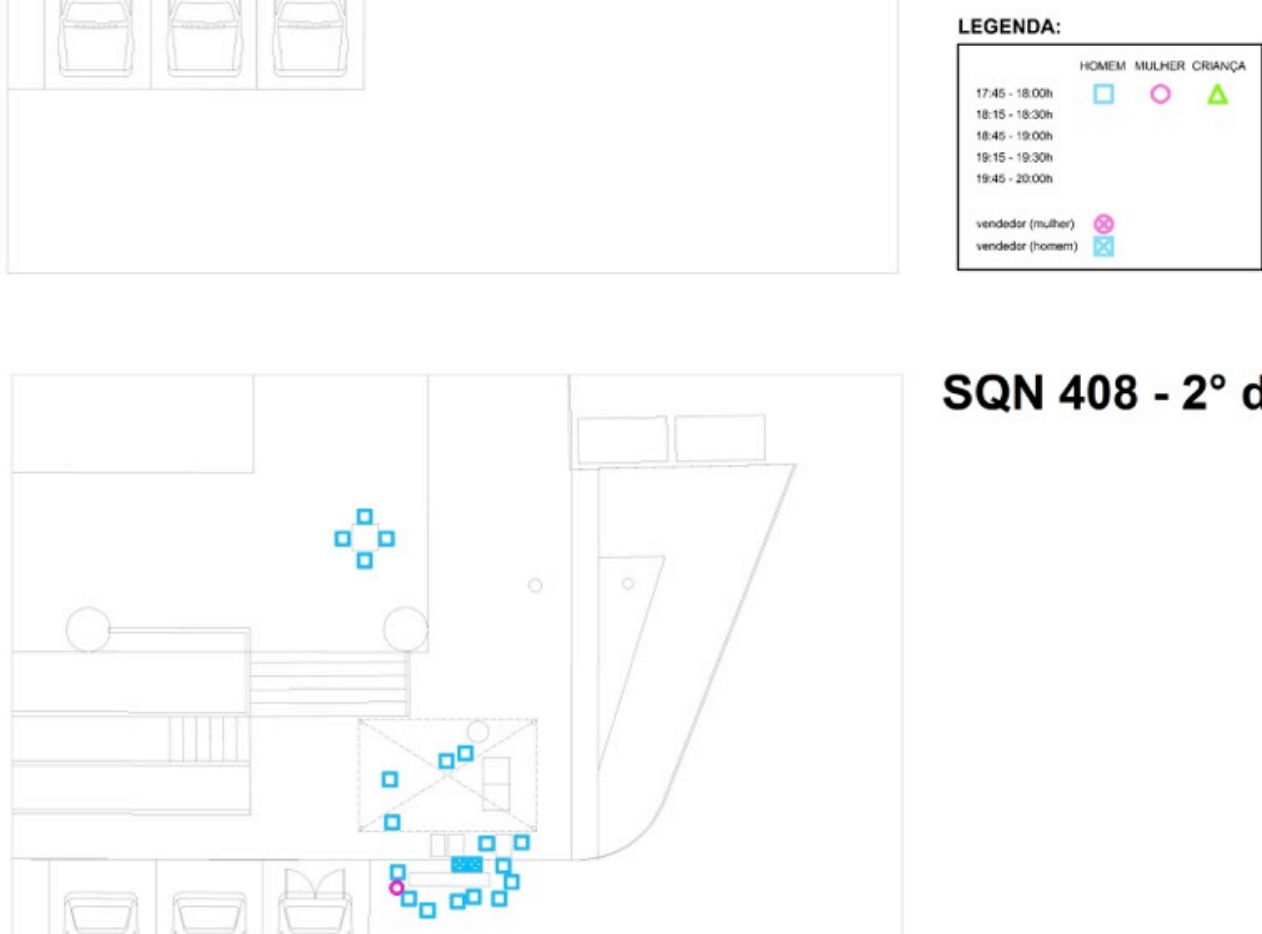

SQN $408-2^{\circ}$ dia

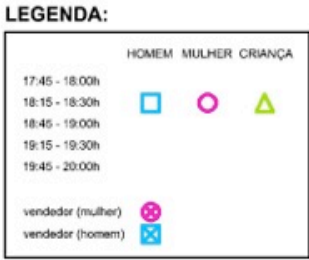




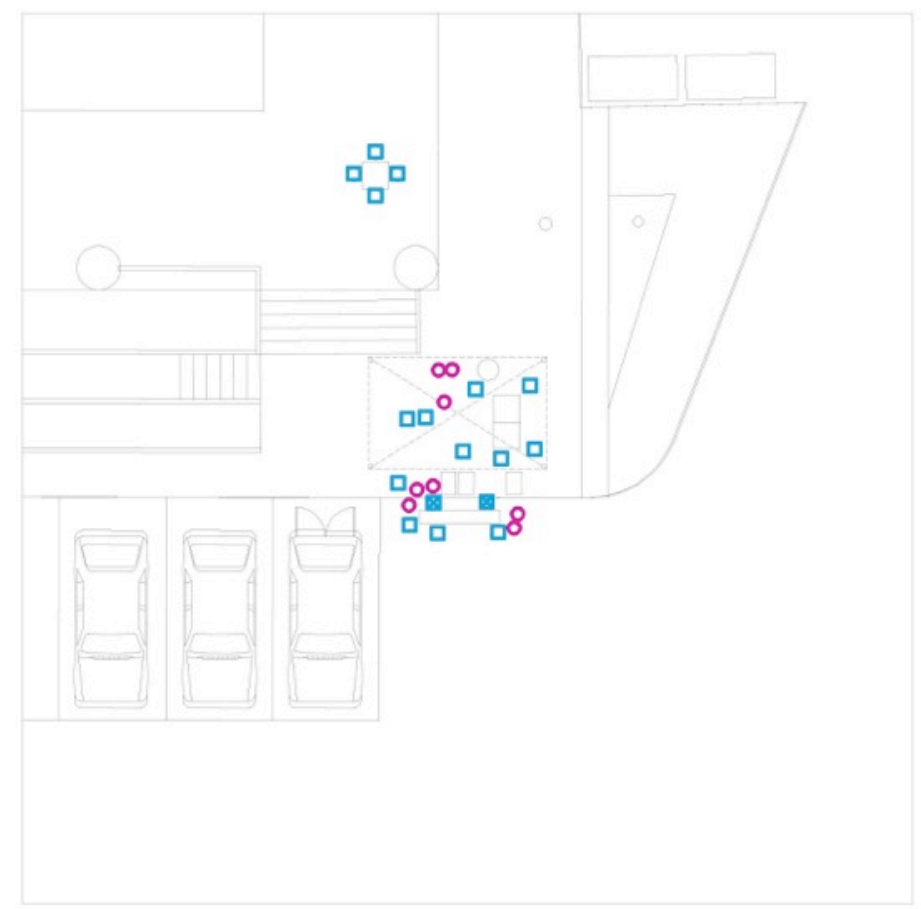

SQN $408-2^{\circ}$ dia
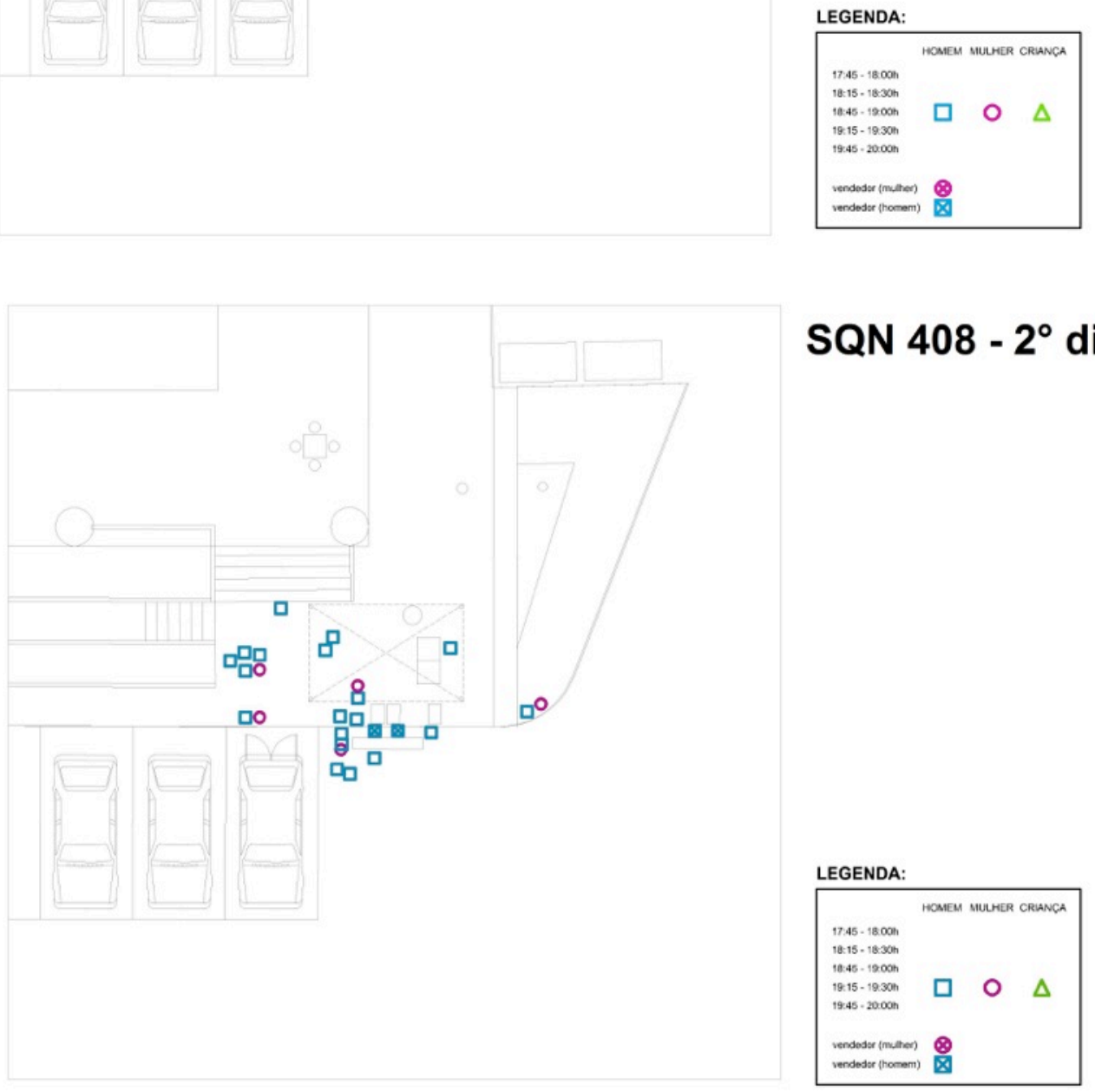


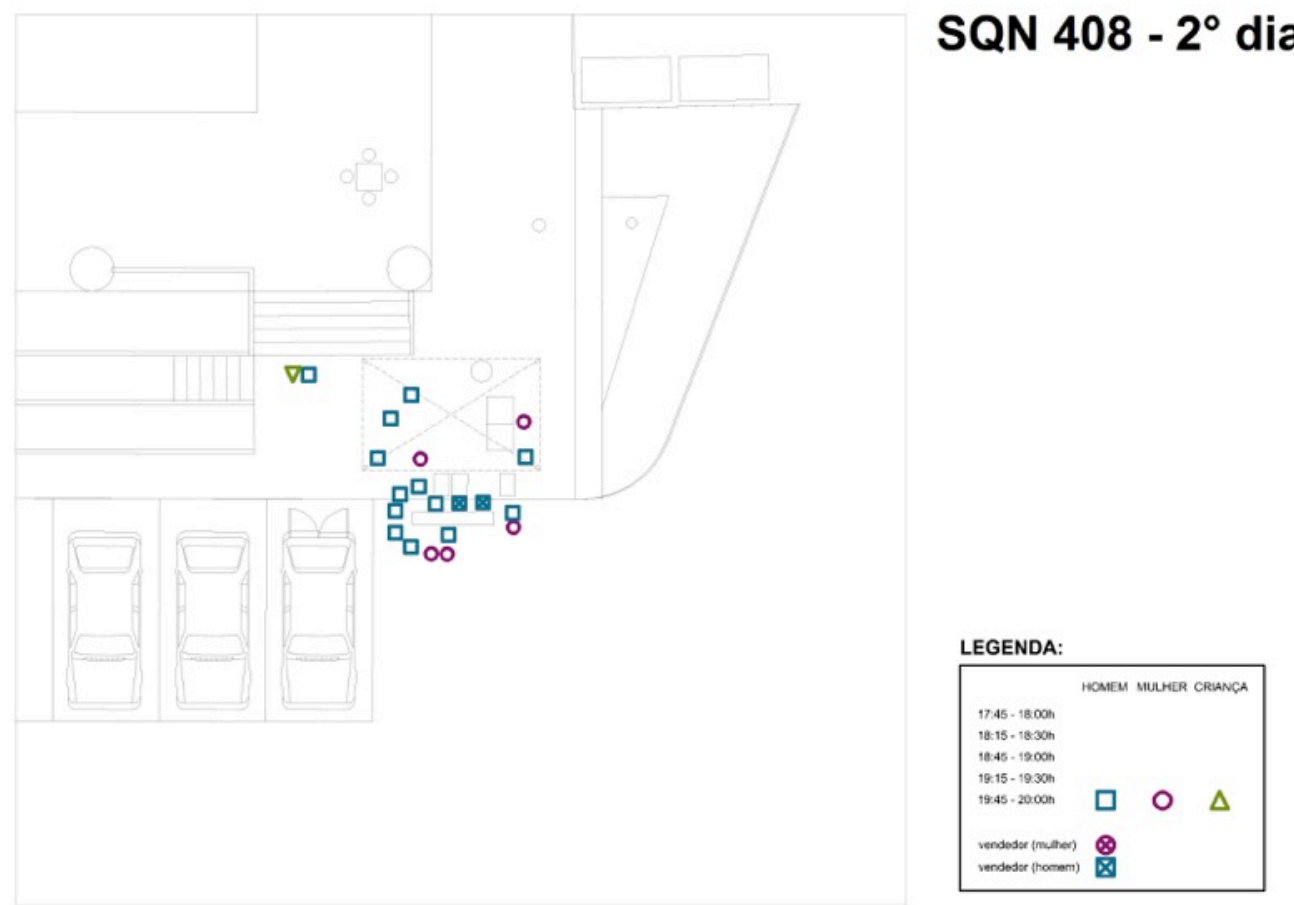

